\title{
História do ensino da literatura infantil na formação de professores no estado de São Paulo (1947-2003)
}

\author{
Fernando Rodrigues de Oliveira
}

OLIVEIRA, FR. História do ensino da literatura infantil na formação de professores no estado de São Paulo (1947-2003) [online]. São Paulo: Editora UNESP; São Paulo: Cultura Acadêmica, 2015,

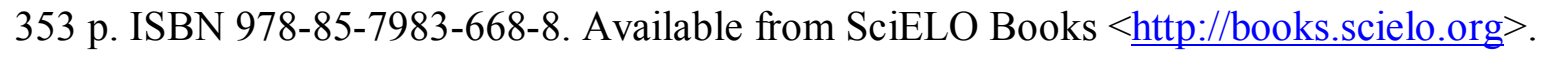

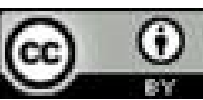

All the contents of this work, except where otherwise noted, is licensed under a Creative Commons Attribution 4.0 International license.

Todo o conteúdo deste trabalho, exceto quando houver ressalva, é publicado sob a licença Creative Commons Atribição $\underline{4.0}$.

Todo el contenido de esta obra, excepto donde se indique lo contrario, está bajo licencia de la licencia Creative Commons $\underline{\text { Reconocimento } 4.0 .}$. 


\section{História do ENSINO DA LITERATURA INFANTIL NA FORMAÇÃO DE PROFESSORES No estado de São Paulo (1947-2003)}


CONSELHO EDITORIAL ACADÊMICO

Responsável pela publicação desta obra

Neusa Maria Dal Ri

Anna Augusta Sampaio de Oliveira

Simone Aparecida Capellini

Carlos da Fonseca Brandão 
FERNANDO RODRIGUES DE OLIVEIRA

\author{
História do ENSINO DA \\ LITERATURA INFANTIL NA \\ FORMAÇÃO DE PROFESSORES \\ no estado de São Paulo \\ (1947-2003)
}

CULTURA $\frac{\text { ACADÊMICA }}{\mathcal{E} d i t a n a}$ 
(C) 2015 Editora Unesp

\section{Cultura Acadêmica}

Praça da Sé, 108

01001-900 - São Paulo - SP

Tel.: (0xx11) 3242-7171

Fax: (0xx11) 3242-7172

www.culturaacademica.com.br

feu@editora.unesp.br

CIP - BRASIL. Catalogação na Publicação

Sindicato Nacional dos Editores de Livros, RJ

O47h

Oliveira, Fernando Rodrigues de

História do ensino da literatura infantil na formação de professores no estado de São Paulo (1947-2003) [recurso eletrônico] / Fernando Rodrigues de Oliveira. -

1. ed. - São Paulo : Cultura Acadêmica, 2015.

recurso digital

Formato: epub

Requisitos do sistema: Adobe Acrobat Reader

Modo de acesso: World Wide Web

Inclui bibliografia

ISBN 978-85-7983-668-8 (recurso eletrônico)

1. Literatura infantojuvenil - São Paulo (Estado) - História. 2. Professores -

Formação - São Paulo (Estado) - História. 3. Educação - São Paulo (Estado) -

História. 4. Livros eletrônicos. I. Título.

15-27091

CDD: 379.8161

CDU: $37.014 .5(815.6)$

Este livro é publicado pelo Programa de Publicações Digitais da Pró-Reitoria de Pós-Graduação da Universidade Estadual Paulista "Júlio de Mesquita Filho" (Unesp)

Editora afiliada:

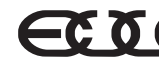

Asociación de Editoriales Universitarias de América Latina y el Caribe

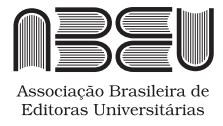


Para Benício e Arthur, com o desejo de que a literatura lhes possibilite a leveza necessária para viver. Para Orlando e Ednéia, pelo amor que não sei explicar; apenas sinto. 


\section{Agradecimentos}

Este livro, originalmente apresentado sob a forma de tese de doutorado, é resultado de quase uma década de minha trajetória de formação e de pesquisa, na qual contei com apoio, incentivo e colaboração de muitas pessoas. Embora não seja possível nominar todas elas, menciono, em especial, aquelas cuja participação nessa trajetória foi decisiva para que eu pudesse chegar aos resultados que apresento aqui.

Maria do Rosário Longo Mortatti, mais do que orientadora, nos últimos oito anos guiou-me nos caminhos da formação intelectual e humana como apenas os grandes sábios são capazes de fazer. A sua participação em minha história de vida e formação me possibilitou pensar em ousar transpor muitos dos meus limites e me possibilitou aprender, na sutileza de seus gestos, palavras e ações, a ver o mundo como "configuração textual".

Aos meus pais e familiares, que são a razão do meu esforço e do meu empenho em crescer a cada dia. Obrigado por nunca hesitarem em apoiar os meus sonhos, dando-me sempre o conforto e carinho necessários para seguir em frente.

A Mirian Jorge Warde, Rosa Fátima de Souza Chaloba, Justino Pereira de Magalhães e João Luís Ceccantini, interlocutores especiais, que aceitaram o desafio de pensar sobre a "história" que me propus a "narrar". A participação de tão renomados pesquisadores nos diferentes momentos da pesquisa, em especial na defesa da tese, possibilitou-me ganhar clareza e sobressaltar muitos dos limites.

Às integrantes do GPHELLB, que me possibilitaram vivenciar o real sentido da palavra "grupo". Nas muitas formações pela qual o GPHELLB 
passou, somente tenho a agradecer a todas que, de algum modo, tiveram participação no meu processo formativo. Com as integrantes desse grupo, partilhei os mais diversos e singulares momentos da minha vida pessoal e acadêmica e aprendi muito mais do que o "fazer" da pesquisa, aprendi sobre a vida e sobre a importância de ter bons amigos.

Agradeço especialmente Franciele Ruiz Pasquim, Thabatha Aline Trevisan, Agnes Iara Domingos Moraes, Bárbara Cortella Pereira e Monalisa Renata Gazoli, pela parceria de vida.

A meus amigos, daqui e do além-mar, pelas boas risadas, pelas palavras de conforto, pela paciência e pela amizade incondicional. Sem vocês, eu não teria conseguido alçar muitos dos voos que fiz e ainda farei.

A meus alunos do passado, do presente e do futuro. Espero ter sido e continuar a ser cada vez melhor um professor que corresponda à altura da responsabilidade que é atuar na formação de outros sujeitos.

À Coordenadoria de Aperfeiçoamento de Pessoal de Nível Superior (Capes) e à Fundação de Amparo à Pesquisa do Estado de São Paulo (Fapesp), pela concessão de bolsas durante o desenvolvimento da pesquisa que resultou neste livro. 


\section{SUMÁRIO}

Introdução 13

1 As primeiras manifestações discursivas sobre a literatura infantil brasileira: o processo de construção de saberes 29

2 A institucionalização do ensino da literatura infantil na formação de professores: a criação de uma matéria de ensino (1947-1956) 87

3 Sistematização do saber escolar sobre a literatura infantil: a disciplina "literatura infantil" (1957-1970) 151

$4 \mathrm{O}$ ensino da literatura infantil e os novos modelos de cursos de formação de professores: a consolidação de um campo de ensino, estudos e pesquisa (1971-2003) 239

5 O ensino da literatura infantil na formação de professores: quais sentidos? (à guisa de conclusão) 323

Referências 339 
[...] a figura do passado guarda seu valor primeiro de representar o que faz falta. Com um material que, para ser objetivo, está necessariamente lá, mas conotativo de um passado na medida em que remete de imediato a uma ausência, ela introduz também a fenda de um futuro.

(Certeau, 1976, p.41) 


\section{INTRODUÇÃO}

No Brasil, pensar as questões relativas à literatura infantil e seu ensino é algo que data de mais de um século. Pesquisas do tipo "estado da arte", que visam mapear o conhecimento acumulado sobre esse assunto, como as desenvolvidas por Mortatti (2003; 2011), têm possibilitado compreender que, desde o final do século XIX, observa-se a preocupação com os usos que a escola faz do texto literário destinado à criança, de modo que, nas últimas décadas, vem crescendo o número de sujeitos envolvidos com estudos e pesquisas nesse campo.

Nesse processo de formação e acúmulo de conhecimento sobre a literatura infantil e seu ensino, nos últimos 30 anos iniciou-se a disseminação, no Brasil, de uma compreensão a respeito desse fenômeno literário, baseada na ideia de sua "literariedade", em contraposição a uma produção de e sobre literatura infantil denominada, a partir de então, "didadista", "pedagogizante" e/ou com fins "utilitários". Essa perspectiva "literária” de se compreender a produção de literatura infantil e os estudos sobre esse gênero começou a se desenvolver no meio acadêmico-universitário brasileiro, especialmente a partir da década de 1980, quando foram criados, no país, os primeiros cursos de pós-graduação em Educação e em Letras.

Desses cursos, responsáveis pelos primeiros textos acadêmicos brasileiros sobre o assunto (muitos dos quais publicados posteriormente em livros, artigos e capítulos), formou-se o que se pode denominar de uma geração de pesquisadores que, em maior ou menor escala, ligados ao movimento de reabertura política do país e à compreensão crítica das relações dialéticas e 
contraditórias entre escola, sociedade e literatura, tornaram-se responsáveis por um tom "renovador" nos discursos sobre os livros para crianças.

Esse tom "renovador", conforme se pode observar em textos de Zilberman (1981), Lajolo (1982), Lajolo e Zilberman (1984), Rosemberg (1985), Perrotti (1986), Cadermatori (1986), Sandroni (1987) e Yunes e Pondé (1988), entre outros, caracteriza-se pela tentativa de pensar os livros de literatura infantil como obra literária, com os mesmos padrões estéticos e éticos, portanto, atribuídos como válidos para a literatura "adulta”. E, como obra literária, os livros de literatura infantil não devem servir para os fins pragmáticos e "utilitários" da escola, como se compreendia até então.

Com isso, essa "nova”" geração de pesquisadores universitários, em seus diferentes textos, quase em uníssono, passou a defender a ideia de que, atéa década de 1970, a produção literária nacional voltada à infância se tinha desenvolvido sob a tutela da escola, sob a égide do ensino. E somente a partir do final da década de 1970 é que se observou uma produção literária "[...] cuja função lúdica está aliada a uma visão questionadora de falsos valores e comportamentos característicos da sociedade contemporânea" (Sandroni, 1987, p.13).

Esses discursos sobre literatura infantil, publicados a partir de 1980, embora tratem de livros literários destinados à infância e não da produção sobre literatura infantil, de certo modo também se apresentam como contraposição teórica, num formato de contradiscurso à concepção de literatura infantil e de seus usos, materializada nas publicações existentes até então. Um exemplo dessa situação é a tese de Lajolo (1979), na qual essa pesquisadora afirma que, no Brasil, o ensino da literatura até os anos de 1970 se dava num modelo de "educação pela literatura", como instrumento pedagógico e com preleções morais, cívicas e familiares. Contrariamente a essa situação, Lajolo (1979) propunha que o caminho desejável para o ensino da literatura era o centrado na ideia de "educação para a literatura", visando à “[...] sensibilização para o estético literário, função diametralmente oposta à manipulação da sensibilidade intuitiva do aluno para reforçar um quadro de valores éticos, sociais, afetivos, ideológicos" (Lajolo, 1982, p.15, grifos da autora).

A tese de Lajolo (1979) e os demais textos publicados no mesmo período passaram a ser posteriormente tomados como referência e como "a verdade" em termos de estudos e pesquisas nesse campo, fazendo com que con- 
ceitos como "literariedade" e "utilitarismo" fossem (e ainda são) utilizados por outros pesquisadores por vezes de forma ingênua ou em repetição ao já feito, demonstrando a força de criação de uma "nova" tradição nos estudos sobre literatura infantil.

Nesses aproximados 30 anos do despontar dessa geração de pesquisadores acadêmico-universitários e da publicação de seus primeiros e principais textos, o que se nota é uma relativa estagnação de reflexões de fundo teórico-conceitual, que busca dialogar, problematizar e repensar a concepção de literatura infantil defendida por esses pesquisadores que se destacaram nos anos 1980. Como vem demonstrando alguns estudos nesse sentido (Oliveira, 2012), as publicações sobre literatura infantil, disseminadas a partir de então (que não são poucas), assumiram o posicionamento teórico, histórico e conceitual defendido por eles, sem que se fossem questionados aspectos centrais e essenciais, entre outros, relacionados à história da literatura infantil brasileira, às relações desses livros com o ensino escolarizado e ao processo de formação de uma teoria e crítica específicas sobre esse gênero ao longo do século XX e XXI, no Brasil.

Como exemplo de um, entre os muitos silêncios eloquentes que ainda se têm no campo da literatura infantil, pode-se destacar a recorrente rotulação dos livros para crianças e da produção teórica sobre esse gênero, até a década de 1970, como "didatista", "pedagogizante", "moralista" e "utilitária", sem que se questionem os sentidos e as implicações dessas adjetivações para a produção de e sobre literatura infantil.

No esteio dessa questão, outras relacionadas a ela também permanecem silenciadas. Em que consiste essa concepção de literatura infantil e seu ensino, hoje considerada "didatista", "pedagogizante", "moralista" e "utilitária”? Como essa concepção de literatura infantil se constituiu e se consolidou ao longo do século XX no Brasil? Por qual/quais razão/ões ela passou a ser caracterizada e combatida, posteriormente, como "didatista", "pedagogizante", "moralista" e "utilitária"? Quais sujeitos estiveram envolvidos com essa concepção de literatura infantil? Qual foi o seu lugar privilegiado de disseminação? Quais campos científicos estiveram na base da sua formulação? Que mudanças, permanências e rupturas se observam, ou não, ao longo da história de sua formulação e a partir da década de 1980, quando passou a ser questionada e combatida? O que, de fato, se propunha em relação à litera- 
tura infantil e seu ensino, ao longo do século XX, e o que mudou, ou não, a partir da "renovação" do campo, depois da década de 1980?

Esse conjunto de questões abre um leque de possibilidades investigativas, entre as quais a história do ensino da literatura infantil na formação de professores primários. ${ }^{1}$

Instado a pensar, sobre essa faceta da literatura infantil e a buscar novas possibilidades investigativas nesse campo, desenvolvi ampla pesquisa ${ }^{2}$ documental e bibliográfica sobre a história do ensino da literatura infantil nos cursos de formação de professores primários no estado de São Paulo entre 1947 e 2003, tendo como objetivo contribuir para a compreensão do lugar desse ensino na história da literatura infantil e da formação de professores e na produção de uma história, teoria e crítica específicas desse gênero literário no Brasil.

A opção por abordar questões do passado, diante de um presente histórico em que são urgentes os problemas relativos ao ensino da literatura (infantil, juvenil ou "adulta") e à formação dos leitores, decorreu do fato de que, como explica Bloch (s.d.), a ignorância sobre o passado resulta, inevitavelmente, numa problemática e improdutiva incompreensão do presente. Nesse sentido, voltar-se às questões do passado é uma forma de "historicizar o atual”, é explicitar "[...] a razão reinante como um lugar próprio que, por oposição a um 'passado', se torna o presente” (Certeau, 1974, p.40).

Pensar sobre a história do ensino da literatura infantil na formação de professores como uma das formas de se compreender e refletir sobre os problemas do presente requer o cuidado, por um lado, para que não se permita:

1 Em relação à expressão "professores primários", refiro-me à formação de professores para lecionar nos quatro ou três primeiros anos do curso primário, hoje equivalente aos cinco primeiros anos do ensino fundamental. Embora a expressão "professor primário" tenha deixado de ser utilizada oficialmente na década de 1970, com implantação do ensino de $1^{\circ} \mathrm{e}$ $2^{\circ}$ graus, ela permaneceu no cotidiano do fazer escolar e entre o público em geral como forma de caracterizar o professor dos anos/séries iniciais da escolarização de crianças. Assim, ainda que a expressão "professor primário" não seja condizente com todo o período abrangido neste livro, ela é utilizada pela força simbólica que carrega consigo, sobretudo no imaginário dos próprios professores e da sociedade em geral.

2 Trata-se de pesquisa de doutorado, desenvolvida entre março de 2011 e dezembro de 2014 (bolsa Fapesp; PDSE-Capes), junto ao Programa de Pós-Graduação em Educação, da Faculdade de Filosofia e Ciências, da Universidade Estadual Paulista "Júlio de Mesquita Filho", campus de Marília, sob orientação da professora Maria do Rosário Longo Mortatti, e no âmbito do GPHELLB - Grupo de Pesquisa "História do Ensino de Língua e Literatura no Brasil". 
[...] obliterarem-se as diferenças constitutivas $\mathrm{d}[$ esse] passado nem tampouco que se o enquadre, anacronicamente [...] neste presente histórico [...]; e, por outro lado, permita compreender os problemas atuais em sua diversidade e historicidade, sem se confundir a crítica do presente seja com a nostalgia, seja com a exorcização do passado. (Moratti, 2000b, p.20-21)

Abordar, portanto, historicamente aspectos do ensino da literatura infantil na formação de professores é um processo investigativo diretamente relacionado ao desafio contemporâneo das pesquisas acadêmico-científicas, conforme descrito por Chauí (1996), que implica a acolhida de novos temas, novos métodos, novas técnicas e novas abordagens de pesquisa, "[...] não por serem novos nem porque sejam garantia de ocupação [...], mas porque fazem sentido, correspondem a necessidades e experiências reais que pedem interpretação e compreensão" (Chauí, 1996, p.170).

Para tratar da história do ensino da literatura infantil na formação de professores primários, estabeleci como marcos históricos os anos de 1947 e 2003. Cabe destacar, no entanto, que a definição dessa cronologia decorreu de características internas ao objeto e não pretendeu demarcar com exatidão início e fim desse ensino. Com isso, o marco inicial, 1947, corresponde ao ano de promulgação, no estado de São Paulo, do Decreto Estadual n. 17.698, de 26 de novembro, a partir do qual identifiquei, pela primeira vez, a presença da disciplina "Literatura infantil" no currículo do Curso Normal do Instituto de Educação Caetano de Campos, situado na capital paulista, e o qual instituiu, oficialmente, o ensino desse gênero literário pela primeira vez. O marco final, 2003, corresponde ao ano de publicação da Resolução n. 119, de 7 de novembro, da Secretaria de Educação do Estado de São Paulo, a qual foi responsável pela extinção, no estado, dos cursos de formação de professores de nível médio (antigos cursos normais ou cursos de $2^{\circ}$ grau), nos quais o ensino da literatura infantil podia se fazer presente como disciplina ou como parte do conteúdo de outras disciplinas. Apesar de o marco inicial corresponder ao ano de 1947, abordo, neste livro, aspectos dos principais discursos brasileiros sobre literatura infantil, publicados entre 1882 e 1946, a fim de compreender como se iniciou o processo de formação de saberes a respeito desse gênero literário, posteriormente envolvidos com a formação do "saber escolar" sobre literatura infantil. 
Ao longo do período delimitado, 1947-2003, conforme se observa na legislação educacional brasileira e paulista, funcionaram, nesse estado, os seguintes cursos para formação de professores primários (cursos de nível médio): Cursos Normais, de Escolas Normais e Institutos de Educação; Habilitação Específica de $2^{\circ}$ Grau para o Magistério (HEM), oferecida em escolas de $2^{\circ}$ grau; e curso de formação de professores dos Centros Específicos de Formação e Aperfeiçoamento do Magistério (Cefam). São os aspectos a respeito do ensino da literatura infantil nesses cursos que abordo neste livro, uma vez que foi neles que esse ensino foi instituído oficialmente na formação dos professores paulistas. Em relação aos cursos de nível superior, como os de Pedagogia ou Letras, que também funcionaram no estado de São Paulo nesse período, cabe destacar que a literatura infantil nunca foi instituída, de modo oficial, como disciplina dos currículos desses cursos. Sempre que as discussões sobre literatura infantil figuraram em cursos de nível superior nesse período, isso se deu por iniciativas isoladas, sem ter vinculação com as deliberações oficiais de órgãos responsáveis por gerenciar o sistema de ensino paulista. Por essa razão, a discussão sobre o ensino da literatura infantil que apresento aqui centra-se nos processos de tematizações, normatizações e concretizações desse ensino nos Cursos Normais, na HEM e nos Cefams.

A delimitação ao estado de São Paulo decorreu do fato de que, embora esse ensino tenha sido implementado no currículo dos cursos de formação de professores também em outros estados brasileiros, nenhuma dessas experiências se fixou por tanto tempo - quase 60 anos - como no caso paulista. Além disso, foi a institucionalização desse ensino no estado de São Paulo que serviu de modelo para esses outros estados, resultando em uma série de iniciativas que influenciaram diretamente na construção de um campo de estudos e investigações sobre literatura infantil, no Brasil.

Tendo em vista a opção pela abordagem histórica do tema - ensino da literatura infantil na formação de professores - e essas delimitações em relação ao objeto de investigação de que trato aqui, cabe explicitar como compreendo alguns conceitos operativos que utilizei recorrentemente, bem como as opções teórico-metodológicas implementadas na análise e interpretação dos documentos.

Em relação ao conceito de literatura infantil, embora haja a dificuldade de defini-lo por conta de sua resistência "[...] ao enquadramento em defi- 
nições precisas e à clara delimitação e descrição, situando-se numa espécie de limbo acadêmico [...]" (Ceccantini, 2004, p.20), optei por utilizá-lo da seguinte forma, com base em Mortatti (2000a).

Por literatura infantil entendo um conjunto de textos - escritos por adultos para serem lidos por crianças e/ou jovens - que constituem um corpus/gênero historicamente oscilante entre o literário e o didático e que foram paulatinamente sendo denominados como "literatura infantil e/ou juvenil", em razão de certas características do corpus e certos funcionamentos sedimentados historicamente, por meio, entre outros, da expansão de um mercado editorial específico e de certas instâncias normatizadoras, como a escola e a academia. (p.13)

A literatura infantil, como fenômeno "literário-cultural-social", na medida em que se tornou objeto de estudo e de investigação, ao longo do século $\mathrm{XX}$, deu origem a um correspondente campo de conhecimento/investigação, observável em discursos sobre/produção sobre literatura infantil (Mortatti, 2008). Por isso, pela expressão "literatura infantil” também me refiro a esses discursos sobre os livros literários escritos para crianças.

Ao considerar os textos sobre literatura infantil como discursos, entendo esse conceito conforme proposto por Bakhtin (2002), como uma enunciação, que se constitui sempre como resposta a outra(s) enunciação(ões), num processo de interação verbal entre diferentes interlocutores, mesmo que essa interação não se dê de forma explícita. Como explica Bakhtin (1998):

[...] todo discurso concreto (enunciação) encontra aquele objeto para o qual está voltado, sempre, por assim dizer, desacreditado, contestado, iluminado pelo discurso de outrem que já falaram sobre ele. O objeto está amarrado e penetrado por idéias gerais, por pontos de vista, por apreciações de outros e por entonações. Orientado para seu objeto, o discurso penetra neste meio dialogicamente perturbado e tenso de discursos de outrem, de julgamentos e de entonações. Ele se entrelaça com eles em interações complexas, fundindo-se com uns, isolando-se de outros, cruzando com terceiros; e tudo isso pode formar substancialmente o discurso, penetrar em todos os seus estratos semânticos, tornar complexa a sua expressão, influenciar todo o seu aspecto estilístico. (p.86) 
Como a pesquisa que desenvolvi se relaciona com a formação de professores, cabe explicar que utilizo essa expressão como o "[...] preparo específico para o desenvolvimento da função de ensinar" (Labegalini, 2009, p.16). De acordo com Magnani (1993), trata-se de processo formativo que se caracteriza como:

[...] parte do processo de formação de sujeitos, num dado momento histórico, em determinadas relações sociais de trabalho. O preparo específico e a prática dessa profissão caracterizam-se por aprender a ensinar, a aprender, a analisar e formular concepções de mundo e formas de atuação. (p.30)

No período histórico que delimitei para a pesquisa - 1947 a 2003 -, observa-se que, gradativamente, a Psicologia, especialmente a Experimental, tornou-se ciência diretora da educação. Como explica Manacorda (1989):

Desde que surgiu, com Wundt, a moderna psicologia experimental, com todas as sucessivas ramificações e especializações, é impossível ocupar-se da pedagogia ignorando a psicologia (e mais tarde a psicanálise) [...]. Da psicologia e da pedagogia inevitavelmente fará parte, junto com a criança como sujeito, também o seu modo inicial de expressar-se nas atividades sensório-motoras, e, portanto, o jogo-trabalho e, no fundo, o trabalho social do adulto. (p.306)

Esse processo em que a Psicologia foi tomada como uma das principais ciências de referência ${ }^{3}$ para a educação é denominado, neste livro, "psicologização" do ensino. Esse termo se refere, portanto, à apropriação, desde o final do século XIX e, sobretudo, ao longo do século XX, no pensamento educacional brasileiro, dos conceitos da ciência psicológica para sustentar e justificar a proposição de determinadas práticas educativas.

No que diz respeito às fontes documentais que elegi como corpus privilegiado da pesquisa, utilizei os "programas de ensino", os quais se caracterizam como um plano ou conjunto de planos de ensino, elaborados e divulgados por órgãos ou instituições oficiais, para orientar os professores no ensino de determinada disciplina. Esses programas de ensino apresen-

3 Conforme explica Cunha (1995), juntamente com a Psicologia, a Sociologia e a Biologia foram as ciências que se destacaram, entre 1930 e 1960, no pensamento educacional brasileiro, especialmente na formação de professores. 
tam, sobretudo, o conjunto de conteúdos, sob o formato de "pontos", a serem ensinados ao longo de um ano letivo no âmbito de uma matéria/ disciplina escolar.

Em razão das mudanças ocorridas nos cursos de formação de professores na segunda metade do século XX, os programas de ensino foram substituídos, a partir de 1971, por documentos denominados "guias curriculares". Esses documentos, embora organizados de modo diferente em relação aos programas de ensino, também tinham a função de orientar os professores quanto ao que se devia ensinar no âmbito de cada disciplina. Esses guias curriculares apresentam, além dos pontos/conteúdos programáticos a serem trabalhados, os objetivos, justificativa e bibliografia referentes às disciplinas a que correspondem.

Em relação aos manuais de ensino, esses são aqui compreendidos como um tipo de livro didático destinado à utilização em cursos de formação de professores e que contém os saberes teóricos e práticos considerados necessários para que os professorandos aprendam a ensinar determinada disciplina ou matéria do curso primário. A expressão "manual de ensino" é aqui utilizada como equivalente a outras, a saber: "manual pedagógico", "manual escolar", "tratado" e "compêndio".

Nesses manuais, tratados ou compêndios, conforme explica Mortatti (2014):

[...] eram compendiados (sumariados, resumidos, sintetizados, disseminados, abreviados) os conhecimentos/noções básicos que caracterizavam um conjunto de saberes considerados necessários para o exercício do ofício de professor [...] visando à profissionalização do magistério. Além de textos de estudo para os professorandos, funcionavam como manual de ensino, pois eram constituídos predominantemente de prescrições e instruções relativas a normas, procedimentos e atividades a serem executadas pelos professores, com o objetivo de concretizar os princípios e finalidades político-educacionais. (p.203)

Como "objeto cultural" e meio de transmissão de saberes e informações, os manuais de ensino integraram "[...] um complexo estrutural constituído por binômios: leitura/leitor; regulação/mercado; pedagogia/ordem de conhecimento; técnica editorial/meio didáctico; autoria/escrituração". (Magalhães, 2011, p.9) Desse modo, a importância de se tomar os manuais 
de ensino como fonte documental se resguarda, principalmente, como explica Magalhães (2011), no fato de que eles se configuram como meio pedagógico-didático, com "[...] estatuto de representação escrita do educacional escolar" (p.15).

Para Valdemarin (2008), os manuais e seus autores:

[...] ocupam posição intermediária no campo relacional pedagógico, entrelaçam diferentes elementos culturais e interferem decisivamente no processo de formação institucionalizada. Nessas fontes documentais estão expressas as concepções teóricas balizadas pela possibilidade de uso em sala de aula, reveladoras, portanto, de uma apropriação tática para tornar o novo semelhante ao já praticado. São, simultaneamente, dispositivos modeladores de procedimentos e elementos estratégicos para a implementação de políticas públicas que se pretendem inovadoras. (p.26)

Além desses documentos, utilizei outros, como fontes auxiliares da pesquisa, como: leis, decretos, artigos em revistas, textos em jornais e livros sobre literatura infantil.

Em decorrência dos tipos de fontes documentais que utilizei, optei por classificá-los, conforme propõe Mortatti (2000b), com base em critérios relacionados a sua condição de fontes, tendo em vista conteúdo, finalidade e forma de vinculação. Com isso, utilizo a seguinte classificação para os documentos de que trato neste livro:

a) tematizações - contidas especialmente em artigos, conferências, relatos de experiência, memórias, livros teóricos e de divulgação, teses acadêmicas, prefácios e instruções de cartilhas e livros de leitura;

b) normatizações - contidas em legislação de ensino (leis, decretos, regulamentos, portarias, programas e similares); e

c) concretizações - contidas em [...] [manuais de ensino], "guias do professor", memórias, relatos de experiência e material produzido por professores e alunos no decorrer das atividades didático-pedagógicas. (Mortatti, 2000b, p.29)

Em relação às opções teórico-metodológicas, utilizei principalmente as contribuições da vertente historiográfica que se convencionou denominar "História Cultural", pautando-me principalmente em: Certeau (1974), 
Chartier (1990a,1990b, 2009); Chervel (1990); e Le Goff (2003). Embora não pertencente a essa vertente historiográfica, utilizo-me também das considerações de Benjamin (1994) sobre o conceito de história.

Caracterizada por um movimento de descontinuidades metodológicas na sua constituição e de diferentes posicionamentos de seus adeptos, relativamente aos modos de se produzir e compreender a história, a História Cultural trouxe à tona o olhar para fontes e objetos antes inexplorados pela historiografia, sobretudo no campo da História da Educação. Com essa nova vertente historiográfica, passou-se a priorizar:

[...] uma história que já não confunde os discursos sobre educação com os reais processos educativos e que pode propor (uma vez clarificados a função e o funcionamento da escola em seus diferentes níveis) um novo exame dos antigos interesses: as teorias e projectos pedagógicos, os métodos de ensino, os conteúdos ensinados. (Chartier, 1990a, p.162)

Partindo desse ponto de vista, a pesquisa histórica, tal como é entendida aqui, centra-se na compreensão de que "o que fabrica o historiador", quando desenvolve pesquisa na área de História, não é a reconstrução do passado, mas a produção de um discurso (uma escrita) sobre um evento situado no tempo, escolhido pelo historiador como um acontecimento (Certeau, 1974). Desse modo, produzir uma pesquisa histórica não é dar a conhecer o passado como ele de fato foi, mas "[...] apropriar-se de uma reminiscência tal como ele relampeja no momento de um perigo" (Benjamin, 1994, p.224). Por isso, a história não é entendida aqui como um lugar cujo "[...] tempo é homogêneo e vazio, mas um tempo suturado de 'agoras"” (Benjamin, 1994, p.229).

Com base nessa concepção historiográfica, o trabalho do historiador consiste em uma "operação", como afirma Certeau, que significa necessariamente a articulação de um "lugar social" (um recrutamento, um ofício) e de "práticas científicas" (técnicas de seleção e análise do objeto) (Certeau, 1974).

Para Certeau (1974), ao tratar a pesquisa histórica como uma "operação", o historiador: 
[...] trabalha sobre um material para transformá-lo em história [.... Transformando de início as matérias-primas (uma informação primária) em produtos standard (uma informação secundária), transporta-o de uma região da cultura (as "curiosidades", os arquivos, as coleções etc.) a uma outra (a história) [...]. Mas o historiador não se contenta em traduzir uma linguagem cultural para outra [...]. Desde a sua documentação (onde introduz seixos, sons etc.) a seu livro (onde plantas, micróbios, geleiras adquirem o estatuto de objetos simbólicos), ele procede a um deslocamento da articulação natureza/cultura. $\mathrm{O}$ historiador modifica o espaço [...]. (Certeau, 1974, p.29-30, grifos do autor)

Especificamente em relação à pesquisa histórica no campo da educação, ela se caracteriza, coerentemente com essa concepção, por ser " [...] um tipo de pesquisa científica, cuja especificidade consiste, do ponto de vista teórico-metodológico, na abordagem histórica - no tempo - do fenômeno educativo em suas diferentes facetas". (Mortatti, 1999, p.73)

Em vista disso, para o desenvolvimento de pesquisa histórica, faz-se necessária a utilização de documentos, os quais, escolhidos pelo historiador dentro de um conjunto de possibilidades, funcionam como um inconsciente cultural e, por isso, não são inócuos (Le Goff, 2003). Esses documentos são, antes de tudo:

[...] resultado de uma montagem, consciente ou inconsciente, da história, da época, da sociedade que o produziram, mas também das épocas sucessivas durante as quais continuaram a viver, talvez esquecidas, durante as quais continuou a serem manipuladas, ainda que pelo silêncio. (Le Goff, 2003, p.538)

A partir dessa compreensão, os documentos que analisei foram aqui tratados como "configurações textuais":

[...] resultantes de um trabalho discursivo, consciente ou não, de determinado(s) sujeito(s) do momento histórico em que foi produzido, assim como de seus pósteros, para os quais continuam a existir, manipulados seja pelo combate acusatório, seja pelo esquecimento silencioso nem sempre inocente. (Mortatti, 2000b, p.30) 
Por considerar os documentos como "configurações textuais", para a sua análise utilizei método decorrente desse conceito, o qual não consiste simplesmente na aplicação de determinadas técnicas, mas em um ato interpretativo, que busca compreender o conjunto dos aspectos que constituem o sentido de um texto, a saber:

[...] às opções temático-conteudísticas (o quê?) e estruturais-formais (como?), projetadas por um determinado sujeito (quem?), que se apresenta como autor de um discurso produzido de determinado ponto de vista e lugar social (de onde?) e momento histórico (quando?), movido por certas necessidades (por quê?) e propósitos (para quê), visando a determinado efeito em determinado tipo de leitor (para quem?) e logrando determinado tipo de circulação, utilização e repercussão. (Mortatti, 2000b, p.31)

Segundo Mortatti (2000b, p.15), por meio do método de análise da "configuração textual”, busca-se a "[...] construção de uma representação, a partir da problematização de outras representações construídas e tomadas como corpus, mas que não devem ser confundidas com o objeto de investigação, uma vez que não são 'dados' e 'só falam, quando se sabe interrogá-los"”.

Desse ponto de vista, o desenvolvimento da pesquisa que resultou neste livro visa à compreensão do objeto investigado, no movimento em que dele se extrai:

[...] uma época determinada do curso homogêneo da história; do mesmo modo, ele extrai da época uma vida determinada e, da obra composta durante essa vida, uma obra determinada. Seu método resulta em que na obra o conjunto da obra, no conjunto da obra a época e na época a totalidade do processo histórico são preservados e transcendidos. O fruto nutritivo do que é compreendido historicamente contém em seu interior o tempo, como sementes preciosas, mas insípidas. (Benjamin, 1994, p.231, grifos do autor)

Ainda de modo diretamente relacionado com os objetivos da pesquisa e com a fundamentação teórica apresentada, aqui, utilizei-me dos estudos sobre a história das disciplinas escolares, especialmente as contribuições de Chervel (1990). 
Para esse autor, uma disciplina "[...] é igualmente, para nós, em qualquer campo que se encontre, um modo de disciplinar o espírito, quer dizer, de lhe dar os métodos e as regras para abordar os diferentes domínios do pensamento, do conhecimento e da arte" (Chervel, 1990, p.180).

Para esse historiador francês, o ensino escolar é a "[...] parte da disciplina que põe em ação as finalidades impostas à escola e provoca aculturação conveniente" (Chervel, 1990, p.192). O ato de ensinar, entendido como "fazer conhecer pelos sinais", reteve-se como correspondente exato do termo "disciplina", aludindo à ideia de que ensinar é "[...] fazer com que a disciplina se transforme, no ato pedagógico, em um conjunto significante que terá como valor representá-la e por função torná-la assimilável” (Chervel, 1990, p.192).

As disciplinas escolares, ao se constituírem em torno de valores, necessidades e interesses diversos, mais do que comportar apenas as práticas docentes em sala de aula, relacionam-se ao fenômeno de aculturação de massa (Chervel, 1990). Isso quer dizer que a escola, ao "encarnar" determinados saberes e recriá-los para uso em sua lógica interna, transforma-os em um tipo peculiar de saber, o saber escolar.

Esse saber escolar, transmitido no âmbito das disciplinas como conteúdos escolares, é entendido como:

[...] entidade sui generis, próprio da classe escolar, independente, numa certa medida, de toda realidade cultural exterior à escola, e desfrutando de uma organização, de uma economia interna e de uma eficácia que elas não parecem dever a nada além delas mesmas, quer dizer à sua própria história. (Chervel, 1990, p.180)

Chervel (1990) explica que, embora o saber escolar seja comumente considerado como vulgarização do saber científico ou dos saberes de referência, ele, na verdade, interfere na cultura de uma sociedade, por vezes demandando a formulação de conceitos ou mesmo sendo responsáveis por tal feito. Nesse sentido, o saber escolar, como uma espécie de "reinvenção da cultura”, resultante de um processo (de disputas) de seleção, de escolhas e de renúncias realizadas no meio cultural, não consiste apenas em mera "transposição didática" dos saberes, tais como foram produzidos em outros locais (Saviani, 1996). Ele se configura como um tipo de saber, de outra 
ordem, com finalidades, formas de transmissão e espaço de utilização específico: a escola. O saber escolar contém em si um conjunto de outros saberes, os quais foram compilados, reinventados e adaptados, dando origem a um tipo de "saber escolar".

Se o saber escolar se forma a partir de uma "reinvenção" da cultura, dos saberes, práticas e ritos nela imbricados, na relação dessa "cultura" com os saberes de referência, pode-se dizer, então, que se manifesta um conjunto de saberes/formas de conhecimento e de percepção transmitidos na/pela cultura e que a constituem como tal. A esse conjunto de saberes/formas de conhecimento, de ordem comum, mas que não deixa de ter relação com a ciência e/ou com outras formas de saber, denomino, neste livro, "saber não sistematizado".

Optei por essa denominação para me referir especialmente às primeiras tentativas de esboçar um tipo de saber/conhecimento sobre a literatura infantil, quando ainda não havia, sobre esse assunto, no caso brasileiro, um tipo de teoria, saber de referência ou saber científico.

No Capítulo 1, apresento uma síntese dos primeiros discursos brasileiros sobre literatura infantil, a fim de compreender como se iniciou o processo de formação de saberes a respeito desse gênero literário; no Capítulo 2, apresento aspectos da legislação paulista para o Ensino Normal no estado de São Paulo, no período entre 1947 e 1956, quando se deu a primeira iniciativa de criação da matéria "Literatura infantil" nesse estado. Além disso, apresento análise das primeiras propostas de "concretização" do ensino da literatura infantil, publicadas no Brasil; no Capítulo 3, apresento aspectos da legislação paulista para o Ensino Normal no estado de São Paulo, no período entre 1957 e 1970, quando foi criada a disciplina "Literatura infantil" em todo o estado, o que gerou um processo de sistematização do ensino da literatura infantil. Apresento, também nesse capítulo, a análise dos manuais de ensino de literatura infantil publicados entre 1957 e 1970 e as iniciativas que surgiram por conta da institucionalização desse ensino; no Capítulo 4, apresento aspectos da legislação paulista para os cursos de formação de professores em São Paulo, no período entre 1971 e 2003, após a implantação da Habilitação Específica de $2^{\circ}$ Grau para o Magistério (HEM) e a 
instalação dos Centros Específicos de Formação e Aperfeiçoamento do Magistério (Cefam). Em vista disso, apresento a análise dos documentos e manuais destinados ao ensino da literatura infantil publicados entre 1971 e 2003 e os desdobramentos desse ensino com relação às mudanças ocorridas no modelo de formação de professores no Brasil. Por fim, à guisa de conclusão, apresento reflexões sobre o "lugar" da história do ensino da literatura infantil na constituição do campo da literatura infantil e os sentidos que essa história possibilita traçar em relação ao que sabemos e fazemos sobre esse gênero literário. 


\section{1 \\ AS PRIMEIRAS MANIFESTAÇÕES DISCURSIVAS SOBRE A LITERATURA INFANTIL BRASILEIRA: O PROCESSO DE CONSTRUÇÃO DE SABERES}

\section{$\mathrm{Na}$ "origem" da literatura infantil brasileira, reflexões iniciais sobre o tema (1882-1912)}

No Brasil, ainda hoje, quando se trata de pensar ou problematizar aspectos da história da literatura infantil, as pesquisas e estudos sobre esse assunto recaem, inevitavelmente, sobre o trabalho inaugural de 1968, de autoria do jornalista Leonardo Arroyo (1918-1985), Literatura infantil brasileira: ensaio de preliminares para sua história e suas fontes. Mesmo com o crescimento das pesquisas acadêmico-científicas sobre o assunto, a versão da história da literatura infantil contida nesse livro, retomada e ampliada especialmente por Marisa Lajolo e Regina Zilberman, em 1984, em Literatura infantil brasileira: história $\mathcal{E}$ histórias (1984), ${ }^{1}$ permanece como referência para os pesquisadores do campo, com força de um "mito de criação" (Mortatti, 2000a).

Segundo Arroyo (1968), a "origem" desse gênero, no Brasil, encontra-se nos livros escolares, destinados ao ensino da leitura, publicados entre o final do século XIX e início do século XX. Aponta Arroyo (1968), que esses livros consistiam em traduções portuguesas, feitas a partir de livros europeus, cenário que se modificou após a instauração da República, quando ganhou força o movimento de "reação nacional" em favor da "nacionali-

1 Além do trabalho de Lajolo e Zilberman (1984), merecem destaque, no que concerne à historiografia da literatura infantil brasileira, os trabalhos de Nazira Salem (1959) e Nelly Novaes Coelho (1981; 1984). Cabe destacar, no entanto, que esses trabalhos não fundaram modos específicos de se pensar essa história, como os de Arroyo (1968) e Lajolo e Zilberman (1984). 
zação" da literatura infantil. Disso decorreu, na última década do século XIX, a publicação das primeiras traduções brasileiras dos livros infantis europeus e a produção de algumas obras originais de autores nacionais.

Esses livros, traduzidos e/ou escritos por brasileiros, além de configurarem, conforme a visão de Arroyo (1968), a “origem” da literatura infantil brasileira, também foram responsáveis por dar a conhecer as primeiras reflexões sobre o gênero.

Tendo em vista explicitar os propósitos com os quais determinados livros foram escritos, os contributos que representavam para a formação do leitor da época e o espaço que deviam ocupar no ensino primário e na formação das crianças (republicanas), os autores e/ou editores desses livros produziram prefácios, apresentações e prólogos, que constituem os primeiros discursos brasileiros sobre literatura infantil (Magnani, 1998).

Ainda que "esparsos" e "episódicos” (Magnani, 1998), esses prefácios, apresentações e prólogos são fundamentais para compreender o processo de constituição de saberes relacionados à literatura infantil, de modo a entender como se foram constituindo, no Brasil, as diferentes concepções desse gênero literário e de seu ensino na formação de professores.

O primeiro desses prefácios, que busca refletir sobre o livro literário destinado às crianças e que aqui merece destaque, foi escrito por Joaquim Maria Machado de Assis, em 1882, para a edição brasileira de Contos seletos das mil e uma noites, na versão traduzida e adaptada à "mocidade" brasileira pelo escritor e tradutor alemão radicado no Brasil, Carlos Jansen. ${ }^{2}$

Nesse prefácio, Machado de Assis (1882) afirma que a escolha feita por Carlos Jansen, por adaptar alguns dos contos de Mil e uma noites a partir da versão alemã de Frans Hoffman, foi bastante conveniente, pois privilegiou

2 Filho de Anton Herbert Jansen e de Henriette Charlotte de Wied-Neuwied, Carl Jacob Anton Christian Jansen, conhecido como Carlos Jansen, nasceu em 1829, na cidade de Colônia, Alemanha, e morreu em 1889, no Rio de Janeiro, sede da Corte Imperial. Jansen se mudou para o Brasil em 1851, como soldado voluntário para servir em Porto Alegre-RS. No período em que residiu nessa cidade, atuou como jornalista e, após desligar-se do serviço militar, trabalhou como professor no Colégio de Porto Alegre. Após curta temporada residindo em Buenos Aires, Argentina, Jansen retornou ao Brasil, porém acabou fixando residência na sede da corte, Rio de Janeiro, dedicando-se ao jornalismo, à escrita de livros didáticos, às traduções e à literatura (Hohlfeldt, 2003). 
um "repositório de cousas alegres e sãs", ${ }^{3}$ diferentemente da lógica da fabulação oriental encontrada na versão original.

Por essa razão, Machado de Assis (1882) considerava esse livro uma novidade completa para os jovens da época, dada sua peculiaridade e variedade. Segundo ele, por mais que se passem os anos e esse livro "povoado" de ideais morais e "lições graciosas" pudesse se perder na mudança de gosto dos leitores, continuaria com o mesmo valor e mérito por ser uma "bela" e "interessante" obra.

Por ser Carlos Jansen alemão de nascimento e possivelmente prevendo críticas no sentido de que o livro podia incorrer no mesmo problema das traduções portuguesas que circulavam no país - o distanciamento linguístico do texto com a realidade dos leitores brasileiros -, Machado de Assis (1882) destaca a "precisão", a "facilidade" e o "vocabulário numeroso" de Carlos Jansen. Com isso, considera que, apesar de se notarem pequenos detalhes que podiam ser substituídos ou melhorados, o trabalho de Carlos Jansen foi exemplar, indicando o talento e aplicação desse "brasileiro de adoção".

Para concluir, Machado de Assis (1882) afirma entender que o livro adaptado por Carlos Jansen se destina aos "adolescentes" como um "brinquedo graciosíssimo", com o qual os jovens leitores podem "[...] entreter algumas horas dos seus anos em flor" (p.262).

Quatro anos após a publicação de Contos seletos das mil e uma noites, as irmãs Adelina Lopes Vieira ${ }^{4}$ e Júlia Lopes de Almeida ${ }^{5}$ escreveram um

3 Por se tratar de pesquisa histórica, mantive aqui e em todo o livro a ortografia apresentada nos documentos que cito e/ou transcrevo.

4 Nascida em Lisboa, Portugal, em 1850, Adelina Lopes Vieira, antes mesmo de completar dois anos, mudou-se com os pais para o Brasil, onde, posteriormente, formou-se professora pela Escola Normal do Rio de Janeiro. Atuou como professora e como escritora, tendo publicados livros de poesias e textos em prosa. A data de falecimento de Adelina Lopes Vieira é desconhecida (Stanislavski, 2001).

5 Nascida no Rio de Janeiro, sede da Corte Imperial, em 1862, Júlia Valentina da Silveira Lopes de Almeida, irmã de Adelina Lopes Vieira, viveu parte de sua infância em Campinas-SP. Casada com o poeta português Felinto de Almeida, Júlia Lopes de Almeida foi mãe de três filhos, todos poetas: Afonso Lopes de Almeida, Albano Lopes de Almeida e Margarida Lopes de Almeida. Ao longo de sua carreira, Júlia Lopes de Almeida produziu extensa obra, composta por 40 títulos. O seu primeiro livro publicado foi Traços e iluminuras, em 1886. Júlia Lopes de Almeida faleceu no Rio de Janeiro, em 1934, com 72 anos (Coelho, 2006; Stanislavski, 2001). 
novo livro de contos para crianças, intitulado Contos infantis ${ }^{6}$ (1886), publicado pela Typographia Mattos Moreira, em Lisboa-Portugal. Dado o sucesso desse livro e sua aprovação para uso nas escolas primárias por parte da Inspectoria Geral da Instrucção Primaria e Secundaria da Capital Federal dos Estados Unidos do Brasil, em 1891, a Casa Editora Laemmert publicou a $2^{\mathrm{a}}$ edição de Contos infantis, à qual as autoras acrescentaram um prólogo.

Em tom bem menos literário que o de Machado de Assis (1882), com palavras recorrentemente no diminutivo e com maior destaque para os elementos que podiam interessar ao ensino escolar, o prólogo de Contos infantis tem como principal objetivo explicar as características desse livro e suas contribuições para o ensino primário. Por isso, as autoras explicam que a obra é composta de narrações "singelas", com as quais elas procuram despertar as "boas paixões" nos pequenos leitores. Segundo elas, o livro foi escrito com o objetivo de contribuir para a "[...] educação moral e esthetica: um desejo que, por ser bem intencionado, nos deve ser permitido” (Almeida, 1891, p.6).

Para atingir esse objetivo, Almeida e Vieira (1891) enfatizam que escreveram histórias simples, algumas sobre "factos realizados" e outras de sentido "não naturaes" (inverossímeis), todas com "correção" e "naturalidade", visando à "clareza dos conceitos" e à "verdade". Com isso, as irmãs escritoras entendem que Contos infantis pode contribuir para a formação, "sem esforço", do espírito infantil, pois as histórias que escolheram contêm a "seiva natural e vivificadora" de que os pequenos precisam.

Em vista disso, elas esclarecem que, apesar de reconhecerem que havia a possibilidade de não alcançarem com Contos infantis tudo o que desejavam em termos de formação do pequeno leitor, esse livro é útil na medida em que fornece ao "[...] espírito móbil infantil umas phrases bondosas, em que a virtude derrame o seu perfume suave, capaz de modificar ímpetos de gênio e indifferença pelo soffrimento alheio" (Vieira; Almeida, 1891, p.6). E, citando trecho do prefácio de Comedie enfantine, de Luiz Ratisbonne, fazem uma crítica a algumas publicações da época, que segundo elas repre-

6 A data de publicação da $2^{a}$ edição - 1891 - é uma data presumida, pois não foi possível localizar essa informação com precisão. Apenas pude localizar a informação de que a 4 a edição foi publicada em 1896 (Arroyo, 1968). Para informações mais detalhadas sobre esse livro, ver, especialmente, Stanislavski (2001) e Vidal (2005). 
sentavam uma ameaça ao espírito das crianças por lhes dar a ler textos com incorreções e maus exemplos.

Para concluir o prólogo de Contos infantis, Vieira e Almeida (1892) afirmam que se uma única criança que ler a obra praticar "[...] imitando um de nossos heroes, uma acção boa [...]” (p.6), elas ficarão bem pagas pela "canseira".

Em 1896, partícipe do anseio de nacionalização da literatura destinada às crianças brasileiras, Alberto Figueiredo Pimentel ${ }^{7}$ teve publicado seu terceiro ${ }^{8}$ livro voltado a esse público, Histórias da avozinha (1896), que integra a coleção "Biblioteca Infantil” da Livraria Quaresma. Esse livro, motivado pelo sucesso que tiveram seus dois livros anteriores, constitui o terceiro volume de sua coleção de contos para crianças. Nele, apesar de bastante curto, encontra-se um prefácio, assinado pelo editor, o qual explicita o principal objetivo de Figueiredo Pimentel: fazer que os pequenos leitores encontrem em Histórias da avozinha “[...] agradável passatempo, aliado a lições de moralidade, porque tais contos encerram sempre um fundo moral e piedoso" (Editor, 1896, p.10). Ainda segundo consta nesse prefácio, para Figueiredo Pimentel o prazer de ser útil à formação dos "jovens patrícios" é o que fazia bem pago o trabalho que teve na escrita do livro.

Um ano após a publicação do livro de Figueiredo Pimentel, passou a ser distribuído nas escolas públicas paulistas o livro de poesias intitulado Livro das crianças, de Zalina Rolim, ${ }^{9}$ editado em 1897, em Boston, pela C.F. Hammet \& Company. Esse livro, publicado com financiamento do

7 Nascido em Macaé, província do Rio de Janeiro, em 1869, Alberto Figueiredo Pimentel atuou como jornalista e cronista, tornando-se figura marcante na sociedade carioca. Escreveu romances, contos, poesias e novelas, mas ficou conhecido como escritor de literatura infantil. Foi o primeiro brasileiro a traduzir os maravilhosos contos europeus para o português brasileiro. Faleceu em 1914, aos 45 anos (Coelho, 2006).

8 O primeiro livro que Figueiredo Pimentel teve publicado foi Histórias da carochinha, em 1894, e Histórias do arco da velha, cuja data de publicação da $1^{a}$ edição não localizei. Não apresentei os prefácios desses livros, pois não consegui acesso a exemplares com o prefácio da $1^{\mathrm{a}}$. edição.

9 Nascida em Botucatu/SP, em 20 de julho de 1869, Maria Zalina Rolim Xavier de Toledo aprendeu as primeiras letras em sua casa, com o pai e com professores particulares, dentre os quais João Köpke. Em 1893, mudou-se para São Paulo-SP, onde passou a atuar como colaboradora em jornais e como escritora. Em 1896, foi nomeada auxiliar de diretor do Jardim de Infância anexo à Escola Normal de São Paulo, tendo permanecido nesse cargo por quatro anos. Nesse período, produziu adaptações literárias para a Revista do Jardim da Infância. Zalina Rolim faleceu em 1961, em São Paulo/SP (Coelho, 2005). 
governo do estado de São Paulo, contém um importante prefácio, datado de 29 de agosto de 1896, assinado por Gabriel Prestes, à época diretor da Escola Normal de São Paulo.

Nesse prefácio, Gabriel Prestes (1897) sintetiza alguns dos elementos que considera fundamentais num livro destinado ao público infantil e, diferentemente dos autores dos prefácios anteriores, não se ocupou da questão dos valores morais que o livro de Zalina Rolim apresenta ou deveria apresentar. Seu enfoque foi muito mais nas contribuições do livro para o ensino da leitura e da escrita. Em vista disso, adverte Gabriel Prestes (1897) que não é seu objetivo fazer crítica literária do livro, mas apresentar explicações sobre as "contribuições pedagógicas" que ele oferece às escolas do estado de São Paulo.

Entre as contribuições que Gabriel Prestes (1897) considera que o Livro das crianças proporciona, está a de se tratar de um "modelo sugestivo" de ensino da linguagem oral e escrita, uma vez que as poesias são "simples" e "atraentes" e possibilitam uma "observação espontânea e sem esforço". Também as gravuras são ponto de destaque, pois, segundo ele, a partir delas os alunos poderão produzir pequenas descrições, que facilitam a compreensão do livro. Além dessas contribuições, Gabriel Prestes (1897) entende que a obra "[...] presta-se admiravelmente à leitura expressiva e aos exercícios de recitação” (p.8), sendo esse o objetivo mais direto a que se presta esse livro.

Gabriel Prestes (1897) considera 'Livro das crianças' "magnífico", de modo que satisfaz todas as condições estéticas e literárias exigíveis em um trabalho voltado ao público infantil. Com isso, ele conclui que, se "[...] em uma frase apenas fosse possível resumir este prefácio, eu diria que o valor deste trabalho vai além do que indica o seu título: não é apenas um Livro das crianças, é também um livro para crianças e, mais do que isso, é um livro para os bons mestres" (Prestes, 1897, p.8, grifos do autor).

Já na primeira década do século XX, outro prefácio que merece destaque é o de Olavo Bilac, ${ }^{10}$ publicado na $1^{\text {a }}$ edição de Poesias infantis, de 1904, e a

10 Nascido no Rio de Janeiro, sede da Corte Imperial, em 1865, Olavo Braz Martins dos Guimarães Bilac cursou medicina e direito, porém não concluiu nenhum desses cursos. Desde muito jovem, começou a atuar como jornalista e escritor, o que lhe possibilitou um cargo como inspetor escolar. Em virtude de suas publicações, Bilac consagrou-se como um grande nome do Parnasianismo brasileiro e como um importante intelectual nacionalista do século 
nota "Ao leitor", que, por esquecimento da "officina impressora", foi publicada apenas na $2^{\mathrm{a}}$ edição desse livro.

No prefácio de Poesias infantis, Bilac explica que não quis, com esse livro, produzir uma obra de arte. Seu intento foi "[...] dar às creanças alguns versos simples e naturaes, sem difficuldades de linguagem e métrica, mas, ao mesmo tempo, sem exaggerada futilidade com que costumam ser feitos os livros do mesmo genero" (Bilac, 1904, p.4). Com isso, ele afirma ter buscado, por meio da "boa vontade" de um escritor brasileiro, contribuir para a "[...] educação moral das crianças do país" (p.4). Por esse motivo, explica que, se os pequenos leitores gostarem de seus versos, ficaria satisfeito e daria como "optimamente empregados" o seu tempo e seu trabalho.

Na nota "Ao leitor", também publicada em Poesias infantis, Bilac (1916), ${ }^{11}$ com um pouco mais de detalhamento, comenta que, quando foi convidado pela casa Alves \& Cia. para escrever um livro de poesias para crianças, sua maior preocupação foi preparar poesias simples e acessíveis à inteligência dos pequenos leitores. Explica que, por ser um escritor conhecido, de "complicadas construcções de frase", seu cuidado foi o de não incorrer no perigo de produzir um livro ingênuo demais ou repleto de coisas falsas, histórias maravilhosas e tolas, que "[...] desenvolvem a credulidade das crianças, fasendo-as ter medo de cousas que não existem” (Bilac, 1916, p.2). Desse modo, esse poeta afirma ter buscado encontrar assuntos "simples", "humanos", "naturais", que fujam da banalidade e que não "fatiguem o cérebro" dos pequenos leitores, como muitos livros do gênero publicados à época. Assim, em Poesias infantis não há, segundo Bilac (1916):

[...] os animaes que falam, nem as fadas que protegem ou perseguem creanças, nem as feiticeiras que entram pelos buracos das fechaduras; há aqui descripções da natureza, scenas de família, hymnos ao trabalho, à fé, ao dever; allusões ligeiras à história da pátria, pequenos contos em que a bondade é louvada $\mathrm{e}$ premiada. (p.3)

XIX. No conjunto de sua obra, destacam-se as publicações voltadas ao público infantil, algumas das quais em coautoria com Coelho Neto ou Manuel Bonfim. Bilac faleceu em 1918, no Rio de Janeiro-DF, aos 53 anos de idade (Coelho, 2006).

11 Não foi possível localizar exemplar da $2^{a}$ edição de Poesias infantis, tampouco a data de sua publicação. Por essa razão, sempre que me refiro ou cito a nota "Ao leitor", desse livro, utilizo exemplar da $5^{a}$ edição, publicado em 1916. 
Em relação ao estilo que escolheu para compor suas poesias, Bilac (1916) explica que, para poder apurar o ouvido das crianças de dar-lhes "o amor da harmonia e da cadência", optou por um estilo centrado na sintaxe e na metrificação. Explica que fez o possível para não escrever de forma que fosse fútil demais aos artistas e complicada demais às crianças. Apesar do esforço, conclui que, se sua tentativa falhar, fica-lhe o "consolo" de que quis "[...] dar à literatura escolar do Brasil um livro que lhe faltava” (Bilac, 1916, p.3).

Seis anos após a publicação de Poesias infantis, em 1910, Olavo Bilac, em parceria com Manuel Bonfim, ${ }^{12}$ teve publicado um novo livro para crianças - Atravéz do Brazil -, no qual apresenta uma "Advertência e explicação" sobre como ele e Bonfim compreendiam, à época, como deviam ser os livros de leitura para crianças.

Bilac e Bonfim (1910) esclarecem nessa "Advertência e explicação" que, no início do século XX, a pedagogia recomendava que o livro de leitura escolar fosse um único livro ofertado aos alunos das primeiras classes do ensino primário. Apesar de compreenderem que Atravéz do Brazil atendia a essa "fórmula pedagógica", explicam que esse livro apenas contém uma simples narrativa sobre os "cenários" e os "costumes" da vida brasileira. De modo geral, para Bilac e Bonfim (1910) não era possível que um único livro de leitura contivesse tudo o que era preciso ensinar na escola primária, como gramática, aritmética, história, geografia, lições de coisas, ciências físicas e naturais, higiene e instrução cívica. Se assim o fosse, o livro de leitura assumiria feição de enciclopédia, o que os autores de Atravéz do Brasil consideram um erro. Para Bilac e Bonfim, o livro de leitura deveria ser um auxiliar do professor, que é a "verdadeira enciclopédia" na sala de aula.

Coerentemente com essa compreensão, afirmam que esse livro oferece diversos "motivos", "ensejos", "oportunidades", "conveniências" e "assuntos" para o professor ensinar suas lições. Por meio da leitura de Atravéz

12 Nascido em Aracaju, então província de Sergipe, em 1868, Manuel Bonfim formou-se médico pela Faculdade de Medicina do Rio de Janeiro, em 1890. No período em que ainda estudava, iniciou sua atuação como colaborador do jornal Correio do Povo. Em 1894, Bonfim abandonou a medicina e iniciou a sua carreira como professor de Educação Moral e Cívica na Escola Normal do Rio de Janeiro. Em 1902, a mando da prefeitura do Rio de Janeiro-DF, viajou para a França, para estudar as inovações pedagógicas desse país. Em 1903, ainda em Paris, França, estudou Psicologia, na Sorbonne. Após retornar ao Brasil, entre os cargos que ocupou, foi Diretor Geral da Instrução Pública do Distrito Federal e teve rápida participação na política, como deputado federal. Bonfim morreu aos 64 anos, em 1932, no Rio de Janeiro (Aguiar, 2000). 
do Brazil, a criança "[...] já lucrará alguma cousa: aprenderá a conhecer um pouco o Brasil; terá uma visão, a um tempo geral e concreta, da vida brasileira; as suas gentes, os seus costumes, as suas paisagens, os seus aspectos distintivos" (Bilac; Bonfim, 1910, p.VII). Além desses aspectos, explicitam que desejam que esse livro seja uma grande lição de "energia", em "grandes lances de afeto", que suscite a "coragem", a "harmonia" e o "cultivo da bondade”, pois, para eles, essa é a fórmula da educação humana e esse é o verdadeiro propósito dos livros de leitura.

Para concluir a "Advertência e explicação" de Atravéz do Brazil, Bilac e Bonfim (1910) discorrem sobre o estilo do livro e explicam que optaram por um "tom singelo", com "linguagem natural", acessível à inteligência infantil, e a descrição de heróis com características para serem "[...] amados e admirados no que representam de generoso e nobre os estímulos que os impeliram, nos diversos transes por que passaram” (Bilac; Bonfim, 1910, p.VIII).

Ainda em relação aos prefácios, apresentações e prólogos contidos em livros para crianças, publicados entre o final do século XIX e início do século XX, destaco o prefácio de Alma infantil, de 1912, de Francisca Júlia ${ }^{13}$ e Júlio César da Silva. ${ }^{14}$

Nesse prefácio, esses autores afirmam que Alma infantil foi publicado para preencher uma grande lacuna no campo das leituras escolares, uma vez que contém, "[...] além de um flagrante interesse anedótico, uma edificante lição de moral” (Júlia; Silva, 1912, s.p.). Segundo os autores de Alma infantil, as escolas primárias estavam invadidas, à época, por livros "medíocres", a maior parte com linguagem incorreta, que ressaltava o "calão popular" e o "termo chulo". Para os autores, esses livros, "[...] em vez de

13 Nascida na antiga vila de Xiririca, atual município de Eldorado-SP, em 31 agosto de 1871, Francisca Júlia da Silva Müster começou, aos 20 anos, a colaborar com jornais do Rio de Janeiro-RJ e São Paulo-SP. Considerada uma das mais importantes poetisas do Parnasianismo brasileiro, faleceu em $1^{\circ}$ de novembro de 1920, possivelmente em decorrência de uso excessivo de calmantes, após a morte de seu marido. Informações disponíveis em: <http:// educacao.uol.com.br/biografias/francisca-julia.jhtm>. Acesso em: 21 de ago. 2014.

14 Também nascido na vila de Xiririca, atual município de Eldorado-SP, em 23 de dezembro de 1872, Júlio César da Silva, irmão de Francisca Júlia, formou-se em Direito, mas desde os anos de estudo se dedicou à literatura parnasiana. Depois de uma juventude boemia e aventurosa, Júlio César da Silva também foi funcionário público da Prefeitura de São Paulo. Aos 65 anos de idade, faleceu em São Paulo-SP, no dia 15 de julho de 1936. Informações disponíveis em: <http://literatodovale.blogspot.com.br/2009/01/jlio-csar-da-silva-um-poeta-esquecido.html>. Acesso em: 21 ago. 2014. 
educar as crianças, guiando-lhes o gosto para as cousas belas e elevadas, vicia-as desde cedo, familiarizando-as com as formas dialectais mais plebeias" (Júlia; Silva, 1912, s.p.).

Em vista dessa concepção, Júlia e Silva (1912) afirmam ter escrito Alma infantil a fim de que fosse um livro "[...] rigorosamente didático, falando de perto à alma da infância [...]” (s.p.), ao mesmo tempo que se constitui como uma "obra de arte".

\section{Iniciativas de formulações mais sistematizadas sobre a literatura infantil: quatro discursos fundadores}

Na segunda década do século XX, na medida em que foi aumentando a produção dos livros destinados ao público infantil, começaram a ser publicados alguns textos específicos sobre o assunto, os quais problematizam, de modo mais geral, aspectos desse tipo de publicação. Se até a década de 1910 a literatura infantil era tematizada apenas nos prefácios, prólogos e apresentações dos livros destinados às crianças, a partir de então o assunto começou a tomar corpo, resultando em alguns textos em revistas especializadas e capítulos de livros. Desse modo, é possível compreender que os primeiros textos específicos sobre literatura infantil, publicados no Brasil, a partir da década de 1910, são decorrentes da importância que a leitura escolar vinha ganhando no processo de escolarização e na formação das crianças, de modo que buscam explicitar algumas concepções em torno desse gênero.

Esses primeiros textos específicos sobre literatura infantil, apesar de consistirem em discursos mais elaborados sobre a literatura infantil, ainda se configuram como tentativas bastante iniciais de sistematização de conhecimento sobre o assunto. O que se apresenta neles são os aspectos para os quais a leitura literária escolar podia contribuir na formação do leitor e, portanto, a que requisitos deveriam atender, ou não, esse tipo de publicação.

Além disso, esses primeiros artigos ou capítulos sobre literatura infantil, publicados entre as décadas de 1910 e 1920, retratam a oscilação e dificuldade de classificação/denominação dos livros de literatura infantil. Em relação a esses textos, cabe destacar, ainda, que a expressão "literatura infantil" não era consensual para se referir às publicações destinadas à leitura das crianças. Para se referir aos livros que, hoje, denominam-se "literatura 
infantil", eram recorrentes expressões como: "livros escolares", "livros para crianças", "livros de crianças", "leituras para crianças" e "literatura didática”.

\section{Alexina de Magalhães Pinto (1917) e o "esboço" de uma biblioteca infantil}

No conjunto dos primeiros textos específicos sobre literatura infantil publicados no início do século XX, destaca-se "Esboço provisório de uma biblioteca infantil", de Alexina de Magalhães Pinto, ${ }^{15}$ publicado em 1917, no livro Provérbios populares, máximas e observações usuais.

A proposta de um "esboço" de biblioteca infantil elaborada por Alexina de Magalhães Pinto comporta uma relação mínima dos livros que ela considerava, à época, adequados às crianças. Esse esboço foi iniciado por Alexina em 1906, quando era colaboradora do Almanaque Guarnier. Nessa ocasião, ela pediu ao diretor da Academia Brasileira de Letras que se dirigisse aos "imortais" para interrogá-los sobre quais livros dariam aos seus filhos, de idade entre 7 e 11 anos; no entanto, não obteve sucesso, restando como alternativa se amparar nos catálogos de editoras da época.

Embora iniciado em 1906, esse "esboço" foi publicado em 1917, por motivos alheios à vontade de Alexina de Magalhães Pinto, conforme ela mesma explica.

Nesse texto, Pinto (1917), antes de apresentar a relação dos livros que considera indispensáveis para se ofertar a uma criança, explica que a importância do hábito de ler reside no "[...] bem do progresso pátrio e da unidade nacional” (p.159). Segundo ela, a "[...] implantação do hábito da

15 Nascida em uma fazenda do Além Paraíba-MG, em 4 de julho de 1870, Alexina de Magalhães Pinto pertencia a uma família de grande prestígio na região de São João Del-Rey, província de Minas Gerais. Em 1890, com apenas 20 anos, viajou para a Europa para estudar por um ano. Após retornar ao Brasil, trabalhou na recolha de cantigas de roda e foi uma das precursoras no uso do método global para o ensino da leitura. Sua atuação se registra importante também no campo dos estudos sobre o folclore, tendo sido a primeira a elaborar livros didáticos a partir dessa temática. Entre os cargos que ocupou, destaca-se o de professora da cadeira de Desenho e Caligrafia da Escola Normal de São João Del-Rey. Aos 45 anos, ficou surda, o que a levou a uma morte trágica. Em 1921, quando estava em Correas-RJ para desenvolver algumas pesquisas, não ouviu a aproximação de um trem e acabou atropelada e morta (Coelho, 2002; Carnevali, 2009). 
leitura subsidiária desde os bancos escolares primários é problema com esse entrelaçado e a pedir solução prática” (Pinto, 1917, p.159).

Em relação aos livros que Pinto (1917) inclui no seu "esboço" de biblioteca infantil, ela inicia por apresentar uma relação de livros ilustrados, os quais considera se destinarem ao trabalho com a "audição" e "análise de imagens”. Explica que, antes de as crianças começarem a aprender a ler, elas precisam ouvir histórias e, por meio das "estampas", repeti-las. Essa atividade, para a autora do "esboço" de "biblioteca infantil", educa a vista e a linguagem. Sobre os livros ilustrados indicados no "esboço" de uma biblioteca infantil, Pinto (1917) relaciona os que constam no Quadro 1.

Quadro 1 - Títulos dos livros ilustrados relacionados por Alexina de Magalhães Pinto em seu "esboço" de biblioteca infantil ${ }^{16}$

\begin{tabular}{|l|l|}
\hline Título do livro & Editora (quando indicada) \\
\hline João Felpudo & - \\
\hline O menino verde & - \\
\hline Viagem numa casquinha de noz & - \\
\hline Aves do Brasil & Garnier \\
\hline Mamíferos do Brasil & Garnier \\
\hline Aventuras de Hilário & - \\
\hline Cristóvão Colombo - A mebiose & - \\
\hline Ride comigo & - \\
\hline O anjo-da-guarda & - \\
\hline João Patusco & - \\
\hline O que vem agora & - \\
\hline Chapéu preto & - \\
\hline Para todos & Lothar Magendorf \\
\hline Eu sei ler & Lothar Magendorf \\
\hline Os irmãos de Pedro Oriçado & - \\
\hline A baratinha & - \\
\hline Álbum de gravuras de Puigari & - \\
\hline Juca e Chico & - \\
\hline Alfabeto Ilustrado & Laemmert \\
\hline & \\
\hline
\end{tabular}

Fonte: Pinto (1923).

16 Apresento, no Quadro 1 e em todos os quadros deste livro, os títulos dos livros exatamente conforme estão indicados nas fontes. 
Após a indicação dos livros ilustrados, que considera se destinarem ao período pré-ensino da leitura, Pinto (1917) apresenta relação de livros que indica para a "leitura subsidiária", de uso na escola primária. Essa relação, embora não apresente uma organização bem definida, de certa forma contém algumas divisões e classificações dos livros, que se referem a aspectos da formação da criança para os quais concorrem melhor.

O primeiro desses aspectos se refere à "aprendizagem simultânea" da leitura, da escrita, da contação de histórias, do cálculo, do desenho, do canto e do bom tratamento dos outros. Quando se trata desses aspectos, Pinto (1917) indica os livros de três séries graduadas de leitura. São elas: a escrita por Maria de Andrade ${ }^{17}$ a escrita por Hilário Ribeiro e a escrita por João Köpke.

Para Pinto (1917), ainda que uma única coleção desses livros de leitura pudesse ser ofertada no ensino primário, ela considera que devem ser lidos outros, como “[...] portadores de informações subsidiárias sobre esse ou aquele ponto, sobre essa ou aquela qualidade que precisamos reforçar ou amparar no educando" (Pinto, 1917, p.161-162).

Para essa finalidade, Pinto (1917) relaciona em seu "esboço" os seguintes livros: Segundo livro de leitura, de Abílio César Borges; Segundo livro de leitura, de Thomaz Galhardo; os Primeiro livro, Segundo livro e Terceiro livro, de Francisco Vianna; e Leituras morais, de João Köpke.

Na sequência, Pinto (1917) apresenta os livros de poesia que considera adequados às crianças e os quais devem integrar o acervo de uma biblioteca infantil. São eles: Poesias infantis, de Olavo Bilac; Livro das crianças, de Zalina Rolim; e Musa das escolas, de Luiz Leopoldo Fernandes Pinheiro. Além desses livros de poesia, sugere a seleção de alguns poemas dos seguintes livros: Contos infantis, de Adelina Lopes Vieira e Júlia Lopes de Almeida; Antologia brasileira, de Eugênio Werneck; Seleta, de Clemente Pereira; e Literatura nacional, de Mello Morais Filho.

Pinto (1917) apresenta também uma extensa relação de livros, os quais servem para "entoar o bem", conforme a "melhor pedagogia primária". Esses livros estão relacionados no Quadro 2.

17 Embora no texto não haja informações detalhadas nem sobre as séries graduadas de leitura nem sobre os autores, presumo que o nome "Maria Andrade" refira-se à professora Maria Guilhermina Loureiro de Andrade. 
Quadro 2 - Títulos dos livros relacionados por Alexina de Magalhães Pinto em seu "esboço" de biblioteca infantil, destinados a "entoar ao bem"

\begin{tabular}{|c|c|}
\hline Título do livro & Autoria \\
\hline Teatro infantil & Olavo Bilac e Coelho Neto \\
\hline A queda de um anjo & Figueiredo Pimentel \\
\hline Leituras recreativas em prosa e verso & - \\
\hline História do reino encantado & - \\
\hline As férias & Max Fleius \\
\hline Contos para nossos filhos & M. Amélia e G. Crespo \\
\hline Contos para crianças & M. Pinto Figueirinhas \\
\hline Contos para crianças & Guerra Junqueiro \\
\hline Contos (da $1^{a}$ à $12^{a}$ série $)$ & Anna de Castro Osório \\
\hline Amiguinho do Nhonhô & Menezes Vieira \\
\hline Escolha de histórias morais & Trad. P. Carolino Duarte \\
\hline Rosa e Branca - ou benefícios da educação & $\mathrm{M}^{\mathrm{me}} . \mathrm{A}$ \\
\hline Tesouro dos meninos & - \\
\hline Cestinho de flores & Cônego Schimidt \\
\hline O carneirinho; a mosca & Cônego Schimidt \\
\hline A rola; o canário; o pirilampo & Cônego Schimidt \\
\hline A capela da floresta & Cônego Schimidt \\
\hline Rosa de Tannenburg & Cônego Schimidt \\
\hline Henrique d'Eichenfels & Cônego Schimidt \\
\hline A cruz de madeira e o menino perdido & Cônego Schimidt \\
\hline Ovos de páscoa & Cônego Schimidt \\
\hline Matilde ou a órfã suiça & Anônimo \\
\hline Bruno & - \\
\hline Chiquinho & - \\
\hline Lídia ou a menina bem-educada & - \\
\hline$O$ amigo das crianças & - \\
\hline Contos de fadas & Perrault \\
\hline Desastres de Sofia & Segur \\
\hline As meninas exemplares & Segur \\
\hline As férias & Segur \\
\hline La Bible d'une grande mére & Segur \\
\hline A novena da Candelária & Trad. Ramiz Galvão \\
\hline Mil e uma noites & Trad. Carlos Jansen \\
\hline Dom Quixote & Trad. Carlos Jansen \\
\hline Aventuras do Barão de Munkausen & - \\
\hline Robinson Crusoé $e^{18}$ & - \\
\hline
\end{tabular}




\begin{tabular}{|l|l|}
\hline Aventura de Juca & - \\
\hline Viagem ao redor do mundo em 80 dias & Júlio Verne \\
\hline O menino da mata e o seu cão piloto & Júlio Verne \\
\hline O Brasil, edição do $4^{\circ}$ centenário & Ramiz Galvão \\
\hline Sertões & Affonso Arinos \\
\hline Os sertões ${ }^{19}$ & Euclides da Cunha \\
\hline Contos fluminenses & Machado de Assis \\
\hline Galpi, narrativas brasileiras & - \\
\hline
\end{tabular}

Fonte: Pinto (1923).

Para complementar o seu "esboço" de biblioteca infantil, Pinto (1917) indica livros de viagens, livros sobre história do Brasil e livros sobre história da civilização. Os livros de viagens por ela indicados são: Em Minas, de Carlos de Laet; e História do Brasil, de João Ribeiro. Além desses, recomenda outros dois livros, dos quais apenas informa os nomes dos autores: Virgílio Mello Franco e Joaquim Nogueira Paranaguá. Os livros sobre história do Brasil por ela indicados são: Compêndio de história antiga, de Moreira de Azevedo; e A retirada da Laguna, de Alfredo d'Escragnolle Taunay, o Visconde de Taunay. E os livros sobre história da civilização por ela indicados são: Cartas a Luisa, Mulheres e crianças e $O$ reino da mulher, de Maria Amélia Vaz de Carvalho.

Para concluir o seu "esboço" de uma biblioteca infantil, Pinto (1917), após consultar o catálogo da Editora Laemmert, apresenta, "laconicamente", alguns dos livros publicados por essa editora e que ele considera essenciais para os pequenos leitores. Os livros da Editora Laemmert indicados por Alexina de Magalhães Pinto (1917) são os que relaciono no Quadro 3.

Quadro 3 - Títulos dos livros do catálogo da Editora Laemmert, relacionados por Alexina de Magalhães Pinto em seu "esboço" de biblioteca infantil

\begin{tabular}{|l|l|}
\hline Título do livro & Autoria \\
\hline Dicionário biográfico de brasileiros célebres & - \\
\hline O Brasil no século XVI & Capistrano de Abreu \\
\hline Biografia de Guttemberg & - \\
\hline Cidade de Mato-Grosso & Taunay \\
\hline Tesouro dos meninos & Mateus J. da Costa \\
\hline Tesouro de meninas & J. Ignacio Faria \\
\hline A ciência do bom homem Ricardo & B. Franklin \\
\hline
\end{tabular}




\begin{tabular}{|c|c|}
\hline As ciências naturais & Huxley, Trad. Said Ali \\
\hline O que o berço dá & Fr. Serra \\
\hline Pedro Sem & Burgain \\
\hline Recreio & - \\
\hline Preceitos & - \\
\hline Novos contos & - \\
\hline Mundo animado & - \\
\hline O menino verde e a paulista em viagem & - \\
\hline Livrinho de canto & - \\
\hline Leituras práticas & - \\
\hline Jardim da mocidade & - \\
\hline Galeria pitoresca dos homens célebres & - \\
\hline Excertos & - \\
\hline Enciclopédia popular & - \\
\hline Emma de Tannenbourg & - \\
\hline Contos para filhas e netos & Carlos Jansen \\
\hline Diálogos sobre a história romana & - \\
\hline Animais falantes & - \\
\hline Alegria da casa & - \\
\hline O lar doméstico & - \\
\hline Desinfecção & J. B. Lacerda \\
\hline Cuidado das crianças & Knup \\
\hline Plantas anuais & - \\
\hline Manual do bom-tom & - \\
\hline História natural popular & Anstett \\
\hline Guia do jardineiro & - \\
\hline A educação das mães de família & - \\
\hline Biblioteca do jardineiro & - \\
\hline Arte de formar homens de bem & Dr. Jaguaribe Filho \\
\hline Apontamentos & Dr. Ladislao Netto \\
\hline A pele de burro & - \\
\hline Pelo mundo afora & Maria Amélia Vaz de Carvalho \\
\hline Como e por que sou romancista & Alencar \\
\hline Como me tornei kneipista & Taunay \\
\hline Máximas de Maricá & - \\
\hline Astúcias de Bertoldo & - \\
\hline Luiz Figuier - As grandes invenções & - \\
\hline Selecta nacional & Caldas Aulete \\
\hline
\end{tabular}




\begin{tabular}{|c|c|}
\hline Selecta clássica & João Ribeiro \\
\hline Vida e trabalho & Smiles \\
\hline O poder da vontade & Smiles \\
\hline O dever & Smiles \\
\hline Economia doméstica & Smiles \\
\hline O livro das donas-de-casa & Silvino \\
\hline O confeiteiro popular & - \\
\hline Le prémier livre de lecture courante & G. Lebreton \\
\hline Cours de langue française & Said Ali \\
\hline Grammaires & Larrivé Fleury \\
\hline Cours de compositions & Carré \& Moi \\
\hline Enseignement scientifique & Paul Bert \\
\hline Cours preparatoire, $1^{e} ., 2^{\text {èm }}, 3^{\text {ème }}$ annés & - \\
\hline Lectures géographiques & Foncin, Mappa \\
\hline La mythologie racontée aux enfants & Lamé Fleury \\
\hline Voyages aux sept merveilles du monde & Angé Lassus \\
\hline $\begin{array}{l}\text { Le premier voyage du capitaine Cook au tour du monde } \\
\text { raconté par lui même }\end{array}$ & - \\
\hline Morceaux choisis de littérature françoise & Lebaigne \\
\hline Biographie d'hommes illustres & Louis Cons \\
\hline
\end{tabular}

Fonte: Pinto (1923).

Pinto (1917) aproveita também o espaço da publicação de seu texto para "recomendar" aos professores alguns textos, os quais ela considera contribuir para sua atuação profissional. São eles: o livro As lições de moral, do "Sr. Armstrong"; a revista Teacher's Magazine; e a "literatura" da Liga de Educação Moral Inglesa. Com essa recomendação aos professores, Pinto (1917) finaliza a indicação do que ela considera ser o acervo básico de uma biblioteca infantil.

\section{Sampaio Dória (1918) e a "literatura didática"}

Um ano após a publicação do "esboço" de uma biblioteca infantil de Alexina de Magalhães Pinto, foi publicado, em 1918, na Revista de ensino, ${ }^{18}$

18 Criada em 1902, a Revista de Ensino foi uma iniciativa da Associação Beneficente do Professorado Público de São Paulo, responsável pela delimitação e organização do espaço destinado ao debate de questões relativas ao ensino (Catani, 2003). 
um artigo de Antônio Sampaio Dória, ${ }^{19}$ no qual ele trata de alguns aspectos do que denomina "literatura didática".

Reconhecido professor da cadeira de Psicologia, pedagogia e educação cívica da Escola Normal Secundária de São Paulo e uma das mais importantes figuras da educação paulista no início do século XX, Antônio de Sampaio Dória, em artigo intitulado "Methodologia de ensino e literatura didática”, busca compreender a relação entre a literatura didática e os métodos de ensino (especialmente o método intuitivo e o método analítico), como forma de atender às finalidades da educação.

Nesse artigo, Sampaio Dória utiliza a expressão "literatura didática" para se referir a todos os livros destinados à leitura por parte das crianças. Apesar de essa ser a expressão que aparece no título do artigo e também a mais recorrentemente usada por ele, é possível, no entanto, notar em sua exposição que essa expressão oscila como sinônima de outras, por exemplo "livro didático", "literatura para criança" e "livro para criança". De modo geral, Sampaio Dória busca com todas essas expressões tratar dos livros para crianças, de uso escolar, que se caracterizam, ao mesmo tempo, como arte literária e texto didático-instrutivo.

No que se refere à sua argumentação, com base na ideia de que a educação tem como finalidade a formação do corpo e do espírito e a formação profissional, o método intuitivo e o método analítico correspondiam, para Sampaio Dória (1918), à metodologia mais adequada para se atingir esse fim educativo. Nesse sentido, a literatura didática contribui com esse fim educativo, pois sua função é propiciar o contato com "[...] realidades em si, ou por ilustrações aos sentidos externos ou internos [...]” (Dória, 1918, p.68), que seria a base do ensino intuitivo-analítico.

Coerentemente com essa função, Sampaio Dória (1918) defende a ideia de que ela deve ser repleta de imagens de qualidade e se adequar às neces-

19 Antonio de Sampaio Dória nasceu em 1883, em Belo Monte, província de Alagoas, e em 1889 se mudou para São Paulo-SP, onde se bacharelou em Ciências Jurídicas e Sociais, em 1908. Durante o tempo em que fez o seu bacharelado e após a sua conclusão, Sampaio Dória foi acumulando larga experiência como professor, chegando ao cargo de Diretor-Geral da Instrução Pública do estado de São Paulo. Ocupando esse cargo, Sampaio Dória criou e instituiu uma das reformas educacionais mais significativas do estado: o Decreto n. 1.750, de 8 de dezembro de 1920, que ficou conhecido como "Reforma Sampaio Dória". Além de sua importante atuação no campo da educação/ instrução pública, Sampaio Dória também foi um importante jurista (Carvalho, 1999; Medeiros, 2005). 
sidades do leitor. Sobre esse aspecto, com base na Psicologia, esse educador afirma que:

Há realidades que, numa idade, interessam com energia, e, não obstante, aborrecem solennemente em outra idade. Romances de aventuras, capa e espada, comedias fanfarronas e zombeteiras, fantoches, palhaçadas e polichinellos, que eram a nossa delicia até quasi os vinte annos, já não são de molde a nos agradar aos trinta. [...] Mercê destas razões, a literatura didactica tem, primeiro, de selecionar, entre os assumptos possíveis, aquelles que mais se adaptem à idade do leitor, a que se destina. Além disso, força-lhe a trata-los de modo a manter, contra as indisposições do momento, o agrado e o prazer da leitura. (Dória, 1918, p.71-72)

Além do aspecto relativo às ilustrações, Sampaio Dória (1918) ressalta a importância de se cuidar, na literatura didática, da realidade a ser representada aos pequenos leitores. Segundo ele, essa realidade deve partir do "todo" e não de "atributos" ou "elementos de relações", tendo em vista que isso se opõe ao raciocínio intuitivo-analítico. É a partir da contemplação desses requisitos que Sampaio Dória (1918) entende que a literatura didática contribui para se atingirem os fins da educação, especialmente de formar o espírito das crianças.

Sampaio Dória (1918) entende que a literatura didática incide diretamente sobre três pontos essenciais e indispensáveis na formação do futuro homem: a moralidade, a verdade e a estética.

Em relação à moralidade, Sampaio Dória (1918) adverte que, por ser a literatura didática uma forma de arte, ela não pode se eximir da responsabilidade de transmitir valores morais válidos e adequados à infância. É justamente por ser arte que esse tipo de literatura precisa ser moralizadora. Sobre esse aspecto, afirma que: "Mais do que qualquer outro gênero de literatura, a didática deve insinuar suavemente, no espírito infantil, como o ar que se respira e tonifica, a pureza e a moralidade da vida" (Dória, 1918, p.74).

Em decorrência do caráter de instrumento moralizador, Sampaio Dória (1918) entende que a literatura didática não pode se desvencilhar do compromisso de transmissão da verdade. Para ele, ao transmitir valores mentirosos e deturpações da realidade, a literatura didática arruína todo o futuro 
de uma criança, tornando-a refém de uma visão intolerante, preconceituosa, inferiorizada e supersticiosa da vida. E explica que a literatura didática:

[...] há de ser uma escola de horror à mentira, ainda que provisória. O que lhe cumpre, é o culto fervoroso da verdade pura e límpida. Porque ideas falsas, que se embebem na infância, se consolidam na madureza, para enfreiar no erro e na maldade toda uma existência falha. (Dória, 1918, p.74)

Sampaio Dória (1918) conclui seu texto com a defesa de que a literatura didática precisa se constituir como suporte de ensino "intuitivo-analítico". "Intuitivo, no seu espírito, para dar nascimento á clareza; analytico, na sua marcha, para criar e manter o interesse; educativo, nos seus fins, para melhor formação moral, amor á verdade e affeiçoamento á beleza e á graça" (Dória, 1918, p.75).

\section{Afrânio Peixoto (1923) e a "literatura infantil"}

Seguindo uma linha de raciocínio semelhante à de Sampaio Dória, Júlio Afrânio Peixoto, ${ }^{20}$ em 1923, teve publicado um ensaio intitulado "Literatura infantil" no livro Ensinar a ensinar: ensaios de Pedagogia aplicada à educação nacional.

Esse livro, publicado pela Livraria Francisco Alves, reúne sete ensaios sobre diferentes aspectos da educação nacional da época. Segundo o autor, esses ensaios decorreram de sua atuação como diretor da Escola Normal do Distrito Federal e como diretor-geral da Instrução Pública do Distrito Federal, cargos que ocupou nas primeiras década do século XX e os quais

20 Nascido em 1876, em Lençóis-BA, Júlio Afrânio Peixoto diplomou-se, aos 21 anos de idade, em medicina, na Faculdade de Medicina da Bahia, tendo passado a atuar como professor nessa mesma faculdade a partir do ano de 1901. Em 1902, mudou-se para o Rio de Janeiro-DF, onde ocupou importantes cargos: professor de Medicina Legal e Higiene da Faculdade de Medicina do Rio de Janeiro; professor da Faculdade de Direito do Rio de Janeiro; diretor da Escola Normal do Distrito Federal; e diretor-geral da Instrução Pública do Rio de Janeiro-DF. Além desses cargos e de sua intensa atuação como educador médico e legislador, Afrânio Peixoto também se dedicou à literatura, tendo publicado uma quantidade significativa de romances e livros de poemas. Por isso, em 1911, foi nomeado membro da Academia Brasileira de Letras. 
lhe permitiram atuar em favor de amenizar os problemas da educação no Rio de Janeiro.

Peixoto (1923) explica que, do período em que ocupou os cargos de diretor da Escola Normal e de diretor-geral da Instrução Pública, restaram-lhe algumas ideias e páginas escritas, que ele reuniu em Ensinar a ensinar. Por isso, o seu objetivo com os ensaios ${ }^{21}$ foi oferecer aos professores da época subsídios para melhor compreenderem as questões relativas ao ensino. Isso se deu porque, para Peixoto (1923), um dos maiores problemas da educação nacional da época era o fato de os professores ensinarem sem ter aprendido a ensinar.

Dados os propósitos da publicação de Ensinar a ensinar e o certo prestígio no campo educacional de que gozava seu autor, é possível presumir que as questões relacionadas à literatura infantil, já na década de 1920, vinham ganhando maior importância entre os professores e no âmbito das discussões sobre a educação nacional.

No que se refere ao conteúdo do ensaio "Literatura infantil", ele inicia sua argumentação partindo do princípio de que a criança não é a redução da alma do adulto ou a "abreviatura do futuro homem". Para Peixoto, a criança é um indivíduo no qual o "ser homem" está presente, porém, em "[...] latência de evolução: assim do corpo e do espírito infantis, o espírito e o corpo do homem, não preformado, em resumo, mas a se formar, a se perfazer, por incessante desenvolvimento do esbôço originário" (Peixoto, 1923, p.147-148). A criança desenvolve o "ser homem" que está dentro dela à imagem dos bons exemplos dos homens já formados e, nesse aspecto, os adultos e a literatura infantil são formas de dar a conhecer esses bons exemplos de homens.

Apesar desse importante papel que pode desempenhar a literatura infantil, Peixoto (1923) adverte sobre uma importante distinção existente nesse gênero literário: os livros sobre crianças e os livros para crianças.

Em relação aos livros sobre crianças, esse educador e escritor entende que se trata de narrativas sobre as infâncias célebres, que só interessam aos adultos. Para ele, são os adultos, e não as crianças, que se encantam “[...]

21 Os ensaios reunidos nesse livro, sob a forma de capítulo, são: "Educação nacional: aspectos masculinos", "Educação nacional: aspectos femininos", "O ensino da linguagem", "A linguagem e a gramática", "Literatura infantil”, "O ensino secundário e a educação nacional” e "O regime universitário e a educação nacional". 
com gestos, as palavras, as acções dêsses pequenos heróis, nos quais nos revemos, ou nos idealizamos, se a saudade se junta à aspiração paterna, ou ainda apenas altruísta” (p.149).

Apesar de entender que uma das funções da literatura infantil é a exposição de exemplos de bons homens, ele entende que não é por meio dos livros de infâncias célebres, ou seja, das narrativas sobre crianças que os pequenos leitores compreenderão a importância de se formarem homens íntegros no futuro. Segundo Peixoto, isso somente ocorre com livros de fantasia, com personagens crianças que se comportam como adultos. É esse tipo de literatura infantil, os chamados livros para crianças, que desperta o interesse dos pequenos leitores para os valores que se devem ensinar na escola. Em vista disso, afirma serem os livros repletos de fantasia e de cultura do maravilhoso que devem ser destinados às crianças, visando à transmissão e formação, nelas, do bem, do belo e do justo.

Em consonância com essa concepção, Peixoto (1923) alerta, no entanto, que é preciso ter cuidado com a fantasia e a imaginação que se proporcionam às crianças. Apesar de esses quesitos serem essenciais num livro de literatura infantil, não é qualquer tipo de fantasia ou imaginação que está a serviço do "triunfo" do bem, do belo e do justo. Ele explica que os livros de literatura infantil, construídos em torno da cultura do maravilhoso, devem tratar:

[...] primeiramente, ou preferentemente, sobre a vida, isto é, sobre os grandes, que os pequenos desejam ser... mães nobres, generosas, amantes, que tenham filhos, como elas teem bonecas, e por elas façam coisas ternas e carinhosas, coisas que lhe falem aos sentidos já abertos e ávidos para sensações... casas, castelos, alfaias, joias, parques, festas, guloseimas, cerimónias, tudo o que pode exigir uma imaginação feminina, até mesmo a adivinhação do amor... o que eles desejam ser, soldados, generais, conquistadores... (Peixoto, 1923, p.156).

Desse modo, a literatura infantil constitui, para Peixoto (1923), meios para se atingirem outras faculdades essencialmente educativas, pois, por meio da fantasia e imaginação que transmitem bons exemplos, esses livros se convertem em "[...] imagem sublimada de vida, que, longe de conduzir ao pessimismo, pelo desengano na realidade, predispõe ao ideal, pela aspi- 
ração. Por ela [literatura infantil] se chega à arte, à sciência, à invenção, ao prazer, às vezes mesmo ao consôlo de viver..." (Peixoto, 1923, p.161).

Com esse entendimento, ele considera que a cultura do maravilhoso, a fantasia ou imaginação não podem ser "vividas" senão por “[...] personagens grandes, que vivam vida heroica, trabalhosa, imprevista, e, portanto, curiosa" (Peixoto, 1923, p.1961). Os livros que contêm essas características apresentam, segundo Peixoto (1923), algumas "vantagens" formativas:

Além da vantagem educativa do "conto pelo conto", excitando a imaginação, e, por elas, às outras funções mentais, nas histórias infantis pode ser tentada uma instrução moral e cívica, mas discreta, ou melhor, implícita, para evitar a prevenção e ao enfado. Mais tarde, havemos de querer também que a arte seja desinteressada. (p.162)

Nessa perspectiva, Peixoto (1923) conclui seu ensaio afirmando que os aspectos estéticos, a cultura do maravilhoso e o desenvolvimento da imaginação e da criatividade proporcionados pela literatura infantil são meios para a moralização e civilização dos pequenos leitores, futuros homens de nossa sociedade. "Não há forma de arte mais difícil e mais sublime que um livro de bons contos infantis, que constituem a delícia dos pequenos, na infância, e a saudade dos grandes, tôda a vida..." (Peixoto, 1923, p.162).

\section{Alceu Amoroso Lima (1927) e a "literatura de crianças"}

No final da década de 1920, quando os livros destinados às crianças já haviam ganhado maior volume e as discussões sobre a distinção do valor estético e do didático estavam mais delineadas, o escritor Alceu Amoroso Lima, ${ }^{22}$ sob o pseudônimo Tristão de Athayde, teve publicado o texto "Li-

22 Nascido em Petrópolis-RJ, em 11 de dezembro de 1893, Alceu Amoroso Lima fez os estudos primários no Colégio Pedro II e formou-se bacharel em Direito, em 1913, pela Faculdade de Direito do Rio de Janeiro. Em 1926, teve seu primeiro livro publicado sob o pseudônimo Tristão de Athayde. Na década de 1930, teve um conjunto de livros publicados, sobre diferentes assuntos. Nessa mesma década, com a morte de Miguel Couto, candidatou-se à Academia Brasileira de Letras, tendo sido eleito. No âmbito de sua atuação profissional, Alceu Amoroso Lima foi: catedrático de Literatura Brasileira na Faculdade Nacional de Filosofia; um dos fundadores da Pontifícia Universidade Católica do Rio de Janeiro; e Diretor de Assuntos Culturais da Organização dos Estados Americanos. Concunhado de Afrânio Pei- 
teratura infantil”, como capítulo de seu livro Estudos - $1^{\text {a }}$ série. Esse livro foi publicado em 1927, pela Editora A Ordem (RJ).

Nesse ensaio, Amoroso Lima (1927) começa por afirmar que, à época, era possível falar da literatura infantil em duas acepções: uma literatura escrita para crianças e outra literatura escrita por crianças, a qual ele denomina "literatura de crianças".

Tendo em vista essa distinção, segundo Amoroso Lima (1927), ainda que o campo da literatura infantil se constitua como campo extenso, o seu interesse nesse texto é tratar apenas dos aspectos da "literatura de crianças", pois essa é, para ele, a melhor literatura que se pode ofertar para os pequenos leitores.

Esse propósito decorre do fato de ele observar, à época, que a literatura infantil brasileira vivia "maculada" entre dois "defeitos antagônicos". De um lado, uma literatura feita por professores, "impregnada de pedagogismos", deformada "[...] em seu interesse e naturalidade pela preoccupação de instruir e moralizar" (Amoroso Lima, 1927, p.190). De outro lado, uma literatura infantil feita por "amadores", profissionais da "fantasia de mascate", o que a faz cair "[...] no grosseiro, no máo gosto, na vulgaridade barata. Pedagogismo e mercantilismo” (Amoroso Lima, 1927, p.190).

Esses dois problemas que permeavam a literatura infantil do início do século XX eram, para esse escritor, decorrentes da "dissociação das idades", ou seja, da iniciativa (ou tentativa) do adulto em escrever com "alma infantil", para atingir o universo dos pequenos.

Sobre esse aspecto, Amoroso Lima (1927) explica que os autores de literatura infantil, na sua grande maioria, empenhavam-se em se colocar à altura de seus leitores, para então ser possível explorar o "espírito da infância” que há em todos os adultos. No entanto, para ele, o escritor que planeja os efeitos e sentimentos que quer despertar em um leitor é, na verdade, um "agenciador de coisas estranhas", um "técnico", um "manipulador de fantasias infantilizantes". Explica que o "[...] erro de muitos autores de literatura infantil, como de professores etc., é justamente julgarem que o facto de conhecermos melhor o seu mundo interior [da criança] nos permitta penetrar melhor nesse mundo" (p.192).

xoto, Alceu Amoroso Lima faleceu em 14 de agosto de 1983. Informações disponíveis em: <http://www.academia.org.br/abl/cgi/cgilua.exe/sys/start.htm?infoid=69\&sid=359>. Acesso em: 21 ago. 2014. 
Para esse escritor a Psicologia ajuda a entender o quão "nebulosa" e "indecisa" é a lógica dos pequenos, o que faz que não seja "[...] possível [um adulto] penetrar na alma infantil, ou, pelo menos, tocar profundamente essa alma, sem viver no ambiente dessa lógica infantil” (Lima, 1927, p.194).

Em vista disso, todos os que desejam escrever para as crianças e produzir arte para elas precisam compreender o mundo infantil "visto de dentro da infância”, o que torna esse tipo de literatura bastante rara e difícil. Segundo ele, um dos poucos livros que consegue esse feito é Narizinho arrebitado (1921), de José Bento Monteiro Lobato.

Por causa da dificuldade e raridade da literatura infantil feita por adultos, que atenda a contento à alma infantil, Amoroso Lima (1927) defende que a melhor literatura infantil a ser oferecida aos pequenos leitores é aquela produzida por eles mesmos.

Desde que o mundo infantil é um mundo de qualidade diversa da do nosso; desde que a criança vê as coisas, comprehende os factos, reflecte as fórmas, interpreta os actos de maneira diversa do que nós fazemos, nada mais natural do que procurar, entre as próprias crianças, o que deve mais interessar ás crianças. (p.197)

Com essa proposição, esse escritor afirma que nada é mais justo que a arte literária para a infância ser produzida pelas crianças, pois é esse tipo de arte que pode tocar realmente a alma infantil e penetrar esse universo tão misterioso.

O que os adultos fazem, em termos literários, por mais esforço que se empenhe, é sempre uma atitude "artificial" de vencer a natureza própria do adulto e chegar à natureza infantil. Já a literatura escrita pelas crianças, ainda que não tenha a "riqueza de invenção" da literatura feita por um adulto, terá de sobra a imaginação infantil, como uma qualidade que não se encontra no adulto.

Apesar de reconhecer que a "literatura de crianças" seja a mais adequada aos pequenos leitores, explica que não é qualquer criança que pode escrever para outra criança. É preciso saber selecionar os textos.

Em geral, só se presta attenção ás obras infantis, quando são obras de crianças prodígios. Isto é - quando justamente não são obras infantis. Quando o que se deve procurar não é o que ha de adulto, e portanto de falso, na criança, 
mas o que tiver de bem criança, portanto de espontaneo. A própria imitação do adulto, que é tão commum na criança, tem um caráter inconfundível. (p.200)

Para concluir, Amoroso Lima (1927) afirma que a literatura escrita pelas crianças era, naquele momento histórico, a mais adequada e produtiva para a formação do futuro homem. Nesse sentido, entende que no "[...] dia em que houver boas histórias de crianças para crianças é que se poderá falar da existência de uma literatura infantil” (Lima, 1927, p.204).

\section{A literatura infantil tematizada na imprensa periódica}

Concomitantemente à publicação dos artigos de Pinto (1917), Dória (1918), Peixoto (1923) e Amoroso Lima (1927) e também nas duas décadas subsequentes, a concepção de literatura infantil apresentada por esses autores foi abordada por outros, em artigos publicados em revistas especializadas e em textos de jornais de circulação diária.

Nesse período, quatro primeiras décadas do século XX, conforme apontam Lajolo e Zilberman (1984), a produção de literatura infantil teve um crescimento significativo, decorrente da ampliação da escolarização primária, da especialização de algumas editoras e da profissionalização de alguns escritores nesse ramo. Com o aumento da produção de livros de literatura infantil no país, esse assunto ganhou certa visibilidade e notoriedade, de modo que esses livros começaram a ser tomados como objetos de reflexão em textos de circulação mais ampla, como os artigos publicados em revistas especializadas em Educação e em estudos literários e os textos publicados em jornais de notícias, de circulação diária.

As revistas especializadas e os jornais de notícias, se comprados aos livros, parecerem conferir menor prestígio aos textos que publicam. Porém, no caso dos textos sobre literatura infantil, são importantes suportes, que indicam que o assunto passou a ser de interesse mais amplo e não apenas de escritores e educadores.

Pelas razões expostas, problematizar os textos sobre literatura infantil publicados em revistas especializadas e jornais de notícias é mais do que dar a conhecer o que se produziu e se publicou sobre o assunto nesses suportes. Problematizar esses textos é buscar compreender quais concepções de lite- 
ratura infantil se disseminavam entre os leitores dessas revistas especializadas e dos jornais de notícias e buscar entender como se foi delineando, no Brasil, a formação de saberes em torno desse gênero literário.

\section{Os artigos em revistas especializadas}

Em relação aos artigos em revistas especializadas, no mesmo ano em que foi publicado o livro de Afrânio Peixoto (1923), a Revista da Sociedade de Educação, ${ }^{23}$ de responsabilidade da Sociedade de Educação de São Paulo e editada pela Companhia Gráfica-Editora Monteiro Lobato, publicou, na seção "Revistas e Jornaes", um texto sobre literatura infantil de autoria do escritor Gilberto Amado. ${ }^{24}$ Nessa seção, a Revista da Sociedade de Educação publicava resenhas, resumos, trechos ou reproduções integrais de artigos publicados originalmente em outros suportes, cujos assuntos eram do interesse do público leitor dessa revista. Esse texto de Gilberto Amado havia sido publicado originalmente no jornal O Paiz, do Rio de Janeiro, e foi republicado na Revista da Sociedade de Educação, em 1923.

Amado (1923) apresenta uma série de exemplos de livros destinados às crianças, publicados na Inglaterra, Alemanha, França, Espanha e Estados Unidos, que ele considera como verdadeiras “[...] histórias de lição de coisas, um encanto indefinível, que lhes aumenta ainda mais essa saudade da infância, tocante lugar commun do sentimento" (Amado, 1923, p.297). Ele defende a necessidade de dar ao público infantil brasileiro a possibilidade

23 A Revista da Sociedade de Educação foi um periódico de iniciativa particular, criado pela Sociedade de Educação e editado por José Bento Monteiro Lobato. Esse periódico foi publicado entre 1923 e 1924, totalizando nove números (Nery, 2009). Para informações mais detalhadas sobre esse periódico e também sobre a Sociedade de Educação, ver, especialmente: Nery (2009).

24 Nascido em Estância-SE, em 7 de maio de 1887, Gilberto Amado fez os estudos primários em Itaporonga-SE. Posteriormente, estudou Farmácia na Bahia e diplomou-se bacharel em Direito pela Faculdade de Direito de Recife. Em 1910, mudou-se para o Rio de Janeiro, quando começou a colaborar com jornais locais. Gilberto Amado também teve importante participação política. Em 1915, foi eleito deputado federal pelo Sergipe e, em 1936, foi senador pelo mesmo estado. Entre os cargos que ocupou, foi consultor jurídico do Ministério das Relações Exteriores; membro da Comissão de Direito Internacional da ONU; e delegado do Brasil em diferentes Assembleias Gerais da ONU. Em 1963, foi eleito membro da Academia Brasileira de Letras, sendo recebido por Alceu Amoroso Lima. Gilberto Amado faleceu no dia 27 de agosto de 1969. Informações disponíveis em: <http://www.academia.org.br/abl/ cgi $/$ cgilua.exe/sys/start.htm? infoid=586\&sid=264> . Acesso em: 21 ago. 2014 . 
de acesso a essas histórias produzidas nos países europeus e também defende a necessidade, a exemplo dessas, de se produzirem histórias sobre a realidade do Brasil, como a chegada dos descobridores. Em vista disso, esse autor conclui que:

Será talvez por falta dessas leituras luminosas e incomparáveis no começo da vida - que o espírito dos rapazes e das raparigas de hoje é em geral tão triste e desenxabido.

Tenho a íntima conviç̧ão de que muitos dos almofadinhas que enodôam as nossas ruas com a sua presença ambígua seriam homens mais homens, seriam homens de facto - se as grandes emoções communicadas por essas leituras estimulantes - lhe houvesse eccendido na alma recém-aberta às sensações da vida, o calor, a exaltação, o enthusiasmo que ellas despertam. (Amado, 1923, p.298)

Em 1929, foi publicado, na Revista de Educação, de São Paulo, o artigo "A literatura escolar e a escola activa” (Menucci, 1929, p. 105-114), de autoria do educador Sud Menucci. ${ }^{25}$ Nesse artigo, Menucci (1929) utiliza-se de li-vros denominados por ele "literatura escolar", para apresentar reflexões sobre a situação educacional da época e os princípios da Escola Ativa.

Por considerar que a "literatura escolar" é fruto da "Pedagogia Moderna”, advinda com a Escola Ativa, Menucci (1929) entende que não havia, no Brasil, à época, uma crítica literária especializada para a análise desses livros. Para ele, apesar disso, pensar sobre essa literatura significava pensar sobre os problemas enfrentados pelo ensino no estado de São Paulo e lançar a dúvida se a Escola Ativa, com sua "Pedagogia Moderna" (como a criação da literatura didádica), era capaz de dar conta desses problemas educacionais do país.

25 Nascido em Piracicaba, em 20 de janeiro de 1892, Sud Menucci fez os estudos primários em um grupo escolar de sua cidade natal, onde também diplomou-se professor pela Escola Complementar. Em 1910, iniciou sua carreira como professor na cidade de Cravinhos e, posteriormente, em Piracaia e Dourado. Entre os muitos cargos que ocupou e escolas e instituições nas quais atuou, Sud Menucci fez parte da Missão Paulista que reorganizou escolas de Belém-PA; chefiou o recenseamento escolar de 1920; foi delegado de ensino em Campinas; foi diretor da Imprensa Oficial do estado de São Paulo; foi, por duas vezes, diretor do Departamento de Educação da Secretaria de Educação do estado de São Paulo; e colaborou como jornalista em diferentes jornais e revistas. Faleceu em São Paulo, em 22 de julho de 1948 (Mello, 1954). 
Embora o enfoque inicial do artigo de Menucci (1929) seja a chamada "literatura didática", ele acaba por se desviar desse foco, centrando-se mais no levantamento de dúvidas e questões em relação à Escola Ativa.

Após a publicação desse artigo de Sud Menucci, localizei apenas um artigo sobre literatura infantil publicado na década de 1930. Trata-se de artigo de autoria de Jorge Amado, publicado na Revista Brasileira, ${ }^{26}$ da qual não pude localizar exemplar físico.

Na década seguinte, 1940, com um acúmulo maior de conhecimento sobre a literatura infantil e também com classificação/conceituação mais acentuadas sobre esse tipo de publicação, os artigos sobre o assunto, publicados nas revistas especializadas, passaram a ter características mais científicas e a se basear em dados de pesquisa empírica.

Esse é o caso, por exemplo, do artigo "Algo de que as crianças gostam de ler: estudo de dois livros preferidos por meninos e meninas", de Betti Katzenstein ${ }^{27}$ e Beatriz de Freitas ${ }^{28}$, publicado na Revista do Arquivo Municipal, ${ }^{29}$ de São Paulo-SP. Esse artigo, publicado em 1941, contém os resultados de uma pesquisa elaborada pelo Laboratório de Psicologia da Faculdade de Filosofia, Ciências e Letras da Universidade de São Paulo,

26 Criada em 1885, por Francisco de Paula Menezes, a Revista Brasileira, ligada à Academia Brasileira de Letras, passou, ao longo de sua existência, por oito fases de organização, conforme os editores responsáveis que teve. Informações disponíveis em: <http://www.academia.org.br/abl/cgi/cgilua.exe/sys/start.htm? sid=31>. Acesso em: 10 de set. 2014.

27 Nascida na Alemanha, em 1906, Betti Katzenstein Schoenfeldt se formou psicóloga na Universidade de Hamburgo e se doutorou em Psicologia, em 1931. Mudou-se para o Brasil em 1936, quando ingressou no Laboratório de Psicologia do Instituto de Educação da Universidade de São Paulo. A partir da década de 1940, passou a atuar em diferentes instituições, como: o Serviço de Educação Pré-Primária do Estado de São Paulo, Escola de Enfermagem da USP, Escola de Sociologia e Política de São Paulo e Departamento de Psicologia da Unesp-campus de Assis. Betti Katzenstein atuou, sobretudo, com aplicação e adaptação de testes de desenvolvimento, aptidão e personalidade. Faleceu em São Paulo, em 1981. Informações disponíveis em: <http://www.crpsp.org.br/memoria/betti/default.aspx>. Acesso em: 20 ago. 2014.

28 Não foi possível localizar nenhuma informação sobre Beatriz de Freitas.

29 A Revista do Arquivo Municipal foi criada em 1934, pela Diretoria do Protocolo e Arquivo da Prefeitura de São Paulo. Em 1936, passou a fazer parte do Departamento de Cultura de São Paulo, à época, sob a direção de Mário de Andrade. Ao longo de seu ciclo de publicações, essa revista não teve uma periodicidade constante, chegando ao ponto de ficar por dez anos sem ser publicada. Em 2002, a publicação foi retomada pelo atual Departamento de Patrimônio Histórico da Prefeitura de São Paulo. 
em pareceria com a Biblioteca Infantil Municipal, ${ }^{30}$ do Departamento de Cultura da Prefeitura de São Paulo.

Nesse artigo, as autoras começam por apresentar algumas considerações sobre o conceito de literatura infantil e a influência exercida por esse tipo de livro na formação das crianças. Em relação a essa influência, Katzenstein e Freitas (1941) destacam que é preciso atentar para o papel das editoras, visto que, antes de os pais escolherem os livros para seus filhos, as editoras são quem escolhem o que se dará a ler às crianças. Por isso, defendem a necessidade de um cadastro dos livros infantis, que permitisse conhecer o que havia, que satisfizesse tanto os interesses dos educadores quanto os dos leitores.

Após salientarem a necessidade de se conhecer melhor a produção de literatura infantil, Katzenstein e Freitas (1941), com objetivo de propiciar uma "[...] contribuição psicológica para a compreensão daquilo que a criança gosta de ler e para a orientação de suas leituras” (p.12), apresentam aspectos da análise de dois livros, que identificaram como os mais lidos pelas crianças que frequentavam a Biblioteca Infantil de São Paulo.

Para que chegassem a esses dois livros, Katzenstein e Freitas (1941) tomaram como base quais livros havia disponíveis no acervo da Biblioteca Infantil, de São Paulo, e cujos enredos foram "aproveitados" em filmes. Dessa delimitação, identificaram 15 livros, ${ }^{31}$ cujas fichas de leitura consultaram.

Ao todo, Katzenstein e Freitas (1941) analisaram 204 fichas, todas preenchidas pelas crianças. A partir disso, identificaram que os livros mais lidos eram, entre os 15: Mulherzinhas, de Louise May Alcott, e Rancho do

30 Por meio da atuação de Lenyra de Arruda Fraccaroli, em 14 de abril de 1936, foi fundada, em São Paulo-SP, a Biblioteca Infantil Municipal. A partir do ano de 1945, essa Biblioteca foi transferida para um espaço maior, e, em 1950, passou a ser denominada Biblioteca Infantil Monteiro Lobato, em homenagem ao escritor José Bento Monteiro Lobato. Essa biblioteca foi a primeira específica para o público infantil no estado de São Paulo e é a mais antiga Biblioteca infantil em funcionamento no Brasil (Prefeitura de São Paulo, s.d.).

31 Os 15 livros identificados foram: Miguel Strogoff, de Júlio Verne; Robin Hood, adaptado por Monteiro Lobato; O príncipe e o pobre, de Mark Twain; Heidi e Heidi nos Alpes, de Johanna Spyri; Branca de Neve, dos Irmãos Grimm; As viagens de Tom Sawyer, de Mark Twain; Sonho de Moça, de Kate Douglas Wiggin; Último dos mohicanos [sic.], de James Fenimore Cooper; $O$ pimpinela escarlate, de Baronesa Orezy; As pupilas do Sr. Reitor, de Júlio Diniz; A ilha do tesouro, de Robert Louis Stevenson; Mulherzinhas, de Louise May Alcott; As quatro raparigas, adaptado de M. P. Azevedo; O rancho do fantasma, adaptado de A. Brussolo; Sete provas, adaptado de A. Brussolo; e Mascote do regimento, adaptado de A. Brussolo (Katzenstein; Freitas, 1941). 
fantasma, adaptado de "A. Brussolo" e cujo autor não foi identificado. O primeiro livro - Mulherzinhas - foi lido por 100 crianças do sexo feminino e uma do sexo masculino, com idade entre 8 e 17 anos. O segundo livro Rancho do fantasma - foi lido por 104 crianças do sexo masculino e 19 do sexo feminino, com idade entre 7 e 15.32 A partir da obtenção desses dados, Katzenstein e Freitas (1941) detiveram-se na analise do conteúdo dos livros, dos recursos materiais e gráficos e das opiniões dos leitores registradas nas fichas de leitura, visando coletar " [...] conhecimentos essenciais sôbre a literatura preferida por meninas e meninos” (p.16).

Em relação à análise do conteúdo dos livros, as autoras do artigo puderam identificar que o ambiente familiar se apresenta como mais agradável ao público feminino, ao passo que o ambiente de "far-west" agrada mais ao público masculino. Ainda em relação ao conteúdo, identificaram as personagens que mais agradaram os leitores. No caso de Mulherzinha, a personagem "Maria João" foi escolhida por 61,1\% das leitoras como a personagem preferida. Essa personagem apresenta características como: modos de menino, alegria, bondade, é levada e demonstra amor dedicado à família. No caso do livro Rancho do fantasma, a personagem que mais agradou foi "Ken Maynard", escolhida por 60,7\% dos leitores como a preferida. Essa personagem se apresenta como um sujeito valente e corajoso, que derrota os bandidos.

Katzenstein e Freitas (1941) concluem que o estudo desses livros contribui para se entender os critérios de escolha de livros por parte das crianças. Ou seja, como as crianças avaliam os livros escolhidos e como se envolvem com o enredo, de modo a viver a vida de seus heróis preferidos.

Ainda na década de 1940, a Revista Brasileira de Estudos Pedagógicos $(\mathrm{RBEP})^{33}$ publicou um conjunto de artigos sobre literatura infantil, com essa característica de divulgação de resultados de pesquisa. O primeiro artigo sobre literatura infantil publicado na RBEP data de 1944, quando se iniciou nessa revista a publicação, em quatro partes, dos resultados de uma pesquisa

32 Katzenstein e Freitas (1941) explicam que também desenvolveram estudo sobre o livro As 4 raparigas, porém, por se tratar de um livro muito semelhante a Mulherzinhas, não apresentam dados detalhados dessa análise no artigo. Elas apenas mencionam alguns aspectos, para estabelecer uma comparação.

33 Criada no ano de 1944, a RBEP foi uma iniciativa do Ministro da Educação e Saúde, Gustavo Capanema Filho. Essa revista foi criada como um órgão desse Ministério, com objetivo de reunir, divulgar e pôr em debate os assuntos relativos à Educação. 
realizada pelo Instituto Nacional de Estudos Pedagógicos (Inep), sobre os jornais e revistas infantis e juvenis brasileiros. A divulgação dos resultados obtidos com o desenvolvimento dessa pesquisa do Inep se deveu ao "[...] interêsse geral do assunto e a atualidade das conclusões a que chegou êsse órgão do Ministério da Educação [...]” (Investigação..., 1944a, p.255).

$\mathrm{O}$ artigo se intitula "Uma investigação sôbre jornais e revistas infantis e juvenis", e a primeira e a segunda partes foram publicadas na edição n. 5, de 1944. Em 1945, na edição n. 7, foi publicada a terceira parte desse artigo e, também em 1945, na edição n. 8, foi publicada a quarta e última parte desse artigo.

Conforme dados apresentados nas quatro partes desse artigo, uma das motivações para o Inep ter realizado essa pesquisa decorreu do fato de que os jornais e revistas ${ }^{34}$ destinados ao público infantil alcançavam grande influência na formação de seus leitores. Em vista disso, o Inep considerou necessário promover uma análise dos aspectos materiais e do conteúdo dessas publicações, além de investigar de que modo as crianças, mães e professores compreendiam as influências exercidas por esses jornais e por essas revistas.

Para atender aos objetivos dessa pesquisa, foram selecionados pelo Inep 96 exemplares de nove diferentes revistas e jornais infantis, que foram analisados a partir da apresentação material (formato, linhas, tipo de material, diagramação etc.), do programa de publicações e do conteúdo dos textos publicados. Após essa etapa, foram aplicados questionários aos alunos, mães e professores, todos da cidade do Rio de Janeiro, para compreender a opinião dessas pessoas a respeito da influência desse tipo de publicação. Os resultados dessa pesquisa apontaram que os jornais e revistas destinados às crianças e aos jovens, durante a década de 1940, apresentavam alguns problemas no que se refere à parte material. Os maiores problemas referiam-se, no entanto, ao conteúdo dos textos publicados.

Embora a pesquisa realizada pelo Inep tenha demonstrado que os textos publicados nesses jornais e nessas revistas eram de caráter recreativo e não educativo-instrutivo, os dados analisados por eles apontam a predominância de narrativas com forte apelo para a violência, acidentes, desastres e

34 Trata-se, aqui, de revistas e jornais específicos para as crianças, que continham textos narrativos, histórias em quadrinhos e poemas, entre outros tipos de textos. 
uso de armas. E, coerentemente com isso, as personagens dessas narrativas representam figuras criminosas e aventureiras.

Em relação às impressões dos alunos, das mães e dos professores, os dados coletados pelo Inep apontam que as mães se posicionaram menos resistentes a esses jornais e a essas revistas. Os professores, por sua vez, opinaram sobre a forte influência negativa que podem propiciar os textos publicados em jornais e revistas infantis.

Entre as influências perturbadoras, assinalam-se as de repercussão emotiva, decorrente da leitura de contos e histórias policiais e de aventuras, influência essa especialmente apurada entre crianças de 9 a 11 anos; maior turbulência, ou combatividade, em brinquedos, ou jogos, em virtude da imitação das personagens das aludidas composições; atitudes de rebeldia, ou desobediência, no lar ou na escola, diretamente motivadas pelo interêsse na leitura de publicações, com prejuízo do estudo e do trabalho escolar; uso de expressões ou modismos de linguagem pouco recomendáveis; perda de interêsse por leituras de melhor quilate, eu a apresentada pelos jornais e revistas em estudo. (Investigação..., 1945a, p.229)

A partir dessas observações, explica-se, como considerações finais, que não é possível desenvolver um estudo sobre a literatura infantil se não se levar em conta que a finalidade dessa arte é a formação de valores estéticos e éticos nos seus leitores. Essa arte tem "função psicopedagógica", por isso: "Não é possível que, tomando em mira ao que é belo, não se alcance o que é bom” (Investigação..., 1945b, p.233).

\section{Os textos em jornais de circulação diária}

O primeiro texto ${ }^{35}$ sobre literatura infantil que localizei publicado em um jornal de notícias data de 1909. Esse texto foi escrito por ocasião da publicação do livro Aos nossos amigos, de Ana de Castro Osório e Paulino

35 Embora o primeiro texto que localizei date de 1909, é possível que outros textos sobre literatura infantil tenham sido publicados antes, sobretudo para tratar dos livros que passaram a ser publicados no final do século XIX. No entanto, por serem os jornais um tipo de documento cuja consulta e localização de informações são mais difíceis, não pude localizar textos sobre literatura infantil com data anterior a essa. 
de Oliveira, e foi publicado na seção "Biografias", do jornal O Estado de S. Paulo, no dia 10 de outubro de 1909, sem título e sem indicação de autoria.

Essa "biografia" inicia-se com a afirmação de que um dos maiores problemas da época era, sem dúvida, o da educação da infância. Esse problema preocupava o "espírito humano", porque a educação das crianças constitui a base da família, "[...] como cellula viva dos Estados, que hão de constituir-se de indivíduos aptos a promover e realizar o seu adiantamento e suas propriedades" (Bibliographia, 1909, p.2).

Conforme se afirma nessa "biografia", as crianças, após atingirem a segunda infância, apresentam um interesse cada vez maior pelos fenômenos da natureza, que as levam a desenvolver a curiosidade. No entanto, isso caracteriza uma dificuldade, pois é difícil satisfazer esse interesse de forma que a criança possa se desenvolver e abranger, depois, todos os conhecimentos, "[...] sem sacrifício dos verdadeiros princípios, nem da lógica, em qualquer ordem, da actividade psychica” (Bibliographia, 1909, p.2).

Por essa razão, reconhece-se nessa "biografia" a importância dos livros na satisfação da curiosidade infantil, porém faz-se a ressalva de que são "raríssimos", entre os escritores que se dedicam à literatura infantil, os que conseguem " [...] compor livros de leituras desse genero, que não sejam imperfeitos e deficientes" (Bibliographia, 1909, p.2). A título de bom exemplo de literatura infantil apropriada às crianças, destaca-se o livro Os nossos amigos, de Ana de Castro Osório e Paulino de Oliveira. Nesse livro, conforme consta nessa "biografia", os escritores conseguem ofertar à infância um livro de qualidade, "[...] e a prova é que o conselho de Instrução Pública de Minas o approvou e adoptou para uso em suas escolas” (BIbliographia, 1909, p.2).

Em embargo de alguns senões, que se notam em suas narrativas, resultantes do falso conhecimento que possuem autores estrangeiros acerca não só de nossa fauna e de nossa flora, como dos nossos hábitos e costumes, essa adopção, parece-nos, foi bem acertada, porquanto estas páginas estão escriptas em linguagem de uma singeleza encantadora e se esboçam nellas uns pequenos paineis tão seductores da attenção infantil, que as crianças não resistem á vontade de as lêr constantemente, em modo a poderem assimilar com proveito as lições ahi contidas (Bibliographia, 1909, p.2). 
Para concluir essa "biografia", afirma-se que, embora possa haver críticos que discordem desse ponto de vista sobre o livro Os nossos amigos, isso não acarreta nenhum prejuízo, pois, "[...] ademais, criticar a obra alheia é mais fácil, parece-nos, do que executá-la” (Bibliographia, 1909, p.2).

Em 1922, o jornal O Estado de S. Paulo voltou a publicar um novo texto sobre literatura infantil, de autoria de J. A. Nogueira, intitulado "Literatura infantil". Esse texto foi publicado no dia 28 de setembro de 1922 e, no ano seguinte, 1923, foi transcrito na seção "Revista e jornaes", da edição de n. 1 da Revista da Sociedade de Educação.

Partindo do relato de um professor que era contra a presença dos elementos fantásticos e maravilhosos nos livros destinados às crianças, Nogueira (1922a) apresenta um conjunto de argumentos contrários a esse entendimento da literatura infantil, pois, para ele, "[...] seria um crime e uma insensatez tentarmos desfeiar o mundo encantador em que vivem [as crianças] [...]” (Nogueira, 1922a, p.5).

Apesar de defender a presença dos elementos maravilhosos na literatura infantil, esse autor adverte que não é qualquer fantasia que se pode dirigir a esse público. As histórias maravilhosas adequadas ao público infantil são as que "[...] espelham a alegria e optimismo da infância" (p.5), como os livros Narizinho arrebitado e Fábulas, de Monteiro Lobato, e o livro Como se aprende a língua, de Sampaio Dória.

Ainda em 1922, J. A. Nogueira teve outro texto sobre literatura infantil publicado no jornal $O$ Estado de S. Paulo. Esse segundo texto, publicado no dia 30 de outubro de 1922, contém indícios de que se trata de uma continuidade das reflexões que esse autor apresentou no artigo anterior, porém essa informação não aparece de forma explícita.

Nogueira (1922b) apresenta um conjunto de considerações sobre o livro Narizinho arrebitado (1921), de Monteiro Lobato, e afirma que esse livro é "uma arte das mais belas", pois Lobato operou "[...] o milagre de reitegrar no ambiente das nossas escolas a leve revoada dos gênios e gnomos, das fadas inoffensivas e bondosas, dahi expulsas pelo espírito da velhice [...] que predomina em geral a organização dos jardins de infância e dos cursos primários” (Nogueira, 1922b, p.2).

Em relação ao modo como Lobato construiu o enredo de Narizinho arrebitado, afirma Nogueira (1922b) que a simplicidade desse livro não exclui o efeito "complexo" e "nebuloso", característicos do "antropomorfismo" 
presente no universo infantil. Também para ele, Lobato não deixou de lado os princípios educativos, como alguns críticos da época afirmavam. Com isso, conclui que Lobato, seguindo o exemplo de "Pelo de asno" ou "A bela e a fera”, apresenta uma "[...] corrente subterrânea de suggestiva moralidade, levando a alma da criança, segundo a bella phrase de Perrault: 'o desejo de espelhar-se nos que se tornam felizes e o temor das desgraças em que cahiram os maus por suas maldades'” (Nogueira, 1922b, p.2).

Ainda na década de 1950, no dia 6 de setembro de 1928, foi publicado no jornal Estado de S. Paulo o texto "Assunptos agrícolas - arvores milagrosas", de autoria de "O.F.". Esse texto trata da publicação de Árvores milagrosas, de Thales Castanho de Andrade, ${ }^{36}$ de modo a ressaltar a contribuição desse livro para ensinar os pequenos sobre minúcias de questões agrícolas. Nesse texto, o autor afirma que Thales de Andrade, "mestre distinto entre os de sua época”, contribuiu para preencher uma lacuna na "paupérrima literatura infantil" ao escrever Árvores milagrosas, descrito como "livrinho de propaganda da cultura da laranjeira".

Ainda nesse artigo de 1928, a partir de uma síntese de Árvores milagrosas e do estabelecimento de algumas relações entre o assunto tratado nesse livro e as questões agrícolas da segunda década do século XX, o autor afirma que Thales de Andrade, por meio de sua facilidade em falar às crianças, produziu um livro fundamental, sobretudo para os paulistas, cujo "sangue carrega o amor pela terra".

Na década de 1930, no dia 13 de setembro de 1938, o jornal Folha da Manhã, de São Paulo-SP, fez publicar o texto intitulado "O crime na literatura infantil”, de Celso Barroso. Esse autor apresenta argumentos contrários ao caminho pelo qual a literatura infantil da época estava enveredando, que era o da narração de histórias de aventuras criminosas, de assaltos, de assassinatos, de detetives e de gangsters. Ele entende que essa literatura, centrada nas narrativas de crime, podia resultar em um grande dano na alma infantil, mesmo levando em conta o princípio da psicologia, de que uma criança, quando imersa na criminalidade, tem possibilidade de formar um espírito elevado e justo.

36 As informações sobre Thales Castanho de Andrade serão dadas no Capítulo 3, deste livro, onde apresento um texto sobre literatura infantil de autoria desse escritor. 
Desse modo, para Barroso (1938), a "[...] literatura criminosa representa, na infância e no período da puberdade, um verdadeiro attentado às diretrizes da pedagogia, além de constituir para o Estado um elemento de desordem, e, para a sociedade, um instrumento de ódio e desarmonia" (1938, s.p.). A partir dessa compreensão, ele conclui com a defesa da ideia de que as autoridades nacionais precisavam interferir na produção dos livros de literatura "gangsteriana", como forma de evitar que as crianças leitoras dessas histórias não se tornassem adultos de alma corrompida.

No ano seguinte, em 1939, no dia 17 de dezembro, o jornal O Estado de S. Paulo voltou a publicar novo texto sobre literatura infantil: "Aspectos da literatura infantil", de Eurico Branco Ribeiro. Trata-se de "ligeiro artigo" enviado à seção "Cartas à Redação" desse jornal, escrito por ocasião da aproximação do Natal.

Em “Aspectos da literatura infantil”, Ribeiro (1939) afirma que o Natal faz recordar a atenção necessária que requerem as crianças para que se encaminhem de forma correta na vida. Por essa razão, ele "lança um golpe de vista" sobre a questão das leituras destinadas às crianças, como cartazes, jornais, revista e livros, os quais podem, segundo ele, exercer influências prejudiciais no desenvolvimento moral do pequeno leitor.

Em relação aos cartazes, normalmente expostos em lugares públicos, Ribeiro (1939) entende que eles, por vezes, eram constituídos por palavras ou expressões que podiam conduzir o espírito infantil para coisas para as quais ainda não estão preparados. No caso das revistas e jornais, com base em inquérito feito por Lourenço Filho, destaca os perigos que esse tipo de publicação pode oferecer, sobretudo pelas notícias de crimes e identificação de pessoas astuciosas e perigosas. Por isso, defende que era necessário submeter esses jornais e revistas a uma higienização no que se refere às notícias de crimes, para que então eles pudessem ser, de fato, úteis na formação das crianças.

Dados esses problemas que considera terem os cartazes, as revistas e os jornais, Ribeiro (1939) propõe que o tipo de leitura menos prejudicial para as crianças são os livros. Apresenta, no entanto, alguns requisitos a que as publicações infantis devem atender para que possam servir às necessidades infantis. O principal requisito, segundo Ribeiro (1939), a que um livro infantil deve atender é o referente à recreação, sem se esquecer da "união íntima" desse requisito com outro, o da educação. 
Ribeiro (1939) conclui o seu texto afirmando que: "Essas questões de literatura infantil seriam dignas de um pouco de estudo e meditação por parte de autores, editores e educadores e oxalá estas férias de Natal lhes dêm tempo para traçar uma orientação mais consentânea com as realidades da vida contemporânea" (Ribeiro, 1939, p.9).

$\mathrm{Na}$ edição do dia 24 de julho de 1940, o jornal O Estado de S. Paulo publicou o texto intitulado "Literatura infantil", de Amadeu Amaral Júnior. Esse texto, motivado pela passagem nos cinemas da versão cinematográfica de Viagens de Gulliver, contém algumas problematizações sobre o que esse autor considera serem as qualidades a que deve atender à literatura infantil.

Amaral Júnior (1940) afirma que a pergunta sobre quais são as qualidades de que depende o sucesso de um livro corresponde a uma pergunta ainda não satisfatoriamente respondida. "Ninguém pode dizer com segurança a causa da acceitação de alguns livros pelas crianças e a recusa de outros" (Amaral Júnior, 1940, p.4). No entanto, ao pensar nos livros recorrentemente aceitos pelas crianças, é possível notar que a questão da boa linguagem representa um aspecto fundamental para a boa aceitação por parte dos pequenos.

Além do bom trabalho com a linguagem, Amaral Júnior (1940), com base nas fichas de leitura que as crianças preenchiam na Biblioteca Infantil de São Paulo, afirma que a escolha adequada do assunto que compõe o enredo de um livro também é um aspecto importante na escolha das crianças. Juntamente com isso, destaca a simplicidade dos textos, que não significa ausência de ação, como forma de atrair o público infantil.

Tomando como base o livro Reinações de Narizinho, de Monteiro Lobato, Amaral Júnior (1940) afirma que esse escritor é o único que tem condições de agradar inteiramente o público infantil e, talvez, num futuro próximo ao seu, outros escritores, como Affonso Schmidt, também o tivessem.

Em 1941, foram publicados no jornal O Estado de S. Paulo três textos sobre literatura infantil, um de autoria de Jeronimo Monteiro e dois de autoria de J. O. Orlandi. Esse gradativo aumento de textos sobre literatura infantil nos jornais paulistas é indicativo, entre outros, do crescimento do interesse que esse assunto vinha despertando no público leitor em geral.

O primeiro desses textos de 1941 se intitula "Literatura para menores", de Jeronimo Monteiro, datado de 13 de agosto. Nele, esse autor problema- 
tiza o fato de algumas pessoas da época afirmarem que os livros de literatura infantil eram os grandes responsáveis pelo crescimento da delinquência entre os jovens, apesar de esse problema ser anterior ao aparecimento dos livros infantis.

Por essa razão, Monteiro (1941) acredita que esse tipo de afirmação tem "[...] um propósito deliberado em se aproveitar tais desagradáveis acontecimentos [de delinquência] para atacar a moderna literatura juvenil” (Monteiro, 1941, p.4). Para ele, a justificativa para os crimes que cometiam os jovens delinquentes não podia ser explicada apenas pelas leituras que esses faziam, sobretudo porque muitos deles não sabiam ler. O mais prudente era "[...] pesquisar as taras criminosas, a influência da hereditariedade, a existência de distúrbios morais e mentais" (p.4), para entender e descobrir as causas reais da delinquência infantil e juvenil.

Por discordar dessa associação entre literatura infantil e delinquência entre jovens, Monteiro (1941) afirma que os romances policiais ou narrativas de aventuras, não instigam para a criminalidade; pelo contrário, esses livros são "[...] doses de ensinamentos morais e que se devem, por necessidade de educação nesse mundo moderno, ministrar às crianças o mais amplamente possível” (Monteiro, 1941, p.4). Por isso, a literatura infantil é a melhor fonte dessa oposição, pois, por meio das lutas, do movimento e da vivacidade dos textos, as crianças "bebem" dos ensinamentos morais, de modo que o pequeno leitor grave o que deve e o que não deve fazer.

Para encerrar seu artigo, Monteiro (1941) chama a atenção do poder público com relação às publicações estrangeiras que chegavam ao país e que se destinavam às crianças, para que elas pudessem ser mais consistentes na formação da boa moral desse público leitor.

No dia 11 de outubro de 1941, O Estado de S. Paulo publicou o texto "De literatura infantil”, de J. O. Orlandi. Aproveitando a aproximação da comemoração do Natal e a exploração das livrarias com a venda de livros, esse autor comenta a variedade e a abundância desse tipo de literatura e ressalta a pouca adequação que grande parte deles tinha para esse público. $\mathrm{Na}$ maioria dos casos de inadequação dos livros infantis, o problema maior era a falta do "[...] colorido de uma linguagem familiar aos ouvidos e aos corações dos petizes” (Orlandi, 1941a, p.9). Isso não quer dizer, segundo ele, que faltavam aos livros estilos repletos de adjetivos, de períodos bem postos, primorosos do ponto de vista gramatical. Ainda que muitos defen- 
sores da gramática pensem dessa forma, Orlandi (1941a) considera que a escrita de um livro infantil que se assemelhe a um "cânone gramatical" o torna inacessível.

Por isso, quando trata da questão da linguagem, Orlandi (1941a) se refere a uma linguagem puramente nacional, que não entre em discordância com as normas gramaticais, mas que represente o falar e a sintaxe típicos do Brasil. Somente assim ele entende ser possível uma literatura infantil brasileira emotiva e interessante.

No dia 29 de outubro de 1941, em continuidade às reflexões que vinha formulando sobre a literatura infantil brasileira, J. O. Orlandi teve publicado outro texto no jornal $O$ Estado de S. Paulo, no qual afirma que, dos gêneros literários existentes no mundo, o mais traiçoeiro é a literatura infantil, seja a "[...] de pura ficção, da educativa ou da propriamente pedagógica" (Orlandi, 1941b, p.3). Isso se deve, segundo ele, à ilusória aparência de facilidade na escrita para crianças.

Orlandi (1941b) afirma que escrever para crianças é uma arte, a qual não é acessível para todos, apenas para os que têm "pendor" para ela. Nesse sentido, se não se levar em consideração esse aspecto, os livros para crianças recaem no mal fundamental da inadequação da linguagem e do assunto, e o efeito disso é que esse tipo de livro se constrói em torno de "artifícios efêmeros", de "engodo friável e momentâneo". O primordial na produção da literatura infantil é buscar escrever para crianças, de modo a compreender suas especificidades, e não apenas construir narrativas ou versos com gírias da "petizada", como comumente se fazia.

Com isso, esse autor conclui com a seguinte ressalva:

[Isso] não quer dizer que se deva escrever livro para crianças contendo somente tais coisas. Entretanto, aproveitando-se do seu interesse pelas lutas, far-se-á uso das que têm por fim a defesa dos fracos, a conquista de um objetivo humano. Dentro desse quadro, o literato encontrará matéria para escrever um livro interessante e que não choque no patrimônio moral e cívico. (Orlandi, 1941b, p.3)

Também em 1941, possivelmente em decorrência das reclamações, denúncias e apontamentos da má influência que certos livros de literatura infantil podiam ter na formação moral das crianças, o Ministério da Edu- 
cação tomou algumas providências em relação a esse problema, que foram relatadas em texto publicado no jornal Diário Popular, de São Paulo-SP.

Nesse texto, intitulado "Contra a má literatura infantil", afirma-se que o Ministério da Educação, diante das constantes denúncias contra a literatura de qualidade questionável, passou a aconselhar escritores e editoras na produção de livros de reconhecido valor cívico e instrutivo. Além desses aspectos, nesse texto publicado no Diário Popular em 1941 consta o relato das ações do Juiz de Menores de Manaus-AM, que criou no seu juizado o Serviço de Literatura infantil, para fiscalizar e controlar os livros que se davam para as crianças ler.

No ano seguinte, 1942, também no jornal Diário Popular, foi publicado o texto "Boas leituras para auxiliar a formação moral das crianças", sem autoria. Nesse texto, aborda-se a ausência de cuidado das Bibliotecas Municipais em relação ao que se disponibilizava, à época, para a leitura das crianças. Aproveitando que nesse período estava sendo construído o novo prédio para a Biblioteca Municipal de São Paulo, relata-se a história de uma criança, que em visita a uma biblioteca, tomou para leitura um livro considerado altamente pernicioso para sua formação, porque não havia orientação e cuidado sobre esse aspecto. Em vista disso, defende-se a construção de espaços adequados para as crianças utilizarem as bibliotecas, sobretudo para que se possa fiscalizar o que elas tomam para leitura.

Também em 1942, no dia 25 de dezembro, J. O. Orlandi teve publicado um outro texto no jornal $O$ Estado de S. Paulo, o qual se intitula "Livros, brinquedos etc." . Aproveitando, a exemplo de outros, as comemorações do Natal, esse autor problematiza a questão dos brinquedos e livros infantis, os quais geralmente abundavam nas vitrines de lojas e livrarias. Para ele, essas vitrines se tornavam verdadeiros caleidoscópios aos olhos infantis.

Em observação aos brinquedos mais recorrentemente comercializados, Orlandi (1942) explica que a maior parte se relaciona com o "festejo" do espírito guerreiro da humanidade, ou seja, remetem a combates e morticínio.

No caso dos livros, o que prevalecia eram os que tratam de fadas, reis e anões, quando internacionais. No caso da literatura nacional, as figuras do saci, do lobisomem e da onça era as mais recorrentes.

Ao pensar especificamente sobre a abundância dos livros e o assunto que abordavam, Orlandi (1942) explica que, apesar da variedade de formas, qualidade e categorias, poucos eram os livros de literatura infantil que 
mereciam essa classificação. Ou seja, apesar de abarrotadas as vitrines e do investimento das editoras na impressão da maior variedade possível de livros, ele explica que a caracterização da literatura infantil como um gênero literário pobre decorre da "[...] falta de uma 'corrente literária' que se orienta pela exploração desse manancial do modismo da língua no Brasil”" (Orlandi, 1942, p.2).

Orlandi (1942) conclui seu texto afirmando que o fato de se repetirem na literatura infantil as fórmulas já canonizadas cria certo modismo, pouco produtivo. Para ele, ainda se esperava na literatura infantil transformação e inovação.

Em 1943, no dia 23 de janeiro, Orlandi voltou a escrever para o jornal O Estado de S. Paulo, dessa vez para problematizar a iniciativa da Editora Melhoramentos de ter convidado o escritor Guilherme de Almeida para traduzir uma coleção de livros de literatura infantil.

Segundo Orlandi (1943), essa iniciativa da Melhoramentos, à primeira vista, parecia ter preocupação apenas comercial, pois dado o prestígio que o nome de Guilherme de Almeida representava à época, era muito provável que essa coleção obtivesse sucesso. No entanto, ainda que o interesse comercial tivesse, de fato, se sobressaído na decisão da Melhoramentos, Orlandi (1943) reconhece que a escolha por Guilherme de Almeida como tradutor dessa coleção foi bastante feliz, pois ele, como poucos, demonstrava "[...] habilidade funcional de acompanhar o espírito infantil na mais rudimentar curiosidade” (Orlandi, 1943, p.4).

Além dos elogios à escolha de Guilherme de Almeida para traduzir essa coleção de literatura infantil, Orlandi (1943) também destaca o papel primoroso da Melhoramentos na edição, ilustração e impressão dos livros dessa coleção. Segundo ele, esses são aspectos importantes, que enriquecem um livro de literatura infantil.

Ainda em janeiro de 1943, o italiano Angelo Patri, no texto intitulado "Dai livros à petizada", publicado em jornal cujo nome não consegui localizar, detém-se na questão da importância das leituras para crianças no contexto de guerra. Ele defende a ideia de que durante um período de guerra, quando se pensa em quais são as necessidades básicas de uma família, em hipótese nenhuma podem faltar os livros infantis. Para ele, é necessário que se reúnam todos os bons livros e garanta-se o acesso a eles por parte das crianças. 
Patri (1943) defende essa ideia, porque entende que a leitura de um livro pode ser para a criança, em meio ao contexto de uma guerra, uma forma de alívio e desafogo. Com isso, conclui que: "É de tanta importância fazer um estoque de bons livros para crianças [durante uma guerra], como comprar para os maiores o bom pão, a manteiga, o leite e os ovos necessários à alimentação. Hoje, os bons livros são uma necessidade realmente positiva para as crianças" (Patri, 1943, s.p.).

Em janeiro de 1945, o jornal Diário Popular, em decorrência da proximidade da realização do Congresso de Escritores Brasileiros, publicou o texto intitulado "Nocividade de certa literatura infantil", no qual apresenta a tese que a crítica literária Lúcia Miguel Pereira preparava para defender em sua exposição nesse Congresso.

Conforme consta nesse texto, cuja autoria não foi indicada, Lúcia Miguel Pereira iria suscitar discussão em torno da tese de que há na literatura infantil brasileira certa nocividade, a qual vinha "envenenando" a alma das crianças há algum tempo.

A relevância, à época, dessa tese formulada por Lúcia Miguel Pereira é explicada nesse texto da seguinte forma:

[..] lúcida ensaísta da mais bela e compreensiva monografia sobre Machado de Assis vai versar sobre um tema essencialmente digno das mais amplas atenções de todos os que compreendem a necessidade inadiável de zelar pela formação harmoniosa de nossas crianças. Com efeito, se é certo que nosso mercado está abarrotado de livros para crianças, também é incontestável que a conformação dessa leitura com o leitor a que a mesma se destina vem a ser um problema quase sempre descuidado. Em verdade se algum nome se pode dar à maior parte da bagagem literária destinada às crianças, parece ser irrazoável este: "literatura relativamente infantil". (Nocividade..., 1945, p.11)

Segundo consta nesse texto, para Lúcia Miguel Pereira, essa nocividade presente na literatura infantil se resguarda no fato de os escritores da literatura infantil fazerem dos seus leitores suas cobaias. Com isso, eles dão ao público livros de literatura infantil que de infantil não têm nada, exceto o "[...] padrão de linguagem próxima da linguagem dos primitivos" (Nocividade..., 1945, p.11). Por essa razão, com base no conjunto dos livros que havia disponíveis à época, afirma-se nesse texto que Lúcia Miguel Pereira 
considerava que apenas os de Monteiro Lobato, Paulo Ribeiro de Magalhães e os de mais três escritores cujos nomes não são revelados se configuram como verdadeiramente infantis. Isso se dava, para Lúcia Miguel Pereira, conforme se explica nesse texto, porque os:

[...] escritores souberam compreender, com sagacidade, o que é literatura infantil. Fizeram boa literatura para a pirralhada do Brasil. O resto (e na expressão "o resto" incluímos uma porção de fabricantes em série de borracheiras que de forma alguma deveriam andar nas mãos das crianças) ou se dedica àquela literatura relativamente infantil de que falamos ou faz coisa pior ainda: imita a má literatura infantil oriunda dos Estados Unidos, intermináveis histórias de bandidos de "gangsters" de G. Men - aventuras policiais que causam um mal imenso à formação espiritual da juventude. (Nocividade..., 1945, p.11)

Tendo em vista os problemas que apresentava a literatura infantil da época, esse texto do jornal Diário Popular apresenta a seguinte conclusão:

A tese da Sra. Lúcia Miguel Pereira é pois, de um enorme alcance moral e intelectual. Dar a esse trabalho a atenção que ele requer não é, nem pode ser apenas um dever dos autores, dos jornalistas e dos intelectuais. Deve ser uma obrigação e, principalmente, dos órgãos a que estão afetados os problemas atinentes aos menores. (Nocividade..., 1945, s.p.)

Ainda em janeiro de 1945, o jornal O Estado de S. Paulo publicou uma nota do Departamento de Educação do Estado de São Paulo, que trata da seleção de livros e jornais infantis e da organização de bibliotecas escolares. Embora essa nota não se configure como um texto, nos moldes dos demais aqui apresentados, ela contém informações importantes sobre como esse departamento vinha atuando no campo da literatura infantil, especialmente no que se refere às medidas tomadas em decorrência das crescentes acusações da má qualidade ou dos problemas presentes nos livros desse gênero literário.

Nessa nota, publicada no dia 16 de janeiro de 1945, com o título "O Departamento de Educação e a orientação pedagógica da infância”, afirma-se que um dos grandes problemas da educação da infância consistia, à época, na boa seleção de livros e jornais, na orientação dos livros didáticos e na 
formação de bibliotecas escolares. Por isso, o Departamento de Educação vinha buscando melhorar os seus métodos educacionais, "[...] no sentido de proporcionar à infância oportunidades para o seu desenvolvimento cultural" (O Departamento..., 1945, p.8).

Entre as medidas tomadas pelo Departamento de Educação, esclarece-se nessa nota que esse órgão, por meio do Serviço de Literatura Infantil, tinha passado a fiscalizar os livros infantis, para evitar a circulação de livros considerados prejudiciais à educação das crianças. Essa fiscalização se dava da seguinte forma: o Serviço de Literatura Infantil, cada vez que tinha um conjunto de livros para analisar, designava uma comissão de professores especializados, a qual emitia um parecer sobre o livro, de modo a observar: "[...] a propriedade da matéria ao fim que se propõe, a pureza da linguagem, a graduação, a ortografia etc.” (O Departamento..., 1945, p.8). Depois de avaliados e emitidos os pareceres, os livros aprovados eram indicados na relação dos livros que poderiam ser adotados nas escolas públicas do estado de São Paulo. No entanto, para que isso ocorresse, havia uma exigência quanto ao preço dos livros. Eles não podiam exceder um limite, não explicitado, de forma a garantir que o orçamento do Departamento de Educação não fosse comprometido.

Explica-se ainda nessa nota que o Serviço de Literatura Infantil também se encarregava do "julgamento" dos livros didáticos, das revistas e dos jornais infantis e desenvolvia atividades de orientação voltadas à constituição e ao funcionamento de bibliotecas escolares. E se conclui que, apesar das dificuldades que existiam em torno desse gênero literário, o Serviço de Literatura Infantil, "[...] pelo alto sentido social das suas atividades, [vinha] contribuindo de forma valiosa para o aperfeiçoamento moral de nossa juventude, na obra grandiosa da criação de um Brasil Novo" (O Departamento..., 1945, p.8).

Também em 1945, no dia 14 de novembro, o jornal O Estado de S. Paulo publicou o texto "A literatura infantil na formação do caráter humano", de Genesio Pereira Filho. Esse autor defende a ideia de que a escrita da literatura infantil não pode ser atividade desenvolvida ao "bel prazer" dos adultos. Esse é, para ele, um ato "criminoso", pois o livro infantil que não respeita os princípios da Psicologia atrapalha a construção de uma "mente sadia" por parte da criança. 
Tendo vivenciado o momento histórico da Segunda Guerra Mundial, Pereira Filho (1945) entende que a responsabilidade dos adultos é deixar para as crianças um mundo melhor, para que elas não venham a testemunhar épocas de "miséria", "traições" e "lutas truculentas", como se vivenciava. Segundo ele, no caminho para a construção desse mundo melhor cabe à Educação papel destacado, pois: “[...] Do seio de uma nação culta, não nascerão tiranos; um povo culto não será oprimido. Só a educação gera a consciência da liberdade" (Pereira Filho, 1945, p.6).

Por entender que os destinos das crianças são traçados desde o berço, Pereira Filho (1945) afirma que as cenas vividas na infância são guardadas para sempre na memória das pessoas, dependendo disso a formação de um sujeito "pessimista" ou "otimista", "sadio mentalmente" ou não. É por isso que o que se vivencia na educação escolar e familiar é considerado por ele tão importante. Em vista dessa concepção, ele explicita uma tese psicológica sobre os períodos de formação da mentalidade infantil, dividida em três fases. A primeira é conhecida como fase do "egoísmo" e é aquela em que a criança se projeta em tudo e em todos. A segunda fase é a em que o mundo exterior começa a ganhar autonomia na visão da criança, mas a figura do eu infantil ainda está muito presente. A terceira fase é a chamada de "juvenil", porque é nela que o interesse objetivo começa a existir na criança, de modo que essa se veja menos presente nos seres e nas coisas.

Com base nessa tese psicológica, Pereira Filho (1945) apresenta algumas orientações no que concerne à adequação da literatura infantil às fases do desenvolvimento mental da criança, pois para ele é somente dessa forma que se podem ter livros de literatura infantil que de fato ajudem na boa formação da criança.

Ainda segundo Pereira Filho (1945), quando a criança está na fase do "egoísmo", os livros mais adequados são os das histórias maravilhosas. "Sem preocupação de lógica ou de conclusões morais. Estas devem ser tácitas e diluídas na própria história, pois a criança, sem o mecanismo do raciocínio ainda formado, somente mais tarde 'encontrará' a razão de ser da fábula" (Pereira Filho, 1945, p.6). Na fase de transição e na fase "juvenil", conforme a criança vai crescendo e adquirindo preocupação com o mundo objetivo, esse autor afirma que é necessário retirar as histórias maravilhosas e oferecer uma literatura "hígida", com a qual a criança possa "[...] desco- 
brir que há um destino superior para cada homem e que para cada um existe uma grande missão" (Pereira Filho, 1945, p.6).

A partir desse ponto de vista, conclui que, com "honrosas exceções", a literatura infantil brasileira peca por não conhecer as fases da formação da mentalidade infantil, "[...] não discernindo dos vários campos de exigências do espírito da criança” (p.6). Para ele, entre os poucos escritores que não cometem esse "pecado", encontra-se Francisco Marins, que "[...] com simplicidade de estilo e justeza de conceitos, dá interesse real à história" (Pereira Filho, 1945, p.6). Por essa razão, a obra desse autor merece "calorosos aplausos".

\section{Sistematização dos saberes sobre a literatura infantil brasileira: Lourenço Filho}

Na década de 1940, concomitantemente à publicação de alguns desses textos em jornais, o educador, administrador e psicólogo Manoel Bergströn Lourenço Filho ${ }^{37}$ teve publicado o artigo "Como aperfeiçoar a literatura infantil”" ${ }^{38}$, resultante de conferência que proferiu na Academia Brasileira de Letras.

Nesse artigo, datado de 1943 e publicado na Revista Brasileira, Lourenço Filho, como explica Bertoletti (2006), sob a forte marca da Psicologia e

37 Nascido em Porto Ferreira-SP, em 1897, Manoel Bergström Lourenço Filho se formou professor pela Escola Normal de Pirassununga, em 1914, e pela Escola Normal Secundára da Capital, em 1917. Ao longo de sua atuação profissional, ocupou cargos como: chefe da Instrução Pública do Ceará; professor de Psicologia da Escola Normal de São Paulo; delegado de ensino, em São Paulo; diretor do Instituto de Educação do Distrito Federal; reitor da Universidade do Distrito Federal; membro do Conselho Nacional de Educação; presidente da Comissão Nacional do ensino primário; diretor do Departamento Nacional de Educação; presidente da Comissão Nacional para a elaboração da LDB (Lei de Diretrizes e Bases da Educação Nacional); e presidente do Instituto Brasileiro de Educação, Ciência e Cultura (Ibecc), da Unesco. Além de ter ocupado esses cargos, Lourenço Filho é autor de importantes livros e textos sobre Educação (Monarcha; Lourenço Filho, 2001).

38 Esse artigo de Lourenço Filho, bem como toda a sua produção de e sobre literatura infantil desse educador, foi exaustivamente analisado por Bertoletti (2006; 2012). Por isso, apenas sintetizo alguns aspectos do conteúdo desse artigo, a fim de situá-lo no processo de construção de um saber sobre a literatura infantil. 
das ideias escolanovistas, ${ }^{39}$ busca sistematizar, de forma pioneira, o conhecimento disperso sobre a literatura infantil que circulava no Brasil. Para tanto, ele organiza seu artigo em torno da apresentação de uma história da literatura infantil e busca formular princípios teóricos e críticos aplicados a esse gênero literário. Bertoletti (2006) considera que esse artigo de Lourenço Filho foi responsável por fundar uma tradição no campo da literatura infantil, a qual influenciou a formação de diferentes gerações.

Por isso, Bertoletti (2006) e Mortatti (2008) entendem que esse artigo, no conjunto dos primeiros discursos sobre a literatura infantil brasileira, ocupa lugar de destaque, pois nele se encontra a base de uma primeira sistematização dos dispersos saberes que vinham sendo divulgados e disseminados a respeito do assunto.

Em Como aperfeiçoar a literatura infantil", Lourenço Filho (1943) inicia sua argumentação apresentando um resumo do histórico desse gênero literário na Europa e destaca a sua oscilação entre a "literatura didática", característica da escola, e a "literatura infantil", entendida como Arte e a qual contribui para a formação do espírito da criança.

Especificamente sobre o histórico da literatura infantil brasileira, Lourenço Filho (1943) destaca a origem dessa produção nos livros didáticos e nas traduções e adaptações publicadas no final do século XIX. Para ele, até 1894, quando foi publicado Contos da Carochinha, traduzido e adaptado por Figueiredo Pimentel, as crianças brasileiras apenas conheciam os livros escolares. Depois disso, aos poucos é que foram aparecendo traduções,

39 O Escolanovismo ou Movimento da Escola Nova teve início, no Brasil, a partir da década de 1920, quando diferentes educadores passaram a "[...] considerar novos problemas [educacionais], tentando solvê-los com a aplicação de recentes descobertas relativas ao desenvolvimento da criança [...]” (Lourenço Filho, 1978, p. 17). Em 1933, as ideias que motivaram esse movimento foram sintetizadas no documento "O manifesto dos pioneiros da educação nova”, assinado por 26 intelectuais brasileiros. Conforme explica Lourenço Filho (1978), o nome "Escola Nova" se refere a um amplo movimento, que não diz respeito "[...] a um só tipo de escola, ou sistema didático determinado, mas a todo um conjunto de princípios tendentes a rever as formas tradicionais do ensino. Inicialmente, esses princípios derivam de uma nova compreensão de necessidades da infância, inspirada em conclusões de estudos da biologia e da psicologia. Mas alargaram-se depois, relacionando-se com outros muito numerosos, relativos às funções da escola em face de novas exigências, derivadas de mudanças da vida social. (p. 17). Sobre o movimento da Escola Nova, no Brasil, ver, especialmente, Lourenço Filho (1978), Cunha (1995) e Saviani (2008). 
adaptações e obras originais, que constituem uma produção mais planejada da literatura infantil brasileira.

Nesse processo de constituição da literatura infantil brasileira, Lourenço Filho (1943) entende que a publicação, em 1921, do livro Narizinho arrebitado: segundo livro de leitura para uso das escolas primárias, de Monteiro Lobato, foi responsável pelo "aparecimento" de uma nova época na produção dos livros para crianças no Brasil.

A partir desse livro e com o subsequente crescimento da produção de obras originais e a especialização dos escritores, entre as décadas de 1920 e 1940, Lourenço Filho (1943) afirma se iniciar um estágio da literatura infantil brasileira propriamente dita, coerente com os anseios do país.

Como na fase anterior se teria processado marcada distinção entre "leitura escolar" e "leitura recreativa", diferencia-se agora a produção para as várias idades, separando-se a literatura pròpriamente "infantil" da "juvenil”; e, ainda, dentro desta, as das idades de "pre-leitura", dominada pelos álbuns de gravuras, hoje numerosos; a da idade escolar inicial, especialmente atendida pelos contos de fada; as de idade mais avançada, em que se admitem quer com o fim de mera recreação, quer com os de iniciação ao estudo literário, livros de gêneros variados, como aventuras, narrativas de viagens, biografias romanceadas, romances históricos, e a adaptação de grandes obras primas. (Lourenço Filho, 1943, p.153)

Com o advento dessa nova "época" da literatura infantil, esse educador, psicólogo e administrador afirma ter crescido o interesse dos educadores e administradores da educação por esse tipo de publicação, de modo que passaram a serem publicados diferentes textos sobre o assunto. Também explica que o interesse pela literatura infantil crescera a tal ponto que em 1936 o Ministério da Educação, sob a gestão de Gustavo Capanema, criou a Comissão Nacional de Literatura Infantil para incentivar, fiscalizar e orientar a produção desse gênero literário. ${ }^{40}$

A partir do resumo histórico da literatura infantil, Lourenço Filho (1943) detém-se à conceituação desse gênero literário, uma vez que, se-

40 Sobre a Comissão Nacional de Literatura Infantil ver, especialmente, Bertoletti (2006) e Costa (2011). 
gundo ele, a expressão "literatura infantil" possibilita "[...] compreensão lata de todo material de letras produzido para o uso de crianças" (Lourenço Filho, 1943, p.155).

Para esse educador, psicólogo e administrador é possível distinguir o que recorrentemente se chamava de "literatura infantil" em dois tipos de textos: a "literatura didática", que se destinava ao uso de crianças na escolarização; e a "literatura infantil" propriamente dita, que consiste em "expressão de Arte", cuja finalidade é a transmissão do belo, sem fins didáticos diretos.

Com essa distinção, embora ele defenda a compreensão da "literatura infantil" como "expressão da Arte", sem fins didáticos diretos, ressalta que é evidente que essa literatura pode e deve ser objeto de ensino, oferecendo "[...] manancial para exercícios escolares" (p.156). Para ele, a literatura infantil, que tem como finalidade a emoção estética "necessariamente desinteressada", pode e deve servir a um fim prático. O que distingue a "literatura infantil" da "literatura didática" é a intencionalidade, pois a "literatura didática" é produzida para ensinar, ao passo que a "literatura infantil” é produzida para exprimir o belo - serve para o ensino, mas não é seu propósito primeiro.

Ainda com base nessa distinção entre "literatura infantil" e "literatura didática", Lourenço Filho (1943) defende a hipótese de que a "literatura infantil” contém uma especificidade, que é conferida pelo leitor também específico a que se destina. Para ele, aceitar a existência de uma literatura específica para as crianças é aceitar a sua direta relação com os níveis da evolução psicológica infantil, pois é esse aspecto que possibilita a comunicabilidade do belo para a criança.

Sobre essa relação entre a literatura infantil e o desenvolvimento psicológico da criança, ele explica que:

A compreensão artística da literatura infantil demanda, portanto, a aceitação de uma estética "evolutiva”, ou genética, a ser estudada ou, ao menos, sentida pelos que escrevem para crianças. E como, também necessariamente, êsse desenvolvimento estético se relaciona com as demais evolução psicológica da criança, e, em particular, com a de sua formação estática [...] segue-se que o livro para crianças, embora aspire, por si mesmo, apenas ao belo, mas o belo das idades infantis, torna-se, queiramos ou não, instrumento de profunda ação educativa. (p.157) 
Com base nessa hipótese, esse educador, psicólogo e administrador apresenta quatro funções a que a literatura infantil deve servir, sobretudo do ponto de vista de sua contribuição para o desenvolvimento psicológico infantil. A primeira dessas funções é a da "contenção estética" voltada para o deleite do espírito. A segunda é a da leitura como "recreação", entendido o conceito de recreação como "criar de novo", "renascer". A terceira é de transmissão de uma "lição permanente de linguagem". E a quarta e última é a sugestão do belo, que "[...] concorre para a formação do gôsto artístico; [que] coopera no equilíbrio emocional da criança; dá-lhe horas de sadio entretenimento e de libertação espiritual; faz amar o idioma nacional; desperta o gôsto literário, [...]; e [...] prepara o consumidor das belas letras no homem futuro" (Lourenço Filho, 1943, p.160).

Além de conceituar e explicitar as funções da literatura infantil, por entender que esse gênero literário é um domínio especial da literatura, ele elenca e problematiza as diferentes modalidades de textos que integram a produção literária para crianças. Para ele, o material destinado ao público infantil e que se enquadra na literatura infantil são: álbuns de gravuras; contos de fadas e narrativas simples; narrativas longas; histórias de viagens e aventuras; e biografias romanceadas.

$\mathrm{Na}$ medida em que apresenta essas modalidades da literatura infantil, Lourenço Filho (1943) destaca a sua destinação e adequação às diferentes fases do desenvolvimento psicológico/mental da criança.

Em cada modalidade referida, certos aspectos peculiares ao desenvolvimento mental e emocional da idade, ao nível da linguagem, ao movimento da narrativa, por cento que deverão ser considerados. Intuição psicológica, conhecimento geral da psicologia infantil. Nenhuma receita específica, porém, poderá ser fixada, à vista da qual um autor medíocre possa tornar-se o artista que todo e qualquer gênero reclama. (Lourenço Filho, 1943, p.163)

Definidos os princípios teóricos, o conceito, as funções e a classificação da literatura infantil, Lourenço Filho (1943) se detém num balanço da "situação" desse gênero literário no Brasil e apresenta alguns elementos necessários para a melhora dessa "situação". Em relação ao balanço da produção de literatura infantil, informa que, pelo último levantamento que fizera das obras editadas no Brasil, até o ano de 1942 haviam sido publicados 605 
livros, dos quais 434 eram traduções, adaptações e "grosseiras imitações" de livros estrangeiros. Entre os 171 livros originais, de autoria de escritores brasileiros, segundo ele, metade era de "[...] medíocre qualidade, quer pela concepção e estrutura, quer também pela linguagem" (Lourenço Filho, 1943, p.164). Desse modo, não mais que a metade dos livros publicados no Brasil até a década de 1940 podia integrar acervos de bibliotecas infantis, se fossem devidamente "apurados" no que se refere à "forma" e ao "fundo".

Apesar dessa situação, ele não deixa de reconhecer o esforço de escritores e editoras que se vinham empenhando no "progresso" de melhores resultados em relação à literatura infantil, que já era visível. No entanto, para que esse "progresso" necessário e desejável da literatura infantil fosse maior e mais rápido, o que faltava era disseminar melhor a adequada conceituação desse gênero literário. Além disso, faltavam “[...] medidas sistemáticas tendentes à sua elevação, ou 'significação social', [...] que encorajem maior número de autores de alta qualificação a se juntar aos que, do mesmo valor, de modo continuado ou acidentalmente, tenham já dedicado a necessária atenção ao assunto" (Lourenço Filho, 1943, p.165).

Com essa argumentação, Lourenço Filho (1943) explica que o convite que recebeu para tratar do assunto em Conferência na Academia Brasileira de Letras resultou do interesse do então presidente dessa Academia, José Carlos de Macedo, de incentivar e promover a valorização da literatura infantil. Visando, então, colaborar com esse interesse da Academia Brasileira de Letras, esse educador, psicólogo e administrador indica algumas providências que essa instituição deveria tomar, "[...] para segurança dos objetivos que a Ilustre Companhia tem em vista” (p.166). No âmbito das medidas, ele propõe: realização de palestras e conferências anuais, publicação de folhetos, organização de biblioteca especializada na Academia, incentivo a investigações sobre o assunto e dotação, pela Academia, de traduções das obras-primas da literatura infantil. Também recomenda medidas de estímulo a autores nacionais, realizados mediante concursos nacionais e atribuição de prêmios, e medidas de estímulo a editores e ilustradores, mediante atribuição de prêmios a editora e ilustradores, e também aquisição, pela Academia, de milheiro de exemplares dos livros premiados. Por fim, Lourenço Filho (1943) recomenda que a Academia Brasileira de Letras promova incentivo e oferte patrocínio para a realização de exposições sobre a literatura infantil. 


\section{O movimento de formação de saberes sobre a literatura infantil: delineando alguns sentidos}

Ainda que a delimitação cronológica privilegiada, neste livro, tenha seu marco inicial em 1947, optei por abordar os primeiros discursos brasileiros sobre a literatura infantil, publicados entre o fim do século XIX e a primeira metade do século XX, porque com eles busco compreender como se deu o movimento de formação de saberes sobre esse gênero literário e que relações eles estabelecem com o movimento de construção de um saber escolar, a partir de 1947.

Ao considerar que esses primeiros discursos representam o movimento de formação de saberes sobre a literatura infantil, entendo que neles estão materializadas as primeiras formulações brasileiras sobre o assunto. Essas formulações contribuíram para formar um conjunto de saberes, que gradativamente foi sendo retomado, ampliado, contestado e reformulado por diferentes gerações. Desse modo, ainda que por vezes divergentes entre si, em tom às vezes opinativo (no sentido de não terem pretensões teóricas) ou visando apenas a apresentar ou propagandear livros específicos, esses discursos estão na base dos modos como se deu a conhecer a literatura infantil, no Brasil,

Em vista disso, ao tratar da ideia de formação de saberes sobre a literatura infantil por meio dos textos aqui sintetizados, utilizo o conceito de "formação" conforme proposto por Candido (2009). ${ }^{41}$ Esse conceito, resguardadas as diferenças de objeto e propósitos de pesquisa, no caso em que aqui é tomado, alude ao movimento em direção: à existência de um conjunto de sujeitos, mais ou menos conscientes de seu papel, envolvidos na produção escrita sobre a literatura infantil; a um conjunto de "consumidores" dessa produção escrita (no caso, pais, professores e população em geral), formando diferentes públicos a que se destina; a mecanismos de transmissão, acesso e consumo dessa produção (jornais, revistas, livros etc.); e a linguagem e formatação textual específicas (Candido, 2009). Ou seja, com base no conceito de "formação" de Candido (2009), quando trato

41 Candido (2009), quando formula o conceito de "formação", o faz para se referir ao sistema literário brasileiro. Ainda que se trate de objetos diferentes - formação de um sistema literário e formação de um saber cultural -, entendo que esse conceito ajuda a entender o movimento em direção à sistematização do conhecimento, de um saber sobre a literatura infantil no Brasil. 
da formação de saberes sobre a literatura infantil, refiro-me ao movimento em que alguns sujeitos passaram a se dedicar à produção escrita sobre esse gênero literário ao mesmo tempo que se foi formando certo público consumidor desses textos, tendo em vista meios/suportes específicos em que foram dados a ler (Chartier, 1990a).

Nesse sentido, se os primeiros textos sobre literatura infantil não foram produzidos com a intencionalidade de tratar especificamente desse gênero literário, como é o caso dos prefácios, apresentações e prólogos, posteriormente, já se nota uma destinação específica dos textos, visando a certo público e circulação por meio de determinados suportes.

Pensando especificamente nesse movimento de formação da literatura infantil, é possível observar, conforme as sínteses apresentadas neste capítulo, que esse gênero literário foi, gradativamente, tornando-se assunto de interesse específico de professores e sujeitos ligados ao cenário educacional brasileiro. Por ser a escola o lugar privilegiado de circulação dos livros de literatura infantil, foram, de modo geral, as pessoas ligadas a essa instituição e às práticas que nela se desenvolviam que se debruçaram com maior empenho na tentativa de compreender e sistematizar os saberes sobre literatura infantil.

De modo geral, os textos sobre literatura infantil aqui apresentados buscam enfatizar as contribuições ou "denunciar" os riscos que alguns livros representavam para a formação moral das crianças em fase de escolarização. No entanto, observa-se que os sentidos dados a essa noção de "formação moral", do que podia ou não ser considerado literatura infantil ou, ainda, quais eram os elementos prejudicais ou benéficos desse tipo de produção literária se foi alterando entre o final do século XIX e as quatro primeiras décadas do século XX.

No caso dos primeiros discursos sobre a literatura infantil, os prefácios, apresentações e prólogos, o que se identifica são textos de ordem menos sistematizada, cujo enfoque está, sobretudo, nos requisitos que os livros apresentavam (ou deveriam apresentar) e que se adequavam ao público leitor previsto. De modo geral, por terem sido escritos por sujeitos ligados ao campo da literatura ou pelos escritores, esses prefácios, prólogos e apresentações buscam enfatizar as qualidades literárias de um texto para criança, conforme concepções da época em que foram publicados. 
Ainda no final do século XIX, uma dessas apresentações de livros sinaliza um primeiro movimento de mudança de concepção em torno da literatura infantil, especialmente das bases de conhecimento que sustentariam, num futuro próximo, a compreensão desse fenômeno literário.

Em 1897, quando Gabriel Prestes prefacia o livro de Zalina Rolim, Livro das crianças, sua ênfase, como então diretor da Escola Normal de São Paulo, deixa de ser a formação da boa moral, do bom cidadão, para chamar a atenção às contribuições que a obra dava para o ensino da linguagem, os exercícios de recitação, a leitura expressiva e o uso da ilustração como forma de construção oral de descrições. Ou seja, esse prefácio de 1897 de Gabriel Prestes indica certo deslocamento do entendimento a respeito da literatura infantil de uma área mais opinativa, sob a forma quase de resenha, para uma tentativa de associar esse gênero literário ao ensino escolar, do ponto de vista dos métodos de ensino. Esse deslocamento se configura com maior solidez nos textos da segunda década do século XX, especialmente, os de Alexina de Magalhães Pinto (1917), Antônio de Sampaio Dória (1918), Afrânio Peixoto (1923) e Alceu Amoroso Lima (1927).

No primeiro, Alexina de Magalhães Pinto (1917), ao explicar os critérios que adotou para formar um "esboço" de biblioteca infantil, enfatiza a escolha de livros ilustrados para, por exemplo, treinar a "audição" e "análise de imagens", como forma de as crianças aprenderem a ler e escrever. Ainda que ela não faça em seu texto uma associação direta com o método intuitivo, é possível presumir que o destaque que dá aos livros ilustrados tenha relação com os pressupostos desse método, no qual a criança, antes de aprender uma lição, analisa e descreve, decompondo em partes, oralmente, a estampa apresentada. ${ }^{42}$

Essa relação entre literatura infantil e métodos de ensino apenas sugerida no texto de Alexina de Magalhães Pinto (1917) é abordada como eixo central da argumentação de Sampaio Dória, em seu artigo publicado na Revista de Ensino, em 1918. Nesse artigo, Sampaio Dória (1918) associa a chamada "literatura didática" ao método intuitivo e ao método analítico, de modo que o que pode ser considerado como um bom livro de literatura para crianças é o livro que propicia a aprendizagem de forma "intuitivo-analítica".

42 Sobre os métodos de ensino de leitura, ver, especialmente, Mortatti (2000b). 
Nos dois textos subsequentes, de Afrânio Peixoto (1923) e Alceu Amoroso Lima (1927), embora não tratem explicitamente da associação da literatura infantil a um método de ensino, ambos buscam situar esse gênero literário na formação escolar das crianças. Daí a preocupação também de ambos em identificar quais são os principais elementos literários e textuais que devem conter os livros de literatura infantil em função do ensino escolar.

Nesses textos publicados no início do século XX, o que se observa, portanto, é que pensar sobre a literatura infantil era pensar sobre a sua relação (e adequação) com métodos de ensino. Ainda que as questões morais, a representação do fantástico e o uso de formas "simples" e "objetivas" na escrita literária fossem destacadas como primordiais, elas eram em função, especialmente, do propósito de se ensinar.

Na continuidade da produção sobre literatura infantil, na década de 1940, especialmente nos artigos publicados em revistas especializadas, é possível notar um novo deslocamento do lugar de onde se fala a respeito desse gênero literário. Nos textos publicados nessa década, nota-se que as questões da psicologia do desenvolvimento, especialmente de base experimental, foram-se tornando a base das reflexões sobre literatura infantil. Exemplo disso são as investigações executadas pelo Laboratório de Psicologia da Faculdade de Filosofia, Ciências e Letras da Universidade de São Paulo e pelo Inep, que resultaram em artigos publicados na Revista do Arquivo Municipal e na Revista Brasileira de Estudos Pedagógicos, respectivamente.

Em relação aos textos em jornais, publicados entre o fim da década de 1930 e a década de 1940, coerentemente com o suporte no qual foram publicados, o enfoque não se deu de forma tão estruturada, como resultado de uma investigação. No entanto, isso não significa que as questões da Psicologia não estejam na base da argumentação dos textos sobre literatura infantil. Pelo contrário, a questão mais recorrentemente tratada nos textos em jornais se refere à boa ou má influência dos livros de literatura infantil na formação de uma "mente sã". O que fez que questões sobre criminalidade, vandalismo infantil, formação de sujeitos não inclinados para guerra e conflitos fossem questionadas se se associavam, ou não, à literatura infantil.

Nesse sentido, apesar de a questão moral também estar presente nos discursos sobre a literatura infantil da década de 1940, é possível afirmar 
que não se trata de uma moralidade com o mesmo sentido que a dos textos do século XIX.

Nos prefácios, prólogos e apresentações, quando a questão moral é tocada, isso se dá muito mais no sentido da formação de valores ligados ao convívio social, de preparação das crianças para agirem conforme se considerava adequado socialmente, num sentido mais rousseauniano. No caso dos textos publicados na década de 1940, sobretudo pela difusão cada vez maior da Psicologia, quando se trata da questão moral ou da formação da "mente sã", os autores desses textos parecem se referir muito mais à questão de formação do caráter, da personalidade infantil, que implica o seu comportamento futuro, quando adulto. Ou seja, de uma noção mais ligada às regras sociais, observa-se a mudança para uma noção de moralidade que se aproxima da questão psicológica-comportamental.

É possível presumir que essa associação entre literatura infantil e Psicologia esteve intimamente ligada ao processo de "psicologização" do ensino, que ganhou forças no Brasil com o movimento da Escola Nova. Esse aspecto é possível de se presumir especialmente porque eram pessoas ligadas à educação, alguns dos quais ao movimento escolanovista, como Lourenço Filho, que na primeira metade do século XX estava à frente da produção sobre literatura infantil.

Em linhas gerais, o que se pode notar, portanto, é que o movimento de formação de saberes sobre a literatura infantil, acompanhando também o movimento do campo educacional brasileiro, origina-se como um saber não sistematizado. A partir disso, na medida em que se amplia a produção e consumo dos livros de literatura infantil, a produção sobre esses livros também ganha mais consistência, de modo a buscar amparo nas bases "científicas" dos métodos de ensino, e, depois, nas bases "científicas" da psicologia do desenvolvimento, de base experimental.

A partir da década de 1940, são esses saberes sobre a literatura infantil, que se encontram materializados discursivamente nos prefácios, artigos em revistas especializadas e textos em jornais de notícias, que vão concorrer para a formulação de um saber escolar em relação a esse assunto. 


\section{2 \\ A INSTITUCIONALIZAÇÃO DO ENSINO DA LITERATURA INFANTIL NA FORMAÇÃO DE PROFESSORES: A CRIAÇÃO DE UMA MATÉRIA DE ENSINO (1947-1956)}

\section{O Ensino Normal paulista e a matéria "Literatura infantil"}

A partir da década de 1940, conforme Lourenço Filho (1943) assinala em "Como aperfeiçoar a literatura infantil”, a produção literária voltada ao público infantil vinha crescendo de forma bastante acentuada, sobretudo se comparada à produção do final do século XIX e primeiras décadas do século XX.

Lajolo e Zilberman (1984) afirmam que esse crescimento da produção de livros de literatura infantil, que resultou em produção intensa e fabricação em série desse tipo de livro, esteve relacionado ao processo de profissionalização e especialização de editoras e escritores, bem como do aumento significativo do mercado consumidor. Com isso, observam essas autoras que, a partir da década de 1940, a "[...] indústria do livro para crianças se firmara como consequência do trabalho da geração modernista. Para os autores novos, a tarefa não era mais a de conquistar um mercado, mas de mantê-lo cativo e interessado" (Lajolo; Zilberman, 1984, p.86).

O crescimento acentuado da produção de livros de literatura infantil a partir da década de 1940 foi registrado, por exemplo, na publicação, em 1953, da Bibliografia de literatura infantil em língua portuguesa, organizada por Lenyra Fraccaroli, ${ }^{1}$ então chefe da Divisão de Bibliotecas Infantoju-

1 Nascida em 1906, segundo Coelho (1983) em Rio Claro-SP, e segundo Mello (1954) em Anápolis-GO, Lenyra de Arruda Camargo Fraccaroli realizou seus estudos primários em 
venis de São Paulo. ${ }^{2}$ Nessa bibliografia, consta a indicação de mais de dois mil títulos, considerados por essa autora como livros de literatura infantil. Fraccaroli (1953) organizou essas indicações em quatro seções, cada uma referente à faixa etária do público a que cada livro se destina, a saber: de 3 a 6 anos; de 7 a 9 anos; de 10 a 12 anos; e de 13 a 15 anos.

Concomitantemente ao crescimento da produção dos livros de literatura infantil, também a produção sobre esse gênero literário aumentou, de modo que, dos primeiros textos "esparsos" e "episódicos" (Magnani, 1998) do final do século XIX, na década de 1940 se observa produção mais consistente, que contava, entre 1930 e 1945, com 20 textos em jornais.

Nesse contexto, possivelmente em função do crescimento da produção de livros e também como decorrência de um acúmulo maior de conhecimento sobre o assunto, o governo do estado de São Paulo desenvolveu algumas iniciativas relacionadas à literatura infantil. Entre elas, a criação de uma Lei, ${ }^{3}$ que designou a criação da "Comissão Orientadora de Literatura Infanto-juvenil”, que tinha como finalidade "[...] investigar, colher dados e apresentar conclusões opinativas ao Secretário da Educação, sobre a literatura considerada nociva à mentalidade infantil e juvenil” (São Paulo, 1948, p.1).

Rio Claro e, em 1932, diplomou-se professora pela Escola Normal Caetano de Campos, na capital paulista, onde atuou na organização da Biblioteca Infantil e como Inspetora escolar por dois anos. Após se diplomar professora, em 1935, Lenyra Fraccaroli foi convidada pelo Departamento de Cultura da Prefeitura Municipal para organizar a primeira Biblioteca Infantil do Estado de São Paulo, atual Biblioteca Infantil Monteiro Lobato. Na década de 1940, diplomou-se em Biblioteconomia pela Faculdade de Sociologia de São Paulo (Mello, 1954). Entre suas diferentes atuações, Lenyra Fraccaroli participou da criação do Centro de Estudos de Literatura Infantil e Juvenil (Celiju) e da criação da Academia Brasileira de Literatura Infantil e Juvenil, ambas na cidade de São Paulo. Lenyra Fraccaroli faleceu na capital paulista, em 1991.

2 A Divisão de Bibliotecas Infantojuvenis de São Paulo era um órgão ligado do Departamento de Cultura do município de São Paulo, responsável pela administração das bibliotecas destinadas ao público infantil, instaladas na capital paulista.

3 A Lei estadual n. 171, de 11 de outubro de 1948, define que a Comissão Orientadora de Literatura Infantojuvenil seria formada por cinco membros, três nomeados pelo governo e dois nomeados por instituições ligadas à literatura infantil. A função principal dessa comissão era denunciar ao secretário de Educação a publicação de livros nocivos e esse, por sua vez, encaminharia a denúncia para as autoridades competentes. Essa Lei previa também que a comissão deveria formular um estatuto, no qual se preveria, entre outras coisas, a organização de critérios para classificar os livros analisados em "didáticos" e para “diversão". Essa comissão funcionaria anexa à Secretaria de Educação, tendo suas atividades financiadas com crédito de Cr\$3.000.000,00 (São Paulo, 1948). 
Outra iniciativa foi a criação, em 1947, da matéria4 "Literatura infantil" no Curso Normal do Instituto de Educação Caetano de Campos, ${ }^{5}$ localizado na capital paulista. A criação dessa matéria de ensino ocorreu no âmbito da reforma do Ensino Normal do estado de São Paulo, ocasionado pela promulgação do Decreto-lei federal n. 8.530, de 2 de janeiro de 1946, conhecido como Lei Orgânica do Ensino Normal.

A fim de situar a criação da matéria "Literatura infantil" no Ensino Normal paulista em 1947, apresento, a seguir, aspectos gerais da Lei Orgânica do Ensino Normal e as decorrências, no estado de São Paulo, da promulgação dessa Lei.

\section{A Lei Orgânica do Ensino Normal}

Decorridos 100 anos da criação do Ensino Normal no estado/província de São Paulo, ${ }^{6}$ no ano de 1946, quando promulgada a primeira lei brasilei-

4 A expressão "matéria de ensino" é aqui utilizada como equivalente à expressão "disciplina escolar". Conforme se pode observar na legislação paulista sobre o Ensino Normal, até 1957 utilizava-se a expressão "matéria de ensino" para designar os diferentes componentes do currículo dos cursos de formação de professores. A partir de 1957, a expressão deixou de ser utilizada, substituída por "disciplina escolar".

5 O Instituto de Educação Caetano de Campos, antiga Escola Normal de São Paulo e Escola Normal da Praça da República, passou a ser assim denominado a partir de 1933, após reforma do Ensino Normal em São Paulo. Nesse período, com o fim da Primeira República e o advento de novas ideias relativas à educação, no conjunto das ações reformadoras da instrução pública paulista, a antiga Escola Normal de São Paulo, à época denominada Escola Normal da Praça da República, foi transformada em Instituto de Educação Caetano de Campos, em homenagem a um de seus ex-diretores (Tanuri, 2000; Reis Filho, 1995, Monarcha, 1999).

6 O Ensino Normal no estado/província de São Paulo remonta à primeira metade do século XIX. Embora a lei que aprovou a criação do Ensino Normal na província de São Paulo date de 1843, a primeira Escola Normal foi instalada apenas em 1846, numa sala da Catedral da Sé. Por 20 anos, essa escola funcionou apenas com um professor, tendo sido fechada em 1866. Nove anos depois, em 16 de fevereiro de 1875, a Escola Normal de São Paulo foi reaberta, tendo permanecido em funcionamento por três anos, quando, em 1878, foi fechada novamente. Em 1880, foi reaberta e não teve mais suas atividades interrompidas. Após a instauração do regime republicano, em 1889, a escola sofreu importantes transformações sob a direção de Antônio Caetano de Campos e, logo em seguida, foi transferida para prédio definitivo, na Praça da República, na capital paulista. Foi também com o advento da República que o Ensino Normal começou a se expandir para o interior do estado de São Paulo. Entre 1894 e 1912, foram criadas as seguintes Escolas Normais no estado: Itapetininga, Piracicaba, Campinas, Guaratinguetá, Piraçununga, Botucatu e no bairro do Brás, na capital (Tanuri, 1979; Moscaro, 1956; Reis Filho, 1995). 
ra de caráter centralizador relativa ao Ensino Normal, a Lei Orgânica do Ensino Normal, a formação de professores passou por uma significativa reforma, que entre outros aspectos resultou numa mudança das matérias de ensino que se ofertavam nos Cursos Normais desse estado. Até então, todas as ações reformadoras desse ensino haviam sido de responsabilidade dos estados/províncias, o que gerou o funcionamento de diferentes formatos de cursos para formação de professores no Brasil (Tanuri, 2000).

Essa reforma centralizadora do Ensino Normal decorreu de um conjunto de ações do então ministro da Educação e da Saúde, Gustavo Capanema Filho, ${ }^{7}$ para reestruturar o seu Ministério. Esse político mineiro, que assumiu o cargo de ministro em 1934, após Getúlio Vargas ter assumido a Presidência da República, foi responsável pela criação de leis que tinham como objetivo centralizar alguns aspectos da educação nacional, as quais geraram reformas em todos os níveis de ensino no Brasil. Denominadas "leis orgânicas do ensino" e conhecidas também como "Reforma Capanema”, essas leis foram elaboradas pelo Ministério da Educação e Saúde em conformidade com a Constituição dos Estados Unidos do Brasil, de 10 de novembro de 1937, que estabelecia ser competência da União "[...] fixar as bases e determinar os quadros da educação nacional, traçando as diretrizes a que deve obedecer à formação física, intelectual e moral da infância e da juventude" (Brasil, 1937, s.p.).

O conjunto dessas leis orgânicas do ensino passou a vigorar entre 1942 e 1946, apesar de Capanema ter deixado o cargo de ministro em 1945. Entre as leis publicadas após a saída de Capanema, encontra-se a Lei Orgânica do Ensino Normal, que foi promulgada por meio do Decreto-lei n. 8.530, de 2 de janeiro de 1946.

Esse Decreto-lei, cuja elaboração foi assinada por José Linhares, Raul Leitão da Cunha e Antônio de Sampaio Dória, estabeleceu uma nova organização para o Ensino Normal no Brasil, como a criação de dois cursos: o de regentes do ensino primário, com duração de quatro anos; e o de formação

7 Nascido em Pitangui-MG, em 1890, Gustavo Capanema Filho se formou bacharel em Ciências Jurídicas e Sociais, em 1924. Ao longo de sua vida, teve intensa participação política em órgãos administrativos do estado de Minas Gerais e da União, entre os quais ministro da Educação e Saúde, oficial de Gabinete e deputado federal. Capanema foi um dos apoiadores do golpe militar de 1964. Depois de encerrar sua carreira política, fixou residência no Rio de Janeiro, onde faleceu em 1985 (Horta, 1999) 
de professores primários, com duração de três anos. Estabeleceu, ainda, a criação dos cursos de especialização de professores primários e os cursos de habilitação para administradores escolares de grau primário, os quais ficaram conhecidos como cursos post-graduados.

As instituições que passariam a oferecer o Ensino Normal a partir desse Decreto-lei seriam: os Cursos Normais Regionais, as Escolas Normais e os Institutos de Educação. Os Cursos Normais Regionais podiam oferecer apenas o curso de regentes do ensino primário. As Escolas Normais podiam oferecer os cursos de regentes do ensino primário e o curso de formação de professores primários. Além disso, as podiam oferecer os cursos do ensino secundário. Com característica mais abrangente, os Institutos de Educação, por sua vez, podiam oferecer ambos os cursos de formação de professores, os cursos do ensino secundário e também os cursos de pós-graduação.

Em vista das alterações previstas na organização do Ensino Normal em âmbito nacional, o Decreto-lei de 1946 também estabeleceu novo conjunto de disciplinas para os cursos de regente do ensino primário e para o curso de formação de professores primários. As disciplinas do curso de regentes de ensino primário ficaram assim estabelecidas:

\section{Art. $7^{\circ}[\ldots]$}

Primeira série: 1) Português. 2) Matemática. 3) Geografia Geral. 4) Ciências Naturais. 5) Desenho e caligrafia. 6) Canto orfeônico. 7) Trabalhos manuais e economia doméstica. 8) Educação física.

Segunda série: 1) Português. 2) Matemática. 3) Geografia do Brasil. 4) Ciências Naturais. 5) Desenho e caligrafia. 6) Canto orfeônico. 7) Trabalhos manuais e atividades econômicas da região. 8) Educação física.

Terceira série: 1) Português. 2) Matemática. 3) História Geral. 4) Noções de anatomia e fisiologia humana. 5) Desenho. 6) Canto orfeônico. 7) Trabalhos manuais e atividades econômicas da região. 8) Educação física, recreação e jogos.

Quarta série: 1) Português. 2) História do Brasil. 3) Noções de Higiene. 4) Psicologia e Pedagogia. 5) Didática e prática de ensino. 6) Desenho. 7) Canto orfeônico. 8) Educação física, recreação e jogos (Brasil, 1946, p.2).

Em relação ao curso de formação de professores primários, as disciplinas ficaram assim estabelecidas: 
Art. $8^{\circ}[\ldots]$

Primeira série: 1) Português. 2) Matemática. 3) Física e química. 4) Anatomia e fisiologia humanas. 5) Música e canto. 6) Desenho e artes aplicadas. 7) Educação física, recreação e jogos.

Segunda série: 1) Biologia educacional. 2) Psicologia educacional. 3) Higiene e educação sanitária. 4) Metodologia do ensino primário. 5) Desenho e artes aplicadas. 6) Música e canto. 7) Educação física, recreação e jogos.

Terceira Série: 1) Psicologia educacional. 2) Sociologia educacional. 3) História e filosofia da educação. 4) Higiene e puericultura. 5) Metodologia do ensino primário. 6) Desenho e artes aplicadas. 7) Música e canto. 8) Prática do ensino. 9) Educação física, recreação e jogos (Brasil, 1946, p.3).

O texto desse Decreto-lei traz também a possibilidade de os estados fazerem adequações a essas mudanças. Conforme estabelecido no Capítulo III desse Decreto-Lei: "A organização interna e demais condições de funcionamento dos estabelecimentos de ensino normal serão definidas, para cada unidade federada, na conformidade da legislação complementar e regulamento que, sôbre a matéria, forem expedidos pelos Estados e pelo Distrito Federal” (Brasil, 1946, p.7-8).

Esse Decreto-lei prevê ainda que a "[... ] legislação de cada unidade federada poderá acrescer disciplinas à seriação indicada nos artigos $7^{\circ}, 8^{\circ}$ e $9^{\circ}$, ou desdobrá-las, para maior eficiência do ensino” (Brasil, 1946, p.8).

\section{A adequação do Ensino Normal paulista à Lei Orgânica do Ensino Normal: a matéria "Literatura infantil"»}

Tendo em vista as mudanças estabelecidas pelas leis orgânicas do ensino, foi publicado no estado de São Paulo, por meio do Decreto n. 17.698, de 26 de novembro de 1947, a Consolidação das leis e demais normas relativas ao ensino. Com um texto de aproximadamente 140 páginas, esse Decreto foi responsável por reorganizar todo o sistema de ensino do estado de São

8 A respeito da organização do Ensino Normal paulista, entre 1933 e 1975, especialmente nos Institutos de Educação, há estudo exaustivo de Labegalini (2005; 2009). Por isso, para a elaboração deste tópico, tomei como base o estudo dessa pesquisadora, especialmente o que se refere à legislação sobre o Ensino Normal. 
Paulo, em conformidade com as alterações estabelecidas pela "Reforma Capanema", consolidada nas leis orgânicas do ensino.

Em relação ao Ensino Normal, com o Decreto estadual n. 17.698, de 1947, ficou estabelecido no estado de São Paulo que esse ensino seria ministrado em dois tipos de instituição: as Escolas Normais, situadas no interior do estado, no litoral e também em bairros da capital; e o Instituto de Educação Caetano de Campos, situado na capital paulista.

No caso das Escolas Normais, elas passariam a oferecer: o curso de formação profissional do professor primário, com duração de dois anos; e o curso pré-normal, com duração de um ano. O curso de formação profissional destinava-se a formar os professores primários, e o curso pré-normal visava preparar os alunos para o ingresso no curso de formação profissional do professor primário. Os programas estabelecidos no estado de São Paulo pelo Decreto de 1947, para esses cursos foram os seguintes:

Artigo 449 - O curso de Formação Profissional do Professor [...] se distribui pelas seguintes seções:

$1^{a}$ Secção - Educação;

$2^{\text {a }}$ Secção - Biologia Educacional;

$3^{\text {a }}$ Secção - Sociologia;

$4^{a}$ Secção - Artes;

$\S 1^{\circ}-\mathrm{A} 1^{\mathrm{a}}$ Secção compreende:

1 - Psicologia;

2 - Pedagogia;

3 - Prática de Ensino;

4 - História da Educação;

$\S 2^{\circ}-\mathrm{A} 2^{\mathrm{a}}$ Secção compreende:

1 - Biologia Educacional e Crescimento da criança;

2 - Higiene e Educação Sanitária;

$\S 3^{\circ}-\mathrm{A} 3^{\mathrm{a}}$ Secção compreende:

1 - Fundamentos da Sociologia;

2 - Sociologia Educacional;

3 - Investigações Sociais em nosso Meio.

$\S 4^{\circ}-\mathrm{A} 4^{\mathrm{a}}$ Secção compreende:

1 - Música;

2 - Desenho Pedagógico; 
3 - Artes industriais e domésticas.

$[\ldots]$

Artigo 482 - O curso pré-normal, de duração de 1 ano, abrangerá o ensino das seguintes cadeiras e aulas;

Cadeiras

$1^{\text {a }}$ Português

$2^{\mathrm{a}}$ História da Civilização Brasileira

$3^{\text {a }}$ Matemática e Noções de estatística

$4^{\mathrm{a}}$ Ciências Físicas e Naturais

$5^{\mathrm{a}}$ Anatomia e Fisiologia Humana e Noções de Higiene

Aulas

$1^{\text {a }}$ Música e canto orfeônico

$2^{\mathrm{a}}$ Desenho

$3^{\text {a }}$ Trabalhos Manuais

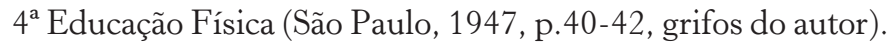

Como se pode observar, para os cursos pré-normal e de formação profissional do professor primário não foi instituída a matéria "Literatura infantil" nem outra que sugerisse o ensino desse gênero literário. A criação dessa matéria somente se deu no Instituto de Educação Caetano de Campos, que, à época, era tido como instituição modelo no estado. Em relação a esse instituto, o Decreto estadual de 1947 estabeleceu uma organização completamente diferenciada, comparativamente às demais instituições que ofereciam o Ensino Normal no estado de São Paulo.

A partir do Decreto de 1947, o Instituto de Educação Caetano de Campos passou a ser responsável pela oferta dos seguintes cursos: Curso Normal; Curso Secundário Ginasial; Curso Primário; o Curso Pré-Primário (Jardim de Infância); Curso de Aperfeiçoamento; Curso de Administradores escolares de grau primário; e Curso de Especialização.

O curso responsável especificamente pela formação de professores nesse Instituto era o Curso Normal, que também se diferenciava dos cursos pré-normal e do curso de formação profissional do professor primário, ambos ministrados nas Escolas Normais. O Curso Normal era um curso com duração de três anos, cujo ingresso se dava mediante realização de exame vestibular. Nas demais Escolas Normais, no caso do curso pré-normal, que tinha duração de um ano, a matrícula era feita mediante apresentação 
do certificado de conclusão do curso ginasial. E o curso de formação profissional do professor primário, também ofertado nas Escolas Normais, tinha duração de dois anos, e a matrícula era feita mediante apresentação de comprovante de aprovação no curso pré-normal.

Por conta dessa diferenciação entre o Curso Normal do Instituto de Educação Caetano de Campos e os cursos de formação dos professores primários nas demais Escolas Normais do estado, o Decreto estadual de 1947 estabeleceu um conjunto de matérias de ensino diferentes para esse Instituto.

Conforme o artigo 604 desse Decreto, as matérias de ensino do Curso Normal do Instituto de Educação Caetano de Campos ficaram assim definidas:

Artigo 604 - O curso normal compreende as seguintes matérias: Português; História da Civilização Brasileira; Matemática; Física e Química; Anatomia e Fisiologia Humanas; Higiene; Puericultura e Educação Sanitária; Biologia Geral; Biologia Educacional; Pedagogia; História da Educação; Filosofia da Educação; Psicologia Geral; Psicologia Educacional; Sociologia Geral; Sociologia Educacional; Metodologia do Ensino Primário e Prática do Ensino Primário; Literatura Infantil; Desenho Pedagógico; Música e Canto Orfeônico; Artes Aplicadas; Educação Física; Recreação e Jogos; Medidas Educacionais; Instruções Escolares (São Paulo, 1947, p.53, grifos meus).

Ainda de acordo com o Decreto estadual de 1947, essas matérias de ensino eram distribuídas em cadeiras, da seguinte forma:

Artigo 605 - $\mathrm{O}$ ensino será distribuído pelas seguintes cadeiras:

$1^{a}$ cadeira - Pedagogia e Filosofia da Educação;

$2^{\text {a }}$ cadeira - História da Educação;

$3^{\text {a }}$ cadeira - Psicologia Geral;

$4^{\text {a }}$ cadeira - Psicologia Educacional;

$5^{\mathrm{a}}$ cadeira - Biologia Educacional, Anatomia e Fisiologia humanas;

$6^{\text {a }}$ cadeira - Higiene Geral;

$7^{\text {a }}$ cadeira - Sociologia Geral;

$8^{\text {a }}$ cadeira - Sociologia Educacional;

$9^{\text {a }}$ cadeira - Metodologia e Prática do Ensino Primário; 
$10^{a}$ cadeira - Metodologia e Prática do Ensino Pré-Primário;

$11^{\text {a }}$ cadeira - Português;

$12^{\mathrm{a}}$ cadeira - Literatura Didática;

$13^{\mathrm{a}}$ cadeira - Matemática;

$14^{\mathrm{a}}$ cadeira - Física e Química;

$15^{\mathrm{a}}$ cadeira - História da Civilização Brasileira;

$18^{\mathrm{a}}$ cadeira - Artes Aplicadas (Secção Feminina);

$17^{\mathrm{a}}$ cadeira - Música e Canto Orfeônico;

$18^{\mathrm{a}}$ cadeira - Artes Aplicadas (Secção Feminina);

$19^{a}$ cadeira - Artes Aplicadas (Secção Masculina);

$20^{a}$ cadeira - Educação Física, Recreações e Jogos (Secção Feminina);

$21^{a}$ cadeira - Educação Física, Recreações e Jogos (Secção Masculina) (São Paulo, 1947, p.53-54, grifos meus).

De acordo com essa organização, a literatura infantil foi instituída pela primeira vez no estado de São Paulo como matéria de ensino. E, pela distribuição das matérias por séries do Curso Normal, "Literatura infantil" devia ser ministrada no $3^{\circ}$ ano desse curso, com carga horária de duas horas-aula semanais (São Paulo, 1947).

Apesar de criada em 1947, em consulta aos livros de registros de matrículas e notas do Instituto de Educação Caetano de Campos observa-se que a matéria "Literatura infantil", por vezes, não consta no conjunto das matérias de ensino. Quando não há essa matéria, em seu lugar consta a matéria "Literatura didática". Além disso, há situações em que nesses livros de registros de notas e diplomas consta a denominação "Literatura didática", mas com alteração manuscrita para "Literatura infantil".

De acordo com o conjunto de disciplinas estabelecido pelo Decreto de 1947, não havia nenhuma matéria de ensino denominada "Literatura Didática”. No entanto, nesse mesmo Decreto, na distribuição da carga-horária das matérias de ensino, no $2^{\circ}$ ano, consta a matéria "Português - Literatura didática". É possível presumir, portanto, que, quando no registro das notas dos alunos do $3^{\circ}$ ano do Curso Normal do Instituto de Educação Caetano de Campos se encontra a matéria "Literatura didática", no lugar de "Literatura infantil”, trate-se apenas uma oscilação de denominação, uma vez que "Literatura didática" era matéria do $2^{\circ}$ ano do curso e "Literatura infantil” matéria do $3^{\circ}$. Por essa razão, em algumas situações, encontra-se 
rasurada, de forma manuscrita, a informação sobre a matéria "Literatura didática" para a matéria "Literatura infantil".

É possível presumir, ainda, que essa oscilação seja decorrente da utilização dessas expressões para se referir à produção literária para crianças na primeira metade do século XX. A expressão "Literatura infantil” não era unânime e consensual para sujeitos que se detiveram à produção literária destinada às crianças. Em diferentes textos da primeira metade do século XX, as expressões "Literatura infantil" e "Literatura didática" são usadas como sinônimas.

O Decreto n. 17.698, de 1947, estabeleceu, também, a criação da disciplina "Literatura infantil" no Curso de Administradores Escolares, que se destinava "[...] a habilitar diretores de escolas, orientadores de ensino, inspetores escolares, auxiliares de estatística e encarregados de provas e medidas escolares [...]" (São Paulo, 1947, p.57). Esse curso era ministrado apenas no Instituto de Educação Caetano de Campos, com duração de dois anos, e podiam cursá-lo apenas os professores que já haviam concluído o Curso Normal. Em relação à organização das matérias desse curso, o Decreto estadual de 1947 fixou o seguinte:

$1^{\text {a }}$ Série - Sociologia Geral, Biologia Educacional, Psicologia Geral, Estatística aplicada à educação, Metodologia geral do ensino primário, Metodologia e prática do ensino das seguintes disciplinas:

Linguagem (linguagem oral, leitura e escrita);

Geografia, História e Conhecimentos Gerais de Literatura Infantil

Orientação Educacional e Instituições Escolares, Organização e administração escolar.

$2^{\mathrm{a}}$ Série - Pedagogia e Filosofia da Educação, Sociologia Educacional - fundamentos sociais da educação, Psicologia Educacional, História da Educação, Higiene Escolar e Puericultura, Metodologia e Prática de Ensino das seguintes disciplinas:

Linguagem (literatura infantil, composição, gramática e ortografia);

Matemática;

Desenho e trabalhos manuais, Orientação e Instituições Escolares, Técnicas de Pesquisa e Medidas Educacionais, Organizações e Administração Escolar (São Paulo, 1947, p.57, grifos meus). 
Apesar de a Lei Orgânica do Ensino Normal ter estabelecido um padrão de organização para os cursos de formação de professores primários no território nacional, o estado de São Paulo teve organização bastante diferenciada. Essa diferenciação se deveu, como aponta Campos (1987), à Constituição dos Estados Unidos do Brasil, promulgada em 18 de setembro de 1946, a qual, em seu artigo 171, título IV, Capítulo II, previa que: “[...] Os Estados e o Distrito Federal organizarão os seus sistemas de ensino. Parágrafo único - Para o desenvolvimento desses sistemas a União cooperará com auxílio pecuniário, o qual, em relação ao ensino primário, provirá do respectivo Fundo Nacional” (Brasil, 1946, s.p.).

Em relação à criação da matéria "Literatura infantil", embora tenha sido uma iniciativa isolada, que remete até à ideia de uma "experiência", o ensino da literatura infantil, ofertado por meio dessa matéria, foi-se expandindo na década seguinte, conforme se foi expandindo a criação de novos Institutos de Educação no interior do estado.

\section{A expansão do ensino da literatura infantil no estado de São Paulo: os novos Institutos de Educação}

A partir da década de 1950, tendo em vista a experiência modelar do Instituto de Educação Caetano de Campos, passou a ser publicada um conjunto de leis que, entre 1951 e 1967, foram responsáveis pela criação de novos Institutos de Educação ou pela transformação de antigas Escolas Normais do interior do estado em Institutos de Educação.

Após a transformação, em 1933, da Escola Normal da Praça da República em Instituto de Educação Caetano de Campos, as primeiras Escolas Normais transformadas em Instituto de Educação foram: a Escola Normal Padre Anchieta, situada na capital paulista; e a Escola Normal e Ginásio Estadual Carlos Gomes" situada em Campinas-SP, ambas no ano de 1951 (Labegalini, 2009).

Com a transformação dessas Escolas Normais em Instituto de Educação, elas passaram a ser organizadas de modo idêntico ao Instituto de Educação Caetano de Campos, o que significou, entre outros, a instituição da matéria "Literatura infantil" nos Cursos Normais e nos cursos de Administradores Escolares desses Institutos. 
Conforme dados apresentados por Labegalini (2009), durante a década de 1950, foram transformados em Institutos de Educação 53 Escolas Normais paulistas, as quais se encontravam distribuídas pelo interior, litoral e capital do estado.

Em relação ao funcionamento desses novos Institutos, ficou assegurado que os alunos matriculados anteriormente à transformação das Escolas Normais em Institutos de Educação podiam terminar o curso que haviam iniciado. Assim, os que haviam se matriculado no curso pré-normal e/ou o curso de formação profissional do professor primário poderiam concluir o Ensino Normal com base nesse modelo de formação de professores, o que possibilita presumir que a expansão do ensino da literatura infantil não ocorreu imediatamente após a criação dos novos Institutos de Educação.

A fim de apresentar quais Escolas Normais foram transformadas em Instituto de Educação, com base em Labegalini (2009), sintetizo, no Quadro 4, a relação dessas Escolas, o ano de transformação e a lei responsável por essa transformação. Destaco que, nesse quadro, apresento apenas informações relativas às Escolas Normais que foram transformadas em Instituto de Educação entre 1951 e 1956, tendo em vista que em 1957 o Ensino Normal paulista passou por uma nova reforma, a qual extinguiu essa diferenciação de currículo entre Escolas Normais e Institutos de Educação.

Quadro 4 - Escolas Normais transformadas em Institutos de Educação, entre 1951 e 1956

\begin{tabular}{|c|c|c|c|}
\hline Nome do Instituto & Localidade & $\begin{array}{l}\text { Data } \\
\text { Transformação }\end{array}$ & Legislação \\
\hline Instituto de Educação Carlos Gomes & Campinas & $21 / 12 / 1951$ & Lei n. 1.416 \\
\hline Instituto de Educação"Padre Anchieta & São Paulo-SP & $28 / 12 / 1951$ & Lein. 1.537 \\
\hline Instituto de Educação Peixoto Gomide & Itapetininga & $07 / 08 / 1953$ & Lein. 2.218 \\
\hline $\begin{array}{l}\text { Instituto de Educação Cardoso de } \\
\text { Almeida }\end{array}$ & Botucatu & $07 / 08 / 1953$ & Lein. 2.218 \\
\hline Instituto de Educação Ernesto Monte & Bauru & $07 / 08 / 1953$ & Lei n. 2.218 \\
\hline $\begin{array}{l}\text { Instituto de Educação Monsenhor } \\
\text { Gonçalves }\end{array}$ & $\begin{array}{l}\text { São J. do Rio } \\
\text { Preto }\end{array}$ & $07 / 08 / 1953$ & Lein. 2.218 \\
\hline $\begin{array}{l}\text { Instituto de Educação de Ribeirão } \\
\text { Preto }\end{array}$ & Ribeirão Preto & $07 / 08 / 1953$ & Lei n. 2.218 \\
\hline
\end{tabular}




\begin{tabular}{|l|l|l|l|}
\hline $\begin{array}{l}\text { Instituto de Educação Torquato } \\
\text { Caleiro }\end{array}$ & Franca & $07 / 08 / 1953$ & Lei n. 2.219 \\
\hline Instituto de Educação de Pirassununga & Pirassununga & $07 / 08 / 1953$ & Lei n. 2.220 \\
\hline Instituto de Educação Álvaro Guião & São Carlos & $07 / 08 / 1953$ & Lei n. 2.221 \\
\hline $\begin{array}{l}\text { Instituto de Educação Cons. Rodrigues } \\
\text { Alves }\end{array}$ & Guaratinguetá & $07 / 08 / 1953$ & Lei n. 2.222 \\
\hline Instituto de Educação Barão de Suruí & Tatuí & $07 / 08 / 1953$ & Lei n. 2.223 \\
\hline Instituto de Educação Sud Mennucci & Piracicaba & $07 / 08 / 1953$ & Lei n. 2.224 \\
\hline $\begin{array}{l}\text { Instituto de Educação Leônidas do } \\
\text { Amaral Vieira" }\end{array}$ & $\begin{array}{l}\text { Santa Cruz do } \\
\text { Rio Pardo }\end{array}$ & $07 / 08 / 1953$ & Lei n. 2.218 \\
\hline Instituto de Educação de Jaú & Jaú & $20 / 10 / 1953$ & Lei n. 2.336 \\
\hline Instituto de Educação Fernando Costa & $\begin{array}{l}\text { Presidente } \\
\text { Prudente }\end{array}$ & $20 / 10 / 1953$ & Lei n. 2.337 \\
\hline $\begin{array}{l}\text { Instituto de Educação Dr. Francisco } \\
\text { Tomaz Carvalho }\end{array}$ & Casa Branca & $03 / 11 / 1953$ & Lei n. 2.366 \\
\hline Instituto de Educação de Jundiaí & Jundiaí & $29 / 12 / 1953$ & Lei n. 2.449 \\
\hline $\begin{array}{l}\text { Instituto de Educação Bento de Abreu } \\
\text { Instituto de Educação de Mogi das } \\
\text { Cruzes }\end{array}$ & $\begin{array}{l}\text { Araraquara } \\
\text { Cruzes }\end{array}$ & $05 / 01 / 1954$ & Lei n. 2.490 \\
\hline $\begin{array}{l}\text { Instituto de Educação Santo Amaro } \\
\text { São Paulo-SP }\end{array}$ & $13 / 11 / 1956$ & Lei n. 3.594 \\
\hline
\end{tabular}

Fonte: Labegalini (2009).

Dos 53 Institutos de Educação que passaram a funcionar no estado de São Paulo na década de 1950, conforme os dados apresentados no Quadro 4, 23 passaram a funcionar entre 1951 e 1956 . E desses 23 institutos, 16 deles passaram a funcionar no ano de 1953. Apenas um Instituto de Educação não resultou de transformação de uma Escola Normal: o Santo Amaro, criado em 1956, na capital paulista. Desse modo, no período compreendido entre 1951 e 1956, foram transformadas em Institutos de Educação 22 Escolas Normais e foi criado um novo Instituto de Educação.

A partir desses dados, é possível afirmar que o ensino da literatura infantil se deu de modo mais efetivo no estado de São Paulo a partir de 1956. Considerando que o ano de 1953 foi o ano em que se criou o maior número de Institutos de Educação no estado de São Paulo, as primeiras matrículas 
no Curso Normal, com organização idêntica do Instituto de Educação Caetano de Campos, ocorreram partir de 1954. Como a matéria "Literatura infantil" era ministrada no $3^{\circ}$ ano desse curso, somente a partir de 1956 é que o ensino da literatura infantil se expandiu para outros Institutos.

\section{Da criação de uma matéria de ensino, às iniciativas de "concretização" do ensino da literatura infantil}

Mesmo a matéria "Literatura infantil" tendo sido criada, no estado de São Paulo, em 1947, os programas de ensino que vigoravam nessa época não eram condizentes com o conjunto de matérias estabelecido pelo Decreto estadual n. 17.698, de novembro de 1947, para o Instituto de Educação Caetano de Campos.

Depois da reforma promovida por esse Decreto de 1947, somente em 1954 é que foram publicados novos programas de ensino, que atendiam às mudanças ocorridas com essa reforma. Até então, permaneceu em vigor o documento Programmas das escolas normaes, publicado em 1938, e que continha as prescrições relativas às matérias de ensino dos cursos Normais, da década de 1930.

Visando adequar as orientações relativas ao que ensinar em cada matéria, coerentemente com a reforma promovida pelo Decreto estadual de 1947, o Departamento de Educação do estado de São Paulo fez publicar, em 1954, o documento Programas das escolas normais e instruções metodológicas. Esse documento foi elaborado pela Chefia de Serviço do Ensino secundário "[...] para servir de base ao ensino nos cursos pré-normal e de formação profissional do professor primário daqueles estabelecimentos de ensino no Estado de São Paulo" (São Paulo, 1954, p.3). Embora o Decreto de 1947 previsse organização diferente entre os cursos oferecidos nas Escolas Normais e o curso oferecido no Instituto de Educação Caetano de Campos, os programas de ensino de 1954 não fazem menção às matérias de ensino específicas do Curso Normal desse Instituto.

Apesar disso, logo após a criação da matéria "Literatura infantil" no Curso Normal do Instituto de Educação Caetano de Campos, começaram a circular no estado de São Paulo alguns manuais de ensino, os quais contêm 
capítulos destinados ao "ensinar a ensinar" literatura infantil em cursos de formação de professores.

Ao todo, entre 1947 e 1956, foram publicados três manuais de ensino com capítulos sobre literatura infantil. Desses três, dois são manuais de metodologia da linguagem e um é manual mais geral, de prática de ensino.

Possivelmente essas propostas iniciais de "concretização" do ensino da literatura infantil na formação de professores se derm sob o formato de capítulos de livros porque, nesse período, também o espaço reservado ao ensino da literatura infantil era bastante restrito. Apesar de contar com duas horas-aula semanais no $3^{\circ}$ ano do Curso Normal, como muitas outras matérias, essa se restringia ao currículo de um Instituto.

Cabe destacar que o fato de dois, dos três capítulos sobre literatura infantil, constarem em manuais de metodologia da linguagem pode estar associado à situação de que a matéria "Literatura infantil" integrava o conjunto das matérias da Cadeira "Português".

\section{A primeira "concretização" brasileira para o ensino da literatura infantil: Metodologia da linguagem (1949), de J. Budin}

A primeira proposta de "concretização" do ensino da literatura infantil foi publicada no Brasil em 1949, sob a forma de capítulo, contido no manual Metodologia da linguagem: para uso das escolas normais e institutos de educação, ${ }^{9}$ de Janetta Budin, publicado pela Companhia Editora Nacional (SP)..$^{10}$

Nascida em 14 de dezembro de 1914, no Rio Grande do Sul, Budin se diplomou, em 1937, em Letras pela Escola de Filosofia da Universidade do Distrito Federal. Budin passou a atuar como professora catedrática do

9 Para informações mais detalhadas sobre Metodologia da linguagem, de J. Budin, ver Sales (2009) e Mortatti (2014).

10 A Companhia Editora Nacional foi fundada em 1925, por Octalles Marcondes Ferreira e José Bento Monteiro Lobato, tendo se destacado especialmente na produção e livros didáticos. Após o falecimento de Octalles Marcondes Ferreira, em 1973, a Companhia Editora Nacional passou ao controle do Banco Nacional de Desenvolvimento Econômico (BNDE) e, posteriormente, foi adquirida pelo Ibep. Entre as décadas de 1950 e 1960, a Nacional gozou do status de uma das editoras mais bem-sucedidas do Brasil (Hallewell, 2005). 
Instituto de Educação do Rio de Janeiro, onde permaneceu até 1953, quando faleceu precocemente, aos 39 anos (Sales, 2009). No período em que atou no Instituto de Educação do Distrito Federal, foi responsável pelas matérias "Língua portuguesa" e "Literatura" do Curso Normal e do Curso Secundário Ginasial (Sales, 2009).

Nesse período em que atuou como professora no Instituto de Educação do Distrito Federal, Budin teve publicados outros manuais de ensino, todos relacionados ao ensino de língua, linguagem e literatura. O primeiro manual que teve publicado foi Metodologia da linguagem, em 1949. Na sequência, em 1951, teve publicado, em coautoria com Silvio Elia, Compêndio de Língua e Literatura: Gramática - Literatura - Antologia e, em 1953, teve publicado três volumes de Compêndio de Língua e Literatura: para uso das Escolas Normais, Institutos de Educação, Faculdades de Filosofia e alunos do Colegial (Sales, 2009).

Com relação à Metodologia da linguagem, publicado em 1949, pela Companhia Editora Nacional (SP), além de ser o primeiro manual de ensino escrito por Budin, trata-se também do primeiro manual específico para o ensino de linguagem publicado no Brasil (Mortatti, 2014). Sua elaboração, como indicam aspectos de sua configuração textual, decorreu da atuação de Budin como professora da área da linguagem no Curso Normal e no Curso Secundário Ginasial no Instituto de Educação do Distrito Federal.

Além de ter resultado da atuação de Budin, como professora no Instituto de Educação do Distrito Federal, é possível pressupor que a elaboração de Metodologia da linguagem (1949) também tenha tido como base a atuação e/ou produção escrita de outras três professoras desse Instituto, a saber, a poetisa e também professora Cecilia Meireles e as professoras de literatura infantil do Instituto de Educação do Distrito Federal Elvira Nizinski e Maria Reis Campos, para quem Budin dirige seus agradecimentos, pelas "[...] aulas, apostilas e resumos [que] tanto me ajudaram neste trabalho" (Budin, 1949, agradecimentos).

Um aspecto importante sobre esse manual é que ele foi elaborado com base no programa de linguagem do Curso Normal do Instituto de Educação do Distrito Federal. Apesar disso, ele foi publicado por uma editora paulista, a Companhia Editora Nacional, e seus aspectos estruturais-formais permitem compreender que o objetivo da autora era que esse manual fosse de uso em qualquer Escola Normal ou Instituto de Educação do país. Por 
essa razão, ele circulou em outros estados, especialmente São Paulo, onde pude encontrar exemplares em quase todos os acervos de antigas Escolas Normais e Institutos de Educação a que tive acesso.

Ainda em relação à circulação desse manual, é possível afirmar que ele teve uma tiragem significativa para esse tipo de livro e para a época, pois, entre os exemplares a que tive acesso, um deles contém numeração de impressão acima de 5.000. Isso possibilita afirmar que teve, pelo menos, 6.000 exemplares impressos em sua $1^{a}$ edição.

Em relação à organização do conteúdo, esse manual foi dividido em sete unidades, as seis primeiras referentes à $2^{\mathrm{a}}$ série do Curso Normal e a última referente à $3^{\mathrm{a}}$ série desse curso. A primeira unidade trata da origem da linguagem, suas formas, natureza e função; a segunda unidade trata da relação entre a criança e a linguagem; a terceira unidade trata dos fundamentos metodológicos do ensino da linguagem; a quarta unidade trata do ensino da leitura e da escrita; a quinta unidade trata do ensino da composição; a sexta unidade trata do ensino da ortografia e da gramática; e a sétima unidade trata do ensino da literatura infantil.

Essas sete unidades, ao todo, constituem 168 páginas, das quais as 43 últimas são sobre literatura infantil.

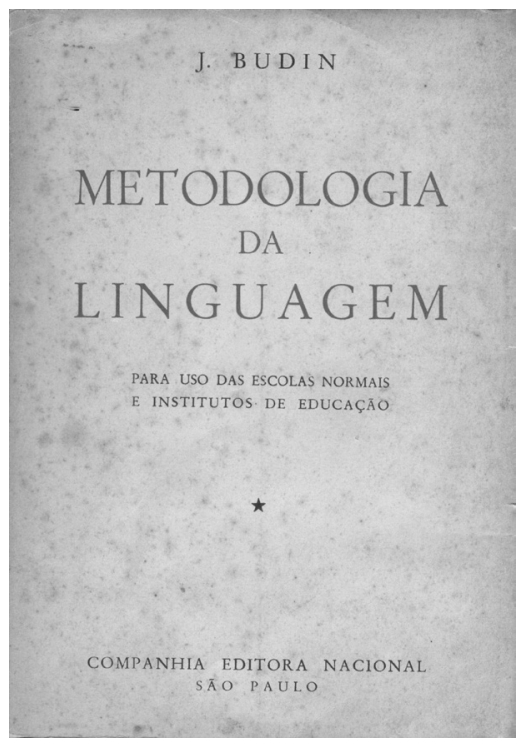

Figura 1 - Capa de Metodologia da linguagem (1949), de J. Budin Fonte: Acervo do GPHELLB. 
A unidade sete, que trata das questões relativas ao "ensinar a ensinar" literatura infantil está organizada em cinco tópicos, a saber: "a) Conceito da literatura infantil: seu objetivo, valor da compreensão e conclusões gerais"; "b) A Literatura infantil: finalidades didáticas, gêneros preferidos, requisitos do livro e maneira de fichá-lo”; "c) Relações da literatura folclórica com a literatura infantil. Os contos populares: origem, característica, interpretação"; "d) A literatura infantil tradicional e moderna"; e "e) O ensino da literatura infantil”.

Ao final de cada um desses tópicos, Budin (1949) apresenta um roteiro de questões, intitulado "Sugestões para trabalhos", que varia de três a 14 questões, e uma relação de livros recomendados para aprofundamento nos assuntos de que ela trata.

No primeiro tópico - "a) Conceito da literatura infantil: seu objetivo, valor da compreensão e conclusões gerais” - Budin (1949) define literatura como um tipo de arte expressa por meio das palavras. Para ela, a literatura constitui "[...] instrumento de cultura, de aquisição de conhecimentos, de aperfeiçoamento do caráter, do gôsto artístico, da socialização” (Budin, 1949, p.125). Por isso, o objetivo de ensiná-la na escola decorre da necessidade de desenvolver o gosto e interesse da criança pela "boa" literatura com base, sobretudo, na recreação.

Budin (1949) afirma que, por muito tempo, perdurou na prática dos professores a ideia de que quando se ensina literatura o enfoque deve ser a aprendizagem da "boa poesia" e da "boa prosa". Contrária a essa compreensão, ela defende que a prática de ensino da literatura deve visar ao enriquecimento da experiência, pois, por meio dela, "[...] a criança entra em contato com variadas e úteis experiências, interpretações de modos de vida, visão de características humanas e tôdas as suas relações" (Budin, 1949, p.126).

A partir disso, Budin (1949) detém-se à explicação das finalidades didáticas dos gêneros literários, os tipos de textos preferidos das crianças e os requisitos a que esses livros devem atender.

Em relação às finalidades didáticas da literatura infantil, o ponto central é que esse gênero literário se constitua num:

[...] meio de "oferecer à criança um rico tesouro de nobres pensamentos e belas formas de expressão na língua materna" e "abrir amplos horizontes à inteli- 
gência e ao coração dos alunos, fazendo que estes prezem e compreendam os ideais e valores mais puros do seu povo e da humanidade, como se refletem na história, na lenda, no conto e na poesia" (Budin, 1949, p.129).

Com base nessa finalidade mais ampla, Budin (1949) apresenta vários "princípios gerais" do ensino de literatura infantil, que correspondem ao detalhamento das finalidades didáticas desse gênero literário. No âmbito desses "princípios", destacam-se: utilização de métodos e materiais que auxiliem a criança a vivenciar a experiência literária; a literatura deve ser vista como atividade criadora; o material a ser oferecido para a leitura deve ser fonte de prazer; o professor deve solucionar as dificuldades que os alunos encontram na hora da leitura; as informações sobre autor e obra não significam nada no processo de "reviver" experiências pela leitura; a criança deve ter a oportunidade de expressar suas ideias a partir da leitura; não é indispensável que o aluno perceba o conteúdo moral da história; a análise do tema da história não tem utilidade se estiver a serviço do ensino elementar; a memorização espontânea contribui para formação do gosto; os resumos escritos e orais de livros conhecidos são "enormes" vantagens; quando possível, a poesia deve ser acompanhada de música; recomenda-se aplicar testes de literatura, para verificar o que a criança pensa sobre as personagens e as situações narradas; e se deve incentivar a familiarização da criança com "boas" fontes da literatura infantil (Budin, 1949).

Budin (1949) se detém a como orientar a escolha do livro a ser utilizado na escola. Para ela, esse é um problema de "vital importância”, pois é preciso "[...] ter certeza de que se trata de bom material, pois não há lugar para literaturas sentimentais, de caráter vulgar e barato” (Budin, 1949, p.131). Como forma de identificar os bons e adequados livros para as crianças, ela recomenda como ponto de partida o "mérito literário". Além disso, sintetiza informações de algumas publicações relacionadas às escolhas de leituras por parte das crianças, como forma de melhor orientar os futuros professores na escolha dos livros. São elas: o livro Interest Factors in Primary Reading, de Miss Dunn; o documento Scientific Determination of the Content of the Elementary School Course in Reading; o livro A Study of Children's Interests in Poetry, de Mac-Intosh; o livro A Study of Children's choice in prose, de Garnett; e o livro Children's Reading, de Termann e Lima. 
Em relação aos requisitos gerais que os livros de literatura infantil devem conter, Budin (1949) apresenta quatro, a saber: assunto bem tratado, com linguagem correta; livros agradáveis e interessantes, cujos assuntos e formas sejam capazes de prender a atenção do leitor; livro que não prejudique a boa formação moral do aluno; e livros que tenham "predicados" literários, com boa "feitura" material e artística.

Budin (1949) também busca problematizar as relações entre esse gênero literário e o folclore. Para ela, a literatura infantil pode ser culta ou folclórica. No caso da literatura folclórica, se trata basicamente dos contos populares, os quais, ligados à tradição oral e construídos em torno do mito, oferecem ao leitor o "[...] genuíno sabor primitivo, a beleza sem atrativos, o tôsco encanto da palavra que brotou do coração e não sofreu polimento de espécie” (Budin, 1949, p.136).

A partir do entendimento de que a literatura infantil tem a sua forma primeira no folclore, essa professora estabelece uma distinção entre literatura infantil "tradicional" e literatura infantil "moderna". A literatura infantil "tradicional" é decorrente dos contos populares, não originalmente escrito para crianças, mas que se identificam com o gosto infantil. Já a literatura infantil "moderna" se originou no século XVIII, sobretudo depois dos estudos de Jean Jacques Rousseau, como uma literatura escrita intencionalmente para a criança. Com isso, Budin (1949) elenca alguns dos principais nomes de escritores ingleses, franceses, espanhóis, italianos e brasileiros da chamada literatura infantil "moderna". Entre esses nomes, estão: em inglês, Jonathan Swift, Daniel Defoe, Lewis Caroll e Oscar Wilde; em francês, Condessa de Ségur e Júlio Verne; em espanhol, Miguel de Cervantes; em italiano, Carlo Collodi e Edmundo de Amicis; e em português, Monteiro Lobato, Viriato Correia, Olavo Bilac, Malba Tahan, Hildebrando Lima, Tales de Andrade e Lúcia Miguel Pereira.

Budin (1949) também propõe uma forma de destinação dos livros, conforme a faixa etária das crianças. Essa proposição é por ela assim feita: até 7 anos, crianças que não sabem ler, livros de estampas, histórias em quadrinhos, com títulos e "dizeres" grandes, com letras espaçadas, que tratam de cenas de contos de fadas, da vida diária e de fábulas; dos 7 aos 8 anos, livros iguais ao do primeiro grupo, porém, com textos mais extensos; dos 8 aos 9 anos, livros com bastante ilustrações, com histórias sobre a vida real ou contos de fadas, fábulas, lendas, vidas de animais e poesias curtas; dos 9 aos 
10 anos, livros do "tipo normal", com algumas ilustrações, que tratem de novelas, viagens, mitologia e histórias bíblicas; dos 12 aos 16 anos, mesmos livros recomendados às crianças entre 9 e 10 anos, porém com nível mais elevado; e dos 16 aos 18 anos, livros da literatura para adultos (Budin, 1949).

Para concluir, Budin (1949) se centra na caracterização do ensino da literatura infantil e explica que, muitas vezes, os professores não observam que o texto literário é um "laboratório". Por isso, o que se deve buscar numa aula de literatura é "[...] o mesmo que se busca no cinema ou no teatro: alegria, emoção, sentimento, entusiasmo...” (Budin, 1949, p.164). Não basta ao professor colocar o livro diante da criança, é essencial que ele ensine a importância da leitura os alunos, quando lhes oferta um livro. Por isso, as atividades literárias mais adequadas no ensino da literatura infantil são:

a) leitura oral pelo professor;

b) leitura oral por crianças aso colegas, individualmente;

c) leitura oral por crianças aos colegas, em grupo;

d) leitura livre;

e) leitura de livros pela classe (leitura silenciosa, seguida de discussão);

f) comentários sobre obras lidas;

g) memorização de poesia;

h) relacionamento de poesia à música;

i) dramatização, nas quais se consideram três tipos: leitura por crianças a quem cabem os diferentes papéis; representação por alunos, que decidem desempenhar as diversas partes; representação mediante o emprego de bonecos (Budin, 1949, p.166).

Embora o manual de Budin (1949) não apresente citações literais nem mesmo referências bibliográficas ou bibliografia, no caso da unidade 7, na qual ela trata de aspectos da literatura infantil, consta uma relação de livros a serem consultados. Esses livros são indicados como forma de complementar as informações que ela apresenta em cada um dos tópicos da unidade 7 de seu manual, o que possibilita compreender que se trata também dos livros que ela utilizou como base para elaboração de seu manual. Por essa razão, apresento, no Quadro 5, a relação dos títulos que ela indica com sugestão na unidade VII, com os respectivos autores e os respectivos tópicos para os quais ela os recomenda. 
Quadro 5 - Relação dos textos recomendados para leitura em Metodologia da linguagem (1949)

\begin{tabular}{|c|c|c|}
\hline $\begin{array}{l}\text { Titulo do livro } \\
\text { recomendado para } \\
\text { consulta }\end{array}$ & Autor & $\begin{array}{l}\text { Tópico(s) para o(s) qual (quais) é (são) } \\
\text { recomendado(s) }\end{array}$ \\
\hline $\begin{array}{l}\text { Reading and Literature in the } \\
\text { Elementary school }\end{array}$ & Mckee & $\begin{array}{l}\text { "A) Conceito da literatura infantil" } \\
\text { "B) A literatura infantil: finalidades } \\
\text { didáticas; gêneros preferidos; requisitos do } \\
\text { livro; maneira de fichá-lo" } \\
\text { "E) O ensino da literatura infantil" }\end{array}$ \\
\hline $\begin{array}{l}\text { Teaching Composition and } \\
\text { Literature }\end{array}$ & Mirrieles & $\begin{array}{l}\text { "A) Conceito da literatura infantil" } \\
\text { "E) O ensino da literatura infantil" }\end{array}$ \\
\hline $\begin{array}{l}\text { Enciclopédia e Dicionário } \\
\text { Internacional }\end{array}$ & $\begin{array}{l}\text { Jackson } \\
\text { Editores }\end{array}$ & "A) Conceito da literatura infantil" \\
\hline Escola moderna & $\begin{array}{l}\text { Maria Reis } \\
\text { Campos }\end{array}$ & $\begin{array}{l}\text { "B) A literatura infantil: finalidades } \\
\text { didáticas; gêneros preferidos; requisitos do } \\
\text { livro; maneira de fichá-lo" } \\
\text { "D) A literatura infantil tradicional e } \\
\text { moderna" }\end{array}$ \\
\hline A literatura infantil & $\begin{array}{l}\text { Marcel } \\
\text { Braunschwing }\end{array}$ & $\begin{array}{l}\text { "B) A literatura infantil: finalidades } \\
\text { didáticas; gêneros preferidos; requisitos do } \\
\text { livro; maneira de fichá-lo" }\end{array}$ \\
\hline "Programa de linguagem" & - & $\begin{array}{l}\text { "B) A literatura infantil: finalidades } \\
\text { didáticas; gêneros preferidos; requisitos do } \\
\text { livro; maneira de fichá-lo" } \\
\text { "D) A literatura infantil tradicional e } \\
\text { moderna" }\end{array}$ \\
\hline Didática da Escola Nova & Aguayo & $\begin{array}{l}\text { "B) A literatura infantil: finalidades } \\
\text { didáticas; gêneros preferidos; requisitos do } \\
\text { livro; maneira de fichá-lo" } \\
\text { "E) O ensino da literatura infantil" }\end{array}$ \\
\hline O folclore & João Ribeiro & $\begin{array}{l}\text { "C) Relações da literatura folclórica com a } \\
\text { literatura infantil" }\end{array}$ \\
\hline O folclore no Brasil & $\begin{array}{l}\text { Basílio de } \\
\text { Magalhães }\end{array}$ & $\begin{array}{l}\text { "C) Relações da literatura folclórica com a } \\
\text { literatura infantil" }\end{array}$ \\
\hline $\begin{array}{l}\text { Introdução ao estudo do } \\
\text { folclore }\end{array}$ & $\begin{array}{l}\text { Joaquim } \\
\text { Ribeiro }\end{array}$ & $\begin{array}{l}\text { "C) Relações da literatura folclórica com a } \\
\text { literatura infantil" }\end{array}$ \\
\hline Através do folclore & $\begin{array}{l}\text { Gustavo } \\
\text { Barroso }\end{array}$ & $\begin{array}{l}\text { "C) Relações da literatura folclórica com a } \\
\text { literatura infantil" }\end{array}$ \\
\hline Minute Myths and Legends & Marie Schubert & $\begin{array}{l}\text { "C) Relações da literatura folclórica com a } \\
\text { literatura infantil" }\end{array}$ \\
\hline The Golden Bough & James G. Fazer & $\begin{array}{l}\text { "C) Relações da literatura folclórica com a } \\
\text { literatura infantil" }\end{array}$ \\
\hline Bulfinch's Mythology & Bulfinch & $\begin{array}{l}\text { "C) Relações da literatura folclórica com a } \\
\text { literatura infantil" }\end{array}$ \\
\hline Orpheus & $\begin{array}{l}\text { Salomon } \\
\text { Reinach }\end{array}$ & $\begin{array}{l}\text { "C) Relações da literatura folclórica com a } \\
\text { literatura infantil" }\end{array}$ \\
\hline
\end{tabular}




\begin{tabular}{|c|c|c|}
\hline Histoire des réligions & Denis Saurat & $\begin{array}{l}\text { "C) Relações da literatura folclórica com a } \\
\text { literatura infantil" }\end{array}$ \\
\hline Contes des fées & $\begin{array}{l}\text { Perrault, Mme. } \\
\text { D'Aulnoy e } \\
\text { outros }\end{array}$ & $\begin{array}{l}\text { "C) Relações da literatura folclórica com a } \\
\text { literatura infantil" }\end{array}$ \\
\hline $\begin{array}{l}\text { India - la subidura de sus } \\
\text { leyendas }\end{array}$ & $\begin{array}{l}\text { José Mora } \\
\text { Garnido y } \\
\text { Manual Garcia } \\
\text { Miranda }\end{array}$ & $\begin{array}{l}\text { "C) Relações da literatura folclórica com a } \\
\text { literatura infantil" }\end{array}$ \\
\hline Las mil y uma noches & $\begin{array}{l}\text { Golland (trad. } \\
\text { para espanhol } \\
\text { Pedro Pedroza } \\
\text { y Paíz) }\end{array}$ & $\begin{array}{l}\text { "C) Relações da literatura folclórica com a } \\
\text { literatura infantil" }\end{array}$ \\
\hline $\begin{array}{l}\text { Obras com as coletâneas de } \\
\text { Grimm e Andersen }\end{array}$ & - & $\begin{array}{l}\text { "C) Relações da literatura folclórica com a } \\
\text { literatura infantil" }\end{array}$ \\
\hline La Mythologie Primitive & Lévy-Bruhl & $\begin{array}{l}\text { "C) Relações da literatura folclórica com a } \\
\text { literatura infantil" }\end{array}$ \\
\hline $\begin{array}{l}\text { Os deuses do Olimpo e } \\
\text { heróis da Grécia antiga }\end{array}$ & João de Barros & $\begin{array}{l}\text { "C) Relações da literatura folclórica com a } \\
\text { literatura infantil" }\end{array}$ \\
\hline Les contes populaires & Gédeon Huet & $\begin{array}{l}\text { "C) Relações da literatura folclórica com a } \\
\text { literatura infantil" }\end{array}$ \\
\hline La mitologia comparada & $\begin{array}{l}\text { Edição } \\
\text { Larousse }\end{array}$ & $\begin{array}{l}\text { "C) Relações da literatura folclórica com a } \\
\text { literatura infantil" }\end{array}$ \\
\hline La mentalité primitive & Lévy-Bruhl & $\begin{array}{l}\text { "C) Relações da literatura folclórica com a } \\
\text { literatura infantil" }\end{array}$ \\
\hline $\begin{array}{l}\text { El desarrollo espiritual del } \\
\text { niño }\end{array}$ & Carlos Bühler & $\begin{array}{l}\text { "C) Relações da literatura folclórica com a } \\
\text { literatura infantil" }\end{array}$ \\
\hline $\begin{array}{l}\text { Díoses, mitos y heroes de la } \\
\text { humanidad }\end{array}$ & $\begin{array}{l}\text { M. Ciges } \\
\text { Aparicio y F. } \\
\text { Peyro Carrio }\end{array}$ & $\begin{array}{l}\text { "C) Relações da literatura folclórica com a } \\
\text { literatura infantil" }\end{array}$ \\
\hline Manual de folk-lore & P. Saintyves & $\begin{array}{l}\text { "C) Relações da literatura folclórica com a } \\
\text { literatura infantil" }\end{array}$ \\
\hline História da literatura geral & A Peixoto & $\begin{array}{l}\text { "D) A literatura infantil tradicional e } \\
\text { moderna" }\end{array}$ \\
\hline $\begin{array}{l}\text { Dicionário universal de } \\
\text { literatura }\end{array}$ & $\begin{array}{l}\text { Henrique } \\
\text { Perdigão }\end{array}$ & $\begin{array}{l}\text { "D) A literatura infantil tradicional e } \\
\text { moderna" }\end{array}$ \\
\hline El mundo poético infantil & $\begin{array}{l}\text { Fryda Schultz } \\
\text { de Mantovani }\end{array}$ & "E) O ensino da literatura infantil" \\
\hline $\begin{array}{l}\text { Directing Language Power in } \\
\text { the Elementar School }\end{array}$ & $\begin{array}{l}\text { Thommer and } \\
\text { Regan }\end{array}$ & "E) O ensino da literatura infantil" \\
\hline
\end{tabular}

Fonte: Budin (1949).

Como se pode observar pelo Quadro 5, a maior parte dos livros sobre literatura infantil ou ensino de leitura recomendados por Budin (1949) se 
trata de livros estrangeiros. Entre eles, o que ela mais vezes mencionou foi Reading and Literature in the Elementary School, Mckee.

Além de recomendar livros cujos títulos indicam questões sobre o ensino da leitura e da literatura, Budin (1949) recomenda livros mais ligados ao campo educacional, como: A escola moderna, de Maria dos Reis Campos, e Didática da Escola Nova, de Miguel Aguayo.

Ao observar os títulos dos livros que essa professora recomenda, é possível notar que, apesar de a produção sobre literatura infantil, à época, estar em vias de se sistematizar, essa autora não faz menção a nenhum texto de autoria de brasileiro que trata especificamente da literatura infantil. Desse modo, é possível presumir que Budin (1949), por restrição de acesso ou por desconhecer a produção sobre literatura infantil da época, toma como base para formular sua proposta de ensino da literatura infantil os livros estrangeiros sobre o assunto.

\section{O ensino da literatura infantil segundo Orlando Leal Carneiro: Metodologia da linguagem (1951)}

Em 1951, Orlando Leal Carneiro teve publicado um manual de ensino também intitulado Metodologia da linguagem, ${ }^{11}$ pela Editora Agir (RJ). ${ }^{12}$

Nascido em 1893, Orlando Leal Carneiro atuou como professor catedrático de Metodologia da linguagem junto ao Instituto de Educação do Distrito Federal e atuou como professor de Pedagogia junto à Universidade Católica. Além desses cargos, foi chefe de Distrito Educacional da Prefeitura do Distrito Federal. Faleceu em 1977, aos 84 anos de idade.

Metodologia da linguagem (1951) foi publicado, conforme consta na orelha da capa e quarta capa, em decorrência da expansão do Ensino Normal pelo Brasil, especialmente após a promulgação da Lei Orgânica do Ensino Normal. Com o objetivo de colaborar com as discussões sobre o ensino da

11 Para informações mais detalhadas sobre Metodologia da linguagem (1951), de Orlando Leal Carneiro, ver Galuzzi (2006) e Mortatti (2014).

12 A Agir - Livraria e Editora Artes Gráficas Reunidas S.A, foi fundada por Cândido Guinle de Paula Machado e, apesar de sua data de fundação ser desconhecida, foi possível localizar a informação de que ela "cerrou" suas portas no ano de 1990, mesmo tendo sido, segundo Hallewell (2005), uma das editoras mais bem administradas de toda a história editorial brasileira. 
linguagem nos diferentes Institutos de Educação e Escolas Normais que se criavam no país, à época, a Editora Agir lançou a coleção "Biblioteca de Cultura Pedagógica”, cujo primeiro volume é Metodologia da linguagem (1951), de Orlando Leal Carneiro.

Ainda na orelha da capa e quarta capa desse manual, consta a seguinte informação: "Pela primeira fez, surge uma sistematização dos problemas da Literatura Infantil e o estudo da evolução no ensino da Linguagem, no mundo e no Brasil, é um outro traço de originalidade de sua utilíssima obra didática" (Carneiro, 1951, orelha). Apesar de esse não ser o primeiro manual que apresenta uma sistematização a respeito do ensino da literatura infantil, esse é um ponto utilizado pela Editora Agir para despertar o interesse dos professorandos por esse manual. Isso possibilita compreender, de certo modo, que as questões sobre literatura infantil faziam falta e que chamavam a atenção de normalistas e outros públicos afins, tanto que servia como forma de propaganda.

Em relação à organização desse manual, a sua $1^{\text {a }}$ edição, publicada em 1951, está dividida em cinco partes, que totalizam 11 unidades. A primeira parte - "Fundamentos filosóficos da linguagem" - contém apenas uma única unidade, que trata da conceituação da linguagem. A segunda parte - "Fundamentos psicológicos da linguagem infantil" - também contém apenas uma unidade, que trata relação entre criança e linguagem. A terceira parte - "Objetivos e fundamentos históricos do ensino da linguagem" - também só conta com uma unidade, que trata dos princípios do ensino da linguagem. A quarta parte - "Fundamentos psicológicos do ensino da linguagem" - contém apenas uma única unidade, que trata dos sentidos da linguagem e as anomalias. A quinta e última parte - "Fundamentos metodológicos do ensino da linguagem" - contém sete unidades, das quais uma que trata da literatura infantil.

Ao todo, Metodologia da linguagem contém 300 páginas, das quais 44 são destinadas ao "ensinar a ensinar" literatura infantil. Essa unidade específica sobre o ensino da literatura infantil está organizada em nove tópicos, nos quais se abordam os seguintes assuntos: conceito de literatura infantil; literatura para criança; literatura da criança; importância e requisitos da literatura infantil; contos populares; contos de fada; histórias maravilhosas; novelas de aventuras; e organização de bibliotecas escolares (Carneiro, 1951). A final de cada tópico, Carneiro (1951) apresenta um resumo do 
assunto tratado, um texto ou trecho de texto para leitura, alguns temas para discussão e alguns exercícios.

Esse manual, diferentemente do anterior, teve três edições: a primeira, em 1951, a segunda, em 1955, e a terceira em 1959. A segunda e terceira edições, conforme consta em seus exemplares, foram revistas e melhoradas, porém, no que se refere à unidade sobre literatura infantil, não houve alterações.

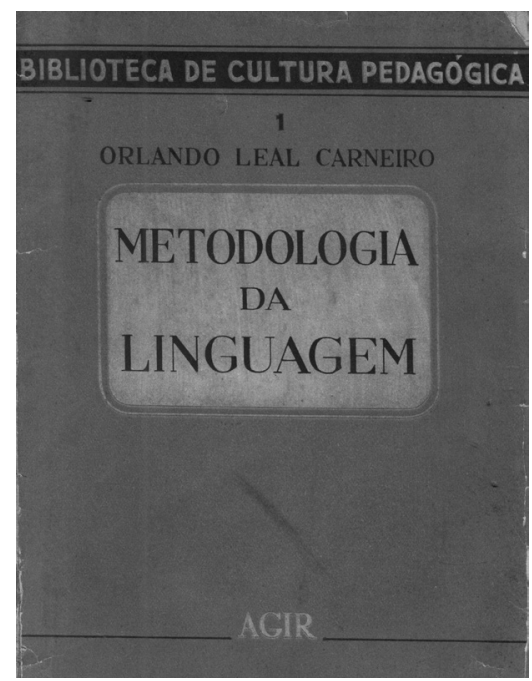

Figura 2 - Capa de Metodologia da linguagem (1951), de Orlando Leal Carneiro. Fonte: Acervo do GPHELLB.

Na unidade "A literatura na escola", Carneiro (1951) inicia a discussão sobre como conceituar a literatura infantil com a afirmação de que a arte literária se caracteriza como tal, por ter como principal instrumento a palavra. Esse professor questiona sobre a existência ou não de uma literatura destinada especificamente ao público infantil, ou seja, se existe uma literatura "para" ou "da" criança.

Para solucionar esse problema, Carneiro (1951) busca amparo na Psicologia infantil, pois, segundo ele, essa é a primeira ciência a mostrar que existe uma arte literária "ajustada" ao psiquismo da criança.

Já então, colocado nesse pé o problema, é possível definir a Literatura infantil como sendo a própria "expressão literária em geral" com valores ou caracte- 
rísticas determinadas que se ajustam à evolução mental da criança. Na verdade, só na resposta às exigências do psiquismo infantil, encontra-se uma literatura infantil, realmente digna dêsse nome, porquanto, de outro modo, há o risco de se dar êsse nome a banalidades, que não se dirigem à verdadeira alma da criança, ou de se não ser entendido pela inteligência infantil. (Carneiro, 1951, p.195, grifos do autor)

Além da literatura infantil escrita "para" a criança, Carneiro (1951) entende que existe uma literatura "da" criança, que "[...] deve ser despertada pela leitura e ensinada, dentro do possível, na escola” (Carneiro, 1951, p.195, grifos do autor). Carneiro (1951) entende, como Amoroso Lima (1927), que ambas as produções literárias, "para" ou "da" criança, constituem o que se denomina de "literatura infantil".

A partir da definição desse conceito de literatura infantil, ao tratar especificamente da literatura "para" crianças, Carneiro (1951) afirma que, no conjunto dos livros escritos intencionalmente para os pequenos leitores, há aqueles de que eles gostam, a chamada "boa" literatura infantil, e os livros de que esses pequenos leitores não gostam, a chamada "má" literatura infantil. No entanto, a "[...] má literatura infantil que não deleita a criança, é, todavia, a mais numerosa. Não basta querer escrever para a criança, é preciso poder" (p.197-198).

No âmbito do que denomina "má" literatura infantil, Carneiro (1951) identifica como principais problemas o tratamento da criança com excesso de puerilidade e um tom moralizador, convertido em certa obsessão. Em relação à "boa" literatura para crianças, esse professor identifica que os principais requisitos são: o "movimento" e a "melodia; a simplicidade poética; a graça; a fantasia; a ação rápida; a clareza; o vigor; a emoção; e a vivência (Carneiro, 1959).

Em relação à literatura "de" crianças, citando trechos do texto de Alceu Amoroso Lima (1927), Carneiro (1951) afirma que, dada a dificuldade dos adultos em escrever satisfatoriamente para as crianças, "modernamente" se aceitava a literatura escrita pelos pequenos. No entanto, ressalta que não são todas as crianças que podem escrever literatura infantil. Para tal empreitada, é necessário que demonstrem "espontaneidade" e "imaginação".

Carneiro (1951) também propõe uma divisão das publicações voltadas às crianças, conforme seus suportes: os jornais, as revistas e os livros infan- 
tis. Especificamente sobre os jornais e as revistas, Carneiro (1951) afirma que há alguns autores que condenam essas publicações, sobretudo pela alegação de que elas deformam o espírito infantil. Outros autores, contudo, defendem os jornais e revistas infantis, por entenderem que essas publicações apresentam "sugestibilidade" incontestável.

Sobre as publicações em formato de livros, Carneiro (1951) destaca os requisitos materiais que esses devem conter, a fim de serem úteis na formação da criança. Como requisitos materiais, destaca: proporção do tamanho e do formato; graça e riqueza das letras; boa encadernação; papel e tinta de qualidade; e boas ilustrações.

Assim como Budin (1949), Carneiro (1951) também trata das contribuições dos contos populares (ou contos folclóricos) para a literatura infantil. De acordo com esse professor, os contos populares encantam as crianças, porque lidam com o maravilhoso, com o imaginário e com o sonho. Para Carneiro (1951), o conto popular é poesia, uma poesia maravilhosa, que encanta os olhos deslumbrados das crianças e os leva a um mundo de realidades da vida cotidiana.

No âmbito ainda das considerações sobre os contos populares, Carneiro (1951) enfatiza a importância dos contos de fadas. Segundo ele, esses contos são importantes na formação do pequeno leitor, pois desenvolvem a imaginação, não "falseiam" a moralidade e não prejudicam a sua boa índole. Ainda que alguns "adversários" dos contos argumentem que esse tipo de texto possa causar confusão no espírito infantil, corromper o sentimento de verdade e ameaçar um desajuste na criança, Carneiro (1951) os considera essenciais para o desenvolvimento dos leitores menores, pois se trata de estímulo à imaginação e às demais faculdades mentais.

Carneiro (1951) também aborda algumas questões das histórias maravilhosas, que se trata de uma denominação mais geral, para se referir às narrativas que lidam com o "imaginismo", com o maravilhoso. Por isso, para ele, os contos de fada são um dos tipos de histórias maravilhosas, pois contemplam encantamento, ambiente vago, semelhança com o sonho, motivações variadas, técnica especial de exposição dos fatos e triunfo fácil das personagens (Carneiro, 1951). Por conter essas características, Carneiro (1951) afirma que as histórias maravilhosas corroboram para o desenvolvimento das "faculdades infantis", estimulam a imaginação e provocam encantamento. 
Com relação às novelas de aventura, Carneiro (1951) explica que se relacionam a uma fase do desenvolvimento infantil chamado de "robinsionismo". Esse professor explica que, conforme tese da Psicologia, o desenvolvimento infantil passa por três fases: a do "imaginismo", a do "robinsionismo" e a do "realismo". As histórias maravilhosas e os contos de fada pertencem ao período do "imaginismo". Já as novelas e histórias de aventuras correspondem à fase do "robinsionismo" e ao início do pensamento racional.

Em relação à denominação da segunda fase do desenvolvimento do psiquismo infantil de "robinsionismo", Carneiro (1951) explica que a utiliza com base em um autor chamado Bühler. Para esse autor, essa fase é assim chamada porque o livro Robinson Crusoé, de Daniel Defoe, corresponde ao tipo de leitura apropriada nessa fase do desenvolvimento do psiquismo infantil. Carneiro (1951) completa que: "É nessa época que a criança se sente mais adaptada à realidade, com o pensamento lógico já em pleno desenvolvimento, com grande interêsse pelas fitas de mocinho e menos interêsse pelas fadas, bruxas e encantamentos" (p.227).

No âmbito das novelas e histórias de aventuras, Carneiro (1951) faz uma distinção entre novelas e história heroicas, novelas e contos de viagens e histórias universais, nacionais e regionais. As novelas e histórias heroicas são as que têm certo fundamento na realidade histórica. As novelas de viagens são as que misturam sonho e realidade. E as histórias universais pertencem à realidade histórica e relatam, por vezes, acontecimentos de nossa época.

Sobre a poesia, Carneiro (1951) explica que, à época, havia um movimento contrário a esse tipo de literatura, por se considerar o gênero lírico inacessível às crianças. No entanto, para ele, a literatura escrita em versos é extremamente recomendável para o público infantil, pois a poesia se aproxima da tradição oral e da constituição da linguagem.

É evidente que a poesia didática já é por si um argumento a favor da poesia na escola, mas é necessário acentuar que a poesia, qualquer que ela seja, sendo verdadeira poesia, tem um valor em si e é fundamento de uma educação estética.

O verso, por mais livre que seja, disciplina e o poeta acha (trouver é parte de trovador) proporções, harmonias e equilíbrios.

E se o pensamento estimula e se as idéias se interpenetram, por que não se transmitirão sentimentos de harmonias e de proporções? 
Nada mais poético que a infância e nada mais infantil que a poesia, porque a criança é criadora e o poeta não cria sem inocência (Carneiro, 1951, p.233, grifos do autor).

Carneiro (1951) também aborda algumas questões sobre a organização de bibliotecas escolares e explica que, por biblioteca escolar, entende o conjunto de todos os livros existentes na escola e que podem ser manuseados por crianças. Com isso, enfatiza a necessidade de os professores saberem diferenciar, no acervo de uma biblioteca, os livros didáticos dos livros de literatura infantil, pois os livros didáticos são para leitura em classe e os livros de literatura infantil são para serem emprestados, para leitura em casa, na escola, ou em horário especial.

Com base em texto de Lorenzo Luzuriaga, ${ }^{13}$ Carneiro (1951) afirma que a biblioteca escolar tem dupla finalidade: "De um lado deve contribuir para despertar o interêsse das crianças pelos livros, pelas leituras livres e espontâneas [...]; de outro, há de servir de complemento e afirmação do trabalho docente do professor, mediante as leituras complementares que este indique" (Carneiro, 1951, p.236).

Com relação aos princípios de organização de uma biblioteca escolar, Carneiro (1951) entende que essa é tarefa simples. Para tal empreitada, afirma que se podem tomar como base livros doados pelos alunos, professores ou "beneméritos de ensino". Após reunir esses livros, Carneiro (1951) sugere dividi-los em seções, conforme as faixas etárias das crianças: "[...] uma para crianças de 7 a 9 anos; outra para crianças de 10 a 12 anos e, finalmente, outra para crianças de 13 a 15 anos e antigos alunos" (Carneiro, 1951, p.236).

Apesar de considerar a organização de uma biblioteca escolar tarefa simples, Carneiro (1951) apresenta alguns problemas que os futuros professores podem encontrar. São eles: aquisição de livros; ordenação e catalogação; e difusão e utilização da biblioteca.

Diferentemente de Budin (1949), Carneiro (1951) apresenta a bibliografia que utilizou como base para a elaboração de seu manual, porém, essa bibliografia consta ao final das partes que compõem o manual. Como a

13 Carneiro (1951) não apresenta informação sobre qual texto de Lorenzo Luzuriaga utiliza, apenas informa que se baseia em texto desse educador. 
unidade sobre literatura infantil está contida na quinta parte, composta por outras sete unidades, não é possível saber quais livros ele utilizou especificamente na unidade sobre literatura infantil. Porém, é possível presumir alguns. São eles: A criança, o sonho e os contos de fadas, de Theobaldo Miranda Santos; La educación nueva, de Lorenzo Luzuriaga; artigo "Del mito primitivo a la sinfonia tenta”, de Jesualdo Sosa; e Los titanes de la literatura infantil, cuja autoria não foi informada.

Além dessas quatro publicações, é possível que Carneiro (1951) tenha tomado como base outros livros para elaborar suas reflexões sobre literatura infantil, porém, como não há citações literais em seu manual, não é possível identificar quais outros livros ou textos ele utilizou para tratar desse assunto.

Outro aspecto que cabe ressaltar aqui em relação a esse manual é a semelhança com o manual de Budin (1949). A unidade sobre literatura infantil contida no manual de Carneiro (1951) apresenta forma de organização e até mesmo conteúdo bastante semelhantes aos do manual de Budin (1949). O único aspecto diferente entre eles é que no manual de Budin (1949) não há nenhuma discussão sobre bibliotecas escolares, o que Carneiro (1951) apresenta com certo detalhamento.

Apesar das semelhanças entre as propostas de ensino da literatura infantil contidas nos manuais de Budin (1949) e de Carneiro (1951), este último não faz nenhuma menção e/ou citação ao manual anterior. Pelo contrário, como mencionei, na olha da capa e quarta capa do manual de Carneiro (1951) consta a informação esse manual é o primeiro a conter discussão detalhada sobre a literatura infantil, ignorando totalmente a publicação do manual anterior.

Esse aspecto é bastante importante, pois ambos os professores atuavam no Instituto de Educação do Distrito Federal, em disciplinas correlatas. Por isso, é possível presumir que a proximidade de ambos levou Carneiro (1951) a não citar o manual de Budin (1949) ou foi uma simples estratégia editorial. Fato é que Carneiro (1951) não faz nenhuma menção ao manual de Budin (1949), embora trabalhassem na mesma instituição, em áreas correlatas. 


\section{A "concretização" do ensino da literatura infantil segundo Antônio d'Ávila: Práticas escolares (1954)}

Ainda na década de 1950, foi publicado outro manual de ensino que contém um capítulo sobre literatura infantil. Trata-se do terceiro volume de Práticas escolares: de acordo com a orientação do ensino primário e curso de transição entre o primário e o secundário, ${ }^{14}$ de Antônio d'Ávila, publicado pela Saraiva (SP)..$^{15}$

Nascido em Jaú-SP, em 1903, Antônio d'Ávila diplomou-se professor pela Escola Normal de São Paulo, em 1920. Durante as décadas de 1920 e 1930, atuou como professor em cidades do interior do estado de São Paulo e, a partir de 1931, passou a atuar na capital do estado, como professor de Escola Normal Livre (Trevisan, 2003; 2007).

Além desses cargos, Antônio d'Ávila ocupou importantes cargos na administração escolar do estado de São Paulo, tais como: lente de Didática na Faculdade de Filosofia, Ciências e Letras de Campinas; diretor do serviço de Orientação Pedagógica do Departamento de Educação de São Paulo; e diretor geral desse Departamento. Em 1989, aos 86 anos de idade, Antônio d'Ávila faleceu na cidade de São Paulo (Trevisan, 2003; 2007).

Concomitantemente à sua atuação profissional, Antônio d'Ávila teve publicados diferentes manuais de ensino, sendo o primeiro deles Práticas escolares Práticas escolares. Esse manual, dividido em três volumes, teve o primeiro deles publicado em 1940. O segundo volume foi publicado em 1944 e o terceiro, em 1954, todos pela Edições Saraiva (SP).

Antônio d'Ávila explica no prefácio do terceiro volume de Práticas escolares, no qual está contido capítulo sobre literatura infantil, que a publicação desse novo volume decorreu do "generoso acolhimento" dos volumes anteriores, os quais, à época, encontravam-se, respectivamente, com seis e quatro edições. Desse modo, o objetivo de d'Ávila (1954) com o terceiro volume de

14 Para informações mais detalhadas sobre Práticas escolares, ver Trevisan (2003) e Mortatti (2014). E, para informações mais detalhadas sobre a vida, formação, atuação profissional e produção escrita de Antônio d'Ávila, ver: Trevisan (2003; 2007).

15 Segundo Hallewell (2005), a Editora Saraiva foi fundada no ano de 1906, com o nome de Saraiva e Cia. Contudo, conforme informações contidas no site dessa editora, ela foi fundada em 1914, por Joaquim Inácio da Fonseca Saraiva. Essa editora, quando foi fundada, centrou-se na publicação de livros da área jurídica e, a partir da década de 1960, passou a diversificar sua atividade editorial, tornando-se os livros didáticos seu principal ramo de atuação (Hallewell, 2005). 
Práticas escolares foi "[...] corresponder aos renovados desejos do professorado e de oferecer-lhe mais um volume do livro que lhe foi, segundo parecer unânime da crítica letrada pedagógica, de suma e provada utilidade" (p.5).

Para atender a esse objetivo, d'Ávila (1954) informa que no terceiro volume de Práticas escolares ele buscou ampliar a discussão dos volumes anteriores até o ensino secundário e contemplou alguns assuntos da atualidade e de interesse geral dos professores. "Assim, trazem estas PRÁTICAS capítulos relativos a exames de admissão ao ginásio, referentes às relações entre ambas as escolas, à de orientação educacional e profissional, à literatura para jovens e crianças, à recreação e processos de estudo" (D’Ávila, 1954, p.5).

Esses novos assuntos incluídos no terceiro volume de Práticas escolares estão organizados em 11 capítulos, todos seguidos de bibliografia. Além desses 11 capítulos, contém uma relação de anexos e apêndices. Ao todo, esses 11 capítulos, os anexos e os apêndices totalizam 267 páginas.

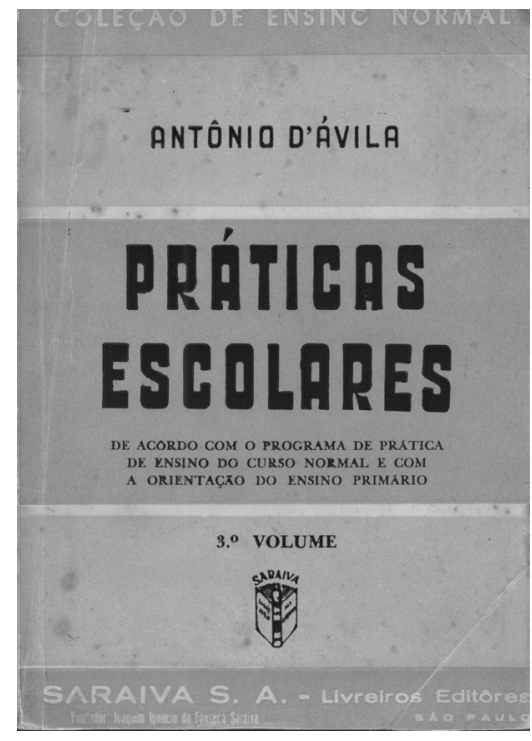

Figura 3 - Capa de Práticas escolares (1954), de Antônio d'Ávila. Fonte: Acervo do GPHELLB.

O capítulo de Práticas escolares, no qual d'Ávila trata do ensino da literatura infantil, intitula-se "Literatura infanto-juvenil" e tem 35 páginas.

Nesse capítulo, esse professor, ao tratar dos aspectos relativos à literatura infantil, parte da ideia de que foi a partir do interesse que os adultos 
passaram a manifestar em relação à infância, no século XVIII, que decorreu a criação de uma produção literária voltada a esse público. Explica que, no anseio de os adultos criarem um "novo homem" a partir do conhecimento biológico, mental e moral das crianças, " [...] empenharam-se escritores de todos os tempos em alimentar o crescimento espiritual, social e moral, com o recurso de lições [...] para oferecer à criança nas suas várias idades - como substância e fundo da literatura escolar didático-recreativa" (D’Ávila, 1954, p.212-213).

Para entender melhor essa literatura, d'Ávila (1954) afirma ser necessário se debruçar sobre alguns dos aspectos que a constituem como tal. Entre esses aspectos, entende que o primeiro é a necessidade de conceituação da literatura para crianças e jovens e o segundo a observação de suas finalidades e características.

Com base em texto de Tristão de Ataíde (Alceu Amoroso Lima), que apresentei no capítulo anterior, d'Ávila (1954) afirma o seguinte: "A verdadeira finalidade da literatura infantil, a primordial, é divertir para educar" (p.213). Ainda que alguns defendam que a literatura infantil seja apenas recreação ou outros insistam unicamente no seu caráter educativo, o conceito mais adequado é o que o compreende essa literatura como "[...] meio de educação pelo divertimento [...]” (p.213). Nesse sentido, a ideia de educar "[...] é justamente conduzir tôdas as inclinações naturais à formação do homem, [e] deseducar é permitir que essas inclinações levem à deformação da personalidade e à dissociação da comunidade" (D'Ávila, 1954, p.213).

D’Ávila (1954) explica que esse gênero literário se originou da exploração do "campo do maravilhoso". Foi das fábulas, da fantasia, das fadas, das aventuras e das "histórias estranhas" que a literatura infantil construiu seu "espírito". Ele entende também que a organização e a sistematização desse gênero literário decorreram de iniciativas ligadas às bibliotecas escolares, especialmente a partir de 1926, após importantes inciativas tomadas por Lourenço Filho e Fernando de Azevedo, quando eles estavam à frente da direção do ensino paulista e do distrito federal, respectivamente.

Segundo d'Ávila (1954), nas décadas de 1920 e 1930, com a expansão das bibliotecas escolares e as ações das Diretorias Regionais de Ensino do estado de São Paulo em favor da leitura, preparou-se o terreno para a expansão do livro de literatura infantil, o que demandou, então, a necessidade de "selecionar" e "depurar" esses livros. 
Como se havia feito com o livro didático, sentiu-se a necessidade de estabelecer padrões de textos para idades, sexos e leitores de meios sociais diversos, definindo-se leitura para a infância, para a meninice, para a adolescência, com temas adequados às meninas, ao menino, ao rapaz, leituras para o meio urbano, rural, etc. (p.215).

Para essa "seleção" e "depuração" dos livros de literatura infantil, d'Ávila (1954) relata que, em 1936, a Secretaria dos Negócios da Educação e da Saúde Pública do estado de São Paulo criou o Catálogo da Biblioteca Infantil Modelo para ser distribuído aos diretores de escolas, com o objetivo de orientá-los na escolha dos livros para as bibliotecas de suas instituições. Com isso, ele destaca os problemas "didático-pedagógicos" desse gênero literário, pois para que um livro fosse considerado aceitável, era necessário observar algumas questões, tais como: a adequação da linguagem ao público a que se destina; o nome da obra e das personagens; o uso da ilustração; a impressão; e o modo pelo qual o leitor escolhe o livro e a impressão que faz dele (D'Ávila, 1954, p.216). Para que os professorandos pudessem se aprofundar na compreensão desses problemas, d'Ávila (1954) indica a leitura do artigo "Algo de que as crianças gostam de ler", de Betti Katzenstein e Beatriz de Freitas, publicado em 1941, na Revista do Arquivo Municipal, que apresentei no capítulo anterior.

Na sequência, d'Ávila (1954) aborda o problema da formação ou "deformação" dos leitores, causada por esse gênero literário. Na discussão desse assunto, ele toma como ponto de reflexão três tipos de textos, os quais eram alvos recorrentes de divergência: os contos de fadas, as histórias em quadrinhos e as histórias científicas ou romances policiais.

Com relação aos contos de fadas, explica, com base em Laboulaye, que a imaginação proporcionada por esse tipo de texto é uma faculdade tão fundamental quanto a razão. Apesar disso, ele entende que outros autores, como Eurico Branco Ribeiro, discordam dessa corrente de pensamento, porque pensam que os contos de fadas levam as crianças a um mundo irreal, ocasionando um erro no espírito infantil.

No caso das histórias em quadrinhos, informa que as críticas que se faziam a esse tipo de publicação eram relativas à "substância" das histórias. Normalmente, afirmava-se que as histórias em quadrinhos, pelo tema que abordavam, eram motivadoras de crimes, de comportamento de "gangste- 
riano" e de ações grosseiras. Embora as críticas com relação às histórias em quadrinhos fossem maioria entre os que se ocupavam da literatura infantil, d'Ávila (1954) apresenta uma opinião discordante desse problema. Trata-se da opinião de Jerônimo Monteiro, expressa em artigo publicado no jornal O Estado de S. Paulo, o qual também apresentei no capítulo anterior.

D’Ávila (1954) explica que, para Monteiro, as histórias em quadrinhos não podem ser vistas como "deformadoras" apenas porque tratam de crimes, cenas de violência, bandidos e cenas de ação. Afirma que Monteiro entende que tudo isso é exemplo vivo para que a criança aprenda o bem, em comparação com o mal. As histórias em quadrinhos ensinam "pela ação", pois são a forma mais eficiente de a criança "gravar" a "[...] vitória do bem, da ordem, da lei, do direito” (D’Ávila, 1954, 221.).

Ainda em relação às histórias em quadrinhos, d'Ávila (1954) apresenta uma "palavra justa e serena", que busca conciliar os efeitos formadores e "deformadores" desse tipo de texto. Trata-se do posicionamento tomado por Gilberto Freyre. Segundo d'Ávila (1954), esse sociólogo, ao tratar dos quadrinhos, "discerniu agudamente" sobre o assunto, propondo "duas faces": a técnica e a "substância”. Com relação à técnica, d'Ávila (1954) explica que Freyre afirmava não ser possível "incriminar" as histórias em quadrinhos. Nesse aspecto, essas histórias são verdadeiros "[...] instrumentos de propagação de ideias e divulgadoras do saber, além de elementos recreativos" (D’Ávila, 1954, p.21). Com relação à “substância”, porém, d'Ávila (1954) explica que Freyre apresentava algumas críticas, sobretudo pela presença maciça de "americanidade de motivos".

O último tipo de texto que d'Ávila (1954) aborda para tratar da questão da formação ou "deformação" que a literatura infantil representa para o leitor é a história científica e/ou romance policial. Segundo esse professor, embora houvesse os que defendiam que as histórias científicas ou romances policiais fossem prejudiciais aos leitores, sobretudo porque o enredo gira em torno de crimes, para outros, como Arthur Leite de Barros Júnior, esse tipo de literatura é um dos passatempos mais agradáveis para os jovens.

Em vista desses posicionamentos divergentes, d'Ávila (1954) compreende ser fundamental pensar sobre como orientar as crianças " [...] contra a fôrça corruptora da má literatura, preservando-a ao mesmo tempo de perigos que a ameaçam por meio de gibis, jornalzinhos, revistas de quadrinhos etc." (D’Ávila, 1954, p.223, grifo do autor). Independentemente de qual 
seja o tipo de literatura infantil que se oferte às crianças, d'Ávila (1954) entende que é preciso ter cuidado com a "má" literatura.

A orientação de quais leituras as crianças podem fazer, segundo d'Ávila (1954), é responsabilidade dos pais, professores e bibliotecários. Para que estes saibam como orientar, esse professor atribui papel destacado à crítica literária, pois por meio dela os pais, os professores e os bibliotecários se orientam com relação ao nome dos escritores e aos livros, para saber se são consagrados de maneira positiva, ou se são de mérito questionável. Com isso, ele destaca a importância de campanhas contra a "má" literatura infantil, como a que existia na Itália, na época, e algumas que vinham sendo iniciadas no Brasil, como a realização de congressos.

Para encerrar o seu capítulo sobre literatura infantil, d’Ávila (1954) apresenta um histórico desse gênero literário no Brasil, desde as primeiras cartilhas, como Cartilha maternal ou arte da leitura, do poeta João de Deus, até a publicação dos livros Saudade, de Thales de Andrade, e Narizinho arrebitado, de Monteiro Lobato.

Ao final desse capítulo sobre literatura infantil, d'Ávila (1954) apresenta a bibliografia que utilizou, a qual apresento no Quadro 6.

Quadro 6 - Relação dos textos indicados em Práticas escolares (1954) na bibliografia do capítulo "Literatura infanto-juvenil"

\begin{tabular}{|l|l|l|l|}
\hline Título & Autor & Editora/Revista & $\begin{array}{l}\text { Ano de } \\
\text { publicação }\end{array}$ \\
\hline Evocação nacional & José Veríssimo & Tavares Cardoso \& Cia. & 1890 \\
\hline Vida de Júlio Verne & $\begin{array}{l}\text { George H. Waltz } \\
\text { Júnior }\end{array}$ & José Olímpio & 1948 \\
\hline Vida de Júlio Verne & Luís Villaronga & $\begin{array}{l}\text { Biblioteca de Autores } \\
\text { Pueretorriqueños }\end{array}$ & 1939 \\
\hline As crianças querem ler & $\begin{array}{l}\text { Regina Mellilo de } \\
\text { Souza }\end{array}$ & Revista Formação & - \\
\hline Um livro e um autor & Antônio d'Ávila & Revista Formação & - \\
\hline $\begin{array}{l}\text { Literatura infantil na } \\
\text { Argentina }\end{array}$ & Nair Durão Barbosa & Revista Formação & - \\
\hline Literatura infantil & Rosita Lacombe & Revista Formação & - \\
\hline Literatura infantil & $\begin{array}{l}\text { Mário Gonçalves } \\
\text { Viana }\end{array}$ & Evocação Nacional & 1942 \\
\hline
\end{tabular}

Fonte: d'Ávila (1954). 
Diferentemente do que ocorre nos manuais de Budin (1949) e Carneiro (1951), d’Ávila (1954) apresenta bibliografia específica sobre o seu capítulo sobre literatura infantil. Nessa bibliografia, é possível observar que ele não fez uso de textos em língua estrangeira, especialmente em língua inglesa, como foi o caso dos manuais anteriores. D’Ávila (1954) indica apenas um título que se presume estar em língua estrangeira, pois a editora responsável pela publicação é a Biblioteca de Autores Puertorriquenõs e indica um livro publicado no Porto-Portugal.

No conjunto dos oito textos que d'Ávila (1954) indica nessa bibliografia, quatro são artigos publicados na revista Formação e os outros quatro são livros. Desses livros, nenhum dos títulos sugere o tratamento de aspectos mais amplos da literatura infantil. Dois indicam se referir a aspectos biográficos de dois escritores - Júlio Verne e Constancio Vigil -, um dos livros consiste em coletânea de fábulas - Fabulário - e o último presume-se tratar de um livro sobre aspectos gerais da educação nacional.

Os textos específicos sobre literatura infantil utilizados por d'Ávila (1954) foram todos artigos em revista, um de autoria de Nair Durão Barbosa (s.d.) e outro de Rosita Lacombe (s.d.).

Apesar de d'Ávila (1954) apresentar esses oito títulos na bibliografia do capítulo sobre literatura infantil de seu manual, nenhum deles é citado ou mencionado nesse capítulo. Ao invés disso, outros autores são mencionados por ele nesse capítulo, mas não são indicados na bibliografia. Entre os nomes mencionados e ou/citados por d'Ávila (1954), têm-se: Tristão de Ataíde (Alceu Amoroso Lima), Maria do Souza Campos Artigas, Lúcia Machado, Maria Gonçalves Viana, Jerônimo Monteiro, Alberto Comte, Otávio Goulart de Camargo, Austregésilo de Ataíde e Gilberto Freyre.

Um aspecto bastante importante a ser mencionado com relação ao terceiro volume de Práticas escolares é que a $3^{\mathrm{a}}$ edição desse volume, publicada em 1967, foi atualizada com dois novos capítulos, um intitulado "Educação moral e cívica" e outro, "Constituição Federal”. Também nessa 3 a edição o subtítulo foi alterado para: "De acordo com a orientação de ensino primário e cursos de transição entre o primário e o secundário”.

No caso específico do capítulo sobre literatura infantil publicado nessa $3^{\mathrm{a}}$ edição revista e ampliada, embora o conteúdo se tenha mantido idêntico ao da $1^{\text {a }}$ edição, de 1954, a sua bibliografia foi ampliada com sete novos títulos. Apresento, no Quadro 7, a relação dos livros que d'Ávila (1967) indica na 
bibliografia de seu capítulo sobre literatura infantil na $3^{\text {a }}$ edição do terceiro volume de Práticas escolares.

Quadro 7 - Relação dos livros indicados em Práticas escolares (1967) na bibliografia do capítulo "Literatura infanto-juvenil"

\begin{tabular}{|l|l|l|l|}
\hline Título do livro & Autor & Editora/Revista & $\begin{array}{l}\text { Ano de } \\
\text { publicação }\end{array}$ \\
\hline Educação nacional & José Veríssimo & Tavares Cardoso \& Cia. & 1890 \\
\hline Vida de Júlio Verne & $\begin{array}{l}\text { George H. Waltz } \\
\text { Júnior }\end{array}$ & José Olímpio & 1948 \\
\hline Constancio C. Vigil & Luís Villaronga & $\begin{array}{l}\text { Biblioteca de Autores } \\
\text { Pueretorriqueños }\end{array}$ & 1939 \\
\hline As crianças querem ler & $\begin{array}{l}\text { Regina Mellilo de } \\
\text { Souza }\end{array}$ & Revista Formação & - \\
\hline Um livro e um autor & Antônio d'Ávila & Revista Formação & - \\
\hline $\begin{array}{l}\text { Literatura infantil na } \\
\text { Argentina }\end{array}$ & Nair Durão Barbosa & Revista Formação & - \\
\hline Literatura infantil & Rosita Lacombe & Revista Formação & - \\
\hline Fabulário & $\begin{array}{l}\text { Mário Gonçalves } \\
\text { Viana }\end{array}$ & Evocação Nacional & 1942 \\
\hline $\begin{array}{l}\text { Palestras sob os auspícios } \\
\text { do Instituto Cultural } \\
\text { Monteiro Lobato }\end{array}$ & $\begin{array}{l}\text { Antenor Santos de } \\
\text { Oliveira (Org.) }\end{array}$ & Santos Oliveira & - \\
\hline $\begin{array}{l}\text { Edmundo De Amícis, } \\
\text { História de uma vida }\end{array}$ & Antônio d'Ávila & $\begin{array}{l}\text { Gazeta de Limeira } \\
\text { Editora }\end{array}$ & 1946 \\
\hline Literatura infanto-juvenil & Antônio d'Ávila & Editora do Brasil & - \\
\hline $\begin{array}{l}\text { Literatura infantil } \\
\text { de Carvalho }\end{array}$ & Jesualdo & - & - \\
\hline La literatura infantil & Nazira Salém & - & - \\
\hline Literatura infantil \\
\hline
\end{tabular}

Fonte: d'Ávila (1954).

Em relação aos títulos que d'Ávila acrescentou no capítulo sobre literatura infantil da $3^{\text {a }}$ edição do terceiro volume de Práticas escolares, têm-se dois de sua autoria, um deles um manual que teve publicado em 1961: Literatura Infanto-Juvenil. ${ }^{16}$

O que se observa em relação aos seis títulos que d'Ávila acrescenta nessa bibliografia é que todos tratam especificamente da literatura infantil. No caso do livro de Antenor Santos Oliveira (1958), embora ele tenha indicado

16 Sobre o manual Literatura Infanto-Juvenil (1961), de Antônio d'Ávila, apresento aspectos de sua análise no Capítulo 3, deste livro. 
como Palestras sob os auspícios do Instituto Cultural Monteiro Lobato, penso tratar-se do livro Curso de literatura infantil, publicado em 1958, que resultou de um ciclo de palestras realizados na Biblioteca Infantil Monteiro Lobato.

Também no caso de livro de Bárbara Vasconcelos de Carvalho, embora ele indique genericamente Literatura infantil, penso tratar-se de Compêndio de literatura infantil: para o $3^{\circ}$ ano normal, publicado em 1959, pois esse era o único livro sobre literatura infantil que essa autora havia publicado até 1967.

Embora d'Ávila mantenha todos os títulos que indicou na edição de 1954, corrigiu o título do livro de José Veríssimo. Na $1^{a}$ edição, esse livro consta com o título Evocação nacional, porém na $3^{\text {a }}$ edição consta como Educação nacional.

\section{A circulação do "livro de Jesualdo" no Brasil: ética, estética e psicopedagogia aplicadas ao ensino da literatura infantil}

Ainda na década de 1950, em julho de 1955, a editora argentina Editorial Losada, publicou a $2^{a}$ edição do livro La literatura infantil: ensayo sobre ética, estética y psicopedagía de la literatura infantil, do uruguaio Jesualdo Sosa. Desde então, esse livro passou a circular no Brasil, tornando-se, ao longo do século XX, um dos livros sobre literatura infantil mais citados pelos estudiosos e pesquisadores brasileiros que tratam desse assunto.

Embora a $1^{a}$ edição de La literatura infantil date de 1944, também pela Editorial Losada, essa edição não circulou no Brasil. Apenas quando a $2^{\mathrm{a}}$ edição foi publicada em 1955, no momento em que as questões sobre o ensino da literatura infantil na formação de professores se haviam se tornado assunto de interesse mais amplo no país, especialmente em São Paulo, é que esse livro chegou até os brasileiros.

Apesar de La literatura infantil ter circulado no Brasil somente após a década de 1950, a associação ao nome de Jesualdo Sosa como referência nos estudos sobre literatura infantil já aparece em Metodologia da linguagem (1951), de Orlando Leal Carneiro, que contém na bibliografia menção a um artigo desse autor. 
Desde que passou a circular no Brasil, La literatura infantil teve e continua a ter papel importante na história do ensino desse gênero literário, uma vez que se tornou, desde a década de 1950, um referencial sobre o assunto e um "clássico" dos estudos sobre literatura infantil.

\section{Sobre Jesualdo Sosa ${ }^{17}$}

Nascido em Tacuarembó, no Uruguai, em 22 de fevereiro de 1905, Jesualdo Sosa é considerado um dos mais importantes intelectuais latino-americanos do século XX. Seu prestígio se deve a sua intensa atuação como educador, defendendo a criação de uma escola única no Uruguai e em toda a América Latina, como forma de as sociedades latinas se desenvolverem política e economicamente.

Jesualdo, como ficou conhecido, estudou na cidade uruguaia de Tranqueras, para onde se mudou com seus pais quando tinha 5 anos de idade. Embora tenha iniciado seus estudos nessa cidade, concluiu-os em Riviera, Uruguai. Em 1921, ele se mudou para Montevidéu, onde ingressou no Instituto Normal para Varões. Três anos após o seu ingresso nesse curso, diplomou-se professor e passou a lecionar em escolas uruguaias.

Seu primeiro trabalho foi em 1925, na Escola n. 1 de Riviera. Após lecionar por um ano nessa escola, foi aprovado em concurso para professor efetivo da Escola Departamental n. 1 de Montevidéu, onde permaneceu por dois anos. No período em que atuou na capital uruguaia, começou a escrever os seus primeiros textos para um jornal local e, em 1927, teve publicados dois livros de sua autoria: Lecturas, biografías y héroes de leyenda e Nave del alba pura.

No ano de 1928, mudou-se para Riachuelo, Uruguai, onde se casou com María Cristina Zerpa, diretora da Escola Rural n. 56 de Canteras de Riachuelo. Tendo atuado nessa escola até 1935, foi nela que Jesualdo iniciou suas experiências sobre a expressão e criação infantil, que, ao longo de sua vida, formulou como a teoria da "expresión creadora del niño".

As experiências que passou a ter como professor na escola de Canteras de Riachuelo foram interrompidas em 1935, quando as autoridades uru-

17 Para apresentação dos aspectos biográficos de Jesualdo Sosa, utilizo-me de dados apresentados por Hinostroza Ayala (2007) e Sosa (1935). 
guaias, em decorrência da ditadura no país, destituíram-no do cargo de professor e o proibiram de dar continuidade às experiências e investigações que vinha desenvolvendo.

Apesar dessa proibição, ainda no ano de 1935, Jesualdo teve publicado o livro Vida de un maestro, no qual apresenta reflexões sobre sua experiência profissional e investigativa na escola de Canteras de Riachuelo.

Embora perseguido pelo governo ditatorial do Uruguai, Jesualdo voltou a lecionar em 1936, após ter sido aprovado em concurso para o cargo de professor de literatura no Liceu n. 6 Francisco Bauzá, em Montevidéu.

No âmbito de sua atuação como professor e militante em defesa de melhorias da escola pública no Uruguai (e, posteriormente, em toda a América Latina, Europa e Ásia), Jesualdo dedicou especial atenção às questões ligadas à alfabetização, visto que para ele a condição de alfabetizado era indispensável para que o povo participasse da vida política, econômica e social de seu país. Em decorrência disso, no ano de 1939, Jesualdo participou de uma campanha de alfabetização no México, e, em 1961, de outra, em Cuba.

Nesse período em que esteve no México, atuou como professor de literatura infantil na Escola Nacional de Professores do México, resultando na publicação do livro La literatura infantil, em 1944.

Por conta da repercussão do pensamento e atuação de Jesualdo para além das fronteiras uruguaias, esse educador passou a circular em diferentes países da América Latina, Europa e Ásia, disseminando o seu pensamento político e educacional. Entre as inúmeras atuações de Jesualdo, destaco: foi nomeado decano da Faculdade de Educação de Cuba, em 1962; participou como convidado especial da Assembleia Mundial de Educação, no México, em 1964; participou como membro da Federação Internacional do Sindicado de Ensino no Congresso Internacional de Educadores em Argel, em 1965; ministrou cursos na Universidade da Venezuela, em 1966; e ocupou cargo de primeiro presidente da Casa Bertold Brecht" o que resultou na criação do Instituto Cultural de Amizade Uruguai-Alemanha.

Concomitantemente a sua ativa e engajada atuação profissional, Jesualdo teve uma série de livros, artigos e textos poéticos publicados ao longo de sua vida. Entre os livros publicados, destaco: 180 poemas de los niños de la escuela de Jesualdo (1938); José Artigas, del vasallaje a la revolución (1940); Problemas de la educación y la cultura en América (1943); Los fundamentos de la Nueva Pedagogía (1943); 500 poemas de los niños de la escuela de Jesu- 
aldo (1945); 17 educadores de América (1945); La expresión creadora del niño (1950); Mi viaje a la U.R.S.S. (1952); La escuela lancasteriana (1954); Conocí China en otoño (1959); Antología de la poesía latinoamericana (1961); El tiempo oscuro (1966); Pedagogía de la Expresión (1968); Lenin y la educación (1970); El garañón blanco (1971); e La escuela politécnica humanista (1974).

Em decorrência dessas publicações, Jesualdo recebeu prêmios, como o Prêmio Poesía del Banco de la República, Prêmio Nacional de Ensaio do Ministério da Instrução Pública do Uruguai e o Prêmio Anual da Universidade Uruguaia.

Aos 77 anos de idade, Jesualdo faleceu em Montevidéu, no dia 28 de dezembro de 1982.

Sus inquietudes lo inscribieron desde el comienzo de su actividad docente, aunque desde una actitud crítica, en los caminos renovadores de la corriente de la escuela nueva o activa que proponía el traslado del interés que había existido por los métodos de enseñanza, hacia lo relacionado con la psicología del niño e del aprendizaje, privilegiando nuevas pautas actividad, liberad y autonomía. Jesualdo profundizó en particular el tema de la expresión otorgándole una dimensión mucho más rica de la que se le daba corrientemente. (Hinostroza Ayala, 2007, p.164)

\section{Sobre o livro La literatura infantil}

Resultante de sua atuação como professor, especialmente de literatura infantil na Escola Nacional de Professores do México (Sosa, 1955), Jesualdo teve publicado o livro La literatura infantil, em 1944, em Buenos Aires, pela Editorial Losada, conhecida como a "editora dos exilados". No ano de publicação da $1^{a}$ edição de La literatura infantil, 1944, esse livro recebeu o prêmio do Ministério da Instrução Pública do Uruguai.

A editora, fundada na Argentina em 1938, por Gonzalo Losada, Guillermo de Torre e Atilio Rosi, com sucursais instaladas no Uruguai, Chile, Brasil, Peru, Colômbia, México, Guatemala, Estados Unidos, Inglaterra e França (Muñoz, s.d.), possibilitou a ampla circulação de La literatura infantil, tornando-o uma das principais referências na América Latina, sobre literatura infantil. 
Embora não tenha sido possível localizar com exatidão quantas edições teve La literatura infantil, é possível afirmar que após a $1^{\text {a }}$ edição, em 1944, foram editadas pelos menos mais três edições: em 1955, foi publicada a $2^{\mathrm{a}}$ edição; em 1967, foi publicada uma nova edição; e, em 1973, foi publicada a edição mais recente que localizei. Sobre as edições de 1967 e 1973, não pude localizar a informação do número de edição a que se referem. No entanto, é possível afirmar que nenhuma dessas edições foi revista, aumentada ou ampliada.

Em todas as suas edições pela Editorial Losada, La literatura infantil foi publicado como um dos 20 títulos $^{18}$ da coleção "La escuela activa", dirigida, à época, por Lorenzo Luzuriaga (Sosa, 1955).

La literatura infantil, composto em 291 páginas, tem o seu conteúdo organizado em quatro capítulos, uma "advertência", agradecimento e epígrafe. No primeiro capítulo, Jesualdo (1955) trata das características e funções da literatura infantil, a fim de discutir a especificidade desse gênero literário. Ainda no primeiro capítulo, aborda o problema da moral e da didática dos livros para crianças. No segundo capítulo, detém-se a questões do desenvolvimento psicológico infantil, como sua característica, evolução, transcendência da mentira para a fabulação e o desenvolvimento da linguagem e da imaginação. No terceiro capítulo, o mais breve, detém-se à associação da mentalidade primitiva com a da criança, discute os valores estéticos da literatura infantil e problematiza a questão da adequação ou não do mito nos livros para crianças. No quarto e último capítulo, o mais extenso, Jesualdo (1955) discute sobre as principais formas de manifestação da literatura infantil: contos de fadas, fábulas, histórias e novelas de aven-

18 Além de La literatura infantil, fizeram parte da coleção "La escuela activa", da Editorial Losada, os seguintes livros: Iniciacion general al método Decroly, de Decroly e Boon; El plan de los grupos de estúdio, de E. R. Magire; Los centros de interés em las escuelas, de C. G. de Rzzano; El nuevo programa escolar, de W. H. Kilpatrick; El método de trabajo por equipos, Maria Luisa Navarro; Um programa desarrollado em proyectos, de M. E. Wells; La autonomia em la escuela, de J. Piaget e M. J. Heller; El trabajo individual según el plan Dalton, de A. J. Lynch; Las actividades dirigidas, de L. Dumas; La escuela viva, de Olga Cossettini; La escuela pública renovada, de F. Bovesse; La escuela individualizada, de C. Washburne; El método de proyectos em las escuelas urbanas, de M. Comas; El método de proyectos em las escuelas rurales, de F. Sainz; El folklore em la escuela, de F. M. Torner; La cooperación escolar, de B. Profit; La imprenta em la escuela de H. Almendros; La práctica de las pruebas mentales, de J. Comas e R. Lage; La escuela del trabajo, de José Mallart; e Um nuevo método de trabajo libre por grupos, de R. Cousinet (Sosa, 1955). 
turas, contos "robinsonianos", as novelas em geral, as novelas policiais e sentimentais, a poesia e o teatro.

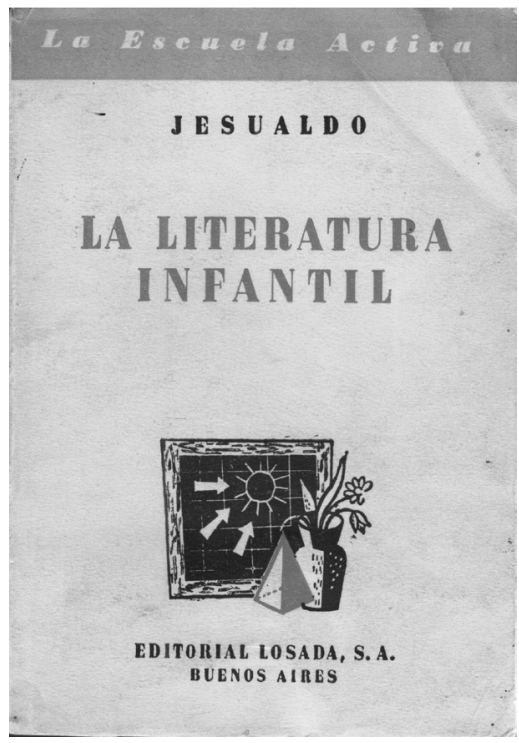

Figura 4 - Capa de La literatura infantil (1955), de Jesualdo Sosa. Fonte: Acervo pessoal do autor.

$\mathrm{Na}$ "advertência" de La literatura infantil, que "funciona" como introdução do livro, Jesualdo (1955) explica que, por ser a literatura infantil um fenômeno literário recente quando da publicação de seu livro, o número de trabalhos sobre esse assunto era ainda restrito. Em decorrência disso, ele inicia a sua argumentação apontando que não pretende apresentar um "guia de leituras" relacionadamente à literatura infantil. Seu objetivo é mais "audacioso", busca apresentar a questão da "totalidade" desse gênero, segundo ele ainda não feita na bibliografia disponível sobre o assunto até então.

Para Jesualdo (1955), essa "totalidade" da literatura infantil consiste na sua ética, estética e psicopedagogia, “[...] limitada a su propria y exclusiva estructura desgajada del resto del arte al servicio del niño" (Sosa, 1955, p.11).

Para dar conta desse objetivo, Jesualdo (1955) aborda nos quatro capítulos de La literatura infantil aspectos, como: problematização da existência da literatura infantil; suas funções; o problema da moralização e do didatismo; as teorias psicológicas sobre a evolução do pensamento, da linguagem e da inteligência infantil; o estudo das diferentes formas de manifestação da 
literatura infantil; e a adequação desses textos a cada faixa etária da criança. Para tratar desses aspectos, Jesualdo (1955) toma como aporte teórico os estudos de: Roger Cousinet, Édouard Claparèd, Jean Piaget, Anatole France e Aníbal Ponce, entre outros.

Para Jesualdo (1955), embora a estética literária tenha aceitado a literatura infantil como uma forma particular no quadro geral da arte literária, é preciso problematizar se a literatura infantil existe, de fato. Para ele, o que se observa em relação à literatura infantil é que os livros escritos intencionalmente para a leitura das crianças são os que menos interessam a elas. Historicamente, o que tem despertado o interesse de leitura das crianças são livros que, embora não escritos para elas, atendem as suas necessidades psíquicas, contribuem para a sua moralização e, por isso, despertam o interesse pela leitura nesse público específico.

Jesualdo (1955) explica que existe uma literatura escrita intencionalmente para as crianças, adequada ao seu léxico e rotulada de "infantil", mas que pouco interessa a elas. São outros livros, cuja finalidade não tinha em vista o público infantil, que acabam por despertar o interesse desses pequenos leitores.

Lo que existiría, entonces, serían valores, elementos o caracteres determinados, dentro de la expresión literaria en general, escrita o no para los niños, que responden a las exigencias de su psique durante su proceso de conocer y aprender, que se ajustan al proceso de su evolución mental, y en especial al de determinados poderes intelectivos. (Sosa, 1944, p.18, grifos do autor)

Com base nessa concepção de literatura infantil, Jesualdo (1955) afirma que esse gênero literário desempenha algumas funções na psique infantil, a saber: função instrutiva, função moralista e função lúdica. Embora as leituras a serem oferecidas para as crianças possam ser múltiplas, as que são "verdadeiramente proveitosas" são as que proporcionam distração e prazer, num primeiro momento, e que, depois, "[...] responden a las necessidades del niño, y ejercem, o pueden ejercer, uma influencia muy feliz em el desarollo de su psique" (Sosa, 1955, p.36).

Jesualdo (1955) destaca que, apesar de a literatura infantil ter função instrutiva e moralista, não é a leitura por si só desses livros que proporcionará o desenvolvimento psicológico da criança. Para esse educador uruguaio, é o 
tratamento didático que é dado aos livros de literatura infantil que os torna tão importantes na formação psíquica das crianças.

Por isso, apresenta uma discussão sobre a didática da literatura infantil, propondo que o "anarquismo empírico", caracterizado pelo ensino centrado apenas na história de leitura dos próprios professores, seja substituído pelo ensino científico, baseado na psicologia do desenvolvimento infantil.

Segundo Jesualdo (1955), a partir dos avanços nos estudos da "Psicologia infantil", a didática da literatura infantil de base cientificista consiste em "[...] ajustar, racional y científicamente, tanto como sea posible, sin menoscabar para nada el santo sentido transmisión de conocimientos, a fin de que se efectúe la más perfecta educación entre el niño y la obra [...]" (Sosa, 1955, p.72).

Essa proposta da didática científica e racional da literatura infantil, formulada por Jesualdo (1955), tem como princípio maior ajustar as obras literárias às etapas do desenvolvimento psicológico da criança. Como afirma esse autor:

[...] de la misma manera que es necesario conocer y considerar el origen y evolución del lenguaje del niño para crear [...] los instrumentos que la capaciten para el aprendizaje de la lectura, decimos también que es necesario conocer el mecanismo mental y sensitivo del niño, luego de situar su evolución en las distintas etapas por que atraviesa su psique, para de este modo saber qué literatura ha de ser más conveniente (por lo mejor aprovechable o asimilable), ya en qué cantidad y oportunidad ha de servir a sus distintos intereses y tendencias. (Sosa, 1955, p.72)

Para compreender as etapas do desenvolvimento psíquico da criança e saber qual tipo de texto é mais "conveniente" à formação da criança, Jesualdo (1955) se utiliza dos estudos de Aníbal Ponce (1930; 1931). Com base nesse autor, ele apresenta as seguintes fases do desenvolvimento infantil: na primeira fase, chamada de "maturação", a criança está no início de seu desenvolvimento mental juntamente com o seu desenvolvimento orgânico; a segunda fase, chamada de "técnica", é marcada pela "invenção da mão" e a utilização dessa parte do corpo como facilitadora das ações humanas; na terceira fase, chamada de "egocêntrica", a criança é marcada pelo monó- 
logo; e, na quarta fase, chamada de "racional", a criança passa a atuar com base na razão.

Jesualdo (1955) se atém mais detidamente à terceira fase, a "egocêntrica”, por ser a fase do desenvolvimento que coincide com a entrada da criança na escola e, por conseguinte, com o contato direto com a literatura infantil.

Para compreender melhor a fase "egocêntrica" do desenvolvimento infantil, Jesualdo (1955) se utiliza também dos estudos de Piaget (1933). Com base nos estudos desse intelectual genebrino, afirma que a criança, entre os 4 e 8 anos, passa por um processo de desenvolvimento mais pautado na imaginação. Após isso, ela inicia uma fase mais centrada nas suas próprias atividades, que culmina na etapa de racionalização, a quarta fase do desenvolvimento infantil.

A partir desse entendimento, Jesualdo (1955) apresenta quais são os gêneros literários mais adequados para cada uma das fases do desenvolvimento infantil, de modo a atender às necessidades psíquicas, morais, educativas e recreativas da criança.

Para Jesualdo (1955), para as crianças que se encontram na fase do "imaginismo" (por volta dos 3 a 4 anos), as lendas, mitos, contos, contos de fadas e fábulas são os tipos de textos mais adequados. Na faixa etária de 5 a 6 anos, quando a criança já se centra mais em suas próprias atividades, os textos literários recomendáveis são as narrativas, histórias e novelas de aventuras, pois as crianças já são capazes de lidar com textos de maior complexidade. Mencionando o nome de Bühler, Jesualdo denomina essa fase "robinsionismo". Na fase seguinte, quando as crianças têm entre 7e 8 anos, a racionalização já está presente, por isso os textos mais adequados são os romances sentimentais e policiais.

Jesualdo (1955) também aponta a importância da poesia e do teatro como altamente instrutivos e moralizantes na formação da criança. Por isso, para ele, esses textos também são instrumentos indispensáveis na escola.

Para finalizar a sua discussão sobre a "totalidade" da literatura infantil, Jesualdo (1955) ressalta a importância do tratamento material, especialmente das ilustrações, dos livros voltados para as crianças. Segundo ele, livros sem cores, com letras inadequadas e com estampas pouco atrativas não despertam nas crianças o desejo de aprender, de formar a ética, estética e moral por meio da literatura infantil. Por isso, cuidar da questão material 
dos livros não é um aspecto menor da literatura infantil, mas essencial e indispensável para se atingirem os objetivos que se têm com esse gênero literário.

\section{Sobre a circulação do "livro de Jesualdo" no Brasil}

Embora publicado por uma editora argentina e escrito e publicado em castelhano, La literatura infantil chegou até o Brasil, presumivelmente, por meio de sucursal da Editorial Losada instalada no Rio de Janeiro. À época, por ser escassa a bibliografia sobre o assunto, como se pode notar pela bibliografia citada nos manuais de Budin (1949), Carneiro (1951) e d'Ávila (1954), é possível entender que esse livro preenchia uma considerável lacuna na produção sobre literatura infantil. Tanto que d'Ávila, na $3^{\mathrm{a}}$ edição do terceiro volume de Práticas escolares, acrescentou a indicação desse livro em sua bibliografia sobre literatura infantil, conforme se observa no Quadro 7.

Em virtude da circulação, importância e influência que exerceu o livro de Jesualdo no debate sobre o ensino da literatura infantil na formação e professores no Brasil, em 1978 La literatura infantil foi traduzido para o português brasileiro por James Amado e publicado pela Editora Cultrix (SP), em coedição com a Editora da Universidade de São Paulo (Edusp) (SP).

Como afirma Ceccantini (2010), a tradução desse livro representou uma raríssima exceção de tradução para o português de obra teórica sobre literatura infantil que circulou no Brasil.

$\mathrm{Na}$ tradução para o português brasileiro La literatura infantil foi traduzido com o título A literatura infantil. Essa versão traduzida teve nove edições, num intervalo de 15 anos. A edição mais recente que localizei, a 9 , foi publicada em 1993, pela Cultrix (SP).

A partir de quando foi publicada a versão traduzida desse livro, a versão original, publicada na Argentina, deixou de ser citada nos livros e textos sobre literatura infantil, porém, isso não significou diminuição do uso desse livro, no Brasil. Pelo contrário, a facilitação do acesso e também a facilitação proporcionada pela tradução o fizeram circular ainda mais, sendo A literatura infantil, na sua edição de 1978 ou nas posteriores, quase bibliografia obrigatória em todos os textos que tratam da literatura infantil e de seu ensino, especialmente. Esse aspecto poderá ser confirmado, por exemplo, 
nos capítulos seguintes, nos quais apresento informações sobre os manuais específicos para o ensino da literatura infantil publicados no Brasil.

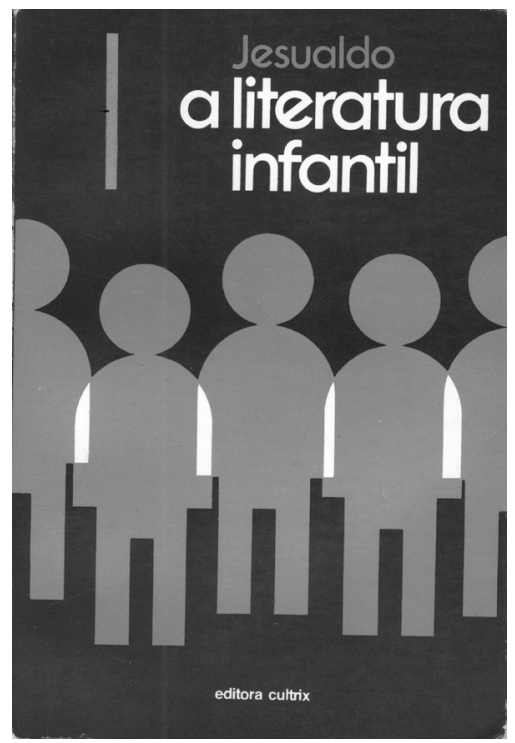

Figura 5 - Capa de A literatura infantil (1978) (edição brasileira), de Jesualdo Sosa. Fonte: Acervo do GPHELLB.

\section{Os discursos sobre a literatura infantil, entre 1947 e 1956}

No mesmo período de publicação desses manuais de ensino e da chegada, ao Brasil, do "livro de Jesualdo", a produção sobre literatura infantil em formato de artigos em periódicos especializados e de textos em jornais continuava a se expandir. Com isso, em 1951, “[...] surge o primeiro livro (Problemas da literatura infantil, [...] de Cecília Meireles), que tematiza especificamente a literatura infantil [...]” (Magnani, 1998, p.249).

Esses textos sobre literatura infantil publicados em jornais e revistas, entre 1947 e 1956, embora não escritos para tratar do "ensinar a ensinar" literatura infantil, como os manuais de Budin (1949), Carneiro (1951) e d'Ávila (1954), de certa forma contribuíram para esse intento, visto que a produção nacional sobre o assunto era ainda escassa. Esses textos, de modo geral, contribuíram para se ir acumulando um tipo de saber sobre a literatu- 
ra infantil, que de certo modo passou a ser didatizado nos capítulos sobre literatura infantil contidos em manuais de ensino.

O primeiro artigo que aqui destaco foi publicado na Revista Brasileira de Estudos Pedagógicos, em 1947. Trata-se de artigo de Maria dos Reis Campos, professora do Instituto de Educação do Distrito Federal e a quem J. Budin (1949) dedica seu manual, Metodologia da linguagem.

Esse artigo, intitulado "Literatura infantil", conforme nota nele contida, consiste em uma "Súmula do Curso de Especialização para Orientadores de Parques de Recreação Infantil, organizado pela Secretaria Geral de Educação e Cultura da Prefeitura do Distrito Federal” (Campos, 1947, p.178).

Dada essa característica, Campos (1947) apresenta uma tentativa de sistematização do conhecimento sobre a literatura infantil, a partir da apresentação de sua conceituação, dados históricos (mundiais e brasileiros) e finalidades a que responde esse gênero literário.

Em relação ao conceito de literatura infantil, Campos (1947) compreende que se trata de livros destinados à leitura das crianças, cuja prioridade é o "fator de ordem estética". Ela entende que há outro fator que caracteriza esse gênero literário: a moralidade.

A par de tais qualidades, de ordem "literária" ou intelectual avultam, evidentemente, os fatores de natureza moral. Não queremos dizer com isso que um livro de literatura infantil deva ser, como tem sido às vezes considerado, um compêndio de educação moral. O que êle deve ser é - livro de boa moral -, isto é, ai não deve existir elementos que levam a criança a falsos conceitos éticos e ai não se deve, de maneira alguma, pregar a má moral, isto é, procurar no ânimo infantil conceitos condenáveis ou prematuros para seus verdes anos. (Campos, 1947, p.1780)

Também de acordo com Campos (1947), quando defende a necessidade de os livros contemplarem fatores morais, ela se refere à moral cívica, ao civismo, necessária à formação do espírito do futuro cidadão.

Partindo dessa concepção de literatura infantil, Campos (1947) apresenta um breve histórico das publicações para crianças, no qual identifica a origem da literatura infantil na tradição oral. No caso específico da literatura infantil brasileira, esse gênero literário surgiu no país a partir das traduções de originais europeus, passando pela "fase da adaptação", até que 
alguns autores nacionais passaram a criar "obras originais". Para ela, nessa fase em que surgem as "obras originais", os nomes de maior destaque são: Monteiro Lobato, Viriato Correia, Érico Veríssimo, Arnaldo de Oliveira Barreto, Tales de Andrade, Renato Sêneca Fleury, Malba Tahan e Alaíde Lisboa de Oliveira.

Campos (1947) discute as finalidades a que respondem esse gênero literário e aponta que a literatura infantil que a principal delas é a educativa. A “[...] formação do caráter, com aproveitamento dos bons exemplos e, mesmo, dos maus para estabelecerem êstes a sombra a par da qual brilhará mais viva a luz do bem" (Campos, 1947, p.183). Campos (1947) entende que a literatura infantil serve para o "treino" das técnicas de leitura e de formação do gosto literário. Assim:

O aluno que aprende a apreciar o belo, o verdadeiro e o bom, pelo uso da boa literatura, não irá achar prazer em ler a escória melodramática e sentimental que tem agora proeminência de lugar e de espaço em muitas livrarias e bibliotecas públicas. É dever do professor e deve ser para êle um prazer cultivar nos alunos gôsto pela boa literatura que os conduza a escolher o bom e rejeitar o mal, gôsto que lhes proporciona a cultura que a boa literatura dá. (p.183)

Dois anos após a publicação desse artigo de Campos (1947), a RBEP publicou, em 1949, a transcrição integral do artigo "Literatura infanto-juvenil”, de autoria de Adauto de Resende, o qual havia sido publicado originalmente no jornal Diário de Notícias, do Rio de Janeiro-DF.

Nesse artigo, Resende (1949) apresenta algumas reflexões sobre o desejo (e necessidade) de os livros juvenis, além de recrearem, propiciarem a formação educacional de seus leitores. Segundo ele, a "[...] leitura representa papel de grande importância na formação moral dos jovens e ninguém de boa-fé poderá negar sua influência, considerando-se as reações psicológicas peculiares a essa idade, que exige cautelosa orientação” (Resende, 1949, p.183).

Resende (1949) defende a ideia de que é preciso ter cuidado com a literatura infantojuvenil nociva à formação do espírito infantil e jovem, sobretudo as que incentivam o crime, o medo e a transgressão dos valores morais. Ainda segundo Resende (1949), apesar de o governo da época estar atendo a essa literatura perniciosa, é responsabilidade, sobretudo, dos pais e professores afastar as crianças desse mal. Com isso, Resende (1949) conclui: 
Será trabalho do mais elevado patriotismo, defender os interêsses da juventude, grantindo-lhe possibilidades para se educar dentro dos princípios da moral.

Por êsses motivos, achamos que combate sistemático à má literatura infanto-juvenil é um dos mais valiosos recursos à mocidade. (Resende, 1949, p.184)

No início da década de 1950, como mencionei, foi publicado Problemas da literatura infantil, de Cecília Meireles, considerado o primeiro livro brasileiro que trata exclusivamente de questões sobre esse gênero literário (Magnani, 1998).

Esse livro foi publicado em 1951, pela Imprensa Oficial de Minas Gerais, como decorrência de um curso de férias que Cecília Meireles ministrou, em 1949, em Belo Horizonte-MG, a convite da Secretaria de Educação do Estado de Minas Gerais (Meireles, 1951).

Dois anos após ter ministrado esse curso, Cecilia Meireles foi "Solicitada para dar forma escrita a essas palestras [...]" (Meireles, 1951, p.15), originando-se, em 1951, a $1^{\text {a }}$ edição de Problemas da literatura infantil. Esse livro foi reeditado, em 1979, pela Summus Editorial (SP), que lançou pelo menos três edições. Em 1984, foi publicada também a $3^{a}$ edição pela Nova Fronteira (RJ), a qual também publicou, em 1990, a $4^{\text {a }}$ edição desse livro, a mais recente que localizei.

Problemas da literatura infantil foi organizado por Cecília Meireles em 159 páginas, com 19 capítulos, todos breves e com tom ensaístico, prefácio de Abgar Renault ${ }^{19}$ e uma "explicação prévia", que funciona como introdução do livro.

Nesse livro, Meireles (1951) enfatiza que seu objetivo não é dar "soluções" aos "inúmeros" problemas da literatura infantil, mas "insistir" sobre a importância de alguns dos variados aspectos que envolvem esse gênero literário. Por isso, ao longo dos capítulos desse livro, ela explicita conceitos fundamentais para a compreensão de sua concepção de literatura infantil e aborda alguns dos problemas relacionados aos livros para crianças, sem necessariamente propor soluções para eles.

19 Abgar de Castro Araújo Renault nasceu em 1901, no estado de Minas Gerais, e morreu em 1995, no estado do Rio de Janeiro. Formou-se bacharel em Direito e atuou como professor, deputado estadual, ministro da Educação e Cultura e foi autor de diversos livros de poesia e livros sobre educação (Peixoto, 2002). 
Por literatura infantil, Meireles (1951) entende o conjunto de livros de que as crianças gostam e que escolhem para ler, pois, para ela, são as crianças quem delimitam o que é a literatura infantil. Por entender que não há distinção entre a literatura infantil e a "Literatura Geral", pois tudo é "uma literatura só”, Meireles (1951) alerta que a única dificuldade está apenas na delimitação do que se deve ou não considerar como especialmente do âmbito infantil.

Para identificar o que é e o que não é do âmbito infantil, ela entende que a forma mais adequada é submeter os livros ao uso e à leitura das crianças. Com isso: "Não haveria, pois, uma Literatura Infantil a 'priori', mas 'a posteriori”" (Meireles, 1979, p.19).

Se Cecília Meireles (1951) defende a ideia de que não há distinção entre "Literatura Geral" e literatura infantil, ela enfatiza que é necessário fazer uma distinção entre o que se publica e se dá a ler para a criança. Assim, para Meireles (1951), há uma distinção entre "livro infantil" e "literatura infantil". Os livros infantis abrangem as séries de leitura graduada, livros "de aprender a ler", livros de diferentes disciplinas escolares e livros não utilizados na educação formal. Já os livros de literatura infantil são aqueles que "[...] sugerem mundos de prazer espiritual [para a criança] [...]" (Meireles, 1979, p.23). Ou seja, nem tudo o que é destinado às crianças é por ela considerado literatura infantil.

Em decorrência dessa compreensão, ela afirma que o que constitui o acervo de literatura infantil é o que "[...] de século em século e de terra em terra, as crianças têm descoberto, têm preferido, têm incorporado ao seu mundo, familiarizadas com seus heróis, suas aventuras, até seus hábitos e sua linguagem, sua maneira de sonhar e suas glórias" (Meireles, 1951, p.28).

Meireles (1951) detém-se a questão da origem desse gênero literário. Para ela, a literatura infantil tem como "precedente" a literatura oral, que é a forma literária mais remota, da qual se origina toda a literatura em geral. Meireles (1951) explica que, das formas orais e dos ensinamentos por elas transmitidos, surgiu a necessidade de escrevê-las.

Um dia, o Ocidente procurou repetir essa lição [oral], por escrito: Charles Perrault, Mme. d'Aulnouy, os irmãos Grimm e outros coligiram narrativas que 
encontraram ainda sob a forma oral, entre a gente do povo, para que perdurassem escritas, quando o último narrador houvesse desaparecido. (Meireles, 1951, p.41)

Outro aspecto importante da argumentação de Meireles (1951) é o referente à questão da moral. Esse tema, bastante recorrente na produção sobre literatura infantil da época, é tratado por essa poetisa com uma visão menos instrutiva e muito mais como decorrência da vinculação desse gênero literário à literatura tradicional.

Para Meireles (1951), independentemente de qual seja o tempo, a ideia de ensinamento útil transmitido sob o "adorno ameno" da literatura sempre se "repercutirá". A questão é como a forma narrativa é construída em favor de seu conteúdo. Ainda que um escritor busque dizer "[...] coisas úteis de maneira tão agradável que suscite o interesse do leitor ou do ouvinte, para melhor aproveitamento da mensagem" (Meireles, 1951, p.52), é possível que a questão estética transcenda e gere o culto à "beleza gratuita", que define a "obra-prima".

Para concluir Problemas da literatura infantil, Meireles (1951) aborda a questão da "crise" da literatura infantil, que consistia, à época, no crescente desinteresse pela leitura. Segundo essa poeta, ao contrário do que se podia pensar em relação a essa crise, ela não era, no caso da literatura infantil, uma crise de carência, pelo contrário, era de abundância. "De tudo temos, e, no entanto, a criança cada vez mais parece menos interessada pela leitura. $\mathrm{O}$ mundo vai acontecendo em redor dela, e de certo modo parece um espetáculo absurdo, mas de que o homem consegue tirar vantagens, instantâneas e opulentas" (Meireles, 1951, p.115-116).

Em 1952, a revista Sociologia (SP) fez publicar texto de Fernando de Azevedo, ${ }^{20}$ no qual ele problematiza esse fenômeno literário do ponto de vista da sociologia.

20 Nascido na cidade de São Gonçalo do Sapucaí-MG, em 1894, Fernando de Azevedo se formou em Direito, em 1918, na Faculdade do Largo São Francisco, em São Paulo-SP, e foi professor da Escola Normal da Capital, em São Paulo-SP; Chefe da Instrução Pública do Distrito Federal; Diretor-Geral da Instrução Pública de São Paulo; diretor da Faculdade de Filosofia, Ciências e Letras da Universidade de São Paulo; Secretário de Educação e Saúde do estado de São Paulo; e fundou a Sociedade Brasileira de Sociologia. Além de sua intensa atuação profissional, Fernando de Azevedo é autor de importantes livros e artigos sobre Educação, tendo sido o responsável por redigir o Manifesto dos pioneiros da educação nova (Pilletti, 1999). 
Intitulado "A literatura infantil numa perspectiva sociológica", esse artigo de Fernando de Azevedo demonstra que o interesse na literatura infantil vinha se ampliando, sobretudo para áreas correlatas com a da Educação.

Partindo da compreensão de que a literatura infantil é fruto de modificações na estrutura social, econômica, cultural e ideológica do mundo moderno, Azevedo (1952) considera que a literatura infantil sempre existiu, porém não sob a forma de livros, mas na cultura popular e tradição oral.

Com as mudanças do mundo moderno e o impulso dos estudos pedagógicos:

[...] a criança passou a ser objeto constante das reflexões de filósofos e educadores e das observações e pesquisa científicas de especialistas que trabalham no campo de duas ciências novas e vizinhas: a sociologia e a psicologia. [...] É desse interesse cada vez mais vivo pela criança que começaram a participar escritores, dando-nos, já no século XVIII e sobretudo a partir do século XIX, livros preciosos que se tornaram clássicos [...].

Nesse processo evolutivo da literatura infantil, para o qual concorreram as mudanças de estrutura e o progresso da ciência e interesse pedagógico, Azevedo (1952) observa a ocorrência de uma "diversificação interna" do gênero, tendo surgido livros variados, para diferentes idades e diferentes níveis mentais. Azevedo (1952) também aponta que ocorria uma disputa entre "produtores", escritores e editores, o que, ainda que favorecesse a produção de livros originais e de valor, favorecia igualmente um "surto" de literatura "banal", "vulgar" e "insuportável”. "Assim, pois, como é cada vez maior a procura de livros, e a pressão que exerce o público, ainda recente e mal orientado, [...] a literatura infantil arriscou-se a se transformar num refúgio de medíocres” (Azevedo, 1952, p.55).

Azevedo (1952) alerta para o cuidado em ofertar às crianças apenas livros apropriados para a transmissão de valores morais, de forma didática, pois somente assim é que se poderá proporcionar a felicidade que os pequenos merecem.

No mesmo período de publicação dos artigos de Campos (1947), Resende (1949), Azevedo (1952) e do livro de Meireles (1951), foram publicados no estado de São Paulo diferentes textos em jornais de notícias, que tratam de aspectos da literatura infantil. Localizei e selecionei 21 textos sobre lite- 
ratura infantil publicados nesses jornais de notícias, entre 1947 e 1956. Por não conterem reflexões ou informações consoantes com as dos demais artigos, capítulos em manuais e livros aqui sintetizados, optei por não apresentar os textos um a um, de forma detalhada. Apenas cito dados referentes à publicação e apresento, de modo geral, as principais questões que abordam.

No Quadro 8, exponho a relação dos 21 textos em jornais que localizei publicados entre 1947 e 1956 e que tratam da literatura infantil.

Quadro 8-Textos sobre literatura infantil publicados em jornais, entre 1947 e 1956

\begin{tabular}{|c|c|c|c|}
\hline $\begin{array}{l}\text { Ano de } \\
\text { publicação }\end{array}$ & Título do texto & Autor(es) & Jornal \\
\hline \multirow[t]{3}{*}{1947} & "Literatura miúda" & "V. Cy" & $\begin{array}{l}\text { O Estado de S. } \\
\text { Paulo }\end{array}$ \\
\hline & $\begin{array}{l}\text { "Concurso de obras literárias } \\
\text { especialmente escritas para a juventude" }\end{array}$ & - & $\begin{array}{l}\text { O Estado de S. } \\
\text { Paulo }\end{array}$ \\
\hline & "Livros infantis" & "V. Cy" & $\begin{array}{l}\text { O Estado de S. } \\
\text { Paulo }\end{array}$ \\
\hline \multirow[t]{5}{*}{1948} & $\begin{array}{l}\text { "A literatura infantil carece de } \\
\text { fiscalização rigorosa" }\end{array}$ & - & Diário Popular \\
\hline & "A literatura infanto-juvenil" & - & $\begin{array}{l}\text { O Estado de S. } \\
\text { Paulo }\end{array}$ \\
\hline & "Literatura infantil-juvenil" & - & $\begin{array}{l}\text { O Estado de S. } \\
\text { Paulo }\end{array}$ \\
\hline & "Na Assembleia Legislativa Estadual..." & - & $\begin{array}{l}\text { O Estado de S. } \\
\text { Paulo }\end{array}$ \\
\hline & "Da literatura infantil" & $\begin{array}{l}\text { J. C. de Oliveira } \\
\text { Torres }\end{array}$ & $\begin{array}{l}\text { O Estado de S. } \\
\text { Paulo }\end{array}$ \\
\hline \multirow[t]{4}{*}{1949} & "O problema da literatura infantil" & - & Diário Popular \\
\hline & $\begin{array}{l}\text { "A Secretaria de Educação e o problema } \\
\text { da literatura infantil" }\end{array}$ & - & $\begin{array}{l}\text { O Estado de S. } \\
\text { Paulo }\end{array}$ \\
\hline & $\begin{array}{l}\text { "Literatura infantil em face das } \\
\text { livrarias" }\end{array}$ & $\begin{array}{l}\text { Eunice Breves } \\
\text { Duarte }\end{array}$ & $\begin{array}{l}\text { O Estado de S. } \\
\text { Paulo }\end{array}$ \\
\hline & "Leitura para crianças" & Francisco Pati & $\begin{array}{l}\text { Correio } \\
\text { Paulistano }\end{array}$ \\
\hline 1951 & "Um livro para crianças" & J. O. Orlandi & $\begin{array}{l}\text { O Estado de S. } \\
\text { Paulo }\end{array}$ \\
\hline \multirow[t]{3}{*}{1952} & "A força educativa do livro infantil" & Ester Aliventi & Diário Popular \\
\hline & $\begin{array}{l}\text { "As bibliotecas infantis desenvolvem } \\
\text { importante função social e educativa" }\end{array}$ & - & $\begin{array}{l}\text { O Estado de S. } \\
\text { Paulo }\end{array}$ \\
\hline & $\begin{array}{l}\text { "A literatura destinada à infância e à } \\
\text { adolescência" }\end{array}$ & Aurélio Leite & $\begin{array}{l}\text { O Estado de S. } \\
\text { Paulo }\end{array}$ \\
\hline
\end{tabular}




\begin{tabular}{|l|l|l|l|}
\hline 1954 & "Biografia de livros infantis" & - & $\begin{array}{l}\text { O Estado de S. } \\
\text { Paulo }\end{array}$ \\
\hline 1955 & "Má literatura infantil" & - & $\begin{array}{l}\text { O Estado de S. } \\
\text { Paulo }\end{array}$ \\
\cline { 2 - 4 } & "Lobato" & Plínio Barreto & $\begin{array}{l}\text { O Estado de S. } \\
\text { Paulo }\end{array}$ \\
\cline { 2 - 4 } & $\begin{array}{l}\text { "Campanha contra a má literatura } \\
\text { infantil e juvenil" }\end{array}$ & - & $\begin{array}{l}\text { O Estado de S. } \\
\text { Paulo }\end{array}$ \\
\hline 1956 & $\begin{array}{l}\text { "A semana e os livros - literatura } \\
\text { infantil" }\end{array}$ & $\begin{array}{l}\text { Edgard } \\
\text { Cavalheiro }\end{array}$ & $\begin{array}{l}\text { O Estado de S. } \\
\text { Paulo }\end{array}$ \\
\hline
\end{tabular}

Fonte: Oliveira (2014).

Conforme se pode observar pelo Quadro 8, dos 21 textos publicados em jornais, entre 1947 e 1956, dez se configuram como artigos de opinião, nos quais consta a autoria, e 11 se configuram como textos de notícias.

Ao se observarem os títulos tanto desses artigos quanto dessas notícias, pode-se compreender que, assim como ocorreu com os textos em jornais publicados até a década de 1940, o assunto mais tratado em relação à literatura infantil é o de sua contribuição para a formação da criança e, consequentemente, o risco que a dita "má" literatura infantil pode implicar.

Por isso, alguns desses textos enfatizam a necessidade de fiscalizar o que se publica com destinação às crianças, como forma de evitar que os pequenos leitores tomem contato com livros prejudiciais à boa formação moral. Esse é o caso, por exemplo, do texto "A literatura infantil carece de fiscalização rigorosa”, publicado no dia 17 de setembro de 1948, no jornal Diário Popular. Nesse texto, relatam-se alguns dos perigos da literatura infantil e apresentam-se algumas informações sobre projeto de lei sobre o assunto.

Ainda em 1948, com o mesmo teor de incentivo à fiscalização da literatura infantil, foram publicados os seguintes textos no jornal O Estado de S. Paulo: "Na Assembleia Legislativa Estadual...", de 15 de julho, "A literatura infanto-juvenil", de 13 de outubro, e "Literatura infantil-juvenil", de 30 de novembro.

O primeiro desses textos versa sobre o projeto de lei paulista, aprovado em outubro de 1948 (Lei n. 171), que estabeleceu a criação da Comissão Orientadora de Literatura Infanto-Juvenil. Os dois últimos, possivelmente inspirados nessa iniciativa paulista, tratam da defesa do deputado Aureliano Leite, na Câmara Federal, de criação de medidas para "proteção" da literatura infantil, como a criação de uma emenda constitucional. 
No texto "A Secretaria de Educação e o problema da literatura infantil", publicado em 23 em março de 1949, noticia-se a reclamação do deputado Gabriel Migliori, autor do projeto que deu origem a essa lei, sobre a Secretaria de Educação de São Paulo nada ter feito para pôr em prática as medidas estabelecidas.

Outro aspecto que se pode observar nesses textos é que a questão sobre as bibliotecas infantis e escolares começou a figurar com maior regularidade na discussão sobre literatura infantil. Esse aspecto se deve, presumivelmente, à expansão desse tipo de espaço, seja na escola, seja em lugares públicos, a partir da década de 1940.

\section{Características do ensino da literatura infantil entre 1947 e 1956}

Em vista dos aspectos apresentados neste capítulo, no período compreendido entre 1947 e 1956, que se caracteriza pela criação da matéria "Literatura infantil" no Instituto de Educação Caetano de Campos, notam-se as primeiras iniciativas em torno da constituição de um saber sobre a literatura infantil e destinado à formação de professores. Ainda que essa matéria tenha sido criada oficialmente no currículo do Instituto de Educação Caetano de Campos, em termos prescritivos, o estado de São Paulo não tomou nenhuma providência para orientar os professores sobre o que se devia ensinar em relação à literatura infantil.

A orientação, sobre o que se ensinar no âmbito dessa matéria, pode-se assim dizer, ficou a cargo dos capítulos sobre literatura infantil publicados nos manuais de Budin (1949), Carneiro (1951) e d'Ávila (1954), principalmente.

Essas primeiras iniciativas de "concretização" do ensino da literatura infantil, apesar de curtas e com características de textos que buscam apenas dar a conhecer o assunto, foram importantes para iniciar um processo de formação de um saber sobre esse gênero, tornando-se basilares na construção de uma didática da literatura infantil.

Em relação a como esses capítulos em manuais de ensino apresentam propostas de "concretização" do ensino da literatura infantil, observa-se a menção às questões da Psicologia, a exemplo do que já se vinha observan- 
do nos textos e artigos da década de 1940. De modo geral, esses capítulos não apresentam nenhuma concepção inovadora sobre a literatura infantil, apenas no caso dos manuais de Carneiro (1951) e d'Ávila (1954) o assunto relativo às bibliotecas escolares passou a figurar também como um assunto relativo ao ensino desse gênero literário. Cabe destacar em relação a esse aspecto, que a discussão sobre bibliotecas e sobre os livros escolares, como elementos fundamentais para a formação de leitores, tornou-se recorrente entre alguns dos disseminadores do movimento da Escola Nova, no Brasil. Esse aspecto se observa, por exemplo, nos diferentes textos que o sociólogo e educador Fernando de Azevedo, um dos principais nomes do escolanovismo no Brasil, teve publicado sobre o assunto, na década de $1930 .{ }^{21}$

Ao apresentar o que os professores precisam saber para ensinar literatura infantil, esses capítulos são consensuais em praticamente tudo. A discussão se inicia sempre pela definição de um conceito de literatura infantil, seguida da apresentação da origem desse gênero literário e das funções e requisitos desse tipo de literatura para a formação de crianças. Sobre essa questão das funções e dos requisitos, os capítulos de Budin (1949), Carneiro (1951) e d'Ávila (1954) apresentam esboço da categorização dos livros por faixa etária, porém não expandem muito essa proposição.

Sobre a bibliografia que é citada, mencionada ou indicada nesses manuais, exceto no manual de d'Ávila (1954), tem-se predominância de livros estrangeiros, na sua maioria sobre ensino de leitura e questões gerais da educação. Há apenas um ou outro título que sugere tratar da literatura infantil, mas nada como o que veio a ocorrer, posteriormente, como a circulação do livro de Jesualdo.

Em relação aos livros indicados nessas bibliografias e que se referem ao campo educacional, destacam-se os de autores ligados ao movimento da Escola Nova, como Miguel Agauyo.

De um modo geral, pode-se dizer que os autores dessas primeiras propostas de "concretização" do ensino da literatura infantil, tiveram também como referência, além da bibliografia que indicaram, os textos em jornais e artigos em revistas que vinham sendo publicados, principalmente, desde

21 Entre os textos que Fernando de Azevedo teve publicados sobre bibliotecas e livros escolares, têm-se: "A renovação educacional e o livro" (1933), "A nova função do livro escolar" (1933), "As bibliotecas e os laboratórios" (1933) e "A formação e a conquista do público infantil (a literatura infantil numa perspectiva sociológica)" (1952). 
o início da década de 1940. Esse aspecto pode ser observado, por exemplo, quando os autores desses capítulos mencionam ou fazem referência a textos como os de Alceu Amoroso Lima, publicado em 1927, em um livro de sua autoria; Jerônimo Monteiro, publicado no jornal O Estado de S. Paulo, em 1941; de Betti Katzenstein e Beatriz de Freitas, publicado na Revista do Arquivo Municipal, em 1941; e dos resultados da investigação realizada pelo Inep, publicados, em 1945, na Revista Brasileira de Estudos Pedagógicos.

Além desses, cuja menção e/ou citação é explícita, é possível presumir que outros textos em jornais e artigos em revistas tenham subsidiado as reflexões sobre a literatura infantil contidas nos capítulos de Budin (1949), Carneiro (1951) e d'Ávila (1954). Um caso desses é, por exemplo, o do artigo de Maria dos Reis Campos, publicado em 1947, na Revista Brasileira de Estudos Pedagógicos. Embora esse artigo não conste na bibliografia do manual de Budin (1949), a autora do primeiro capítulo sobre literatura em um manual de ensino afirma, em seus agradecimentos, ter utilizado materiais de aulas e textos, entre outros, de Maria dos Reis Campos.

Depois da publicação desses capítulos, em 1955, com a circulação, no Brasil, do livro de Jesualdo, gradativamente as questões sobre literatura infantil foram ganhando maior estofo.

Embora o impacto desse livro tenha somente ocorrido mais diretamente no final da década de 1950 e início de 1960 (como se nota na $3^{\text {a }}$ edição do manual de d'Ávila), a importância do livro de Jesualdo se deu, sobretudo, pela sua busca por dar à literatura infantil uma visão "científica". Ao se basear em autores como Roger Cousinet, Anatole France e Jean Piaget, esse autor tentou em seu livro não apenas associar literatura infantil às questões da Psicologia e da Educação, mas estabelecer uma relação mais intrínseca entre esse gênero literário e esses campos de conhecimento. O livro de Jesualdo, nesse sentido, parece ter tido a função catalizadora de congregar e sistematizar as esparsas e introdutórias relações que se vinham formulando em torno da literatura infantil, Psicologia e Educação. O subtítulo de seu livro já alude a esse propósito: "Ética, estética e psicopedagogia da literatura infantil".

Com relação ao livro de Cecília Meireles, Problemas da literatura infantil, ele se apresenta um pouco diferente dos capítulos de Budin (1949), Carneiro (1951) e d'Ávila (1954) e do livro de Jesualdo. Talvez pela sensibilidade de poeta, já reconhecida à época, ou também pelo tom mais 
ensaístico e literário de seu texto, o livro de Cecília Meireles contém uma concepção de literatura infantil menos ligada às funções instrutivas e pragmáticas da escola. Também no caso desse livro não se nota a recorrente presença de conceitos da Psicologia, como nos demais textos da época. Por isso, observa-se que esse livro, mesmo tendo sido publicado em 1951, foi mencionado nos manuais de Carneiro (1951) e d'Ávila (1954) e em outros publicados durante a década de 19960.

O que se nota é que as questões sobre literatura infantil de que trata Cecília Meireles em seu livro não se adequavam ao ensino da literatura infantil, conforme o ponto de vista da formação moral e do desenvolvimento psíquico infantil.

A partir dos aspectos aqui apontados, compreendo que, entre 1947 e 1956, ainda que do ponto de vista da legislação quase nada se fez em termos do ensino da literatura infantil, já se notam importantes iniciativas no processo de organização e sistematização do saber escolar relativo a esse gênero literário. 


\section{3 \\ SistematizaÇÃo do SABER ESCOLAR SOBRE A LITERATURA INFANTIL: A DISCIPLINA "LITERATURA INFANTIL" (1957-1970)}

\section{A reforma de 1957 do Ensino Normal paulista}

Em 1957, os Cursos Normais do estado de São Paulo passaram por uma nova reforma. Tanuri (2000) explica que, nesse período, a "[...] euforia desenvolvimentista dos anos 50 , as tentativas de "modernização" do ensino, que ocorriam na escola média e na superior, atingiram também o ensino primário e a formação de seus professores" (p.78).

Entre as justificativas apresentadas pelo então Secretário de Estado dos Negócios da Educação, Vicente de Paula Lima, para que o Ensino Normal paulista se submetesse a uma nova reforma, encontra-se a de que, à época, esse ensino vinha sofrendo um processo de facilitação, que tendia ao relaxamento da formação profissional do professor primário. Ele esclarece que a:

[...] estrutura dada em 1933 pelo Código de Educação ao ensino normal em São Paulo, desfigurada pela legislação posterior, superada também que foi pelas circunstâncias sociais e pedagógicas supervenientes, já não servem mais, como tão bem serviu anteriormente, às necessidades educacionais para cuja satisfação existe. (Lima, 1960, p.9)

Por essas razões, o Departamento de Educação da Secretária de Estado dos Negócios da Educação realizou, à época, sob a supervisão de Sólon Borges dos Reis, um estudo sobre a questão da reforma do Ensino Normal. Desse estudo, resultou a elaboração de anteprojeto de lei "[...] suficiente para, sem ensejar o risco de radicais transformações na estrutura do ensino 
normal, permitir que se reunissem as medidas que a experiência aconselha como urgentes [...], com vistas ao alteamento do padrão de formação profissional do professor primário" (Lima, 1960, p.10).

No conjunto das medidas de mudança no Ensino Normal paulista propostas nesse anteprojeto, destacam-se: a equiparação das Escolas Normais com os Institutos de Educação, a obrigatoriedade do ensino de língua portuguesa em todos os anos do Ensino Normal, a introdução do ensino moral e cívico, a simplificação do currículo dos cursos de aperfeiçoamento e especialização e a fixação de nota mínima, por matéria, para aprovação no curso (Lima, 1960).

Após apresentado ao então chefe do Executivo, Jânio da Silva Quadros, esse anteprojeto de lei foi aprovado na Assembleia Legislativa do estado de São Paulo, que gerou a promulgação, em 21 de janeiro de 1957, da Lei estadual n. 3.739.

Essa Lei, conforme previa seu anteprojeto, apresentava as novas disposições sobre a organização do Ensino Normal nesse estado, revogando todas as leis sobre esse ensino em vigor, até então.

Com isso, foi fixado, a partir da Lei n. 3.739, um modelo único de Curso Normal para todo o estado de São Paulo, extinguindo-se, portanto, a diferença que havia anteriormente entre os Cursos Normais dos Institutos de Educação e os cursos pré-normal e de formação profissional do professor primário das Escolas Normais.

A partir da Lei n. 3.739, de janeiro de 1957, o:

[...] Curso Pré-normal das Escolas Normais passa a constituir o primeiro ano do Curso Normal, o primeiro ano do atual curso de formação profissional de professôres passa a constituir o segundo ano do curso normal; e o segundo passa a constituir o terceiro, sempre com as adaptações e modificações decorrentes desta lei. (São Paulo, 1957, p.161-162)

Com a equiparação das instituições que ofereciam o Ensino Normal no estado de São Paulo, o curso de formação de professores passou a ter duração de três anos, e o ingresso nesse ensino era feito mediante aprovação em exame vestibular, como ocorria anteriormente apenas nos Cursos Normais dos Institutos de Educação. 
No caso dos Cursos Normais ministrados em período noturno, a Lei n. 3.739, de 1957, estabeleceu um tempo de duração diferente, de quatro anos, e a forma de ingresso também era mediante vestibular.

Além dessas alterações e das demais previstas no anteprojeto de reforma do Ensino Normal, segundo Labegalini (2009, p.98), com a promulgação da Lei n. 3.739, de 1957, “[...] o currículo, que anteriormente compreendia 'matérias' cujo ensino era distribuído em 'cadeiras' (que abrangiam uma ou mais 'matérias'), passou a ser distribuído em 'disciplinas"”.

As disciplinas estabelecidas tanto para os Cursos Normais diurnos quanto para os noturnos foram as seguintes:

Artigo $3 .^{\circ}[\ldots]$

1 - Pedagogia e Psicologia geral e Educacional;

2 - Filosofia e História da Educação;

3 - Metodologia e Prática do Ensino Primário;

4 - Anatomia e Fisiologia Humanas, Higiene e Biologia Educacional;

5 - Sociologia Geral e Educacional;

6 - Desenho Pedagógico;

7 - Português, Linguagem e Literatura Infantil;

8 - Matemática e Estatística aplicada à Educação;

9 - Ciências Físicas e Naturais;

10 - História da Civilização Brasileira;

11 - Música e Canto Orfeônico;

12 - Educação Física, Recreação e Jogos;

13 - Trabalhos Manuais e Economia Doméstica; e

14 - Educação Social e Cívica.

(São Paulo, 1957, p.160, grifos meus).

Conforme consta no artigo $3^{\circ}$ da Lei n. 3.739, de 1957, o ensino da literatura infantil, antes restrito ao Curso Normal dos Institutos de Educação, passou a integrar todos os currículos de Cursos Normais do estado de São Paulo. Essa disciplina compunha, juntamente com as disciplinas "Português" e "Linguagem", um único bloco, que garantia a exigência de manter o ensino de língua portuguesa em todos os anos do curso Normal. Assim, em cada ano do curso, ofertar-se-ia uma dessas três disciplinas. 
A disciplina "Literatura infantil", nos Cursos Normais diurnos, integrava o conjunto das disciplinas do $3^{\circ}$ ano, com carga horária de 2 horas-aulas semanais e, nos Cursos Normais noturnos, integrava o conjunto das disciplinas do $4^{\circ}$ ano, também com carga horária de 2 horas-aula semanais.

\section{Iniciativas após a criação da disciplina "Literatura infantil"}

A partir da criação da disciplina "Literatura infantil" em todo o currículo do Ensino Normal do estado de São Paulo, ocorreram, nesse estado, algumas ações visando a contribuir para a sistematização do ensino da literatura infantil na formação dos professores.

Embora com a reforma do Ensino Normal, em 1947, a matéria "Literatura infantil" tivesse sido criada no Instituto de Educação Caetano de Campos e depois se expandido para os novos Institutos, por se tratar de iniciativas pontuais, as questões relativas ao ensino da literatura infantil ainda eram pouco familiares para a maioria dos professorandos ${ }^{1}$ e dos professores primários em exercício. Mesmo com a expansão dos Institutos de Educação, a partir de 1951, o ensino da literatura infantil ainda não tinha tomado as proporções que alcançou a partir da reforma de 1957.

Anteriormente à reforma do Ensino Normal, em 1957, não haviam se consolidado, nesse estado, "tematizações", "normatizações" e "concretizações” específicas e de maior abrangência a respeito do ensino da literatura infantil. Por essa razão, a criação da disciplina "Literatura infantil" em todo o currículo do Ensino Normal do estado de São Paulo, a partir da reforma de 1957, representou a necessidade de mobilização mais ampla dos educadores e intelectuais da época, para suprir a inexistência de estudos sobre a literatura infantil e seu ensino.

Em relação a esse aspecto, a professora Bárbara Vasconcelos de Carvalho, em 1957, após a promulgação da Lei n. 3.739, teve publicado no jornal A Gazeta (SP) o artigo intitulado "A literatura infantil na escola normal", no qual afirma que 0 :

1 Na legislação paulista sobre o Ensino Normal, o termo "professorando" é utilizado para se referir ao aluno que frequentava os Cursos Normais. 
[...] novo programa do curso normal, com a inclusão, no $3^{\circ}$ ano, de Literatura infantil, é, sobre todos os aspectos, um passo que vem preencher uma lacuna na formação do professor primário, capacitando-o a dar completa orientação cultural, estética e espiritual a suas crianças. Já não estava cedo para cogitar-se em nossa terra. Que o Brasil chegue atrasado; mas que chegue... E São Paulo está de parabéns. (1957, p.19)

Carvalho (1957) ressalta também que os títulos sobre literatura infantil, disponíveis no mercado, à época, eram quase todos em francês, espanhol e inglês, o que se configurava como um problema.

\section{O Curso Intensivo de Literatura infantil}

Tendo em vista o problema com a escassez de bibliografia especializada sobre ensino da literatura infantil, conforme relatado por Carvalho (1957) e também conforme se pode observar pelas informações que apresentei no Capítulo 2, a Biblioteca Central do Departamento de Educação do estado de São Paulo teve a iniciativa de organizar, ainda em 1957, o primeiro Curso Intensivo de Literatura Infantil. Esse curso, realizado no Instituto Cultural Monteiro Lobato, na cidade de São Paulo, era destinado aos alunos matriculados nos Cursos Normais e também aos professores dessa disciplina, atuantes nas Escolas Normais e Institutos de Educação do estado.

Esse curso, conforme notícia divulgada no jornal A Gazeta, no dia 29 de maio de 1957, realizou-se entre os dias 27 de maio de 1957 e $1^{\circ}$ de junho de 1957 e contou com a participação de mais de 50 inscritos. Esse número de inscritos demonstra o interesse que o assunto despertava nos professores ou alunos dos Cursos Normais.

Levando em consideração ainda a "[...] falta de um compêndio útil a professôres e formandas do Curso Normal, a Editôra Santos de Oliveira ouviu os apelos que lhe foram dirigidos no sentido de editar as respectivas aulas" (Oliveira, [1958], p.5). E, em 1958, com o título Curso de literatura infantil, a Editora Santos de Oliveira (SP) publicou, mediante organização de Antenor Santos de Oliveira, ${ }^{2}$ livro contendo seis das aulas ministradas

2 Não foi possível localizar informações a respeito de Antenor Santos de Oliveira. 
no Curso Intensivo de Literatura Infantil. ${ }^{3}$ São elas: "A literatura infantil através dos tempos", de Antenor Santos de Oliveira; "A arte de escrever para infância", de Thales Castanho de Andrade; "Aspectos da literatura infantil na escola primária", de Consuelo da Silva Dantas; "Influência da má literatura na infância e juventude", de Aldo de Assis Dias; "Teatro infantil", de Júlio Gouveia; e "O folclore - base da literatura infantil”, de Hernâni Donato. Esses autores, à época, eram importantes figuras ligadas à educação nacional e às discussões sobre literatura infantil, tendo, praticamente todos eles, atuação reconhecida pelos seus contemporâneos.

Além da versão escrita dessas seis aulas, foi acrescido em Curso de literatura infantil o capítulo "Organização e funcionamento de uma biblioteca escolar", de Lenyra Fraccaroli, que trata de um assunto que não havia sido abordado durante o Curso Intensivo.

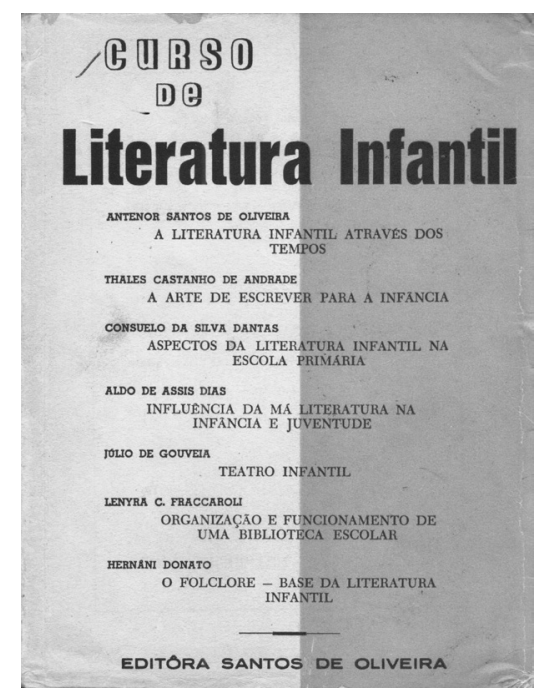

Figura 6 - Capa de Curso de literatura infantil (1958), organizado por Antenor S. de Oliveira. Fonte: Acervo pessoal do autor.

No primeiro capítulo - "A literatura infantil através dos tempos" - Oliveira (1958) busca situar o aparecimento e desenvolvimento da literatura

3 Embora seja possível presumir que tenha ocorrido um número de aulas maior que seis durante o I Curso Intensivo de Literatura infantil, não foi possível localizar essa informação. Apenas consta no prólogo de Curso de literatura infantil (1958), que nem todos os palestrantes puderam contribuir com texto para a coletânea. 
voltada às crianças. Para ele, a literatura infantil, "arte da pena”, representa o "[...] ritmo e a cadência da alma adulta, conduzida à alma da criança" (p.9). Por isso, a sua origem se resguarda no desejo da humanidade de transmitir aos pósteros algo que os adultos aprenderam com seus antepassados, quando, pela oralidade, começaram as mães a transmitir para os pequenos cantigas e histórias que alimentavam a imaginação.

Segundo Oliveira (1958), com o desenvolvimento das civilizações, as histórias e as formas de transmiti-las foram se modificando. "De grosseiros relatos, à medida que passavam os tempos, foram-se modificando os gostos e os contos. Custaram, todavia, muito, os homens a fazer literatura para a criança” (Oliveira, 1958, p.10).

Antes de a literatura para crianças surgir, explica Oliveira (1958) que na Grécia e Roma antigas alguns textos eram lidos aos pequenos, porém era quase tudo desvio do "ético", do "belo" e do "construtivo". Apenas Esopo, embora sem ter escrito para as crianças, conseguiu "alcançar" a mente infantil.

Oliveira (1958) relata que, embora desde as fábulas de Esopo já se tinham textos que "alcançavam" a mente infantil, a literatura para crianças apenas surgiu quando Charles Perault escreveu seu livro de contos, em 1697. Após a publicação desse livro, surgiu um conjunto de escritores que se dedicaram à literatura infantil, especialmente na França. Porém, para Oliveira (1958), Perrault, juntamente com os alemães irmãos Grimm, e o dinamarquês Hans Christian Andersen constituem os "maiores" da literatura infantil desse tempo.

Com relação ao caso do Brasil, Oliveira (1958) entende que o primeiro trabalho publicado no Brasil para as crianças foi o de Alberto Figueiredo Pimentel, em Contos da Carochinha, de 1896. Porém, o primeiro a fazer "literatura própria” foi Thales Castanho de Andrade, com A filha da floresta, publicado em 1918. Oliveira (1958) também destaca o nome de Monteiro Lobato, que segundo ele, é "[...] o maior escritor brasileiro de contos infantis $[\ldots] "$ (p.16).

Sobre os escritores do século XX, Oliveira (1958) destaca os seguintes nomes: Lourenço Filho, Paulo Menotti Del Picchia, Francisco Ferrari Marins, Renato Sêneca Fleury, Lúcia Machado de Almeida, Maria Lúcia Amaral, Virgínia Lefévre, Antônio de Pádua Morse, Mário de Medei- 
ros, Cecilia Meireles, Hernani Donato, Mário Donato, Leonardo Arroyo, Olavo Bilac, Agnelo Rodrigues de Melo e Corrêa Júnior.

Para concluir, Oliveira (1958) alerta para a dúvida em relação às contribuições, ou não, da literatura infantil para o desenvolvimento psíquico da criança e alerta que esse gênero literário deve ser "[...] a boa aplicação dos princípios de psicologia da criança [...]” (p.26).

O escritor Thales Castanho de Andrade,$^{4}$ autor do segundo capítulo do Curso de literatura infantil (1958) - "A arte de escrever para crianças" - aborda como ele, escritor de literatura infantil, compreende a produção desse gênero literário.

Andrade (1958) inicia seu texto por apresentar reflexões sobre a delimitação da infância, aspecto, segundo ele, sem o qual não se pode pensar a produção literária voltada a esse público. Embora Andrade (1958) considere difícil delimitar qual período da infância corresponde a literatura infantil, toma, como ponto de partida, o momento em que as crianças desenvolvem a linguagem e, como ponto de encerramento, o início da puberdade. Com essa delimitação, Andrade (1958) afirma que, do ponto de vista literário, o escritor se vê frente a diferentes fases da "capacidade mental". Por isso, a literatura infantil, fonte de "alimentação" do espírito, precisa se adequar a cada uma das fases. Ela tem de "[...] proceder como a farmacopeia em relação aos medicamentos” (Andrade, 1958, p.41).

Andrade (1958) enfatiza que a arte de escrever para a infância requer respeitar um conjunto de preceitos, "[...] atinentes ao seu próprio objeto e de conformidade com os seus fins" (p.45). O primeiro desses preceitos se refere à ideia comum, à época, de que a literatura infantil ideal seria a produzida pela criança. Para Andrade (1958), essa literatura é impossível e, mesmo que não fosse, o seu intento seria apenas o de divertir, agradar o leitor. Por essa razão, a literatura feita pelo adulto, como se fosse feita pela

4 Nascido em 1890, em Piracicaba-SP, Thales Castanho de Andrade se diplomou professor pela Escola Normal de Piracicaba e foi uma das figuras marcantes na educação brasileira, sobretudo por sua atuação como escritor. Entre os cargos que ocupou durante sua atuação profissional, foi professor em escolas do interior do estado de São Paulo, Diretor-Geral do Departamento de Educação do Estado de São Paulo; e foi responsável pela organização de uma coleção para a Companhia Editora Melhoramentos. Como escritor, Thales de Andrade escreveu dezenas de livros de literatura infantil, "onde ecoam as mais diversas fontes por ele aproveitadas.” (Coelho, 1983, p. 861). Faleceu em 1977, em São Paulo-SP. 
criança, incorre em erro grave e "lacuna inadmissível", pois não tem valor educativo, o seu valor se resguarda apenas na diversão, no prazer.

Segundo Andrade (1958), a literatura ideal é a que educa e agrada ao mesmo tempo. Isso requer, para esse escritor, "[...] escrever como criança, para agradá-la, e escrever para educá-la, como não sendo escritor adulto" (p.48). Essa relação, "agradar + educar”, é, para Andrade (1958), a "receita" da literatura infantil.

Definido esse preceito, Andrade (1958) explica os demais, quais sejam: reunir elementos que "se prestam" a livros para crianças, escolher forma adequada para os livros, usar elementos úteis à vida das crianças, usar de situações cômicas e que despertam o interesse do leitor, escolher assuntos apropriados ao universo infantil, evitar brinquedos e diversões "condenáveis”, empregar linguagem simples, fazer uso de começos simples e que gerem a curiosidade, buscar manter suspense, para manter o interesse do leitor, não usar de "matérias" extensas e não usar "falas" falsas ou inventadas.

Com esses princípios, Andrade (1958) conclui que a literatura infantil, feita "irremediavelmente" pelo adulto, tem de "[...] instruir, educar e edificar, como se o não estiver fazendo” (Andrade, 1958, p.52).

No capítulo "Aspectos da literatura infantil na escola primária", a professora Consuelo da Silva Dantas, ${ }^{5}$ ao levantar o problema do excesso de livros decorrentes da ambição econômica da indústria editorial, entende que vinham "penetrando" na escola primária livros de qualidade questionável, que "deformam" o propósito educativo dos programas de ensino. Por essa razão, destaca a criação da disciplina "Literatura infantil” no Ensino Normal paulista como uma "nova fase" de aquisição, por parte dos professores, de conhecimentos "metodizados", com finalidade do ensino da "boa leitura".

Dantas (1958) detém-se à exploração das maneiras que a leitura literária pode corresponder ao propósito escolar de educar e dar o melhor para a criança. Com isso, ela afirma que o primeiro contato das crianças com a literatura infantil se dá pelas cartilhas de alfabetização. Gradativamente, vão aparecendo outros tipos literários, como a imprensa escolar. E, quando as crianças começam a ler textos durante as aulas, outras situações de trabalho

5 Não foi possível localizar informações a respeito de Consuelo da Silva Dantas. 
com a leitura literária se apresentam como "[...] auxiliares à planificação dos seus trabalhos" (p.70).

Dantas (1958) conclui a sua exposição enfatizando que, quando se trata de pensar a literatura infantil dentro da escola, o que se quer é:

[...] reduzir as distâncias do país em função de aprendizagem sem classes que a diferenciem, unificar as crianças, num grupo homogêneo com as mesmas possibilidades já que ao educarmos queremos dar ao país cidadãos e não subpopulação, sem rumo, sem autonomia, sem desenvolvimento integral. (p.76)

No quarto capítulo de Curso de literatura infantil, Aldo de Assis Dias ${ }^{6}$ aborda algumas questões, do ponto de vista legal, entre a chamada "má" literatura infantil e a formação de crianças e jovens.

Nesse capítulo, intitulado "Influência da má literatura na infância e juventude”, Dias (1958), então Juiz de Menores, entende que a leitura é uma das mais poderosas formas de "aprimoramento" e "elevação" da personalidade e nível cultural dos seres humanos. Por isso, "[...] quando mal orientada, a leitura pode contribuir e favorecer a degradação da personalidade, principalmente quando ainda em formação" (Dias, 1958, p.83). Por essa razão, defende que a "má" literatura infantil, entendida como as publicações que ferem a moral e os bons costumes, precisa ser combatida com toda força e energia, para que se possa "preservar a alma" das crianças.

Sobre essa "preservação das almas", do ponto de vista legal, Dias (1958) explica que, no Brasil, competia ao Juiz de Menores, em conformidade com a Lei da Imprensa, Lei n. 2.083, de 12 de novembro de 1953, artigo $53^{\circ}$, "[...] declarar quais publicações de caráter obsceno, a fim de impedir a respectiva circulação” (Dias, 1958, p.87). Com base nessa lei, ele que havia baixado duas portarias em sua comarca, proibindo a exposição e venda de 100 publicações, 40 nacionais e 60 internacionais, por considerá-las ofensivas à moral e inconvenientes do ponto de vista da formação da criança e do jovem. Dias (1958) explica que, embora muitos jornais paulistanos vinham veiculando injúrias e calúnias sobre a sua atuação e a de sua comarca, seu objetivo era encorajar e levar adiante essa "Campanha de Saneamento Moral".

6 Não foi possível localizar informações a respeito de Aldo de Assis Dias. 
Ainda com base na Lei da Imprensa, Lei n. 2.083, de 1953, além da penalidade de proibição da venda de publicações imorais, previa-se de 3 a 6 meses de detenção e multa entre $\operatorname{Cr} \$ 8.000,00$ e $\operatorname{Cr} \$ 12.000,00$ para os responsáveis por dar ao mercado os livros considerados perniciosos.

Dias (1958) conclui com o seguinte "apelo caloroso" aos "pais e mestres":

[...] todos os que aqui me ouvem para cooperarem com o Juizado de Menores nesta causa, pois que, amparar e assistir a uma criança, bem como defender os jovens dos perigos que a vida oferece, e principalmente, salvar a juventude de nossa terra das garras criminosas da má imprensa e dos elementos sem consciência, não é, tão-sòmente, praticar um ato de solidariedade social ou de piedade cristã. Mas também, engrandecer-se aos olhos da Sociedade e conquistar as bençãos de Deus! (Dias, 1958, p.93)

No quinto capítulo de Curso de literatura infantil, "O teatro para crianças e adolescentes - bases psicológicas, pedagógicas, técnicas, estéticas e econômicas para a sua realização",7 o médico Júlio Gouveia ${ }^{8}$ defende a ideia de que é necessário formar as pessoas para o hábito do teatro, os quais se apresentam "conscientes" e de "elevado padrão artístico". Para isso, Gouveia (1958) entende que o teatro infantil tem papel fundamental, pois, desde cedo, as crianças, futuros adultos, são formados para uma cultura teatral.

Gouveia (1958) ressalta que é necessário que esse tipo de teatro seja orientado dentro de algumas normas de ordem psicológica, pedagógica, técnica, estética e econômica, pois, sem isso, “[...] estaremos contribuindo para formar um público pior ainda do que se o tivéssemos deixado entregue à sua própria sorte" (p.99).

7 No sumário e capa de Curso de literatura infantil, esse capítulo é intitulado "Teatro infantil", porém, no interior do livro, é intitulado "O teatro para crianças e adolescentes - bases psicológicas, pedagógicas, técnicas, estéticas e econômicas para a sua realização”.

8 Nascido em 1914, Júlio Gouveia se formou em Medicina e posteriormente se especializou em Psiquiatria. Juntamente com alguns amigos e sua esposa, Tatiana Belinky, criou, em 1948, o grupo “Teatro Escola de São Paulo" (Tesp). Também com sua esposa adaptou para a TV Tupi Os três ursinhos, em 1951, e criou, em 1953, a versão televisiva de O Sítio do Pica-pau Amarelo, exibida pela TV Paulista. Após vários anos se dedicando à televisão brasileira, Julio Gouveia resolveu se afastar da vida artística e passou a atuar apenas como médico, tendo falecido em 1988, aos 74 anos de idade (PRÓ TV, s.d.). 
Para concluir, Gouveia (1958) apresenta algumas considerações sobre as bases econômicas do teatro infantil e destaca que, por requerer cenário variado, figurino "vistoso", músicas, efeitos e elenco considerável, o teatro infantil não costuma dar lucro, nem sequer se sustentar sozinho. Por isso, ele entende que o teatro infantil apenas funcionará no Brasil em situação ideal, quando houver Companhias e Sociedades destinadas a esse fim.

No sexto capítulo de Curso de literatura, "Organização e funcionamento de uma biblioteca escolar", a bibliotecária Lenyra Fraccaroli, ${ }^{9}$ ao retomar a importância da leitura e da literatura infantil, afirma que, para que esse gênero literário pudesse "[...] exercer todo o benefício que lhe é próprio, faltava um impulso, um veículo de divulgação, um meio edificante de acordar o interêsse: Bibliotecas infantis [...]” (p.120).

Segundo essa autora, as bibliotecas infantis, ao funcionarem como complementos das escolas, constituem-se em "admiráveis" centros de ação social e concorrem "poderosamente" para o progresso do ensino. Por isso, afirma que não "[...] se pode admitir uma escola primária sem sua biblioteca escolar, ou uma cidade civilizada sem sua biblioteca pública infantil" (p.120).

Para que as bibliotecas infantis desempenhassem o papel que lhes cabia, Fraccarroli (1958) destaca que a figura do bibliotecário era fundamental. O "[...] bibliotecário hábil fará da biblioteca o centro vital da escola. Assim, como em muitas escolas, um bom corpo docente compensa a falta de um prédio próprio, assim, também, a presença na biblioteca de um bibliotecário capaz, suprirá até mesmo a deficiência do material [...]" (Fraccaroli, 1958, p.121-122).

Além de destacar o conceito de biblioteca que trabalha e o papel do bibliotecário nesse tipo de espaço, Fraccaroli (1958) apresenta algumas orientações sobre como proceder com relação ao espaço, ao mobiliário, à organização dos livros, ao museu, ao acervo, ao empréstimo de livros, às estatísticas de retirada de livros, às doações, à portaria da biblioteca e às exposições.

No sétimo e último capítulo de Curso de literatura infantil, "O folclore - base da literatura infantil”, o professor e editor Hernâni Donato, ${ }^{10}$

9 As informações biográficas sobre Lenyra Fraccaroli foram apresentadas no Capítulo 2 deste livro.

10 Nascido na cidade de Botucatu-SP, em 1922, Hernâni Donato, em 1940, matriculou-se na Escola Livre de Sociologia e Política de São Paulo e, em 1942, foi contratado para lecionar como 
ao entender que literatura é um tipo de arte e o folclore, a manifestação criativa não erudita, afirma que: "Uma e outra são formas de pesquisa e de conhecimento do mundo e do homem" (p.145). E, por ser a literatura um tipo de arte, ela tem função "estetizante", "recreativa". Já o folclore, pelo seu caráter de manifestação não erudita, tem função "sublimadora", "moralizante", "libertadora". Por isso: "Folclore e Literatura, frequentes vêzes se confundem e esta bebe seguidamente no remanso darto que é aquêlo" (Donato, 1958, p.151).

Dada essa relação entre literatura e folclore, Donato (1958) faz uma extensa explicação histórica sobre as relações entre essas duas manifestações culturais, especialmente no que se refere à literatura para crianças. Ele entende que a literatura infantil, que não "nasceu" infantil, originou-se como tal, no século XVIII, do folclore.

Em relação à literatura infantil brasileira e à representação do folclore nacional, Donato (1958) entende que se trata de algo recente, pois Lobato ainda recorreu em sua literatura ao folclore universal.

Donato (1958) conclui fazendo o seguinte alerta e pedido:

[...] é forçoso que as professôras [...] tomem conhecimento e sob cuidados, as manifestações da alma popular brasileira. Só êsse apelo foi o objeto de minha palestra, neste Curso em homenagem a Monteiro Lobato. Ouçam-no com boa vontade os que têm a responsabilidade da formação da consciência das gerações escolares. E façam melhores brasileiros pelo melhor conhecimento da genuína alma nacional: a sua expressão folclórica. (Donato, 1958, p.169)

\section{A I Semana de Literatura Infantil de São Paulo}

Também no movimento de tentar solucionar os problemas relativos ao desconhecimento e ao despreparo dos professores e alunos dos Cursos Normais no que se refere ao ensino da literatura infantil, foi organizada a

professor de "Merceologia" e "Tecnologia Merceológica" da Escola Técnica de Comércio Nossa Senhora de Lourdes, de Botucatu-SP. Entre os cargos ocupados por Donato, destacam-se: professor da cadeira "português", da Escola Técnica de Comércio Nossa Senhora de Lourdes, de Botucatu-SP; redator e diretor de diversos jornais e revistas; e professor de "Geografia Humana” na Escola de Formação de Líderes Sindicais (Mello, 1954; Coelho, 2006). 
I Semana de Literatura Infantil, pelos alunos do curso de Administradores Escolares do Instituto de Educação Caetano de Campos, juntamente com a professora Maria Nilde Mascellani ${ }^{11}$, responsável pela disciplina "Literatura infantil" desse curso. Essa Semana foi realizada em São Paulo, entre os dias 21 e 28 de outubro de 1957, no auditório do Instituto de Educação Caetano de Campos.

De acordo com o panfleto de divulgação desse evento, a sua realização do fato de que:

o número de pessoas interessadas na solução dos nossos problemas educacionais e em tôda obra que reverta em favor da criança, é com alegria que nos dirigimos a todos aquêles que labutam no campo da educação, a fim de convidá-los, professôres, primários, professôres de ensino secundário e normal, estudantes normalistas e pais em geral, para participarem das atividades que integram o programa desta I Semana de Literatura Infantil (Instituto..., 1957, página única).

Para atingir os objetivos a que visavam com a realização dessa I Semana de Literatura infantil, ficou estabelecida a seguinte programação de palestras:

Dia 21 - segunda-feira - 19, 30 horas

1 - Sessão de abertura, no Auditório do Instituto de Educação Caetano de Campos.

2 - "Formação e posição do professor primário em relação ao problema da Literatura infantil" - palestra pelo prof. Antônio d'Ávila.

3 - Abertura da Exposição de Literatura infantil na sala n. 325 do Instituto Dia 22 - terça-feira

11 Nascida em São Paulo-SP, em 1931, Maria Nilde Mascellani se diplomou professora pela Escola Normal Padre Anchieta, na capital paulista, e depois se graduou em Pedagogia pela Universidade de São Paulo. Atuou como professora em diferentes instituições do estado de São Paulo, foi Secretária de Educação de Rio Claro-SP, coordenadora do Serviço de Ensino Vocacional e professora da Pontifícia Universidade Católica de São Paulo (PUC-SP). No ano de 1990, defendeu sua tese de doutorado junto à Faculdade de Educação da USP e faleceu aos 68 anos de idade, em 1999. Informações disponíveis em: <http://www.pucsp.br/cedic/ memoria_educacao/root/galeria_videos.html>. Acesso em: 15 de out. 2014. 
19,30 hs. - "Escrevendo para a infância..." - palestra pelo professor Dr. Francisco Marins.

20,30 hs. - "Literatura e teatro infantil" - palestra pela escritora Maria Clara Machado.

Dia 23 - quarta-feira

19,30 hs. - "Organização e orientação de uma biblioteca infantil" - palestra pela profa. Lenira Fracarolli.

20,30 hs. - "História da Literatura Infantil" - palestra pela profa. Matilde Brasiliense.

Dia 24 - quinta-feira

19,30 hs. - "Fundamentos psicológicos da Literatura Infanto-Juvenil" palestra pela profa. Noemy da Silveira Rudolfer.

20,30 hs. - "Literatura infantil e Folclore" - palestra pelo prof. Rossini Tavares de Lima.

Dia 25 - sexta-feira

19,30 hs. - "Aspecto jurídico social da literatura infanto-juvenil" - palestra pelo Desembargador Dr. João Batista Arruda Sampaio.

Dia 28 - segunda-feira

19,30 hs. - 1 - Sessão de encerramento com apresentação das conclusões gerais da I Semana de Literatura Infantil

2 - Apresentação da peça teatral infantil Pluft, o Fantasminha, de autoria de Maria Clara Machado, a cargo do Grupo de Teatro do I Ano de Administradores Escolares (Instituto..., 1957, página única).

A realização desse evento, ao longo dos dias em que ele ocorreu, foi noticiada pelo jornal A Gazeta, que apresentou breves informações das atividades que vinham ocorrendo na I Semana de Literatura Infantil.

Entre essas notícias, no dia 25 de outubro de 1957, relatou-se sobre o número de inscritos na atividade, que excedera as expectativas dos organizadores. Segundo essa notícia do jornal A Gazeta, isso demonstrava o interesse crescente dos professores em relação à literatura infantil. As fotos desse evento possibilitam observar que o número de pessoas que participaram das palestras era realmente significativo.

Com relação às palestras realizadas, cabe destacar que as temáticas abordadas se assemelham bastante às do I Curso Intensivo de Literatura Infantil, ocorrido no mesmo ano, porém os palestrantes foram todos diferentes. 
No âmbito das palestras programadas para a I Semana de Literatura Infantil, cabe destacar o tema da palestra de Antônio d'Ávila - "Formação e posição do professor primário em relação ao problema da Literatura infantil" -, que faz referência indireta à institucionalização do ensino da literatura infantil nos Cursos Normais paulistas. Muito possivelmente, esse foi o tema escolhido por Antônio d'Ávila ou indicado para ele, por conta de sua experiência com a proposição de "concretização" de ensino da literatura infantil, contida no terceiro volume de Práticas escolares (1954). Esse professor, o primeiro com atuação no estado de São Paulo a escrever um capítulo sobre literatura infantil em manuais de ensino, de certa forma, acabou se tornando referência no assunto por essa condição.

\section{Lourenço Filho e a elaboração de um "anteprojeto" de programa de ensino}

Também em 1957, após a criação da disciplina "Literatura infantil" no currículo dos Cursos Normais do estado de São Paulo, a Chefia do Serviço do Ensino Secundário e Normal desse estado publicou, em caráter emergencial e provisório, um programa de ensino para o conjunto das disciplinas "Português", "Linguagem" e "Literatura infantil".

A pedido do escritor Francisco Marins, Lourenço Filho, por entender que a parte de literatura infantil não era de conhecimento dos professores normalistas, elaborou "[...] algumas notas e observações sobre a matéria, com o simples intuito de facilitar a obra em que se empenha a digna Chefia do Ensino Secundário e Normal” (Lourenço Filho, 1957a, p.1).

Essas "notas e observações", datilografadas, compõem um documento dividido em duas partes: a primeira, com considerações preliminares sobre a disciplina "Literatura infantil" e sobre o programa emergencial; a segunda, com um anteprojeto de programa de ensino para essa disciplina.

Esse documento foi entregue à Chefia do Ensino Secundário e Normal, visando, então, colaborar com a elaboração dos programas definitivos para a disciplina "Literatura infantil".

Na primeira parte desse documento, Lourenço Filho (1957a), após justificar seu empenho na elaboração do anteprojeto de programa de ensino, explica que a melhor forma de tratar a literatura infantil nos Cursos Nor- 
mais era associá-lo às disciplinas que tratam de metodologia. ${ }^{12}$ Essa proposição decorre do fato de que, para Lourenço Filho (1957a), a "[...] literatura infantil é um instrumento pelo qual se deverá fazer na escola primária a iniciação literária, devendo assim associar-se à metodologia da leitura" (p.1, grifos do autor).

Lourenço Filho (1957a) explica que o ensino da literatura infantil não deve se centrar na análise de textos, exceto se essa análise tiver razão de ser na identificação das funções educativas que os livros apresentam, coerentemente com as fases do desenvolvimento infantil. Nesse sentido, Lourenço Filho (1957a) propõe que, com a inclusão da disciplina "Literatura infantil" no currículo dos Cursos Normais, era necessário associar essa disciplina com aquelas que tratam de metodologia e a disciplina "Prática de ensino". Por isso, ele apresenta algumas críticas ao programa emergencial, porque considerava que ele não contemplava os objetivos a que um programa deve atender. Para ele, o modo como esse programa emergencial foi estruturado parecia visar apenas ao objetivo de dar aos futuros professores uma visão simplesmente literária dos textos infantis.

Para Lourenço Filho (1957a), no caso da disciplina "Literatura infantil", o verdadeiro objetivo do programa devia ser o de dar uma noção aos futuros professores "[...] que os habilite a bem se servir dos textos para as funções educativas hoje universalmente reconhecidas na literatura de caráter recreativo [...]" (Lourenço Filho, 1957a, p.2). Por isso, Lourenço Filho (1957a) considera que não foi correta a organização dada ao programa emergencial, em quatro pontos - "Origem da literatura infantil", "Literatura infantil propriamente dita (traduções e adaptações)", "A literatura infantil nacional. Seu Folclore" e "Conceito de folclore". Segundo esse educador, faltou entre outros aspectos uma parte histórica, "[...] para caracterizar a literatura infantil por suas funções educativas gerais, dar-lhes os tipos e modalidades, e, enfim, discutir problemas de adaptação aos vários níveis de desenvolvimento infantil” (Lourenço Filho, 1957a, p.2).

Lourenço Filho (1957a) relaciona outros problemas ou erros que apresenta o programa emergencial: erros tipográficos; o modo como foi disposto o ponto "Literatura infantil propriamente dita (traduções e adaptações)"

12 Lourenço Filho (1957) não especifica quais são as disciplinas sobre metodologia que a disciplina "Literatura infantil" devia se associar. Ele apenas menciona, de forma genérica, que se tratam de disciplinas de metodologia. 
gera a ideia equivocada de que a literatura infantil "propriamente dita" se origina nas traduções e adaptações; há informação errada de que a literatura infantil "intencionalmente educativa e instrutiva" se inicia com Charles Perrault; e falta menção e explicação sobre os "precursores" da literatura infantil brasileira.

Para cada um desses problemas, Lourenço Filho (1957a) apresenta uma explicação breve sobre como corrigi-los. E explica que entende que o programa definitivo da disciplina "Literatura infantil" deverá ser apresentado:

[...] em relação ao próprio desenvolvimento das práticas educativas, razão por que hoje é considerada como importante na escola primária, facilitando, antes de tudo, a iniciação literária, sôbre as demais funções de servir como entretenimento ou de ocupação das horas de lazer, com vantagens à formação cultural e ao enriquecimento da personalidade dos educandos (Lourenço Filho, 1957a, p.4, grifo do autor).

Para encerrar essa primeira parte do documento que elaborou, Lourenço Filho (1957a) faz a ressalva de que, embora o termo "juvenil" não apareça na denominação dessa disciplina, isso não significa que esse assunto deva ser excluído da formação dos professores. Para ele, o “[...] ideal, na escola primária, é que os alunos cheguem a desejar a literatura de trabalhos desse nível, reafirmando assim o objetivo a ter em vista, que é o de uma boa iniciação literária" (Lourenço Filho, 1957a, p.4, grifos do autor).

Na segunda parte do documento, Lourenço Filho (1957) apresenta, em conformidade com as proposições que fez na primeira parte, um anteprojeto de programa para a disciplina "Literatura infantil". Esse seu anteprojeto comporta quatro páginas datilografadas e se organiza em três pontos: "Origem e desenvolvimento da literatura infantil"; "Caracterização e funções da literatura infantil"; e "Parte prática".

No que diz respeito ao primeiro ponto - "Origem e desenvolvimento da literatura infantil” -, Lourenço Filho (1957a) apresenta a relação da literatura infantil com a remota tradição oral de contar e ouvir. Para esse educador, são as cantigas de ninar, a parlendas, as rondas infantis e o hábito de ouvir e contar histórias que marcam a origem da literatura infantil.

Lourenço Filho (1957a) aponta que, a partir do século XVII, foram as coletâneas de contos maravilhosos, destinados inicialmente aos adultos, 
que passaram a constituir o acervo da literatura infantil europeia. Para ele, são as recolhas e adaptações de contos populares feitas por Charles Perrault, Irmãos Grimm e Hans Christian Andersen, após o século XVII, que caracterizam o surgimento "propriamente dito" da literatura infantil. Também a partir do século XVII, os "[...] estudos sobre a criança e sua evolução, bem como a renovação educativa deveriam fazer prosperar a ideia" (Lourenço Filho, 1957a, p.5) de literatura destinada especificamente ao público infantil.

Com o desenvolvimento da literatura infantil na Europa, os primeiros textos voltados ao público infantil, no Brasil, decorreram das traduções dos originais europeus. Segundo Lourenço Filho (1957a), os precursores da literatura infantil no Brasil foram: Alberto Figueiredo Pimentel, Arnaldo de Oliveira Barreto, Olavo Bilac, Osório Duque Estrada e Coelho Neto. Após o surgimento dessas traduções no Brasil, iniciou-se a produção de literatura infantil verdadeiramente brasileira, a qual tem no nome de Monteiro Lobato a sua principal figura.

No que diz respeito ao segundo ponto - "Caracterizações e funções da literatura infantil" -, Lourenço Filho (1957a) distingue o livro "propriamente didático" da "obra de literatura recreativa". Para ele, a literatura infantil se caracteriza por ter a função dupla de "[...] ensinar e recrear com sentido útil à formação emocional e ao ajustamento social” (Lourenço Filho, 1957a, p.6). Por isso, defende a ideia de ajustamento da literatura infantil ao desenvolvimento psicológico das crianças.

A partir dessa concepção de literatura infantil, Lourenço Filho (1957a) apresenta as "funções capitais" e os requisitos a que esses livros devem atender. Para ele, as funções da literatura infantil são: estimular o desenvolvimento da leitura, exercitar o bom gosto da linguagem, enriquecer os interesses infantis para a boa formação da personalidade, transmitir hábitos sadios de aproveitamento do tempo de lazer e "[...] dar oportunidade para evasão da vida cotidiana, com incentivo, porém, à afirmação de nobres 'níveis de aspiração' pessoal, compreensão normal dos sentimentos familiares, cívico e de larga compreensão humana [...]" (Lourenço Filho, 1957a, p.6).

Para que a literatura infantil corresponda a essas funções, segundo Lourenço Filho (1957a), precisa atender a alguns requisitos: uso de linguagem adequada ao público infantil; escolha de conteúdos informativos, que equilibrem o imaginário e o real conforme as fases da evolução psíquica da 
criança; adequação a literatura infantil à aprendizagem da leitura; e boa apresentação material.

No que diz respeito ao terceiro ponto - "Parte prática" -, Lourenço Filho (1957a) defende a necessidade de o professor catedrático da disciplina "Literatura infantil" aplicar exercícios práticos. E sugere a realização de investigações a respeito da literatura infantil, com o objetivo de compreender o valor educativo e geral desse gênero literário.

Lourenço Filho (1957) conclui o terceiro ponto com a sugestão de que toda a parte prática desse programa seja feita em parceria com os trabalhos das disciplinas de metodologia e a disciplina "Prática de ensino".

Após a elaboração desse anteprojeto de programa de ensino, o jornal $A$ Gazeta, no dia 29 de maio de 1957, iniciou a publicação desse documento, a fim de auxiliar alunos e professores dos Cursos Normais, com as questões sobre o ensino da literatura infantil. A publicação desse anteprojeto foi feita em seis dias: o primeiro ponto nos dias 29 e 31 de maio de 1957; o segundo ponto nos dias 3, 4 e 5 de junho de 1957; e o terceiro ponto no dia 06 de junho de 1957 (A Gazeta, 1957).

Nessa publicação, o jornal A Gazeta não publicou a parte em que Lourenço Filho (1957) apresenta suas considerações sobre a disciplina "Literatura infantil" e sobre o programa provisório. Apenas foi publicada a segunda parte desse documento, com o anteprojeto de programa de ensino.

\section{O primeiro programa oficial para o ensino da literatura infantil do estado de São Paulo}

Em 1958, a Chefia de Serviço do Ensino Secundário e Normal publicou, por meio do Comunicado n. 18, de 3 de março de 1958, o conjunto dos novos programas de ensino do Curso Normal, entre os quais o programa de "Literatura infantil".

Esse comunicado teve como objetivo apresentar as "[...] alterações necessárias, à vista da nova distribuição de disciplinas e de aulas, constante do Quadro de Aulas publicado a 29-01-1958 ou introduzidas em atenção às sugestões que lhe foram apresentadas" (São Paulo, 1958, p.3). Até então, estavam em vigor os programas de ensino aprovados pela Portaria n. 49, de 5 de dezembro de 1954, os quais precisavam ser alterados e adequados 
conforme a reforma do Ensino Normal ocorrida mediante a promulgação da Lei n. 3.739, de janeiro de 1957 (Labegalini, 2009).

De acordo com as adequações dos programas de ensino do Curso Normal, estabelecidas em 1958, o programa da disciplina "Literatura infantil" ficou assim definido:

\section{I - Literatura infantil.}

1 - Origem e desenvolvimento da Literatura infantil.

a) A tradição oral

b) Fábulas, viagens, contos de fadas para adultos.

c) Primeiras coletâneas dos contos maravilhosos para adultos.

d) a literatura de ficção creativa no século XIX.

e) A literatura infantil no Brasil. Os precursores (século XIX), os propulsores do movimento: homens de letras e professôres (século XX).

f) a expansão da literatura infantil brasileira nos últimos tempos. As publicações infantojuvenis.

2 - Caracterização da literatura infantil

a) A literatura didática e a recreativa: fases e modalidades.

b) $\mathrm{O}$ ajustamento do literato à evolução da criança: a fase do egocentrismo e da socialização.

c) A poesia na literatura infantil: Os pequenos poemas e as fábulas em verso. Os cantos escolares.

d) Os requisitos morais e materiais do livro de literatura infantil.

3 - Finalidades didáticas, psicológicas, sociais e morais da literatura infanto-juvenil.

4 - A Biblioteca escolar infanto-juvenil: finalidade e organização. Clubes de leitura.

5 - O Teatro Infantil: representações infantis, teatro de sombras, de bonecos, de fantoches.

II - Prática de composição:

a) Reprodução, narração, descrição, desenvolvimento de provérbios, biografia em função do Curso Primário.

b) Redação de contos para crianças.

c) Adaptação de obras clássicas e folclóricas para crianças.

d) Organização de programas para comemorações cívicas.

e) Dramatizações de fatos históricos, fabulas e contos infantis. 
f) Composição de pequenas peças para Teatro Infantil.

III - A Leitura em função do programa.

O aluno continuará os exercícios dos anos anteriores, mas usando como texto obras de literatura infantil (São Paulo, 1958, p.9-10).

De acordo com o Comunicado n. 18 e em conformidade com a reforma estabelecida pela Lei n. 3.739, de 1957, esse programa de literatura infantil se referia ao $3^{\circ}$ ano dos Cursos Normais paulistas ministrados no período diurno e ao $4^{\circ}$ ano dos Cursos Normais paulistas ministrados no período noturno.

Destaco que, como a disciplina "Literatura infantil" integrava um bloco de disciplinas juntamente com "Português" e "Linguagem", os programas de ensino dessas três disciplinas eram organizados em três partes: a primeira sempre referente ao conteúdo específico de cada disciplina, com caráter mais teórico; a segunda, denominada "Prática de composição", que prescreve o ensino da escrita de textos condizentes com a parte teórica da disciplina; e a terceira, "A leitura em função do programa", que prescreve as práticas de leitura dos normalistas em vista do conteúdo teórico que consta na primeira parte desses programas.

No caso da disciplina "Literatura infantil", pode-se observar que, na parte específica do programa, o ensino desse gênero literário está organizado em cinco pontos, sendo o primeiro ("Origem e desenvolvimento da literatura infantill”) e o segundo ("Caracterização da literatura infantil”) subdivididos em outros subpontos. No caso da "Prática de composição", o que se pode observar são prescrições a serem desenvolvidas que correspondem à execução de atividades que serviriam para uso da literatura infantil no cotidiano da escola primária. Por essa razão, são prescritas "práticas" como adaptação de histórias folclóricas, composição de peças teatrais, elaboração de dramatizações a partir de fábulas e organização de atividades com a literatura infantil em função das datas cívicas.

Com relação à "A leitura em função do programa", prescreve-se que os alunos continuariam a realizar os exercícios das disciplinas ministradas nos anos anteriores - "Português" e "Linguagem" -, porém, por meio de livros de literatura infantil.

Conforme consta no Comunicado n. 18, de março de 1958, as prescrições para a "Leitura em função do programa", para a disciplina "Português", no $1^{\circ}$ ano, eram: 
III - A leitura em função do programa.

O texto é o elemento primeiro para o estudo da língua. Em torno da leitura gira tudo o mais: o professor fará o estudo da gramática através do texto. $\mathrm{O}$ aluno deverá, ainda, ser orientado para: a) pesquisa de vocabulário; b) apreciação do autor; c) organização de ficheiro de leituras individuais (São Paulo, 1958, p.9).

No $2^{\circ}$ ano, as prescrições para a "Leitura em função do programa", da disciplina "Linguagem", eram as seguintes:

III - A leitura em função do programa.

O aluno continuará os exercícios do ano anterior, na pesquisa de vocabulário crítica literária, enriquecimento do fichário de leituras individuais de livros e artigos de revistas e jornais. Com os conhecimentos teóricos que houver adquirido, o julgamento escrito ou verbal do que haja lido, deverá obedecer as normas da crítica literária (São Paulo, 1958, p.9).

Nessas prescrições, é possível compreender que o que se propõe no âmbito da disciplina "Literatura infantil", na "Leitura em função do programa”, é o trabalho de análise de texto, com vistas ao vocabulário, ao autor e ao "julgamento" escrito ou verbal. O que se pode observar em relação a esse programa é que ele apresenta bastante similaridade, do ponto de vista da organização e das prescrições, com o anteprojeto de programa de ensino elaborado por Lourenço Filho.

Todos os pontos que Lourenço Filho (1957a) indicou como básicos para a formação do futuro professor no que se refere ao ensino da literatura infantil constam nesse programa de ensino, publicado em 1958. Lourenço Filho (1957a), propôs a organização das prescrições para o ensino da literatura infantil em três pontos: "Origem e desenvolvimento da literatura infantil", "Caracterização e funções da literatura infantil" e "Parte prática". O primeiro ponto do anteprojeto de Lourenço Filho (1957a) é praticamente idêntico ao primeiro do programa de 1958, também denominado "Origem e desenvolvimento da literatura infantil".

O segundo ponto do anteprojeto de Lourenço Filho (1957a), "Caracterização e funções da literatura infantil”, no detalhamento que esse autor apresenta, corresponde, com algumas adequações de denominação e de 
divisão dos assuntos, aos segundo, terceiro e quinto pontos do programa de 1958. O único ponto que consta nesse programa de 1958 e que Lourenço Filho (1957a) não se deteve em seu anteprojeto é o relativo às bibliotecas escolares e clubes de leitura.

Em relação a "Prática de composição" e "A leitura em função do programa” do programa da disciplina "Literatura infantil”, de 1958, também elas se assemelham às proposições de Lourenço Filho (1957a), que destaca que o estudo do texto e a sua análise eram importantes, desde que aplicados aos propósitos educacionais. O que se prescreve no programa de 1958, na "Prática de composição" e na "Leitura em função do programa" são basicamente as recomendações de Lourenço Filho (1957a) sobre como proceder com os livros e a sua utilização na escola primária.

Isso pode ser observado, por exemplo, no seguinte: em seu anteprojeto, Lourenço Filho (1957a) recomenda que, após a análise dos textos e de pesquisa sobre contos e fábulas, os normalistas comporiam "[...] ficheiro de real utilidade para os futuros professores, e ademais, dar-se-lhes-á o hábito de sentir o valor funcional da literatura infantil como auxiliar do ensino" (Lourenço Filho, 1957a, p.6). No programa da disciplina "Literatura infantil", de 1958, na parte "A leitura em função do programa”, que prevê seguir as mesmas atividades dos programas das disciplinas "Português" e "Linguagem", nota-se, também, a sugestão de organização de ficheiros e de formação de repertórios de leituras.

Apesar das semelhanças entre o anteprojeto de Lourenço Filho (1957a) e o programa da disciplina "Literatura infantil" de 1958, não há nenhuma menção no Comunicado n. 18, a esse anteprojeto ou às contribuições desse autor para a elaboração da versão definitiva desse programa.

\section{A regulamentação dos Cursos Normais (1959) e os novos programas de ensino}

Após os Cursos Normais paulistas terem passado pela reforma de 1957, a Assembleia Legislativa do estado de São Paulo aprovou o Decreto n. 35.100, de 17 de junho desse ano, que: "Regulamenta a Lei n. 3.739, de 22 de janeiro de 1957, que dispõe sôbre a organização do Ensino Normal no 
Estado de São Paulo, modificada pela Lei n. 5.304, de 15 de abril de 1959, e dá outras providências" (São Paulo, 1960, p.14).

Anteriormente à publicação do Decreto 35.100, de junho de 1959, havia sido promulgada a Lei n. 5.304, em 15 de abril de 1959, a qual alterou de quatro para três anos a duração dos Cursos Normais noturnos. Após isso, foi promulgado o Decreto 35.100, de junho de 1959, que regulamentou o Ensino Normal em vista dessa e de outras alterações necessárias.

Conforme consta na disposição do Decreto n. 35.100, de 1959, ele tinha apenas função de regulamentar a reforma estabelecida pela Lei 3.739, de 1957. Ou seja, sua função era complementar essa Lei e possibilitar a sua efetiva aplicação.

De acordo com o então Diretor Geral Substituto do Departamento de Educação do estado de São Paulo, Carlos Pasquale ${ }^{13}$, as razões que levaram esse Departamento a propor a regulamentação da Lei n. 3.739, de 1957, por meio do Decreto n. 35.100, de junho de 1959, decorreram do fato de a Lei de 1957, mesmo tendo sido promulgada havia certo tempo, ainda carecia de "[...] falta de regulamentação capaz de consolidar a aplicação dos princípios que a informam” (Pasquale, 1960, p.23). Por essa razão, Carlos Pasquale afirma que a:

[...] regulamentação proposta está fundada na lei e atende aos seus objetivos. Sem nada inovar, no que constitui matéria legislativa, já constante de direito positivo, procura o projeto estabelecer normas para a aplicação das disposições legais pertinentes ao ensino normal, conferindo-lhes, no todo, a necessária organicidade de estrutura.

A fixação das normas regulamentares inspirou-se sempre no propósito de, sem sacrifício de lágrimas prerrogativas dos educadores e sem prejuízo do prestígio público da escola, cercar a realização de todos os atos escolares da maior autenticidade, e concorrer, assim, para a elevação dos padrões de ensino (Pasquale, 1960, p.24).

13 Nascido em Piracicaba, em 1906, Carlos Pasquale se diplomou professor, tendo lecionado por mais de 40 anos, e também médico. Entre os cargos que ocupou, estão os de Diretor-Geral do Departamento Nacional de Educação, Secretário de Educação do estado de São Paulo e diretor do Departamento Regional do Serviço Nacional de Aprendizagem Industrial. Carlos Pasquale faleceu em 1970 (Dias, 1999). 
Embora o Decreto n. 35.100, de 1959, tinha como propósito regulamentar a Lei n. 3.739, de 1957, ele também previa algumas alterações no Ensino Normal, entre as quais: a fixação do Ensino Normal como responsável pelos Cursos de Formação de professores primários, Cursos de Aperfeiçoamento e Cursos de Especialização; criação dos Cursos de Especialização de Professores de ensino Rural e de Professores de Ensino de Deficientes Mentais; e nova definição da distribuição das disciplinas e carga-horária dos cursos de especialização.

Em relação ao currículo dos Cursos Normais, o Decreto n. 35.100, de 1959, não previa nenhuma alteração. Apesar disso, esse Decreto contém a deliberação, no seu artigo $15^{\circ}$, parágrafo único, sobre a formação de comissões para elaborar novos programas de ensino para todas as disciplinas do currículo desse curso. Com isso, Diretor Geral Substituto do Departamento de Educação do Estado de São Paulo, Carlos Pasquale, por meio da Portaria n. 69, de 10 de setembro de 1959, nomeou algumas comissões para elaboração dos novos programas de ensino dos Cursos Normais e dos Cursos de Especialização.

A comissão nomeada para elaboração do programa de ensino relativo às disciplinas "Português", "Linguagem" e "Literatura infantil" era constituída das seguintes professoras: Edith Pimentel Pinto, do Curso Estadual e Escola Normal Domingos Faustino Sarmiento, situado na capital paulista; Célia de Souza, do Instituto de Educação Fernão Dias, também situado na capital paulista; e irmã Ana Francisca Braga, da Escola Normal Particular Santa Inês, também da capital paulista.

Após os trabalhos desenvolvidos pelas comissões, ainda em 1959, foram publicados os novos programas de ensino para o Curso Normal, "[...] atendendo ao que lhe apresentou o Chefe do Serviço do Ensino Secundário e Normal [...]" (São Paulo, 1959, p.40). Segundo informações que constam no texto desses novos programas, a partir de então eles poderiam "[...] ser adotados como roteiros pelos professôres do curso do Ensino Normal” (São Paulo, 1959, p.40).

No caso específico da disciplina "Literatura infantil", o novo programa, elaborado a partir dos trabalhos da Comissão formada por Edith Pimentel Pinto, Célia de Souza e irmã Ana Francisca Braga, ficou assim definido: 
$3^{\mathrm{a}}$ série

Duas aulas semanais.

I - Gramática: Estudo do programa de gramática do Curso Primário

II - Literatura infantil:

a) origem e desenvolvimento;

b) literatura folclórica;

c) literatura de ficção no século XIX;

d) Literatura Infantil no Brasil: precursores e propulsores do movimento;

e) o Teatro Infantil;

f) Poesia na Literatura Infantil;

g) Objetivos da Literatura Infanto-juvenil: Didático, Psicológico, Social e Moral;

h) biblioteca escolar infanto-juvenil.

III - Composição:

a) redação para crianças;

b) adaptação de obras clássicas e folclóricas para crianças;

c) dramatização de fábulas e contos;

d) composição de peças para teatro infantil.

IV - Leitura em função do programa (São Paulo, 1960, p.45).

Como se pode observar, esse novo programa, comparativamente ao programa de ensino de 1958, não apresenta grandes mudanças. No programa de 1959 não há proposição de um novo ponto ou mesmo alteração na organização dos pontos que constam no programa de 1958.

O que se pode observar é que o modo de descrever e organizar os pontos a serem estudados no âmbito da disciplina "Literatura infantil" ficaram mais sucintos no programa de 1959, comparativamente ao programa de 1958. A única mudança mais significativa que se observa é a inclusão, no programa de ensino de 1959, do ponto "Gramática - estudo do programa de gramática do curso primário”. Essa mudança ocorreu com o programa das disciplinas "Português" e "Linguagem", que também passaram a ter um ponto específico para o estudo de assuntos relacionados à gramática da língua nacional.

A inclusão desse ponto sobre o ensino da gramática está relacionada, possivelmente, ao fato de que na Lei n. 3.739, de janeiro de 1957, havia 
estabelecido que o estudo da língua portuguesa fosse obrigatório em todas as séries do Curso Normal. No entanto, até 1959, isso não ocorria.

Como o Decreto n. 35.100, de 1958, tinha função de regulamentar a Lei de 1957, a fim de dar as providências para sua ampla execução, é possível afirmar que a inclusão do ponto sobre gramática nos programas das disciplinas "Português", "Linguagem" e "Literatura infantil" ocorreu com o objetivo de atender ao disposto na Lei 3.739, de 1957.

\section{O primeiro manual específico para o ensino da literatura infantil no Brasil: Compêndio de literatura infantil (1959), de Bárbara V. de Carvalho}

Após a publicação, em 1958, do primeiro programa de ensino para a disciplina "Literatura infantil" e concomitantemente à regulamentação dos Cursos Normais paulistas e à elaboração do novo programa para essa disciplina, foi publicado, em 1959, pela Companhia Editora Nacional (SP), Compêndio de literatura infantil: para o $3^{\circ}$ ano normal..$^{14}$

Esse manual, de autoria da professora baiana Bárbara Vasconcelos de Carvalho, foi o primeiro manual específico para o ensino da literatura infantil publicado no Brasil e no qual a autora buscou formular uma proposta para esse ensino coerente com os programas da disciplina "Literatura infantil" do estado de São Paulo.

Nascida no dia 5 de novembro de 1915, na cidade de Alagoinhas-BA, Bárbara Isabel Vasconcelos realizou seus estudos primários e formou-se professora na cidade de Salvador-BA, onde, na realidade, teve seu nascimento registrado. Em 1936, ela diplomou-se professora pelo Colégio Nossa Senhora da Soledade e, no mesmo ano, casou-se com Aurivaldo Farias de Carvalho, a partir de quando passou a assinar Bárbara Vasconcelos de Carvalho. Após ficar viúva precocemente, essa professora passou a atuar em diferentes escolas no estado da Bahia e, concomitantemente a isso,

14 Para maiores informações sobre Bárbara V. de Carvalho e Compêndio de literatura infantil, ver, Oliveira (2010; 2013), onde se encontram análise detalhada desse manual e biografia dessa professora. Aqui, apresento alguns dos aspectos da configuração textual desse manual, a fim de situá-lo no conjunto dos outros manuais e das ações em relação à formação de um saber escolar sobre a literatura infantil. 
graduou-se em Letras Neolatinas, em 1949, pela Faculdade de Filosofia da Universidade da Bahia.

Em 1953, Bárbara Vasconcelos de Carvalho mudou-se para o estado de São Paulo, para atuar como professora em escolas do interior e da capital. Em 1957, enquanto atuava como diretora do Ginásio de Vila Formosa, ela "[...] coordenou a equipe responsável pela reformulação dos programas de Português do Curso Pedagógico, quando apresentou projeto e introduziu o ensino da literatura infantil nos programas do referido Curso [...]" (Santos, 2001, p.45). Foi em decorrência dessa atividade, principalmente, que Bárbara Vasconcelos de Carvalho escreveu, pioneiramente, Compêndio de literatura infantil.

Até a publicação desse manual, somente haviam sido publicados no Brasil os capítulos em manuais de ensino de Budin (1949), Carneiro (1951) e d'Ávila (1954) e o livro Curso de literatura infantil (1958), que "funcionou" como um manual de ensino. No caso desses capítulos, dois deles, o de Budin (1949) e o de Carneiro (1951), foram elaborados com base no programa de linguagem do Instituto de Educação do Distrito Federal. No caso do capítulo de d'Ávila (1954) e do livro Curso de literatura infantil, embora decorrentes da criação, respectivamente, da matéria "Literatura infantil", em 1947, e da disciplina "Literatura infantil”, em 1957, eles foram publicados num momento em que ainda não havia sido publicado nenhum programa para o ensino da literatura infantil em São Paulo.

Em vista dessa situação, conforme explica Carvalho (1959), a publicação desse manual decorreu da necessidade de "[...] orientar os alunos [normalistas] para as suas aulas [de literatura infantil] e o desenvolvimento de suas teses" (Carvalho, (1959, p.6). Com isso, continua Carvalho (1959): "Não pretendemos fazer outra cousa senão oferecer-lhes material, sistematizado e condensado, para facilitar-lhes o estudo, cabendo, então, ao professor orientá-los e dirigi-los" (p.6).

Para atender a esse propósito, Carvalho (1959) organizou a $1^{\text {a }}$ edição de Compêndio de literatura infantil com introdução, agradecimento, nota "aos colegas", dedicatória, 19 capítulos e bibliografia. Esses 19 capítulos intitulam-se: "Origem e desenvolvimento da literatura infantil"; "Primeiras coletâneas de contos maravilhosos: século XVIII"; "Ainda no século XVIII"; "A literatura de ficção no século XIX"; "Literatura infantil no 
Brasil: precursores e seguidores"; "Monteiro Lobato: o século XX"; "Publicações - revista - outras atividades recreativas"; "Caracterização da literatura infantil: fases e modalidades"; "A literatura didática e recreativa"; "Poesia na literatura infantil”; "Requisitos literários, morais, psicológicos e materiais do livro de literatura infantil"; "Finalidades didáticas, psicológicas, sociais e morais da literatura infantil e juvenil"; "O Teatro"; "Teatro Infantil"; "Fábula"; "O folclores nacional"; "Biblioteca"; "Biblioteca Infantil"; e "Prática: algumas sugestões". Ao todo, a $1^{\text {a }}$ edição de Compêndio de literatura infantil contém 169 páginas.

Dois anos após a publicação da $1^{a}$ edição desse manual, em 1961, foi publicada a sua $2^{\mathrm{a}}$ edição, pela Edições Leya. A $2^{\mathrm{a}}$ edição foi revista e ampliada, de modo que esse manual passou a conter 200 páginas, divididas em 28 capítulos. Ainda presumivelmente na década de 1960, em ano que não localizei, foi publicada a $3^{\text {a }}$ edição de Compêndio de literatura infantil, pelo Instituto Brasileiro de Edições Pedagógicas (Ibep). A $3^{\text {a }}$ edição também foi ampliada, porém, mantiveram-se os 28 capítulos da $2^{a}$ edição, com 183 páginas.

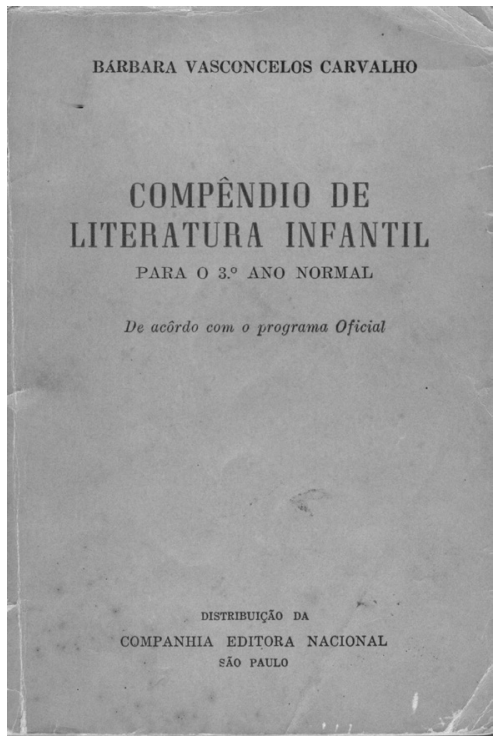

Figura 7 - Capa de Compêndio de literatura infantil (1959), de Bárbara V. de Carvalho. Fonte: Acervo pessoal do autor. 
Carvalho (1959) ${ }^{15}$ explica que, em consonância com o programa da disciplina "Literatura infantil", o objetivo que almeja com seu manual é "recomendar" para as "jovens professôras" como orientar as leituras de seus alunos, de acordo com a idade de cada um deles. Para ela, essa atividade precisava levar em consideração o desenvolvimento psicológico e moral dos pequenos leitores, de modo a "[...] substituir tudo aquilo que não convém à sua formação psicológica” (Carvalho, 1959, p.5).

Tendo em vista esse objetivo, Carvalho (1959) explica que esse manual:

[...] é produto de aulas e de leituras escassas, evidentemente, pela pobreza de material no gênero, em nosso meio. Apesar de ser um assunto que sempre nos atraiu, avolumou-se, tornou-se complexo, em se tratando de transmitir, disciplinadamente, com a responsabilidade de ensinar (Carvalho, 1959, p.9).

Carvalho (1959) apresenta, ao longo dos capítulos de seu manual, os conceitos e aspectos fundamentais para a compreensão de sua proposta para o ensino da literatura infantil.

Segundo essa professora, a literatura infantil, entendida como " $[\ldots]$ todo acervo de bela e agradável leitura, que também não deixa de ser cultural [...]" (Carvalho, 1959, p.23), originou-se da tradição oral e passou a existir como "intencionalmente infantil" somente no século XVII, quando foram publicados os primeiros textos de Charles Perrault e Fénelon. No caso brasileiro, a literatura infantil “[...] só começou a esboçar-se nos fins do século passado [século XIX], quando a preocupação educacional se tornou uma realidade" (Carvalho, p.47).

No âmbito da produção de literatura infantil, Carvalho (1959) considera que há uma distinção entre "literatura didática" e "literatura recreativa". Para ela, toda literatura, seja ela didática ou recreativa, é "instrutiva" ou "educativa”. No entanto, denomina-se "literatura didática" quando se tem "[...] objetivo especial e único: instruir" (Carvalho, 1959, p.70).

A "literatura recreativa", por sua vez, são os livros agradáveis e belos que se dedicam às crianças e que visam:

15 Optei por apresentar, aqui, apenas aspectos relacionados ao conteúdo da $1^{\text {a }}$ edição de Compêndio de literatura infantil, pois, embora esse manual tenha sido revisto e ampliado nas edições subsequentes, não houve alteração significativa (Oliveira, 2012; 2013). 
[...] formar e desenvolver o hábito e o gôsto pela leitura; disciplinar a atenção; estimular a inteligência e a memória; cultivar a imaginação; despertar o interêsse pela sociedade humana e seus problemas comuns; vivificar o espírito, dando-lhe agucidade e penetração; finalmente, aperfeiçoar o caráter, pois sabemos que a arte é, sobretudo, edificante e moralizadora, predispondo o espírito para os valores estéticos e éticos, para o Bem e para o Belo (p.72)

A partir dessa caracterização da literatura infantil, Carvalho (1959) explica que a "literatura recreativa" deve ser "ajustada" à evolução da criança.

Dos 4 aos 7 anos, a criança percorre a fase egocêntrica, faz de fabulação ou imaginismo. Esta é a fase dos contos de fadas, de animais, de fatos da vida real. [...] Quando mais fantástico, mas ao seu agrado. [...]

Dos 8 aos 12 anos, já o interêsse varia, embora os contos maravilhosos agradem sempre. Surge uma nova atração, esta é uma fase de transição entre a infância e a adolescência, de inquietação: é a fase de socialização ou racional, fase do robinsonismo, isto é, das aventuras. [...]

Dos 13 aos 16 anos, inicia-se a fase do realismo, a fase da adolescência. Esta fase, mais capacitada, conjuga os 3 elementos, fundindo as 3 características psicológicas: drama, ação e realismo. É o predomínio da novela sentimental, em que encontramos tôdas as emoções (Carvalho, 1959, p.68-69).

Com base nesse "ajustamento" dos livros, Carvalho (1959) apresenta os objetivos com os quais o professor deve utilizar um livro de literatura infantil. Segundo ela, objetivos são de ordem didática, psicológica, social e moral. Em relação aos objetivos didáticos, ela explica que consiste na "fixação" de conhecimentos já adquiridos pelas crianças e a transmissão de novos conhecimentos. Os objetivos psicológicos referem-se à "[...] formação da conduta ou caráter, por meio da evolução do senso estético, não só em relação aos valores literários, mas também a todos os demais valores humanos" (Carvalho, 1959, p.89). Os objetivos sociais dizem respeito ao "despertar" na criança da necessidade de relações humanas, de "[... interdependência entre as criaturas, nas suas atividades, nas suas profissões, no auxílio mútuo, na compreensão, em tudo isto que comunica os homens entre si”" (Carvalho, 1959, p.92). Por fim, os objetivos morais são para essa autora os que desper- 
tam os "bons sentimentos", que "[...] ressaltam o respeito e amor à Pátria, aos pais, à família e ao seu semelhante" e "exaltam" a "[...] admiração pela natureza e o amor pelo seu Criador” (Carvalho, 1959, p.93).

Carvalho (1959) apresenta também reflexões sobre as diferentes formas de manifestação desse gênero literário (fábula, conto, teatro, poesia, folclore, revistas, jornais) e indica alguns dos requisitos literários, morais, psicológicos e materiais a que esse gênero deve atender.

Com base no exposto, para Carvalho (1959), a principal razão para que os "alunos-mestres" estudem a literatura infantil no Ensino Normal é para que eles aprendam a utilizá-la com seus futuros alunos, visando "[...] despertar na criança e no adolescente o prazer da leitura, e iniciá-los na cultura, de modo atraente, para dar-lhes a devida formação" (Carvalho, 1959, p.6). Por isso, Carvalho (1959) considera que nas mãos dos "alunos-mestres" “[...] está a responsabilidade das virtudes e dos vícios adquiridos na educação intelectual da criança [...]” (Carvalho, 1959, p.73).

Para concluir, Carvalho (1959) transcreve um texto de Lenyra Fraccaroli, sobre a organização de bibliotecas infantis e relaciona algumas sugestões de atividades práticas em relação à literatura infantil. Essas sugestões de atividades práticas eram destinadas ao professorandos dos Cursos Normais, a fim de que eles pudessem treinar a análise de livros e treinar a preparação de suas futuras aulas de literatura infantil. A título de exemplo, transcrevo duas das atividades sugeridas por Carvalho (1959):

Adaptação - adapte para crianças de 7 a 8 anos "As mil e uma noites"; "A viagem de Vasco da Gama"; "Os Lusíadas"; ou uma história de nosso folclore, como o "Negrinho do pastoreio"; "A vitória régia", etc.

$[\ldots]$

Organize um programa para comemorar o dia de "Tiradentes", ou da "abolição de escravos", contendo dados sôbre o fato histórico e seus principais vultos (Carvalho, 1959, p.138).

Em relação à bibliografia que utilizou, Carvalho (1959) apresenta, na $1^{\mathrm{a}}$ edição, 13 títulos, os que constam no Quadro 9. 
Quadro 9 - Relação de textos e respectivos autores que constam na bibliografia de Compêndio de literatura infantil (1959)

\begin{tabular}{|l|l|}
\hline Títulos & Autores \\
\hline Histoire de La littérature enfantine & Jean de Tigon \\
\hline Metodologia da linguagem & J. Budin \\
\hline La enseñanza del lenguaje & Domingo T. Benetí. \\
\hline Arte de hablar & Hermosilla Salva \\
\hline Monteiro lobato: vida e obra & Edgard Cavalheiro \\
\hline Comment raconter des histoires a nos enfants & Sara C. Bryant \\
\hline Metodologia da linguagem & Orlando Leal Carneiro \\
\hline O teatro na escola & Olga Obry \\
\hline La literatura infantil & Jesualdo Sosa \\
\hline A arte da leitura & Gonçalves Viana \\
\hline La presse, le film et la radio pour enfants & Bauchard \\
\hline Como fazer teatrinho de bonecas & Maria Clara Machado \\
\hline Instrución ética de la juventud & Fr. W. Foerster \\
\hline
\end{tabular}

Fonte: Carvalho (1959).

Como se pode observar, Carvalho (1959) relaciona os manuais de Budin (1949) e Carneiro (1951), como mencionei, que são os dois primeiros manuais com capítulos sobre literatura infantil publicados no Brasil.

Cabe destacar aqui que a maior parte da bibliografia indicada por Carvalho (1959) é composta por livros estrangeiros. No âmbito desses livros, encontra-se o livro La literatura infantil, de Jesualdo Sosa.

Nas edições seguintes de Compêndio de literatura infantil, às quais, como mencionei, foram revistas e ampliadas, a bibliografia indicada por Carvalho se alterou. De 13 títulos, essa autora passou a indicar, na $2^{\mathrm{a}}$ edição, 16 títulos, porém alguns dos indicados na $1^{\text {a }}$ edição foram excluídos na $2^{\mathrm{a}}$ edição.

Entre os títulos que constam na bibliografia da $1^{a}$ edição e que foram excluídos da bibliografia da $2^{\mathrm{a}}$ e $3^{\mathrm{a}}$ edições de Compêndio de literatura infantil estão: Metodologia da linguagem, de J. Budin; La enseñanza del linguaje, de Domingo T. Benetí; Arte de hablar, de T. Benetí; e A arte da leitura, de Gonçalves Viana.

Os livros acrescentados na $2^{\mathrm{a}}$ e $3^{\mathrm{a}}$ edições desse manual são: Il livro del fanciullo, de Vicenzina Battistelli; Canto alle rondini, de Piero Bargellin; $O$ pequeno jornalista, de Adelmo Rielli; Teatro brasileiro, de Joracy Camargo; 
História de la literatura infantil española, de Carmem Bravo-Vilassante; $7^{a}$ arte: cinéma pour enfants, de Mary Field; e Histoire du cinéma, de Lo Puca. Com base no exposto, é possível observar que o conteúdo de Compêndio de literatura infantil apresenta estreita relação com os programas de ensino da disciplina "Literatura infantil", tanto o de 1958 quanto o de 1959.

Ao comparar os títulos e o conteúdo dos capítulos desse manual com os pontos apresentados nos programas de ensino dessa disciplina, é possível observar que:

[...] mais do que contemplar os temas relacionados à literatura infantil que constam no programa de 1958, Compêndio de literatura infantil foi elaborado com a mesma estrutura desse programa de ensino, de forma que a organização dos capítulos segue a sequência de "pontos" contida nesse programa. (Oliveira, 2010, p.177)

Além desse aspecto, esse manual apresenta uma concepção de literatura infantil coerente com a que circulava em outros textos e documentos da época. Ainda que Carvalho (1959) não se detenha à questão da "má" literatura infantil, assunto em voga na época, a distinção que ela faz, por exemplo, entre "literatura didática" e "literatura de recreação" se identifica com o modo como se pensava esse gênero literário desde meados da primeira metade do século XX. Essa distinção também havia sido feita por outros autores de textos sobre literatura infantil, como Lourenço Filho (1943), Budin (1949) e d'Ávila (1954).

Também a associação entre literatura infantil, formação moral e desenvolvimento psíquico infantil, marca importante da concepção de literatura infantil desse período, é tomada por Carvalho (1959) em sua proposta de "concretização" de ensino da literatura infantil, como fizeram praticamente todos os autores de textos sobre literatura infantil, publicados a partir da década de 1940.

Sobre esse último aspecto, embora Carvalho (1959) não faça citações diretas ou indiretas, é possível presumir que as suas formulações sobre a relação entre literatura infantil, formação moral e desenvolvimento psíquico tenha sustentação teórica no livro La literatura infantil, de Jesualdo Sosa. 


\section{Nazira Salém e a história da literatura infantil adaptada aos programas do Ensino Normal}

Também em 1959, mesmo ano de publicação de Compêndio de literatura infantil, Nazira Salém, então consultora da Biblioteca Infantil Monteiro Lobato, teve publicado o livro Literatura infantil, pela Editora Mestre Jou (SP), o qual, embora não tenha sido escrito com o propósito de um manual de ensino, teve como objetivo atender ao programa de literatura infantil do Ensino Normal paulista e ser útil aos alunos e professores ligados a esse ensino.

Em Literatura infantil (1959), Nazira Salém explica que se empenhou na elaboração desse livro porque, no exercício de suas atividades na Biblioteca Infantil Monteiro Lobato, observava um crescente interesse em torno desse gênero literário. Segundo ela:

Os leitores que nos procuraram disseram-nos de sua dificuldade em encontrar livros referentes à história ou ao desenvolvimento dessa literatura.

Muitos dêles, vindos do interior do Estado especialmente para êsse fim, os fizeram sentir a obrigação de fornecer informações sôbre o assunto (Salém, 1959, p.1).

No prefácio de Literatura infantil (1959), o advogado e professor de Direito da USP, José Cretella Júnior, explica que, depois que os programas de ensino dos Cursos Normais paulistas foram publicados, o interesse dos professores na literatura infantil, em busca de material útil às suas aulas, cresceu significativamente. Segundo ele, o " [...] contacto com professôres do nosso ensino secundário colocou a professora Nazira Salém frente ao problema, pois que, tendo de orientá-los, como consultora da Biblioteca de São Paulo, ficava, ela mesma, impressionada com a pobreza verificada nesse importante setor [...]" (Cretella Júnior, 1959, p.7-8).

Por essa razão, Salém (1959) empenhou-se na escrita de Literatura infantil, de modo a adaptá-lo ao programa da disciplina "Literatura infantil” do Ensino Normal do estado de São Paulo. Seu objetivo, com isso, foi ajudar os professores a suprir a carência de bibliografia específica sobre história da literatura infantil.

Salém (1959) explica que, embora coubesse o tratamento da literatura infantil do ponto de vista de seu conceito, caracterização e finalidades, conforme prescrevia o programa da disciplina "Literatura infantil", ela optou 
por abordar apenas o aspecto histórico desse gênero literário por entender que, para os demais assuntos, havia trabalhos satisfatórios. Nesse sentido, ainda que abordando apenas um dos pontos prescritos no programa de ensino da disciplina "Literatura infantil", esse livro de Nazira Salém esteve intrinsecamente ligado ao Ensino Normal, especialmente porque se trata do primeiro livro brasileiro específico sobre história da literatura infantil.

Salém (1959), para dar conta de seu propósito de atender ao prescrito no programa de ensino da disciplina "Literatura infantil" dos Cursos Normais e produzir um livro sobre história da literatura infantil útil aos professores, organizou seu livro em duas partes: a primeira, "Esboço histórico da literatura infantil: da antiguidade clássica até nossos dias", com quatro capítulos; a segunda, "Compilação de biografias e bibliografias", com dois capítulos.

Na primeira parte, os capítulos de Literatura infantil (1959) são: "Origem"; "Desenvolvimento"; "A literatura infantil no Brasil"; e "Livros célebres adaptados à leitura infanto-juvenil”. Na segunda parte, os capítulos de Literatura infantil (1959) são: "Da antiguidade clássica até fins do séc. XIX"; e "Século XX - Autores de diversos países e especialmente o Brasil". Esses seis capítulos totalizam, em Literatura infantil, 261 páginas.

Em 1970, Nazira Salém teve publicada a $2^{a}$ edição desse livro, que foi reformulado e ampliado, sendo o seu título também alterado para História da literatura infantil.

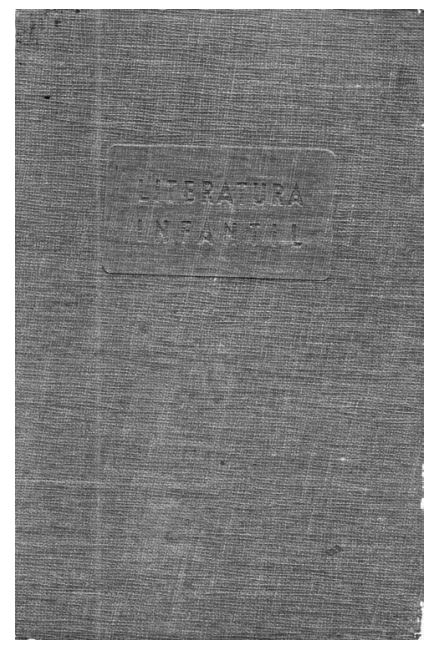

Figura 8 - Capa de Literatura infantil (1959), de Nazira Salém. Fonte: Acervo do GPHELLB. 
Em Literatura infantil, Salém (1959), ao apresentar como que se originou e se desenvolveu a literatura infantil, explica que muitas das históricas comumente destinadas às crianças datam de longa data, antes mesmo de se pensar em produzir literatura especifica para esse público. Segundo essa autora, o que se observa em torno da literatura infantil é que ela decorreu da tradição oral, do hábito diário dos serões, que eram formas de divertimento e de transmissão de histórias e ensinamentos de geração em geração.

Antes, no entanto, de se originar a literatura fantástica, que resguarda os primeiros livros que as crianças, posteriormente, adotaram para si, Salém (1959) afirma que existiu na Grécia antiga uma literatura satírica e uma moralista, às quais ensinavam o homem a viver de forma virtuosa. Para ela, esses textos também constituem acervo da literatura infantil.

Já no século XI, Salém (1959) destaca o livro Contos seletos das mil e uma noites, que, embora escrito para adultos, figurava nas bibliotecas infantis, como leitura apropriada à infância. Ainda no período medieval, no século XIV, segundo Salém (1959), na “[...] ordem cronológica, vamos encontrar [...] o relato das Viagens de Marco Polo, célebre viajante italiano [...]” (p.19, grifos do autor). Para ela, esse livro que contém um relato de viagem é também um dos livros que resguardam a origem da literatura infantil.

Após a Idade Média, no século XVII, Salém (1959) relaciona os nomes de Miguel de Cervantes, La Fontaine, Charles Perrault e Fénelon, pois considera que eles "[...] constituíram a base da literatura infantil, porque, desaparecido o significado intrínseco, permanece a literatura em sua forma pitoresca de encantamento, resistindo ao tempo, por seu ganho e graça" (Salém, 1959, p.28).

Para Salém (1959), com a constituição dessa "base da literatura infantil”, no século seguinte, XIX, surgiram os primeiros livros escritos especialmente para crianças, quando também eles se tornaram alvo das ciências psicológicas, sociológicas e educacionais. Nesse período, Salém (1959) destaca entre as principais figuras da literatura infantil os seguintes escritores: Irmãos Grimm, Hans Christian Andersen, Condessa de Ségur, Júlio Verne, Carlo Collodi, Joel Chandler Harris, Edmundo de Amicis, Maria Amélia Vaz de Carvalho, Ana de Castro Osório e Alberto Figueiredo Pimentel.

Avançando com a produção de literatura infantil, Salém (1959) explica que, no século XX, por ser esse o "século da criança”, os autores e livros se multiplicaram, o que possibilitou, por exemplo, a existência de uma litera- 
tura própria para a infância (3 a 6 anos), para "meninice" ( 7 a 12 anos), para a puberdade (13 a 14 anos) e para a adolescência (15 a 18 anos).

Ainda na primeira parte de seu livro, Salém (1959) detém-se especificamente à história da literatura infantil brasileira, que, segundo ela, teve início no século XIX, com Alberto Figueiredo Pimentel, Olavo Bilac, Arnaldo de Oliveira Barrto, Thales de Andrade, Gustavo Barroso e Monteiro Lobato, entre outros. Essa afirmação de Salém (1959), sobre os escritores que "iniciaram" a literatura infantil brasileira, não difere em nada das afirmações sobre a "origem" da literatura infantil brasileira, feitas por autores anteriores, como Lourenço Filho (1943), Oliveira (1958) e Carvalho (1959), entre outros.

Na segunda parte de Literatura infantil, Salém (1959) apresenta, em dois capítulos, aspectos biográficos e bibliográficos de mais de 82 autores, desde a Antiguidade Clássica, até o século XX. E, para concluir, apresenta a "Bibliografia geral" de seu livro, que contém 24 títulos, que apresento no Quadro 10.

Quadro 10 - Relação de textos e respectivos autores que constam na bibliografia de Literatura infantil (1959)

\begin{tabular}{|c|c|c|c|}
\hline Título & Autor(es) & Data & Editora \\
\hline Arquivo bibliográfico universal & - & s.d. & Nova Jurisprudência (SP) \\
\hline $\begin{array}{l}\text { Noções de história da } \\
\text { literatura }\end{array}$ & $\begin{array}{l}\text { Manuel } \\
\text { Bandeira }\end{array}$ & 1942 & $\begin{array}{l}\text { Companhia Editora Nacional } \\
\text { (SP) }\end{array}$ \\
\hline Histoire des légendes & $\begin{array}{l}\text { Jan Pierre } \\
\text { Bayard }\end{array}$ & s.d. & Presses Universitaires (Paris) \\
\hline $\begin{array}{l}\text { Cassell's Encyclopaedia of } \\
\text { Literature }\end{array}$ & - & 1953 & Cassell (Londres) \\
\hline $\begin{array}{l}\text { Dicionário enciclopédico Lello } \\
\text { Universal }\end{array}$ & - & s.d & Livraria Lello (Porto) \\
\hline $\begin{array}{l}\text { Dicionário-catálogo da } \\
\text { Biblioteca Infantil Monteiro } \\
\text { Lobato }\end{array}$ & - & - & - \\
\hline $\begin{array}{l}\text { Enciclopédia dicionário } \\
\text { internacional }\end{array}$ & & s.d. & Jackson (SP) \\
\hline $\begin{array}{l}\text { Bibliografia de literatura } \\
\text { infantil }\end{array}$ & $\begin{array}{l}\text { Lenyra } \\
\text { Fraccaroli }\end{array}$ & 1955 & Jornal dos Livros (SP) \\
\hline Your Child's Reading Today & Josette Frank & 1954 & Doubleday (Nova York) \\
\hline $\begin{array}{l}\text { Grande enciclopédia brasileira } \\
\text { e portuguesa }\end{array}$ & & s.d & Editorial Enciclopédia (Lisboa) \\
\hline
\end{tabular}




\begin{tabular}{|l|l|l|l|}
\hline $\begin{array}{l}\text { Das antecipações de Júlio } \\
\text { Verne às realizações de hoje }\end{array}$ & A. Jacobson & & Casa Publ. (Lisboa) \\
\hline The Junior Book of Authors & & 1940 & Wilson (Nova York) \\
\hline $\begin{array}{l}\text { Introdução ao estudo da } \\
\text { Escola Nova }\end{array}$ & $\begin{array}{l}\text { Manoel B. } \\
\text { Lourenço Filho }\end{array}$ & s.d. & Melhoramentos (SP) \\
\hline $\begin{array}{l}\text { Algumas achegas para uma } \\
\text { bibliografia infantil }\end{array}$ & $\begin{array}{l}\text { Henrique } \\
\text { Marques Júnior }\end{array}$ & 1928 & Casa Publ. (Lisboa) \\
\hline História da educação & Paul Monroe & 1946 & $\begin{array}{l}\text { Companhia Editora Nacional } \\
\text { (SP) }\end{array}$ \\
\hline Mil libros & Luiz Nueda & 1956 & Aguilar (Madri) \\
\hline $\begin{array}{l}\text { Dicionário universal de } \\
\text { literatura }\end{array}$ & $\begin{array}{l}\text { Henrique } \\
\text { Perdigão }\end{array}$ & 1940 & Lopes da Silva (Porto) \\
\hline $\begin{array}{l}\text { Pequena história da literatura } \\
\text { norte-americana. }\end{array}$ & $\begin{array}{l}\text { Brenno da } \\
\text { Silveira }\end{array}$ & s.d. & Martins (SP) \\
\hline Tesouro da juventude & - & s.d. & Jackson (SP) \\
\hline $\begin{array}{l}\text { Webster's Biographical } \\
\text { Dictionary }\end{array}$ & - & 1956 & Merriam (Springfield) \\
\hline Who's Who in the World & - & 1952 & $\begin{array}{l}\text { Adam and Charles Block } \\
\text { (Londres) }\end{array}$ \\
\hline Who's Who in Latin América & Ronald Hilton & - & University Press (Sanford) \\
\hline
\end{tabular}

Fonte: Salém (1959).

A partir dos títulos relacionados no Quadro 10, é possível observar que também Salém (1959) fez uso majoritário de bibliografia estrangeira.

Cabe destacar que, embora essa autora apresente uma versão da história da literatura infantil universal, ela não indica em sua bibliografia nenhum título específico sobre esse assunto. Isso também se observa nos textos anteriores, como os de Lourenço Filho (1943), Budin (1949), Carneiro (1951), d'Ávila (1954), Oliveira (1958) e Carvalho (1959). Em todos eles, embora seja apresentada síntese de aspectos da história da literatura infantil (brasileira e universal), não há, na bibliografia desses textos, indicação de livros que tratem desse assunto.

No caso do livro de Salém (1959), o que se nota é um conjunto significativo de dicionários, enciclopédias e bibliografias, que somam nove dos 24 títulos relacionados na bibliografia desse livro, que aparentemente foram utilizados como "fontes" para a história da literatura infantil que ela apresenta. 
Ainda que Salém (1959) não trate diretamente de questões educacionais ou da relação entre literatura infantil e a educação escolar, ela relaciona na sua bibliografia o livro Introdução ao estudo da Escola Nova, de Lourenço Filho, e História da educação, da Paul Monroe. Isso possibilita compreender, em certo sentido, que, mais do que ter indicado livros que serviram para ela elaborar seu livro, Salém (1959) apresenta bibliografia útil para o estudo do assunto em questão - literatura infantil -, tendo em vista o programa de ensino da disciplina "Literatura infantil".

\section{As reformas do Ensino Normal paulista na década de 1960}

Na década de 1960, ocorreram algumas mudanças significativas no âmbito do ensino da literatura infantil nos Cursos Normais, algumas das quais incidiram na permanência, ou não, dessa disciplina.

A primeira legislação promulgada sobre o Ensino Normal paulista na década de 1960 foi o Decreto estadual n. 38.026, de 2 de fevereiro de 1961, o qual deu nova redação ao Decreto n. 35.100, de 1959. Conforme explica Labegalini (2009, p.103), esse Decreto de 1961 não apresentou “[...] alteração quanto à estrutura do Curso de Formação de Professores Primários no estado de São Paulo, nem na distribuição semanal das aulas das disciplinas".

Ainda no ano de 1961, durante a gestão de João Goulart a frente da presidência do Brasil, foi promulgada a Lei Federal n. 4.024, de 20 de dezembro desse ano, a qual fixou as "Diretrizes e Bases da Educação Nacional". Essa Lei de 1961, conhecida como a primeira Lei de Diretrizes e Bases da Educação Nacional (LDB), tramitava no Congresso Nacional desde 1948, após terem entrado em vigor as Leis Orgânicas do Ensino. A sua promulgação "[...] modificou significativamente o quadro educacional do País" (Almeida, 1993, p.85), como a definição de que a formação dos professores primários se desse a partir de dois tipos de instituição: Escola Normal de grau Ginasial, cujo curso teria duração de quatro anos; e Escola Normal de grau Colegial, cujo curso teria duração de três anos.

A diferenciação entre esses dois tipos de instituições se deu porque as Escolas Normais de grau Ginasial formariam o regente de ensino primário, que atuaria como professor no ensino primário, e as Escolas Normais de 
grau Colegial formariam o professor primário, para atuar como no ensino ginasial.

Além dessa alteração, a LDB de 1961 estabeleceu a criação: do Conselho Federal de Educação (CFE), que, entre outros, tinha como objetivo "[...] homogeneizar a preparação dos professores em todo o país" (Almeida, 1993, p.86); e dos Conselhos Estaduais de Educação (CEE), que, no conjunto de suas atribuições, encontrava-se a de legislar "[...] quanto ao número de disciplinas que fariam parte do currículo [...]” (Almeida, 1993, p.86).

Após a ser aprovada e passar a vigorar a LDB de 1961, o Departamento de Educação do estado de São Paulo publicou no Diário Oficial desse estado uma regulamentação ${ }^{16}$ referente ao Ensino Normal e Secundário, visando atender às alterações estabelecidas, em âmbito federal, pela LDB. Nessa regulamentação, publicada no dia 8 de outubro de 1964, já durante o regime da ditadura militar, ${ }^{17}$ foram asseguradas algumas conquistas já alcançadas pelo estado de São Paulo no âmbito do Ensino Normal (Campos, 1987).

16 Essa regulamentação do Ensino Normal paulista não foi publicada sob o formato de Decreto, portaria, lei ou comunicado. Conforme consta na página do Diário Oficial de 8 de outubro de 1964, essa regulamentação foi publicada no conjunto de várias publicações do Departamento de Educação do Estado de São Paulo, apenas com uma subdivisão intitulada "Ensino Normal". Por essa razão utilizo a denominação genérica "regulamentação".

$17 \mathrm{O}$ segundo regime ditatorial brasileiro, esse liderado por militares, iniciou-se em $1^{\circ}$ de abril de 1964, com golpe arquitetado pelos líderes militares brasileiros, que destituíram o então presidente, João Goulart, de seu cargo. O regime militar se estendeu até 1985, quando José Ribamar Ferreira Araújo da Costa Sarney assumiu a presidência da República, em substituição ao então presidente eleito, Tancredo de Almeida Neves, falecido em 21 de abril de 1985. Embora Tancredo Neves e seu vice, José Sarney, não tivessem sido eleitos pelo voto direto, eles foram os primeiros presidentes civis eleitos após 21 anos de ditadura miliar. Ao longo desses 21 anos de ditadura, o Brasil for marcado por repressões, censuras e a disseminação de um caráter nacionalista e desenvolvimentista, contrário ao comunismo. Também conhecido como os "anos de chumbo", durante a ditadura militar, o Brasil teve como presidente da República cinco militares, são eles: o marechal Humberto de Alencar Castello Branco, que assumiu a presidência em 1964 e a deixou em 1967; o marechal Artur da Costa e Silva, que governou entre 1967 e 1969; o general Emílio Garrastazu Médici, que governou o Brasil entre 1969 e 1974; o general Ernesto Geisel, que governou entre 1974 e 1979; e o general João Batista Figueiredo, que governou entre 1979 e 1985. Ao longo do período da ditadura militar, os dez primeiros anos ficaram conhecidos como os mais críticos, violentos e repressores. A partir de 1974, quando Ernesto Geisel assumiu a presidência, iniciou-se o processo, ainda lento, de reabertura política do pais, consolidado, de fato, em 1985, com a eleição de um civil para o maior cargo político do país (Fausto, 2010). 
De acordo com essa regulamentação do estado de São Paulo, o Ensino Normal tinha como finalidades:

a - formar professôres, orientadores, supervisores e administradores escolares, destinados ao ensino primário;

b - aperfeiçoar a formação profissional do professor primário e ensejar a especialização para o ensino dêsse grau;

c - desenvolver e propagar conhecimentos e técnicas relativas à educação da infância;

$\mathrm{d}$ - contribuir para integração da escola na comunidade, promovendo o quanto possível o desenvolvimento cultural desta. (São Paulo, 1964, p.23)

A partir dessas finalidades, ficou estabelecido que a partir de 1964 o Ensino Normal fosse ministrado em: Cursos de Formação de Professores Primários, com duração de três anos; Curso de Aperfeiçoamento, com duração de um ano; Curso de Especialização, com duração de um ano; e Curso de Administradores Escolares, com duração de dois anos.

O Curso de Formação de Professores Primários funcionava como equivalente ao Curso Normal de grau colegial, destinando-se a formar os professores que atuariam no ensino primário. Desse modo, o estado de São Paulo, diferentemente dos demais estados brasileiros, não adotou a organização estabelecida pela LDB, de 1961, que estabeleceu a formação dos professores em dois tipos de curso: o de grau Colegial e o de grau Ginasial.

Em conformidade com essas mudanças, a regulamentação do Ensino Normal paulista de 1964 também alterou o modo de organização do currículo dos Cursos Normais de grau Colegial, em conformidade com o estabelecido na LDB de 1961.

A partir dessa regulamentação, o currículo dos Cursos Normais de grau Colegial passou a ser organizado em: disciplinas obrigatórias, indicadas pelo Conselho Federal de Educação; disciplinas complementares, indicadas pelo Sistema estadual de Ensino; disciplinas optativas, indicadas pelos próprios estabelecimentos de ensino; e práticas educativas.

As disciplinas obrigatórias estabelecidas pelo Conselho Federal de Educação eram: "Português"; "Matemática"; "Ciências físicas e biológicas"; "História”; "Geografia” e "Educação religiosa”. 
As disciplinas complementares definidas pelo Sistema estadual de ensino, conforme a Resolução n. 7, Ato n. 6, do Departamento de Educação do estado de São Paulo, eram "Metodologia e prática de ensino", "Psicologia da Educação", "Sociologia da Educação" e "Biologia educacional".

As disciplinas optativas, indicadas pelo artigo $3^{\circ}$ da Resolução n. 7, Ato n. 6, do Departamento de Educação do estado de São Paulo, eram "Filosofia e história da educação" e "Desenho pedagógico".

As práticas educativas, também indicadas pelo artigo $3^{\circ}$ da Resolução n. 7, Ato n. 6, do Departamento de Educação do estado de São Paulo, eram "Educação física" e "Música e canto orfeônico" e podiam ser também "Artes aplicadas", "Economia doméstica", "Técnicas audiovisuais aplicadas à educação", “Técnicas comerciais”, "Técnicas agrícolas” e "Artes plásticas".

Um ano após a publicação dessa regulamentação do Ensino Normal paulista, foi promulgado o Decreto n. 45.159-A, de agosto de 1965, o qual aprovou o regimento interno dos estabelecimentos oficiais de ensino secundário e normal do estado de São Paulo.

Esse Decreto de 1965 não apresentou nenhuma alteração no que diz respeito à organização do Ensino Normal no estado de São Paulo - apenas oficializou, sob a forma de decreto, a regulamentação do ensino normal publicada no dia 8 de outubro de 1964.

Sobre a disciplina "Literatura infantil", como se pôde observar, ela não foi inserida no currículo dos Cursos Normais de grau Colegial ministrados no estado de São Paulo, depois das mudanças ocorridas em 1964. No entanto, em consulta aos livros de registros de notas e diplomas do Instituto de Educação Caetano de Campos, pude verificar que a disciplina "Literatura infantil" continuou a ser ministrada no Curso Normal dessa instituição, durante toda a década de 1960, ininterruptamente. Isso se deve, talvez, ao fato de que a disciplina "Literatura infantil" integrava, conforme a reforma de 1957 e a regulamentação de 1959, o bloco disciplinar de "Português". Ainda que não apareça especificada nos currículos, o que se pode presumir é que o ensino da literatura infantil correspondia ao ensino de português na série final do Curso Normal.

Outro aspecto a ser ressaltado é que, embora tenha localizado nos livros de registro de notas e diplomas do Instituto de Educação Caetano de Campos a informação de que a disciplina "Literatura infantil" continuou a ser 
ministrada na década de 1960, isso não significa que outras instituições do estado, especialmente as particulares, fizeram o mesmo. Sobre esse aspecto, localizei indícios de que em algumas instituições não havia uma disciplina ou conteúdo no âmbito de uma disciplina que se relacionava à literatura infantil, durante a década de 1960. No entanto, dada a dificuldade de acesso aos documentos das diferentes Escolas Normais e Institutos de Educação que funcionaram no estado, não pude verificar se essa situação foi recorrente, ou não.

Também a regulamentação do Ensino Normal paulista de 1964 e o decreto n. 45.159-A, de 1965, não apresentam nenhuma informação sobre a possibilidade de as Escolas Normais e Institutos de Educação do estado terem currículo organizado de forma diferenciada.

Ainda na década de 1960, quando se iniciou o período mais repressivo da ditadura militar brasileira, com o estabelecimento do Ato Institucional n. 5 (AI-5), de 13 de dezembro de $1968,{ }^{18}$ o Departamento de Educação do estado de São Paulo reestruturou todo o seu sistema de ensino.

Segundo Campos (1987), essa reforma se deu com o objetivo de minimizar os problemas da escola primária e da escola secundária no estado e estabelecer uma visão integradora e articuladora para todos os níveis de ensino.

Dentro dessa iniciativa, fez-se necessária a reforma do Ensino Normal, "[...] responsável pelo elemento mais importante nesse processo de mudanças: o professor” (Campos, 1987, p.78). De acordo com Campos (1987, p.79), os Cursos Normais paulistas "[...] representavam, naquele momento, uma situação problemática que exigia da Administração Pública uma atitude enérgica e decisiva busca de solução. Os educadores questionavam a formação dada nos cursos normais e os dados acusavam seu crescimento desordenado”. Campos (1987) relata que o estado de São Paulo vivia, no final da década de 1960, um processo de saturação do mercado de trabalho para o professor, pois havia uma quantidade excessiva de profissionais formados. Também o Ensino Normal carecia de uma formação pedagógica

18 O Ato Institucional n. 5 (AI-5) foi implantado, no Brasil, em 1968, durante o governo militar, pelo então presidente, marechal Artur da Costa e Silva, tendo vigorado até 1978. O AI-5 dava ao Presidente da República poderes plenos para governar o país, de modo a se sobrepor à Constituição Federal vigente (Fausto, 2010). Esse ato “[...] não só se impunha como um instrumento de intolerância em um momento de intensa polarização ideológica, como referendava uma concepção de modelo econômico em que o crescimento seria feito com 'sangue, suor e lágrimas"” (D’Áraújo, s.d., p.1). 
com base em formação geral mais sólida e, para agravar tudo isso, a escolha de jovens em cursar o Ensino Normal era feita de forma muito prematura (Campos, 1987). Esses, completa Campos (1987), concorreram diretamente para que o Ensino Normal fosse incluído no processo de reforma que se vinha projetando para o sistema de ensino paulista, e que culminou na promulgação da Lei estadual n. 10.038, de 5 de fevereiro de 1968.

Essa Lei dispõe sobre a organização do Sistema de Ensino do estado de São Paulo e, para regulamentar a parte específica sobre o Ensino Colegial, que compreende o Ensino Secundário e Normal, foi promulgado, ainda em 1968, o Decreto estadual n. 50.133, de 2 de agosto.

Esse Decreto estabelece a organização do Ensino Colegial em grau médio e grau primário. O grau médio era dividido nos ciclos ginasial, de caráter formativo, e colegial, de caráter formativo e profissionalizante. Dentro do ciclo colegial, esse Decreto estabeleceu que o Ensino Normal, responsável pela formação de professores, compreendia: um Curso de Formação de Professores para o ensino de grau primário, correspondente ao antigo Curso Normal de grau Colegial; e os Cursos de Pós-Graduação para preparação do professor do ensino pré-primário e para preparação do pessoal técnico e administrativo também para o ensino primário.

Em relação à reorganização do currículo do Curso de Formação de Professores, o Decreto n. 50.133, de 1968, fixou o seguinte:

Artigo $6^{\circ}$ - Nas duas primeiras séries anuais do curso colegial, o currículo será comum para o ensino secundário e normal, podendo sê-lo também para os demais ramos.

Artigo $7^{\circ}$ - A terceira série do ciclo colegial, secundário e normal, considerada como ano de orientação, será amplamente diversificada pela organização de áreas de estudo, diferenciais e optativas, cada uma delas correspondente a um setor integrado de conhecimento e de atividades.

$[\ldots] \S 1^{\circ}$ - Dentre outras a serem especificadas pelo Conselho Estadual de Educação, poderá haver as seguintes áreas:
a) Artes
b) Educação
c) Ciências Físicas e Biológicas
d) Ciências Humanas
e) Ciências Contábeis e Administração 


\section{f) Letras}

$\S 2^{\circ}$ - A área de "Educação" é obrigatória para o estabelecimento que mantiver curso normal e facultativa para os demais (São Paulo, 1968, p.8).

Com essa organização curricular estabelecida pelo Decreto de 1968, o Conselho Estadual de Educação de São Paulo publicou, nesse mesmo ano, a Resolução CEE n. 36, que estabeleceu a organização dos currículos do ciclo colegial, composto pelo Ensino Secundário e Normal.

De acordo com a Resolução CEE n. 36, de 1968, nas duas primeiras séries dos Cursos de Formação de Professores seriam ministradas as disciplinas obrigatórias e complementares definidas pelo Decreto n. 45.159-A, de agosto de 1965. Na terceira e quarta série desse curso, ficaram estabelecidas como disciplinas obrigatórias: "Português e literatura infantil", "Biologia aplicada à educação e saúde pública", "Psicologia aplicada à educação", "História da educação e educação brasileira”, "Teoria e prática de ensino”, "Sociologia aplicada à educação" e "Teoria geral da educação".

Além dessas disciplinas obrigatórias, a Resolução CEE n. 36, de 1968, estabeleceu para os $3^{\circ}$ e $4^{\circ}$ anos do Curso de Formação de Professores as disciplinas optativas e as práticas educativas.

Em vista do exposto, pode-se observar que a partir da reforma do Ensino Normal paulista ocorrida em 1968 o ensino da literatura infantil voltou a figurar no currículo dos cursos de formação de professores do estado de São Paulo, porém em disciplina denominada "Português e literatura infantil".

Apesar dessas mudanças, não foram publicados novos programas de ensino, condizentes com as alterações ocorridas. Com isso, é possível presumir que continuaram a vigorar os programas de 1959, ainda que não de forma oficial. Se considerarmos que grande parte dos professores em exercício em 1959 ainda permaneceu atuando na década de 1960, mesmo que os programas de 1959 não fossem recomendados mais como oficiais, na ausência de outros, como foi o caso, é possível presumir que os professores tenham continuado a utilizar esses programas para organizar usas aulas.

Esse aspecto se confirma, por exemplo, pelo conjunto de manuais de ensino publicados na década de 1960, os quais trazem em seus subtítulos a informação "de acordo com os programas de ensino". 


\section{Os novos manuais e capítulos para o ensino da literatura infantil publicados na década de 1960}

Com a sistematização do ensino da literatura infantil nos três últimos anos da década de 1950, na década seguinte, alguns professores tiveram publicados manuais e capítulos específicos para o ensino da literatura infantil. Durante a década de 1960, ainda que a disciplina "Literatura infantil" nem sempre conste nos currículos oficiais do Ensino Normal Paulista, foram publicados, em São Paulo, três novos manuais destinados ao ensino da literatura infantil e um manual de ensino com capítulo sobre esse gênero literário. Esse aspecto leva à compreensão de que o ensino da literatura infantil vinha se expandindo e ganhando forças no estado de São Paulo, apesar de a legislação não indicar uma disciplina específica para tratar desse assunto.

Além desses manuais e capítulos publicados em São Paulo, também na década de 1960 circulou entre os normalistas desse estado um manual de autoria de uma professora mineira, Maria Antonieta Antunes Cunha, publicado em Belo Horizonte-MG.

Cabe destacar, aqui, que os únicos materiais publicados até então e que se destinavam ao ensino da literatura infantil eram: os manuais com capítulos sobre esse gênero literário, de autoria de Budin (1949), Carneiro (1951) e d'Ávila (1954); e o manual de Carvalho (1959). Os demais - Oliveira (1958) e Salém (1959) - embora também fossem usados no ensino da literatura infantil, não haviam sido publicados especificamente para esse propósito.

Nesse sentido, pode-se observar que, após as mudanças ocorridas na década de 1960, especialmente após o golpe militar de 1964, adensaram-se as publicações de manuais que tratam do ensino da literatura infantil. Durante a década de 1960, além das reedições dos manuais publicados entre as décadas de 1940 e 1950, foram lançados cinco novos manuais: Literatura infanto-juvenil (1961), de Antônio d'Ávila; O ensino da literatura (1966), de Nelly Novaes Coelho e o qual contém um capítulo sobre literatura infantil; Pontos de literatura infantil (1967), de José Benedicto Pinto; Como ensinar literatura infantil (1968), de Maria Antonieta Antunes Cunha; e Prática da literatura infantil na escola primária: antologia de contos e planos de aula (s.d.), de Therezinha J. Franco Farah. 


\section{A segunda proposta de "concretização" do ensino da literatura infantil de Antônio d'Ávila (1961)}

O primeiro manual específico para o ensino da literatura infantil publicado na década de 1960 foi Literatura infanto-juvenil: de acordo com o programa das escolas normais, ${ }^{19}$ de Antônio d'Ávila. Esse manual, publicado no mesmo ano em que passou a vigorar a LDB de 1961, integra a coleção "Didática do Brasil", da Editora do Brasil, ${ }^{20}$ como o $20^{\circ}$ volume da série "Normal".

Literatura infanto-juvenil (1961), de Antônio d'Ávila, está organizado em 22 capítulos, os quais, ao final, contêm temas para estudo e sugestões de trabalhos práticos. Os capítulos desse manual são assim intitulados: "A infância do homem", "Literatura geral e literatura infanto-juvenil", "Três mágicos do conto infantil", "Técnica da literatura infanto-juvenil”, "O livro", "Jornais e revistas", "A biblioteca", "O leitor criança”, "O leitor adolescente", "Folclore”, "As lendas", "Fábulas", "Contos defadas”, "Histórias típicas”, "Viagens e explorações”, "O romance policial”, "Teatro”, "Poesia", "Biografia e bibliografia de escritores", "Preservação e defesa da criança" e "Estudo do material".

Publicado poucos anos depois da institucionalização do ensino da literatura infantil em todo estado de São Paulo, esse manual, conforme relata d'Ávila (1961), decorreu de um conjunto de atividades relacionadas a esse ensino, que ele vinha se envolvendo. Após a publicação da Lei n. 3.739, de 1957, e a publicação dos programas da disciplina "Literatura infantil", d'Ávila (1961) afirma ter notado a dificuldade dos professores com relação ao assunto.

De certo modo participante dêsse programa, quando na Direção do Departamento de Educação, pudemos sentir de perto, constante, a dificuldade em que se encontravam os estudantes normalistas, no domínio dessa literatura, já por ser matéria nova no currículo, já por não haver professor preparado para ministrar êsse ensino, logo no seu primeiro ano, já por ser pobre, paupérrima a nossa bibliografia sôbre ela. (D’Ávila, 1961, p.9)

19 Para informações mais detalhadas sobre esse manual, ver Oliveira e Trevisan (2012).

20 Fundada em 1943, a Editora do Brasil foi criada por um grupo de professores que atuavam junto à Companhia Editora Nacional, na área de livros didáticos (Hallewell, 2005). Segundo Hallewell (2005), essa editora se especializou na publicação de livros didáticos e infantis, tornando-se, na segunda metade do século XX, uma das mais importantes editoras brasileiras nesse ramo. 
Em decorrência da constatação dessas dificuldades, d'Ávila (1968) explica que para atender a necessidade de ensinar literatura infantil nos Cursos Normais e minimizar os problemas e dificuldades em torno desse ensino, antes de ter publicado Literatura infanto-juvenil, desempenhou algumas atividades, que lhe "sensibilizaram" para as "necessidades" dos normalistas e professores, o que o levou a escrever esse manual.

Com isso, em 1961, a Editora do Brasil fez publicar a $1^{\text {a }}$ edição de Literatura infanto-juvenil e, após a publicação dessa $1^{\text {a }}$ edição, em 1962, foi publicada a $2^{\mathrm{a}}$ edição, em decorrência do esgotamento e sucesso que teve esse manual. Além da $2^{\mathrm{a}}$ edição, pude localizar exemplares da $3^{\mathrm{a}}, 4^{\mathrm{a}}, 6^{\mathrm{a}}, 8^{\mathrm{a}}$ e $9^{\mathrm{a}}$ edições. A $3^{\mathrm{a}}$ edição data de 1964; a $4^{\mathrm{a}}$ e a 6 $6^{\mathrm{a}}$, de 1967; a 8 $8^{\mathrm{a}}$, de 1968; e a 9 ${ }^{\mathrm{a}}$, de 1969.

A partir da $3^{a}$ edição, esse manual foi revisto e ampliado, passando a conter 314 páginas. Entre as mudanças ocorridas, foi acrescida, ao final de cada capítulo, uma bibliografia. Na $1^{\text {a }}$ edição desse manual não constam, nem ao final dos capítulos, nem ao final do manual, indicações bibliográficas. Isso passou a ocorrer apenas após a publicação da $3^{\mathrm{a}}$ edição.

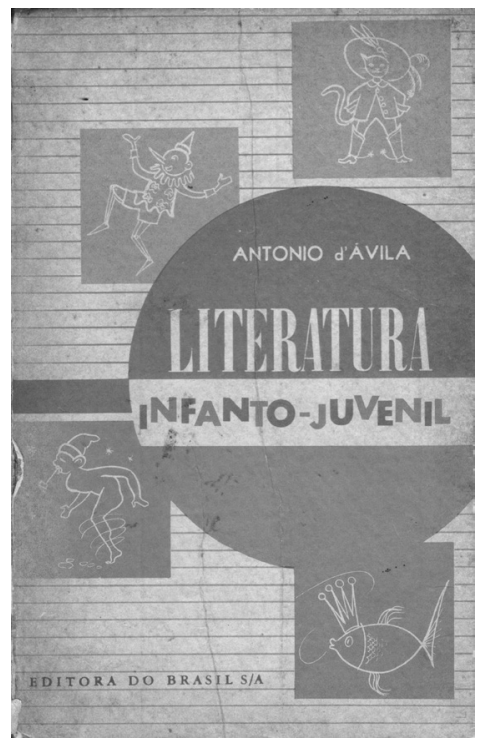

Figura 9 - Capa de Literatura infanto-juvenil (1961), de Antônio d'Ávila.

Fonte: Acervo pessoal do autor.

Em Literatura infanto-juvenil, d'Ávila (1961), assim como os autores dos textos e livros que sintetizei neste e nos capítulos anteriores deste livro, 
afirma ser a origem da literatura infantil a tradição oral, em especial as trovas e cantigas, e faz uma distinção entre "literatura geral" e literatura infantil. Ele explica que a literatura, de modo geral, é o "[...] desenvolvimento do que [o povo] tem de mais sublime nas ideias, de mais filosófico no pensamento, de mais heroico na moral, e de mais belo na natureza [...]" (d'Ávila, 1961, p.21). A literatura infantil, nesse sentido, caracteriza-se também como a "literatura geral", no entanto, contém a especificidade da destinação intencional ao público infantil e juvenil, tendo de se "acomodar" à "Psicologia da criança e do jovem".

Com isso, d'Ávila (1961) define a literatura infantil como "[...] o conjunto de obra de ficção, poesias, viagens, biografias, teatro, escritas para êsses leitores muito embora haja livros catalogados como de literatura infantil, mas que não tinham êsse enderêço" (d'Ávila, 1961, p.25).

Por conter características específicas e ter de estar de acordo com a Psicologia, d'Ávila (1961) considera ser bastante difícil a arte de escrever para crianças e jovens. Segundo ele, era muito comum encontrar autores que incorrem em erros, como, produção de textos "pueris" e uso de tom moralizador com "virtude recompensada e o vício castigado". Na contramão desses "erros", para d'Ávila (1961), também se identificam outros livros, de excelente qualidade, os quais conseguem:

[...] guiar, expandir e apurar o gôsto das crianças, o desejo de conhecimento do mundo, atendendo o seu pendor para a fôrça, coragem, beleza, estoicismo; apuração do gôsto estético; ideais nobres de ação e desenvolver sentimentos, afastando as crianças do sentimentalismo piegas e pernicioso. (d'Avila, 1961, p.26)

Com base nessa argumentação, d'Ávila (1961) define que função maior da literatura infantil é a diversão educativa: "[...] divertir para educar e não somente divertir ou apenas educar [...]" (d'Ávila, 1961, p.28). Ele destaca que a literatura infantil precisa funcionar como mecanismo criador de virtudes, sabedoria, astúcia e outros atributos necessários à natureza humana.

D’Ávila (1961) também destaca em seu manual a associação entre literatura e a "Psicologia infantil", pois, segundo ele, conhecer os estágios do desenvolvimento psicológico da criança é essencial para entender os interesses desse público e as suas necessidades "psicobiológicas". Citando um texto de Virgínia Cortes Lacerda, d'Ávila afirma que o: 
[...] livro de literatura infantil, visto nos aspectos que constituem a sua unidade própria - texto (conteúdo e linguagem) e ilustração - exige da criança esclarecida um conhecimento profundo da psicologia da infância em relação às estruturas estéticas, éticas e psicológicas que entram em jogo sob a influência da leitura. (d’Ávila, 1961, p.112)

Após tratar da relação entre literatura e psicologia, d'Ávila (1961) apresenta informações sobre as diferentes formas de manifestação da literatura infantil, a fim de apresentar as suas características, adequação e contribuições para o desenvolvimento psíquico das crianças e dos jovens. Ele aborda aspectos sobre o folclore, os jornais e revistas, o teatro, a poesia, as lendas, as fábulas, as histórias típicas, os romances policiais, os contos de fadas, o teatro e a literatura de viagens e exploração. Também trata da questão das bibliotecas infantis, que, segundo ele, são muito mais que um espaço no qual se guardam livros. As bibliotecas demandam planejamento, organização e são espaços fundamentais para o desenvolvimento da literatura infantil.

Para concluir d'Ávila (1961) apresenta algumas biografias de escritores de literatura infantil, elenca alguns modelos de "fichas-guia" para os normalistas analisarem livros desse gênero literário e se detém ao problema da "má" literatura infantil.

Sobre esse último aspecto - a "má" literatura infantil -, explica que com o "extraordinário" desenvolvimento das artes gráficas também se desenvolveu a preocupação em torno dos perigos e prejuízos de determinadas leituras, denominadas de "má" literatura infantil. Pelo caráter "deseducador" desse tipo de literatura, ele relata que foram realizados estudos sistemáticos sobre o assunto, alguns dos quais pelo Inep, a fim de combater essa produção literária “deplorável”. Apesar disso, explica que há opiniões discordantes sobre o assunto e, por isso, transcreve algumas falas, como as dos educadores, Aldo de Assis Dias, Ofélia Fontes, Brito Viana, Lenyra Fraccaroli e Elza Kirilo, tentando destacar os pontos positivos e negativos da dita "má literatura infantil".

Como mencionei, a $1^{\text {a }}$ edição de Literatura infanto-juvenil não contém bibliografia. A partir da $3^{\text {a }}$ edição, de 1964, que ele acrescentou essa informação. A fim de compreender quais livros embasaram a elaboração desse manual, ainda que a partir de sua $3^{\mathrm{a}}$ edição, apresento, no Quadro 11, a relação dos textos indicados na bibliografia de cada um dos capítulos de Literatura infanto-juvenil. 
HISTÓRIA DO ENSINO DA LITERATURA INFANTIL 203

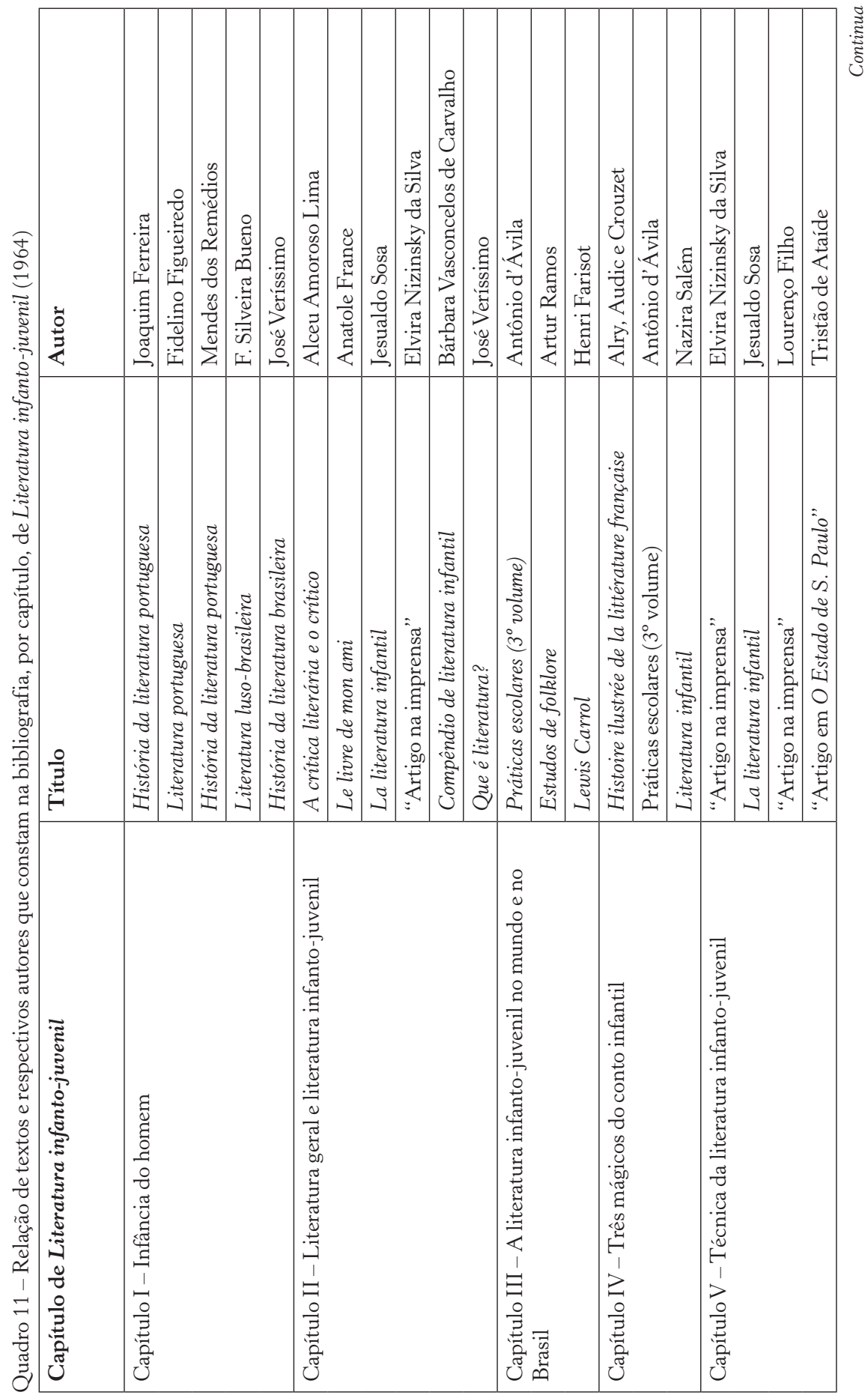




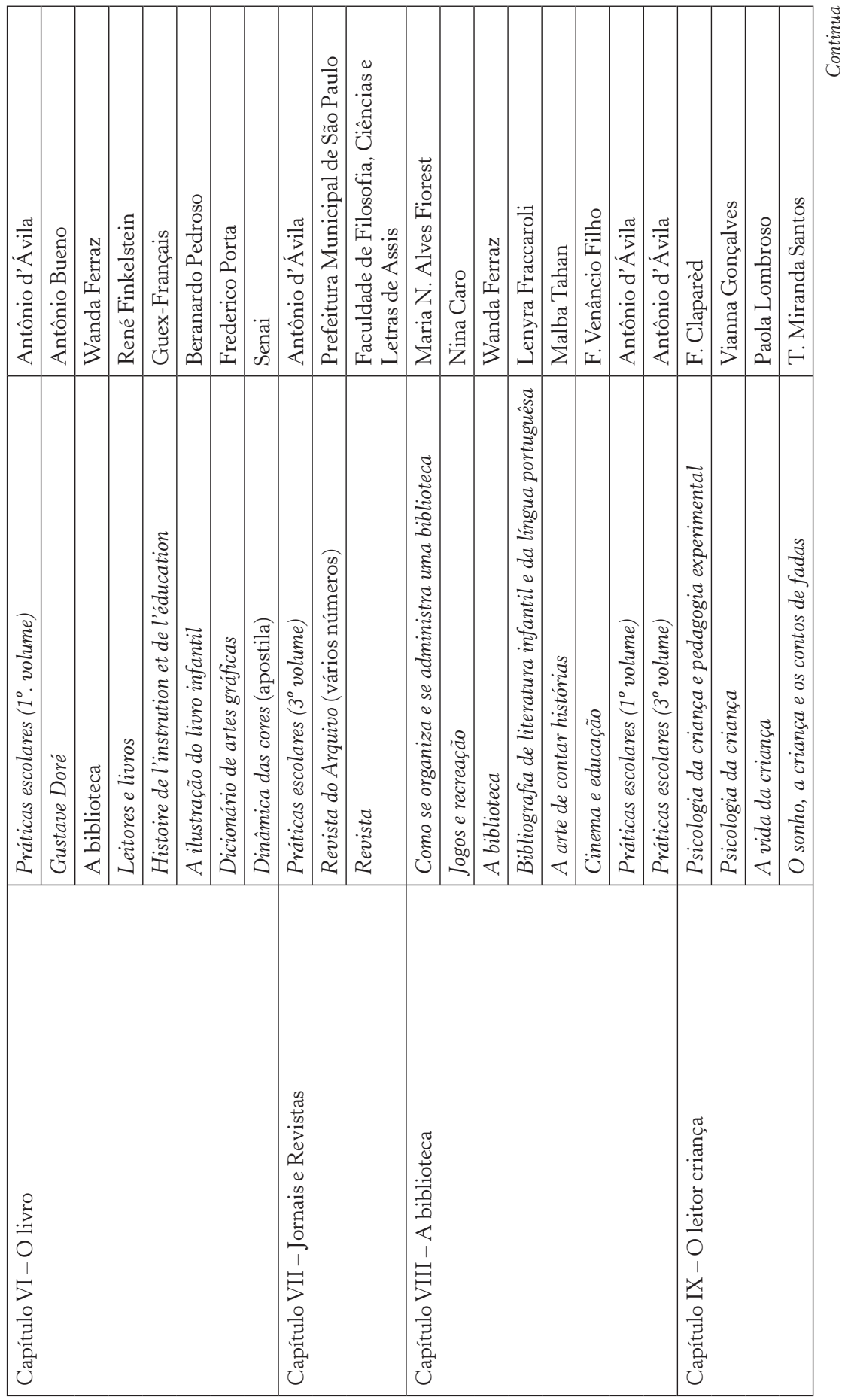




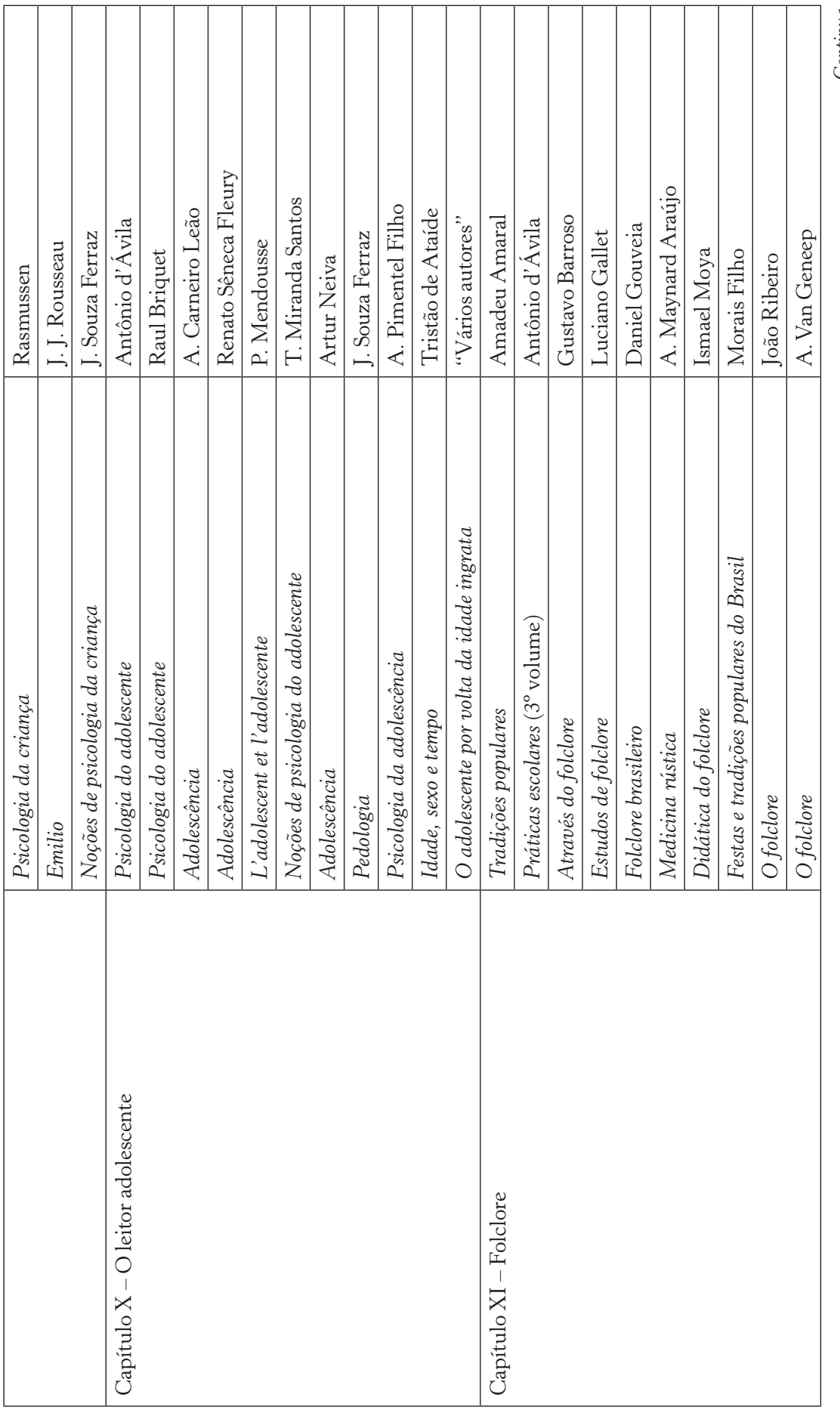




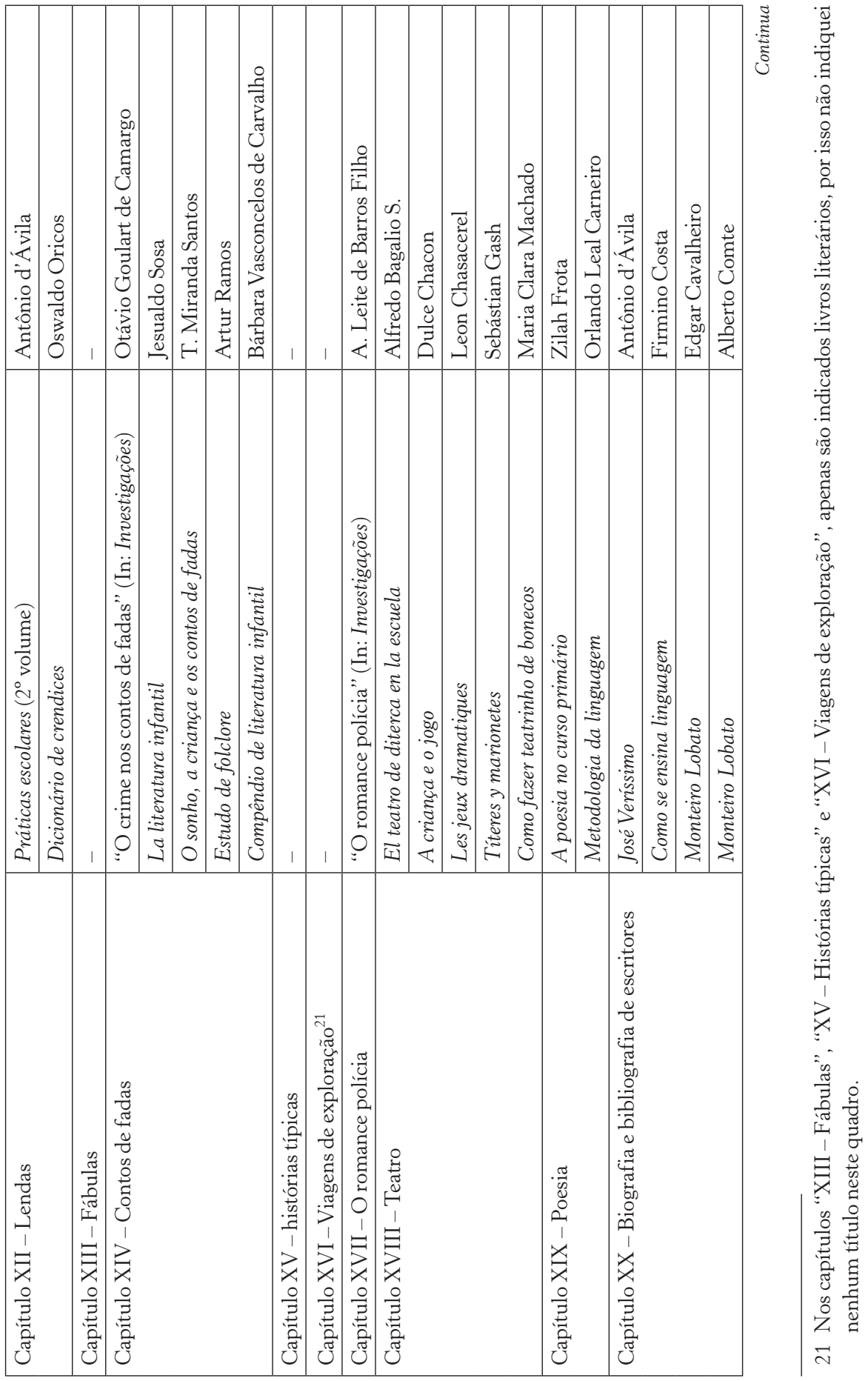


HISTÓRIA DO ENSINO DA LITERATURA INFANTIL 207

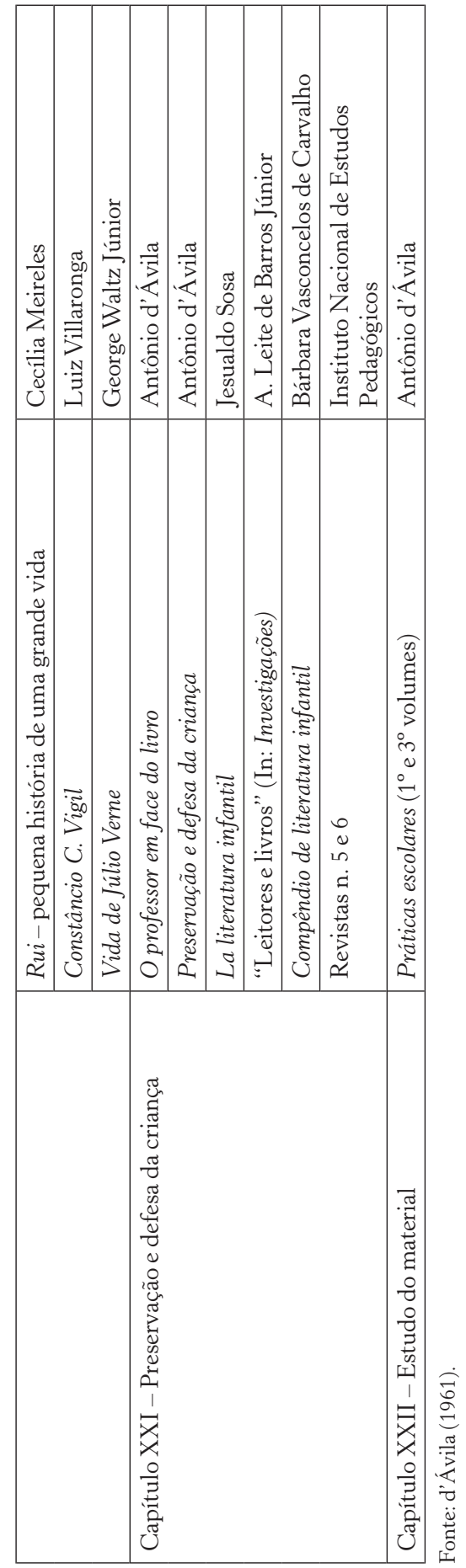


Como se pode observar, a bibliografia indicada por d'Ávila (1961) é bastante extensa. Ao todo, sem contar os livros literários, ele indica 85 títulos. Por ele ter optado por apresentar a bibliografia de seu manual por capítulos, alguns títulos se repetem com certa frequência. Dos 85 títulos, sete se repetem em diferentes capítulos. São eles: o primeiro e terceiro volumes de Práticas escolares, de sua própria autoria; um artigo de Elvira Nizinsky da Silva, publicado em jornal que ele não específica qual é; o livro La literatura infantil, de Jesualdo Sosa; o livro O sonho, a criança, e os contos de fada, de T. Miranda Santos; o livro Estudo de folclore, de Artur ramos; e o manual Compêndio de literatura infantil, de Bárbara Vasconcelos de Carvalho.

De todos esses títulos, os que mais se repetem nas indicações bibliográficas são: o terceiro volume de Práticas escolares (sete vezes); La literatura infantil; o primeiro volume de Práticas escolares (quatro vezes cada); e Compêndio de literatura infantil (três vezes cada).

\section{O ensino da literatura infantil segundo Nelly Novaes Coelho (1966)}

No ano de 1966, a professora de teoria literária da Faculdade de Filosofia, Letras e Ciências Humanas da USP, Nelly Novaes Coelho, teve publicado, pela Editora $\mathrm{FTD}^{22}(\mathrm{SP})$, o manual $\mathrm{O}$ ensino da literatura: sugestões metodológicas para o curso secundário e normal. Nesse manual, ela apresenta um capítulo destinado ao ensino da literatura infantil. O qual se intitula "O ensino da literatura infantil".

Nascida na cidade de São Paulo, em 1922, Nelly Novaes Coelho ${ }^{23}$ graduou-se em Letras Neolatinas pela Universidade de São Paulo, em 1959, e

22 De acordo com informações disponíveis no site da Editora FTD, ela foi fundada em 1902, por adeptos da Congregação Irmão de Maria, em decorrência da necessidade de ampliação das atividades na área de Educação dos membros dessa congregação. Ainda de acordo com informações localizadas no site da editora, a denominação FTD é uma homenagem ao francês Frère Théophane Durand, que por muitos anos foi diretor dessa Congregação. Ainda hoje, o principal ramo de atuação da FTD são os livros didáticos e os destinados às crianças (Editora FTD, s.d.). Informações disponíveis em: <http://www.ftd.com.br/v4/view/institucional/historico/100anos_historia.cfm>. Acesso em: 30. out. 2011.

23 As informações biográficas de Nelly Novaes Coelho foram extraídas de um informe da Faculdade de Filosofia, Letras e Ciências Humanas da USP, disponível em: <http://comunicacao.fflch.usp.br/node/1835>. Acesso em: 10 de mar. 2014. Para informações mais detalhadas sobre o manual $O$ ensino da literatura, ver, especialmente, Oliveira (2014). 
doutorou-se em Letras, em 1967. Em 1960, ela iniciou sua carreira como professora universitária junto à Faculdade de Filosofia, Letras e Ciências Humanas da USP e junta à Faculdade de Filosofia, Ciências e Letras de Marília-SP (FFCL). Na década de 1980, atuando apenas na USP, Nelly Novaes Coelho criou, pioneiramente, a disciplina "Literatura infantil e juvenil" no curso de graduação em Letras. E, ainda nessa década, ingressou no Programa de Pós-Graduação em Letras da FFLCH-USP, passando a orientar dissertações de mestrado e teses de doutorado especialmente sobre literatura infantil. Aposentada desde 1992 pela USP, Nelly Novaes Coelho continua exercendo suas atividades no campo dos estudos de teoria e crítica literárias.

Em relação ao seu interesse nos estudos sobre literatura infantil, embora afirme que isso tenha se dado somente a partir dos anos de 1970 (Coelho, 2012), já em 1960 ela apresenta considerações sobre o ensino da literatura infantil para os normalistas, público a que destina seu manual.

O ensino da literatura, por ser destinado, além dos normalistas, aos alunos do Ensino Secundário, está organizado em três partes, que totalizam 546 páginas. Essas três partes estão assim organizadas: a primeira, destina-se à problemática do ensino de literatura no curso Ginasial; a segunda, destina-se à problemática do ensino de literatura no curso Colegial e Normal; e a terceira, trata de aspectos da literatura contemporânea. Desse total de 546 páginas, 15 são destinados à discussão sobre o ensino da literatura infantil.

Além dessas três partes que constituem o conteúdo de $O$ ensino da literatura, esse manual contém uma dedicatória aos professores da USP, Fidelino de Figueiredo, Antonio Augusto Soares Amora e Antônio Cândido de Melo e Souza, e contém um prefácio elaborado por Segismundo Spina, filólogo e também professor da USP, à época.

Após a publicação da $1^{a}$ edição, $O$ ensino da literatura teve, pelo menos, outras três edições: a $2^{a}$, de 1973; a $3^{a}$, de 1974; e a $4^{a}$, de 1975. A partir da $2^{a}$ edição, esse manual foi revisto e ampliado e passou a ser publicado por outras editoras. A $2^{a}$ edição foi publicada pelo Instituto Nacional do Livro (DF) em parceria com a Editora José Olympio (RJ) e a $3^{\mathrm{a}}$ e $4^{\mathrm{a}}$ edições apenas pela José Olympio (RJ).

Em relação à revisão e ampliação desse manual, consta na introdução da $2^{a}$ edição, que, em virtude de sua ampliação, foi desmembrado em três volumes. Porém, os volumes II e III estavam em preparação. Não localizei informações de que esses dois volumes chegaram a ser publicados. De 
qualquer modo, o capítulo sobre literatura infantil contido nesse manual faz parte do volume I, como a terceira parte de três que constituem os exemplares da $2^{a}$ edição em diante.

A partir dessas mudanças, o capítulo sobre literatura infantil, na $2^{\mathrm{a}}$ edição em diante passou a comportar 69 páginas, de um total de 222. Esse capítulo sofreu algumas alterações, porém, tendo em vista os objetivos da pesquisa, optei por enfocar apenas o capítulo da $1^{\text {a }}$.

Cabe destacar, ainda, que a partir da $2^{a}$ edição $O$ ensino da literatura teve o subtítulo alterado, por causa das mudanças que ocorreram na organização do ensino, no Brasil, a partir de 1971.

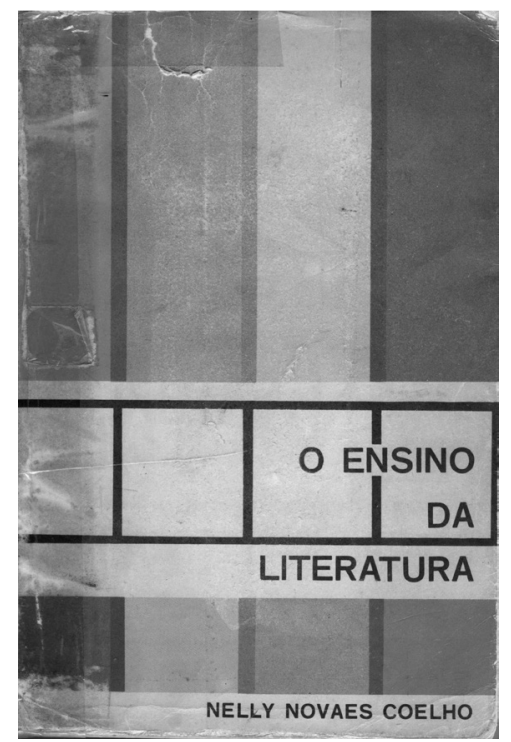

Figura 10 - Capa de O ensino da literatura (1966), de Nelly Novaes Coelho. Fonte: Acervo pessoal do autor.

No capítulo em que trata da literatura infantil, Coelho (1966) explica que, ao analisar os programas de Português do Curso Normal, chamou a sua atenção um ponto referente à disciplina "Literatura infantil": "Folclore e Literatura Infantil: 'objetivos didáticos e de mero entretenimento na literatura infantil”" (Coelho, 1966, p.123). Segundo ela, vê-se aí “[...] colocado em penúltimo lugar, numa sequência de aspectos a serem focalizados, um item que nos parece dos mais importantes nessa orientação a ser dada aos alunos, futuros mestres de crianças” (p.123). 
Para Coelho (1966), é justamente o aspecto lúdico e o entretenimento que a literatura infantil possibilita que deviam ser enfocados na formação dos futuros professores nos Cursos Normais. Por isso, ela apresenta três pontos que deveriam servir como um "roteiro" para o ensino desse gênero literário.

O primeiro ponto se refere à função da literatura infantil como instrumento de educação das crianças. Ela entende que os contos maravilhosos, as fábulas, os contos de fadas e as histórias fantásticas são os tipos de textos mais apropriados para se possibilitar às crianças a "aferição" dos valores positivos e negativos do mundo que as circula.

O segundo ponto se refere à escolha dos livros adequados às crianças, pois, nessa situação, os professores precisavam levar em conta duas questões: se os livros oferecem condições para atrair o aluno; e se esses livros atendem ao estágio de desenvolvimento psíquico desses alunos.

O terceiro ponto se refere à adequação dos livros ao desenvolvimento psicológico das crianças. Ela explica que, assim como fez Lourenço Filho (1943) e os autores de manuais que já apresentei: "A par dessas características básicas, a escolha da história deve atender também ao desenvolvimento psicológico da criança, à sua idade mental" (Coelho, 1966, p.127). Para o professor saber quais livros se adequam ao desenvolvimento psíquico da criança, Coelho (1966) apresenta o seguinte esquema: para crianças entre 5 e 7 anos, consideradas na fase do pensamento lúdico, os textos mais adequados são os contos maravilhosos, os contos de fadas e as histórias fantásticas; para crianças entre 8 e 11 anos, consideradas na fase do pensamento mágico, os textos mais adequados são as narrações de aventuras, os contos de heróis, contos populares regionais e histórias humorísticas; para crianças entre 12 e 14 anos, consideradas na fase do pensamento lógico, os textos mais adequados são os romances em geral, as biografias romanceadas, romances policiais e as lendas folclóricas (Coelho, 1966).

Sobre essa questão da adequação dos livros ao desenvolvimento psicológico da criança, Coelho (1966) alerta que não é suficiente saber qual livro se adequa e apenas ofertá-lo a uma criança, é preciso saber utilizá-lo durante as aulas. Por essa razão ela apresenta algumas sugestões de trabalho com a literatura infantil, como: a leitura do texto deve ocorrer antes pelo professor e, 
depois, pelos alunos; e o professor deve levar os alunos a refletirem sobre o que leram a partir de perguntas em torno de questões "essenciais da narrativa". ${ }^{24}$

Por fim, Coelho (1966) adota procedimento igual ao dos autores, cujos textos sintetizei nos capítulos anteriores deste livro, e apresenta uma breve análise do livro Reinações de Narizinho, de José Bento Monteiro Lobato, a fim de mostrar um bom exemplo de texto adequado à formação da criança.

Nas últimas páginas de $O$ ensino da literatura, Coelho (1966) indica a bibliografia que utilizou no capítulo sobre literatura infantil, na qual apresento o Quadro 12.

Quadro 12 - Relação de textos e respectivos autores que constam na bibliografia de $O$ ensino da literatura $(1966)^{25}$

\begin{tabular}{|c|c|c|c|}
\hline Título & Autor & Ano & Editora/revista \\
\hline $\begin{array}{l}\text { "Literatura infantil } \\
\text { brasileira" }\end{array}$ & $\begin{array}{l}\text { Leonardo } \\
\text { Arroyo }\end{array}$ & 1963 & $\begin{array}{l}\text { Conselho Estadual de Cultura } \\
\text { (SP) }\end{array}$ \\
\hline $\begin{array}{l}\text { Improving Reading } \\
\text { Instruction }\end{array}$ & $\begin{array}{l}\text { Donald D. } \\
\text { Durrell }\end{array}$ & 1956 & $\begin{array}{l}\text { World Book Company (Nova } \\
\text { York) }\end{array}$ \\
\hline $\begin{array}{l}\text { Bibliografia de literatura } \\
\text { infantil }\end{array}$ & $\begin{array}{l}\text { Lenyra } \\
\text { Fraccaroli }\end{array}$ & 1955 & Jornal dos Livros (SP) \\
\hline La literatura infantil & Jesualdo Sosa & $1938^{47}$ & Editorial Losada (Buenos Aires) \\
\hline Literatura infantil & Nazira Salém & 1959 & Mestre Jou (SP) \\
\hline $\begin{array}{l}\text { The Improvement of } \\
\text { Reading }\end{array}$ & $\begin{array}{l}\text { MacCulloug } \\
\text { Strang }\end{array}$ & 1961 & $\begin{array}{l}\text { McGraw Hill Book Company } \\
\text { (Nova York) }\end{array}$ \\
\hline $\begin{array}{l}\text { The Language Arts in the } \\
\text { Elementary School }\end{array}$ & Ruth Strickland & - & $\begin{array}{l}\text { D. C. Heath and Company } \\
\text { (Boston) }\end{array}$ \\
\hline Leitura na escola primária & Juracy Silveira & 1960 & Inep (RJ) \\
\hline $\begin{array}{l}\text { Histoire de la littérature } \\
\text { enfantine }\end{array}$ & Jean Trigon & 1930 & s.n. (Paris) \\
\hline $\begin{array}{l}\text { Publicações do Programa } \\
\text { de Assistência Brasileira- } \\
\text { Americana ao Ensino } \\
\text { Elementar (Pabaee) }\end{array}$ & Pabaee & - & s.n. (MG) \\
\hline
\end{tabular}

Fonte: Coelho (1966).

24 Coelho (1966) apresenta como sugestão as seguintes perguntas que o professor deve fazer aos alunos: "Sobre quem é contada a história?”; "Quem é o herói ou a heroína”; "Quais são suas virtudes ou seus defeitos?”; “Como são fisicamente?"; "Onde vivem?”; "O que acontece com eles?”; e "Quem são as personagens que rodeam o herói ou a heroína?” (Coelho, 1966, p. 129-130).

25 As informações que constam neste quadro foram transcritas exatamente como se encontram em $O$ ensino da literatura (1966).

26 Embora esse livro não tenha tido nenhuma edição publicada em 1938, mantive, neste quadro, a informação conforme consta na bibliografia de $O$ ensino da literatura (1966). 
Dos dez textos que Coelho (1966) relacionou na sua bibliografia, cinco são estrangeiros e cinco são brasileiros. Especificamente sobre esse gênero literário, ela relacionou cinco textos: um capítulo de livro de Leonardo Arroyo, a bibliografia de literatura infantil de Lenyra Fraccaroli, o livro de Jesualdo Sosa, o livro de Nazira Salém e um livro do francês Jean Trigon.

Além de livros e o capítulo de Leonardo Arroyo, Coelho (1966) indicou na sua bibliografia, genericamente, as publicações do Programa de Assistência Brasileira-Americana ao Ensino Elementar (Pabaee), ${ }^{27}$ que tinha sua sede instalada em Belo Horizonte-MG, mas que atendeu a professores bolsistas de todas as regiões do país.

A partir da $2^{\text {a }}$ edição de $O$ ensino da literatura, essa bibliografia deixou de constar nesse manual, que passou a conter apenas a indicação de alguns textos teóricos, recomendados para os alunos aprofundarem o conhecimento no assunto. São eles: Literatura infantil brasileira (1968), de Leonardo Arroyo; Compêndio de literatura infantil (1959), de Bárbara Vasconcelos de Carvalho; História da literatura infantil (1970), de Nazira Salém; e Histoire de la littérature enfantine (1930), de Jean Trigon.

\section{Pontos para o ensino da literatura infantil segundo José Benedicto Pinto (1967)}

Em 1967, o professor José Benedicto Pinto ${ }^{28}$ teve publicado, também pela Editora FTD (SP), a $4^{\text {a }}$ edição de Pontos de literatura infantil: para os alunos do $3^{\circ}$ ano normal. Embora nesse manual conste a informação de que a edição de 1967 seja a $4^{\mathrm{a}}$ edição, não localizei nenhuma informação a respeito das edições anteriores, nem de edições posteriores a ela. Nos muitos exemplares desse manual que localizei e a que tive acesso, todos contêm a informação de que se trata da $4^{\text {a }}$ edição, de 1967. Apesar de não ter localizado nenhuma edição anterior a 1967, é possível afirmar que, desde a década

27 O Pabaee foi um programa desenvolvido entre 1956 e 1964, como parte do acordo assinado entre o governo brasileiro e americano, para assistência à educação elementar no Brasil. No âmbito desse programa, alguns professores recebiam bolsas de estudos, para participarem dos programas de formação, a fim de replicarem em sua prática docente novas práticas em favor da melhoria da educação elementar no país. No caso do estado de São Paulo, localizei um programa de "Metodologia da leitura, da linguagem e da literatura infantil", de 1959, referente às atividades do Pabaee no Instituto de Educação Caetano de Campos (Paiva; Paixão, 2012).

28 Não foi possível localizar informações sobre José Benedicto Pinto. 
de 1950, José Benedicto Pinto, cujos indícios apontam que sua atuação tenha ocorrido na cidade de Bauru-SP, vinha trabalhando com questões ligadas à literatura infantil.

Em notícia publicada no jornal O Estado de S. Paulo, no dia 21 de outubro de 1958, consta a informação de que esse professor ministraria, na Faculdade de Filosofia de Bauru-SP, um curso sobre literatura infantil que compreendia o seguinte programa: "Origem da literatura infantil sua introdução no Brasil", "Fases e modalidades da literatura infantil", "A forma em literatura infantil", "Características e funções da literatura infantil" e "A má literatura infantil e juvenil e suas consequências" (Faculdade..., 1958, p.24). Com isso, pode-se presumir que as edições anteriores de Pontos de literatura infantil tinham tido circulação mais restrita, entre os alunos dos cursos e/ou das aulas que José Benedicto Pinto ministrava, por isso não localizei nenhum exemplar dessas edições. Também é possível que as edições anteriores desse manual tenham sido publicadas por editoras pequenas ou por editoras não comerciais, o que acarretou a sua não circulação de forma mais ampla e a sua não preservação em acervos, arquivos e bibliotecas.

Pelo exposto, entendo que a 4a edição de Pontos de literatura infantil seja a que, de fato, circulou no estado de São Paulo, pois foram muitos os exemplares dessa edição que localizei. Nessa $4^{a}$ edição de Pontos de literatura infantil, Pinto (1967) apresenta seis capítulos, os quais se assemelham muito aos temas que ele abordou no curso que ministrou em 1958.

Os capítulos que ele apresenta nessa edição são: "Origens da literatura infantil", "Desenvolvimento da literatura infantil”, "A literatura infantil no Brasil”, "Características e funções da literatura infantil”, "As principais funções da literatura infantil" e "Requisitos que os livros infantis e juvenis devem apresentar”. Além desses seis capítulos, Pinto (1967) apresenta em seu manual um prefácio e agradecimento a sua esposa, o que totaliza 114 páginas.

No prefácio de Pontos de literatura infantil, Pinto (1967) alerta para o fato de que, com esse manual, ele não quis produzir um livro completo, pelo contrário, ele considera o ser um ponto de partida para que outros produzam outros livros sobre literatura infantil. Desse modo, ele explica, como os outros autores de manuais que o antecederam, que apenas quis suprir uma falha no preparo dos normalistas no que se refere à " [...] uma das mais im- 
portantes missões do professor primário: formar nos seus alunos, o hábito e o gôsto pela boa leitura" (Pinto, 1967, p.7).

Em relação à adequação de Pontos de literatura infantil ao ensino da literatura infantil, Pinto (1967) esclarece que "[...] o que está desenvolvido neste livro constitui o programa de literatura infantil para o curso normal e, me parece, ainda, que pode servir para quantos se interessem por êsse problema que deve constituir, sem dúvida, um subsídio à cultura de cada um” (p.7).

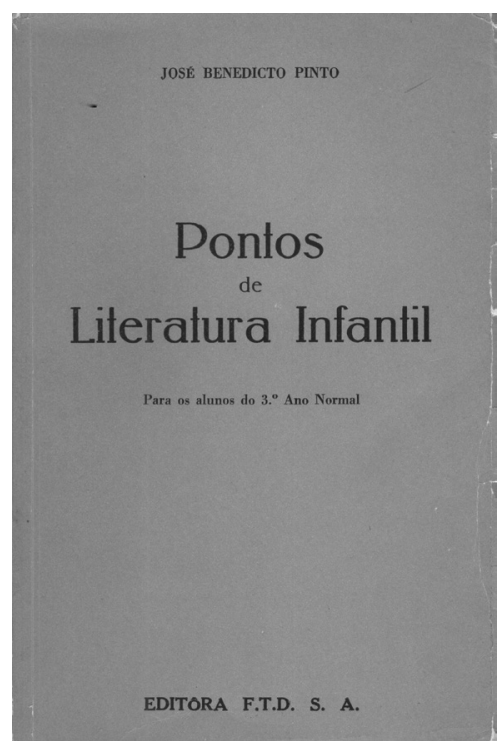

Figura 11 - Capa de Pontos de literatura infantil (1967), de José Benedicto Pinto. Fonte: Acervo do GPHELLB.

Em vista das ressalvas que faz e do intento de adequar Pontos de literatura infantil ao programa da disciplina "Literatura infantil", Pinto (1967) inicia o seu manual com a apresentação de três teorias que buscam explicar a origem da literatura infantil. Segundo ele, perguntar-se sobre qual é a origem desse gênero literário, o que era recorrente nos manuais publicados até então, é algo bastante complexo e cuja resposta não é fácil. À época, explica Pinto (1967), havia três teorias que buscavam responder sobre essa origem e, em verdade, as três tinham sua "razão de ser".

A primeira teoria que Pinto (1967) apresenta sobre a origem da literatura infantil é a chamada "Teoria da origem remota", que entende estar o "primórdio" da literatura infantil resguardado na Grécia e Roma antigas. 
A segunda teoria é denominada "Teoria da origem oriental", que defende a ideia de que a origem da literatura infantil está nos contos originários da Pérsia, Índia, China e Arábia. A terceira e última teoria é a "Teoria da contribuição do folclore", que afirma ser origem da literatura infantil as lendas, canções e narrações folclóricas. De modo geral, nos manuais publicados anteriormente ao de Pinto (1967), essas três teorias são apresentadas de forma indistinta, como se as três explicassem, ao mesmo tempo, a "origem" da literatura infantil. Autores, como Budin (1949), Carneiro (1951), d’Ávila (1954; 1961), Oliveira (1958), Carvalho (1959), Salém (1959) e Coelho (1966) afirmam que a literatura infantil se "originou" da tradição oral, folclórica, desenvolvendo-se a partir de textos remotos, como as fábulas de Esopo, e os contos árabes, como os reunidos no livro Contos seletos das mil e uma noites.

Ao apresentar essas teorias, Pinto (1967) explica que, independentemente de qual se tenha como base, é inegável que desde a antiguidade a literatura infantil existiu, [...] embora não se possa asseverar com absoluta certeza que as histórias que conhecemos ainda hoje e, dêles advindas, fôssem realmente, para crianças" (Pinto, 1967, p.15). Fato é que, com os avanços nos estudos sobre as crianças e o processo de "renovação" educacional, a literatura infantil "prosperou", tornando-se um ramo de especialidade da literatura em geral. Por essa razão, ele explica: "A literatura infantil progride sempre e há hoje a necessidade do seu conhecimento pelos pais e mestres, dada a sua importância no desenvolvimento da criança (desenvolvimento não só intelectual, mas, sobretudo, moral e psicológico)" (p.17-18).

No caso da "origem" da literatura infantil brasileira, Pinto (1967) afirma que ela surgiu, em formato escrito, apenas na segunda metade do século XIX. Antes disso, porém, havia uma literatura infantil no Brasil de cunho oral, sustentada pelas histórias contadas pelas "mães-pretas" e "pais Joãos". Ainda em relação à literatura infantil brasileira, afirma, conforme os autores de textos sobre literatura infantil que o antecederam, que foi em 1921, com a publicação de Narizinho arrebitado, de Monteiro Lobato, que essa literatura iniciou-se "propriamente".

Abordados os aspectos históricos, Pinto (1967) se detém às características e funções da literatura infantil. Para isso, ele toma como base os estudos da "Psicologia infantil", que, segundo ele, era muito benéfica para a literatura infantil. Para Pinto (1967), a importância de se ter a "Psicolo- 
gia infantil" como base nos estudos sobre a literatura para crianças se deve ao fato de que essa teoria "[...] tem-nos mostrado que a criança realmente precisa do maravilhoso, mas também necessita do contacto com o real e, sobretudo, que, muitas vêzes, êsse maravilhoso pode e deve ser encontrado na vida real" (Pinto, 1967, p.30, grifos do autor).

Com relação às características que os livros de literatura infantil devem conter, conforme a idade e desenvolvimento psíquico da criança, Pinto (1967) segue a mesma proposição que os outros autores de manuais: crianças entre 4 e 6 anos, livros de estampas, com texto reduzido ou sem texto, que possibilitem a exploração da memória visual; criança entre 6 e 8 anos, livros com narrativas breves e singelas, ainda com algumas ilustrações ou estampas e que apresentem certa dose de "maravilhoso"; crianças entre 9 e 10 anos, histórias de temas diversos, que associam o maravilhoso com a vida, e que contenham descrição e aventuras; crianças entre 10 e 13 anos, a histórias de aventuras e narrativas complexas, com aventuras na selva e no mar, para os meninos, e com heroínas e novelas "singelas" para as meninas.

Pinto (1967) também elenca as principais funções desse gênero literário: estimular o desenvolvimento da leitura autônoma, de modo que sirva para as atividades de linguagem e leitura desenvolvidas na escola primária; preparar o futuro apreciador das "letras"; enriquecer o interesse infantil; e dar oportunidade do as crianças evadirem-se da vida, motivando as aspirações pessoais e a "[...] compreensão normal dos sentidos familiares, cívicos e de larga compreensão humana” (Pinto, 1967, p.45).

Com isso, estabelece quais são os requisitos básicos que um livro de literatura infantil deve atender e explica que, para "[...] que a literatura infantil possa melhor atender às finalidades e bem atingir suas funções, necessário é que os livros destinados às crianças (e aos jovens) tenham certos requisitos [...]" (Pinto, 1967, p.49).

Para concluir, Pinto (1967) elenca os objetivos didáticos, psicológico e moral e social da literatura infantil e apresenta algumas sugestões de atividades de composição com textos desse gênero literário. Em relação a esses objetivos, ele os define da seguinte forma: os objetivos didáticos se referem ao fato de que todo livro para crianças deve contribuir para o desenvolvimento da capacidade de leitura, além de ser fonte de informação; os objetivos psicológicos referem-se à formação da personalidade da criança e do adolescente; e os objetivos sociais e morais são os que se referem à constru- 
ção, por parte da criança, de uma visão geral da sociedade e que contribuem para a formação de "padrões de dignidade" e de "padrões elevadíssimos de moral".

Diferentemente do que ocorreu com os demais manuais até aqui apresentados, Pinto (1967) não apresenta nenhuma bibliografia em seu manual, tampouco faz menções ou citações de outros textos.

\section{Como ensinar a literatura infantil segundo Maria Antonieta A. Cunha (1968)}

Em 1968, Maria Antonieta Antunes Cunha teve publicado, pela editora Bernardo Álvares (MG), ${ }^{29}$ o manual Como ensinar literatura infantil: para os colégios normais.

Nascida em Belo Horizonte-MG, Maria Antonieta Antunes Cunha, ${ }^{30}$ em 1960, formou-se professora pelo Instituto de Educação de Minas Gerais e, em seguida, diplomou-se em Letras, em 1964, pela Faculdade de Filosofia e Ciências Humanas (Fafich), da Universidade Federal de Minas Gerais (UFMG). Recém-graduada em Letras, ainda em 1964, essa professora foi convidada a substituir um professor de língua portuguesa do Instituto de Educação de Minas Gerais, quando, pela primeira vez, tomou contato com questões sobre a literatura infantil e seu ensino (Cunha, 2014). Ainda atuando nesse Instituto, em 1969, ela passou a atuar junto à UFMG, onde, em 1971, doutorou-se em Letras.

A partir de 1973, essa professora mineira passou a atuar exclusivamente na UFMG, quando começou a ocupar diferentes cargos nessa instituição. Ao longo de sua atuação profissional, Maria Antonieta Antunes Cunha esteve sempre ligada ao campo da cultura, da promoção da leitura e da literatura infantil, permanecendo em exercício com atividades nesse campo até hoje. ${ }^{31}$

29 Não foi possível localizar informações sobre a editora Bernardo Álvares.

30 As informações biográficas sobre Maria Antonieta Antunes Cunha foram extraídas de entrevista concedida por essa professora, a saber: Cunha (2014).

31 Entre os cargos mais recentes que Maria Antonieta Antunes Cunha ocupou, têm-se: foi Secretária Municipal de Cultura de Belo Horizonte; foi integrante do Conselho Curador e do Conselho Diretor da Fundação Nacional do Livro Infantil e Juvenil; foi Presidente da Câmara Mineira do Livro e presidente da Fundação Municipal de Cultura de Belo Horizonte; foi secretária-executiva do Plano Nacional do Livro e Leitura, do Ministério da Cul- 
Em meados da década de 1960, quando Maria Antonieta Antunes Cunha foi convidada para lecionar, em substituição a um professor, no Instituto de Educação de Minas Gerais, ela relata que, pela primeira vez, tomou contato com as questões da literatura infantil (Cunha, 2014). À época, explica ela, esse assunto constituía apenas uma unidade do programa de língua portuguesa do Instituto de Educação de Minas Gerais. Porém, ao tomar contato com o assunto da literatura infantil e reconhecer sua importância para a formação dos professorandos, ela transformou essa "unidade" em "[...] um semestre de estudos de Literatura Infantil" (p.3).

Em decorrência dessa experiência já no início de sua carreira como professora e por ter observado a raridade da bibliografia brasileira sobre o assunto, Cunha elaborou Como ensinar literatura infantil, "imaginando" diminuir dois problemas fundamentais que todos os professores de português enfrentavam e que vinham sendo relatados pelos autores dos manuais publicados até então: a pobreza bibliográfica e o pouco valor que se atribuía à literatura infantil (Cunha, 1968).

Dessa forma, Cunha (1968) organizou seu manual em sete unidades de estudo, assim intituladas: "Literatura infantil: situação e extensão", "Características da boa obra para crianças", "Funções da literatura infantil", "Adequação do livro à idade da criança", "Texto para crianças", "Poesia para crianças" e "Folclore - sua utilização".

Cada uma dessas unidades apresenta uma subdivisão em três tópicos, que se relacionam: à exposição de um assunto sobre a literatura infantil, apresentação de três textos literários para estudo e sugestões de trabalho em torno dos textos e em função do assunto apresentado na unidade.

Sobre como elaborou Como ensinar literatura infantil (1968), Cunha (1914) explica:

Consultei vários programas de ensino, e em todos o espaço do assunto Literatura Infantil era muito pequeno. Procurei, na criação do livro, observar os tópicos mais importantes no estudo da própria literatura de adultos, até para ressaltar minha posição de que a literatura para crianças é tão importante e tão arte quanto a feita para adultos. (Cunha, 2014, p.6) 
Em 1970, foi publicada a $2^{a}$ edição desse manual, ainda pela Bernardo Álvares, e em 1971 foi publicada a 3 ${ }^{\mathrm{a}}$, pela Editora Descubra (SP). ${ }^{32}$

A partir da $3^{\text {a }}$ edição, esse manual foi revisto e ampliado, passando a ter oito unidades, assim intituladas: "Leitura extensiva: um problema", "Literatura infantil: situação e extensão", "Funções da literatura infantil", "Características da boa obra para crianças", "A narrativa para crianças", "Poesia para crianças", "O teatro para crianças" e "Folclore - sua utilização na escola".

Em relação à organização interna das unidades da $3^{\mathrm{a}}$ edição, Cunha (1971) não fez nenhuma alteração substancial.

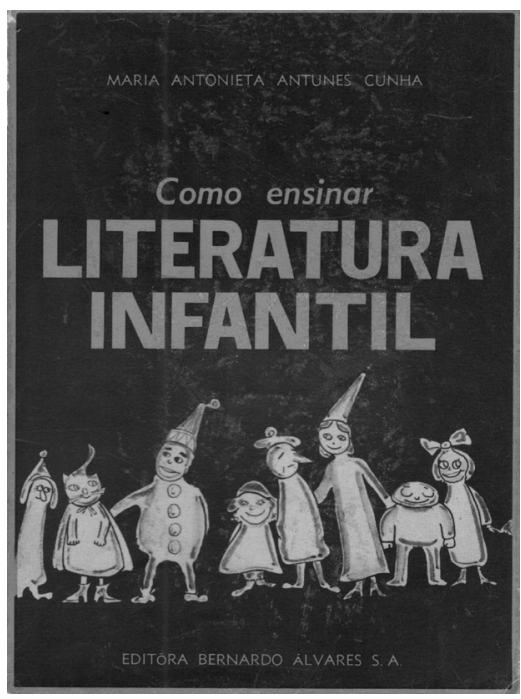

Figura 12 - Capa de Como ensinar literatura infantil (1968), de Maria Antonieta A. Cunha. Fonte: Acervo do GPHELLB.

Em Como ensinar literatura infantil, ao explicar sobre a "situação" e "extensão" dos livros escritos para o público infantil, Cunha (1968), citando textos de Carlos Drummond de Andrade, Anatole France, Alceu Amoroso Lima, Graciliano Ramos e Dora Pastoriza de Etchebarne, explica que, embora haja a defesa de que não existe distinção entre literatura infantil e a literatura para adultos, é inegável que as publicações específicas para crianças vinham crescendo, algumas repletas de erros.

32 Não foi possível localizar informações sobre a Editora Descubra. 
Segundo essa professora, os erros que eram comuns na literatura infantil da época consistiam na "puerilidade" de alguns autores ou, o inverso, linguagem "empolada", com tom moralizador, que não levava a "Psicologia infantil” em consideração. Apesar dessa situação, Cunha (1968) faz a ressalva de que havia também, à época, obras destinadas às crianças que agradavam a elas de forma satisfatória, sem contar os livros escritos para adultos e que os pequenos escolhiam para si, como literatura infantil.

Pensando sobre a literatura infantil que contempla o gosto infantil, Cunha (1968) elenca um conjunto de características que ela considera indispensáveis na boa obra infantil. Para ela, essas características são: uso do recurso da imaginação; a construção de enredos com movimento e dramatização; uso de uma boa técnica de desenvolvimento da história; e a contemplação de qualidades estéticas na escrita do texto. Com isso, ela afirma que esse gênero literário interfere nas áreas vitais o homem, a "atividade", a "inteligência" e a "afetividade", assumindo a função de educar, instruir e distrair.

Ao apresentar essas considerações, Cunha (1968), segundo o exemplo dos autores dos manuais publicados anteriormente ao dela, defende que a literatura infantil precisa ajustar-se à evolução psíquica da criança.

Sabe-se pela Psicologia que a criança passa por uma série de transformações, desde que nasce até entrar na adolescência. Essas transformações estabelecem fases de sua evolução, e devem ser levadas em conta quando se quer dar a cada criança o livro mais interessante para a idade.

Para que a literatura infantil possa desempenhar as suas funções, ela considera três fases da "evolução psicológica" da criança. A primeira fase, chamada de "fase do mito", compreende crianças de 3 a 7 anos, e na qual predomina a fantasia, o animismo. Por isso, para essa fase, Cunha (1968) recomenda fábulas, contos de fadas, mitos e lendas como os tipos de textos mais adequados. A segunda fase, chamada de "robinsionismo", caracteriza-se pelo conhecimento da realidade. Essa fase comporta crianças de 7 a 11 anos e, por isso, os textos mais adequados são as narrativas de aventuras, relatos mitológicos, relatos heroicos, relatos de viagens e as histórias regionais, nacionais e universais. A terceira fase, chamada de fase do "pensamento racional”, caracteriza-se pelo fato de a criança já ter desenvolvido o domínio 
das noções abstratas. Essa fase comporta crianças entre 11 anos até a adolescência e, por isso, os textos mais adequados são os romances em geral.

Para concluir, Cunha (1968) se centra na exploração mais detalhada de três formas de manifestação da literatura infantil: o teatro, a poesia e o folclore, para as quais elenca as contribuições que essas "formas de literatura infantil" apresentam para o desenvolvimento infantil.

Ao final de seu manual, Cunha (1968) apresenta a bibliografia que utilizou. Ao todo, ela indica 21 referências, que são descritas no Quadro 13.

Quadro 13 - Relação de textos e respectivos autores que constam na bibliografia de Como ensinar literatura infantil (1968)

\begin{tabular}{|l|l|l|l|}
\hline Título & Autor & Ano & Editora/revista \\
\hline Curso de folclore & $\begin{array}{l}\text { Aires da Mata Machado } \\
\text { Filho }\end{array}$ & 1957 & Livros de Portugal (RJ) \\
\hline Poesia na escola & $\begin{array}{l}\text { Alaíde Lisboa de } \\
\text { Oliveira }\end{array}$ & 1966 & Bernardo Álvares (MG) \\
\hline $\begin{array}{l}\text { Compêndio de } \\
\text { literatura infantil }\end{array}$ & $\begin{array}{l}\text { Bárbara Vasconcelos de } \\
\text { Carvalho }\end{array}$ & 1961 & $\begin{array}{l}\text { Companhia Editora Nacional } \\
\text { (SP) }\end{array}$ \\
\hline "Literatura infantil" & $\begin{array}{l}\text { Carlos Drummond de } \\
\text { Andrade }\end{array}$ & 1964 & Companhia Aguilar (RJ) \\
\hline $\begin{array}{l}\text { História de la } \\
\text { literatura infantil } \\
\text { española }\end{array}$ & $\begin{array}{l}\text { Carmem Bravo- } \\
\text { Villasante }\end{array}$ & 1959 & Revista de Occiente (Madri) \\
\hline $\begin{array}{l}\text { "Expressão feminina } \\
\text { América" }\end{array}$ & Cecília Meireles & s.d. & MEC \\
\hline $\begin{array}{l}\text { El cuento en la } \\
\text { literatura infantil }\end{array}$ & $\begin{array}{l}\text { Dora Pastoriza } \\
\text { Etchebarne }\end{array}$ & 1966 & Kapelusz (Buenos Aires) \\
\hline $\begin{array}{l}\text { Monteiro Lobato- } \\
\text { vida e obra }\end{array}$ & Edgard Cavalheiro & 1962 & Brasiliense (SP) \\
\hline Dinâmicas do folclore & Édison Carneiro & 1965 & Civilização Brasileira (RJ) \\
\hline $\begin{array}{l}\text { El niño y el folklore } \\
\text { Giuseppe Maria Sciacca }\end{array}$ & 1965 & $\begin{array}{l}\text { Editorial Universitária (Buenos } \\
\text { Aires) }\end{array}$ \\
\hline $\begin{array}{l}\text { Infância } \\
\text { Teoria literária }\end{array}$ & Hênio Tavares & 1967 & Bernardo Álvares (MG) \\
\hline La literatura infantil & Jesualdo Sosa & 1955 & Editorial Losada (Buenos Aires) \\
\hline
\end{tabular}

33 Como mencionei neste capítulo, a edição de 1961, de Compêndio de literatura infantil, de Bárbara V. de Carvalho foi publicada pela Edições Leya. No entanto, Cunha (1968) indica como a editora desse manual, na edição de 1961, a Companhia Editora Nacional. Por se tratar de pesquisa histórica, optei por manter, neste quadro, a informação conforme consta em Cunha (1968). 


\begin{tabular}{|l|l|l|l|}
\hline $\begin{array}{l}\text { "Espetáculos para } \\
\text { crianças e higiene } \\
\text { mental" }\end{array}$ & Joy Arruda & 1957 & Revista Pediatria Prática (SP) \\
\hline $\begin{array}{l}\text { "O teatro para } \\
\text { crianças" }\end{array}$ & Júlio Gouveia & 1958 & Santos de Oliveira (SP) \\
\hline $\begin{array}{l}\text { "O folclore: literatura } \\
\text { oral e popular" }\end{array}$ & $\begin{array}{l}\text { Luis da Câmara } \\
\text { Cascudo }\end{array}$ & 1956 & Editorial Sul América (SP) \\
\hline $\begin{array}{l}\text { Manual de coleta } \\
\text { folclórica }\end{array}$ & Renato Almeida & 1965 & - \\
\hline $\begin{array}{l}\text { Comment raconter des } \\
\text { histoires à nos enfants }\end{array}$ & Sara Coue Bryant & 1928 & Fernand Naphan (Nova York) \\
\hline $\begin{array}{l}\text { Fábulas completas } \\
\text { Somás de Iriarte e Felix }\end{array}$ & 1949 & Ediciones Castilla Madri) \\
\hline $\begin{array}{l}\text { Interpretación y } \\
\text { análisis de la obra } \\
\text { literaria }\end{array}$ & Wolfgang Kayser & 1961 & Gredos (Madri) \\
\hline
\end{tabular}

Fonte: Cunha (1968).

Com base no Quadro 13, comparativamente aos outros manuais de ensino, é possível notar que em Como ensinar literatura infantil (1968) há certa diminuição do uso de bibliografia estrangeira. Dos 21 títulos indicados na bibliografia desse manual, apenas sete foram publicados fora do Brasil.

Também é possível notar que Cunha (1968), assim como d'Ávila (1961) e Coelho (1973), relaciona Compêndio de literatura infantil, de Bárbara V. de Carvalho, em sua bibliografia.

Um aspecto que merece destaque em relação à bibliografia indicada por Cunha (1968) é o fato de ter relacionado um conjunto significativo de títulos específicos sobre literatura infantil. Como se pode observar nas publicações anteriores, normalmente os livros indicados nas bibliografias tratam de questões mais amplas sobre ensino da leitura ou do folclore, sendo poucos os títulos específicos sobre literatura infantil.

Outro aspecto que merece destaque é que nessa bibliografia há referência de um título sobre teoria literária - Teoria literária (1967), do professor Hênio Tavares. Até então, nenhum autor de manual havia feito menção a livros dessa área. Nem mesmo Nelly Novaes Coelho ou Bárbara Vasconcelos de Carvalho, que também eram formadas em Letras, indicaram livros de teoria literária nas bibliografias de seus manuais.

A partir da $3^{\text {a }}$ edição de Como ensinar literatura infantil, a qual foi revista e ampliada, Cunha acrescentou 14 títulos à bibliografia da obra e excluiu três que constavam na $1^{\mathrm{a}}$ edição. Com isso, a bibliografia da $3^{\mathrm{a}}$ edição pas- 
sou a conter 32 títulos. Os livros que constam na bibliografia da $1^{\mathrm{a}}$ edição e que foram excluídos na $3^{a}$ edição são: Infância (1961), de Graciliano Ramos; Teoria literária (1967), de Hênio Tavares; e O teatro para crianças (1958), de Júlio Gouveia.

Os títulos acrescentados na $3^{\text {a }}$ edição são: Tres siglos de literatura infantil (1968), de Bettina Hurlimann; Criança é criança (literatura infantil e seus problemas) (1971), de Maria Lúcia Amaral; Literatura infantil brasileira (1968), de Leonardo Arroyo; Psicologia da criatividade (1971), de Maria Helena Novaes; Estudio sobre literatura infantil (1971), de Hermínio Almendros; Cinema e animação, arte nova/arte livre (1971), de Carlos Alberto Miranda; A explosão criativa dos quadrinhos (1972), de Moacyr Cirne; História da literatura infantil (1970), de Nazira Salém; Como fazer teatrinho de bonecos (1970), de Maria Clara Machado; Literatura oral par a infância e juventude (1970), de Maria Clara Machado; Narraciones infantiles y cambio social (1971), de Antonio Menchén Martinez; La educación artística del niño (1965), Lark-Horovitz; A comicidade em Maria Clara Machado (1971), de Antonieta Antunes Cunha; e Boletim da Fundação Nacional do Livro Infantil e Juvenil.

A partir da $3^{\text {a }}$ edição foi acrescida uma significativa quantidade de textos publicados em língua espanhola. Também Cunha (1971) acrescentou referência da $2^{a}$ edição do livro de Nazira Salém, História da literatura infantil (1970). Outro livro, com objetivo semelhante a esse de Nazira Salém, que foi acrescido na bibliografia do manual de Maria Antonieta Antunes Cunha foi o livro Literatura infantil brasileira (1968), de Leonardo Arroyo.

De modo geral, observa-se que a ampliação da bibliografia desse manual, na $3^{\mathrm{a}}$ edição, se deu com títulos sobre história da literatura infantil brasileira e de outros países e com livros sobre aspectos específicos desse gênero ou a ele relacionado. Apenas um dos títulos acrescidos na $3^{\mathrm{a}}$ edição não se refere diretamente à literatura infantil. Trata-se do livro Psicologia da criatividade (1971), de Maria Helena Novaes.

\section{Therezinha Franco Farah e as "práticas" de ensino da literatura infantil}

Presumivelmente ainda na década de 1960, em ano que não pude localizar, outro manual destinado ao ensino de literatura infantil foi publicado no Brasil. Trata-se de Práticas da literatura infantil na escola primária: anto- 
logia de contos e planos de aula, de autoria de Therezinha J. Franco Farah, publicado pelo Ibep (SP)..$^{34}$

Nascida na cidade de Mirassol-SP, possivelmente na década de 1930, Therezinha J. Franco Farah ${ }^{35}$ graduou-se em Sociologia e, após concluir seus estudos, mudou-se para Belo Horizonte. Nessa cidade, foi bolsista, ${ }^{36}$ estagiária e assistente, por cinco anos junto ao Departamento de Linguagem do Centro Regional de Pesquisas Educacionais João Pinheiro. E há 40 anos reside em Fortaleza-CE, onde atuou como professora, por 15 anos, na Universidade de Fortaleza (Unifor).

Sobre seu manual, foi escrito aos professores primários e normalistas, visando contribuir com a prática desses profissionais e estudantes em torno da literatura infantil. Farah (s.d.) explica que esse manual "[...] nasceu da necessidade de auxiliar certo grupo de professôres que se ressentem da falta de uma Antologia de Contos que lhes proporcionasse, ao lado de um material adequado uma orientação didática” (Farah, s.d., p.5).

Por essa razão, ela, "intencionalmente", afastou-se dos problemas de conceituação da literatura infantil e da elaboração de um manual que contemplasse estudos específicos de teoria literária. Sua proposta foi a de constituir um conjunto de sugestões de várias atividades em torno da literatura infantil, todas de orientação didática, de modo que esse manual se configure como uma antologia.

Para dar conta desse propósito, Farah (s.d.) organizou seu manual em duas partes: na primeira, apresenta: introdução, dedicatória, agradecimento e 12 capítulos; na segunda, apresenta 80 contos, como sugestões para o trabalho com a literatura no ensino primário.

34 De acordo com informações contidas no site do Ibep, essa editora foi fundada em 1965, por Jorge Antonio Miguel Yunes e Paulo Cornado Marte, e desde então a sua principal área de atuação é a publicação de livros didáticos. Em 1980, a Ibep comprou a Companhia Editora Nacional e, desde então, os livros publicados por essa editora saem com os selos Ibep/Cia. Nacional (Hallewell, 2005).

35 Apenas pude localizar essas informações esparsas sobre Therezinha Franco Farah. Essas informações foram relatadas por ela mesma em entrevista que concedeu à Rádio Sociedade de Assistência aos Cegos de Fortaleza-CE. A entrevista que contém essas informações está disponível em áudio digital no seguinte endereço eletrônico: <http://www.sac.org.br/ Radio.HTM>. Acesso em: 26 out. 2014.

36 Presume-se que Therezinha Franco Farah tenha sido bolsista do Pabaee, no âmbito dos acordos MEC-Usaid. 
Os capítulos que compõem a primeira parte de Práticas da literatura infantil na escola primária são: "Valores do programa de literatura", "Programa de literatura infantil", "Sugestões de atividades em literatura", "Gênero da literatura", "Aplicação da literatura infantil na escola primária”, "Importância a biblioteca de classe", "Poesia", "Hinos e canções", "Planejamento de aula de côro falado", "Estórias", "Dramatização" e "Influência da literatura na dramatização infantil”.

Em cada um desses capítulos, Farah (s.d.) apresenta, no início, alguns breves parágrafos sobre o assunto de que trata e, na sequência, um plano de aula sobre a literatura infantil.

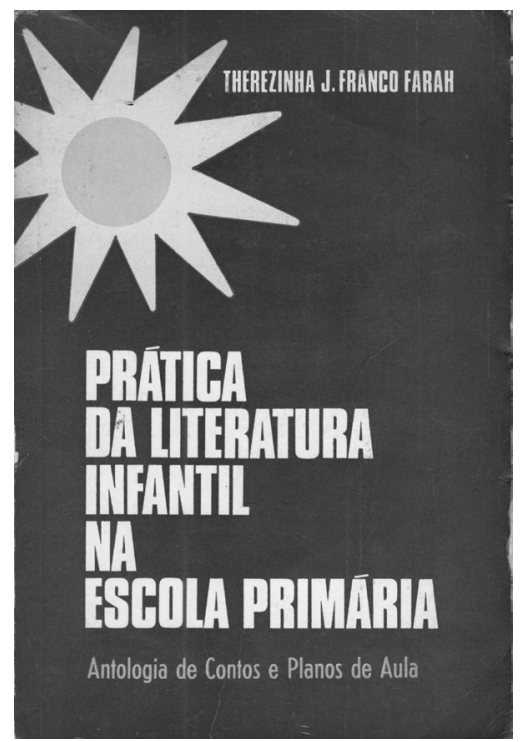

Figura 13 - Capa de Prática da literatura infantil na escola primária (s.d.), de Therezinha Franco Farah.

Fonte: Acervo do GPHELLB.

Na introdução de Práticas da literatura infantil na escola primária, Farah (s.d.) afirma que, por entender o significado e a importância dos valores morais dentro de uma sociedade, "[...] valoriza-se a importância da literatura em relação ao aspecto formativo da criança, pois o programa [que apresenta em seu manual] não aparecerá única e exclusivamente em função de doutrinar, mas sim de suscitar [...] as mais nobres emoções da criança [...]" (Faraha, s.d., p.11). Ela explica que a literatura tem como principal 
função educar, pois desperta uma série de valores latentes, atua no desenvolvimento das potencialidades psíquicas da criança, oferece "alimento" para a imaginação e desenvolve a capacidade de leitura.

Segundo Farah (s.d.), ao se elencar essas funções da literatura infantil:

[...] tem-se como objetivo tornar o professor ciente de sua responsabilidade em planejar e executar o seu programa, de tal forma que a literatura não fique relegada a segundo plano por objeções referentes a premência de tempo. Nem mesmo a deficiência e escassez de material de literatura infantil justificará a ausência desta atividade, que deverá ser iniciada desde o jardim da infância, uma vez que ficou sobejamente comprovado que uma escola sem literatura é uma escola que não vibra. (Farah, s.d., p.14)

Farah (s.d.) sugere ser necessário trabalhar na escola as mais diferentes manifestações da literatura infantil, como contos, lendas, fábulas, mitos, aventuras, poesias, baladas e canções. Ela recomenda um conjunto de atividades, entre as quais ler histórias reais e irreais, contar histórias, ouvir histórias em disco, realizar coro com poesias, fazer uma "coleção de expressões bonitas", dramatização, ilustrar poesias, fazer um livro de poesias favoritas, contar histórias pelas ilustraçõe, incentivar a criança a escrever poesia e discutir as partes do livro que mais foram apreciadas.

Para que todo esse trabalho com a literatura infantil possa ser realizado de modo satisfatório, Farah (s.d.) entende que a formação de uma biblioteca de classe é fundamental. Segundo ela, a biblioteca de classe é um cantinho da sala, onde ficam disponíveis alguns livros, para que os alunos tenham acesso facilitado. Ela explica que com a biblioteca de sala os alunos teriam tempo livre para manusear e ler alguns livros.

Para auxiliar o professor na montagem de uma biblioteca de sala, Farah (s.d.) apresenta uma relação de mais de 60 títulos de livros infantis, os quais ela classifica conforme as séries do ensino primário.

Para concluir a primeira parte de Práticas da literatura infantil na escola primária, Farah (s.d.) destaca as contribuições da literatura infantil no desenvolvimento de atividades de composição, uma vez que essas são boas atividades para promover o aprendizado da composição. 
Na segunda parte deste manual, como mencionei, apenas são transcritas 80 histórias infantis, com o propósito de que o normalista e os professores primários tivessem em mãos uma antologia útil ao ensino da literatura infantil.

Embora a parte teórica desse manual seja bastante sucinta, ao final dele consta uma bibliografia, a qual apresento no Quadro 14.

Quadro 14 - Relação de textos e respectivos autores que constam na bibliografia de Práticas da literatura infantil na escola primária (s.d.) ${ }^{37}$

\begin{tabular}{|c|c|c|c|}
\hline Título & Autor & Ano & $\begin{array}{l}\text { Editora/meio de } \\
\text { publicação }\end{array}$ \\
\hline $\begin{array}{l}\text { Experiências de } \\
\text { linguagem }\end{array}$ & Maria Ivone Atalécio Araújo & 1962 & Pabaee (MG) \\
\hline $\begin{array}{l}\text { As crianças aprendem } \\
\text { a ler }\end{array}$ & $\begin{array}{l}\text { Magdala Bacha e Luella } \\
\text { Keithan }\end{array}$ & 1960 & Pabaee (MG) \\
\hline $\begin{array}{l}\text { Surprêsas e mais } \\
\text { surprêsas }\end{array}$ & Magdala Lisboa Bacha & 1966 & Agir (RJ) \\
\hline O ensino da leitura & Magdala Lisboa Bacha & 1966 & Inep $(M G)^{37}$ \\
\hline $\begin{array}{l}\text { Como contar histórias as } \\
\text { crianças }\end{array}$ & Sara Cone Bryand & s.d. & - \\
\hline $\begin{array}{l}\text { Compêndio de literatura } \\
\text { infantil }\end{array}$ & Bárbara V. de Carvalho & 1959 & Edições Leya (SP) \\
\hline $\begin{array}{l}\text { Metodologia da } \\
\text { linguagem }\end{array}$ & Orlando Leal Carneiro & 1959 & Agir (RJ) \\
\hline As mais belas histórias & Lúcia Monteiro Casassanta & 1964 & Editora do Brasil (MG) \\
\hline $\begin{array}{l}\text { Curso de preparação de } \\
\text { evangelização para a } \\
\text { infância e juventude }\end{array}$ & - & 1967 & - \\
\hline O ensino da literatura & Nelly Novaes Coelho & 1966 & FTD (SP) \\
\hline Arte de contar cuentos & Ada Codinez & - & Editado em Havana \\
\hline A arte de contar histórias & Otilia Chaves & - & - \\
\hline $\begin{array}{l}\text { Literatura infanto- } \\
\text { juvenil }\end{array}$ & Antônio d'Ávila & 1967 & Editora do Brasil (SP) \\
\hline $\begin{array}{l}\text { La enseñanza del } \\
\text { linguage }\end{array}$ & F. Benedi Domingos & - & Labor (Barcelona) \\
\hline Literatura infantil & Terezinha Freire & 1963 & Pabaee \\
\hline Psicologia da criança & Arthur Jersilda & - & Itatiaia MG) \\
\hline
\end{tabular}

Continua

37 Embora o Inep, na década de 1960, não tivesse sua sede instalada em Minas Gerais, optei por manter a indicação desta forma, pois é assim que consta em Farah (s.d.). 


\begin{tabular}{|l|l|l|l|}
\hline $\begin{array}{l}\text { Ensinando na escola } \\
\text { primária }\end{array}$ & Hebert Klausmeier & 1964 & Fundo de Cultura \\
\hline $\begin{array}{l}\text { Las artes del lenguage en } \\
\text { la escuela primaria }\end{array}$ & $\begin{array}{l}\text { Secretaria de Educação } \\
\text { Pública - Tegucigalpa }\end{array}$ & 1960 & $\begin{array}{l}\text { Publicado em } \\
\text { Honduras }\end{array}$ \\
\hline $\begin{array}{l}\text { Linguagem na escola } \\
\text { elementar }\end{array}$ & $\begin{array}{l}\text { Instituto Nacional de Estudos } \\
\text { Pedagógicos }\end{array}$ & - & - \\
\hline $\begin{array}{l}\text { Poesia brasileira para a } \\
\text { infância }\end{array}$ & $\begin{array}{l}\text { Cassiano Nunes e Mário da } \\
\text { Silva Brito }\end{array}$ & - & - \\
\hline Poesia na escola & Alaíde Lisboa de Oliveira & 1966 & Bernardo Álvares (MG) \\
\hline
\end{tabular}

Fonte: Farah (s.d.).

Dos 20 títulos que Farah (s.d.) relacionou em sua bibliografia, apenas dois são estrangeiros. Os demais são todos de autoria de professores brasileiros. Entre esses títulos, assim como Coelho (1966), Farah (s.d.) relacionou alguns documentos do Pabaee.

Com relação a manuais, Farah (s.d.) relaciona em sua bibliografa os seguintes: Compêndio de literatura infantil (1959), de Bárbara Vasconcelos de Carvalho; Literatura infanto-juvenil (1961), de Antônio d'Ávila; e O ensino da literatura (1966), de Nelly Novaes Coelho.

\section{O discurso sobre a literatura infantil entre 1957 e 1970}

No período compreendido entre 1957 e 1970, concomitantemente à criação da disciplina "Literatura infantil", das iniciativas em torno de sua sistematização e da publicação dos manuais aqui mencionados, a produção sobre literatura infantil em formato de livros, capítulos, artigos em revistas e jornais cresceu de forma significativa em relação ao período anterior.

Indicativo do crescimento dessa produção se pode notar, por exemplo, no fato de que até 1951 tinha-se, no Brasil, apenas um livro sobre literatura infantil: Problemas da literatura infantil (1951), de Cecília Meireles. Depois de criada a disciplina "Literatura infantil", somente no período entre 1957 e 1970, conforme dados apresentados por Mortatti (2003), ${ }^{38}$ foram publica-

38 Refiro-me ao documento Ensino de Língua e Literatura no Brasil: repertório documental republicano, que resultou do Projeto Integrado de Pesquisa de mesmo nome, coordenado por Maria do Rosário Longo Mortatti, entre 1999 e 2003. Nesse documento, encontram-se reunidas 2.025 referências de textos publicados por brasileiros entre 1874 e 2002, relativamente às 
dos oito livros sobre o assunto. A saber: A literatura infantil de Monteiro Lobato, ou comunismo para crianças (1957), de Sales Brasil; O tempo e o modo (1963), de Leonardo Arroyo; Interpretação da literatura infanto-juvenil no nordeste (1960), de Paulo Rosas; Poesia na escola: orientação didática (1966), de Alaíde Lisboa de (Oliveira; Literatura infantil brasileira: ensaio de preliminares para sua história e suas fontes (1968), de Leonardo Arroyo; Criança e literatura (1968), de Tereza Casassanta; Guia dos pais na escolha de livros para crianças: útil também a professores e administradores escolares (1969), de Nancy Larrick e Alcina Jorge Almeida; e Fantasia, violência e medo na literatura infantil (1969), de Ofélia Buisson Cardoso;

Ainda de acordo com dados apresentados por Mortatti (2003), entre 1957 e 1970, foram publicados, no Brasil, dez artigos sobre literatura infantil, em diferentes periódicos da área de Educação e de Letras.

Em relação aos textos em jornais, em consulta a acervo digital d'O Estado de S. Paulo, pude localizar quase uma centena de textos sobre literatura infantil, alguns dos quais publicados no formato de notícia e outros no formato de artigos. Também no acervo digital do jornal Folha de S.Paulo, localizei, referente ao período compreendido entre 1957 e 1970, quase uma centena de textos sobre literatura infantil.

Esses dados mostram que, após a criação da disciplina "Literatura infantil”, o número de publicações nessa área cresceu bastante. Além dos manuais de ensino que aqui apresentei, outros livros, capítulos e artigos sobre literatura infantil foram produzidos nesse período, gerando o que Mello Neto (1988) denominou "primeiro surto" da produção de textos sobre esse gênero literário.

Assim como se nota nos manuais de ensino que aqui apresentei, nesses livros, artigos em periódicos e textos em jornais publicados entre 1957 e 1970, alguns conceitos da Psicologia, especialmente a psicologia do desenvolvimento de base experimental, também se constituíram como base científica em que se sustentam as argumentações em favor da literatura infantil.

Sobre esses livros, capítulos, artigos e textos que tratam da literatura infantil, publicados entre 1957 e 1970, por constituírem um volume grande

cinco linhas de pesquisa do GPHELLB. Desse total, 544 se referem à linha "Literatura infantil e juvenil”. Esse projeto foi desenvolvido com apoio e auxílio CNPq e auxílio Fapesp. 
de publicações e não serem objetos centrais de análise neste livro, optei por não apresentá-los um a um.

O único texto que optei por tratar de forma mais específica, apresentando aspectos de sua publicação e seu conteúdo, é Literatura infantil brasileira: ensaio de preliminares para sua história e suas fontes, ${ }^{39}$ de autoria de Leonardo Arroyo ${ }^{40}$ e publicado em 1968. A opção por apresentar esse livro de forma mais específica decorreu do fato de que ele foi o primeiro a propor uma história da literatura infantil brasileira exaustiva.

Até então, com objetivo de historiar aspectos da literatura infantil, havia sido publicado, no Brasil, o livro Literatura infantil (1959), de Nazira Salém. Como apresentei neste capítulo, esse livro aborda uma história da literatura infantil universal e brasileira, a fim de ser útil aos alunos dos Cursos Normais.

Também nos manuais de ensino que aqui apresentei constam, em praticamente todos eles, um ou mais capítulos sobre aspectos da história da literatura infantil brasileira. Porém, nesses manuais são apresentadas informações básicas, com objetivo apenas de dar a conhecer o que se produziu no Brasil em termos de literatura infantil.

Diferentemente do livro de Salém (1959) e dos manuais de ensino, Arroyo (1968) apresenta uma detalhada história da literatura infantil brasileira, lançando a tese de que sua origem se encontra na literatura e imprensa escolar do final do século XIX. Por essas razões, esse livro pode ser considerado o primeiro sobre história da literatura infantil brasileira, elaborado, de fato, numa perspectiva historiográfica, com base em fontes documentais e com problematizações mais amplas e consistentes sobre esse assunto. Por isso optei por apresentá-lo de forma mais detalhada.

39 Estudo detalhado sobre Arroyo e o livro Literatura infantil brasileira vem sendo desenvolvido por Vivianny Bessão de Assis, em nível de pesquisa de doutorado, sob orientação da Profa. Dra. Maria do Rosário Longo Mortatti, junto ao Programa de Pós-Graduação em Educação da FFC-Unesp-Marília. Também sobre esse autor e esse livro, ver, especialmente, Mortatti (2011), texto no qual essa doutoranda se baseia para o desenvolvimento de sua pesquisa.

40 Nascido em São José do Rio Preto-SP, em 1918, Leonardo Arroyo iniciou a atua atuação profissional em 1936, como jornalista, em sua cidade natal. Depois disso, residiu por dois anos em Santos e, em 1940, residindo em São Paulo-SP, Arroyo passou a trabalhar junto ao jornal Folha de S.Paulo. Além de jornalista, Arroyo escreveu e adaptou livros de literatura infantil, livros sobre história e cultura da cidade de São Paulo e livros de crítica e análise literária. Arroyo faleceu em 13 de agosto de 1985, aos 67 anos de idade (Assis, 2014; Melo, 1954; Coelho, 2006). 
Literatura infantil brasileira: ensaio de preliminares para sua história e suas fontes, publicado pela Edições Melhoramentos (SP), foi composto em 248 páginas, divididas em seis capítulos. Nesse livro, para cumprir o propósito de produzir uma história da literatura infantil brasileira, Arroyo (1968) tomou como base a análise de um farto conjunto de documentos, livros, revistas, informações sobre autores, escritores memorialísticos, catálogos de editoras, textos de historiadores e obras de sociólogos e folcloristas.

Com agradecimentos a Arnaldo Magalhães de Giacomo, Decio Diegoli, Francisco Marins, Leão Machado, Lourenço Filho, Otacílio de Carvalho Lopes e Lenyra Fraccaroli. Além do agradecimento a Lourenço Filho, Arroyo (1968) explica que, ao tratar de literatura infantil, entende esse conceito em seu sentido amplo, que designa qualquer publicação que se destina à criança ou que seja a ela relacionada. Nesse sentido, a literatura infantil é, antes de tudo, diversão e ludismo, para, somente depois de despertar o interesse da criança, atingir o seu segundo grau, o de educar e instruir.

Arroyo (1968) apresenta um minucioso histórico das origens e fontes da literatura infantil, desde a tradição oral até a literatura infantil "propriamente", de modo a destacar as diferentes fases pelas quais esse gênero literário passou no Brasil, até atingir o patamar de arte literária.

No processo evolutivo da literatura infantil brasileira, Arroyo (1968) destaca o importante papel desempenhado pelos "velhos negros e negras" contadores de histórias, os quais, pela oralidade, iam transmitindo para as novas gerações a forma mais remota desse gênero literário. Ele destaca a importância da literatura escolar e da imprensa escolar e infantil, de onde se constituiu a chamada literatura infantil brasileira "propriamente". Sobre esse aspecto, Arroyo (1968), assim como os autores de manuais de ensino, toma como exemplar o caso de Narizinho arrebitado, de Monteiro Lobato, que, em 1921, foi publicado como livro de leitura para o segundo ano do ensino primário e, posteriormente, passou a ser considerado o marco da "verdadeira" literatura infantil brasileira.

Sobre a atribuição desse "lugar" de destaque ao livro de Monteiro Lobato, Arroyo (1968) considera que isso decorre do fato de que nele se encontra:

[...] o apelo à imaginação em harmonia com o complexo ecológico nacional; a movimentação dos diálogos, a utilização ampla da imaginação, o enrêdo, a linguagem visual e concreta, a graça na expressão - tôda uma soma de valores 
temáticos e lingüísticos que renova inteiramente o conceito de literatura infantil no Brasil. (Arroyo, 1968, p.198)

Arroyo (1968) também problematiza o fato de não haver, à época, uma crítica especializada sobre literatura infantil, o que acarretava problemas para que esse gênero literário tivesse seu valor reconhecido.

O que se pode observar em relação ao livro de Arroyo (1968) é que, embora ele não apresente uma concepção de literatura infantil diferente da que circulava, por exemplo, nos manuais de ensino, o ineditismo do modo como ele abordou a história desse gênero literário fez com que esse livro se tornasse referência nos estudos sobre literatura infantil. Antes mesmo de Arroyo ter publicado esse livro, em 1968, Nelly Novaes Coelho, em O ensino da literatura (1966), fez menção a um texto sobre literatura infantil desse autor.

Nos manuais publicados durante a década de 1960 e que foram reeditados após a publicação do livro de Arroyo (1968), em quase todos se observa a inclusão da referência desse livro.

\section{Características do ensino da literatura infantil entre 1957 e 1970}

Tendo em vista os aspectos apresentados neste capítulo, entre 1957 e 1970, observa-se um conjunto importante de ações e iniciativas em torno da instituição da literatura infantil como disciplina e da construção de um saber escolar correspondente.

Após a reforma de 1957, que estabeleceu a criação dessa disciplina em todo o Ensino Normal paulista, as iniciativas que ocorreram no mesmo ano e nos subsequentes foram responsáveis por dar a conhecer, de modo mais ampliado, as questões sobre literatura infantil e seu ensino. Ainda que desde 1947 se observassem ações relacionadas ao ensino desse gênero literário, a criação da disciplina, em 1957, motivou ações em larga escala, que resultou em publicações e em diversas formas de disseminação do conhecimento sobre esse assunto. Com isso, entendo terem sido decisivas as iniciativas ocorridas entre 1957 e 1970, no processo de sistematização e consolidação de um saber escolar sobre a literatura infantil, no Brasil.

Logo após a promulgação da Lei que estabeleceu a criação da disciplina "Literatura infantil” (Lei n. 3.739, de 1957), a realização do I Curso Inten- 
sivo de Literatura Infantil e da I Semana de Literatura infantil demonstrou a necessidade que ainda se sentia com relação ao esclarecimento do que se compreendia por ensino da literatura infantil na formação de professores.

Essa falta de compreensão transpareceu, inclusive, em normativa do Departamento de Educação, quando foi publicado o programa emergencial para a disciplina "Literatura infantil". Na ocasião, Lourenço Filho, ao elaborar o anteprojeto de programa de ensino para a disciplina "Literatura infantil", elenca um conjunto de críticas e de erros que continha esse programa emergencial, elaborado pela Chefia do Serviço do Ensino Secundário e Normal.

Lourenço Filho, que em 1943 havia publicado o artigo "Como aperfeiçoar a literatura infantil" e como figura de destaque no campo educacional brasileiro, assumiu para si a responsabilidade de fazer sugestões para a elaboração dos programas de ensino definitivos para a disciplina "Literatura infantil”. Com isso, elaborou, ainda em 1957, o seu anteprojeto de programa para essa disciplina, o qual, como se pôde ver, foi praticamente replicado, em 1958, no Comunicado n. 18, que contém os programas do Ensino Normal.

O anteprojeto de Lourenço Filho, ainda que composto em folhas datilografadas e, depois, publicado no jornal A Gazeta, foi emblemático na definição do que se devia ensinar ao futuro professor, aluno do Curso Normal, a respeito da literatura infantil. Entendo que foi Lourenço Filho, por meio desse seu anteprojeto de programa de ensino que, de certo modo, definiu, no caso paulista, as diretrizes gerais do que se devia ensinar, sobre literatura infantil, ao futuro professor primário.

Cabe destacar que, antes de Lourenço Filho elaborar seu anteprojeto, o Distrito Federal já havia feito publicar um programa de ensino referente à disciplina "Literatura infantil", para uso no Instituto de Educação do Distrito Federal. Foi esse programa que subsidiou a elaboração dos capítulos sobre literatura infantil contidos nos manuais de Budin (1949) e Carneiro (1951).

Conforme transcreve Budin (1949), o programa da disciplina "Literatura infantil" do Instituto de educação do Distrito Federal contém seguintes prescrições:

$3^{\mathrm{a}}$. SÉRIE NORMAL

Unidade VII - LITERATURA INFANTIL 
a) Conceito de literatura infantil: seu objetivo; valor da compreensão; conclusões gerais;

b) A Literatura Infantil: finalidades didáticas; gêneros preferidos; requisitos do livro; maneira de fichá-los;

c) Relações da literatura folclórica com a literatura infantil. Os contos populares: origem, características, interpretação;

d) A literatura infantil tradicional e moderna;

e) O ensino da literatura infantil. (Rio de Janeiro apud Budin, 1949, s.p.)

Como se pode observar, ainda que esse programa apresente alguns pontos que se deviam ensinar aos futuros professores, o anteprojeto de Lourenço Filho apresenta-se de forma mais ampliada e detalhada. Além disso, alguns pontos indicados por Lourenço Filho (1957) e que foram recorrentemente abordados nos manuais não constam nesse programa do Distrito Federal. São eles: estudo das origens e do desenvolvimento desse gênero literário, desde a tradição oral até o estudo da produção literária nacional contemporânea; estudo do teatro infantil e da poesia; estudo sobre organização de bibliotecas escolares; e, principalmente, estudo sobre o "ajustamento" dos livros de literatura infantil ao desenvolvimento psicológico da criança.

Sobre esse último aspecto, cabe destacar que, com ele, Lourenço Filho (1957) fez registrar no seu anteprojeto (e depois nos programas oficiais de ensino) a marca explícita da psicologia do desenvolvimento como base das discussões sobre literatura infantil.

Apesar dessa importância do anteprojeto de Lourenço Filho (1957), cabe destacar que, se por um lado esse anteprojeto foi decisivo na definição do que se devia ensinar ao futuro professor primário, foram os manuais de ensino, publicados a partir de 1959, os responsáveis por dar corpo, substância, ou seja, "concretizar", aos pontos/conteúdos definidos por Lourenço Filho e reproduzidos nos programas oficiais de ensino.

Em relação a esse aspecto, Compêndio de literatura infantil, de autoria de Bárbara Vasconcelos de Carvalho, publicado em 1959, teve lugar destacado. Esse manual, por ter sido o primeiro do gênero publicado no Brasil, ao seguir em seus capítulos os pontos prescritos nos programas oficiais, fez que esses pontos fossem ganhando forma e consistência no formato de um saber escolar. 
A ação desempenhada pelos manuais, de "concretizar" em forma de saber escolar os pontos prescritos nos programas de ensino, foi fundamental para o campo da literatura infantil. Esses manuais, em certo sentido, acabaram por definir uma concepção de literatura, centrada na ideia de recreação e instrução, que deve atender a requisitos morais, psicológicos, sociais e didáticos, conforme as fases do desenvolvimento psíquico infantil. $\mathrm{Na}$ medida em que descreviam como deviam ser os livros que atendiam aos interesses educativos, os escritores tinham que acabar se adequando a essas descrições, caso contrário corriam o risco de seus livros não serem bem vistos ou recomendados para uso nas escolas primárias paulistas (e brasileiras).

Com isso, observa-se que os manuais publicados entre 1957 e 1970 são muito semelhantes do ponto de vista de seus conteúdos. Algumas questões são recorrentes e unânimes em todos os manuais, como: a origem da literatura infantil associada à tradição oral; a ideia de que a literatura infantil "propriamente" somente se iniciou no século XIX; a menção ao nome de Lobato (especialmente por causa de Narizinho arrebitado) como o grande escritor brasileiro não só para crianças; a categorização dos livros por faixa etária e de acordo com o desenvolvimento psíquico infantil; a definição da literatura infantil com instrumento de diversão e educação; e a associação entre literatura infantil e folclore como algo que interessa às crianças.

Em relação ao que se pode considerar como as "fontes teóricas" nas quais os autores desses manuais se ampararam, observa-se, pelas sínteses apresentadas neste capítulo, uma forte recorrência de títulos estrangeiros. Somente nos manuais publicados mais ao final da década de 1960 é que se observa que esses títulos estrangeiros foram deixando de constar nas bibliografias dos manuais.

Além disso, nota-se na bibliografia dos manuais publicados entre 1957 e 1970 que, na maior parte, os títulos indicados não se referem especificamente à literatura infantil. Tratam-se de títulos sobre ensino da leitura, da linguagem ou de outros aspectos mais amplos da educação e da Psicologia. Os únicos textos específicos sobre literatura infantil que constam em quase todas as bibliografias desses manuais são: o livro de Jesualdo, La literatura infantil (1955); e o manual de Bárbara Vasconcelos de Carvalho, Compêndio de literatura infantil (1959). 
Isso possibilita afirmar, por exemplo, que a influência do pensamento de Jesualdo Sosa foi balizadora na formulação das "concretizações" do ensino da literatura infantil no estado de São Paulo. O seu ponto de vista "psicológico" sobre a literatura infantil se tornou a principal teoria compendiada pelos autores de manuais brasileiros. Juntamente com esse livro, o manual de Bárbara Vasconcelos de Carvalho, por ter sido o primeiro a propor uma "concretização" mais aprofundada para o ensino da literatura infantil no Brasil, embora fosse um manual, também acabou "funcionando" como um livro teórico para os autores dos demais manuais publicados entre 1957 e 1970.

Um aspecto que cabe destacar sobre o conjunto das iniciativas relacionadas à literatura infantil e seu ensino, entre 1957 e 1970, é que o tom de crítica contra a chamada "má" literatura infantil, em especial aos quadrinhos e às narrativas de aventuras "gangsterianas", se arrefeceu em relação às décadas anteriores. Como se pôde ver nos capítulos anteriores, até meados da década de 1950, observava-se um forte movimento em defesa do controle e da fiscalização dos livros que eram publicados. E a principal alegação para isso eram as cenas de violência e crime representadas nos quadrinhos e em alguns tipos de narrativas de aventuras. Entendo que essa situação esteja associada ao fato de que os textos publicados até o final da década de 1940 foram produzidos no contexto da $1^{\mathrm{a}}$ e da $2^{\mathrm{a}}$ Guerras Mundiais, quando as questões da violência e dos gangsters, por exemplo, eram vistas pelos estudiosos da literatura infantil como incentivadoras da moral propícia a guerras e conflitos. No caso dos manuais publicados a partir de 1957, por se tratar de período mais distanciado da 2 a Guerra Mundial, a questão da violência ou dos "gangsters" foi relativizada, não sendo considerada prejudicial à formação moral da criança. Pelo contrário, alguns autores, como d'Ávila (1961), afirmam que livros com cenas de crime ou de violência não incitam práticas semelhantes, porque o professor iria orientar as leituras de modo que os alunos pudessem perceber a moral adequada dos livros.

Outro aspecto que cabe destacar é o relativo ao volume de iniciativas e publicações em favor do ensino da literatura infantil na formação de professores. Se até 1957 o que se tinha no Brasil destinado ao ensino da literatura infantil eram apenas os capítulos contidos nos manuais de Budin (1959), Carneiro (1951) e d'Ávila (1954), entre 1957 e 1970 passou-se a ter: cinco manuais específicos para esse ensino, um manual com capítulo também destinado a esse ensino, um livro decorrente de um curso sobre literatura 
infantil e um livro sobre história da literatura infantil adaptado aos programas do Ensino Normal.

A criação da disciplina "Literatura infantil" no Ensino Normal paulista foi motivadora de publicações nessa área, dando volume à produção nacional no campo da literatura infantil. Essa afirmação é confirmada por Mello Neto (1988), que ao fazer estudo dos textos sobre literatura infantil publicados na década de 1950 afirma que as publicações decorrentes da "ligação" da literatura infantil com a Escola Normal foram responsáveis por gerar uma vasta produção, que ele considera ter sido o primeiro "surto" de textos sobre esse gênero literário.

Nesse sentido, ainda que a legislação, sobretudo no início da década de 1960, indique certa oscilação do ensino da literatura infantil na formação de professores, é possível dizer que as ações desempenhadas entre 1957 e 1970 foram responsáveis por sistematizar e consolidar o ensino da literatura e, por conseguinte, construir um saber escolar específico sobre esse gênero literário. Foi nesta inter-relação entre a criação da disciplina, a realização de atividades em torno de seu esclarecimento, a elaboração dos programas de ensino e a publicação dos manuais de ensino que se formou todo um aparado organizado, sistematizado com relação à literatura infantil e seu ensino na formação de professores. 


\section{4 \\ O ENSINO DA LITERATURA INFANTIL E OS NOVOS MODELOS DE CURSOS DE FORMAÇÃO DE PROFESSORES: A CONSOLIDAÇÃO DE UM CAMPO DE ENSINO, ESTUDOS E PESQUISA (1971-2003)}

\section{A Habilitação Específica de $2^{\circ}$ Grau para o Magistério}

No início da década de 1970, no auge da ditadura militar brasileira, os diferentes níveis de ensino existentes no país passaram por importante reformulação. De acordo com Campos (1987), as mudanças ocorridas nesse período decorreram da crise da educação nacional no final da década de 1960, que levou o governo federal a reestruturar todo o sistema de ensino brasileiro no início dos anos 1970.

Nesse período, segundo Souza (2008), o então presidente do Brasil, Emílio Garrastazu Médici, constituiu um grupo de trabalho no âmbito do Ministério da Educação, que tinha a responsabilidade de estudar e apresentar diretrizes para reformar a educação primária, secundária e colegial do país. Dessa situação, decorreu a promulgação da Lei n. 5.692, de 11 de agosto de 1971, que "[...] foi aprovada em regime de urgência, prescindindo da discussão com a sociedade civil desmobilizada e silenciada pelo regime autoritário" (Souza, 2008, p.266).

A Lei n. 5.692, de 1971, fixou as diretrizes para o ensino de $1^{\circ}$ e $2^{\circ}$ graus, que, mais do que mudar simplesmente a nomenclatura escolar, significou mudanças importantes no ensino elementar e médio, em esfera nacional. Entre essas mudanças, destacam-se: a ampliação da escolaridade obrigatória para oito anos (ensino de $1^{\circ}$ grau), tentativa de eliminação da dualidade do sistema educacional e unificação do ensino secundário e técnico no ensino de $2^{\circ}$ grau, entre outros. 
Conforme explica Souza (2008):

[...] a mudança de nomenclatura visava a descontruir a estrutura educacional sedimentada ao longo do século XX, imprimindo uma nova orientação e substituindo os sentidos simbólicos consagrados em torno do ensino primário, secundário e técnico e suas instituições características - os grupos escolares, os ginásios, os colégios com os cursos clássicos e os científicos, os ginásios industriais etc. (p.267)

Em decorrência dessas mudanças, os cursos de formação de professores foram diretamente afetados com a promulgação da Lei n. 5.692, de 1971, pois, ao fixar novas diretrizes e bases para o antigo ensino primário e secundário, dando criação ao ensino de $1^{\circ}$ e $2^{\circ}$ graus, essa Lei tornou incompatíveis os antigos Cursos Normais com o novo modelo de educação elementar e média do país. Dessa forma, coerentemente com a fixação do ensino de $1^{\circ}$ e $2^{\circ}$ graus, a Lei n. 5.692, de 1971, estabeleceu o seguinte com relação aos cursos de formação de professores:

Art. 29. A formação de professores e especialistas para o ensino de $1^{\circ}$ e $2^{\circ}$ graus será feita em nível que se elevem progressivamente, ajustando-se as diferenças culturais de cada região do País, e com orientação que atenda aos objetivos específicos de cada grau, às características das disciplinas, áreas de estudo ou atividades e às fases de desenvolvimento dos educandos.

Art. 30 Exigir-se-á como formação mínima para o exercício do magistério:

a) no ensino de $1^{\circ}$ grau, da $1^{a}$ à $4^{a}$ séries, habilitação específica de $2^{\circ}$ grau;

b) no ensino de $1^{\circ}$ grau, da $1^{a}$ à $8^{a}$ séries, habilitação específica de grau superior, ao nível de graduação, representada por licenciatura de $1^{\circ}$ grau, obtida em curso de curta duração;

c) em todo o ensino de $1^{\circ}$ e $2^{\circ}$ graus, habilitação específica obtida em curso superior de graduação correspondente a licenciatura plena. (Brasil, 1971, s.p.)

Com essas alterações, a Lei n. 5.692, de 1971, foi responsável pela extinção do Ensino Normal em todo o país e, consecutivamente, com a extinção das antigas Escolas Normais e Institutos de Educação. Essas instituições foram, gradativamente, sendo transformadas em escolas de $1^{\circ}$ e $2^{\circ}$ 
graus e o Ensino Normal foi substituído pelo Ensino de $2^{\circ}$ grau, de caráter profissionalizante.

No caso do estado de São Paulo, a adequação à Lei n. 5.692, de 1971, iniciou-se apenas em 1974, com a Deliberação CEE n. 20, que estabeleceu a instalação da HEM com duração de quatro anos. Em 1975, o então Departamento de Ensino Secundário e Normal do estado de São Paulo publicou o Comunicado n. 4, de 21 de janeiro, no qual constam as sugestões de currículo para a HEM.

De acordo com Gatti e Rovai (1977, p.10), “[...] enquanto não se implantou [no estado de São Paulo] a Lei n ${ }^{\circ} 5.692$, continuou vigorando, em termos curriculares, para a rede oficial de ensino, a organização prevista pela Resolução CEE n. 36/68”.

Com o Comunicado n. 4, de 1975, o currículo da HEM ficou organizado em duas áreas: "Educação Geral" e "Formação Especial Predominantemente sobre a Educação". As disciplinas relativas à área "Educação Geral" eram organizadas em: "Núcleo comum", definidas conforme Resolução 8/71, do Conselho Federal de Educação (CFE); e as estabelecidas pelo artigo $7^{\circ}$, da Lei n. 5.692, de 1971. A área "Formação Especial Predominantemente sobre a Educação" era organizada em: "Mínimos profissionalizantes", que se subdivide em "Fundamentos da educação", "Didática" e "Parte diversificada".

As disciplinas do "Núcleo comum" dos currículos da HEM, definidas conforme a Resolução CFE n. 8/71 eram as seguintes: "Língua portuguesa", "História”, "Geografia”, "OSP.B", "Matemática", "Ciências físicas e biológicas” (São Paulo, 1975).

As disciplinas do "Núcleo comum" dos currículos da HEM, estabelecidas pelo artigo $7^{\circ}$, da Lei n. 5.692, de 1971, eram: "Educação artística", "Educação física", "Educação moral e cívica", "Programas de saúde" e "Ensino religioso” (São Paulo, 1975).

As disciplinas estabelecidas para o currículo da HEM como "Mínimo profissionalizante", da parte "Fundamentos da educação", eram: "Psicologia aplicada à educação", "Sociologia aplicada à educação", "História da educação e educação brasileira", "Filosofia da Educação", "Biologia aplica-

1 A disciplina "Organização Social e Política do Brasil” aparece nos documentos oficiais como "OSPB". 
da à educação". As disciplinas estabelecidas para o currículo da HEM como "Mínimo profissionalizante", da parte "Didática”, eram "Metodologia do ensino", "Prática do ensino" e "Estrutura e funcionamento do ensino de $1^{\circ}$ grau” (São Paulo, 1975).

As disciplinas da parte "Diversificada" do currículo da HEM, estabelecidas pela Deliberação 18/72, do Conselho Estadual de Educação de São Paulo (CEE) eram "Psicologia”, "Sociologia", "Técnicas de avaliação do rendimento escolar", "Estatística aplicada", "Recreação e jogos" e "Técnicas audiovisuais de educação" (São Paulo, 1975). E as disciplinas da parte "Diversificada" do currículo da HEM, estabelecidas pelo Parecer 45/72, do Conselho Federal de Educação CFE), eram "Estudos sociais", "Redação e expressão", "Matemática aplicada" e "Língua portuguesa e literatura infantil” (São Paulo, 1975).

Como se pode observar, a disciplina "Língua portuguesa e literatura infantil" passou a integrar o conjunto das disciplinas da "Parte diversificada" do currículo, estabelecido pelo Conselho Federal de Educação. Isso possibilita presumir que, além do estado de São Paulo, outros estados passaram a oferecer essa disciplina na formação de professores.

Ainda em relação ao currículo estabelecido para a HEM, Gatti e Rovai (1977) consideram que, “[...] afora algumas modificações de nomenclatura de disciplinas, tem o mesmo elenco recomendado para as escolas normais em 1957 [...]” (p.11). Segundo elas, essa reorganização não implicou grandes mudanças no modo como o currículo já havia sido definido na "Reforma de 1968" (Gatti; Rovai, 1977).

Especificamente sobre a disciplina "Língua portuguesa e literatura infantil”, ficou sugerido pelo Comunicado n. 4, de 1975, que ela comporia a grade curricular da $3^{\mathrm{a}}$ e $4^{\mathrm{a}}$ séries da HEM, com carga horária de duas horas-aulas semanais.

Em continuidade à implantação da HEM, em 1976, foi promulgada a Deliberação CEE n. 21, que instituiu na HEM paulista o "aprofundamento de estudos", reservado à 4 a série dessa habilitação. De acordo com essa Deliberação, os aprofundamentos se organizavam da seguinte forma:

Artigo $7^{\circ}-\mathrm{Na}$ quarta série, o currículo será organizado de forma a permitir a opção do aluno por uma das seguintes áreas:

a) Ensino de $1^{\mathrm{a}}$ e $2^{\mathrm{a}}$ séries do $1^{\circ}$ grau; 
b) Ensino de $3^{\mathrm{a}}$ e $4^{\mathrm{a}}$ séries, do $1^{\mathrm{o}}$ grau;

c) Magistério na pré-escola. (São Paulo, 1979, p.200)

Mesmo com esse conjunto de ações para implantação da HEM em São Paulo, Leite e Savi (1980) afirmam que "[...] constatou-se [à época], a insuficiência dos sistemas de ensino para instalarem e manterem as habilitações profissionais” (p.7). Por isso, em 1987, na Indicação CEE n. 15/87, o relator do Conselho Estadual de Educação, Arthur Fonseca Filho, fez a seguinte observação:

Já se tornou lugar comum criticar a formação de professores das séries iniciais do $1^{\circ}$ grau. Os meios de comunicação estão repletos dessas críticas, principalmente no período que sucede à realização de concursos públicos a que esses profissionais se candidatam. [...] Há um consenso de que a escola vem habilitando professores sem as condições para assumir as relevantes funções de ensinar as crianças, sem que estejam em condições de realizar a tarefa. E a culpa, conforme se acredita, é da estrutura sobre a qual se assenta essa habilitação de $2^{\circ}$ Grau.

A Secretaria de Educação do Estado de São Paulo, juntando-se a essas críticas, através do Ofício GS 5.710/85 de 11/9/85, encaminha expediente da CENP, com proposta para Reformulação da Habilitação Específica de $2^{\circ}$ grau para o Magistério. (São Paulo, 1987, s.p.)

Ainda em 1987, a HEM passou por uma reformulação no estado de São Paulo, por meio da Deliberação CEE n. 30/87. O currículo dessa habilitação passou a ser organizado em "Parte Comum" e "Parte diversificada". Na "Parte Comum", não houve alterações das disciplinas fixadas. $\mathrm{Na}$ "Parte diversificada", foi estabelecido que algumas disciplinas podiam ser de escolha das próprias escolas, visando atender às necessidades específicas da formação dos professores de cada localidade. Por ser a disciplina "Literatura infantil" integrante da "Parte diversifica" do currículo, a sua inserção na HEM ficou a critério de cada instituição que oferecia esse curso.

Pelas matrizes curriculares ${ }^{2}$ a que tive acesso, pude observar que a disciplina "Literatura infantil" continuou a ser ministrada até, pelo menos,

2 A partir da década de 1970, os documentos nos quais consta a indicação de cada disciplina que compunha o currículo da HEM e a respectiva carga horária de cada disciplina recebera a denominação "Matrizes curriculares". 
1995, em diferentes cidades do estado de São Paulo, como Araraquara, Tupã, Botucatu, Rio Claro e Jaú.

A HEM se manteve em funcionamento no estado de São Paulo até meados da década de 1990, quando, gradativamente, foi extinta. O fechamento definitivo da HEM se deu a partir de 1996, quando foi promulgada a Lei de Diretrizes e Bases da Educação Nacional, Lei n. 9.394, de 20 de dezembro de 1996, que reorganizou todo o sistema de ensino brasileiro, fixando: o Ensino Fundamental, de oito anos, em substituição ao Ensino de $1^{\circ} \mathrm{Grau}$; e o Ensino Médio, de três anos, em substituição ao Ensino de $2^{\circ}$ grau.

\section{Prescrições para o ensino da literatura infantil na HEM}

Em decorrência da implantação da HEM no estado de São Paulo, a Coordenadoria de Estudos e Normas Pedagógicas do Estado de São Paulo (Cenp), ${ }^{3}$ órgão vinculado à Secretaria de Estado da Educação e responsável pela elaboração de documentos relativos ao currículo, publicou, no ano de 1981, o documento Habilitação Específica de $2^{\circ}$ Grau para o Magistério: guias curriculares para a parte diversificada da formação especial. Nesse documento, a Cenp apresenta as sugestões metodológicas relativas às disciplinas "Estatística Aplicada", "Técnicas de Avaliação do rendimento escolar" e "Literatura infantil".

Em relação à disciplina "Literatura infantil", o guia curricular foi elaborado pela professora Zélia de Almeida Cardoso, ${ }^{4}$ com o objetivo de apresentar "[...] sugestões para a elaboração de um planejamento de curso que [...] serão úteis para o desenvolvimento desse componente curricular” (São Paulo, 1981, p.9). Esse guia compreende 23 páginas, de um total de 54, e está organizado em: introdução, objetivos, conteúdos programáticos, pro-

3 No ano de 1976, foi promulgado, no estado de São Paulo, o Decreto n. 7.510, de 1976, que reorganizou a Secretaria de Estado da Educação. A partir dessa reorganização, passou a constar no organograma da Secretaria a criação da Coordenadoria de Estudos e Normas Pedagógicas (Cenp) como órgão responsável por elaborar, executar e normatizar os currículos. Além disso, era função da Cenp desenvolver estudos para melhoria dos materiais metodológicos.

4 Zélia de Almeida Cardoso nasceu em julho de 1934, graduou-se em Letras Clássicas em 1957, pela Universidade de São Paulo (USP), doutorou-se também em Letras Clássicas em 1976 e obteve o título de Livre-docente em Literatura Latina em 1984. Desde 1976 atua como professora do curso de Letras da USP, na área de literatura latina. 
cedimentos, sugestões para a elaboração de um plano de ensino de literatura infantil, sugestões para elaboração de um cronograma, sugestões para o planejamento de pesquisa programada para o primeiro bimestre, sugestões para a escolha de textos teóricos que poderão ser lidos pelos alunos para posterior análise, sugestões para a escolha de textos literários infantis que poderão ser recomendados e analisados em curso de literatura infantil e sugestões bibliográficas.

Diferentemente de como eram organizados os antigos programas do Ensino Normal, os guias curriculares são mais amplos, pormenorizados e diretivos no que se refere à organização de cada disciplina da HEM. Nos programas do Ensino Normal o habitual era apenas conter a indicação dos pontos a serem estudados ao longo de um ano letivo em cada matéria/disciplina, ao passo que os guias curriculares prescrevem, desde os objetivos de cada disciplina, até os procedimentos metodológicos e bibliografia a serem adotados pelos professores.

De acordo com o guia curricular para a disciplina "Literatura infantil", a justificativa para a inserção dessa disciplina no currículo da HEM se relaciona ao fato de que os professores, ao longo de sua atuação, tinham a seu cargo a formação da criança rodeada pelos meios de comunicação e pelos "afazeres" e "entretenimentos", os quais a "desviam" do estudo escolar. Explica-se que por ser o livro escolar, à época, um mero objeto dos trabalhos escolares, o ensino da literatura infantil na HEM se justificava pela necessidade de preparar os professores para ampliar a "força educativa" do livro.

Conhecendo o essencial sobre a importância da literatura para a infância, sobre a motivação que sempre levou o adulto a despertar nas crianças o gosto pela leitura, sobre a atualidade nacional e mundial, em termos de livros infantis e sobre os requisitos fundamentais das obras literárias para crianças, o professorando, que se prepara para exercer o magistério na pré-escola e nas quatro primeiras séries do primeiro grau, estará em condições de desenvolver, nas crianças, hábitos de leitura que poderão acompanhá-las por toda a vida. Tem essa finalidade o programa proposto. (São Paulo, 1981, p.31-32)

Com base nessas justificativas e finalidade do ensino da literatura infantil, são apresentados os objetivos da disciplina "Literatura infantil": refletir sobre o conceito de literatura infantil; problematizar as funções da literatu- 
ra infantil; dar informações a respeito dos gêneros literários mais usuais na literatura infantil; apresentar um panorama da literatura infantil, no Brasil e no mundo; apresentar os requisitos exigidos num livro de literatura infantil; e dar condições para que o professor possa analisar e criticar os livros de literatura infantil (São Paulo, 1981).

Para a consecução desses objetivos, os conteúdos programáticos ${ }^{5}$ definidos para a disciplina "Literatura infantil" se organizam em quatro unidades. Na "Unidade I", intitulada "A literatura infantil: conceito e função; os gêneros literários e a criança”, prescrevem-se os seguintes conteúdos:

\subsection{Conceito de literatura infantil}

1.1.1 O conceito de literatura e a literatura infantil.

1.1.2 A natureza da obra literária para crianças: elementos essenciais do texto; adequação do texto à faixa etária da criança; elaboração estética do texto.

1.1.3 Formas embrionárias da literatura infantil; a literatura oral; a literatura infantil e o folclore.

1.2 Função da literatura infantil.

1.2.1 A função estética do texto literário

1.2.2 As funções subsidiárias da literatura infantil: função didático-informativa; função moralizante; função lúdica.

1.3 Os gêneros literários e a infância.

1.3.1 A poesia vinculada à música (cantigas de embalar e de roda, cantigas infantis, canções folclóricas e populares, hinos escolares e patrióticos); a poesia infantil propriamente dita.

1.3.2 A narrativa infantil: características.

1.3.3 $\mathrm{O}$ teatro infantil: características.

1.3.4 A integração texto-imagem em formas mistas de narrativa para a infância. (São Paulo, 1981, p.33)

$\mathrm{Na}$ "Unidade II", intitulada "História da literatura infantil", prescrevem-se os seguintes conteúdos:

5 Em substituição ao termo "pontos", que designava quais eram os assuntos a serem tratados e desenvolvidos no âmbito de uma disciplina, os documentos da HEM passaram a utilizar a expressão "conteúdo programático". 
2.1 O acesso da criança ao texto literário na antigüidade e na Idade Média.

2.2 A literatura infantil nos séculos XVI, XVII e XVIII.

2.2.1 A obra de Perrault.

2.2.2 Rousseau e a literatura infantil.

2.2.3 A pseudo-literatura infantil de Swift e Defoe.

2.3 A literatura infantil no século XIX

2.3.1 Os contos de fada: Andersen Grimm.

2.3.2 Literatura surrealista e ficção científica: Lewis Carrol e Júlio Verne.

2.4 A literatura infantil no século XX.

2.4.1 Novas experiências na elaboração do texto. As revistas infantis.

2.4.2 O livro e o desenvolvimento tecnológico: o disco, o rádio, o cinema e a televisão a serviço da literatura infantil. (São Paulo, 1981, p.33-34)

$\mathrm{Na}$ "Unidade III", intitulada "A literatura infantil no Brasil", prescrevem-se os seguintes conteúdos:

3.1 Nascimento e desenvolvimento da literatura infantil no Brasil.

3.2 Os "pioneiros" da literatura infantil: Alberto Figueiredo Pimentel, Olavo Bilac, Coelho Neto.

3.3 O mundo literário brasileiro e a literatura infantil: as obras infantis de Manuel Bandeira, Menotti Del Picchia, Guilherme de Almeida, José Lins do Rego, Jorge Amado, Érico Veríssimo, Clarice Lispector, Cecília Meireles, Vinícius de Moraes, Correia Júnior, Osman Lins, Francisco Marins.

3.5 Autores especializados em literatura infantil.

3.5.1 A poesia de Zalina Rolim e Estórgio Wanderley.

3.5.2 A narrativa de Thales Castanho de Andrade, Ofélia e Nerbal Fontes, Lúcia Machado de Almeida, Gondim da Fonseca, Malba Tahan, Viriato Correia e outros.

3.5.3 O teatro de Maria Clara Machado.

3.6 A literatura infantil brasileira na atualidade: polêmica e perspectivas. (São Paulo, 1981, p.34).

$\mathrm{Na}$ "Unidade IV", intitulada "A literatura infantil e a criança brasileira”, prescrevem-se os seguintes conteúdos: 
4.1 Características da criança brasileira.

4.2 $\mathrm{O}$ acesso da criança às formas auditivas e verbovisuais de comunicação de massa: o rádio e o disco; o cinema e a televisão; as revistas.

4.3 O livro infantil no Brasil

4.3.1 O livro didático e o livro recreativo.

4.3.2 Aspecto material do livro infantil: formato, encadernação, paginação, ilustração, colorido, configuração tipográfica.

4.3.3 Aspecto literário do livro infantil: conteúdo e linguagem.

4.4 Bibliotecas escolares e bibliotecas infantis.

4.4.1 Organização

4.4.2 Programação de atividades. (São Paulo, 1981, p.34-35)

Como "procedimentos" para o desenvolvimento desses conteúdos programáticos, recomenda-se que o professor tome cuidado para não realizar aulas apenas expositivas. $\mathrm{O}$ ideal era que "[...] as aulas assumissem a forma de diálogo ou discussão, tomando-se como ponto de partida o conhecimento do próprio aluno” (São Paulo, 1981, p.35).

Ainda como "procedimentos", além das aulas no formato de diálogo ou discussão, recomenda-se que o professor adote outras estratégias, como: exposição oral feita por alunos ou por grupos de trabalhos, debates, seminários, painéis, júris, análise de livros, realização de atividades "extraclasse" e participação em palestras e peças teatrais.

Também é apresentado nesse guia curricular um conjunto de sugestões para a elaboração de um plano de ensino de literatura infantil, a elaboração de um cronograma de trabalho e o desenvolvimento de pesquisa, como atividade prática das aulas sobre literatura infantil.

A fim de subsidiar as aulas de literatura infantil e as discussões que nela se preveem, são apresentadas nesse guia a relação de "[...] textos teóricos que poderão ser lidos pelos alunos para posterior análise em classe" (São Paulo, 1981, p.47). A sugestão desses textos está organizada por 16 “assuntos”, os quais correspondem aos aspectos a serem estudados, conforme os conteúdos programáticos prescritos nesse guia curricular. Os livros sugeridos para esses 16 "assuntos" são: Problemas da literatura infantil (1951), de Cecília Meireles; Compêndio de literatura infantil (1959), de Bárbara Vasconcelos de Carvalho; Curso de literatura infantil ([1958]), de Antenor 
Santos de Oliveira; A literatura infantil (1978), de Jesualdo Sosa; e A literatura e o rádio (1956), de C. Holzamer.

Para cada "assunto", é recomendada a leitura de parte desses livros ou, em algumas situações, a leitura na íntegra.

Além dos livros "teóricos", são sugeridos livros de literatura infantil, que poderão ser objeto de análise no que se refere às atividades práticas.

Para concluir, esse guia curricular contém as sugestões bibliográficas, divididas em "Bibliografia básica" e "Bibliografia complementar". $\mathrm{Na}$ "Bibliografia básica", são indicados os seguintes livros: Compêndio de literatura infantil (1959), de Bárbara Vasconcelos de Carvalho; Literatura infantil: história, teoria e análise (1981), de Nelly Novaes Coelho; A literatura infantil (1978), de Jesualdo Sosa; e Curso de literatura infantil (1958), organizado por Antenor Santos de Oliveira.

$\mathrm{Na}$ "Bibliografia complementar", são indicados 22 textos, que apresento no Quadro 15.

Quadro 15 - Relação de textos e respectivos autores que constam na "Bibliografia complementar" do documento Habilitação específica de $2^{\circ}$ grau para o magistério: guias curriculares para a parte diversificada do currículo (1981)

\begin{tabular}{|l|l|l|l|}
\hline Título & Autor & Ano & Editora \\
\hline Evolução mental da criança & Hans Aebli & 1975 & Vozes (RJ) \\
\hline $\begin{array}{l}\text { Criança é criança: literatura } \\
\text { infantil e seus problemas }\end{array}$ & Maria Lúcia Amaral & 1975 & Vozes (RJ) \\
\hline História em quadrinhos & $\begin{array}{l}\text { Zilda Augusto } \\
\text { Anselmo }\end{array}$ & 1976 & Vozes (RJ) \\
\hline $\begin{array}{l}\text { "A nova função do livro } \\
\text { escolar" (In: A educação e } \\
\text { seus problemas) }\end{array}$ & $\begin{array}{l}\text { Fernando de } \\
\text { Azevedo }\end{array}$ & 1953 & Melhoramentos (SP) \\
\hline $\begin{array}{l}\text { "A renovação educacional e } \\
\text { o livro" }\end{array}$ & $\begin{array}{l}\text { Fernando de } \\
\text { Azevedo }\end{array}$ & 1953 & Melhoramentos (SP) \\
\hline $\begin{array}{l}\text { "As bibliotecas e os } \\
\text { laboratórios" }\end{array}$ & $\begin{array}{l}\text { Fernando de } \\
\text { Azevedo }\end{array}$ & 1953 & Melhoramentos (SP) \\
\hline Histórias e lendas & J. P. Bayard & 1957 & $\begin{array}{l}\text { Difusão Europeia do Livro } \\
\text { (SP) }\end{array}$ \\
\hline $\begin{array}{l}\text { A psicanálise dos contos de } \\
\text { fadas }\end{array}$ & Bruno Bettelheim & 1979 & Terra e Paz (RJ) \\
\hline El arte y el niño & M. Braunschvig & 1914 & s.n. (Madri) \\
\hline A linguagem dos quadrinhos & Moacy Cirne & 1971 & Vozes (RJ) \\
\hline
\end{tabular}




\begin{tabular}{|l|l|l|l|}
\hline Para ler o quadrinho & Moacy Cirne & 1975 & Vozes (RJ) \\
\hline $\begin{array}{l}\text { Como se organiza e se } \\
\text { administra uma biblioteca }\end{array}$ & M. N. A. Floresi & 1951 & $\begin{array}{l}\text { Companhia Editora Nacional } \\
\text { (SP) }\end{array}$ \\
\hline $\begin{array}{l}\text { Como incentivar o hábito de } \\
\text { leitura }\end{array}$ & Cypriano Guariglia & 1975 & Cultrix (SP) \\
\hline A criança e o rádio & C. Holzamer & 1956 & Paulinas (SP) \\
\hline O livro na educação & A. Kruger & 1956 & Paulinas (SP) \\
\hline $\begin{array}{l}\text { Literatura oral para infância e } \\
\text { juventude }\end{array}$ & Henriqueta Lisboa & 1968 & Cultrix (SP) \\
\hline $\begin{array}{l}\text { Poesia para infância e } \\
\text { juventude }\end{array}$ & Henriqueta Lisboa & s.d. & Ed. Ouro (SP) \\
\hline Teatro na escola & Olga Obry & s.d. & Melhoramentos (SP) \\
\hline Arte de ler e contar histórias & Malba Tahan & 1966 & Conquista (RJ) \\
\hline $\begin{array}{l}\text { Histoire de la litterature } \\
\text { enfantine }\end{array}$ & Jean de Trigon & 1950 & Hachette (Paris) \\
\hline $\begin{array}{l}\text { Library Service for Children } \\
\text { Los juegos de los niños }\end{array}$ & E. L. Power & 1930 & $\begin{array}{l}\text { American Library } \\
\text { Association (Chicago) }\end{array}$ \\
\hline
\end{tabular}

Fonte: São Paulo (1981).

Como se pode observar no Quadro 15, embora a bibliografia complementar indicada nesse guia curricular apresente textos que indiquem proximidade com a concepção de ensino de literatura infantil disseminada no Ensino Normal, alguns textos dão indícios da incorporação de novas perspectivas, não necessariamente opostas às que se tinham. Esseé o caso, por exemplo, da apropriação das contribuições da Psicanálise nos estudos sobre literatura infantil.

De qualquer modo, na bibliografia complementar desse guia curricular permanecem livros que se referem aos temas que se haviam tornado recorrentes nos estudos sobre literatura infantil na formação de professores, tais como: poesia e teatro infantil; desenvolvimento mental/psicológico da criança; contação de histórias; quadrinhos; e organização de bibliotecas escolares/infantis.

\section{Os planos para o ensino da literatura infantil elaborados por professores da HEM}

Ainda no âmbito das mudanças ocorridas em decorrência da implantação da HEM no estado de São Paulo, a partir da década de 1970, com a extinção do Ensino Normal e, consequentemente, toda a legislação que o 
regulamentava, esse novo modelo de formação de professores passou a ter como uma de suas características a orientação de que os professores elaborassem seus planos de ensino, a fim projetar o trabalho a ser desenvolvido ao longo do ano letivo.

Foi por essa razão que, no início da década de 1980, os órgãos oficiais ligados à Secretaria de Estado da Educação de São Paulo se empenharam na elaboração dos guias curriculares, visando orientar os professores na preparação de seus planos de ensino.

Esses planos de ensino, resultantes do processo de planejamento escolar, organizam-se, geralmente, em objetivos, conteúdos programáticos, procedimentos metodológicos, avaliação e bibliografia. Por serem um tipo de documento que se caracteriza pelo uso pessoal, elaborado pelo próprio professor, esses planos de ensino não circulavam, o que incorreu na sua pouca preservação nas escolas.

Apesar disso, tive acesso a alguns planos relativos à disciplina "Literatura infantil”, que foram elaborados entre as décadas de 1970 e 1990.

No período relativo à década de 1970, tive acesso a dois planos de ensino, ambos elaborados para o ano letivo de 1975, para uso no ainda denominado Instituto de Educação “Álvaro Guião”, em São Carlos-SP.

O primeiro desses planos data de 20 de março de 1975 e foi elaborado pela professora Maria Carolina Loureiro. Ele refere-se à $3^{\mathrm{a}}$ série da disciplina "Português", do "Curso Normal"'.

Com relação aos objetivos, conteúdos programáticos, procedimentos e avaliação indicados nesse plano, todos estão divididos em três partes: gramática, literatura infantil e redação e ortografia. Na parte específica sobre literatura infantil, consta o seguinte:

\section{II - LITERATURA INFANTIL \\ OBJETIVOS EDUCACIONAIS}

- o aluno deverá adquirir condições para orientar leituras nas séries iniciais do $1^{\circ}$ grau;

- o aluno deverá adquirir condições para orientação e direção de grupos para dramatização infantil, declamação, coros falados;

OBJETIVOS OPERACIONAIS

6 Mantive a denominação "Curso Normal”, porque é assim que consta nesse plano de ensino. 
- conceituar literatura infantil.

- determinar as origens da literatura infantil.

- caracterizar a literatura infantil.

- enumerar os iniciadores e os grandes vultos da literatura infantil mundial.

- ler obras expressivas da literatura infantil.

CONTEÚDO

$1^{\circ}$ PERÍODO

- conceito de literatura infantil;

- origem da literatura infantil. A tradição oral.

- origem histórica da literatura infantil.

$2^{\circ}$ PERÍODO

- a literatura infantil intencionalmente infantil - Perrault, Fénelon, La Fontaine.

$3^{\circ}$ PERÍODO

- a literatura infantil do séc. XIX - Hans Christian Andersen, Grimm; $4^{\circ}$ PERÍODO

- a literatura infantil do séc. XIX aos nossos dias: Collodi, Edmondo de Amicis, Charles Dickens, Matheu Barrie, Lewis Carrol, Mark Tuvon, Antoine Exupéry, Júlio Verne.

ESTRATÉGIAS

- Pesquisa individual do aluno sob orientação do professor;

- Exposição do professor;

- Trabalho em equipe;

- Estudo dirigido;

- Atividades extra-classe: leitura e análise de livros infantis

AVALIAÇÃO

- provas objetivas e subjetivas.

- seminários.

- trabalhos em grupo. (Loureiro, 1975, f. 3-4)

Ainda que a forma de organização dos planos de ensino seja diferente dos documentos que até então prescreviam o ensino da literatura infantil, em comparação aos pontos que se prescreviam nos programas do Ensino Normal, esse plano não apresenta mudanças. Permaneceram os assuntos até então recorrentes no ensino da literatura infantil, como aspectos da origem e desenvolvimento desse gênero literário e sua conceituação. 
Também com data de 1975, localizei o plano datado de 24 de março, de autoria das professoras Heleny Catharina Fraige Acujaro e Rosa Jorge Batarce. Conforme consta nesse plano, ele se refere à disciplina "Português", do $4^{\circ}$ ano do curso de "Educação". ${ }^{7}$

Assim como no plano anterior, esse também tem os elementos que o compõem (objetivos, conteúdos programáticos, estratégias e avaliação) divididos em três partes: gramática, literatura infantil e a redação e ortografia. Na parte específica sobre literatura infantil, consta o seguinte:

B - LITERATURA INFANTIL

B1 - OBJETIVOS EDUCACIONAIS

- O aluno deverá adquirir condições para orientar leituras nas séries iniciais do $1^{\circ}$ grau;

O aluno deverá adquirir condições para orientação e direção de grupos para dramatização infantil, declamação, coros falados;

B2 - OBJETIVOS INSTRUCIONAIS

- Enumerar os iniciadores e precursores da literatura infantil no Brasil;

- Caracterizar a obra de Monteiro Lobato, grande vulto da literatura infantil brasileira;

- Caracterizar a poesia infantil;

- Caracterizar o teatro para crianças;

- Enumerar os requisitos necessários para uma boa obra infantil.

- B3 - CONTEÚDO

- A literatura infantil no Brasil-precursores;

- Literatura infantil no Brasil: século XX-Monteiro Lobato;

- A poesia na literatura infantil;

- Publicações: revistas infantis;

- Requisitos literários, morais, psicológicos e materiais do livro de literatura infantil;

- Finalidades didáticas, psicológicas, sociais e morais da literatura infanto-juvenil.

B4 - ESTRATÉGIAS

- Pesquisa individual do aluno sob orientação do professor;

7 Mantive a denominação "Educação", conforme consta no documento, para referir-me ao curso de formação de professores do Instituto de Educação Álvaro Guião. 
- Exposição do professor;

- Trabalho em equipe;

- Estudo dirigido;

- Atividades extra-classe: leitura e análise de obras de escritores da literatura infantil (Acujaro; Barce, 1975, f. 2).

Embora organizado de forma idêntica ao outro plano, esse plano, por se referir à série seguinte do curso de formação de professores do Instituto de Educação Álvaro Guião - $4^{\mathrm{a}}$. série -, contém a indicação de um conteúdo programático que sugere a ideia de continuidade em relação ao plano anterior. No primeiro plano, os conteúdos indicados se referem a aspectos da origem, desenvolvimento e conceituação da literatura infantil. Nesse, os conteúdos indicados são: poesia, teatro, revistas, requisitos (literários, morais, psicológicos e materiais) e finalidades (didáticas, psicológicas, sociais e morais) da literatura infantil.

Essa divisão do ensino da literatura infantil nas $3^{\mathrm{a}}$ e $4^{\mathrm{a}}$ séries dos cursos de formação de professores, conforme se observa nesses planos, decorre do fato de que, em 1975, quando a HEM foi implantada em São Paulo, a legislação previa que a disciplina "Português e literatura infantil" fosse ministrada nessas duas séries.

Em vista desses aspectos, pode-se afirmar que, embora a HEM estivesse sendo implantada no estado de São Paulo quando esses planos foram elaborados, não se nota nenhuma mudança expressiva no que se consideravam aos conteúdos/pontos relativos ao ensino da literatura infantil. A única mudança ocorrida foi que o conteúdo que antes era reservado em disciplina "Literatura infantil" de uma única série dos Cursos Normais ( $3^{\mathrm{a}}$ ou $4^{\mathrm{a}}$ série), na década de 1970, na HEM, passou a ser dividido em duas séries.

Outro aspecto que se observa em relação a esses dois planos de 1975 é que eles não coincidem com relação à denominação do curso a que se referem. Sobre isso, penso que a explicação esteja no fato de que a implantação da HEM no estado de São Paulo era ainda recente nesse período. A implantação desse modelo de formação de professores se iniciou no estado de São Paulo apenas em 1974, de modo que a sugestão de currículo para a HEM foi publicada apenas em 31 de janeiro de 1975.

Além desses dois planos da década de 1970, localizei outros dois planos de ensino referentes à década de 1980. Em relação ao período de elaboração 
desses outros dois planos, cabe destacar que eles se referem a um momento histórico em que a HEM já estava implantada no estado de São Paulo, de modo que a Cenp havia publicado os guias curriculares para todas as disciplinas que compunham o currículo da HEM.

Os planos referentes à década de 1980, que localizei, elaborados, um, em 1983, e outro, em 1989, ambos para o $4^{\circ}$ ano da HEM da Escola Estadual de Primeiro e Segundo Graus (EEPSG) Índia Vanuíre, da cidade de Tupã-SP.

O plano de ensino de 1983 é de autoria da professora Maria Irene Andrade Adário e se refere à disciplina "Português e literatura infantil". Nesse plano, descreve-se que o objetivo, estabelecido o ensino da língua portuguesa e da literatura infantil, consiste em "[...] exprimir corretamente o pensamento quer falando quer escrevendo” (Adário, 1983, f.1). Em relação ao conteúdo programático, não consta uma divisão para as questões sobre língua portuguesa e sobre literatura infantil, de modo que ambas são apresentadas conjuntamente. Os conteúdos previstos nesse plano eram os seguintes:

\section{CONTEÚDOS}

- conceito de literatura;

- importância da literatura na expressão escrita e linguagem oral;

- critérios que devem ser observados, na seleção das obras literárias, para crianças;

- fases da evolução do interesse infantil;

- Influência da literatura infantil na educação da criança;

- características indispensáveis às obras infantis;

- acentuação gráfica;

- Crase;

- Emprego do pronome "se";

- figura de sintaxe;

- emprego dos verbos haver fazer, ser, parecer;

- semântica: significante e significado, família de idéias, sinonímia, antonímia, homonímia, paronímia, palavras em sentido denotativo e conotativo, linguagem denotativa e conotativa, polissemia. ;

- estilística: figuras de palavras - metáfora, metonímia - catacrese, perífrase, comparação, figuras de construção: elipse, zeugma, pleonasmo, anaco- 
luto, polissíndeto, repetição, inversão, silepse, figuras de pensamento: antítese, prosopopeia (Adário, 19783, f. 1).

Nota-se que, pelo conteúdo programático se referir a dois assuntos distintos - língua portuguesa e literatura infantil -, apresenta-se de forma mais sucinta e com menos pontos a serem trabalhados. Apesar disso, no caso dos pontos relacionados ao ensino da literatura infantil, observa-se a manutenção de alguns elementos que eram recorrentes nesse ensino, desde a década de 1950, como: caracterização da literatura infantil, delimitação de suas funções e requisitos e critérios para se escolher um livro para crianças.

O segundo plano de ensino elaborado na década de 1980, que tive acesso, data de 1989 e é de autoria das professoras Kátia Regina Gíglio da Silva e Maria José Jaqueto. Esse plano, diferentemente do anterior, refere-se à disciplina denominada "Literatura infantil". Nele, o objetivo do ensino da literatura infantil é descrito assim:

Levar o aluno a tomar conhecimento da Literatura infantil, seus precursores, conceituação, a influência da literatura na criança, o valor das figuras, evolução da literatura, produzir textos para criança, CONTAR ESTÓRIAS, reproduzir textos, desenvolver o gosto e o hábito de ler e contar estórias (Silva; Jaqueto, 1989, f.1).

Os conteúdos previstos nesse plano de 1989 eram:

Conteúdo: - Literatura Infantil - conceituação

- A arte e o homem - O Mito; O Folclore (brincadeiras folclóricas;

- A fábula, Fontes da literatura infantil; $\mathrm{O}$ conto; O Universo mágico dos contos de fadas; Simbologia dos contos de fadas;

- O século XIX (Grimm, Anderson, Perrault);

- A literatura infantil no Brasil - Monteiro Lobato;

- A literatura e a criança - faixas etárias;

- Linguagem e estilo na literatura infantil;

- A poesia e a criança, teatro, o cinema;

- Criações de redação em classe para crianças;

- Leituras extra-classe de obras infantis. (Silva; Jaqueto, 1989, f.1). 
Com base nesse conteúdo, as estratégias de ensino descritas eram: a realização de aulas expositivas; a utilização de materiais, como quadro negro, fitas cassete; o desenvolvimento de pesquisas em livros de literatura infantil; e a leitura de obras "consagradas".

Como se pode observar, esse plano de 1989 se apresenta de forma bastante coerente com o guia curricular para a disciplina "Literatura infantil", que havia sido publicado pela CENP, em 1981. Tanto os conteúdos previstos, quanto os procedimentos indicados, assemelham-se aos contidos nesse guia curricular elaborado pela CENP.

Com relação à década de 1990, localizei cinco planos referentes ao ensino da literatura infantil na HEM. Desses cinco, três são da EEPSG Índia Vanuíre, da cidade de Tupã-SP, um da EEPSG Joaquim Ribeiro, de Rio Claro-SP, e um da EEPSG Stélio Machado Loureiro, de Birigui-SP. ${ }^{8}$ Os planos de ensino da escola Índia Vanuíre datam de1991, 1994 e 1995; o plano de ensino da escola Joaquim Ribeiro data de 1993; e o plano de ensino da escola Stélio Machado Loureiro, de 1997.

O plano de ensino de 1991, da EEPSG Índia Vanuíre, é de autoria da professora Marilena Porta e consiste em um formulário, que foi apenas preenchido por ela com informações sucintas sobre a disciplina a que se refere. Nele, constam objetivos e conteúdo relativos ao ensino da literatura infantil, para serem desenvolvidos no $2^{\circ}$ bimestre letivo da disciplina "Língua portuguesa e literatura”, da $4^{a}$ série da HEM. Em relação a esse conteúdo, consta de forma bem genérica, assim descrito: "Literatura infantil: objetivos, estudo da linguagem, leitura de livros infantis" (Porta, 1991, f.1).

Embora elaborados para uso na mesma instituição (EEPSG Índia Vanuíre), os planos de ensino de 1994 e 1995 diferem da estrutura simples do plano de 1991. Neles, não consta o nome do(a) professor(a) responsável por sua elaboração e, como acabou se tornando prática comum, são idênticos um ao outro, alterando-se apenas a indicação do ano letivo: 1994/1995. Outro aspecto que se difere entre os planos de 1994 e 1995 e o plano de 1991 é o fato de que os dois primeiros se referem à disciplina "Literatura infantil", enquanto o de 1991 se refere à disciplina "Língua portuguesa e literatura".

8 Sobre esse Instituto, ver Serra (2004; 2007). 
Nesses planos de ensino de 1994 e 1995, o objetivo geral descrito para o ensino da literatura infantil na HEM é o seguinte: "Desenvolver a habilidade de comunicação e expressão, em termos de recepção e produção adequadas de textos, por meio da observação, análise e compreensão dos processos linguísticos do fenômeno literário e elementos significativos de nossa cultura".

Além desse objetivo geral, são apresentados cinco objetivos específicos, relacionados: à conscientização da importância da literatura infantil; à construção de um saber teórico sobre esse gênero literário; ao desenvolvimento da habilidade para comunicação e expressão compatíveis com a criança; e à conscientização da importância de escritores brasileiros, como Monteiro Lobato.

Para a consecução desses objetivos, o conteúdo definido nesses planos foi:

$1^{\circ}$ Bimestre:

- A literatura infantil e sua importância;

- A fábula: começo de tudo;

- Clássicos da Literatura Infantil;

- Precursores da Literatura Infantil no Brasil.

$2^{\circ}$ Bimestre:

- Monteiro Lobato, o criador da Literatura Infantil no Brasil;

- Ciclo intermediário da literatura infantil;

- Tendências da literatura infantil na atualidade.

$3^{\circ}$ Bimestre

- Textos destinados a leitores da pré-escola e das $1^{\text {a }}$ séries;

- Poesia Infantil Brasileira;

- A leitura teatralizada, os grupos do jogral.

$4^{\circ}$ Bimestre

- O teatro;

- O Folclore e sua projeção na Literatura Infantil;

- A Literatura e os outros meios de comunicação. (Tupã, 1994, p.2) $)^{9}$

Para desenvolver esse conteúdo, os procedimentos previstos eram: estudo dirigido; dinâmica de grupo; debates; sessão de vídeos; dramatização; elaboração de livros de "historinha"; e pesquisas no CIC.

9 Por serem idênticos, optei por citar o plano de 1994, por ser o mais antigo. 
O outro plano que localizei referente à década de 1990 data de 1993 e foi elaborado por Iraídes Valente Ferreira Vilela e Luzia Aparecida Tozzo, ambas professoras das turmas da $4^{a}$ série da HEM, da EEPSG Joaquim Ribeiro, em Rio Claro-SP. Nele, os objetivos, conteúdos, procedimentos e avaliação estão organizados por bimestre.

Para o $1^{\circ}$ Bimestre, o conteúdo programático previsto nesse plano era:

1 - Literatura infantil
a) história e situação atual;
b) aspectos teóricos;
b) análise de textos.
2 - Literatura e Educação:
a) a evolução da literatura infantil - sua relação com a pedagogia;
b) importância do ato de ler. (Vilela; Tozzo, 1993, p.92)

Com o desenvolvimento desse conteúdo, objetivava-se que o aluno da HEM conhecesse as diferentes formas de literatura infantil e se conscientizasse da importância desse gênero literário. Em relação aos procedimentos metodológicos, têm-se: leitura e debate de textos teóricos, leitura de textos informativos, pesquisa entrevista com crianças, pais e professores e visitas a bibliotecas.

Para o $2^{\circ}$ bimestre, o conteúdo programático previsto nesse plano era: " 3 - Caracterização da obra literária infantil" e "4 - A narrativa para criança: origens; situação atual” (Vilela; Tozzo, 1993, p.93). Com relação aos objetivos, têm-se o propósito de levar o aluno a conhecer diferentes formas e gêneros da literatura infantil e estudar mais detidamente o gênero narrativo.

Para o $3^{\circ}$ e $4^{\circ}$ bimestres, o conteúdo programático previsto nesse plano era:

5 - Poesia para crianças:

a. aspectos teóricos;

b. estudo de textos

6 - Literatura em quadrinhos

a. aspectos positivos e negativos;

b. estudo da linguagem;

c. estudo de textos. 
7 - Teatro para crianças

a. aspectos teóricos;

b. estudo de trechos de peças

8 - Folclore na escola:

- como utilizá-lo;

- estudo de textos. (Vilela; Tozzo, 1993, p.92)

Os objetivos para o $3^{\circ}$ e $4^{\circ}$ bimestres eram: conhecer os principais autores de poesia e aprender a ler e gostar desse tipo de texto; saber adequar às histórias em quadrinhos e conhecer os aspectos de sua linguagem; perceber a importância do teatro; e perceber a necessidade de inclusão do regionalismo com suas lendas e crendices.

Como se pode observar em relação a esse plano de 1993, não se nota nenhuma mudança expressiva com relação ao modo como o ensino da literatura infantil era prescrito até então. Nesse plano de 1993, assim como nos documentos publicados anteriormente a ele, esse ensino continuava a se centrar no estudo da origem, do desenvolvimento e da exploração de algumas formas da literatura infantil.

O plano mais recente que localizei data de 1997 e foi elaborado para uso na EEPSG Stélio Machado Loureiro, em Birigui-SP. Nesse plano, não consta o nome do(a) professor(a) responsável por sua elaboração e ele se refere à disciplina "Língua portuguesa e literatura", que compunha a grade curricular da $4^{\mathrm{a}}$ série da HEM dessa escola.

Nesse plano, além do conteúdo sobre literatura infantil, apresenta-se o conteúdo relativo ao estudo da gramática, da literatura brasileira e da redação. O conteúdo específico sobre literatura infantil se refere ao $3^{\circ}$, assim descrito:

III - Literatura infantil

1- Literatura Geral e Literatura Infantil

- o Livro Infantil

- o Livro que a criança prefere

- Fases e Modalidades da Literatura Infantil

2 - Autores infantis

- Século XVIII: Daniel Defoe

- Século XIX: Andersen 
3 - Literatura infantil no Brasil

- Século XX

4 - Características da obra literária infantil

- Análise de textos e obras

5 - Narrativa para crianças

6 - Poesia para crianças

7 - Teatro para crianças (Birigui, 1997, f.3)

Como se pode observar, não se previa o estudo de aspectos ligados à conceituação, finalidade, funções e "ajustamento" da literatura infantil. No entanto, aspectos da história da literatura infantil (origem e desenvolvimento) e também dos tipos literários, como poesia e teatro, ainda permanecem nesse plano como conteúdos específicos do ensino da literatura infantil.

Os aspectos aqui apresentados possibilitam notar que, embora com variações de denominação de disciplina e também de modos de se apresentarem objetivos, conteúdos e procedimentos metodológicos, o ensino da literatura infantil proposto por meio dos planos de ensino da HEM não apresenta grandes mudanças no intervalo entre as décadas de 1970 e 1990. Ainda que os planos a que tive acesso sejam esparsos, penso que são representativos do modo como os professores, em geral, concebiam o ensino da literatura infantil na HEM.

De modo geral, observa-se que algumas questões, como o "ajustamento" dos livros, deixaram de ser assunto recorrente no ensino da literatura infantil, figurando em apenas alguns planos, o que não significa que esse assunto não fosse abordado no ensino da literatura infantil.

Esses planos, juntamente com o guia curricular publicado pela Cenp, em 1981, possibilitam compreender que, mesmo com a implantação da HEM e a mudança no modelo de formação de professores no país, manteve-se, em relação ao ensino da literatura infantil, a mesma concepção que se encontra nos documentos relativos ao Ensino Normal, entre as décadas de 1950 e 1960.

As mudanças mais expressivas no ensino da literatura infantil ocorreram apenas num outro modelo de formação de professores, que funcionou concomitantemente à HEM, na década de 1980: os Centros Específicos de Formação e Aperfeiçoamento do Magistério (Cefam). 


\section{A formação de professores no Cefam}

Na década de 1980, concomitantemente ao funcionamento da HEM, passaram a ser criados no estado de São Paulo e em todo o Brasil os primeiros Centros Específicos de Formação e Aperfeiçoamento do Magistério (Cefam), os quais também ofereciam um curso de formação de professores.

Como mencionei, a partir da segunda metade da década de 1970 e durante a década de 1980, a HEM se tornou alvo constante de críticas de educadores paulistas e também de outras regiões do país. Como explica Moura (1991), os problemas identificados com a HEM e relatados em documentos da Secretaria Estadual de Educação de São Paulo eram também identificados e apontados em outros estados brasileiros. Além disso, a HEM se encontrava fortemente associada ao regime ditatorial instaurado em 1964, uma vez que a criação dessa habilitação decorreu de reforma do ensino promovida pela Lei n. 5.692, de 1971. Isso agravava as críticas em relação a essa habilitação, especialmente a partir da década de 1980, com a gradativa reabertura política do país, que resultou no restabelecimento do regime democrático, em 1985.

De modo geral, as críticas à HEM se relacionavam ao fato de ela ser considerada uma habilitação que não dava aos futuros professores das quatro primeiras séries do ensino de $1^{\circ}$ grau a formação adequada e necessária para atuarem profissionalmente.

O agravamento nas condições de formação do professor em âmbito nacional, a queda nas matrículas da HEM e o descontentamento relativamente à desvalorização da profissão levariam a um movimento em âmbito federal e estadual, com discussões de projetos de estudo, pesquisas e propostas de ação frequentemente denominados de "revitalização do ensino normal", propiciando por parte do Ministério da Educação e de Secretarias Estaduais no sentido de propor medidas para reverter o quadro instalado (Tanuri, 2000, p.82).

Entre as propostas de "revitalização" do Ensino Normal, o Ministério da Educação, por meio da Coordenadoria do Ensino Regular de Segundo Grau, formulou, em parceria com as Secretarias Estaduais de Educação, o projeto do Cefam. Esse projeto tinha a finalidade de atender "[...] aos anseios manifes- 
tados pelos educadores envolvidos na problemática do ensino oferecido nos Cursos de habilitação Magistério [...]” (Cavalcante, 1987, p.5).

O objetivo de criar o Cefam era "[...] expressar alternativas de ampliação da função da Escola Normal na perspectiva de formação, atualização e aperfeiçoamento de recursos humanos para a educação pré-escolar e para o ensino de $1^{\circ}$ grau" (Moura, 1991).

Inicialmente, o Cefam foi implantado, em 1983, em seis estados, Rio Grande do Sul, Alagoas, Minas Gerais, Piauí, Pernambuco e Bahia, totalizando 55 Centros. "Em 1987, por intermédio do projeto 'Consolidação e Expansão dos Cefams', os Centros foram estendidos a mais nove estados: Santa Catarina, Mato Grosso, Mato Grosso do Sul, Sergipe, Paraíba, Rio Grande do Norte, Pará, Goiás e São Paulo [...]” (Tanuri, 2000, p.82).

No estado de São Paulo, mesmo a HEM tendo passado por uma reformulação no ano de 1987, mediante a Deliberação CEE n. 30/87, os Cefams foram implantados com objetivo de melhorar a qualidade da formação de professores e sanar a precariedade em que essa formação se encontrava.

A consciência em relação à gravidade da situação da formação de professores fez desencadear, na Secretaria Estadual de Educação de São Paulo, a partir de 1982, uma série de estudos com vistas a revitalizar a Habilitação Específica para o Magistério. [...] Esse movimento prolongou-se até janeiro de 1988 [...] A Secretaria da Educação do Estado de São Paulo, buscando suplantar esta situação já crônica, cria os Centros de Específicos de Formação e Aperfeiçoamento do Magistério - Cefams (São Paulo, 1992, p.10-11).

Os primeiros Cefams paulistas foram criados em 1988, pelo Decreto n. 28.089, de 13 de janeiro e, tomando como "inspiração" o projeto Cefam do Ministério da Educação, a instalação desses Centros no estado de São Paulo apresentou algumas diferenças.

Em primeiro lugar, na proposta federal, os Centros Específicos de Formação e Aperfeiçoamento de Professores não correspondiam à criação de um novo tipo de escola, mas ao redimensionamento das escolas normais regulares nos seus aspectos qualitativos, na sua amplitude e na sua área de abrangência (MEC, 1989). Em segundo lugar [...] o projeto de São Paulo previa, em sua estruturação, a existência, nos Cefams, de um conjunto de condições que, de 
um lado, atendiam às reivindicações, já históricas, dos educadores em exercício na Rede de Ensino e, de outro, incorporavam sugestões originárias de pesquisa e/ou reflexões sobre a problemática da formação dos professores ao nível do $2^{\circ}$ Grau (São Paulo, 1992, p.11).

Conforme explica Moura (1991), o Cefam paulista não visava apenas reformular os cursos de formação de professores, mas criar uma escola específica para formação desses profissionais, com estrutura e funcionamento específicos. O que se pretendia era que o Cefam paulista exercesse a função de "[...] pólo disseminador e agente transformador da prática educativa, promovendo cursos de aperfeiçoamento e/ou prestando assessoria pedagógica às demais escolas de formação de professores de sua região" (Moura, 1991, p.71).

Para tanto, diferentemente dos Cefams criados em outros estados, em São Paulo, ele funcionou com curso de período integral e com a oferta de uma bolsa de estudos correspondente a um salário mínimo - Projeto Bolsa de Trabalho. Segundo Cavalcanti (1994), a implantação dessa estrutura, especialmente a oferta de bolsa, tinha como objetivo criar condições para que os alunos aprofundassem seus estudos e, ao desenvolver estágio em escolas públicas, contribuíssem para minimizar a evasão escolar e os altos índices de repetência. Somente em 1991 o Projeto Bolsa Trabalho foi lançado com um projeto em âmbito federal, pelo Ministério da Educação, sendo implantado nos Cefams de outros estados.

Em 1988, quando o Cefam foi instalado em São Paulo, foram implantadas 19 unidades, $11 \mathrm{em}$ cidades do interior e oito na capital (Pimenta, 2006). Em 1989, foram implantadas outras 25 unidades, 14 em cidades do interior e 11 na capital (Pimenta, 2006). Na década de 1990, foram implantadas, entre 1990 e 1994, as últimas nove unidades, todos no interior do estado. Desse modo, funcionaram no estado de São Paulo 54 unidades do Cefam, as quais foram implantadas entre 1988 e 1994.

Quatro anos após a implantação das últimas unidades do Cefam em São Paulo, em 1998, iniciou-se um processo gradual de desvalorização desses centros no estado (Souza, 2014). Como consequência desse processo, em 2000, foi decretado pela então Secretária Estadual de Educação, Rose Neubauer, que o curso de formação de professores ofertado nos Cefams teria sua duração de quatro anos reduzida para três anos. Em 2003, foi publicada 
a Resolução n. 119, de 7 de novembro de 2003, que extinguiu a formação de professores em nível médio no estado de São Paulo, para atender ao disposto no Art. 62, da Lei de Diretrizes e Bases da Educação Nacional, Lei n. 9.394, de 20 de dezembro de 1996, que delibera sobre a formação de professores em cursos de nível superior.

Com a Resolução n. 119, a partir de 2003, não houve mais ingresso de alunos nos Cefams paulistas, de modo que as últimas turmas concluíram o curso em 2005. A partir de 2005, esses centros foram fechados. Alguns prédios passaram a funcionar como escolas estaduais de ensino fundamental e/ ou médio, outros foram doados para instalação de escolas técnicas, ligadas ao governo estadual.

\section{A organização do currículo do Cefam e o ensino da literatura infantil}

Quando os Cefams foram instalados no estado de São Paulo, a partir de 1988, eles tiveram sua organização curricular pautada na Deliberação CEE n. 30/87, que havia sido promulgada para reestruturação da HEM.

Além dessa Deliberação, que de certa forma implantava um currículo semelhante na HEM e no Cefam, foram estabelecidas algumas disposições específicas para o Cefam, por meio da Resolução CEE n. 15, de 1988. Nessa resolução, constam três diretrizes importantes para se organizarem os currículos dos cursos de formação de professores nesses centros: necessidade de equilibrar a carga horária das disciplinas da "Parte comum" do currículo com a "Parte diversificada", com a distribuição das disciplinas de formação geral ao longo de todo o curso; destinação de carga horária para as disciplinas de metodologia correspondentes ao currículo da pré-escola e das quatro primeiras séries do $1^{\circ}$ grau; e unificação das disciplinas da área de "Fundamentos da Educação".

Em decorrência dessas diretrizes, o curso de formação de professores do Cefam previa carga horária em período integral, assim distribuída: período da manhã direcionado às disciplinas que compunham o currículo; e período da tarde destinado às disciplinas de enriquecimento curricular e realização do estágio supervisionado.

Até meados da década de 1990, o curso de formação de professores dos Cefams seguiram as mesmas orientações normativas sobre organização 
curricular que a HEM, porém com perspectiva política e teórica específica. Essa especificidade se deu, sobretudo, pelo processo de acompanhamento e de orientação técnica da Cenp, voltados exclusivamente para o Cefam.

Conforme explica Moura (1991), esse acompanhamento se dava por meio de encontros das equipes dos Cefams e pelo assessoramento em assuntos técnico-pedagógicos.

Esses encontros, denominados Orientação Técnica - OT, visavam, prioritariamente, à elaboração de uma proposta de construção coletiva para cada componente do Quadro Curricular das primeiras séries do Curso, assim como iniciar o processo de reciclagem e atualização dos professores que atuam nos Centros, para que, num futuro próximo, eles possam ser agentes multiplicadores, com os demais professores da HEM. Esse trabalho de OT se faz acompanhar de material subsidiário, específico para cada área do currículo. (Moura, 1991, p.89)

Ainda que os dispositivos legais de organização do currículo dos Cefams eram os mesmos que os da HEM, a perspectiva de mudança se deu no seu projeto político-educacional.

Durante a década de 1990, a partir da publicação da LDB n. 9.394, de 20 de dezembro de 1996, o currículo dos Cefams paulistas precisaram ser adequados às novas diretrizes e bases da Educação Nacional. Essa adequação se deu partir da publicação da Resolução SEE n. 11/98, que "[...] estabelece normas para a reorganização curricular do curso normal, em nível médio, da rede estadual de ensino e dá providências correlatas" (São Paulo, 1998, p.1). Com essa Resolução, a "Parte comum" do currículo ficou organizada com as seguintes disciplinas: "Língua portuguesa”, "Matemática”, "História”, "Geografia”, "Biologia”, "Física”, "Química”, "Educação artística" e "Educação física". A "Parte Diversificada" contava com as seguintes disciplinas: "Psicologia da educação", "Sociologia da educação", "Filosofia da educação", "História da educação”, "Conteúdo e metodologia: Língua portuguesa", "Conteúdo e metodologia: estudos sociais", "Conteúdo e metodologia: ciências e matemática" e "Língua estrangeira moderna”. Além dessas disciplinas, cada Cefam podia escolher entre as disciplinas "Filosofia", "Psicologia" ou "Sociologia" para completar a carga horária da "Parte diversificada". 
Em complementação à "Parte Comum" e à "Parte Diversificada", os Cefams contavam com carga horária de enriquecimento curricular, que era feito a partir das seguintes disciplinas: "Língua portuguesa e literatura”, "Matemática”, "História”, "Geografia”, "Ciências físicas e biológicas”,; "Educação artística”, "Educação Física”, "Didática e prática de ensino”, "Conteúdo e metodologia: Língua portuguesa”, "Conteúdo e metodologia: estudos sociais" e "Conteúdo e metodologia: ciências e matemática".

Especificamente em relação ao ensino da literatura infantil, dada a flexibilização do currículo permitido pela legislação, em especial pela Deliberação CEE n. 30/87, a instituição de uma disciplina voltada a esse ensino se deu a critério de cada um dos 54 Cefams que funcionaram no estado de São Paulo. Como a disciplina "Literatura infantil" integrava a "Parte diversificada" do currículo, ela era de livre escolha de cada unidade.

Dada a dificuldade de acesso aos documentos dos Cefams que funcionaram no estado de São Paulo, pude identificar em apenas um deles a manutenção do ensino da literatura infantil. Trata-se do Cefam localizado na cidade de Tupã. Ainda que eu tenha tentado acesso a documentos de outros Cefams, que funcionaram em outras cidades do estado, não tive acesso a esses documentos, porque a maior parte não foi preservada. Apesar disso, localizei informações de que no Cefam de Campinas e de Presidente Prudente havia o ensino da literatura infantil.

No caso do Cefam localizado na cidade de Tupã, localizei o Plano Diretor dessa unidade, datado de 1996, no qual constam os planos de ensino elaborados pelos professores para cada uma das disciplinas do currículo. Nos planos da disciplina "Português", referente às $2^{\mathrm{a}}, 3^{\mathrm{a}}$ e $4^{\mathrm{a}}$ séries do curso de formação de professores, consta, no conteúdo programático, uma parte voltada especificamente para o ensino da literatura infantil.

O plano da disciplina "Português" dessa unidade do Cefam, referente à $2^{a}$ série do curso de formação de professores, foi elaborado pelas professoras Neusa Assad Gonçalves e Cédima Eliane Bueno da Silveira e nele se prevê o seguinte conteúdo:
4.0 - LITERATURA INFANTIL
4.1 - um pouco de sua história;
4.2 - gênero "Literatura infantil";
4.3 - como deve ser a obra literária brasileira; 
4.4 - interesse pela Literatura - fatores a considerar;

4.5 - como descobrir os interesses individuais da criança;

4.6 - atividades de literatura em sala;

4.7 - como formar a biblioteca escolar;

4.8 - despertar o gosto pela literatura;

4.9 - a hora do conto;

4.10 - indicações bibliográficas versus família;

4.11 - indicações bibliográficas versus professor;

4.12 - para ler refletir e questionar;

4.13 - o que deve saber o professor. (Gonçalves; Silveira, 1996, p.41)

O plano da disciplina "Português", para a $3^{\mathrm{a}}$ série, também elaborado para o ano letivo de 1996, é de autoria apenas da professora Cédima Eliane Bueno da Silveira e nele se prevê o seguinte conteúdo:

\subsection{LITERATURA INFANTIL}

3.1 - Conhecimento dos percursores da literatura;

3.2 - O ritmo da poesia;

3.3 - O que pensa da Literatura Infantil quem faz Literatura Infantil;

3.4 - Conhecendo alguns autores de Literatura infantil;

3.5 - Conhecendo alguns autores de Literatura infantil II;

3.6 - As histórias em quadrinhos. (Silveira, 1996, p.51)

O plano da disciplina "Português", para a $4^{\mathrm{a}}$ série, também elaborado para o ano letivo de 1996, é de autoria da professora Cédima Eliane Bueno da Silveira e nele se prevê o seguinte conteúdo:

\subsection{LITERATURA INFANTIL}

3.1 - A literatura como terapia

3.2 - A prática da literatura infantil;

3.2.1 A televisão da bicharada (Sidônio Muralha) / A arca de Noé(Vinícius de Moraes) - poesia.

3.2.2 Pluft, o fantasminha (Maria Clara Machado) - teatro;

3.2.3 História meio ao contrário (Ana Maria Machado) - prosa;

3.2.4 Ou isto ou aquilo (Cecília Meireles) / Pé de pilão (Mário Quintana) - poesia; 
3.2.5 Nicolau tinha uma ideia... / O reizinho mandão (Ruth Rocha). (Silveira, 1996, p.63, grifos da autora)

Nesses três planos o ensino da literatura infantil apresenta algumas mudanças importantes em relação aos planos de ensino elaborados pelos professores da HEM. No caso do plano do Cefam, ainda que as questões históricas sobre a literatura infantil tenham permanecido, são indicados outros conteúdos, como formação do gosto, leitura como forma de interpretação e reflexão e a análise de livros de literatura infantil. O que se observa é que nos planos do Cefam não se identifica a proposição do ensino da literatura infantil voltado apenas para os requisitos, finalidades e "ajustamento" da literatura infantil. Também os livros de literatura infantil indicados nesses planos eram bastante modernos e diferentes dos já tradicionais contos de fadas, do livro Narizinho arrebitado e do livro Contos da Carochinha, normalmente indicados no ensino da literatura infantil até então.

É evidente que, por esses planos se referirem a apenas um Cefam, não é possível afirmar que essa mudança de perspectiva no ensino da literatura infantil também ocorreu em outras unidades. De qualquer modo, penso que por meio deles se pode ter alguns indicativos de como o ensino da literatura infantil, a partir da década de 1990, começou a sofrer algumas alterações.

\section{Os manuais e capítulos para o ensino da literatura infantil, publicados entre as décadas de 1970 e 1990}

A partir de 1971, acompanhando o movimento de reorganização dos cursos de formação de professores por meio da implantação da HEM e dos Cefam, novos manuais destinados ao ensino da literatura infantil foram publicados no Brasil.

Entre as décadas de 1970 e 1990, localizei a publicação de cinco manuais destinados especificamente ao ensino da literatura infantil e um manual de metodologia da linguagem que contém um capítulo sobre literatura infantil. Além desses, localizei um manual sobre ensino de língua e literatura, que contém um tópico, no âmbito de um capítulo, com menções, em poucos 
parágrafos, à literatura infantil. Trata-se do manual ensino de língua e literatura (1979), de Alaíde Lisboa de Oliveira. ${ }^{10}$

Pelo fato de a HEM e os Cefams representarem ideal de novos modelos de formação de professores, esses manuais de ensino apresentam algumas características diferentes em relação aos manuais publicados nas décadas de 1950 e 1960. Se os primeiros manuais destinados ao ensino da literatura infantil tinham como aspecto primordial atender aos programas de ensino dos Cursos Normais, seguindo esses pontos, um a um, os manuais da década de 1970 em diante se associam mais à ideia de um "guia" teórico e prático, como material de apoio ao desenvolvimento dos conteúdos programáticos definidos pelos próprios professores da HEM e dos Cefams.

Os cinco manuais de ensino de literatura infantil que foram publicados, no Brasil, entre as décadas de 1970 e 1990, são: Literatura infantil: teoria \& prática (1983), de Maria Antonieta Antunes Cunha; Introdução à literatura infantil e juvenil (1984), de Lúcia Pimentel Góes; Literatura infantil: gostosuras e bobices (1989), de Fanny Abramovich; e Estudos de literatura infantil (1991), de Manoel Cardoso.

O manual que contém capítulo sobre literatura infantil publicado após 1970 se intitula Metodologia da linguagem (1980), de Maria Helena Cozzolino de Oliveira e Conceição Perkles Monteiro. ${ }^{11}$ Esse manual foi o primeiro publicado no Brasil após a implantação da HEM.

Publicado em 1980, pela Saraiva (SP), com 173 páginas, Metodologia da linguagem está dividido em duas partes. A primeira não é intitulada e comporta quatro capítulos. A segunda se intitula "Como ensinar a ler? Qual método? Um único processo ou a conjugação de vários?” e comporta: quatro capítulos, uma unidade de leituras suplementares, bibliografia geral e relação de exercícios correspondentes a cada um dos oito capítulos.

Em 1982, foi publicada a $2^{a}$ edição desse manual, porém, não foi feita nenhuma alteração, revisão ou ampliação.

10 Por se tratar de um manual cuja discussão sobre literatura infantil contida nele é muito breve e não ocupa lugar relevante em sua proposta de "concretização" de ensino de língua e literatura, optei por não apresentar aspectos de sua configuração textual neste livro.

11 Não foi possível localizar informações sobre Maria Helena C. de Oliveira e Conceição P. Monteiro. 
Oliveira e Monteiro (1980) indicam que escreveram esse manual com o objetivo de "transmitir" noções sobre a didática da linguagem, com a "responsabilidade de ensinar".

Colocamos este livro nas mãos dos nossos alunos-mestre e, sem dúvida, sabemos que todos somos um livro nas mãos de Deus. "Somos uma carta, uma frase rabiscada e corrigida constantemente pela Sabedoria Divina. Se não deixarmos redigir, recompor e reestruturar infinitamente seremos uma obra sem defeito, bem ordenada, bem alinhada e brilhante" (Oliveira; Monteiro, 1980, s.p.).

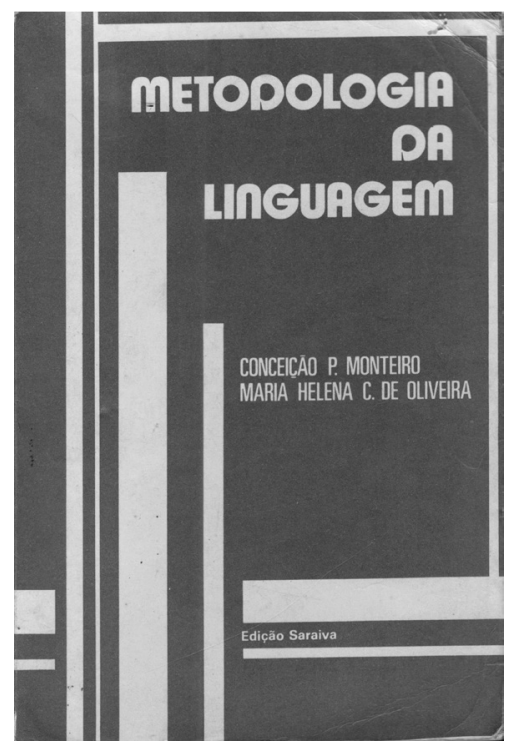

Figura 14 - Capa de Metodologia da linguagem (1981), de Maria H. C. Oliveira e Conceição P. Monteiro.

Fonte: Acervo do GPHELLB.

Em relação ao capítulo sobre literatura infantil, trata-se do oitavo e último capítulo, com 13 páginas. Dividido em sete tópicos, nele Monteiro e Oliveira (1980) abordam questões sobre o conceito de literatura infantil, as formas de manifestação desse gênero literário e procedimentos para organização de atividades de ensino relativamente a esse assunto.

Tomando como base o artigo $4^{\circ}$ da Lei n. 5.692, de 1971 - "No ensino de $1^{\circ}$ e $2^{\circ}$ graus dar-se-á especial relevo ao estudo da língua nacional como 
instrumento de comunicação e como expressão da cultura brasileira" (Brasil, 1971, p.1) -, elas entendem que, ao se ressaltar o ensino da leitura no ensino de $1^{\circ}$ grau, formaliza-se a "manipulação" e "aquisição" de estruturas linguísticas, atividade para a qual o texto literário contribui de forma fundamental.

Para essas autoras, dada a importância do ensino da leitura como instrumento de "comunicação" e "expressão da cultura brasileira", é necessário pensar em uma "[...] literatura específica para faixa que compreende o aluno de $1^{\circ}$ grau, sobre quais os critérios que devem nortear a seleção do livro ou do texto a ser lido e sobre que procedimentos didáticos devem ser utilizados a fim de relacionar esse trabalho com as demais atividades curriculares" (Oliveira; Monteiro, 1980, p.124). Embora a literatura infantil possa parecer apenas diversão, simples brincadeira, essas autoras entendem que esse gênero literário é o "marco" inicial da transmissão da cultura.

A partir dessa conceituação, Oliveira e Monteiro (1980) indicam que esse gênero literário tem como objetivo criar: a admiração pelo que é grande, bom e belo; a melhor compreensão do ser humano e do mundo; o desejo de compreender os problemas alheios; a imitação das boas virtudes; o cultivo de sentimentos altruístas; e a apreciação de belezas naturais.

Os livros de literatura infantil devem atuar de modo a ajudar as crianças a:

- adquirir conhecimentos distantes no tempo e no espaço;

- ampliar e enriquecer suas experiências;

- interessar-se profundamente pela leitura;

- encontrar refúgio espiritual, alívio temporário a seus problemas. (Oliveira; Monteiro, 1980, p.15)

Oliveira e Monteiro (1980) também apresentam de que modo o professor deve proceder para compreender as diferentes formas de "desenvolvimento" da literatura infantil e quais critérios precisa observar em relação a isso. Segundo elas, os livros de literatura infantil constituem "[...] os primeiros passos na formação moral, social e literária. Aí tem início o aprendizado da linguagem oral e escrita, das tradições e dos anseios de um povo na sua marcha para o desenvolvimento" (Oliveira; Monteiro, 1980, p.126). Por isso, é necessário selecionar uma "estória" adequada à evolução 
e ao interesse da criança e em conformidade com as fases de seu desenvolvimento psicológico.

Sobre essa adequação, seguindo a mesma linha de pensamento que os autores de manuais que as antecederam, elas explicam que: entre 5 e 7 anos, a chamada de fase do pensamento lúdico, as crianças se encantam com "histórias" fantásticas, contos maravilhosos e insólitos; entre 8 e 11 anos, a chamada fase do pensamento mágico, as crianças se interessam pela aventura, pelo risco, pela coragem; e, entre 12 e 14 anos, a chamada fase do pensamento lógico, o que interessa às crianças são as "estórias" sobre a vida de heróis, os romances em geral, as biografias romanceadas, os romances policiais e as lendas folclóricas.

Oliveira e Monteiro também tratam de alguns aspectos das histórias em quadrinhos e das poesias. Sobre a primeira, explicam que é necessário dosar esse tipo de publicação, a fim de evitar que esse tipo de leitura vicie a criança. Sobre as poesias, defendem que devem ser lidas para as crianças, porque esse tipo de texto literário é fonte de deleite, de "inculcação" do amor à beleza, de desenvolvimento do gosto estético, da linguagem e do pensamento.

Pela importância que entendem ter a poesia na formação da criança, Oliveira e Monteiro (1980) explicam que esse tipo de texto deve ser apresentado de forma que leve o pequeno leitor a "captar" o sentimento do autor e a perceber a beleza do ritmo e da harmonia.

Para concluírem, Oliveira e Monteiro (1980) abordam a questão dos escritores que, para elas, precisam "[...] possuir a capacidade de ser simples, de ter uma grande riqueza de ideias, conhecer bem o mundo da criança e amar a virtude em si mesma e não na intenção de moralizar. Enfim, é preciso a genialidade do mestre" (Oliveira; Monteiro, 1980, p.135).

Em relação à bibliografia desse manual, trata-se de uma bibliografia geral, referente a todo o seu conteúdo. Apesar disso, não identifiquei nenhum título específico sobre literatura infantil ou que tenha sido indicado em outros manuais e capítulos sobre esse gênero literário.

Em 1983, a professora mineira Maria Antonieta Antunes Cunha teve publicado um novo manual destinado ao ensino: Literatura infantil: teoria \& prática. 
Esse manual, publicado pela Ática (SP), ${ }^{12}$ embora apresente um título bem diferente em relação ao outro manual dessa professora - Como ensinar literatura infantil (1968) -, consiste em uma versão revista, atualizada e ampliada dele.

Conforme explica a própria autora, quando o proprietário da Editora Bernardo Álvares faleceu, a empresa fechou. Em seguida, a Ática a convidou para fazer um manual no mesmo formato do anterior. Com isso, Literatura infantil: teoria \& prática foi elaborado a partir de Como ensinar literatura infantil, com os mesmos "princípios" e "convicções", apenas com ampliação de "mais sugestões" e "mais experiências" (Cunha, 2014).

Publicado com novas dimensões e formatação gráfica, Literatura infantil: teoria \& prática (1983) foi composto em 143 páginas, divididas em oito capítulos, a saber: "Leitura extensiva: um problema", "Literatura infantil: história e situação atual”, "Literatura e educação”, "Características da obra literária infantil”, "A narrativa para crianças", "Poesia para crianças”, "O teatro para crianças" e "Folclore - sua utilização na escola".

Esses capítulos se encontram organizados da seguinte forma: são apresentados aspectos teóricos relacionados ao assunto tratado no capítulo; na sequência, constam, em média, cinco textos literários e um breve questionário; depois é apresentada a análise de uma obra literária; e, por fim, são apresentadas sugestões de trabalho.

$\mathrm{Na}$ organização do conteúdo de cada capítulo de Literatura infantil: teoria \& prática, além da revisão e da ampliação com relação ao manual Como ensinar literatura infantil (1968), foi acrescido um novo ponto de estudo: a análise de uma obra literária. Isso decorreu, segundo Cunha (1983), do fato de que:

[...] os trechos [de textos literários] dão apenas uma visão parcial das obras, pareceu-nos importante incluir no livro análises de textos completos.

12 Fundada em 1965, por Anderson Fernandes Dias, Antonio Narvaes Filho e Vasco Fernandes Dias Filho, a Ática se originou do Curso de Madureza Santa Inês, criado em 1956, em São Paulo-SP. No início dos anos de 1960, os idealizadores do Santa Inês criaram a Sociedade Editora do Santa Inês Ltda., a qual, em 1965, transformou-se na Editora Ática. Desde que foi criada, essa editora se voltou, especialmente, para o ramo dos livros didáticos e também de coleções de literatura juvenil, como foi o caso da série Vaga-lume (Ática, 1995). 
Seria ideal que a obra fosse lida pelos alunos e que a análise proposta fosse discutida em classe. Para possibilitar isso, comentamos obra de fácil aquisição.

Procuramos, nessas análises, fazer um estudo abrangente, mas tivemos a preocupação de não usar nomenclatura técnica e sofisticada, que só estaria ao alcance dos iniciados em estudos literários. (p.4)

Literatura infantil: teoria \& prática (1983), atingiu um número de edições considerável. Ao todo, localizei 18 edições, sendo a mais recente, a $18^{\mathrm{a}}$, de 2003. Num período de 20 anos, esse manual teve quase uma edição por ano.

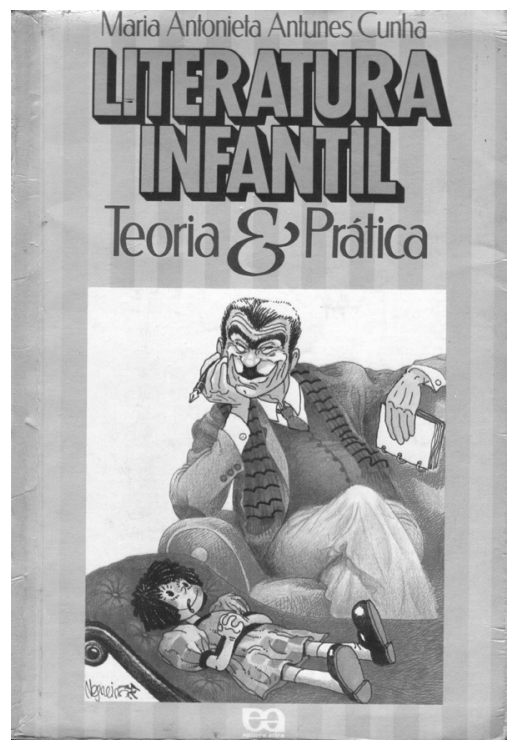

Figura 15 - Capa de Literatura infantil: teoria \& prática (1983), de Maria A. A. Cunha. Fonte: Acervo do GPHELLB.

Ao analisar o conteúdo de Literatura infantil: teoria \& prática (1983), comparativamente ao conteúdo de Como ensinar literatura infantil (1968), nota-se que as maiores alterações ocorreram no segundo e terceiro capítulos do novo manual.

A fim de evitar repetições desnecessárias, apresento apenas os aspectos em que o conteúdo de Literatura infantil: teoria \& prática (1983) se diferencia de Como ensinar literatura infantil (1968).

Tomando como base o crescente problema da época com relação ao desinteresse das crianças e jovens pela leitura, Cunha (1983) apresenta alguns 
resultados de duas pesquisas sobre o assunto, uma realizada em 1973, com 300 alunos do ensino de $1^{\circ}$ grau de Belo Horizonte-MG, e outra realizada em 1980, pela professora Maria Helena Andrade Magalhães.

Embora com essas pesquisas ela considere que seja possível identificar uma melhora desse problema, ele ainda persistia de forma preocupante, sobretudo pelas condições escolares, familiares e sociais a que a leitura vinha sendo submetida.

Cunha (1983) entende que parte do problema do desinteresse pela leitura decorre das condições de trabalho a que os professores eram submetidos.

O educador se vê às voltas com um número assustador de atividades. [...] Não sobra tempo a esses profissionais para acompanhar o movimento editorial da literatura infantil e juvenil. E eles não podem apoiar-se em pesquisas sobre as preferências dos estudantes [...] porque elas não existem, ou quase. Temos de considerar, por outro lado, que os educadores em geral não se empenham muito em "criar o tempo", porque na Universidade não tiveram orientação sobre o assunto, não têm clara uma visão da verdadeira função da literatura na educação. (Cunha, 1983, p.10)

Para ela, o foco principal na solução do problema do desinteresse pela leitura deve incidir sobre o professor. Melhorando os conhecimentos e a visão desse profissional com relação à literatura infantil, ele poderá desenvolver trabalhos mais satisfatórios, que corroborem para a formação do interesse leitor infantil.

O quadro relativo ao hábito de leitura no Brasil só poderá melhorar quando toda a postura do adulto relativa ao livro e à função dele na educação se modificar. Isto surgirá com o melhor conhecimento do fenômeno literário e do leitor infantil, e certamente trará como consequência a produção de obras literárias mais adequadas para a infância, a facilitação do acesso ao livro e melhores opções de leitura e de atividades em torno dela. (p.17)

Cunha (1983) apresenta alguns aspectos da história e da situação da época da literatura infantil e juvenil. Segundo ela, a história da literatura infantil era relativamente recente, tendo começado a se delinear apenas no século XVIII. Antes disso, porém, a criança acompanhava a vida adulta e, 
por isso, também consumia a literatura produzida para o adulto. Citando texto de Zilberman (1981), Cunha (1983) explica que antes da constituição do meio familiar burguês não havia um tratamento específico para a infância, por isso pequenos e grandes compartilhavam das mesmas situações de leitura. Somente com a valorização da infância é que a literatura infantil e a escola se desenvolveram, visando ao controle do desenvolvimento intelectual da criança.

Com isso, Cunha (1983) enfatiza a estreita relação entre a literatura infantil e a "Pedagogia", uma vez que as primeiras iniciativas de se escrever para crianças, na Europa, tinham como propósito fundamental formar e informar o pequeno leitor.

Para ela, no "caminho" que percorreu a literatura infantil na Europa e no Brasil, identificam-se duas tendências, uma de produção e adaptação de clássicos, outra voltada à apropriação do folclore e dos mitos. E, por ser recente a literatura infantil, sobretudo no Brasil, ela relata sobre a pouca aceitabilidade de alguns escritores e críticos com relação à existência de uma literatura infantil com características específicas, ou a categorização desse gênero literário como uma "subliteratura", uma literatura menor.

Sobre a discordância com relação à existência de uma literatura específica para as crianças, Cunha (1983) entende que é inquestionável essa situação. Para ela, não somente há uma literatura específica para o público infantil, como essa é até mais abrangente que a literatura para o adulto. Enquanto a literatura "adulta" somente serve para o adulto ler, a literatura infantil encanta e serve para as crianças e para os adultos. Com isso, Cunha (1983) entende que a literatura infantil é manifestação artística, que se caracteriza " [...] pela abertura, pela possibilidade de vários níveis de leitura, pelo grau de atenção e consciência a que nos obriga, pelo fato de ser única, imprevisível - original, enfim, seja no conteúdo, seja na forma" (Cunha, 1983, p. p.23).

Apresentadas as questões históricas sobre a constituição da literatura infantil e ponderados os problemas em torno desse gênero literário, Cunha (1983) se detém na discussão sobre as intersecções entre literatura e educação. Para ela, se perguntarmos a um professor, bibliotecário ou aos pais, porque ofertam um livro para que as crianças leiam, a resposta sempre será porque se quer que os pequenos criem o hábito de ler. Apesar desse objetivo "louvável”, Cunha (1983) pensa ser importante problematizar as razões 
pelas quais as crianças leem tão pouco. Embora esse problema tenha ligação com diversos fatores, o principal consiste no trabalho equivocado que os professores desenvolvem com o livro, quando o ofertam à criança.

De modo geral, explica Cunha (1983), o professor acaba atuando de forma autoritária, impondo as leituras, sem levar em conta o interesse infantil. Pelo fato de o professor conhecer os benefícios de uma determinada leitura, por considerá-la forma de aprendizado, ele acaba por impô-la à criança. Com isso, um trabalho que era para ser voltado ao campo da arte, torna-se um trabalho semelhante ao das aulas de Matemática ou Geografia.

Cunha (1983) então explica que, ao se desenvolver um trabalho com a literatura infantil, é evidente que ela atua nas áreas vitais do homem, a motora, a cognitiva e a apreciativa, no entanto, deve-se enfatizar a área apreciativa, porque a literatura é manifestação artística.

1) Da perspectiva de uma filosofia de educação, é obrigação do educador mostrar não só a literatura como também as demais artes como as mais fascinantes formas de descoberta do indivíduo, nas relações de recreação e recriação possíveis entre ele e a obra. [...]

2) Da perspectiva de estratégia, cabe ao educador sempre se perguntar se, com uma situação mais eficiente, mais orientada, não poderia ele estar ajudando mais pessoas a optarem por literatura (ou qualquer outra forma de arte ou cultura).

Em continuidade a suas reflexões, Cunha (1983) aborda algumas das formas de manifestação da literatura infantil, como a narrativa, a poesia, o teatro e o folclore. Ao tratar desses assuntos, ela apresenta poucas alterações de conteúdo em relação ao manual de 1968 e mantém a concepção de que para cada fase do desenvolvimento psíquico da criança há um tipo de texto adequado, condizente com a mentalidade infantil.

Em razão das ampliações e atualizações que fez em Literatura infantil: teoria \& prática, Cunha (1983) apresenta uma bibliografia bastante extensa. Ao todo, são 51 títulos.

Entre os títulos relacionados na bibliografia desse manual, têm-se: $L i$ teratura infantil brasileira (1968), de Leonardo Arroyo; Compêndio de literatura infantil (1959), de Bárbara Vasconcelos de Carvalho; O ensino da 
literatura (1966), de Nelly Novaes Coelho; A literatura infantil (1978), de Jesualdo Sosa; e A literatura infantil na escola (1981), de Regina Zilberman.

O que se pode notar por esses títulos é que Cunha (1983), apesar de ter atualizado e revisto o conteúdo de seu primeiro manual, manteve na bibliografia títulos de outros manuais de ensino, produzidos na década de 1950, condizentes com os programas do Ensino Normal. No entanto, Cunha (1983) também incorporou na bibliografia de seu novo manual textos publicados à época, como o livro de Regina Zilberman, A literatura infantil na escola (1981).

Após a publicação desse manual de Cunha (1983), Lúcia Pimentel Góes teve publicado Introdução à literatura infantil e juvenil, como volume coleção "Manuais de estudo", que tinha como objetivo publicar diferentes livros para uso na Universidade e no ensino de $2^{\circ}$ Grau, Editora Pioneira (SP). ${ }^{13}$

Em relação a esse manual, conforme consta em sua quarta capa, ele "[...] interessa a todos que, direta ou indiretamente, estão ligados à produção ou ao consumo da Literatura Infantil e Juvenil, destinando-se, particularmente, aos Cursos de Formação Específica de $2^{\circ}$ Grau para o Magistério" (Góes, 1984, quarta capa).

Nascida na cidade de Amparo-SP, em 1934, Maria Lúcia Pimentel de Sampaio Góes, ${ }^{14}$ em 1952, concluiu um curso de Litterature Française, pela Aliança Francesa, e, em 1957, um curso de música, pelo conservatório Dramático e Musical de São Paulo. No ano de 1958, graduou-se em Ciências Jurídicas e Sociais pela USP e, em 1981, concluiu o seu mestrado em Letras pela mesma universidade. Em 1989, doutorou-se em Letras, também pela USP, sob orientação de Nelly Novaes Coelho. Como professora, atuou na USP, principalmente nas áreas de Estudos Comparados de Literaturas de Língua Portuguesa, Literaturas Clássicas e Literatura infantil. E, além de professora e pesquisadora no campo dos estudos literários, é escritora de livros de literatura infantil.

Em Introdução à literatura infantil e juvenil, Góes (1984) explica que esse manual se originou de pesquisas que desenvolveu e de palestras e cursos que proferiu para tratar do ensino da literatura infantil, por isso o cará-

13 Não foi possível localizar informações sobre a editora Pioneira.

14 As informações biográficas de Lúcia Pimentel Góes foram extraídas de Coelho (2006) e de seu curriculum vitae, disponível na Plataforma Lattes do CNPq. 
ter introdutório. Cabe destacar, em relação a essa explicação, que quando ela teve publicado esse manual, ela já havia iniciado sua pesquisa de doutorado, que posteriormente resultou na tese intitulada Em busca da matriz: a literatura infantil e juvenil portuguesa, suas peculiaridades e evolução das origens à atualidade..$^{15}$

Composto em 189 páginas, esse manual está dividido em quatro capítulos: "Sobre o conceito de literatura infantil"; "Histórico da literatura infantil"; "Breve história da literatura infantil"; e "Tipologia das histórias infantis". Sobre essa organização, consta na quarta capa desse manual que Góes definiu os capítulos e tópicos a serem trabalhados de acordo com os conteúdos programáticos da HEM. Com isso, "[...] a objetividade de seu questionamento, acerca dos problemas mais controversos da área, tornam fácil sua utilização e fecunda a sua aplicação em situação de estudo” (Góes, 1984, quarta capa).

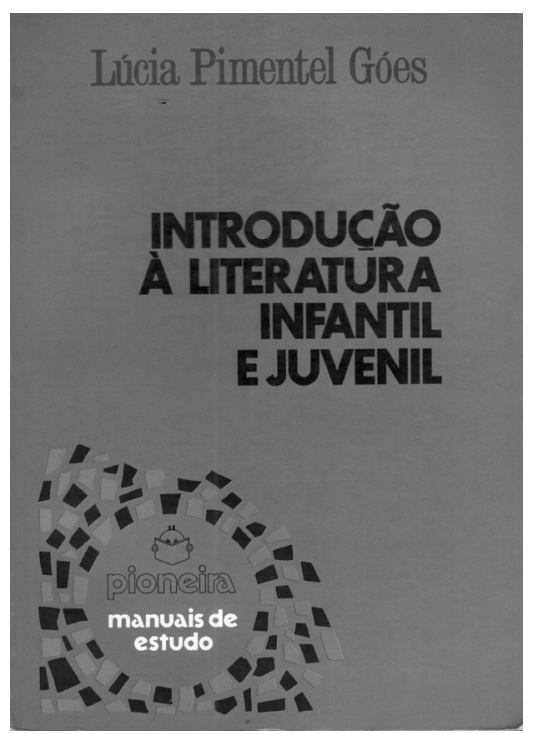

Figura 16 - Capa de Introdução à literatura infantil e juvenil (1984), de Lúcia Pimentel Góes. Fonte: Acervo do GPHELLB.

Com dedicatória à "mestra", "orientadora" e "amiga" Nelly Novaes Coelho, Góes (1984) inicia o seu manual levantando o problema de conceituação da literatura infantil. Segundo ela, o estudo desse gênero literário

15 Lúcia Pimentel Góes defendeu sua tese de doutorado em 1989, junto à FFLCH-USP. 
se deparava com duas questões importantes: a existência de uma literatura infantil propriamente dita e, em caso afirmativo, a sua conceituação.

Buscando respaldo em autores como Jesualdo Sosa, Lourenço Filho, Bárbara Vasconcelos de Carvalho, Cecília Meireles, entre outros, Góes (1984) compreende que há uma literatura específica para o público infantil, o que não a faz deixar de ser literatura, "[...] mensagem de arte, beleza e emoção” (Góes, 1984, p.3). Ela alerta, no entanto, para a necessidade de distinguir literatura infantil da literatura didática.

A literatura didática é aquela com fim pragmático, enquanto a literatura infantil é desinteressada, cuja "[...] linguagem é carregada de significados até o máximo grau possível e dirigida ou não às crianças, mas que responda às exigências que lhes são próprias” (p.15-16).

Góes (1984) apresenta alguns "defeitos" que a literatura infantil podia apresentar, sobretudo a literatura infantil escrita propriamente para a criança. Segundo ela, o primeiro desses "defeitos" era o "tom moralizador". Ainda que Góes (1984) concordasse com a ideia de que o valor moral sempre deva estar presente em um livro, o "tom moralizador", caracterizado como o "castigo dos vícios" e a "recompensa das virtudes", não é adequado na literatura infantil.

Outro "defeito" que ela identifica na literatura infantil é a "puerilidade" dos livros. Em grande parte deles, a linguagem é carregada de diminutivos, "tom adocicado" e falsa simplicidade, explica Góes (1984).

A partir desses "defeitos", Góes (1984) discute a questão das funções desse gênero literário. Com base no manual de 1968, de Maria Antonieta Antunes Cunha, ela afirma que uma das funções da literatura infantil é influir em todos os aspectos na educação do aluno, no aspecto da sua atividade, da sua inteligência e da sua afetividade. "O ideal da literatura é deleitar, entreter, instruir e educar as crianças, e melhor ainda se as quatro coisas de uma vez. [...] O prazer deve envolver tudo o mais. Se não houver arte que produza o prazer, a obra não será literária e, sim, didática” (Góes, 1984, p.32).

Com base em texto de Lourenço Filho (1943), afirma que a "[...] compreensão artística dessa literatura exige a aceitação de uma estética evolutiva ou genética a ser conhecida ou, ao menos, sentida pelos que escrevem para crianças" (p.30). Para explicar como que a literatura infantil se adequada a cada uma das fases evolutivas do psiquismo e interesse infantil, Góes (1984) cita o trecho de um texto de Antônio d'Ávila: 
1) idade dos bichos ( 4 a 6 anos), em que os animais ocupam o centro de seu interesse, tudo sabem, tudo põem.

2) idade das fadas ( 7 a 9 anos), em que as maravilha atribuídas aos bichos passam a ser executadas por seres imaginários que simbolizam determinados poderes e sentimentos, mas cuja esfera de ação ultrapassa os limites do quotidiano e do concreto;

3) idade das aventuras (9 a 11 anos), em que os heróis humanos vão substituindo as personagens imaginárias e os seus atos heroicos começam a sofrer o controle da crítica, indicando, nos últimos anos da infância, já um grau de faculdade lógica a desenvolver-se. (D’Ávila apud Góes, 1984, p.31)

Discordando do ponto de vista de Regina Zilberman, apresentado em $A$ literatura infantil na escola (1981), Góes (1984) reitera a sua afirmação de que a literatura infantil se origina na tradição oral, no imagismo, no mito e na lenda, que acompanham o homem desde o seu princípio. Ainda que na Antiguidade, até o século XVII, não se produziam livros específicos para o público infantil, ela discursa do ponto de vista de Zilberman (1981), sobre a origem da literatura infantil estar relacionada à ascensão da burguesia no século XVIII.

Em relação aos textos que utilizou em seu manual, apesar de Góes (1984) fazer referência a alguns autores, ela não indica nenhuma bibliografia. De qualquer modo, é possível observar que os manuais de Bárbara Vasconcelos de Carvalho e Antônio d'Ávila, os livros de Jesualdo Sosa e de Cecília Meireles e textos de Lourenço Filho foram fundamentais na elaboração de Introdução à literatura infantil e juvenil.

Em 1989, Fanny Abramovich teve publicado o manual Literatura infantil: gostosuras e bobices, pela editora Scipione (SP), ${ }^{16}$ como volume da série "Pensamento e Ação no Magistério", da coleção "Fundamentos para o Magistério”. Essa série, conforme consta na quarta capa desse manual, compreende a reunião de livros teóricos e práticos necessários a todos os professores que desejam modificar o seu fazer pedagógico no dia a dia em sala de aula. Essa série se divide em três coleções, entre as quais, "Fundamentos para o magistério”. Essa coleção, por sua vez, focaliza livros de “[...]

16 A editora Scipione está no mercado há mais de 20 anos. Em 1983, foi adquirida do professor Scipione Di Pierro Netto pela família Fernandes Dias e, em 1999, pelo Grupo Abril. Desde os anos 1990, a Scipione se firmou no ramo dos livros didáticos e, atualmente, também publica livros de literatura infantil e juvenil. Informações disponíveis em: <http://www. scipione.com.br/conhecendoascipione.asp?bt=1>. Acesso em: 19 de nov. 2014. 
fundamentação teórica indispensável à formação pedagógica dos professores de pré-escola, $1^{\circ}$ grau e demais licenciaturas, sem esquecer, contudo, os componentes metodológicos" (Abramovich, 1989, s.p.).

Por integrar essa série e essa coleção, Literatura infantil: gostosuras e bobices se destina, especialmente, a:

Estudantes do curso de Magistério, nas disciplinas: Literatura infantil, Língua Portuguesa, Educação Artística e Didática

Professores de $1^{\circ}$ grau e demais profissionais da área de Pedagogia

Estudantes dos cursos de Licenciatura em Língua Portuguesa, Arte-educação e Pedagogia. (Abramovich, 1989, página de rosto)

Sobre a autora, Fanny Abramovich ${ }^{17}$ nasceu na cidade de São Paulo e se formou em Pedagogia pela Faculdade de Filosofia, Ciência e Letras da USP. Após formar-se professora, atuou na educação infantil, ensino de $1^{\circ} \mathrm{e} 2^{\circ}$ graus e em faculdades da cidade de São Paulo, como, a Faculdade de Belas Artes, a Faculdade Anhembi e a Fundação Armando Álvares Penteado (Faap). No ensino de $2^{\circ}$ grau e nas faculdades, Fanny Abramovich lecionou, especialmente, "Didática", "Prática de ensino" e "Literatura infantil". E, além de ser professora, atuou como orientadora pedagógica, sempre voltada para o campo da arte, do teatro e da literatura infantil. Concomitantemente a sua atuação como professora, Fanny Abramovich colaborou com jornais, fez diversas palestras, ofertou diferentes cursos, integrou júris de concursos e prestou assessoria em editoras voltadas às publicações infantis.

Literatura infantil: gostosuras e bobices contém 174 páginas, divididas em nove capítulos, prefácio, introdução, dicas de livros infantis e bibliografia. Os capítulos desse manual são: "Ouvindo histórias", "Olhando histórias”, Sobre as ilustrações... cadê as caras do terceiro mundo?”, "Humor na literatura infantil", "Poesia para crianças", "Se inteirando das verdade", "Se maravilhando com os contos de fadas", "Trabalhando com a apreciação crítica" e "Frequentando e formando bibliotecas".

Como se pode notar, os títulos dos capítulos desse manual se apresentam de forma bastante diferente dos demais manuais publicados até então. Mas não são apenas os títulos dos capítulos que se diferenciam. O livro de

17 As informações biográficas sobre Fanny Abramovich foram extraídas do seguinte site: <http://www.vidaslusofonas.pt/fanny_abramovitch.htm>. Acesso em: 10 de out. 2014. 
Fanny Abramovich é composto por um conjunto de ilustrações e imagens e ela utiliza linguagem bastante coloquial, em tom de conversa, com fortes marcas da oralidade.

Esses aspectos se relacionam, especialmente, com o fato de que, durante a década de 1980, a produção sobre literatura infantil vinha passando por uma renovação, a qual se centrava no questionamento das finalidades didáticas e moralistas atribuídas à literatura infantil. Os estudiosos e pesquisadores da literatura infantil da década de 1980, especialmente ligados ao meio acadêmico, defendiam a liberdade de criação estética desse gênero literário, desvencilhada dos padrões moralistas predominantes em quase todo o século XX.

As inovações que apresentam o manual de Abramovich são enfatizadas, por exemplo, no prefácio de autoria de Maria Bernadete Marques Abaurre. Nesse prefácio, essa autora afirma que a escolha de Abramovich por esse tipo linguagem foi bastante acertada, pois com toda certeza seria muito mais difícil convencer o leitor do prazer da leitura com uma linguagem excessivamente formal, acadêmica e hermética. Além de destacar a questão da linguagem, Maria Bernadete Marques Abaurre afirma que o manual de Abramovich também possibilita refletir sobre a importância e a necessidade de partilhar experiências de leitura e da cumplicidade que às vezes se desenvolve entre texto e leitor.

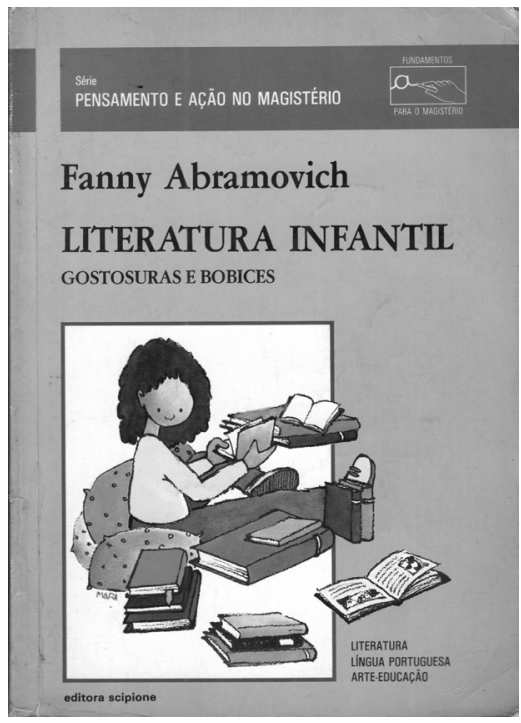

Figura 17 - Capa de Literatura infantil: gostosuras e bobices (1989), de Fanny Abramovich. Fonte: Acervo do GPHELLB. 
Em Literatura infantil: gostosuras e bobices, Abramovich (1989) inicia sua argumentação tratando da contação de histórias. Segundo ela, essa atividade é o meio pelo qual a criança inicia sua aprendizagem como leitora. Normalmente, o primeiro contato da criança com um livro é por meio da oralidade. Quando se lê para os pequenos se suscita a imaginação, se desperta a curiosidade e se possibilita o desenvolvimento de ideias para solucionar questões. É “[...] ouvindo histórias que se pode sentir (também) emoções importantes, como a tristeza, a raiva a irritação, o bem-estar, o medo, a alegria, o pavor, a insegurança, a tranquilidade, e tantas outras mais, e viver profundamente tudo o que as narrativas provocam em quem as ouve [...]" (p.17).

Mas para que a contação de história consiga atingir esses efeitos, Abramovich (1989) alerta para alguns cuidados que o contador ou narrador precisa ter. Segundo ela, contar história é uma arte, que não pode ser feita de qualquer modo. O primeiro aspecto a ser observado é a escolha do texto. Não se pode pegar o primeiro livro que vem à mão e ler para a criança. É necessário que o contador ou narrador conheça o texto, a fim de evitar que "enrosque" na leitura ou não transmita verdade. Para Abramovich (1989), a pessoa que conta ou narra uma história precisa inspirar verdade, pois somente assim despertará o interesse e admiração no ouvinte.

Além da contação de história, Abramovich (1989) destaca o papel dos livros sem texto como possiblidade de formação do leitor. Segundo ela, algumas editoras estrangeiras desenvolveram papel fundamental na publicação de livros apenas de imagens ou de publicações com pouquíssimas palavras. No caso do Brasil, Abramovich (1989) menciona o "incrível" trabalho de Eva Furnari, Angela Lago e Eliardo França.

Abramovich (1989) também se detém sobre os livros ilustrados, os quais instigam o leitor a adentrar no universo da história, reforçando caráter ético e estético do texto.

Pelo fato de os livros ilustrados conterem essas características, Abramovich (1989) considera importante o professor estar atento à forma como as personagens são representadas, não para se analisar a qualidade do desenho em si, mas para identificar estereótipos e representação das relações de poder.

Outro aspecto que Abramovich (1989) destaca seu manual é o uso do humor na literatura infantil. Ainda que o humor parta, recorrentemente, de uma ideia engraçada, ele também pode se inspirar no tédio, aborrecimento, mau humor, irritação, lamúrias, queixas e reclamações. Fazer literatura de humor não é contar piada, fazer graças ou comentários óbvios e "bobocas". O 
humor é, nas palavras de Millôr Fernandes, "[...] uma forma completamente desinibida e descondicionada de ver as coisas" (apud Abramovich, 1989, p.64).

Detendo-se a algumas das formas de manifestação da literatura infantil, Abramovich (1989) faz algumas considerações sobre as poesias em suas diferentes formas e os contos maravilhosos.

Em relação à poesia, ela entende que esse é um dos gêneros da literatura infantil que mais sofrem com o descaso editorial. Segundo ela, poucos livros de poesias eram publicados no Brasil. Também a poesia sofria diferentes preconceitos, como: a sua associação a necessidade de moralização; a compreensão de que a poesia tem que ser curta; a ideia de que poesia tem que tratar de temas nacionais e patrióticos; ou o inverso, que deve tratar de assuntos piegas. Para Abramovich (1989), independentemente de qual seja o tema e a extensão da poesia, o que interessa é ela ser de qualidade. Elas precisam "brincar" com as palavras, de modo lúdico, mexer com a sonoridade e com a atenção da criança.

Em relação aos contos de fadas, ela destaca o fato de que, quando se dá a ler um texto desse gênero, não se imagina que seus registros se encontram "perpetuados" há milênios. Por isso, os contos de fadas são importantes para se trabalhar conteúdos da sabedoria popular, conteúdos essenciais da condição humana, os quais se encontram registros até hoje. Por onta da importância que Abramovich (1989) reconhece terem os contos de fadas, ela destaca que eles vinham tornando objeto de estudo da Psicanálise, da Sociologia e da Antropologia.

Abramovich (1989) também problematiza a literatura infantil como fonte de informação. Ela explica que a curiosidade em conhecer mais sobre as coisas é característica dos seres humanos, em especial das crianças. A literatura, por isso, pode ser fonte de informação, que atua no sentido de sanar essa curiosidade. Porém, Abramovich (1989) alerta o professor que não se deve esquecer que ao se utilizar do livro literário como fonte de informação, trata-se de uma fonte literária,

[...] de ficção, de histórias, onde se aborda um - ou vários problemas - que a criança pode estar atravessando ou pelo qual pode estar se interessando... De uma leitura que não é óbvia, discursiva ou demonstrativa de tal tema.... Onde ele flui naturalmente e límpido, dentro da narrativa - que evidentemente não tratará apenas disso. (Abramovich, 1989, p.99) 
Por ser a literatura infantil um gênero muito associado à escola, Abramovich (1989) apresenta algumas considerações sobre os cuidados que se devem ter com esses livros. Um primeiro aspecto apontado por ela se refere ao modo impositivo que a leitura é disposta na escola. Normalmente, os alunos não escolhem o que iam ler, apenas recebiam as "indicações" dos professores. Essa situação é, para Abramovich (1989, p.140), contraditória, pois não é possível que alguém aprenda a gostar de ler, sem que possa escolher o que ler.

Outro aspecto que Abramovich (1989) aponta é o relacionado às chamadas fichas de leitura. Ela afirma que essa ficha, "bitolada" e "bitoladora", em nada ajuda os leitores a perceber o significado pessoal da leitura. Em vez de perguntar quais emoções sentiu o leitor ao ler o texto, o que o mobilizou, porque gostou ou não gostou, essas fichas se detêm a aspectos superficiais e pontuais. Para Abramovich (1989) a leitura literária precisa ser objeto de discussão crítica, de problematização na escola. As emoções sentidas, as reações precisam ser problematizadas pelo professor e pelos próprios leitores.

Para concluir, Abramovich (1989) trata da questão das bibliotecas, entendidas como espaços de acesso ao livro, que despertar o interesse infantil pela leitura literária.

A bibliografia indicada por Abramovich (1989) é composta por 20 títulos, entre os quais, destaco: O que é literatura infantil (1986), de Ligia Cadermatori; Problemas da literatura infantil (1951), de Cecília Meireles; A literatura infantil (1978), de Jesualdo Sosa; Literatura infantil brasileira (1968), de Leonardo Arroyo; A literatura infantil na escola (1981), de Regina Zilberman; Literatura infantil: histórias \& história (1984), de Marisa Lajolo e Regina Zilberman; A psicanálise dos contos de fadas (1978), de Bruno Bettelheim; Morfologia do conto (1983), de Wladimir Prop; e Mentiras que parecem verdades, de Umberto Eco e Marisa Bonazzi.

Em relação a essa bibliografia, o que se pode notar é que ela se diferencia bastante das bibliografias dos demais manuais. De modo geral, têm-se livros publicados após a década de 1980, exceto os livros de Meireles (1951), Arroyo (1968) e Sosa (1978). Esses livros relacionados por Abramovich (1989) eram todos decorrentes de pesquisas acadêmico-científicas sobre a literatura infantil, de autoria de pesquisadores ligados o movimento de renovação dos discursos sobre esse gênero literário. 
Em 1991, foi publicado, pela Editora do Brasil, o manual de ensino mais recente que localizei: Estudos de literatura infantil, de Manoel Cardoso. ${ }^{18}$ Esse manual foi organizado

[...] visando a completa preparação do futuro professor abrangendo: fonética, morfologia, sintaxe, estudo de texto, estilística, ortografia, pontuação e demais diacríticos, versificação e produção de texto. Trata-se de uma visão completa de tudo o que existe no vastíssimo campo da Literatura Infantil - das fábulas de Esopo e Sedro, aos atuais meios de comunicação [...] (Cardoso, 1991, orelha)

Cardoso (1991), licenciado em Letras e mestre em Literatura Portuguesa, explica que Estudos de literatura infantil surgiu durante as suas aulas, tendo em vista a necessidade de apresentar aos seus alunos uma visão panorâmica de tudo o que se relacionava à literatura infantil. Com isso, relata que foi necessário retroceder no tempo, buscando na Idade Média a compreensão da literatura infantil, até se chegar à modernidade e à contemporaneidade.

Para dar conta dessa proposta, Cardoso organizou o seu manual em 12 capítulos, totalizando 143 páginas. Esses capítulos se intitulam: "A literatura infantil e sua importância”, "A fábula, começo de tudo", "Clássicos da literatura infantil”, "Precursores da literatura infantil, no Brasil”, "Monteiro Lobato, o criador da Literatura infantil brasileira", "Ciclo intermediário na literatura infantil", "Tendências da literatura infantil na atualidade", "Textos destinados a leitores da pré-escola e das primeiras séries", "Poesia infantil brasileira", "A leitura teatralizada", "O folclore e sua projeção na literatura infantil" e "Literatura infantil e outros meios de comunicação".

Cardoso (1991), por entender a importância da literatura infantil na formação do leitor, afirma que cabia à escola de $1^{\circ}$ grau disseminar a leitura e a literatura para crianças e jovens. Para isso, considera fundamental orientar os professores, que eram os responsáveis por conduzir as crianças no universo literário.

18 Não foi possível localizar informações sobre Manoel Cardoso. 


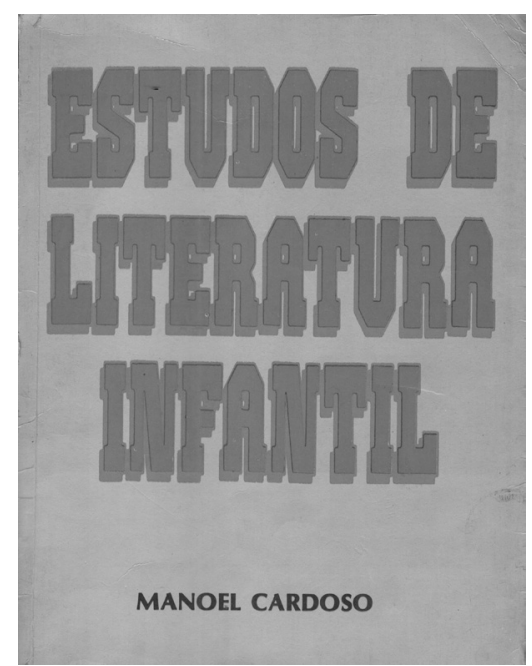

Figura 18 - Capa de Estudos de literatura infantil (1991), de Manoel Cardoso. Fonte: Acervo do GPHELLB.

Ele aborda aspectos históricos da literatura infantil, destacando que a origem desse gênero se encontra na fábula, formato literário que "encobre" a moralidade sob o "disfarce" de ficção. Cardoso (1991) também afirma que os primeiros livros escritos especificamente para as crianças foram os didáticos, o que fez com que elas optassem pela leitura de narrativas originalmente destinadas aos adultos. Entre essas narrativas, ele destaca os livros de Charles Perrault, Irmãos Grimm e Hans Christian Andersen. Esses textos, genericamente denominados de contos maravilhosos, revelam:

[...] verdades importantes sobre a vida e todas as implicações que ela apresenta: nascimento, trabalho, injustiça, castigo, vitória, prêmio, conquista do amor. Tantas vezes, os contos de fadas abordam a necessidade de o ser humano provar-se, sentir medo, para que possa revelar sua capacidade de indivíduo que luta e vence. (Cardoso, 1991, p.25)

Em relação ao Brasil, Cardoso (1991) identifica que os primeiros livros publicados com destinação às crianças foram os de Olavo Bilac e Francisca Júlia. No entanto, apesar de considerar que ambos os autores apresentam contribuição valiosa para a literatura infantil brasileira, os livros escritos 
por ambos ainda se circunscreviam no "tradicionalismo", que não era na literatura infantil contemporaneidade.

Por essa razão, Cardoso (1991) considera que Monteiro Lobato foi quem, de fato, "criou" a literatura infantil brasileira. Esse escritor conseguiu produzir uma literatura que se associava à tradição do folclore, possibilitando ao leitor a consciência de mundo, desde a antiguidade, com Esopo e Fedro, até chegar ao sítio. Cardoso (1991) afirma que, até 1991, “[...] ninguém na literatura Brasileira, adulta ou infantil, conseguiu, com tal largueza, amplitude, universalidade, beirar a obra do Mágico de Taubaté" (Cardoso, 1991, p.46, grifos do autor).

Depois do fenômeno "Monteiro Lobato" e da "libertação" do "ranço" didático e pedagógico que esse escritor promoveu na literatura infantil, Cardoso (1991) afirma que, no período de 1940 a 1970, surgiram outros escritores de destaque, como Érico Veríssimo, Lúcia Machado de Almeida, Odette de Barros Mott, Francisco Maris e Isa Silveira Leal. Concomitantemente ao despontar desses escritores, Cardoso (1991) afirma que a produção de literatura infantil cresceu significativamente. Nesse período, instituíram-se:

[...] concursos literários, criam-se prêmios literários de nível nacional. Funda-se a Academia Brasileira de Literatura Infantil, sediada em São Paulo. A literatura infantil entra numa acelerada publicação, suplantando em muito a considerada adulta, conseguindo status de Literatura Arte e não mais o de disciplina auxiliar, como em décadas passadas. Em parte, beneficia-se pela Lei 5692/71, que valorizava o autor nacional e estimula a leitura, em sala de aula e fora dela, como elemento imprescindível ao enriquecimento do universo da criança. (Cardoso, 1991, p.52)

Nesse movimento crescente da produção de livros de literatura infantil no Brasil, Cardoso (1991) identifica que predominam quatro tendências literárias nos livros para crianças e jovens: Romantismo, Realismo, Simbolismo e Modernismo.

Com relação ao Romantismo, ele entende que essa tendência se manifesta na literatura infantil por meio da aventura, da "luta pelo triunfo da justiça”, no mistério dos detetives, nas lendas e nos mitos. O Realismo, 
por sua vez, bem mais recente na literatura infantil, manifesta-se nesse na preocupação com questões sociais, raciais, étnicas, ecológicas e de desigualdades e injustiças. O Simbolismo se manifesta na literatura infantil pelo mundo da fantasia, das fábulas renovadas, como se faz em A fada que tinha ideias, de Fernanda Lopes de Almeida. O Modernismo, por sua vez, tem a sua forma registrada na literatura infantil por meio da renovação da linguagem, da criação da literatura que provoca a intuição e o questionamento por meio de novas "codificações" para as palavras.

Cardoso (1991) também aborda a questão do uso da literatura infantil na pré-escola e nas duas primeiras séries do ensino de $1^{\circ}$ grau. Para ele, quando a criança está em idade de 3 a 7 anos, o mais adequado é ofertar a ela a literatura oral. Por meio da "contação", deve-se possibilitar o acesso a histórias maravilhosas, com seres mitológicos e lendas, para despertarem a imaginação. Paralelamente à literatura oral, Cardoso (1991) explica que se deve ofertar à criança a literatura na sua forma escrita. No entanto, as histórias devem ser breves e dinâmicas. Ele recomenda que essas histórias sejam repletas de imagens, que possibilitem a crianças recontar a história apenas pela ilustração.

Para concluir, Cardoso (1991) problematiza a relação entre literatura infantil e outros meios de comunicação, como a revista, o jornal, os quadrinhos, a televisão, a música popular e o cinema. Segundo ele, o Brasil tinha grande tradição em associar a literatura infantil a esses meios de comunicação e, por isso, havia, à época, trabalhos nessa área com resultados recomendáveis. Esse era o caso, por exemplo, da revista Tico-tico.

Nessa bibliografia de Estudos de literatura infantil, Cardoso (1991), assim como alguns autores de manuais das décadas de 1980 e 1990, mescla a produção sobre literatura infantil característica dos anos 1950 e 1960, com a produção acadêmica dos anos 1980 .

Entre os livros relacionados na bibliografia desse manual, destaco: $\mathrm{Li}$ teratura infantil brasileira (1968), de Leonardo Arroyo; O que é literatura infantil (1986), de Ligia Cadermatori; Literatura infantil: visão histórica e crítica (1982), de Bárbara Vasconcelos de Carvalho; Literatura infantil: história, teoria, análise (1981), de Nelly Novaes Coelho; Literatura infantil: teoria \& análise (1983), de Maria Antonieta Antunes Cunha; Introdução à literatura infantil e juvenil (1984), de Lúcia Pimentel Góes; O texto sedutor 
na literatura infantil (1986), de Edmir Perrotti; Literatura infantil brasileira: histórias \& história (1984), de Marisa Lajolo e Regina Zilberman; A literatura infantil (1978), de Jesualdo Sosa; A literatura infantil na escola (1981), de Regina Zilberman; Morfologia do conto (1983), de Wladmir Prop; e Psicanálise dos contos de fadas (1978), de Bruno Bettehleim.

Ainda no período abordado neste capítulo, década de 1970 a década de 1990, foi publicado outro manual de ensino, cuja data não pude localizar. Trata-se do Pequeno tratado da literatura infantil e infanto-juvenil, de autoria de Martina Sanchez, pela Imery Publicações (GO). ${ }^{19}$

Nascida em Piraju-SP, em 1937, Martina Sanchez formou-se professora em 1956, no Instituto de Educação Cel. Nhonhô Braga, na mesma cidade. Em, 1957, ingressou na Faculdade de Filosofia, Ciências e Letras de Sorocaba, onde cursou licenciatura em Geografia. Em 1962, passou a atuar como professora de $1^{\circ}$ e $2^{\circ}$ graus e, em 1979 , assumiu a cadeira "Geografia e Estudos Sociais" na E.E.P.G. Ataliba Leonel. Martina Sanchez também se graduou em Pedagogia Educacional e participou da reforma do ensino do estado de São Paulo, para a implantação da Lei n. 5.692, de 1971. Além de atuar como professora e ocupar cargos adminstrativos na educação paulista, Sanchez é escritora de livros de literatura infantil.

Da sua experiência como professora e escritora, Sanchez escreveu $\mathrm{Pe}$ queno tratado de literatura infantil e infanto-juvenil, visando "[...] organizar um conjunto de informações de caráter didático que atendam interesses de Professores, Orientadores e Estudantes em Geral" (Sanchez, s.d., orelha).

Para atender a esse propósito, ela compôs seu manual em 141 páginas, divididas em introdução, oito capítulos, conclusão, apêndice e bibliografia. Os capítulos de Pequeno tratado de literatura infantil e infanto-juvenil são os seguintes: "Literatura infantil”, "A criança através dos tempos e o que tinha para ler", "A Psicologia infantil e a importância da literatura no desenvolvimento infantil”, "Alguns autores e obra da literatura 'clássica' infantil e infanto-juvenil", "Principais formas de literatura infantil", "Biblioteca infantil e o livro na escola",; "Problemas da literatura infantil" e "A mensagem universal - formativa na linguagem infantil”.

19 Não foi possível localizar informações sobre a editora Imery Publicações. 


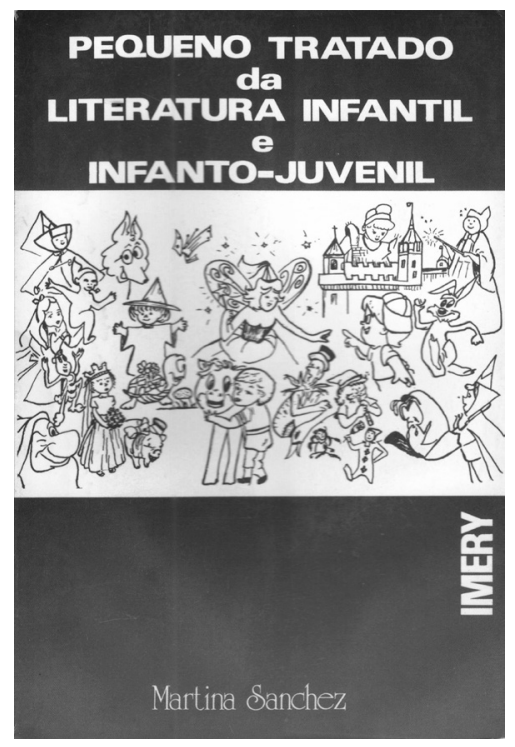

Figura 19 - Capa de Pequeno tratado da literatura infantil e infanto-juvenil (s.d.), de Martina Sanchez.

Fonte: Acervo pessoal do autor.

Nesse manual, Sanchez (s.d.) levanta a discussão de que, ao se definir literatura como "arte de compor obras literárias, em prosa e verso", logo vem à mente dos professores a associação desse fenômeno artístico aos textos escritos. Porém, ela explica que a literatura abrange muito mais que os textos em formato escrito. Desde os povos primitivos, quando a escrita ainda não havia se desenvolvido, observa-se uma importante herança literária, que, para Sanchez (s.d.), é a fonte de toda a literatura, inclusive infantil.

Com essa concepção abrangente de literatura e literatura infantil, ela alerta que é preciso lembrar que no âmbito desse gênero literário há os que são para fins didáticos e os que são para fins de recreação. Com base nos livros de Jesualdo Sosa, Cecília Meireles e Bruno Bettelheim, ela define a literatura infantil, com fins de recreação, como toda obra literária "[...] que ofereça à criança ou ao jovem a oportunidade de crescer intimamente, de realizar em si a síntese do mundo em que vive" (Sanchez, s.d., p.14).

Apesar de entender a literatura infantil dessa forma, Sanchez (s.d.) explica que, entre os séculos XVIII e XIX, esse gênero literário era entendido como instrumento de formação ética das crianças. Essa situação mudou ao longo do século XIX, em especial com os Irmãos Grimm, quando a litera- 
tura enveredou para objetivos mais ligados à fantasia, ao entretenimento, ao maravilhoso. Nesse período, Sanchez (s.d.) entende que a literatura infantil passou a ser entendida como forma de dar "[...] à criança novas informações, que lhe assegurem um poder de flexibilidade de espírito para compreender as situações que terá que enfrentar no dia a dia, no futuro, e entre as quais deverá acomodar harmoniosamente sua vida" (Sanchez, s.d., p.15-16). Por entender que a literatura infantil possibilita ao leitor "crescer intimamente", Sanchez (s.d.), também com base em conceitos da Psicologia, especialmente os de Jean Piaget, afirma que os textos literários deviam se associar às fases do desenvolvimento psíquico da criança. Ela explica que, por volta dos 3 anos de idade, a criança, já munida de imaginação e criação, se interessa por representações dramáticas simples. Também os livros de gravuras são interessantes, pois esse tipo de livro possibilita iniciar a aprendizagem da leitura e do cálculo. Por volta dos 5 anos, quando a criança inicia a aprendizagem de um vocabulário mais amplo, seu interesse intelectual se voltará para livros com figuras e alguns textos simples, pois isso facilita a memorização e repetição. Aos 6 anos, idade pré-escolar, as crianças se esforçam para transferir conhecimentos, tentando ler quaisquer textos que lhes são dados nas mãos. A partir dos 10 anos, permanece o interesse "animista" pela literatura, como o fantástico e o maravilhoso, porém a criança vai se identificando com o mundo real, ganhando espaço as narrativas de aventuras, por exemplo.

Discorridos esses aspectos, trata da questão das bibliotecas infantis, uma vez que, diante da amplitude de possibilidades de leitura que uma criança podia ter, a biblioteca se configurava como espaço de oportunidade de escolhas.

Sanchez (s.d.) o conclui com a afirmação de que o público infantil sempre foi e continuará a ser o de mais difícil acesso pela arte. De qualquer modo, defende a necessidade de se formar um novo "humanismo" por meio da literatura infantil.

O restabelecimento do aprendizado da utilização do bem maior que o homem possui - sua capacidade mental e moral, que o levará a uma perfeita sintonia com o Todo. E a juventude será capaz de realizar esse milagre, se lhe for dada a oportunidade de se conhecerem a si próprios, através do desenvolvimento dessas capacidades. (Sanchez, s.d., p.125). 
Em relação à bibliografia desse manual, Sanchez (s.d.) relaciona 17 títulos. Especificamente sobre literatura infantil, ela indica os seguintes: A literatura infantil (1978), de Jesualdo Sosa; Psicanálise dos contos de fadas (1978), de Bruno Bettelheim; e Problemas da literatura infantil (1979), de Cecília Meireles. Além desses, ela indica em sua bibliografia os livros Biologia y pedagogia, de Ortega y Gasset; El libro de mi amigo, de Anatole France, e L'Émile, de J. J. Rousseau.

\section{A literatura infantil e o ensino de $1^{\circ}$ grau em São Paulo}

Tendo em vista os aspectos apresentados até aqui, embora no período entre 1971 e 2003 o ensino da literatura infantil se destinava à formação do professor, na década de 1980, pela primeira vez, observa-se a publicação de documentos específicos sobre o trabalho com a literatura infantil na escola de $1^{\circ}$ grau.

Na década de 1980, quando a Secretaria de Estado da Educação de São Paulo, visando desempenhar a melhoria do ensino de $1^{\circ}$ grau, publicou alguns documentos destinados aos professores em exercício, com orientações sobre o uso da literatura infantil no ensino da leitura. Tratam-se do "livro de classe" Ciclo Básico em jornada única: uma nova concepção de trabalho pedagógico: recursos didáticos: sua utilização, elaborado pela Cenp e publicado pela Fundação para o Desenvolvimento da Educação (FDE), em 1989, e o Guia de leitura do acervo básico $1^{\circ}$ e $2^{\circ}$ graus: literatura infantil e juvenil (brasileira), organizado por Maria Célia Rua de Almeida e publicado pelo FDE, em 1991.

Esses documentos, embora não tenham sido elaborados especificamente para uso dos alunos da HEM ou Cefams, serviram como material de formação continuada dos professores em exercício. Além disso, por se tratarem de orientações oficiais da Secretaria de Estado da Educação de São Paulo, eles se apresentam em sintonia com o que se propunha ou se esperava que o professor formado na HEM e/ou no CEFAMs soubessem a respeito do assunto.

Pelo exposto, apresento alguns aspectos desses dois documentos, por entender que eles se relacionam, ainda que indiretamente, ao ensino da literatura infantil na formação de professores no estado de São Paulo. 


\section{O ciclo básico em jornada única}

Como mencionei, no início da década de 1980, com o arrefecimento do regime ditatorial e as constantes denúncias em torno do fracasso escolar, sobretudo em alfabetização (Mortatti, 2000b), a Secretaria de Estado da Educação de São Paulo iniciou um processo de reorganização de todo seu sistema de ensino.

No caso da HEM, como apontei, foi publicada, em 1987, a Deliberação CEE n. 30/87, que visava atender os anseios de melhoria da formação de professores no estado de São Paulo. No caso do ensino de $1^{\circ}$ grau, entre outras medidas, em 1984, a Secretaria de Estado da Educação de São Paulo implantou o projeto intitulado Ciclo Básico, que tinha como principal objetivo atender " [...] às novas urgências sociais e políticas decorrentes da pressão pela 'abertura política' e pela reorganização democrática das instituições e relações sociais [...]” (Mortatti, 2000b, p.257).

O projeto do Ciclo Básico "[...] foi a principal medida de um elemento de projetos pedagógicos voltados para a melhoria da qualidade do ensino, ampliação das oportunidades de acesso e permanência na escola pública e busca de maior aproveitamento da comunidade escolar [...]" (Silva; Dalvis, 1993, p.9). Após a implantação desse projeto, a Secretaria de Estado da Educação, em 1988, por meio do Decreto n. 28.170, de 21 de janeiro, instituiu a Jornada Única de Trabalho Docente e Discente no Ciclo Básico, visando dar condições e infraestrutura para os planos dessa Secretaria.

A partir dessas duas medidas, a Secretaria de Estado da Educação de São Paulo incorporou ao seu discurso oficial a teoria construtivista como a "nova" proposta teórica em alfabetização, a qual passou a embasar todas as ações dessa Secretaria no campo do ensino da leitura e da escrita (Mortatti, 2000).

Em razão dessas mudanças e por conta da necessidade de subsidiar a atuação dos professores, em 1988, a Cenp elaborou o documento Ciclo Básico em jornada única: uma nova concepção de trabalho pedagógico: recursos didáticos: sua utilização, no qual apresenta artigos sobre as possiblidades de uso de recursos diferenciados no processo de alfabetização de crianças.

Esse documento, publicado pela FDE, ${ }^{20}$ está dividido em três partes, a saber: "Alfabetização: novos caminhos", "Enriquecimento curricular no

20 Embora a autoria desse documento seja institucional, em sua página de rosto consta o nome dos professores que atuaram em sua organização. São eles: Cláudio César e Araújo, Isis Maria de Palma Augusto, Maria Aparecida Karouze, Maria Zilda da Cunha Lopes, Mar- 
Ciclo Básico" e "Materiais que compõem os módulos de educação física, educação artística, jogos e brinquedos educativos e livros de literatura infantil".

Na parte referente ao "Enriquecimento curricular do ciclo Básico", há uma seção denominada "A literatura infantil no Ciclo Básico", constituída de quatro textos relativos ao trabalho com a literatura infantil na escola de $1^{\circ}$ grau. São eles: "O livro na escola", de Tatiana Belinky; "A leitura e a literatura”, de Lidia Izecson de Carvalho e Jorge Miguel Marinho; "A leitura na escola", de Regina Maria Elero Ferraz Ivamoto; e "Sobre o acervo do Ciclo Básico”, elaborado pela Equipe Técnica da Gerência de Livros e Bibliotecas da FDE.

Conforme nota explicativa da seção "A literatura infantil no Ciclo Básico", o objetivo maior do trabalho com os livros literários se devia ao fato de que muitas crianças não gostavam de ler, porque não conheciam os livros.

Desta forma, essas crianças não desenvolvem certos rituais de iniciação, que são fundamentais para o estabelecimento de expectativas com relação aos livros. Cumpre, então, à escola preencher essa lacuna, acompanhando mais de perto os contatos desses alunos com os livros, não apenas orientando-os quanto a certas convenções (manuseio, leitura da esquerda para a direita etc.), mas, principalmente, enriquecendo suas expectativas através de narrativas orais, poemas, cantigas etc. (São Paulo, 1988, p.93)

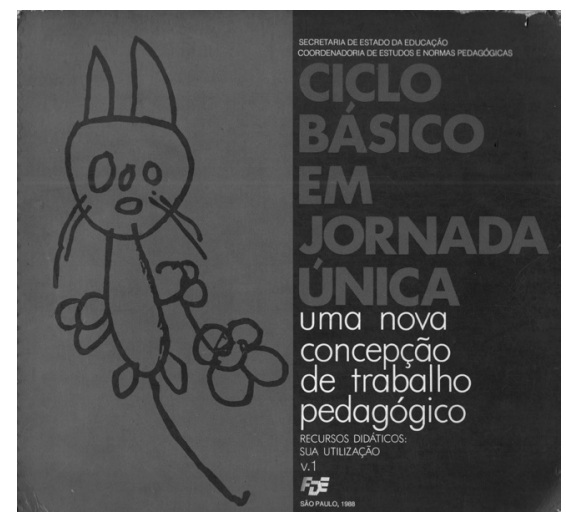

Figura 20 - Capa de Ciclo básico em jornada única: uma nova concepção de trabalho pedagógico (1988).

Fonte: Acervo pessoal do autor.

garida Cecília Corrêa Nogueira Rocha, Marília Claret Geraes Duran, Meire Graça Mattos, Norinês Panicacci Bahia. 
O primeiro artigo da seção "A literatura infantil no Ciclo Básico" é de autoria de Tatiana Belinky e se intitula "O livro na escola". Nele, essa autora inicia sua argumentação expondo que poderia tratar da relação entre o livro e a escola fazendo uso de slogans já famosos, como "um país se faz com homens e livro", de Monteiro Lobato. No entanto, esses slogans tratam de uma importância óbvia dos livros na escolarização, a qual prescinde a existência de uma situação bastante rara à época, a existência de bibliotecas nas escolas. Relata Belinky (1988):

Ah, que sonho: cada escola com sua biblioteca, de livros de consulta e de livros de lazer, em sala de leitura arejada, aconchegante e bem-iluminada para uso dos alunos em horário escolar. E a biblioteca circulante, onde os alunos possam retirar livros de usa própria escolha, para curtir em casa, sem fichas-de-leitura nem cobranças de qualquer espécie. (p.94, grifos da autora)

Além das bibliotecas escolares, Belinky (1988) destaca que se fazia necessário usar os livros literários nas aulas de língua portuguesa, por ser esse um espaço substancial reservado à leitura.

Belinky (1988) opta por, ao invés de uma exposição teórica sobre a relação entre o livro e a escola, relatar uma situação que vivenciou em uma livraria. Ela conta que, em uma de suas visitas a uma livraria, foi abordada por uma criança maltrapilha, que lhe pediu um livro de presente. Ela, surpresa com a situação, ofereceu o dinheiro no lugar do livro; a criança, no entanto, preferiu o livro. Diante dessa situação, ela conta que se pôs a pensar sobre como há tantas crianças, com possibilidade de acesso ao livro, que não sabem o valor que ele tem. Por outro lado, esse menino pobre já havia descoberto o valor da "maravilha" chamada livro.

O segundo artigo da seção "A literatura infantil no Ciclo Básico" é de autoria de Lídia Izecson de Carvalho e Jorge Miguel Marinho, ambos, à época, membros da Equipe técnica de Gerência de Livros e Bibliotecas da FDE.

Nesse artigo, Carvalho e Marinho (1988) expõem que, apesar de ser a leitura a "coluna mestra" de todo o processo de formação escolarizada, o modo como a escola tratava a leitura era desvinculado da própria vida, criando um modo de ler artificial e fragmentado. Eles entendem que: 
[...] o livro de Literatura Infantil se oferece como material privilegiado, na escola, na medida em que seu universo é abrangente: ele tanto possibilita à criança chegar às questões práticas que a leitura propicia resolver, quanto estimula a vivência de emoções as mais variadas, levantando a cortina de um mundo novo que extrapola a realidade imediata e revela uma realidade simbólica que pode ser fascinante. (Carvalho; Marinho, 1988, p.96)

Carvalho e Marinho (1988) explicam que a sua presença do livro, no contexto escolar, é fator de grande estímulo à aprendizagem da leitura e formação do gosto literário. Por meio do trabalho com a literatura infantil, a criança "[...] passa a escrever melhor e a dispor de um repertório mais amplo de informações, a principal função que a literatura cumpre junto a seu leitor é a possibilidade de navegar na aventura da criação" (Carvalho; Marinho, 1988, p.96).

O terceiro artigo da seção "A literatura infantil no Ciclo Básico" é de autoria de Regina Maria Elero Ferraz Ivamoto, à época, membro da Equipe Técnica de Língua Portuguesa da Cenp.

Nesse artigo, intitulado "A leitura na escola", Ivamoto (1988) apresenta uma proposta de trabalho centrada nas seguintes diretrizes: estimular a participação ativa dos alunos em atividades de intercâmbio verbal; dar diferentes opões de leitura; ter o professor como modelo de leitor; evitar leitura pré-dirigida; e saber selecionar os textos a partir dos critérios de linguagem e conteúdo. Além disso, Ivamoto (1989) apresenta sugestões de trabalho com a poesia, o texto narrativo, o texto informativo e a parlenda, todas no contexto das primeiras séries da escola de $1^{\circ}$ grau.

O quarto artigo da seção "A literatura infantil no Ciclo Básico" é de autoria coletiva, registrada, genericamente, como "Equipe de Gerência de Livros e Bibliotecas da FDE".

Nesse artigo, intitulado "Sobre o acervo do ciclo básico", expõe-se sobre a iniciativa da FDE na constituição de um acervo de literatura infantil para o Ciclo Básico, o qual as escolas da rede pública estadual de ensino receberiam. Essa iniciativa decorreu da compreensão de que o primeiro passo para se desenvolver o prazer da leitura literária era saber escolher bem os livros. Por isso, havia sido feita uma seleção diversa e de qualidade de livros de literatura infantil, para que os professores pudessem desenvolver um trabalho que "aguçasse" o interesse de leitura das crianças. 
Além desses quatro artigos, os quais constam na seção "A literatura infantil no Ciclo Básico", na seção "Materiais que compõem os módulos de educação física, educação artística, jogos e brinquedos educativos e livros de literatura infantil" - é apresentado, sob a forma de anexo, a relação dos livros que integram o acervo de literatura infantil do Ciclo Básico.

Ao todo, são apresentadas referências de 112 livros de literatura infantil, os quais variam entre livros de poesias, narrativas longas e narrativas curtas.

\section{O Guia de leitura do acervo básico $1^{\circ}$ e $2^{\circ}$ Graus}

No início da década de 1990, com o processo de implantação de bibliotecas escolares e Centros de Leitura pelo estado de São Paulo, a FDE elaborou documento, no formato de guia, a fim de apresentar " [...] orientações e sugestões para todos que desejam enveredar pelo universo da literatura Infantil e Juvenil". Trata-se do documento Guia de leitura do Acervo Básico de $1^{o}$ e $2^{o}$ graus, publicado em 1991.

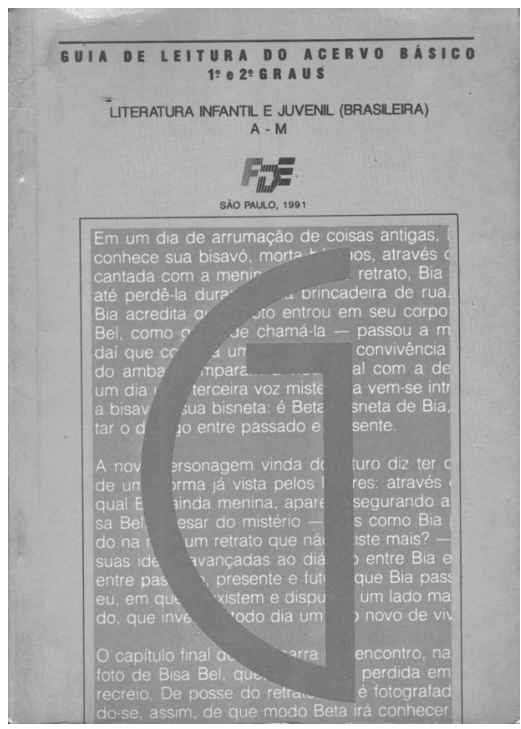

Figura 21 - Capa de Guia de leitura do Acervo Básico de $1^{\circ}$ e $2^{\circ}$ Graus (1991).

Fonte: Acervo pessoal do autor.

Na apresentação desse documento, o então Diretor Técnico da FDE, Sineval Martins Rodrigues, explica o seguinte: "O acesso aos livros já é 
um fato em nossas escolas através da implantação dos Centros de Leitura/ Bibliotecas Escolares. Agora, mais do que nunca, é preciso consolidar essa realidade, estimulando a leitura entre professores e alunos" (Rodrigues, 1991, p.3).

A Gerente de Livros e Bibliotecas da FDE, Maria Aparecida Ceravolo Magnani, por sua vez, ao prefaciar esse guia, explica que, com o objetivo de tornar a escola um espaço de formação de leitores, a Gerência de Livros e Bibliotecas da FDE vinha desenvolvendo estratégias em duas linhas de trabalho: a implantação desses espaços - Bibliotecas e Centros de leitura; e o desenvolvimento de orientação técnica para o trabalho com a leitura na escola. E explica que:

[...] o Guia de leitura do Acervo Básico de $1^{\circ}$ e $2^{\circ}$ graus vem integrar o conjunto de produção da GLB, constituindo-se numa publicação que, ao apresentar de forma sucinta, temas, gêneros, adequação obra/leitor, poderá facilitar aos professores e alunos o conhecimento do acervo básico, bem como auxiliar na indicação e escolha de leitura. (Magnani, 1991, p.5, grifos da autora)

O acervo básico que a FDE havia constituído e que, à época, estava sendo distribuído para as escolas de $1^{\circ}$ e $2^{\circ}$ graus do estado de São Paulo era composto de 180 títulos, alguns de literatura infantil e juvenil e outros de literatura "adulta", "naturalizada" como livros infantis e juvenis.

Por se tratar de títulos "escolhidos" pela FDE, explicam-se os 180 livros que foram previamente analisados por uma equipe técnica especializada, que resultou na formação desse acervo e na elaboração do Guia de leitura do Acervo Básico de $1^{\circ}$ e $2^{\circ}$ Graus. Por isso, esse guia, conforme se explica em uma nota:

[... vem trazer ao professor de $1^{\circ} \mathrm{e} 2^{\circ}$ Graus informações sobre os títulos infanto-juvenil, a fim de auxiliá-lo na escolha do(s) livro(s) que melhor preencha(m) as suas expectativas de leitor e de indicador de leitura. Seus dados se referem ao conteúdo das obras (enredo, tema, ilustração), ao gênero (narrativa, poesia, teatro, livro sem texto) e à adequação livro/leitor. (São Paulo, 1991, p.7)

Nesse guia são apresentados aspectos dos livros de literatura infantil que integram o Acervo Básico de $1^{\circ}$ e $2^{\circ}$ Graus, como: a indicação da série 
para a qual cada um era recomendado, resenha sobre o enredo e as principais características de cada livro. Essas resenhas foram elaboradas por equipo composta por: Ana Maria Domingues de Oliveira, Cláudia Arruda Campos, Lenira Aparecida Buscato, Márcia Garcia Dias, Márcia Maísa Pelachin, Maria Célia Rua de Almeida, Maria da Graça Barreto Baraldi e Regina Maria Hubner.

Entre os títulos que integram o acervo básico e que foram resenhados para integrar esse Guia, destaco: Bisa bia, bisa Bel, de Ana Maria Machado; A bolsa amarela, de Lygia Bojunga Nunes; O gênio do crime, de João Carlos Marinho; Nó na garganta, de Mirna Pinsky; É isso ali, de Elias José; Filó e Marieta, de Eva Furnari; e O mistério do coelho pensante, de Clarice Lispector.

\section{Alguns desdobramentos do ensino da literatura infantil em São Paulo}

Também no período que abordo neste capítulo, 1971 a 2003, além das publicações não diretamente relacionadas ao ensino da literatura infantil na formação de professores, ocorreram outras iniciativas, que indiretamente estavam associadas a esse ensino.

Durante a década de 1970, com o crescente interesse de professores e intelectuais a respeito da literatura infantil e com aumento das publicações de livros desse tipo destinados às crianças, foram criadas duas entidades no estado de São Paulo, bastante significativas no campo da literatura infantil. Tratam-se do Centro de Estudos de Literatura Infantil e Juvenil (Celiju) e da Academia Brasileira de Literatura Infantil e Juvenil (ABLIJ). Embora não tenham sido criadas com objetivo de se ensinar literatura infantil na formação de professoras, ambas decorreram das ações em torno da institucionalização desse ensino, principalmente a partir de 1957. Tanto o Celiju quanto a ABLIJ foram planejadas e criadas por professores envolvidos com o processo de institucionalização e sistematização do ensino da literatura infantil no Ensino Normal paulista, nas décadas de 1950 e 1960. Por essa razão, entendo que ambas estabelecem relações com o ensino da literatura infantil, sobretudo porque por meio delas (e dos sujeitos que as compu- 
nham) se disseminou uma concepção de literatura infantil formada no âmago da formação dos professores primários.

\section{O Centro de Estudos de Literatura Infantil e Juvenil (Celiju)}

Fundado na cidade de São Paulo, no dia 17 de janeiro de 1973, por um grupo de professores, escritores, bibliotecários e editores interessados na leitura para crianças, o Centro de Estudos de Literatura Infantil e Juvenil (Celiju) se originou de uma reunião realizada no auditório da Biblioteca "Mário de Andrade", na cidade de São Paulo.

Idealizado pela escritora Odette de Barros Mott e pela bibliotecária Idaty Brandão Onaga, que consideravam haver uma falta de entrosamento entre pessoas ligadas à literatura infantil, o Celiju foi formado com a finalidade principal de promover o estudo e o desenvolvimento desse gênero literário.

Essa entidade, que não visava a fins lucrativos, teve definidos como objetivos de seu funcionamento:

I - a efetivação, no ensino, da Cadeira de Literatura Infantil e Juvenil;

II - a capacitação específica dos interessados no tema;

III - o apuramento da técnica e qualidade literária do livro infantil e do juvenil;

IV - o empreendimento de palestras, conferências e debates sobre o assunto;

$\mathrm{V}$ - o estabelecimento de intercâmbio com entidades congêneres; nacionais e estrangeiras;

VI - a propugnação por adequada orientação da leitura, por crianças e jovens;

VII - a promoção da divulgação de autores e de livros infantis e juvenis, por todos os meios de comunicação;

VIII - a instituição de cursos para incentivo e descoberta de novos autores;

IX - a manutenção de contacto permanente com editores, livreiros e distribuidores de livros infantis e juvenis, para expansão destes e seu aprimoramento gráfico. (Celiju, s.d., p.1) 
Para atender a esses objetivos, o Celiju, conforme se previa em seu estatuto, desenvolvia atividades, como: reuniões mensais entre associados; cursos sobre literatura infantil; palestras em escolas e bibliotecas especializadas; seminários e exposições de livros em bienais, feiras e eventos; criação de bibliotecas e salas de leitura em regiões da periferia de São Paulo e em cidades do interior do estado; e publicação, anualmente, de um catálogo para orientação bibliográfica de professores e pais.

Em 1976, por exemplo, com apenas três anos de funcionamento, o Celiju, escolheu a cidade de Araçariguama-SP para receber a primeira biblioteca organizada por esse centro. Essa biblioteca era composta por 700 livros, e custou um investimento de $\operatorname{Cr} \$ 30.000,00$. Odete de Barros Mott, então presidente do Celiju, explicou em uma matéria para o jornal O Estado de $S$. Paulo que esse foi um investimento muito bem feito, uma vez que a cidade de Araçariguama-SP não contava com nenhuma biblioteca infantil ou escolar até então (O Estado..., 1976).

Além dessa atividade, as publicações anuais dos catálogos com guia de leitura para pais e professores era um ponto de destaque das atividades do Celiju. Esses catálogos eram publicados com auxílio financeiro da Secretaria de Cultura, Ciência e Tecnologia do estado de São Paulo e se organizam, em sua maioria, da seguinte forma: breve apresentação do Celiju; e apresentação de uma relação de livros de literatura infantil, organizados conforme a faixa etária dos leitores a que se destinavam. Esses catálogos, além de conterem indicação de livros de literatura infantil, apresentam recomendação de livros teóricos sobre esse gênero literário. Esse é o caso, por exemplo, do catálogo de 1981, que contém a indicação de 15 títulos sobre literatura infantil, entre os quais: Literatura infantil brasileira (1968), de Leonardo Arroyo; Psicanálise dos contos de fadas (1978), de Bruno Bettelheim; Literatura infantil: estudos (1973), de Bárbara Vasconcelos de Carvalho; Como ensinar literatura infantil (1968), de Maria Antonieta Antunes Cunha; Literatura infanto-juvenil (1961), de Antônio d'Ávila; Problemas da literatura infantil (1951), de Cecília Meireles; e A literatura infantil (1978), de Jesualdo Sosa.

Com relação aos sujeitos que integraram o Celiju, conforme seu estatuto, para participar das reuniões e assembleias, era necessário ser sócio e estar quite com a anuidade. Para se associar, a Diretoria do Celiju em 
exercício precisava aprovar tal associação, exceto no caso das pessoas que haviam participado da Assembleia de criação dessa entidade.

Pelas informações que localizei, até meados da década de 1970 o Celiju contava com 22 sócias. No final da década de 1970, esse número aumentou para 30 sócias. Em relação a esse período, pude identificar os seguintes nomes de sócias do Celiju: Camila Cerqueira Cesar, Cecília Mascarenhas, Esther Peixoto Mello Gonçalves, Giselda Laporta, Lenyra Fraccaroli, Idaty Onagra, Lia Campos Ferreira, Lilian Malferrari, Lucília de Almeida Prado, Maria Lúcia P. Sampaio Góes, Maria Lúcia Ramos, Eico Susuki, Maria Luiza Martins Campos, Maria Teresa Guimarães Noronha, Nelly Novaes Coelho, Noemia K. Pisani, Odette de Barros Mott, Regina Melillo de Souza e Stella Carr.

No início dos anos 80, o número de sócios do Celiju aumentou, de forma que identifiquei, além dos que mencionei acima, os seguintes nomes: Alfredo Mesquita, Alina Eva Periman, Antonieta Dias de Moraes, Ary Quintella, Chlóris Arruda de Araujo, Cláudia Giannubilo Martini, Elza Cesar Sallouti, Ercília F. de Arruda Pollice, Eva Furnari, Farid Soubhia, Ganymédes José S. de Oliveira, Iza Ramos de Azevedo Souza, Jacy de Abreu Longo, Laís Carr Ribeiro de Souza, Léa Correa Pinto, Lucília J. de Almeida Prado, Manoel Cardoso, Mara Rinaldi, Maria Alice Penna de Azevedo, Maria Ap. F. da Silva Chaves, Maria Dinorah Luz do Prado, Maria Heloisa Penteado, Regis Castro, Sersi Bardari, Sheila Ludwing da Silva, Tatiana Belinky, Terezinha Leal Alvarenga, Yone Quartim, Zilah Mattos Ricci, Lila Figueiredo e Alice Góes.

Em relação ao funcionamento do Celiju, durante a década de 1970, ele funcionou, provisoriamente, em uma sala da sede da Câmara Brasileira do Livro, instalada na cidade de São Paulo. A partir de 1980, após autorização da Prefeitura de São Paulo, essa entidade passou a funcionar no prédio da Biblioteca Infantil Monteiro Lobato.

Sobre a administração do Celiju, além de Odette de Barros Mott, que o presidiu por pelo menos quatro anos, pude localizar a informação de que Nelly Novaes Coelho também foi presidenta dessa entidade, porém não em que período.

Também não pude localizar informações sobre até que período o Celiju se manteve em funcionamento. O que pude verificar é que essa entidade, 
em 1990, ainda funcionava, pois promoveu um curso sobre como se tornar um escritor.

Por conta da importância que o Celiju teve ao longo de seu funcionamento, na década de 1980 essa entidade foi declarada, em âmbito municipal (São Paulo), estadual e federal, como de utilidade pública.

\section{A Academia Brasileira de Literatura Infantil e Juvenil}

Fundada em 21 de março de 1978 e instalada oficialmente em 2 de fevereiro de 1979, a Academia Brasileira de Literatura Infantil e Juvenil (ABLIJ) teve como principal objetivo "[...] a cultura do idioma e da literatura nacional infantil e juvenil, para a formação da infância e da juventude" (Academia..., s.d., p.3).

Com esse objetivo, a ABLIJ teve como um de seus grandes ideais dar aos escritores que se dedicavam à literatura infantil o apoio e o prestígio de que necessitavam para "vender em tão encantadora tarefa" (Academia... 1980, f.2).

Idealizada por Lenyra Fraccaroli, após reunião que realizou em sua casa, a ABLIJ se originou da preocupação com as criações literárias que se dirigiam à criança e ao jovem da época (Tahan, 1979, s.p.). Após essa reunião, foram consultados cerca de 400 escritores, os quais se manifestaram favoráveis à necessidade e importância de se fundar uma academia, como espaço voltado à discussão e problematização das publicações infantis e juvenis.

Depois de consultados esses escritores, durante o ano de 1978, foi instalada uma comissão provisória, ${ }^{21}$ que após receber currículo e bibliografia de diferentes escritores do país, selecionou aqueles que integrariam a ABLIJ, como acadêmicos titulares. Essa comissão provisória também elaborou o estatuto da Academia, o qual definiu a seguinte organização: criação de 40 cadeiras a serem ocupadas por escritores de reconhecido valor, escolhidos

21 Essa comissão foi composta pelas seguintes pessoas e organização: Lenyra Fraccaroli (Presidenta); Hernâni Donato (vice-presidente); Moisés Vilaça (1º secretário); Zilah Mattos Ricci ( $2^{a}$ secretária); Idaty Guerra Brandão Onaga ( $3^{\mathrm{a}}$ secretária); Farid Soubia ( $1^{\circ}$ tesoureiro); Chloris Arruda de Araújo ( $2^{a}$ tesoureira); Isa Silveira Leal, Marina Tricânico, Regina Mellilo de Souza, Antônio d'Ávila, Celso Bentim, Antenor Santos de Oliveira, Lúcia Pimentel Góes e Elza Moraes Barros Kyrillos (conselheiros). 
após "meticulosa" seleção. Para cada cadeira, foi definido um Patrono, escolhido entre os escritores brasileiros já falecidos. Como patrono geral da ABLIJ, foi escolhido, por unanimidade, o nome de Monteiro Lobato.

Em homenagem a ele e para simbolizar a ABLIJ, foi criada uma medalha pelo escultor Luis Morrone, a qual, de um lado, tem a figura de Lobato e, do outro, a do Padre Anchieta.

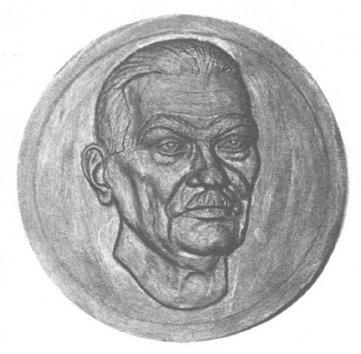

Figura 22 - Design da medalha da Academia Brasileira de Literatura Infantil e Juvenil. Fonte: Biblioteca Infantil Monteiro Lobato.

Essa medalha, conforme consta em alguns documentos da ABLIJ, foi oficializada pelo governo do estado de São Paulo e confeccionada para homenagear pessoas, cuja atuação e produção escrita fizessem jus às honras da Academia.

Em relação à escolha dos "imortais" da ABLIJ, de acordo com seu estatuto, das 40 cadeiras que a compunham, 21 eram destinadas a escritores do estado de São Paulo, sendo as demais para escritores de diferentes estados e regiões do Brasil.

Os 40 "imortais" da literatura infantil, escolhidos pela comissão provisória e que tomaram posse no dia 2 de fevereiro de 1979, estão relacionados no Quadro 16.

Quadro 16 - Composição da Academia Brasileira de Literatura Infantil e Juvenil

\begin{tabular}{|l|l|l|l|}
\hline Cadeira & Patrono & Acadêmico & Estado \\
\hline 1 & Amadeu Amaral & Menotti del Picchia & SP \\
\hline 2 & Léo Vaz & Josué Montello & MA \\
\hline 3 & Otelo Reis & José Reis & SP \\
\hline 4 & Zalina Rolim & Maria José Dupré & SP \\
\hline 5 & Godofredo Rangel & Vicente Guimarães & RJ \\
\hline 6 & Luiz Gonzaga Fleury & Renato Sêneca Fleury & RJ \\
\hline
\end{tabular}




\begin{tabular}{|c|c|c|c|}
\hline 7 & Narbal Fontes & Ofélia Fontes & RJ \\
\hline 8 & Guilherme de Almeida & Lúcia Machado de Almeida & MG \\
\hline 9 & Malba Tahan & Irene de Albuquerque & $\mathrm{RJ}$ \\
\hline 10 & Graciliano Ramos & Paulo Dantas & $\mathrm{SE}$ \\
\hline 11 & Lourenço Filho & Antônio d'Ávila & $\mathrm{SP}$ \\
\hline 12 & Castro Alves & Celso Bentim & $\mathrm{SP}$ \\
\hline 13 & Anchieta & Regina Melillo de Souza & $\mathrm{SP}$ \\
\hline 14 & Maria Massetti & Margarida Ottoni & RJ \\
\hline 15 & Basílio de Magalhães & Henriqueta Lisboa & MG \\
\hline 16 & Cecília Meireles & Hernâni Donato & SP \\
\hline 17 & Isabel Serpa e Paiva & Lia Campos Ferreira & $\mathrm{SP}$ \\
\hline 18 & Coelho Neto & Antenor Santos de Oliveira & $\mathrm{SP}$ \\
\hline 19 & $\begin{array}{l}\text { Arnaldo Magalhães de } \\
\text { Giacomo }\end{array}$ & Maria Teresa C. de Giacomo & $\mathrm{SP}$ \\
\hline 20 & Viriato Correa & Virgínia Lefévre & $\mathrm{SP}$ \\
\hline 21 & Anísio Teixeira & Arthur de Castro Borges & RJ \\
\hline 22 & Jerônimo Monteiro & Maria Teresa G. Noronha & $\mathrm{SP}$ \\
\hline 23 & Oswaldo Storni & Gaymedes José S. Oliveira & SP \\
\hline 24 & Jaçanã Altair & Marina Tricânico & $\mathrm{SP}$ \\
\hline 25 & Joraci de Camargo & Silvio Meira & PA \\
\hline 26 & Paulo Setúbal & Francisco Marins & $\mathrm{SP}$ \\
\hline 27 & Olavo Bilac & Lourdes Póvoa Bley & RJ \\
\hline 28 & Mary Buarque & Maria Lúcia Ramos & SP \\
\hline 29 & Denise Tavares & Bárbara Vasconcelos de Carvalho & BA \\
\hline 30 & Jannart Moutinho Ribeiro & Lucília Junqueira de A. Prado & $\mathrm{SP}$ \\
\hline 31 & Eneida de Moraes & Maria Lúcia Amaral & RJ \\
\hline 32 & Manoel Gondim da Fonseca & Edgard d'Álmeida Victor & DF \\
\hline 33 & Érico Veríssimo & Maria Dinorah Luz do Prado & $\mathrm{RS}$ \\
\hline 34 & Cid Franco & Ivan Engler de Almeida & $\mathrm{SP}$ \\
\hline 35 & Corrêa Júnior & Maria Souza Cempos Artigas & $\mathrm{SP}$ \\
\hline 36 & Erasmo Braga & Homero Homem & RJ \\
\hline 37 & Helen Morley & Isa Silveira Leal & $\mathrm{SP}$ \\
\hline 38 & Thales de Andrade & Elza Moraes Barros Kyrillos & $\mathrm{SP}$ \\
\hline 39 & $\begin{array}{l}\text { Joaquim Osório Duque } \\
\text { Estrada }\end{array}$ & Everaldo Moreira Veras & $\mathrm{PE}$ \\
\hline 40 & Manoel Bandeira & José Carlos Mrigny & RJ \\
\hline
\end{tabular}

Fonte: Academia Brasileira de Literatura Infantil e Juvenil (s.d.).

Depois de diplomados os 40 acadêmicos e instalada oficialmente a ABLIJ, em 1979, essa entidade passou a desempenhar algumas ações importantes em torno da literatura infantil e juvenil. Entre elas, têm-se: a 
divulgação da Academia; realização de cursos, palestras, mesas redondas e entrevistas em rádios; formação de uma biblioteca e um arquivo com documentos pessoais dos acadêmicos; e contato com crianças, jovens e instituições culturais e educacionais para coletar dados sobre a produção de literatura infantil.

No conjunto dessas atividades, entre os anos de 1979 e 1982, a ABLIJ realizou edições do Ciclo de Palestras sobre Literatura Infantil e Juvenil, voltado para professores, pais e interessados no assunto. Das edições que esse Ciclo de Palestras teve, localizei a programação e os textos apresentados em duas: 1981 e 1982.

Em 1981, entre os dias 26 e 30 de outubro, foi realizada a terceira edição desse Ciclo de Palestras sobre Literatura Infantil e Juvenil. Essa edição foi coordenada por Antônio d'Ávila e contou com patrocínio da Secretaria de Estado da Cultura. Conforme consta na programação dessa edição de 1981, as palestras ministradas e os respectivos palestrantes foram: "A pesquisa folclórica e seu aproveitamento no livro infantil”, proferida por Maria Amália Giffoni; "Trabalhos práticos na feitura de bonecos”, proferida por Ilze Celfste Cardoso Franco e Regina Stella C. Franco; "Teatro de bonecos: trabalhos de confecção e montagem”, proferida por Ana Maria Amaral; "A realidade e a fantasia nos livros de literatura infantil", proferida por Homero Homem; e "O elemento histórico na literatura infantil e juvenil", proferida por Francisco Marins.

Em 1982, entre os dias 4 e 15 de outubro, foi realizada a quarta edição desse Ciclo de Palestras sobre Literatura Infantil e Juvenil. Essa edição foi coordenada por Antenor Santos de Oliveira e também contou com patrocínio e colaboração da Secretaria de Cultura do estado de São Paulo. Conforme consta na programação dessa edição de 1982, as palestras ministradas e os respectivos palestrantes foram: "Teatro infantil", proferida por Eurípedes de Castro Júnior; "Possibilidades da literatura infantil e juvenil brasileira junta ao leitor japonês”, proferida por Mitsuko Kaway; "Fontes de assuntos para livros de literatura para crianças e adolescentes. Desejado cunho nacionalista de nossos livros", proferida por Regina Melillo de Souza; "Diferenças de opiniões sobre literatura infantil", proferida por Nelly Novaes Coelho; "Ilustração do livro infantil”, proferida por Luís Camargo; "Língua e linguagem nos livros de literatura infantil e juvenil. Estudo de três obras típicas, modelo”, proferida por Antônio d'Ávila; 
"Conceito de literatura para crianças e adolescentes. Sua implicação e sua importância no campo da literatura infantil”, proferida por Isa Silveira Leal; "Como despertar a criança para a hora do conto, aproveitando jograis e músicas, com expressão corporal”, proferida por Lia Campos Ferreira; "O livro, corpo de letras e seus diversos aspectos: gráfico-ilustrativo, formato, artifícios de apresentação. Breve notícia de artes gráficas. Estilo moderno de livros", proferida por Francisco Marins; e "Ficção científica e problemas do cotidiano", proferida por Homero Homem.

Além desses Ciclos de Palestras, a ABLIJ promoveu cursos sobre literatura infantil, como o realizado em 1985, sob a coordenação de Lia Campos Ferreira. Nesse curso, os temas abordados e os expositores foram: "O folclore, base da literatura infantil", por Hernâni Donato; "A criança dentro de uma literatura nacional”, por Ibiapaba Martins; "O livro e sua ilustração", por Regina Mellilo de Souza; "A criança e a poesia”, por Maria Tricânico; "A criança na aldeia indígena e na cidade grande", por Lia Campos Ferreira; "A obra literária de Selma La Erlöf para crianças", por Antônio d'Ávila; "Lendas brasileiras e japonesas. Confronto”, por Mitsuoko Kawai; "O romance policial, suas raízes e suas motivações”, por Isa Silveira Leal; "Minhas histórias em quadrinhos", por Maria Lúcia Ramos; "O livro e a música, demonstração prática”, por Irmã Patrícia Silva; e "A informática na literatura infantil", cujo palestrante não foi indicado.

Embora a ABLIJ tenha tido uma atuação bastante importante na década de 1980, ela acabou por ser extinta em meados da década de 1990, presumivelmente.

\section{Da "renovação" dos livros de literatura infantil, a também "renovação" do discurso sobre esse gênero literário}

Durante a década de 1970, concomitantemente aos aspectos apresentados neste capítulo e em decorrência, principalmente, das iniciativas relacionadas ao ensino da literatura infantil ocorridas em décadas anteriores, a produção de literatura infantil cresceu e se tornou um "filão" editorial, atraindo múltiplos olhares (Lajolo; Zilberman, 1984, Cadermatori, 1986). 
Se entre as décadas de 1950 e 1960 já se observava, segundo Lajolo e Zilberman (1984), um crescimento das publicações destinadas à infância e um processo de profissionalização de editoras e escritores ligados a esse ramo, a partir da década de 1970, essa produção se avolumou como nunca se tinha visto no Brasil. Somente entre 1975 e 1978, a Fundação Nacional do Livro Infantil e Juvenil registrou a publicação, no país, de 1.890 títulos (Lajolo; Zilberman, 1984).

Nesse período, explicam Lajolo e Zilberman (1984) que o mercado da literatura infantil se apresentava tão promissor que até mesmo escritores já consagrados, como Mário Quintana, Clarice Lispector e Vinícius de Moraes enveredaram para as "letras infantis". O que se observa é que essa "[...] produção maciça de obras para crianças insere-se num contexto social, político e econômico que favorece um modo de produção bastante moderno e condizente com a etapa do capitalismo que os anos 60 inauguraram no Brasil" (Lajolo; Zilberman, 1984, p.125).

Em meio a esse crescimento da produção de literatura infantil, pesquisadores como Lajolo e Zilberman (1984), Perrotti (1986) e Cadermatori (1986) afirmam que muitos escritores, no anseio de publicar e vender seus livros, produziram uma infinidade de obras de qualidade duvidosa. No entanto e concomitantemente a esses, surgiram novos escritores que, retomando a tradição lobatiana, deram início a um movimento de renovação da literatura infantil brasileira, que se aproxima, em termos artríticos e estéticos, da produção literária não infantil da época (Lajolo; Zilberman, 1984). Com isso, afirmam Lajolo e Zilberman (1984):

[...] [foram] muitas as formas pelas quais o texto infantil contemporâneo busca romper com a esclerose a que o percurso escolar e o compromisso com a pedagogia conservadora parece ter confinado o gênero. [...] após ter conquistado a duras penas o direito de falar com realismo e sem retoques da realidade histórica, e ao mesmo tempo que redescobre as fontes do fantástico e o imaginário, a literatura infantil contempla-se a si mesma em seus textos (Lajolo; Zilberman, 1984, p.161).

Num movimento subsequente ao do crescimento e da renovação da produção de literatura infantil, a produção sobre esse gênero literário também se intensificou de forma contundente e em decorrência da "[...] emergên- 
cia, na cena acadêmica, de um campo de conhecimento específico [...]" (Mortatti, 2000a, p.11). Para que essa situação assim se configurasse, explica Mortatti (2000) que contribuíram: a criação da disciplina "Literatura infantil" no Ensino Normal; a organização de entidades e projetos governamentais; a realização de seminários e congressos sobre o assunto; e, principalmente, a criação e expansão dos cursos de pós-graduação.

Em relação a esse último aspecto, desde a criação dos primeiros cursos de pós-graduação em Educação e Letras no Brasil, durante o início da década de 1960, no caso específico da literatura infantil, nota-se um importante impulso quantitativo de pesquisas nesse campo, o que significou (e continua a significar) importante acúmulo de conhecimento nessa área. No entanto, mais do que impulsionar a produção de conhecimento sobre literatura infantil, a expansão dos cursos de pós-graduação e o gradativo processo de "academização" do discurso sobre a literatura infantil significou, à semelhança da produção de livros desse gênero, uma "renovação" nos modos de compreender, analisar, problematizar e pensar o "lugar" da literatura infantil.

De modo geral, essa renovação, como explica Gatti (1983), se deu a partir da composição de temáticas de pesquisa sob a ótica de novas metodologias científicas, utilizadas para se encaminhar a investigação em âmbito acadêmico. No caso da literatura infantil, as pesquisas desenvolvidas na área de Letras trouxeram o olhar, em especial, da teoria e crítica literárias, para os livros destinados às crianças. E, nas áreas de Psicologia e da Educação, esse novo olhar ficou a cargo da perspectiva crítica, com base em teorias marxistas, e na Psicologia Social, especialmente.

Apenas para se ter uma ideia de como a criação dos cursos de pós-graduação impulsionou a produção de discursos sobre literatura infantil, entre as décadas de 1970 e 1980 foram apresentados 33 textos acadêmicos, entre teses de doutorado e dissertações de mestrado, desenvolvidos em cursos de pós-graduação em Letras, Educação e Psicologia (Oliveira, 2012; Mortatti, 2012).

Desse conjunto, o primeiro texto acadêmico, sobre literatura infantil, publicado no Brasil, foi a dissertação de mestrado Alguns fatores condicionantes da literatura infantil didática, de autoria de Zilda Augusta Anselmo, defendida em 1970, junto ao curso de pós-graduação em Psicologia da USP. $\mathrm{Na}$ área de Letras, o primeiro texto acadêmico produzido foi a dissertação 
de mestrado $O$ universo narrativo de Monteiro Lobato, um mundo de mentira e de verdade: visão crítica de sua literatura infanto-juvenil, defendida por Ana Maria Ribeiro Filipouski, em 1977, no curso de mestrado em Letras da Universidade Federal do Rio Grande do Sul (Oliveira, 2012; Mortatti, 2012).

Em relação às teses de doutorado, a primeira a abordar aspectos sobre a literatura infantil foi a tese A língua portuguesa nas obras infantis de Monteiro Lobato, de Nilce Sant'Anna Martins, defendida em 1972, na Faculdade de Filosofia, Letras e Ciências Humanas da USP. Na sequência dessa, em 1979, Marisa Philbert Lajolo defendeu a tese Usos e abusos da literatura na escola: Bilac e a literatura escolar na República Velha, produzida junto ao curso de doutorado em Letras também da Faculdade de Filosofia, Letras e Ciências Humanas da USP.

Em decorrência, sobretudo, desse processo de "academização" dos discursos sobre literatura infantil, a partir de 1980 a publicação de livros, artigos em revistas e textos em jornais se intensificou também. No caso dos livros, no período compreendido entre as décadas de 1970 e 1980, foram publicados cerca de 50 novos títulos (Oliveira, 2012; Mortatti, 2012). Nesse conjunto, alguns deles merecem destaque, principalmente porque se tornaram emblemáticos com relação às novas abordagens e perspectivas que foram se desenvolvendo em torno da literatura infantil a partir da década de 1980.

O primeiro desses livros é de autoria de Nelly Novaes Coelho, intitulado A literatura infantil: história, teoria, análise, publicado em 1981, pela Edições Quíron (SP).

Essa autora, que na década de 1960 havia escrito um manual de ensino e, posteriormente, como professora da FFLCH-USP, criou a disciplina "Literatura infantil" na graduação em Letras dessa Universidade, compreende em seu livro que a literatura infantil, para além de seus objetivos imediatos (como proporcionar o prazer, emoção e divertimento), deve servir de fonte para a "formação cultural" da criança. A literatura infantil entendida essencialmente como Arte desempenha papel importante na formação humana, atuando "[...] de maneira mais profunda e duradoura, no sentido de dar forma e de divulgar os valores culturais que dinamizam uma sociedade" (Coelho, 1981, p.3, grifos da autora).

De acordo com Coelho (1981), o século XX foi marcado pela transformação dos valores de base da sociedade, o que gerou, no campo da literatura 
infantil, uma diversidade de posicionamentos diante do "que é" a literatura infantil e "como" ou "por quê" ela pode/deve interferir na "transmissão" de valores válidos para um dado momento histórico. Apesar das discordâncias, Coelho (1981) defende que a compreensão da literatura infantil não serve apenas para o prazer. "Simultaneamente à 'diversão' da leitura, a criançada precisa começar a descobrir (sem saber o que está descobrindo) que Literatura é algo mais do que um simples passatempo" (Coelho, 1981, p.XVII), ela é "depositária" e "mediadora" de valores decisivos para que se possa viver a vida em plenitude.

Além desses aspectos, Coelho (1981) considera que a crítica sobre literatura infantil produzida até a década de 1980 havia sido feita por "vozes críticas" diversas, o que acarretava perda da "[...] literariedade [da literatura infantil], por ser tratada como simples meio de transmitir valores" (Coelho, 1984, p.38, grifo da autora). Segundo Coelho (1981), fazia-se necessária a produção de uma crítica literária organizada, na qual os pesquisadores se encarregassem de compreender o "valor" do livro de literatura infantil por meio do "critério culturalista", entendido esse critério como as "[...] relações que a obra mantém com as tendências de sua época" (Coelho, 1984, p.40, grifos da autora).

Também no ano de 1981, com um ponto de vista bastante diferente do de Nelly Novaes Coelho, Regina Zilberman, que havia se doutorado em 1976, em romanística, na Alemanha, teve publicado o livro A literatura infantil na escola, pela Editora Global (SP). Nesse livro, com base em teóricos alemães e considerando que os estudos sobre literatura infantil, produzidos no Brasil, não haviam atingido a globalidade do gênero, Zilberman (1981) se propõe a pensar a literatura infantil a partir da teoria literária, por considerar que ela estava envolta de equívocos e preconceitos que "reprimiam" os estudos que evidenciam a sua "validade estética" e as suas "fraquezas ideológicas”. Assim, Zilberman (1981) considera que a constituição da literatura infantil como gênero literário estava diretamente relacionada à constituição de um modelo familiar burguês e à valorização da infância, a partir do século XVII. Nesse período, Zilberman (1981) afirma que a literatura infantil e a escola foram "convocadas" para a missão de controle intelectual e manipulação das emoções das crianças. 
A aproximação entre a instituição e o gênero literário não é fortuita. Sintoma disto é que os primeiros textos para crianças são escritos por pedagogos e professoreas, com marcante intuito educativo. E, até hoje, a literatura infantil permanece como uma colônia da pedagogia, o que lhe causa grandes prejuízos: não é aceita como arte, por ter uma finalidade pragmática; e a presença deste objetivo didático faz com que ela participe de uma atividade comprometida com a dominação da criança (Zilberman, 1981, p.15-16).

Embora a literatura infantil e a escola partilhem de ponto comum - a natureza formativa - para Zilberman (1981), elas não se identificam. A escola participa do processo de manipulação da criança e conformação de padrões de pensamento em vigência, já a literatura infantil é lugar de síntese da realidade do leitor e de questionamento dos valores em circulação. Apesar disso, essa autora considera que ambas não devem ser afastadas. Muito pelo contrário, o fato de a literatura infantil ser lugar de questionamento é o que justifica a sua permanência na escola.

A justificativa que legitima o uso do livro na escola nasce, pois, de um lado, da relação que estabelece com seu leitor, convertendo-o num ser crítico perante sua circunstância; e, de outro lado, do papel transformador que pode exercer dentro do ensino, trazendo-o para a realidade do estudante e não submetendo este último a um ambiente rarefeito do qual foi suprimida toda a referência concreta (Zilberman, 1981, p.25).

De acordo com Zilberman (1981), para que a literatura infantil pudesse se converter nesse elemento transformador, o enfoque dado a ela não podia ser outro, senão o estético, que rompe com o compromisso pedagógico e de doutrinação.

Em 1984, Regina Zilberman, juntamente com Marisa Lajolo, teve publicado o livro Literatura infantil brasileira: histórias \& história, pela editora Ática (SP). Esse livro, dedicado ao "Mestre Arroyo", tem como principal objetivo revisitar a história da literatura infantil produzida por esse autor e atualizá-la até o início dos anos de 1980. Para isso, Lajolo e Zilberman (1984) abordam a literatura infantil do ponto de vista da teoria literária, analisando sua produção, de modo a estabelecer uma relação com outros objetos culturais e com a literatura "não infantil". 
Para Lajolo e Zilberman (1984), as relações existentes entre literatura infantil e "não infantil" são marcadas pela marginalização da primeira em relação à segunda, de modo que a menoridade do público a que se destina a literatura infantil significou também a menoridade dela como produção cultural.

Se esse contraponto não é comum, isto é, se todas as histórias literárias brasileiras até agora deixaram de incluir em seu campo de estudo a literatura infantil, nunca é demais frisar o peso circunstancial que o adjetivo infantil traz para a expressão literária infantil. Ele define a distinção da obra; essa distinção, no entanto, não pode interferir no literário do texto. (Lajolo; Zilberman, 1984, p.11).

A partir da análise de um vasto conjunto de livros, Lajolo e Zilberman (1984) agruparam os textos dessa produção em quatro "ciclos", caracterizados pela relação que estabelecem com o seu contexto histórico, sobretudo com a cultura brasileira. Com isso, essas autoras entendem que a literatura infantil, nos seus 100 anos de existência:

[...] funda um universo imaginário peculiar que se encaminha em duas direções principais. De um lado, reproduz e interpreta a sociedade nacional, avaliando o processo acelerado de modernização [...] De outro lado, dá margem às manifestações do mundo infantil, que se aloja melhor na fantasia, e não na sociedade, opção que sugere uma resposta à marginalização a que o meio empurra a criança. De um modo ou de outro, enraíza-se uma tradição - a de proposição de um universo inventado, fruto, sobretudo da imaginação, ainda quando está em um fundamento social e político. (Lajolo; Zilberman, 1984, p.67)

Mais ligada às pesquisas em Educação e sintonizada com um clima de época, característico do momento de reabertura política do Brasil, em 1985, a professora e pesquisadora Fúlvia Rosemberg teve publicado o livro Literatura infantil e ideologia, que resultou de um amplo trabalho de pesquisa desenvolvido, entre 1975 e 1980, na Fundação Carlos Chagas, no âmbito do projeto Análise dos modelos culturais na literatura infanto-juvenil brasileira.

Com o objetivo de contribuir para a compreensão do significado social da noção de criança, Rosemberg (1985) analisou o conteúdo de mais de 
uma centena de livros de literatura infantil, visando compreender como que se dava a relação adulto-criança veiculada nesses livros.

Por meio do conceito de ideologia, entendido como a reprodução das relações de poder e de produção vigentes, Rosemberg (1985, p.49) aponta que o livro de literatura infantil "[...] se apresenta como um produto cuja feitura é guiada por objetivos que parecem exteriores à criança [...]”. Por isso, esses livros assumem a função de código de ética, normatizando todos os aspectos da vida, sendo a existência deles determinada pela tese de que vão demonstrar situações e contextos das crianças (Rosemberg, 1985).

Em decorrência do exposto, Rosemberg (1985) conclui que há uma contradição aparente na produção de livros de literatura infantil, pois apresentam, ao mesmo tempo, o aspecto "educativo" e "deseducativo", como uma proposta de modelo negada.

A dupla moralidade que propõe é, pelo menos isomorfa aos padrões culturais e às relações de poder dominantes [...] remete a relação de dominação adulto-criança; na medida em que produzida por brancos de classe média e destinada a brancos de classe média, mantém a relação de dominação entre essas categorias sociais (Rosemberg, 1985, p.103).

Em 1986, um ano após a publicação do livro de Fúlvia Rosemberg, o professor, pesquisador e crítico literário Edmir Perrotti teve publicado o livro $O$ texto sedutor na literatura infantil, pela editora Ícone (SP), que resultou de sua dissertação de mestrado, apresentada em 1984, na Escola de Comunicações e Artes da USP.

Nesse livro, com o objetivo de analisar a nova tendência literária para crianças, que surgiu a partir da década de 1970, Perrotti (1986) afirma que, desde que a literatura infantil se desenvolveu no Brasil, predominava uma concepção "utilitária", que não buscava a realidade da criança, mas a transmissão de uma "verdade".

Visto isso, o problema que nos fica é o de que a literatura para crianças e jovens não se satisfaz com a tradição da arte concebida enquanto instrumento apenas em um de seus níveis, mas, exagerando a tradição, reduziu-se a isso, fazendo do contingencial, estrutural e da literatura, propaganda, ao buscar apenas o exortivo, o edificante, o didático, ao realizar obras que, no dizer de Elliot, 
antes de mais nada, tentam "convencer o leitor de determinado ponto de vista do autor”. (Perrotti, 1986, p.38)

Segundo Perrotti (1986), esse "utilitarismo" passou a ser questionado e entrou em crise na produção literária nacional somente na década de 1970, quando um grupo de "lúcidos" escritores passou a ter publicados livros que rompiam com a estética vigente. Para Perrotti (1986), o livro que marca essa transição da literatura "utilitarista" para a renovação estética é $O$ caneco de prata, de João Carlos Marinho Silva, publicado em 1971.

Embora essa renovação estética tenha se dado de forma bastante contundente a partir de 1970, segundo Perrotti (1986) explica que alguns escritores, no anseio de questionar os padrões vigentes e tecer críticas ao modelo burguês e capitalista da sociedade do século XX, acabaram por produzir uma literatura também utilitária, porém, "às avessas".

Perrotti (1986) conclui que, com a ruptura do "utilitarismo" na literatura infantil e a compreensão do papel coercitivo desse tipo de livro, entende-se a importância do discurso estético, condizente com aspirações de liberdade e de participação democrática do leitor. Para ele "[...] somente o discurso estético, dado o seu caráter de 'escritura', mostrou-se, desde sempre, capaz de, ao mesmo tempo, conter interesses históricos e de transcendê-los" (1986, p.153).

Com base nesses textos publicados na década de 1980, ainda que muitos outros tenham sido publicados nesse período, pode-se perceber as principais tendências relacionadas ao estudo e análise da literatura infantil, que passaram a circular, no Brasil, com o processo de "academização" do discurso sobre esse gênero literário.

Entre essas principais tendências, notam-se a associação da literatura infantil à ascensão do modelo de sociedade burguês capitalista e a busca por analisar esses livros do ponto de vista de sua "literariedade", em oposição ao "utilitarismo" "pedagógico" ou "didatista". O que visavam esses autores, cujos textos aqui sintetizei, era reforçar o caráter estético dos livros de literatura infantil, sem, porém, tomar como parâmetro para se definir esse estético, os valores educacionais e psicológicos comportamentais. 


\section{Características do ensino da literatura infantil entre 1971 e 2003}

Com base nas informações apresentadas neste capítulo, no período compreendido entre 1971 e 2003, é possível observar que o ensino da literatura infantil na formação de professores passou por um conjunto de mudanças, de modo que, a partir do final dos anos de 1980, esse ensino foi se tornando menos regular no estado de São Paulo, até que desaparecesse por completo.

De qualquer modo, ainda que os documentos a que tive acesso sejam pontuais e se refiram a escolas específicas, é possível afirmar que o ensino da literatura infantil ainda se manteve com lugar reservado na formação de professores.

Como se nota pelos planos de ensino e pelos guias curriculares que apresentei, além de o ensino da literatura infantil ter permanecido na formação de professores, do ponto de vista legislativo, ele não sofreu mudanças significativas até o final dos anos 1980.

Mesmo com a implantação da HEM, as prescrições para o ensino da literatura infantil, propostas pela Cenp, em 1981, e os planos de ensino que os professores elaboraram, indicam a permanência da mesma concepção de ensino da literatura infantil, que se formou e se disseminou no âmbito do Ensino Normal, entre 1957 e 1970.

Somente no final da década de 1980, quando o discurso acadêmico sobre literatura infantil começou a despontar como um discurso de renovação, é que se observam mudanças nos documentos oficiais do estado de São Paulo. Essas mudanças podem ser notadas, por exemplo, nos planos de ensino do Cefam e também nos documentos sobre o ensino da leitura no ensino de $1^{\circ}$ grau. Neles, a habitual abordagem sobre a origem, desenvolvimento, conceituação e ajustamento da literatura infantil não consta. O que se observa nesses planos e documentos são abordagens da literatura infantil mais ligada à perspectiva de análise literária desses livros, como propunham Zilberman (1981), Lajolo e Zilberman (1984) e Perrotti (1986).

Esse movimento de mudança em torno do ensino da literatura infantil se nota, também, nos manuais de ensino desse período. Nos manuais publicados até meados da década de 1980, observa-se a manutenção da concepção de ensino da literatura infantil centrada na "recreação" e "instrução", por isso eles apresentam conteúdo muito semelhante ao dos manuais publica- 
dos entre 1957 e 1970. Esse é o caso, por exemplo, dos manuais de Oliveira e Monteiro (1981), Cunha (1983) e Pimentel (1984). No caso do manual de Cunha (1983), já se observa a incorporação de algumas reflexões de ordem acadêmica sobre a literatura infantil e certa relativização do valor educativo desse gênero literário, porém essa professora ainda mantém a concepção de literatura infantil centrada na "instrução" pela "recreação".

A partir da segunda metade da década de 1980, os manuais mais recentes que localizei, Abramovich (1989) e Cardoso (1991), apresentam uma concepção de literatura infantil diferente da até então recorrente nos manuais de ensino. Especialmente no manual de Abramovich (1989), observa-se a proposição do ensino da literatura infantil ligado ao objetivo de formação do gosto pela leitura literária, de modo a valorizar a esteticidade dos textos. Esses dois manuais apresentam essa concepção de literatura infantil, porque, conforme apresentei, seus respectivos autores se basearam, majoritariamente, nos livros resultantes de pesquisas acadêmicas recém-publicados, como os de Zilberman (1981), Lajolo e Zilberman (1984) e Perrotti (1986). Ao incorporarem as reflexões desses autores em seus manuais, Abramovich (1989) e Cardoso (1991) produziram "concretizações" para o ensino da literatura infantil que, em certo sentido, se configuram como "renovadoras" da tradição em que se circunscrevia esse ensino.

Ainda em relação aos manuais de ensino publicados entre 1971 e 2003, cabe destacar que o livro de Cecília Meireles, Problemas da literatura infantil, que até então não era comumente mencionado na bibliografia dos manuais das décadas de 1950 e 1960, passou a ser citado ou referenciado com maior frequência. Esse fato está relacionado, principalmente, com a reedição desse livro, no final da década de 1970 e durante a década de 1980, pelas editoras Nova Fronteira (RJ) e Summus Editorial (SP).

Outro aspecto que merece destaque com relação ao ensino da literatura infantil, entre 1971 e 2003, é a criação do Celiju e da ABLIJ. Essas duas entidades, embora não diretamente ligadas ao ensino da literatura infantil na formação de professores, foram criadas e envolveram em suas atividades os principais nomes ligados a esse ensino. Nomes como os de Bárbara Vasconcelos e Carvalho, Antônio d'Ávila, Nelly Novaes Coelho, Lenyra Fraccaroli, Antenor Santos de Oliveira, Hernâni Donato, entre muitos outros, estiveram envolvidos com essas entidades e com as atividades que elas promoveram. Desse modo, pode-se dizer que a concepção de literatura 
infantil antes disseminada apenas por meio do ensino desse gênero literário nos Cursos Normais e na HEM, a partir da década de 1970, ganhou maior amplitude por meio do Celiju e da ABLIJ, cujas ações se davam para público que extrapolava os limites da formação de professores.

Em vista dos aspectos aqui apresentados, é possível afirmar que, entre 1971 e 2003, observa-se, até meados da década de 1980, a manutenção do ensino da literatura infantil nos mesmos moldes das décadas anteriores. Esse ensino começou a mudar, assumindo ponto de vista mais "literário" e mais estético, após a literatura infantil começar a se tornar objeto de investigações acadêmico-científicas.

Nesse processo, observa-se, também, que, com o processo de "academização" dos discursos sobre a literatura infantil, o seu ensino na formação de professores foi se tornando cada vez mais esparso, até ser extinto da formação de professores. Juntamente com o processo em que a literatura infantil se tornou objeto de investigações acadêmico-científicas, esse gênero literário foi perdendo espaço como disciplina escolar na HEM e nos Cefams.

De qualquer modo, ainda que o ensino da literatura infantil tenha caminhado, nesse período, para sua extinção na formação de professores, as ações em torno desse ensino deixaram marcas nas discussões sobre esse gênero literário. Embora a maior parte dos manuais publicados na década de 1980 ainda apresentasse concepção de literatura infantil ligada aos objetivos "instrutivos" e "moralistas", eles continuaram a circular nas décadas seguintes, "funcionando" como livros teóricos, como é o caso de Literatura infantil: teoria \& prática, cuja edição mais recente data de 2003. 


\section{5 \\ O ENSINO DA LITERATURA INFANTIL NA FORMAÇÃO DE PROFESSORES: QUAIS SENTIDOS? (À GUISA DE CONCLUSÃO)}

\section{A "disciplinarização" do ensino da literatura infantil: de saber escolar a uma teorização}

Pensar a história do ensino por meio da disciplina escolar é buscar compreender, como explica Chervel (1990), um aspecto lacunar na historiografia da educação. No caso do Brasil, ainda que desde os anos de 1990 pesquisas desse tipo venham ganhando força e se expandindo rapidamente, algumas disciplinas permanecem inexploradas pelos historiadores da educação. Esse era o caso do ensino da literatura infantil na formação de professores primários no estado de São Paulo, decorrente da criação da matéria/ disciplina "Literatura infantil" nos Cursos Normais.

Possivelmente pelo pouco espaço que essa matéria/disciplina ocupou na formação de professores, configurando-se, no conjunto das demais, como aparentemente pouco relevante ou sem grandes efeitos na amplitude formativa que se pretendia aos professores primários, o ensino da literatura infantil e os dispositivos legais de sua institucionalização eram, até então, apenas objeto de pequenas menções em algumas pesquisas.

Visto dessa perspectiva, o ensino da literatura infantil pode suscitar a ideia de algo sem importância para a história da formação de professores e para a História da Educação em geral. No entanto, conforme explica Chervel (1990), as disciplinas somente podem ter a sua importância questionada se estudadas na sua "economia interna". Uma vez que qualquer que seja a disciplina, ela sempre está no centro da ação em torno da qual se coloca em 
exercício as finalidades educativas, por isso não há disciplina que não seja relevante para se entender o curso histórico da educação (Chervel, 1990).

Pensada no conjunto do currículo dos cursos de formação de professores primários, entende-se que a criação da matéria e, depois, da disciplina "Literatura infantil" esteve associada aos processos de reorganização desses cursos, em decorrência das diferentes necessidades e urgências que foram sendo sentidas, ao longo do século XX, no âmbito educacional. Somente por isso, já se justificaria o estudo dessa disciplina e do ensino materializado por meio dela.

Porém, ainda no caso da matéria/disciplina "Literatura infantil", penso que há pelo menos uma razão a mais para tal empreendimento. Por se tratar de assunto "interdisciplinar" e "multifacetado" (Mortatti, 2008), buscar compreender aspectos do ensino desse gênero literário por meio de sua "disciplinarização" na formação de professores é pensar, também, a sua ressonância em outras instâncias sociais e culturais e em outros campos de conhecimento, direta ou indiretamente ligados à literatura infantil.

Levando em consideração esses aspectos, ao me propor pesquisar sobre o ensino da literatura infantil e tentar entender a sua relação com a formação de professores, o esforço foi o de tentar compreender a "economia interna" desse ensino e identificar como ele se relacionou com o Ensino Normal, a HEM e os Cefams.

A partir do processo de análise do conjunto de documentos que reuni, o que se pode observar é que, entre o final do século XIX e quatro primeiras décadas do século XX, conforme os livros literários destinados às crianças foram se avolumando no país, também a produção de discursos sobre a literatura infantil foi crescendo. Isso contribuiu para a formação, até a década de 1940, de saberes ainda não sistematizados a respeito desse gênero literário, os quais, posteriormente, concorreram para se instituir o ensino da literatura infantil na formação de professores.

Essa contribuição se deu, porque, há época, não havia no Brasil um saber de referência sobre o assunto. O que se tinham eram esses discursos, publicados no formato de prefácios, apresentações, prólogos, textos em jornais e artigos em periódicos, que de certo modo apresentavam algumas concepções do que se considerava, ou não, literatura infantil.

Com isso, em 1947, quando pela primeira vez foi instituído o ensino da literatura infantil na formação dos professores primários paulistas, ainda que 
de forma isolada - apenas no Instituto de Educação Caetano de Campos começou-se a buscar medidas para a construção de um saber específico para o ensino desse gênero literário. Disso, decorreram as primeiras publicações de manuais com capítulos destinados ao ensino da literatura infantil.

Na década seguinte, após reforma dos Cursos Normais, em 1957, com expansão do ensino da literatura infantil por todo o estado, sentiu-se, de forma mais incisiva, a necessidade de identificar, selecionar, classificar, organizar e definir um saber sobre esse gênero literário, coerente com a formação de professores da época. Em vista disso, foram levadas a cabo no estado de São Paulo um conjunto de ações, entre as quais se destacam: a elaboração de programas para a disciplina "Literatura infantil"; e a produção de manuais destinados especificamente para o ensino desse gênero literário.

No âmbito da institucionalização do ensino da literatura infantil como matéria/disciplina escolar, desde 1947, os sujeitos envolvidos na sistematização desse ensino acabaram por compilar, reformular e adaptar os diferentes conhecimentos que se tinha sobre a literatura infantil, gerando a formulação de um "saber escolar" a respeito desse gênero literário. Esse saber, como explica Chervel (1990), embora comumente tratado na historiografia como vulgarização dos saberes de referência ou como mera transposição dos saberes de ordem não escolar, constitui um saber autônomo, "[...] que consegue contudo se infiltrar subrepticiamente na cultura da sociedade global” (Chervel, 1990, p.200).

$\mathrm{Na}$ formulação desse saber escolar, observam-se, por exemplo, ações como: apropriação dos saberes que circulavam nos discursos sobre a literatura infantil; a incorporação de teorias educacionais e de concepções metodológicas de ensino, como as vinculadas ao movimento da Escola Nova; e também a apropriação de conceitos da psicologia do desenvolvimento de base experimental.

Como explica Forquin (1993), a construção do saber escolar:

[...] não se limita a fazer uma seleção entre os saberes e os materiais culturais disponíveis num dado momento, ele deve também, para torná-los efetivamente transmissíveis, efetivamente assimiláveis às jovens gerações, entregar-se a um imenso trabalho de reorganização, de reestruturação [...] (p.16) 
Com esse processo de construção de um saber escolar sobre a literatura infantil, na segunda metade do século XX, por não haver, até então, um saber de referência específico para esse gênero literário, esse saber escolar, "concretizado" nos manuais de ensino, passou a ocupar esse vazio e a "funcionar" com uma teoria desse gênero literário.

$\mathrm{Na}$ medida em que o saber escolar sobre a literatura infantil passou a subsidiar as reflexões em relação a esse gênero literário, para além das finalidades do ensino, é possível afirmar que foi esse saber escolar, num movimento inverso, que passou a ser utilizado como saber de referência. Esse aspecto pode ser observado, por exemplo, na recorrente citação e utilização dos manuais como bibliografia na elaboração de textos, artigos e até mesmo de outros manuais.

No caso de Compêndio de literatura infantil (1959), de Bárbara Vasconcelos de Carvalho, observa-se que, nas décadas de 1970 e 1980, essa autora reformulou esse manual, ampliando algumas informações, e o publicou como diferentes livros sobre teoria, crítica e história da literatura infantil. Os livros decorrentes da reformulação de Compêndio de literatura infantil são: Literatura infantil: estudos (1971); e Literatura infantil: visão histórica e crítica (1982).

Caso semelhante a esse se pode observar com os manuais de Maria Antonieta Antunes Cunha. Essa autora, ainda que tenha reformulado o seu primeiro manual - Como ensinar literatura infantil - também sob o formato de um novo manual - Literatura infantil: teoria \& prática -, o segundo alçou o status de livro teórico, de modo que suas últimas edições datam do século XXI, posteriormente ao processo em que o ensino da literatura infantil foi extinto da formação dos professores primários. Também esse livro, ainda hoje, encontra-se referenciado em número significativo de trabalhos acadêmicos, como teses e dissertações, desenvolvidas nas áreas de Educação e de Letras.

Ainda como exemplo do processo em que as publicações destinadas ao ensino da literatura infantil "funcionaram" como teoria da literatura infantil, tem-se o caso do livro de Jesualdo Sosa. Esse livro, que na sua edição de 1955 circulou no Brasil com forte vinculação ao ensino da literatura infantil na formação de professores, no final do século XX, após ser traduzido para o português, passou a ser utilizado como referencial teórico já nas primeiras teses e dissertações desenvolvidas no país. Nesse sentido, ainda que elaborado a partir da experiência de Jesualdo Sosa como professor de literatura infantil e fortemente relacionado ao ensino desse gênero literário no Ensino Normal, La literatura infantil, por décadas, logrou o status, como afirma 
Ceccantini (2010), de única bibliografia teórica estrangeira traduzida para o português brasileiro.

Com isso, entendo que o movimento em torno da institucionalização do ensino da literatura infantil significou o processo pelo qual o saber que se construiu a fim de atender a urgência e necessidades desse ensino na formação de professores se converteu em um tipo de teorização, sendo usada para subsidiar estudos e investigação no campo da literatura infantil. É essa situação que penso explicar, por exemplo, o fato de que quase todos os manuais tiveram diferentes edições e tiragens (em alguns casos que ultrapassaram a casa dos 5.000 exemplares), mesmo com toda a instabilidade que o ensino da literatura infantil representou, do ponto de vista da legislação. Mesmo quando a legislação não previa o ensino da literatura infantil nos cursos de formação de professores, esses manuais continuaram a ser reeditados, em alguns casos, por diversas vezes. Nesse sentido, como explica Valdemarin (2010), esses manuais de ensino, em razão de “[...] sua ampla difusão, seu manuseio cotidiano e as sucessivas edições, [... ] contribuíram decisivamente para que determinadas interpretações se tornassem hegemônicas" (p.26).

Pelo exposto, pode-se afirmar, com base nas formulações de Chervel (1990), que o saber escolar construído em favor do ensino da literatura infantil na formação de professores carregou consigo uma significação maior. Mais do que formar professores, o ensino da literatura infantil contribuiu para formar modos específicos de se pensar "teoricamente" esse gênero literário e definir formas de produção e interpretação dos livros destinados às crianças.

Foi, portanto, no conjunto das iniciativas de se tematizar, normatizar e concretizar o ensino da literatura infantil nos cursos de formação de professores no estado de São Paulo que se formou o que podemos denominar de uma teoria específica sobre a literatura infantil brasileira.

\section{A "psicologização" da literatura infantil: a construção de uma base científica}

Ao se tomar para análise os textos sobre história da literatura infantil brasileira, é unânime a afirmação de que a produção literária destinada à infância emergiu, neste país, das relações entre literatura e ensino, no interior 
da escola primária. Como detalhadamente indicam Arroyo (1968), Salém (1970) e Lajolo e Zilberman (1984), os primeiros livros de literatura infantil publicados no país foram produzidos com destinação escolar, carregando consigo a marca indelével dos propósitos instrutivos educacionais.

No entanto, se está mais do que explorada e defendida (pelo menos por ora) a tese de que a literatura infantil brasileira tem sua "origem" ou sua "formação" na relação entre literatura, ensino e escola, no que se refere à "origem" dos discursos sobre esse gênero literário ainda se fazem necessárias reflexões.

Nos textos que problematizam os discursos brasileiros sobre literatura infantil (como os de Magnani (1998), Ceccantini (2004) e Souza (2008)), geralmente se aponta a "origem" dessa produção também com vinculação à escola, porém não se exploram questões relativas às bases científicas ou tipos de conhecimento que subsidiaram a formação dos conceitos sobre literatura infantil, que circularam no Brasil, ao longo do século XX.

Conforme se pôde observar nos textos que sintetizei no Capítulo 1 , entre o final do século XIX e primeira década do século XX, os primeiros discursos brasileiros sobre literatura infantil foram publicados sob o formato de prefácios, apresentações e prólogos. Nesses discursos, cujo destinatário não era a criança, para quem os livros eram escritos, mas os pais e professores, que os compravam ou os davam a ler, observa-se a exaltação de características "literárias" em função das necessidades educativas que se consideravam adequadas para a formação (moral) do leitor.

Já no início do século XX, os discursos sobre literatura infantil começaram a ser produzidos em formatos mais consistentes, como artigos em periódicos especializados. Observa-se com isso a tentativa de alguns educadores em conceituar e problematizar a literatura infantil a partir da "cientificidade" dos métodos de ensino, como o método intuitivo e o método analítico. Essa situação, a partir da década de 1940, cedeu espaço para questões de ordem psicológica.

A partir da década de 1920, com a gradativa disseminação do pensamento escolanovista no Brasil, a Psicologia foi ganhando maior destaque como uma das ciências presentes na fundamentação educacional. Conforme explica Antunes (1998), as relações entre a Psicologia e a Escola Nova, particularmente no Brasil, foram indissociáveis. Segundo essa autora: 
[...] a Psicologia deveria subsidiar as transformações da escola: as relações entre professor e aluno, o processo de ensino-aprendizagem, a modernização metodológica, a organização das classes, o conhecimento e o respeito ao desenvolvimento da criança, enfim, deveria a Psicologia tornar-se o mais importante braço científico e técnico da nova concepção de Educação (Antunes, 1998, p.90).

Essa situação, como explica Warde (1995), decorreu, em especial, do fato de que a Psicologia representava, desde o século XIX, um ponto de vista mais moderno, condizente com os tempos urbanos e industriais que se queriam associados à Educação. Em vista disso, a Psicologia foi a "força modeladora" da organização do ensino e do currículo, levando o fazer escolar, no Brasil, a uma quase total dependência do crivo dessa ciência (Warde, 1995).

Nesse processo, nota-se que a literatura infantil, formada no interior da escola, quer como gênero literário, quer como tema de estudo/campo de conhecimento, também passou a ser objeto do olhar psicológico. Com isso, assim como as questões da educação foram sofrendo um processo de "psicologização", também a literatura infantil passou a ter como ciência diretora a Psicologia aplicada à infância, especialmente a psicologia do desenvolvimento, de base experimental.

Os primeiros traços explícitos dessa "psicologização" da literatura infantil se registram no artigo, de 1941, de Betti Katzenstein e Beatriz de Freitas - "Algo de que as crianças gostam de ler: estudo de dois livros preferidos por meninos e meninas" - ambas, à época, ligadas ao Laboratório de Psicologia da Faculdade de Filosofia, Ciências e Letras da Universidade de São Paulo. Ainda na década de 1940, Lourenço Filho, um dos principais representantes das bases psicológicas do movimento renovador escolanovista no Brasil (Saviani, 2008), também apresenta em "Como aperfeiçoar a literatura infantil” importantes conceitos da Psicologia, como suporte para se pensar a produção literária para crianças.

Na sequência desses, no final da década de 1940, quando a literatura infantil vinha se constituindo como objeto de ensino na formação de professores, nas primeiras "concretizações" para esse ensino, nota-se a presença da Psicologia de forma mais delineada. Essa presença da Psicologia se consolidou, definitivamente, a partir de 1957, com as diferentes iniciativas em favor da construção do saber escolar relativo a esse gênero literário, como as publicações dos programas e manuais específicos para o ensino da literatura infantil. 
No caso dos programas, vemos, por exemplo, a prescrição de pontos relacionados ao estudo do "ajustamento" da literatura infantil à evolução psíquica da criança e a definição do estudo dos requisitos morais e materiais, em função das finalidades psicológicas e didáticas desse gênero literário.

No caso dos manuais de ensino ou dos livros que "funcionaram" como manuais, são recorrentes afirmações sobre a necessidade de a literatura infantil se adequar aos princípios da Psicologia. De modo geral, a defesa era a de que os livros devessem servir ao desenvolvimento psíquico e moral da criança, como fonte de formação da personalidade do futuro adulto. Esse aspecto se confirma, também, pelas citações, menções ou indicações, nas bibliografias desses manuais, de textos de intelectuais ligados ao campo da Psicologia, como Édouard Claparède.

Também o livro de Jesualdo Sosa, amplamente disseminado no Brasil e referência recorrente em todos os manuais destinados ao ensino da literatura infantil, confirma a ideia de "psicologização" desse gênero literário. Cabe lembrar, sobre o livro de Jesualdo, que esse autor estabelece relações entre a literatura infantil e a Psicologia, sustentando sua argumentação em textos de importantes nomes ligados à Psicologia do século XX, como: Jean Piaget, Aníbal Ponce, Édouard Claparède e Henri Wallon.

Nesse processo de "psicologização" da literatura infantil, evidentemente não foi uma única vertente da Psicologia que concorreu para tal situação. Inicialmente, observa-se que a psicologia do desenvolvimento, de base experimental, parece ter dado a tônica da discussão sobre o "ajustamento" dos livros literários à idade cronológica e psíquica das crianças. E, mais ao final do século XX, a partir da década de 1970, a Psicanálise, especialmente na visão de Bruno Bettelheim, foi a vertente que começou a despontar como aparato teórico nos estudos sobre literatura infantil. Sobre esse aspecto, cabe destacar, ainda, que a marca da Psicologia como ciência diretora dos estudos relacionados à literatura infantil se apresenta até mesmo na capa de um dos manuais. Em Literatura infantil: teoria \& prática (Figura 15), visualiza-se a representação de uma situação de terapia psicanalítica, na qual a boneca Emilia, protagonista de alguns dos livros de Monteiro Lobato, está deitada num divã, sob o olhar e análise do "psicanalista" Monteiro Lobato.

Na década de 1980, mesmo com o movimento de "academização" do discurso sobre a literatura infantil e o deslocamento dos estudos a respeito desse gênero literário para os campos da teoria e crítica literárias, ainda 
assim as diferentes vertentes da Psicologia continuaram com espaço significativo nesses estudos. Isso se observa pela investigação desenvolvida por Fúlvia Rosemberg (1985) (e replicada por outros), que se amparou, teoricamente, nos princípios da Psicologia Social.

Em vista dessas questões, pode-se afirmar que a literatura infantil, por estar situada no entrecruzamento dos campos sobre criança e-educação, ambas objetos de interesse da Psicologia, esse gênero acabou sofrendo fortes influências dessa ciência. Ou seja, no processo de formulação do saber escolar sobre a literatura infantil, a Psicologia foi a principal base científica, que sustentou a construção desse saber. Foi a partir dos parâmetros e dos conceitos dessa ciência, em suas diferentes vertentes, que foi sendo definido o que servia e o que não servia para ser publicado como literatura infantil, no Brasil.

\section{A definição de um "padrão" de literatura infantil e a construção da noção de "clássico"}

Ao se observarem os documentos relacionados ao ensino da literatura infantil, formulados no âmbito da formação de professores no estado de São Paulo, pode-se notar que, em certa medida, eles foram apresentando as características do que se considerava a "boa" literatura infantil. Com isso, acabaram por "funcionar" como instrumentos balizadores para a escrita dos textos literários destinados às crianças. Conforme a produção de livros desse tipo foi crescendo, sobretudo pela sua maior circulação no âmbito escolar, os escritores, de alguma forma, buscaram atender ao que se compreendia como adequado, ao longo do século XX, para os pequenos leitores.

Muitos dos escritores de literatura infantil, que foram se especializando nesse ramo, nesse período, no anseio de vender e, como afirma Chartier (1998), "tentar viver de sua própria pena", tiveram de se adequar aos padrões de literatura infantil disseminados nos diferentes momentos do século XX. Isso ocorreu, como explica Bragança (2001), porque os livros com destinação escolar, antes de serem publicados, tinham de passar pelo crivo do editor, que avaliava os originais a partir dos parâmetros de exigência das autoridades escolares. 
Dentro desses parâmetros, deve escolher dentre os eventuais originais apresentados aqueles que possam satisfazer aos professores, por onde passa, em maior ou menor nível - de diretores de escola, coordenadores de área até ao professor da sala de aula -, a decisão sobre a adoção e a recomendação do consumo ou não da obra pelos alunos. E, finalmente, deve fazer livros que agradem também aos alunos - e a seus pais - já que seu feedback pode ser decisivo para reverter a decisão ou confirmá-la nos anos seguintes (Bragança, 2001, p.8).

Embora Bragança (2001) teça essas considerações com relação aos livros escolares em geral, essa situação não foi diferente com a literatura infantil.

Apenas para citar um exemplo, Lourenço Filho, que por anos atuou como consultor editorial da Companhia Editora Melhoramentos (SP) e esteve diretamente envolvido na elaboração das prescrições oficiais para o ensino da literatura infantil, adotava como critério de avaliação dos livros os parâmetros educacionais. Como explica Soares (2007), esse educador, sob a ótica educacional e apoiado na Psicologia, "condenava”, por exemplo, livros que "desrespeitavam", pela linguagem, sentido ou apresentação, os estágios de desenvolvimento da criança, enquanto aprovava outros que atendiam aos requisitos ansiados pela escola. Com isso, ao examinar esses livros, Lourenço Filho os submetia a correções de ortografia, de "forma" e de "conteúdo", chegando, em alguns casos, a sugerir a reescrita de trechos para melhorar o trabalho e viabilizar a publicação (Bertoletti, 2006). Lourenço Filho, como consultor editorial de literatura infantil, nos aproximados 5.000 pareceres que emitiu, tentou imprimir nas publicações da época uma determinada concepção de literatura infantil, que se ligava diretamente a um projeto de educação (Bertoletti, 2006).

Além da figura do editor, que de certo modo fazia um tipo de seleção do que se publicava como literatura infantil, a administração da educação paulista, ao longo do século XX, adotou medidas de seleção e recomendação de livros, também fazendo um tipo de seleção do que circularia dentro das escolas públicas do estado. Essas medidas se deram, por exemplo, por meio das Comissões de análise de livros escolares e pela consequente publicação de listas de livros recomendados para adoção pelas escolas públicas paulistas (Oliveira; Trevisan, 2014). Embora as escolas tivessem relativa autonomia na escolha dos seus livros, essas listas funcionaram como forma de incitar a compra de determinados títulos, os quais se compreendiam estar 
de acordo com os anseios educativos defendidos por aqueles que estavam à frente da administração da educação pública paulista.

Por esses aspectos, pode-se dizer que o modo como se define a literatura infantil e se compreendem as suas funções e requisitos nos documentos relativos ao ensino desse gênero literário estava em sintonia com as ações em torno da definição do "bom" livro de literatura infantil.

Penso, porém, que esse ensino significou mais que isso.

Na medida em que os manuais e programas subsidiavam a formação de professores para o ensino da literatura infantil e, posteriormente, passaram a funcionar como "teorização" desse gênero literário, eles tiveram atuação direta na construção, disseminação e conformação de um padrão de literatura infantil para o Brasil. Se os livros de literatura infantil tinham como espaço privilegiado de circulação a escola e cabia aos professores escolher quais livros adotar, nada mais eficaz do que (con)formar os professores para um determinado conceito desse gênero literário.

Desse modo, ao se institucionalizar o ensino da literatura infantil, contribuiu-se para a construção e para a disseminação de um padrão de livro literário para crianças, padrão esse que abarca, desde questões mais complexas, como forma narrativa, tema, estilo, até questões mais pontuais, como tipo de papel e forma de encadernação.

Esse "padrão" de literatura infantil, que foi se construindo nos manuais de ensino e nas prescrições oficiais, contém a descrição das seguintes características: histórias constituídas em torno de personagens que servem como modelo do bom comportamento moral, evitando-se a descrição e/ou narração de cenas violentas e de crimes; utilização de linguagem simples, objetiva, correta e "colorida", mas com o cuidado de não cair na "puerilidade", na infantilização do texto; construção de um texto que possibilite o fácil entendimento das crianças, daí a escolha de assuntos ligados ao universo infantil; a recomendação, para crianças menores, de livros "ricamente" ilustrados, com pouco ou nenhum texto verbal; uso de formas narrativas com "dramatismo" e "movimentação", que, mesmo com personagens que passem por diversos obstáculos, apresentem um desfecho feliz; narrativas que fujam das descrições e digressões longas, bem como do "tom" moralizador, pois a moral deve ser percebida "naturalmente"; com relação aos aspectos materiais, escolha de bom papel para impressão, evitar ilustrações que não contribuem para a compreensão do texto verbal, escolha de boa 
encadernação, que facilite o manejo, letras redondas e grandes, principalmente para crianças pequenas, e uso de cores vivas; e adequação do tipo de texto conforme a idade cronológica e o desenvolvimento psíquico infantil.

Com base nas características que compunham o "bom" livro de literatura infantil, os autores de manuais mencionam um conjunto de livros ou transcrevem trechos desses textos, para os recomendá-los à leitura das crianças.

Em relação ao período de formação da literatura infantil na Europa, por exemplo, é unânime a exaltação de textos, como: Robinson Crusoé, de Daniel Defoe; Viagens de Gulliver, de Jonathan Swift; os contos dos irmãos Grimm; os contos de Hans Christian Andersen; Pinóquio, de Carlo Collodi; as fábulas de Esopo e Fedro; as fábulas de Jean de La Fontaine; Alice no País das Maravilhas, de Lewis Caroll; e diferentes livros de Júlio Verne. No caso do Brasil, os livros de Monteiro Lobato são, sem dúvida, os mais mencionados, em especial Narizinho arrebitado. Também outros escritores brasileiros são recorrentemente mencionados nos documentos sobre ensino da literatura. São eles: Alberto Figueiredo Pimentel, Olavo Bilac, Thales de Andrade, Viriato Corrêa, Francisco Marins, Arnaldo de Oliveira Barreto e Lúcia Machado de Almeida. Cabe destacar que, ainda no caso da literatura infantil brasileira, na maior parte dos casos não eram os livros que eram recomendados, mas toda a obra de cada um desses escritores.

Observa-se com isso que os manuais de ensino, ao se repetirem recorrentemente na menção e/ou recomendação desses livros e escritores, acabaram por construir um rol dos livros "clássicos" da literatura infantil. Essa noção de "clássicos" se associa à ideia de livros e escritores modelares e expoentes, indispensáveis na leitura das crianças e exemplares do "bom modelo" de literatura a ser seguido.

A comprovação dessa noção de "clássico" pode ser notada, por exemplo, na ideia que se tem ainda hoje, entre muitos professores. Sempre que precisam se reportar a algum texto "clássico" ou "indispensável", eles se remetem aos livros de Daniel Defoe, Monteiro Lobato, Viriato Corrêa, Erico Veríssimo, Cecília Meireles e Olavo Bilac, entre outros, escritores esses "entronizados" pela história do ensino da literatura infantil no Brasil como "clássicos" desse gênero. 


\section{Permanências e rupturas no ensino da literatura infantil: uma "tradição inventada"}

Mediante os aspectos que apresentei em relação à história do ensino da literatura infantil nos cursos de formação de professores no estado de São Paulo, penso que é possível compreender essa história como um movimento em favor da "invenção de uma tradição", que pode ser resumida na ideia de que o "Belo" (como valor estético) do texto literário somente faz sentido se estiver a serviço do "Bem" (como valor moral).

Conforme explica Hobsbawn (1984), por "tradição inventada" se compreende:

[...] um conjunto de práticas normalmente reguladas por regras tácita ou abertamente aceitas: tais práticas, de natureza ritual ou simbólica, visam inculcar certos valores e normas de comportamento através da repetição, o que implica, automaticamente, uma continuidade em relação ao passado. (p.10)

Constituída a partir do processo pelo qual se formou um saber escolar sobre a literatura infantil, que funcionou posteriormente como saber teórico, a "tradição" que se "inventou" em torno desse gênero literário contribuiu para disseminar valores (de ordem psicológica e educativa) a respeito dos livros literários destinados às crianças.

Ao explicitar o que se considerava como literatura recomendável ou não recomendável às crianças e indicar comportamentos, sentimentos e reações que deviam se "formar" nesses leitores, os documentos relacionados ao ensino da literatura infantil concorreram para a construção de uma concepção de literatura infantil e de um modelo de leitor e de ensino desse gênero literário.

Outro aspecto que penso confirmar a ideia do ensino da literatura infantil como uma "tradição inventada" é o fato de que, como argumenta Hobsbawn (1984), uma tradição se situa como forma de reação a situações novas "[...] que, ou assumem a forma de referência a situações anteriores, ou estabelecem seu próprio passado através da repetição quase que obrigatória” (p.11).

No caso do ensino da literatura infantil, observa-se que, ao longo do século XX, embora alguns valores relacionados aos livros para crianças 
foram se modificando, identifica-se certa permanência de alguns conceitos. Nos primeiros discursos sobre a literatura infantil, datados entre o final do século XIX e quatro primeiras décadas do século XX, tem-se uma preocupação especial com livros que narram cenas de violência, ou situações com gangsters. Esse aspecto estava relacionado, sobretudo, com a questão da $1^{\text {a }} \mathrm{e}$ $2^{a}$ Guerras Mundiais. A partir do final da década de 1950, essa preocupação perdeu forças, permanecendo, porém, a ideia de que a literatura infantil devia servir para a formação da boa moral, como ferramenta de instrução pela recreação.

Ainda que se possa identificar a ênfase em alguns aspectos da literatura infantil e o arrefecimento de outros, ao longo dos quase 60 anos de história do ensino desse gênero literário identificam-se permanências, mesmo quando se consolidam rupturas, como a que se teve a partir da década de 1980, com os estudos acadêmicos nesse campo.

Apesar de a geração de pesquisadores dos anos 1980 combaterem a "tradição" sobre a literatura infantil formulada ao longo do século XX, especialmente as relações intrínsecas entre esse gênero literário e o ensino de forma pragmática, em nenhum momento se propôs diretamente uma ruptura direta dessa relação. De modo geral, a geração de pesquisadores dos anos 1980 propõe pensar uma outra lógica na relação entre literatura infantil e ensino, sem, no entanto, rompê-la direta e definitivamente.

E, ainda que desde os anos 1980 venha se questionando e combatendo as "antigas" práticas de ensino da literatura infantil, conforme foram sistematizadas no âmbito do Ensino Normal, essas práticas ainda permanecem sendo "praticadas" no cotidiano do fazer escolar, em intensidade muito maior do que se imagina. Apenas a título de exemplo, é ainda muito comum os professores dos primeiros anos do Ensino fundamental defenderem o uso de fábulas ou contos de fada como os textos mais apropriados à formação da criança, porque consideram ser fundamental a criança ler uma narrativa de cunho moral e instrutivo. Também é comum os professores categorizarem os livros que os alunos podem ler, conforme a faixa de idade, pois entendem que é preciso que os livros sejam adequados ao desenvolvimento psíquico infantil.

Nesse sentido, embora o ensino da literatura infantil, tal como foi sistematizado ao longo do século XX, não mais figure na formação dos professores, observa-se, na atualidade, algumas permanências de suas práticas, com 
a força de uma "tradição inventada". Por isso, pensar sobre essa história é muito mais do que rememorar ou dar a conhecer um aspecto do passado, como se se colocasse em cena uma "população de mortos" (Certeau, 2011), seja para venerá-los com admiração nostálgica, seja para não deixar os "novos" esquecerem-se dos "erros" do passado.

Pensar sobre a história do ensino da literatura infantil na formação de professores é trazer à tona aspectos do passado, a fim de se desestabilizar os paradigmas e certezas com as quais nos envolvem o presente, possibilitando direcionar e projetar o futuro com uma maior clareza. Como explica Certeau (1976), a história exerce o papel de crítica, que faz aparecer as exceções apagadas pelos modelos; que abre espaço para as particularidades como limite do pensável; e como a ciência que, ao produzir um evento do passado, dá lugar a um futuro. Esse é o sentido da história que se pretende aqui. 


\section{RefERÊNCIAS}

ABRAMOVICH, Fanny. Literatura infantil: gostosuras e bobices. São Paulo: Scipione, 1989.

ACADEMIA BRASILEIRA DE LITERATURA INFANTIL E JUVENIL. Estatuto. São Paulo: s.e., 1980.

ACUjARO, Heleny Catharina; BATARCE, Rosa Jorge. Plano de ensino: Português $4^{\circ}$ ano de Educação. São Carlos: Instituto de Educação Dr. Álvaro Guião, 1975 (datilografado).

ADÁRIO, Maria Irena Andrade. Plano de ensino de Português e Literatura infantil. Tupã: E.E.P.S.G Índia Vanuíre, 1983 (datilografado).

AGUIAR, Ronaldo Conde. O rebelde esquecido: tempo, vida e obra de Manoel Bomfim. Rio de Janeiro: Topbooks, 2000.

ALMEIDA, Jane Soares de. A escola normal paulista: estudo dos currículos (1846 a 1990) destaque para a prática de ensino. Boletim do Departamento de didática. a.11, n.9, 1993.

ANDRADE, Thales Castanho de. A Arte de escrever para a infância. In: OLIVEIRA, Antenor Santos de (Org.). Curso de literatura infantil. São Paulo: Santos de Oliveira, 1958. p.39-55.

AMADO, Gilberto. Livro para crianças. Revista da Sociedade de Educação, São Paulo, v.1, n.3, p.297-298, 10 dez. 1923.

AMARAL JÚNIOR, Amadeu. Literatura infantil. O Estado de S. Paulo, São Paulo, 24 jul.1940, p.4.

AMOROSO LIMA, Alceu. Literatura infantil. In: Estudos: $1^{\text {a }}$ série. 2. ed. Rio de Janeiro: A Ordem, 1927.

ANTUNES, Mitsuko Ap. Makino. A Psicologia no Brasil: leitura histórica sobre sua constituição. São Paulo: Unimarco; Educ, 1998.

ARROYO, Leonardo. Literatura infantil brasileira: ensaio de preliminares para a sua história e suas fontes. São Paulo: Melhoramentos, 1968. 
ASSIS, Machado. Carlos Jansen: Contos selectos das "Mil e uma noites". In: JANSEN, Carlos. Contos selectos das mil e uma noites. Rio de Janeiro: Laemmert, 1882. ASSIS, Vivianny Bessão. Contribuições de Leonardo Arroyo para a história da literatura infantil brasileira. In: CERECEDO, Alicia Civera; FERNÁNDEZ, Carlos Escalante; ROCKWELL, Elsie. (Org.). Sujeitos, poder y disputas por la educación: textos de historiografía de la educación latinoamericana. Zinacantepec: El Colegio Mexiquense; Universidad Pedagogica Nacional, 2014, p.3413-3423.

ASSOCIAÇÃO BRASILEIRA DE NORMAS TÉGNICAS. Norma Brasileira de Referências (NBR-6023). Rio de Janeiro, 2002.

ASSUMPTOS agrícolas: Árvores milagrosas. O Estado de S. Paulo, 6 set. 1928, p.4. (Sobre livro de Thales de Andrade: Arvores milagrosas).

ATICA. Momentos do livro no Brasil. São Paulo: Ática, 1995.

AZEVEDO, Fernando. A literatura infantil numa perspectiva sociológica. Sociologia(Escola de Sociologia e Política). v.XIV, n.1, mar. 1952.

BAKHTIN, Mikhail. Questões de literatura e de estética: a teoria do romance. São Paulo: Hucitec, 1998.

BARROSO, Celso. O crime na literatura infantil. Folha da Manhã. São Paulo, [s.p.], 13 set. 1938.

BELINKY, Tatiana. O livro na escola. In: SÃO PAULO (estado). Secretaria de Estado de Educação. Coordenadoria de Estudos e Normas Pedagógicas. Ciclo básico em jornada única: uma nova concepção de trabalho pedagógico. v.1. São Paulo: FDE, 1988.

BENJAMIN, Walter. Magia e técnica, arte e política: ensaios sobre literatura e história da cultura. Trad. Sérgio Paulo Rouanet. São Paulo: Brasiliense, 1994.

BELLOTTO, Heloísa Liberalli. Os instrumentos de pesquisa no processo historiográfico. In: Congresso Brasileiro de Arquivologia, 4, 1979, Anais..., p.133-147.

BERTOLETTI, Estela Natalina Mantovani. A produção de Lourenço Filho sobre e de literatura infantil e juvenil (1942-1968): fundação de uma tradição. 2006. $275 f$. Tese (Doutorado em Educação) - Faculdade de Filosofia e Ciências, Universidade Estadual Paulista, Marília. 2006.

Lourenço Filho e a literatura infantil e juvenil. São Paulo: Ed. Unesp, 2012.

BIBLIOGRAPHIA - Anna de Castro Oliveira e Paulino de Oliveira. Os nossos amigos. O Estado de S. Paulo, 10 out. 1909. p.2.

BILAC, Olavo. Poesias infantis. Rio de Janeiro: Francisco Alves, 1904.

BILAC, Olavo. Poesias infantis. 5. ed. Rio de Janeiro: Francisco Alves, 1916.

BILAC, Olavo; BONFIM, Manoel. Atravéz do Brazil. Rio de Janeiro: Francisco Alves, 1910.

BIRIGUI. Instituto de Educação Prof. Stélio Machado Loureiro. $4^{\circ}$ Magistério: Língua portuguesa e literatura. Birigui: Instituto de Educação Prof. Stélio Machado Loureiro, 1997. (Digitado).

BOAS leituras para auxiliar a formação moral da criança. Diário Popular, São Paulo, [s.p.], 13 jan. 1942. 
BRAGANÇA, Aníbal. A função editor de livros escolares. In: CONGRESSO BRASILEIRO DE COMUNICAÇÃO. 14., 2001. Anais... Campo Grande, 2011. Disponível em: <http://www.intercom.org.br/papers/nacionais/2001/papers/ NP4BRAGANCA.pdf> Acesso em: 10 out. 2014.

BRASIL. Constituição dos Estados Unidos do Brasil. 10 nov. 1937. Disponível em: <http://www.planalto.gov.br/ccivil_03/constituicao/ constitui\%C3\%A7ao37.htm>. Acesso em: 15 mar. 2012.

Decreto-Lei n. 8.530, de 2 de janeiro de 1946 - Lei Orgânica do Ensino Normal. In: NÓBREGA, Vandick Londres da. Enciclopédia da legislação do ensino. Rio de Janeiro, 1967.

. Lei n. 4.024, de 20 de dezembro de 1961. Fixa as diretrizes e bases da educação nacional. Lex - Legislação Federal, 1962.

. Lei n. 5.692, de 11 de agosto de 1971. Fixa as diretrizes para o ensino de $1^{\circ}$ e $2^{\circ}$ graus e dá outras providências.

BUDIN, J. Metodologia da linguagem: para uso das escolas normais e institutos de educação. São Paulo: Nacional, 1949.

CADERMATORI, Lígia. O que é literatura infantil. São Paulo: Brasiliense, 1986.

CAMPOS, Maria dos Reis. Literatura infantil. Revista Brasileira de Estudos Pedagógicos, Rio de Janeiro, v.10, n.27, p.178-186, mar./abr. 1947. (Seção Idéias e debates).

CAMPOS, Arlêta Nóbrega Zelante Maryssael. A escola normal paulista: acertos e desacertos. 1987. 123f. Dissertação (Mestrado em Educação) - Faculdade de Educação, Universidade de São Paulo, São Paulo, 1987.

CANDIDO, Antonio. Formação da literatura brasileira: momentos decisivos. 12. ed. São Paulo: Ouro Sobre Azul, 2009.

CARDOSO, Manoel. Estudos de literatura infantil. São Paulo: Editora do Brasil, 1991.

CARNEIRO, Orlando Leal. Metodologia da linguagem. Rio de Janeiro: Agir, 1951.

CARNEVALI, Flávia Guia. A mineira ruidosa: cultura popular e brasilidade na obra de Alexina de Magalhães Pinto. 2009. 234f. Dissertação (Mestrado em História) Faculdade de Filosofia, Letras e Ciências Humanas, Universidade de São Paulo, São Paulo, 2009.

CARVALHO, Bárbara Vasconcelos de. Compêndio da literatura infantil: para o $3^{\circ}$ ano normal. São Paulo: Companhia Editora Nacional, 1959.

. A literatura infantil na Escola Normal. Gazeta de São Paulo. São Paulo, 1957.

CARVALHO, Lidia Izecson; MARINHO, Jorge Miguel. A leitura e a literatura. In: SÃO PAULO (estado). Secretaria de Estado de Educação. Coordenadoria de Estudos e Normas Pedagógicas. Ciclo básico em jornada única: uma nova concepção de trabalho pedagógico. v.1. São Paulo: FDE, 1988.

CARVALHO, Marta Maria Chagas de. Antônio de Sampaio Dória. In: FÁVERO, Maria de Lourdes de A; BRITTO, Jader de M. (orgs.). Dicionário de educadores no Brasil. Rio de Janeiro: UFRJ/MEC-Inesp-Comped, 2002, p.123-130. 
CARVAlHO, Marta Maria Chagas. Antonio de Sampaio Dória. In: FÁVERO, Maria de Lourdes de Albuquerque; BRITTO, Jader de Medeiros. Dicionário de educadores no Brasil. Rio de Janeiro: Editora UFRJ; MEC-Inep, 1999. p.74-81.

CASTILHOS, Gladiomar Saade. A literatura infantil e sua institucionalização como disciplina na formação de professores (1920-1960). 2013. 158f. Dissertação (Mestrado em Educação) - Pontifícia Universidade Católica do Paraná, Curitiba, 2014.

CATANI, Denice. Educadores à meia-luz: um estudo sobre a Revista de Ensino da Associação Beneficente do Professorado Público de São Paulo (1902-1918). Bragança Paulista: EDSF, 2003.

CAVALCANTE, Margarida Jardim. Cefam: uma alternativa pedagógica para a formação do professor. São Paulo: Cortez, 1994.

CECCANTINI, João Luís C. Tápias. Perspectivas de pesquisa em literatura infanto-juvenil. In: (Org.). Leitura e literatura infanto-juvenil: memória de Gramado. São Paulo: Cultura Acadêmica, 2004.

CECCANTINI, João Luís. A literatura infantil brasileira... In: HUNT, Peter. Crítica, teoria e literatura infantil. São Paulo: Cosac \& Naif, 2010.

CENTRO DE ESTUDOS DE LITERATURA INFANTIL E JUVENIL (Celiju). Estatuto. São Paulo, s.d. (datilografado).

CERTEAU, Michel de. A operação histórica. In: LE GOFF, Jacques; NORA, Pierre. História: novos problemas. Rio de Janeiro: Francisco Alves, 1976.

. A escrita da história. 3. ed. Rio de Janeiro: Forense Universitária, 2011.

CHARTIER, Roger. A história cultural: entre práticas e representações. Trad. Maria M. Galhardo. Lisboa: DIFEL; Rio de Janeiro: Bertrand Brasil, 1990a.

. Educação. In: LE GOFF, J.; CHARTIER, R.; REVELS, J. A nova história. Trad. M. Arinto e R. Esteves. Coimbra: Almedina, 1990b. p.160-162.

. A história ou a leitura do tempo. Trad. Cristina Antunes. Belo Horizonte: Autêntica, 2009.

A aventura do livro: do leitor ao navegador. São Paulo: Ed. UNESP, Imprensa Oficial, 1998.

CHAUÍ. Marilena. Perspectivas para o futuro. In: JANCSÓ, I. (Org.). Humanidades, pesquisa, universidade. São Paulo: Comissão de Pesquisa FFLCH-USP, 1996.

CHERVEL, André. História das disciplinas escolares: reflexões sobre um campo de pesquisa. Trad. Guacira Lopes Louro. Teoria E Educação. Porto Alegre, n.2, p.117-229, 1990.

COELHO, Nelly Novaes. O ensino da literatura: sugestões metodológicas para o curso secundário e normal. São Paulo: F.T.D., 1966.

COELHO, Nelly Novaes. Dicionário crítico da literatura infantil e juvenil brasileira. 5. ed. rev. atual. São Paulo: Companhia Editora Nacional, 2006. 1983.

Dicionário crítico da literatura infantil e juvenil brasileira. São Paulo: Quíron, A literatura infantil: história - teoria - análise. São Paulo: Quíron, 1981.

Entrevista. São Paulo, 2012 (digitada). 
CORREIA JR. J. F. A importância da disciplina literatura infantil no curso de habilitação específica para o magistério. 1993. 93f. Trabalho de Conclusão de Curso (Graduação em Pedagogia) - Universidade Estadual Paulista, Rio Claro, 1993.

COSTA, Aline Santos. A Comissão Nacional de Literatura Infantil e a formação do público leitor infanto-juvenil no Governo Vargas (1936 - 1938). Dissertação (Mestrado em Educação) - Faculdade de Educação, Universidade Estadual do Rio de Janeiro, Rio de Janeiro, 2011.

CUNHA, Maria Antonieta Antunes. Literatura infantil: teoria \& prática. São Paulo: Ática, 1983.

. Como ensinar literatura infantil: para os colégios normais. Belo Horizonte: Bernardo Álvares, 1968. Entrevista. Belo Horizonte, 2014. (digitado).

CUNHA, Marcus Vinícius da. A educação dos educadores: da Escola Nova à escola de hoje. Campinas: Mercado das Letras, 1995.

DANTAS, Consuelo da Silva. Aspectos da literatura infantil na escola primária. In: OLIVEIRA, Antenor Santos de (Org.). Curso de literatura infantil. São Paulo: Santos de Oliveira, 1958. p.59-78.

D’ARAÚJO, Maria Célia. O AI-5. Fundação “Getúlio Vargas”, Centro de Documentação de História Contemporânea do Brasil, s.d. Disponível em: <http://cpdoc. fgv.br/producao/dossies/FatosImagens/AI5>. Acesso em: 18 de nov. 2014.

D'ÁVILA, Antônio. Literatura infanto-juvenil: de acôrdo com o programa das escolas normais. São Paulo: Editora do Brasil, 1961.

. Literatura infanto-juvenil: de acôrdo com o programa das escolas normais. 3. ed. rev. aum. São Paulo: Editora do Brasil, 1964.

Práticas escolares: de acordo com o programa de prática do ensino do curso normal e com orientação do ensino primário. v.3. São Paulo: Saraiva, 1954. p.210233.

Práticas escolares: de acordo com o programa de prática do ensino do curso normal e com orientação do ensino primário. 3. ed. v.3. São Paulo: Saraiva, 1967.

DIAS, Aldo de Assis. Influência da má literatura na infância e juventude. In: OLIVEIRA, Antenor Santos de (Org.). Curso de literatura infantil. São Paulo: Santos de Oliveira, 1958. p.81-93.

DIAS, José Augusto. Carlos Pasquale. In: FÁVERO, Maria de Lourdes de Albuquerque; BRITTO, Jader de Medeiros. Dicionário de educadores no Brasil. Rio de Janeiro: UFRJ; MEC-Inep, 1999.

DONATO, Hernâni. O folclore - base da literatura infantil. In: OLIVEIRA, Antenor Santos de (Org.). Curso de literatura infantil. São Paulo: Santos de Oliveira, 1958. p.145-169.

DÓRIA, Sampaio. Methodologia do ensino e literatura didática. Revista de Ensino. São Paulo, 1918.

EDITOR, o. Prefácio. In: PIMENTEL, Figueiredo. Histórias da avozinha: livro para crianças. Rio de Janeiro: Quaresma, 1896. 
FARAH, Therezinha J. F. Prática da literatura infantil na escola primária. São Paulo: Instituto Brasileiro de Edições Pedagógicas. [19--]

FAUSTO, Boris. História do Brasil. 13. ed. São Paulo: EdUSP, 2010.

FORQUIN, Jean-Claude. Escola e cultura. As bases sociais e epistemológicas do conhecimento escolar. Porto Alegre: Artes Médicas, 1993.

FRACCAROLI, Lenyra C. Organização e funcionamento de uma biblioteca escolar. In: OLIVEIRA, Antenor Santos de (Org.). Curso de literatura infantil. São Paulo: Santos de Oliveira, 1958. p.119-142.

Bibliografia de literatura infantil em língua portuguesa. São Paulo: Instituto Nacional do Livro, 1953.

GALLUZZI, Mariana. Um estudo sobre Metodologia da linguagem (1955), de Orlando Leal Carneiro. 2006. 73f. Monografia (Trabalho de Conclusão de Curso de Pedagogia) - Faculdade de Filosofia e Ciências, Universidade Estadual Paulista, Marília. 2006.

GATTI, Bernadete; ROVAI, Evangelina. Alguns aspectos da legislação sobre formação do professor primário (1957a 1975) no estado de São Paulo. Cadernos de Pesquisa, n.20, mar. 1977.

GAZETA, A. Primeira semana de literatura infantil em São Paulo. São Paulo, 23. Out. 1957a.

Primeira semana de literatura infantil em São Paulo. São Paulo, 25. Out. 1957b.

GÓES, Lúcia Pimentel. Introdução à literatura infantil e juvenil. São Paulo: Pioneira, 1984.

GONÇALVES, Neusa; SILVEIRA, Cédma Eliane Bueno da. Plano anual de ensino - 1996 - (Língua Portuguesa - 2a série). Tupã: Centro Específico de Formação e Aproveitamento do Magistério CEFAM, 1996. (digitado).

GOUVEIA, Júlio de. Teatro infantil. In: OLIVEIRA, Antenor Santos de (Org.). Curso de literatura infantil. São Paulo: Santos de Oliveira, 1958. p.97-115.

HALLEWELL, Laurence. O livro no Brasil: sua história. Trad. Maria da Penha Villalobos, Lólio Lourenço de Oliveira e Geraldo G. de Souza. 2.ed. rev. ampl. São Paulo: Editora da Universidade de São Paulo, 2005.

HINOSTROZA AYALA, Aquiles. Enfoque filosófico de la pedagogía. Ayacucho: Universidad Nacional de San Cristóbal de Huamanga, 2007. (Texto Universitário). HOBSBAWN, Eric. Introdução: A invenção das tradições. In: HOBSBAWN, Eric; RANGER, Terence. A invenção das tradições. Rio de Janeiro: Paz e Terra, 1984. p.9-23.

HOHLFELDET, Antonio. Deus escreve direito por linhas tortas. O romance-folhetim dos jornais de Porto Alegre entre 1850 e 1900. Porto Alegre: EDIPUCRS, 2003

HORTA, José Silvério Baía. Gustavo Capanema. In: FÁVERO, Maria de Lourdes de Albuquerque; BRITTO, Jader de Medeiros. Dicionário de educadores no Brasil: da colônia aos dias atuais. Rio de Janeiro: Ed. UFRJ, 1999. 
INSTITUTO DE EDUCAÇÃO CAETANO DE CAMPOS. I Semana de Literatura Infantil em São Paulo - de 21 a 28 outubro de 1957. Convite e Programa. São Paulo, out. 1957 (datilografado).

IVAMOTO, Regina Maria Elero Ferraz. A leitura na escola. In: SÃO PAULO (estado). Secretaria de Estado de Educação. Coordenadoria de Estudos e Normas Pedagógicas. Ciclo básico em jornada única: uma nova concepção de trabalho pedagógico. v.1 São Paulo: FDE, 1988.

INVESTIGAÇÃO sobre jornais e revistas infantis e juvenis. Revista Brasileira de Estudos Pedagógicos, Rio de Janeiro, v.2, n.5, p.255-275, nov. 1944a.

INVESTIGAÇÃO sobre jornais e revistas infantis e juvenis, (II). Revista Brasileira de Estudos Pedagógicos, Rio de Janeiro, v.2, n.6, p.401-422, dez. 1944b.

INVESTIGAÇÃO sobre jornais e revistas infantis e juvenis, (III). Revista Brasileira de Estudos Pedagógicos, Rio de Janeiro, v.3, n.7, p.82-101, jan. 1945a.

INVESTIGAÇÃO sobre jornais e revistas infantis e juvenis, (IV). Revista Brasileira de Estudos Pedagógicos, Rio de Janeiro, v.3, n.8, p.223-241, fev. 1945b.

JULIA, Francisca; SILVA, Júlio César. Alma infantil. Rio de Janeiro: s.e., 1912.

KATZENSTEIN, Betti; FREITAS, Beatriz de. Algo do que crianças gostam de ler: estudo de dois livros preferidos por meninos e meninas. Revista do Arquivo Municipal, São Paulo, 1941.

LABEGALINI, Andréia C. F. B. A formação de professores nos Institutos de Educação do Estado de São Paulo (1933 a 1975). Marília: UNIMAR, 2009.

LABEGALINI, Andréia. C. F. Baraldi. A formação de professores alfabetizadores nos Institutos de Educação do Estado de São Paulo (1933 a 1975). 2005. 315f. Tese (Doutorado em Educação) - Faculdade de Filosofia e Ciências, Universidade Estadual Paulista, Marília, 2005.

LAJOLO, Marisa; ZILBERMAN, Regina. Literatura infantil brasileira: história \& histórias. São Paulo: Ática, 1984.

Usos e abusos da literatura na escola: Bilac e a literatura escolar na República Velha. Rio de Janeiro: ed. Globo, 1982.

LE GOFF, Jacques. História e memória. Trad. Bernardo Leitão. 5.ed. Campinas, SP: Editora da UNICAMP, 2003.

LEITE, Marina Ribeiro; SAVI, Rita de Cássia Barros. Ensino de $2^{\circ}$ grau profissionalizante. Cadernos de Pesquisa, n.36, p.3-25, fev., 1980.

LIMA, Vicente de Paulo. Justificativa da Reforma. In: SÃO PAULO estado). Legislação do ensino normal no estado de São Paulo, atualizada até 30 de abril de 1960. n.4, abr. 1960. São Paulo: Secretaria de Estado dos Negócios da Educação, 1960.

LOPES, Eliane Marta T. Júlio Afrânio Peixoto. In: FÁVERO, Maria de L. A.; BRITTO, Jader M. Dicionário de educadores no Brasil: da colônia aos dias atuais. 2. ed., ed. aum. Rio de Janeiro: Editora UFRJ, 2002. p.659-664.

LOUREIRO, Maria Carolina. Plano de curso: Português $3^{\mathrm{a}}$ série $-2^{\circ}$ grau normal. São Carlos: Instituto de Educação Dr. Álvaro Guião, 1975. (datilografado). 
LOURENÇO FILHO, Manoel Bergströn. Como aperfeiçoar a literatura infantil. Revista Brasileira. Rio de Janeiro, v.3, n.7, p.146-169,1943.

. Programa de literatura infantil nas escolas normais. São Paulo, 1957a. (Datilografado).

Ante-projeto de programa de literatura infantil nas escolas normais. Gazeta de São Paulo, São Paulo, 29 de mai. 1957b.

Programa de literatura infantil (cont.). Gazeta de São Paulo, São Paulo, 31 de mai. 1957c.

. Ante-projeto de um Programa de literatura infantil (cont.). Gazeta de São Paulo, São Paulo, 03 de jun. 1957d.

. Programa de literatura infantil (cont.). Gazeta de São Paulo, São Paulo, 4 de jun.1957e.

Programa de literatura infantil (cont.). Gazeta de São Paulo, São Paulo, 5 de jun.1957f.

Programa de literatura infantil (conclusão). Gazeta de São Paulo, São Paulo, 6 de jun.1957g.

Introdução ao estudo da Escola Nova. São Paulo: Melhoramentos, 1978.

MAGALHÃES, Justino. O mural do tempo: manuais escolares em Portugal. Lisboa: Edições Colibri, 2011.

MAGNANI, Maria do Rosário Mortatti. Em sobressaltos: formação de professora. 2. ed. Campinas: Editora da Unicamp, 1993.

Entre a literatura e o ensino: um balanço das tematizações brasileiras (e assisenses) sobre literatura infantil e juvenil. Miscelânea. v.3, p.247-257, 1998.

Leitura, literatura e escola: sobre a formação do gosto. 2. ed. São Paulo: Martins Fontes, 2001.

MAGNANI, Maria Aparecida Ceravolo. Prefácio. In: SÃO PAULO (estado). Guia de leitura do acervo básico $-1^{\circ}$ e $2^{\circ}$ graus. São Paulo: FDE, 1991.

MANACORDA, Mario. História da educação: da antiguidade aos nossos dias. Trad. Gaetano Lo Monaco. 2. ed. São Paulo: Cortez, 1989.

MASCARO, C. O ensino normal no Estado de São Paulo: subsídios para estudo da sua reforma. São Paulo: Faculdade de Filosofia, Ciências e Letras, USP, 1956.

MEDEIROS, Valéria Antonia. Antonio de Sampaio Dória e a modernização do ensino em São Paulo nas primeiras décadas do século XX. 2005. 358f. Tese (Doutorado em Educação), Pontifícia Universidade Católica de São Paulo, São Paulo, 2005.

MEIRELES, Cecília. Problemas da literatura infantil. Belo Horizonte: Imprensa Oficial, 1951.

MELLO, Luís Correia de. Dicionário de autores paulistas. São Paulo: Comissão do IV centenário, 1954.

MENUCCI, Sud. A literatura escolar e a Escola Ativa. Revista de Educação. v.7, n.1-2, p.105-114, abr./mai., 1929.

MONARCHA, Carlos; LOURENÇO FILHO, Rui (Org.). Por Lourenço Filho: uma biobibliografia. Brasília: Instituto Nacional de Pesquisa Educacionais, 2001. 
Escola Normal da Praça: o lado noturno das luzes. Campinas: Ed. Unicamp, 1999.

MONTEIRO, Jerônymo. Leituras para menores. O Estado de S. Paulo, São Paulo, 13 ago. 1941.

MORTATTI, Maria do Rosário Longo. Leitura crítica da literatura infantil. Leitura: teoria \& prática, Campinas: ALB, ano 19, n.36, p.11-17, dez. 2000a.

. Os sentidos da alfabetização: São Paulo/1876-1994. 1. ed. 2. reimp. São Paulo: Editora Unesp, 2000b.

Notas sobre linguagem, texto e pesquisa histórica em educação. História da educação. Pelotas, v.6, p.69-77, out. 1999.

. Literatura infantil e/ou juvenil: "a prima" pobre da pesquisa em Letras?.

Revista Guavira Letras. Três Lagoas, n.6, p.43-52, 31 mar. 2008.

Ensino de língua e literatura no Brasil: repertório documental republicano. Marília, 2003. (Digitado).

Bibliografia brasileira sobre história do ensino de língua e literatura no Brasil (2003-2011). Marília, 2011. (digitado).

. Manuais para Ensinar a Ensinar Leitura e Escrita (1940-1950), na História da Alfabetização no Brasil. In: ; FRADE, Isabel Cristina Alves da Silva.

(Org.). História do ensino de leitura e escrita: métodos e material didático. São Paulo:

Ed. Unesp; Marília: Oficina Universitária, 2014. p.199-222.

Prefácio. In: ARROYO, Leonardo. Literatura infantil brasileira. 3. ed. São Paulo: Ed. Unesp, 2011.

MUÑOZ, Teresa María Dabusti. Trayectoria de Lorenzo Luzuriaga em Losada, una editorial del exilio. [s.l.:s.d.]. Disponível em: <http://webcache.googleusercontent.com/search?q=cache:fN_XVRECyhwJ:institucional.us.es/revistas/ contemporanea/9_10_II/art_7.pdf $+\& \mathrm{~cd}=2 \& \mathrm{hl}=\mathrm{pt}-\mathrm{BR} \& \mathrm{ct}=\mathrm{clnk} \& \mathrm{gl}=\mathrm{br}>$. Acesso em: mai. 2012.

MOURA, Maria Isabel Gerth Landell de. Centro Específico de Formação e Aperfeiçoamento do Magistério (Cefam) no estado de São Paulo: resgatando sua história e analisando sua contribuição. Dissertação (Mestrado em Educação) - Pontifícia Universidade Católica de São Paulo, São Paulo, 1991.

NERY, Ana Clara Bortoleto. A Sociedade de Educação de São Paulo: embates no campo educacional (1922-1931). São Paulo: Ed. Unesp, 2009.

NOCIVIDADE de certa literatura infantil. Diário de São Paulo, São Paulo, [s.p.], 11 jan. 1945.

NOGUEIRA, J. A. Literatura Infantil. O Estado de S. Paulo, 28 set. 1922a, p.5.

Literatura Infantil: "Narizinho arrebitado", por Monteiro Lobato. O Estado de S. Paulo, 30 out. 1922b, p.2.

O DEPARTAMENTO de Educação e a orientação pedagógica da infância: Seleção de livros e jornais infantis - Organização de bibliotecas escolares - Orientação dos livros didáticos - Atividades do serviço de Literatura Infantil. O Estado de S. Paulo, São Paulo, 16 jan. 1945, p.8 
O ESTADO DE S. PAULO. E a cidade ganha os primeiros livros. 19 de dezembro de 1976, p. 57.

OLIVEIRA, Antenor Santos de (Org.). Curso de literatura infantil. São Paulo: Santos de Oliveira, [1958]. p.9-35

OLIVEIRA, Fernando Rodrigues de. Bárbara Vasconcelos de Carvalho e o ensino da literatura infantil no Brasil. São Paulo: Ed. UNESP, 2013.

O ensino da literatura infantil em Compêndio de literatura infantil: para o $3^{\circ}$ ano normal (1959), de Bárbara Vasconcelos de Carvalho. 2010. 253f. Dissertação (Mestrado em Educação) - Faculdade de Filosofia e Ciências, Universidade Estadual Paulista, Marília, 2010.

Fontes para a história do ensino da literatura infantil nos cursos de formação de professores primários no estado de São Paulo-Brasil. Marília, 2014a. (digitado).

. Bibliografia portuguesa ou em circulação em Portugal sobre literatura infantil e história da educação. Lisboa, 2014b (digitado).

Fontes para a história do ensino da literatura infantil nos cursos de formação de professores em Portugal: um instrumento de pesquisa. Lisboa, 2014c (digitado).

. A produção acadêmico-científica brasileira sobre literatura infantil e juvenil e a constituição de um campo de investigação. In: DÍAZ, José María Herández Org.). Formación de Élites y Educación Superior em Iberoamérica (Ss. XVI-XXI). Salamanca: Hergar, 2012.

Nelly Novaes Coelho na História do ensino da literatura infantil no Brasil. In: CERECEDO, Alicia Civera; FERNÁNDEZ, Carlos Escalante; ROCKWELL, Elsie. (Org.). Sujeitos, poder y disputas por la educación: textos de historiografía de la educación latinoamericana. Zinacantepec: El Colegio Mexiquense; Universidad Pedagogica Nacional, 2014, p.3413-3423.

; TREVISAN, Thabatha Aline A literatura infantil na formação de professores primários no Brasil: contribuições de Bárbara V. de Carvalho (1959) e Antônio d'Ávila (1961). Diálogo Educacional, v.12, n.36., mai./ago. 2012.

; _. Medidas de controle da circulação do livro didático para o ensino de leitura e escrita em São Paulo: A “Commissão Revisora” de 1918. História da Educação. v.19, n.45, jan./abr. 2015 (no prelo).

OLIVEIRA, Maria Helena Cozzolino de; MONTEIRO, Conceição Perkles. Literatura infantil. In: OLIVEIRA, Maria Helena Cozzolino de; MONTEIRO, Conceição Perkles. Metodologia da linguagem. São Paulo: Saraiva, 1980. p.123-137.

ORLANDI, J. O. De literatura infantil. O Estado de S. Paulo, São Paulo, 11 out. 1941 a, p.3.

. De literatura infantil. O Estado de S. Paulo, São Paulo, 29 out. 1941b, p.9. Livros, brinquedos, etc. O Estado de S. Paulo, São Paulo, 25 dez. 1942, p.2.

. Educação: Literatura Infantil. O Estado de S. Paulo, São Paulo, 23 jan. 1943, p.4.

PAIVA, Edil Vasconcellos; PAIXÃO, Lea Pinheiro. Pabaee (1956-1964): a americanização do ensino elementar? Niterói: EdUFF, 2002. 
PASQUALE, Carlos. Exposição de motivos da regulamentação da lei n. 3.739, de 1957. In: Legislação do ensino normal no estado de São Paulo, atualizada até 30 de abril de 1960. n.4, abr. 1960. São Paulo: Secretaria de Estado dos Negócios da Educação, 1960.

PATRI, Angelo. Dai livros à petizada. Jan. 1943.

PEIXOTO, Afrânio. Ensinar a ensinar: ensaios de pedagogia aplicada à educação nacional. Rio de Janeiro: Francisco Alves, 1923.

PEIXOTO, Ana Maria Casasanta. Abgar Renault. In: FÁVERO, M. de L. de A; BRITTO, J. de M. (Org.). Dicionário de educadores no Brasil: da colônia aos dias atuais. 2. ed. aum. Rio de Janeiro: Editora UFRJ, 2002.

PEREIRA FILHO, Genesio. A literatura infantil na formação do caráter humano. $O$ Estado de S. Paulo, São Paulo, 14 nov. 1945, p.6.

PERROTTI, Edmir. O texto sedutor na literatura infantil. São Paulo: Ícone, 1986.

PÍLLETTI, Nelson. Fernando de Azevedo. In: FÁVERO, Maria de L. Albuquerque; BRITO, Jader de Medeiros. Dicionário de educadores no Brasil: da Colônia aos dias autuais. Rio de Janeiro: Editora UFRJ, 1999.

PREFEITURA DE SÃO PAULO. Histórico da Biblioteca Monteiro Lobato. São Paulo, s.d. Disponível em: <http://www.prefeitura.sp.gov.br/cidade/secretarias/ cultura/bibliotecas/monteiro_lobato/index.php? $\mathrm{p}=3821>$. Acesso em: $12 \mathrm{abr}$. 2010 .

PRESTES, Gabriel. Prefácio. In: ROLIM, Zalina. Livro das crianças. Boston: C. F. Hammet \& Company, 1897.

PIMENTA, Selma Garrido. O estágio na formação de professores: unidade teoria e prática? São Paulo: Cortez, 2006.

PINTO, Alexina de Magalhães. Esboço provisório de uma biblioteca infantil. In: Provérbios populares, máximas e observações usuais. Rio de Janeiro: Francisco Alves, 1917. p.159-171.

PINTO, José Benedicto. Pontos de literatura infantil: para os alunos do $3^{\circ}$ ano normal. 4.ed. rev. aum. São Paulo: FTD, 1967.

PORTA, Marilena. Plano de ensino de Língua portuguesa e Literatura. Tupã: E.E.P.S.G Índia Vanuíre, 1991 (datilografado).

PRO TV. Associação dos Pioneiros, Profissionais e Incentivadores da TV brasileira. Seção Biografias. s.d. Disponível em: <http://www.museudatv.com.br/biografias/Julio\%20Gouveia.htm>. Acesso em: 11 set. 2012.

REIS FILHO, Casemiro dos. A educação e a ilusão liberal: origens da Escola Pública paulista. Campinas: Autores Associados, 1995.

RESENDE, Adauto. Literatura infantil. Revista Brasileira de Estudos Pedagógicos, Rio de Janeiro, v.13, n.35, p.182-184, jan./abr. 1949. (Seção Através de revistas e jornais).

RIBEIRO, Eurico Branco. Aspectos da Literatura Infantil. O Estado de S. Paulo, São Paulo, 17 dez. 1939, p.9. 
RODRIGUES, Sineval Martins. Apresentação. In: SÃO PAULO (estado). Guia de leitura do acervo básico - $1^{\circ}$ e $2^{\circ}$ graus. São Paulo: FDE, 1991.

ROSEMBERG, Fúlvia. Literatura infantil e ideologia. São Paulo: Global, 1985.

SALEM, Nazira, Literatura infantil. São Paulo: Mestre Jou, 1959.

SALES, Gizelma Guimarães Pereira Sales. Um estudo sobre Metodologia da linguagem (1949), de J. Budin. 80 f. Trabalho de Conclusão de Curso (Graduação em Pedagogia) - Faculdade de Filosofia e Ciências, Universidade Estadual Paulista, Marília, 2009.

SANCHEZ, Martina. Pequeno tratado da literatura infantil e infanto-juvenil. Goiania: Imery Publicações, [19--]. 141p.

SANDRONI, Laura. De Lobato a Bojunga: as reinações reinventadas. Rio de Janeiro: Agir, 1987.

SÃO PAULO. Programa do Curso Normal. Comunicado $n^{\circ}$ 18, de 3 de março de 1958, da Chefia do Ensino Secundário e Normal. São Paulo: Editôra do Brasil S/A. folheto n.32.

. Programas das Escolas Normais e Instruções Metodológicas. Portaria ${ }^{\circ} 49$, de 2 de Dezembro de 1954, do diretor Geral do Departamento de Educação, do Estado de São Paulo. São Paulo: Editora do Brasil S/A, 1954.

. Lei n ${ }^{\circ} 171$, de 11 de outubro de 1948. Criação de uma comissão mista, denominada "Comissão Orientadora de Literatura Infanto-Juvenil”. São Paulo: Assembleia Legislativa, 1948. Disponível em: <http://www.al.sp.gov.br/repositorio/ legislacao/lei/1948/lei-171-11.10.1948.html>. Acesso em: 10 ago. 2014.

Legislação do ensino normal no estado de São Paulo, atualizada até 30 de abril de 1960. n.4, abr. 1960. São Paulo: Secretaria de Estado dos Negócios da Educação, 1960 .

Programas do curso normal. São Paulo: Editora do Brasil, 1958.

Habilitação específica de $2^{\circ}$ Grau para o magistério: guias curriculares para a parte diversificada da formação especial. São Paulo: CENP, 1981.

Decreto n. 17.698, de 26 de novembro de 1947. In: Coleção de leis e decretos do Estado de São Paulo. São Paulo: Imprensa Oficial, 1947.

. Lei Estadual n. 3.739, de 22 de janeiro. In: Coleção de leis e decretos do Estado de São Paulo. São Paulo: Imprensa Oficial, 1957.

Decreto n. 35.100, de 17 de junho de 1959. In: . Coleção de leis e decretos do Estado de São Paulo. São Paulo: Imprensa Oficial, 1959.

Decreto n. 38.026, de 2 de fevereiro de 1961. In: Coleção de leis e decretos do Estado de São Paulo. São Paulo: Imprensa Oficial, 1961.

Decreto n. 45.159-A, de 19 de agosto de 1965. In: . Coleção de leis e decretos do Estado de São Paulo. São Paulo: Imprensa Oficial, 1965.

Decreto n. 50.133, de 2 de agosto de 1968. In: . Coleção de leis e decretos do Estado de São Paulo. São Paulo: Imprensa Oficial, 1968.

Lei n. 10.125, de 4 de junho de 1968. In: Coleção de leis e decretos do Estado de São Paulo. São Paulo: Imprensa Oficial, 1968. 
. Deliberação CEE n. 21/76 homologada pela Resolução SE, de 21 de janeiro de 1977. Dispõe sobre a habilitação específica de $2^{\circ}$ grau para o magistério. In: Legislação de ensino de $1^{\circ}$ e $2^{\circ}$ graus. São Paulo: SE/CENP, 1977. v.1.

. Resolução SE n. 07/89. Dispõe sobre à adequação dos quadros curriculares das escolas da rede estadual de ensino, à Res. CFE n. 06/86. In: Legislação de ensino de $1^{o}$ e $2^{\circ}$ graus. São Paulo: SE/CENP, 1989.

Lei n. 5.304, de 15 de abril de 1959. Revoga o parágrafo único do artigo $3^{\circ}$ da Lei n. 3.739, de 22 de janeiro de 1957, e dá outras providências. São Paulo, 1959. Disponível em: <http://www.al.sp.gov.br/> . Acesso em: 10 abr. 2012.

. Lei n. 10.038, de 5 de fevereiro de 1968. Dispõe sobre a organização do sistema de ensino do estado de São Paulo. São Paulo, 1968. Disponível em: <http://www. al.sp.gov.br/>. Acesso em: 10 abr. 2012.

Decreto n 28.089, de 13 de janeiro de 1988 de São Paulo. Cria Centros Específicos de Formação e Aperfeiçoamento do Magistério e dá providências correlatas. Disponível em: <http://www.al.sp.gov.br/> . Acesso em: 10 abr. 2012.

Comunicado n. 4, de 3 de janeiro de 1975. Diário Oficial, 5 fev. 1975. p.23.

. Ato n. 6, de 24 de janeiro de 1964. Diário Oficial, n. 190, 8 out. 1964.

Resolução CEE 15/68, de 28 de janeiro de 1988. Legislação do ensino de $1^{\circ}$ e $2^{\circ}$ graus. São Paulo: SE/CENP, 1988.

. Resolução SE 181/96, de 12 de dezembro de 1996. Legislação do ensino de $1^{\circ}$ e $2^{\circ}$ graus. São Paulo: SE/CENP, 1996.

. Resolução SE 11/1998, de 23 de janeiro de 1998. Legislação do ensino de $1^{\circ}$ e $2^{\circ}$ graus. São Paulo: SE/Cenp, 1998.

. Deliberação CEE 30/87. Legislação do ensino de $1^{\circ}$ e $2^{\circ}$ graus. São Paulo: SE/ Cenp, 1987.

Deliberação CEE 21/76. Legislação do ensino de $1^{\circ}$ e $2^{\circ}$ graus. São Paulo: SE/ Cenp, 1976.

. O projeto Cefam - avaliação do percurso. São Paulo: SE/Cenp, 1992.

. Secretaria de Estado de Educação. Coordenadoria de Estudos e Normas Pedagógicas. Ciclo básico em jornada única: uma nova concepção de trabalho pedagógico. v.1. São Paulo: FDE, 1988. 109p. (mais 18 páginas de anexo).

Guia de leitura do acervo básico - $1^{\circ}$ e $2^{\circ}$ graus. São Paulo: FDE, 1991. 88p.

. Secretaria de Estado de Educação. Coordenadoria de Ensino da Região Metropolitana da Grande São Paulo. Os caminhos da formação do professor de $1^{\circ}$ grau: análise e reflexão sobre planos de ensino da Habilitação Específica ao Magistério de escolas da Drecap-3. São Paulo: Divisão Regional de Ensino da Capital - 3, 1986. 98p. (datilografado).

SAVIANI, D. História das idéias pedagógicas no Brasil. 2. ed. Campinas: Autores Associados, 2008.

SAVIANI, Nereide. Saber escolar, currículo e didática. Problemas da unidade conteúdo/método no processo pedagógico. 6. ed. rev. Campinas: Autores Associados, 2010 . 
SERRA, Áurea Esteves. A formação do professor alfabetizador no IE Prof. Stélio Machado Loureiro, de Birigui/S.P. (1961-1976). Araraquara, SP: Junqueira \& Marin; São Paulo: Fapesp, 2007.

. A formação do professor alfabetizador no IE "Prof. Stélio Machado Loureiro", de Birigui/S.P. (1961-1976). 2004. 249f. Dissertação (Mestrado em Educação) Faculdade de Filosofia e Ciências, Universidade Estadual Paulista, Marília. 2004.

SILVA, R. N.; DALVIS, C. É proibido repetir. Estudos em Avaliação Educacional. n.7, p.5-44, jan./jun. 1993.

SILVA, Kátia Regina Gíglio da; JAQUETO, Maria José. Planejamento escolar. Tupã: EEPSG Índia Vanuíre, 1989. (datilografado).

SILVEIRA, Cédma Eliane Bueno da. Plano anual de ensino - 1996 - (Língua Portuguesa - $3^{\mathrm{a}}$ série). Tupã: Centro Específico de Formação e Aproveitamento do Magistério Cefam, 1996a. (digitado).

Plano anual de ensino - 1996 - (Língua Portuguesa - 4ª́rie). Tupã: Centro Específico de Formação e Aproveitamento do Magistério Cefam, 1996b. (digitado).

SOSA, Jesualdo. A literatura infantil. São Paulo: Cultrix; Edusp, 1978.

La literatura infantil. 2. ed. Buenos Aires: Editorial Losada, 1955.

SOUZA, Claudete Cameschi de. A produção sobre literatura infantil e juvenil brasileira. In: SOUZA, Claudete Cameschi; SILVA, Ana Lúcia Gomes da; MELO, Elenir Machado de; FERREIRA, Franchys Marizethe Nascimento. (Org.). Concepções pedagógicas: fundamentos, metodologias e didática. Campo Grande: Editora da UFMS, 2008, p.51-78.

SOUZA, Dirlaine Beatriz França. Desenvolvimento profissional docente no contexto do Cefam: reflexos de trajetórias formativas e inserção profissional de alunas egressas (1992-2005). 2014. 165f. Dissertação (Mestrado em Educação) - Universidade Estadual de Mato Grosso do Sul, Paranaíba, 2014.

SOUZA, Rosa Fátima de. Alicerces da Pátria: história da escola primária no Estado de São Paulo (1890-1976). Campinas, SP: Mercado das Letras, 2009.

STANISLAVSKI, Cleila de Fátima Siqueira. Uma leitura de Contos infantis (1886), de Adelina Lopes Vieira e Júlia Lopes de Almeida. 2001. 58 f. Monografia (Trabalho de Conclusão de Curso de Pedagogia) - Faculdade de Filosofia e Ciências, Universidade Estadual Paulista, Marília. 2001.

TANURI, Leonor Maria. História da formação de professores. Revista Brasileira de Educação. São Paulo, n.14, p.61-88, mai./ago. 2000. Disponível em: <http://www. anped.org.br/rbe/rbedigital/RBDE14/RBDE14_06_LEONOR_MARIA_ TANURI.pdf $>$ Acesso em: 15 jun. 2008.

O ensino normal no estado de São Paulo: 1890-1930. São Paulo: Faculdade de Educação da USP, 1979.

TREVISAN, Thabatha Aline. A pedagogia por meio da Pedagogia: Teoria e prática (1954), de Antonio D’Avila. 2007. 165f. Dissertação (Mestrado) - Faculdade de Filosofia e Ciências, Universidade Estadual Paulista, Marília. 2007. 
Um estudo sobre Práticas escolares (1940), de Antônio D’Ávila. 2003.66 f. Monografia (Trabalho de Conclusão de Curso de Pedagogia) - Faculdade de Filosofia e Ciências, Universidade Estadual Paulista, Marília. 2003.

. Manuais de ensino para formação de professores primários no Brasil: um instrumento de pesquisa. Marília, 2002 (Digitado).

TUPÃ. E.E.P.S.G. Índia Vanuíre. Planejamento de curso: Literatura infantil. Tupã: E.E.P.S.G Índia Vanuíre, 1994 (digitado).

Planejamento de curso: Literatura infantil. Tupã: E.E.P.S.G Índia Vanuíre, 1995 (digitado).

VALDEMARIN, Vera Teresa. História dos métodos e materiais de ensino: a escola nova e seus modos de uso. São Paulo: Cortez, 2010.

O manual didático Práticas escolares: um estudo sobre mudanças e permanências nas prescrições para a prática pedagógica. Revista Brasileira de História da Educação, Campinas: Autores Associados, n.17, p.13-40, mai./ago. 2008.

VIDAL, Diana G. O exercício disciplinado do olhar: livros, leituras e práticas de formação docente no Instituto de Educação do Distrito Federal (1932-1937). Bragança Paulista: Editora da Universidade São Francisco, 2001.

Culturas escolares. Estudo sobre práticas de leitura e escrita na escola pública primária (Brasil e França, final do século XIX). Campinas: Autores Associados, 2005.

VIEIRA, Adelina Lopes; ALMEIDA, Júlia Lopes. Contos infantil. 2.ed. Rio de Janeiro: Francisco Alves, 1891.

VILELA, Iraídes Valente Ferreira; TOZZO, Luzia Aparecida. Planejamento da disciplina literatura infantil para o ano de 1993. Rio Claro: E.E.P.S.G. Joaquim Ribeiro, 1993 (digitado).

WARDE, Mirian Jorge. Currículo e conhecimento: os impactos da Psicologia. Ideias, n.26, p.67-86, 1995. ("Currículo, conhecimento e sociedade").

YUNES, Eliana; PONDÉ, Glória. Leitura e leituras da literatura infantil: por onde começar? São Paulo: FTD, 1988.

ZILBERMAN, Regina. A literatura infantil na escola. São Paulo: Global, 1981. 
SOBRE O LIVRO

Formato: $16 \times 23 \mathrm{~cm}$

Mancha: 27,5 $\times 49,0$ paicas

Tipologia: Horley Old Style 11/15

EQUIPE DE REALIZAÇÃO

Coordenação Geral

Atarukas Studio 